
RUBIA MICHELATO

\section{AVALIAÇÃO DO DESEMPENHO TÉRMICO DE VIDROS REFLETIVOS: ESTUDO DE CASO EM CÉLULAS-TESTE}

Dissertação apresentada ao Departamento de Arquitetura e Urbanismo da Escola de Engenharia de São Carlos da Universidade de São Paulo para obtenção do título de Mestre em Arquitetura e Urbanismo.

Área de concentração: Arquitetura, Urbanismo e Tecnologia

Orientadora: Prof ${ }^{a}$.Dr ${ }^{\mathrm{a}}$.Associada Rosana Maria Caram de Assis 
AUTORIZO A REPRODUÇÃO E DIVULGAÇÃO TOTAL OU PARCIAL DESTE TRABALHO, POR QUALQUER MEIO CONVENCIONAL OU ELETRÔNICO, PARA FINS DE ESTUDO E PESQUISA, DESDE QUE CITADA A FONTE.

Ficha catalográfica preparada pela Seção de Tratamento da Informação do Serviço de Biblioteca - EESC/USP

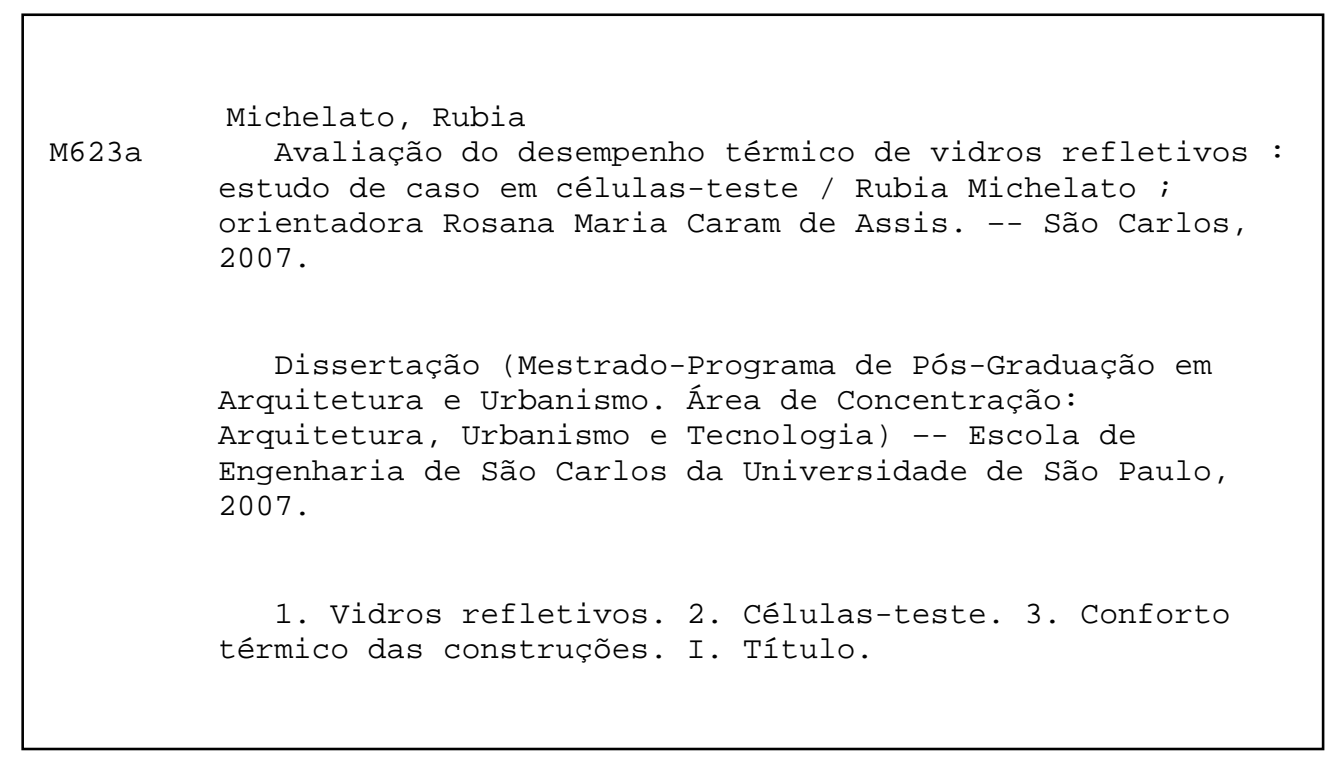


Dedico este trabalho a todos aqueles que me ajudaram a concretizá-lo e estiveram ao meu lado nos momentos em que mais precisei de ajuda, de apoio e principalmente de amigos: à minha mãe e ao meu pai, meus exemplos de vida; à minha irmã, minha conselheira e amiga; e ao João, meu grande incentivador. 


\section{AGRADECIMENTOS}

Primeiramente a Deus, por me dar força de enfrentar mais um desafio.

Em especial, o meu profundo agradecimento à minha família, meus pais Rubens e Helena, e minha irmã Eline, por estarem sempre ao meu lado.

Ao meu namorado João, por estar presente em um momento tão importante na minha vida.

Tenho a oportunidade de compartilhar a autoria deste trabalho com todos aqueles que de uma forma ou de outra o tornaram possível.

Gostaria de agradecer à Rosana Maria Caram de Assis, que orientou este trabalho de forma séria e amiga, sempre me incentivando e me ajudando.

Meus agradecimentos ao professor Dr. Joaquim César Pizzuti dos Santos da Universidade Federal de Santa Maria, pela sua dedicação e ajuda na conclusão desse trabalho.

Gostaria de agradecer à professora Dra. Lucila Chebel Labaki da Faculdade de Engenharia Civil, Arquitetura e Urbanismo da Universidade de Campinas, pelas críticas e comentários durante o exame de qualificação. 
Sou grata ao professor Dr. Maurício Roriz da Universidade Federal de São Carlos, pela elaboração de dados que complementaram essa pesquisa.

Meu agradecimento aos técnicos do LAFAC FEC - Laboratório de Conforto Ambiental de Física Aplicada Obadias Pereira da Silva Júnior e Daniel Celente, pela dedicação e fundamental ajuda durante todo o trabalho experimental.

Sou grata aos funcionários da graduação e pós-graduação da arquitetura da EESCUSP, aos professores da pós-graduação da arquitetura da EESC-USP, em especial ao professor Dr. Eduvaldo Paulo Sichieri.

À Pilkington, na pessoa de Remy Dufrayer Neto, pelas doações dos vidros utilizados nas medidas de campos que foram essenciais para a realização desse trabalho.

Às amigas Cíntia Cristina Vieira e Adriana Petito de Almeida Silva e Castro que se prontificaram a ajudar com vários dados dessa dissertação.

Agradeço a todos que conversaram comigo, cedendo parte de seu tempo para ajudar a mim e a todos que utilizarão essa dissertação para fins acadêmicos ou profissionais. 


\section{RESUMO}

MICHELATO, R. Avaliação do desempenho térmico de vidros refletivos: estudo de caso em células-teste. 2007. 225 f. Dissertação (Mestrado) - Escola de Engenharia de São Carlos, Universidade de São Paulo, São Carlos, 2007.

As superfícies transparentes são bastante frágeis no que se refere ao ganho de calor, permitindo facilmente a entrada da radiação solar no interior das edificações. A proporção entre as superfícies transparentes e as opacas de uma edificação constitui um fator decisivo no conforto ambiental, já que grandes áreas envidraçadas usadas sem nenhum critério são as principais responsáveis pelo ganho de calor no interior dos edifícios. O objetivo do trabalho é estudar o comportamento dos vidros refletivos pirolíticos e metalizados a vácuo em fachadas com relação ao ganho de calor solar. Para tanto, foram realizadas medições em células-teste construídas na UNICAMP com janelas providas desses vidros. Foram analisados nove tipos de vidros, sendo dois planos, quatro refletivos pirolíticos e três refletivos metalizados a vácuo, cuja caracterização através do espectrofotômetro já havia sido feita anteriormente. Analisou-se o desempenho térmico de cada vidro, tendo como referência o vidro plano incolor. A pesquisa consistiu na obtenção de dados através de ensaios de campo e no cálculo do ganho de calor. Dessa forma foi possível fazer uma análise das condições térmicas proporcionadas por esses vidros, verificando se eles constituem uma boa opção para a arquitetura contemporânea e se eles resultam em uma melhor eficiência energética. Dentre os vidros analisados, os vidros refletivos metalizados a vácuo apresentaram o melhor desempenho térmico no que se refere ao menor ganho de calor solar.

Palavras-chave: Vidros refletivos. Células-teste. Conforto térmico. 
ABSTRACT

MICHELATO, R. Evaluation of the thermal performance of reflective glasses: study of case in test-cells. 2007. $225 \mathrm{f}$. Dissertation (Master) - Escola de Engenharia de São Carlos, Universidade de São Paulo, São Carlos, 2007.

The glassed surfaces are so fragile concerning gain of heat, allowing the easy entrance of solar radiation in the interior of buildings. The proportion between glassed surfaces and opaque ones of a building is a decisive factor in the environment comfort, as the big glassed areas used without criterion are the principal responsible for the gain of heat in the interior of buildings. The objective of the work is to study the performance of the reflective glasses produced by pyrolitic process and the reflective glasses obtained by vacuum metal deposition in façades with reference to the gain of solar heat. For this, measurements were made in test-cells constructed at UNICAMP with windows with these glasses. Nine types of glasses were analyzed, two float glasses, four reflective glasses produced by pyrolitic process and three reflective glasses obtained by vacuum metal deposition, whose spectrophotometrical characterization was made before. It was analyzed the thermal performance of each glass, having as reference the colorless float glass. The search consisted of the acquisition of results through measurements in field and through the calculation of heat gain. This way, it was possible to make an analysis of the thermal conditions provided by these glasses, checking if they are a good option for the contemporary architecture and if they result in better energy efficiency. Among the analyzed glasses, the reflective glasses obtained by vacuum metal deposition presented the best thermal performance with reference to solar heat gain.

Keywords: Reflective glasses. Test-cells. Thermal comfort. 


\section{SUMÁRIO}

1 INTRODUÇÃO

$\begin{array}{ll}1.1 \text { Considerações iniciais } & 14\end{array}$

$\begin{array}{ll}1.2 \text { A pesquisa e seus objetivos } & 17\end{array}$

$\begin{array}{ll}1.3 \text { Apresentação da pesquisa } & 17\end{array}$

2 REVISÃO BIBLIOGRÁFICA 19

$\begin{array}{ll}2.1 \text { História do vidro } & 19\end{array}$

$\begin{array}{ll}\text { 2.1.1 Origem do vidro } & 19\end{array}$

2.1.2 Uso do vidro na arquitetura 20

$\begin{array}{ll}2.1 .3 \text { Luz e arquitetura } & 26\end{array}$

$\begin{array}{ll}\text { 2.1.3.1 As aberturas para a luz } & 27\end{array}$

2.1.3.2 A luz natural na arquitetura do século XX 29

2.1.4 Uso do vidro na arquitetura brasileira 30

2.1.4.1 $O$ vidro na arquitetura contemporânea brasileira 31

2.1.4.2 A evolução das fachadas 35

2.1.4.3 Uso dos vidros refletivos na arquitetura contemporânea $\quad 40$

2.2 O material vidro 46

2.2.1 Definição e constituição 46

$\begin{array}{ll}\text { 2.2.2 Processos de fabricação } & 48\end{array}$

2.2.3 Tipos de vidro empregados na construção civil 54

2.2.3.1 Produtos vítreos de base $\quad 54$

2.2.3.1.1 Vidro float $\quad 55$

2.2.3.1.2 Vidro impresso ou "fantasia" 56 
2.2.3.1.3 Vidro “U-glass” $\quad 57$

$\begin{array}{ll}\text { 2.2.3.1.4 Vidro refletivo } & 57\end{array}$

$\begin{array}{ll}\text { 2.2.3.1.5 Vidro insulado } & 63\end{array}$

$\begin{array}{ll}\text { 2.2.3.2 Vidros de segurança } & 64\end{array}$

2.2.3.2.1 Vidro aramado 64

2.2.3.2.2 Vidro temperado $\quad 65$

$\begin{array}{ll}\text { 2.2.3.2.3 Vidro laminado } & 66\end{array}$

2.3 As superfícies transparentes e o conforto térmico 69

$\begin{array}{ll}\text { 2.3.1 Conforto ambiental } & 69\end{array}$

$\begin{array}{ll}\text { 2.3.2 Radiação solar } & 71\end{array}$

2.3.3 Características óticas dos elementos transparentes 76

$\begin{array}{ll}\text { 2.3.4 Comportamento espectrofotométrico } & 77\end{array}$

2.3.5 Parâmetros relacionados ao desempenho térmico 84

$\begin{array}{ll}\text { 2.3.5.1 Fator solar } & 84\end{array}$

2.3.5.2 Ganho de calor solar $\quad 85$

2.3.5.3 Coeficiente de admissão de calor 87

2.4 Experimento em células-teste 88

3 MATERIAIS E MÉTODOS 90

$\begin{array}{ll}3.1 \text { Materiais } & 90\end{array}$

$\begin{array}{ll}3.2 \text { Metodologia } & 91\end{array}$

3.2.1 Caracterização da área de estudo 91

3.2.2 Caracterização das células-teste 92

3.2.3 Medidores de temperatura: termopares 96

3.2.4 Instalação da mini-estação meteorológica 98

3.2.5 Arranjo experimental 99 
$\begin{array}{ll}\text { 3.2.6 Avaliação dos dados obtidos } & 101\end{array}$

3.2.7 Método de tratamento e análise dos resultados 102

3.3 Método de obtenção do ganho de calor 103

4 RESULTADOS $\quad 110$

$\begin{array}{ll}\text { 4.1 Células-teste } & 110\end{array}$

$\begin{array}{ll}\text { 4.1.1 Medições de inverno } & 110\end{array}$

4.1.1.1 Resultados para os grupos de vidros $\quad 110$

$\begin{array}{ll}\text { 4.1.1.1.1 Discussão } & 120\end{array}$

$\begin{array}{ll}\text { 4.1.1.2 Resultados para cada tipo de vidro } & 123\end{array}$

$\begin{array}{ll}\text { 4.1.1.2.1 Discussão } & 139\end{array}$

$\begin{array}{ll}\text { 4.1.2 Medições de verão } & 140\end{array}$

$\begin{array}{ll}\text { 4.1.2.1 Resultados para os grupos de vidros } & 140\end{array}$

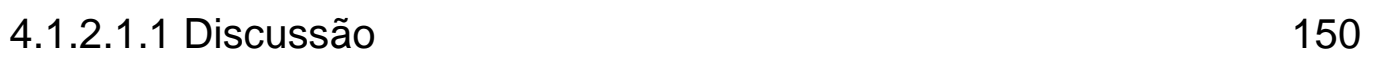

$\begin{array}{ll}\text { 4.1.2.2 Resultados para cada tipo de vidro } & 153\end{array}$

$\begin{array}{ll}\text { 4.1.2.2.1 Discussão } & 169\end{array}$

$\begin{array}{ll}4.2 \text { Ganhos de calor } & 170\end{array}$

$\begin{array}{lr}\text { 4.2.1 Resultados } & 170\end{array}$

$\begin{array}{ll}\text { 4.2.1.1 Discussão } & 183\end{array}$

$\begin{array}{ll}4.3 \text { Considerações finais } & 185\end{array}$

5 CONCLUSÕES $\quad 187$

$\begin{array}{lr}\text { REFERENCIAS } & 189\end{array}$

$\begin{array}{ll}\text { APÊNDICE - A } & 195\end{array}$ 


\section{INTRODUÇÃO}

\subsection{Considerações iniciais}

A partir do Movimento Moderno, o vidro tornou-se um dos principais elementos construtivos. Os edifícios passaram a apresentar fachadas envidraçadas cada vez maiores. Porém, esse uso intensivo do vidro nas fachadas ocasionou uma série de problemas no que diz respeito ao conforto ambiental no edifício. A arquitetura perdeu cada vez mais o contato com a interação entre o edifício e o clima, tornando-se mais propensa ao emprego de equipamentos mecânicos para aquecimento e esfriamento em fachadas altamente envidraçadas.

A fachada de um edifício deve atuar como uma mediação entre o interior e o exterior, e desta forma, controlar as variáveis climáticas que influenciam no conforto do edifício. O conforto térmico influencia diretamente no estado de ânimo, na produtividade, na satisfação e na qualidade de vida dos usuários. De acordo com Harkness (1978), a radiação solar relaciona-se diretamente ao conforto térmico nas edificações. Em se tratando de ganho e perda de calor, as janelas constituem uma parte bastante frágil da edificação (RIVERO, 1986). Szokolay (1997) coloca que " [...] todas as edificações são edificações solares: todas têm algum ganho de energia solar, apenas algumas são melhores que as outras na utilização da energia radiante recebida $[\ldots] "$. 
Os sistemas de envidraçamento, além de afetarem na estética do edifício, são responsáveis pela ventilação e iluminação natural, influenciando diretamente no conforto dos usuários e no consumo energético. De acordo com Carmody et al. (2000), no inverno há perda de calor através desses envidraçamentos, enquanto que no verão ocorre a entrada indesejada de calor.

Cada tipo de vidro possui um comportamento específico em relação à radiação solar e o efeito térmico das superfícies envidraçadas depende das propriedades espectrais dos vidros. Grande parte da radiação é transmitida diretamente ao interior do ambiente, além de ser absorvida nas superfícies internas dos vidros, provocando uma elevação de sua temperatura e o conseqüente aumento de temperatura interior (CARAM DE ASSIS, 2002).

O aquecimento excessivo devido a superfícies transparentes é causado por um efeito térmico conhecido como efeito estufa (GIVONI,1976). Os vidros são transparentes à radiação de onda curta e opacos à radiação de onda longa. A maior parte da radiação solar, que é transmitida diretamente por esses materiais, é absorvida pelas superfícies internas e objetos, aquecendo-os. Essas superfícies aquecidas emitem radiação térmica, de onda longa, que não consegue ser transmitida para o ambiente externo, pois esses materiais são opacos à mesma.

Por esse motivo, a quantidade de superfícies envidraçadas ou a localização das mesmas influenciam muito no controle térmico e luminoso de um edifício. Porém, muitos edifícios são projetados sem a menor preocupação com as questões de conforto, e por isso se faz necessário o uso de sistemas artificiais de iluminação e refrigeração, provocando assim um aumento no consumo de energia.

Antes da crise e do embargo do petróleo em 1974, a energia era relativamente barata e disponível em grande quantidade. Por isso, eram poucos os 
incentivos para que os projetistas e construtores levassem em conta os problemas energéticos dos edifícios.

Após a crise energética, começou a preocupação em construir edifícios mais sustentáveis energeticamente e os edifícios de vidro passaram a ser uma questão fundamental que precisava ser resolvida.

Procurando solucionar estes problemas, foram lançados pelo mercado os vidros termo-absorventes. Porém com o uso desses vidros, os problemas de conforto não foram plenamente resolvidos.

Depois surgiram os vidros refletivos, também com o objetivo de minimizarem os problemas de conforto. Estes vidros, considerados de controle solar, foram e continuam sendo muito empregados na arquitetura nacional e internacional. Porém, muitas vezes estes vidros acabam sendo usados e não se consegue o desempenho térmico e luminoso esperado.

O uso de vidros em fachadas sem o devido critério tem se mostrado nas últimas décadas como um dos grandes responsáveis pelo desconforto térmico, principalmente em locais de grande insolação e calor, como é o caso do Brasil. As fachadas passaram a apresentar áreas cada vez maiores de vidros, chegando a atingir praticamente $100 \%$ em muitos casos, ocasionando um ganho extra de radiação solar (ROMERO; GONÇALVES; DILONARDO, 1999).

Os projetistas têm um papel muito importante ao iniciar o processo de concepção de um projeto. A eficiência energética de um edifício pode ser maior ou menor em função de um projeto consciente que considere as variáveis ambientais envolvidas. Elementos como implantação, orientação, ventilação, materiais e componentes construtivos empregados na obra precisam ser decididos durante a concepção do projeto. Segundo Petrone (1993), a utilização racional de energia não 
consiste apenas na redução do consumo, mas principalmente na adequação e otimização dessa energia.

A presente pesquisa está fundamentada nas medições de temperaturas internas em células-teste e nas superfícies dos vidros. Sentiu-se a necessidade de, após identificar os valores de transmissão de diversos tipos de vidros (SANTOS, 2002), verificar experimentalmente os resultados da aplicação desses materiais em fachadas sujeitas à incidência de radiação solar.

\subsection{A pesquisa e seus objetivos}

O objetivo geral do trabalho é avaliar a pertinência do uso de vidros refletivos pirolíticos e metalizados a vácuo em regiões de clima quente como o Brasil e verificar se estes vidros realmente resultam em um desempenho muito superior em relação aos vidros comuns.

Pode-se citar como objetivos específicos:

- Analisar o desempenho térmico dos vidros refletivos pirolíticos e metalizados a vácuo em células-teste em escala real;

- Comparar com dados obtidos em medições no espectrofotômetro através do cálculo do ganho solar.

\subsection{Apresentação da pesquisa}


A estrutura do trabalho está dividida em cinco capítulos. No capítulo 1 é mostrado o objetivo geral da dissertação, além da justificativa da importância de estudar o tema.

No capítulo 2 são estabelecidas as bases teóricas do trabalho, fazendo um levantamento bibliográfico sobre o uso do vidro na arquitetura e a busca da luz pelo homem, descrevendo a evolução do desenho das janelas até se tornarem grandes panos de vidro na arquitetura moderna. Além disso, mostra como o vidro tem sido empregado na arquitetura contemporânea do país, destacando algumas obras que utilizaram os vidros refletivos com o objetivo de melhorar as condições térmicas dos edifícios. Neste capítulo também são descritos os tipos de vidros empregados na construção civil, destacando suas características e a maneira como são fabricados. Foi realizada também uma pesquisa sobre a influência da radiação solar em superfícies envidraçadas, bem como as propriedades espectrofotométricas dos vidros.

O capítulo 3 refere-se à metodologia e aos vidros analisados na pesquisa, destacando a escolha do método de avaliação e todo o seu planejamento. Esta parte descreve os métodos que foram utilizados e a maneira como foram aplicados.

No capítulo 4 são apresentados e discutidos os resultados obtidos em campo e os cálculos de ganho de calor.

No capítulo 5 são mostradas as considerações finais do trabalho, além de indicar possibilidades de um aprofundamento e trabalhos futuros. 


\section{REVISÃO BIBLIOGRÁFICA}

\subsection{História do vidro}

A história do surgimento do vidro está relacionada com a história da humanidade, através de suas conquistas, suas expansões culturais e territoriais. $\mathrm{O}$ texto a seguir apresenta a história da tecnologia de confecção dos vidros e seu emprego direto como elemento construtivo nos principais movimentos arquitetônicos.

\subsubsection{Origem do vidro}

Apesar de não existirem dados precisos quanto à origem do vidro, alguns historiadores atribuem aos navegadores fenícios a sua descoberta por volta do ano 5000 a.C. O historiador romano Plínio afirma que sua descoberta teria ocorrido por acaso, quando os navegadores fenícios estavam na praia esquentando suas comidas sobre torrões de nitrato de sódio (natrão). Eles perceberam que depois de algum tempo, escorria do fogo um líquido transparente que ao se misturar com a areia solidificava-se. O natrão fundia-se em conseqüência do calor do fogo, e ao misturar-se com a areia formava um novo composto transparente. Outros historiadores atribuem a descoberta do vidro aos egípcios. 
Mesmo havendo uma discordância no que se refere à origem do vidro, não há dúvidas de que ele está intimamente ligado à história da arquitetura. Com o passar dos tempos, essa relação foi se estreitando cada vez mais e a principal conseqüência disso são os edifícios com fachadas totalmente envidraçadas.

Nos primeiros vidros fabricados, as matérias fundidas eram a sílica em forma de areia, o natrão que abaixava o ponto de fundição da sílica, cinzas vegetais com boa quantidade de potássio e alguns óxidos. Essa mistura era fundida em fornos precários e depois havia um processo de purificação bastante demorado e complicado no qual eram adicionados óxidos para a coloração dos vidros. Esta massa vítrea era utilizada para a produção de pequenos objetos de uso pessoal e doméstico.

\subsubsection{Uso do vidro na arquitetura}

O uso do vidro na arquitetura está relacionado com as técnicas que foram desenvolvidas no processo de fabricação dos vidros. Os romanos, por volta dos anos 100 a.C., desenvolveram as primeiras indústrias de vidros. Esta atividade estabeleceu-se em Roma no tempo de Tibério e apresentou grande desenvolvimento. Os vidros eram produzidos em formas e eram aplicados nas janelas das edificações (SANTA MARINA, 1993). Posteriormente os romanos levaram esses processos de fabricação para a Península lbérica e para a Gália.

Com a decadência do Império Romano, as famílias que conheciam a técnica da fabricação do vidro espalharam-se pela Europa. Com a invasão bárbara esta atividade ficou esquecida. Paralelamente, em regiões de influência islâmica a manufatura do vidro desenvolveu-se gradualmente e o uso do vidro na arquitetura 
assumiu seu caráter artístico. O vidro passou a ser usado como proteção de janelas nos séculos III e IV da era cristã.

No mundo cristão, o uso do vidro na arquitetura começou com o imperador Constantino. O vidro era bastante empregado em mosaicos em Constantinopla. No século VI, foram empregados na Catedral de Santa Sofia em Constantinopla os primeiros vidros coloridos. Com a transferência do Império Romano para o Oriente, Constantino fez questão de levar vários artesãos dessa arte, permitindo assim a continuação desta indústria.

Alguns historiadores afirmam que as cruzadas foram responsáveis pela difusão da arte do vidro do Oriente para o Ocidente, onde se estabeleceu ao longo do século XI. Na Idade Média surgem os grandes vitrais que eram então usados apenas nas igrejas, cujos desenhos eram de motivos religiosos. Estes vitrais, além de fornecerem proteção e luz aos ambientes, eram utilizados pela Igreja Católica como forma de difundir o cristianismo, através das imagens representativas dos testamentos.

$\mathrm{Na}$ arquitetura gótica começaram a aparecer grandes janelas e houve uma intensificação do uso dos vidros coloridos. No início do período gótico os desenhos que predominavam nos vidros coloridos tendiam ao primitivo, sendo que as cores eram puras e primárias e eram utilizadas figuras geométricas. As janelas construídas eram compridas e pontiagudas, como mostra a Figura 1. Já no século XIII, começam a aparecer na França janelas circulares e os mosaicos passaram a ter um caráter mais naturalista com a utilização de cores secundárias. 


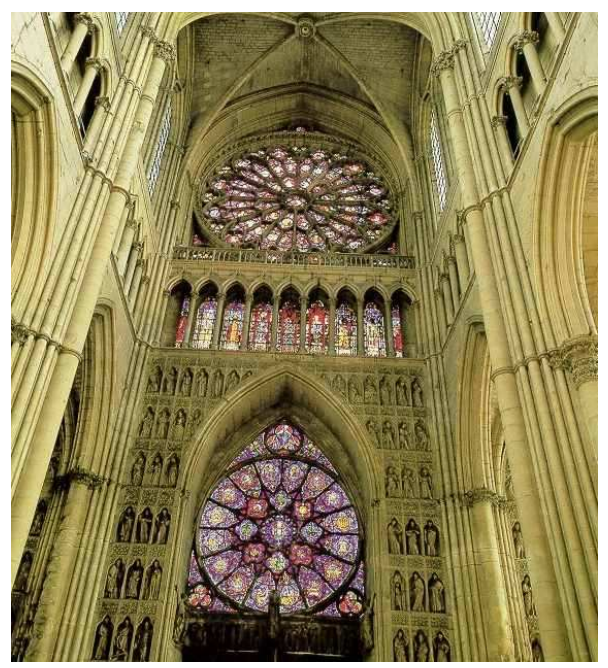

Figura 1. Rosáceas da Catedral de Notre-Dame em Paris

Fonte: CENTRO DE ENSINO DE INFORMÁTICA, Colégio Santa Cruz, 2006

Do Baixo Império até o século XIII da Era Cristã, o Oriente ficou com o monopólio do comércio de vidro. A partir deste período, os venezianos começaram a ter artistas gregos nas suas oficinas, provocando um grande desenvolvimento nesta indústria e uma supremacia sobre as outras nações até o século XVII. Veneza teve um papel muito importante na história da fabricação do vidro. Em 1300 o vidro moldado com "rolo" foi introduzido em Veneza, revolucionando a produção dos vidros planos. Devido aos vários incêndios provocados pelos fornos das fábricas de vidro, foi feito um decreto em 1291 em Veneza exigindo que estas indústrias fossem transferidas para a ilha de Murano, perto de Veneza. Isso pareceu ser uma estratégia para ter maior vigilância sobre os trabalhadores e preservar os "segredos" da fabricação dos vidros (SANTA MARINA, 1993). Murano aperfeiçoou as técnicas da fabricação do vidro, sendo que o primeiro vidro transparente ou cristalino foi produzido na ilha. Apesar deste controle rigoroso, alguns operários e artistas conseguiram ir para a Alemanha e esta conseguiu consolidar sua indústria vidreira.

$\mathrm{Na}$ arquitetura renascentista, as janelas passaram a predominar nas fachadas das edificações. Neste período, devido ao desenvolvimento das cidades, começaram 
a surgir edificações mais elaboradas. Nas igrejas também as pequenas aberturas foram substituídas pelos grandes domus, como por exemplo, o Pantheon em Paris (Figura 2). Foi neste período que ocorreu o desenvolvimento da fabricação de vidro na França.

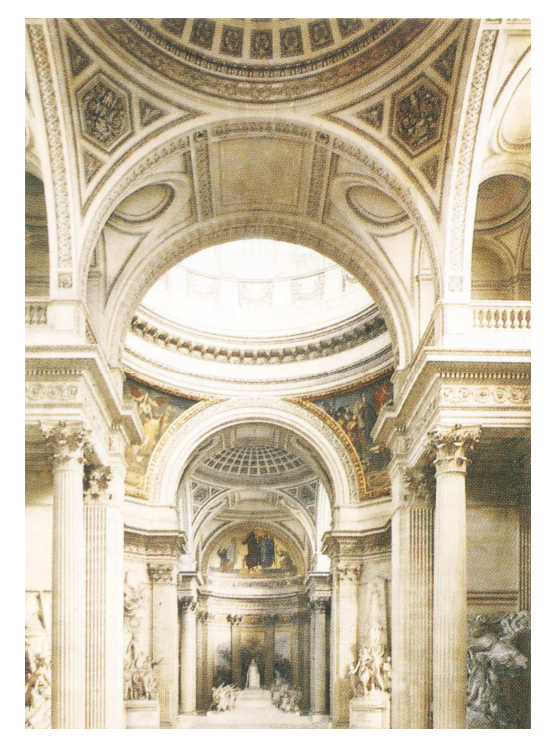

Figura 2. Nave do Pantheon em Paris Fonte: GRANDE ENCICLOPÉDIA LAROUSSE CULTURAL, 1998

No século XVI chegaram muitos artistas de Veneza na Inglaterra, contribuindo para o desenvolvimento das indústrias vidreiras no país. No final do século XVII, o vidro na Inglaterra já era um material utilizado não só em obras mais suntuosas, mas também em casas.

No século XVIII o desenvolvimento do vidro ocorreu mais na parte técnica do material do que do no seu emprego na arquitetura. No final do século XVIII, as indústrias vidreiras da França prosperaram e foi instalada a Companhia SaintGobain para envidraçar o Palácio de Versalhes. Estas indústrias também se desenvolveram na Inglaterra que revolucionou o comércio vidreiro com a fabricação do cristal branco. Foi neste período que a indústria vidreira espalhou-se para várias nações. 
Com a Revolução Industrial no século XIX, ocorreu a mecanização dos processos e o surgimento do método de fabricação do vidro escoado (SANTA MARINA, 1993). Este desenvolvimento tecnológico do vidro foi responsável por uma mudança no uso do vidro na arquitetura. Os holandeses começaram a construir grandes estufas de vidro. O Palácio de Cristal de Joseph Paxton foi considerado uma grande inovação no que se refere ao uso de vidro nas edificações, já que possuía grandes áreas envidraçadas tanto verticais como horizontais, como mostra a Figura 3.

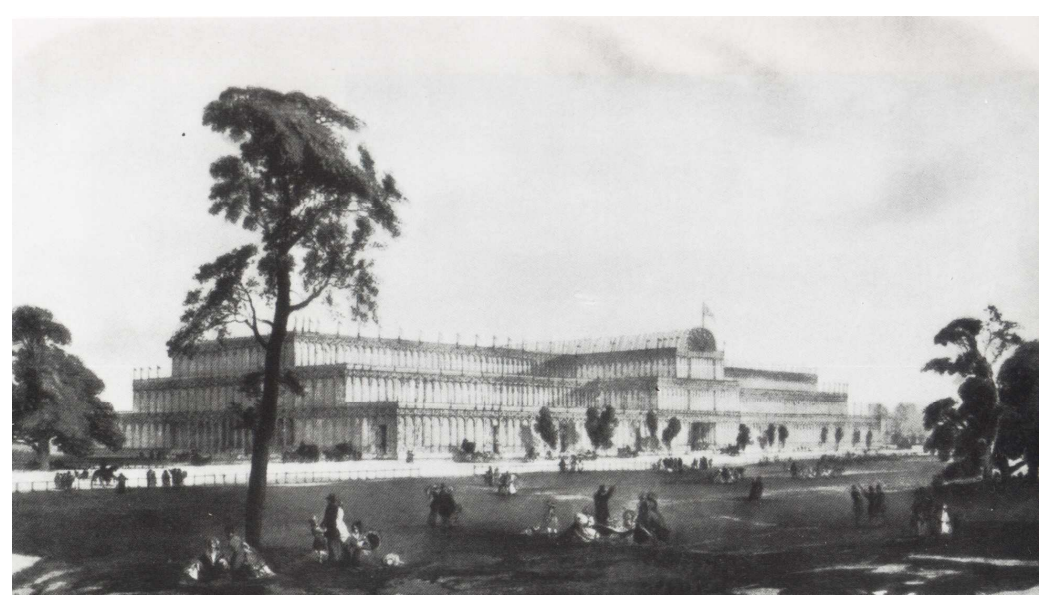

Figura 3. Palácio de Cristal em Londres (1851)

Fonte: Argan, 1998

A indústria do Reino Unido consolidou-se quando a empresa vidreira Pilkington, fundada em 1828, começou a testar novos processos para a fabricação de placas de vidros maiores. No começo dos anos 1920, a demanda da indústria automobilística fez com que a Ford Motor Company criasse um processo de fabricação cujo objetivo era a produção em massa e uma melhoria do produto. Até este momento, os vidros utilizados na construção civil eram os vidros simples.

Com o desenvolvimento do concreto no século $X X$, houve uma significativa transformação da arquitetura e do emprego de janelas, que passaram a ser maiores 
e em maior quantidade. Com a estrutura independe da vedação, os edifícios passaram a ter grandes áreas envidraçadas como um dos principais tipos de vedação. Dessa foram, as janelas deixaram de ser pequenas aberturas na fachada para tornarem-se elementos integrantes dela. Através de arquitetos modernistas como Le Corbusier, Mies van der Rohe e Frank Lloyd Wrigth, o vidro tornou-se um dos principais materiais da construção civil, transformando completamente o conceito de vedação ou fechamento, como mostra a Figura 4.

As grandes paredes de vidro anulam a separação entre espaço externo e interno; as estruturas de sustentação se limitam a uma sucessão de planos ortogonais; o edifício já não é uma massa plástica, e sim uma construção geométrica de planos transparentes no espaço. (ARGAN, 1988, p.273).

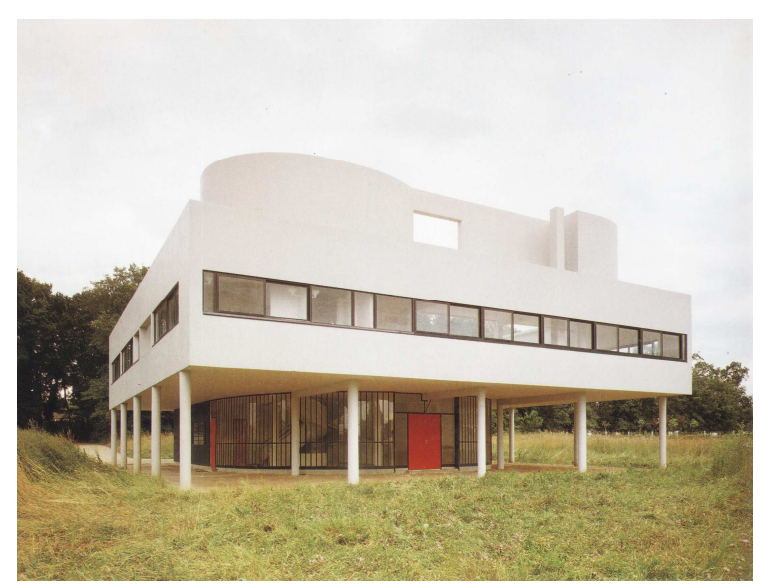

Figura 4. Vidros contínuos na fachada da Vila Savoye Fonte: Gössel e Leuthäuser, 1996

No século $X X$, o desenvolvimento da tecnologia vidreira e dos novos processos de construção possibilitou a execução de obras totalmente de vidro. Paredes externas ou até mesmo grandes torres inteiras de vidro tornaram-se forte presença na arquitetura mundial, adaptando-se à tecnologia do concreto e do aço.

Em 1952 a Pilkington inventou o processo float de fabricação de vidro e a partir de então surgiram novos tipos de vidro. Surgiram os vidros com superfícies tratadas, fibras óticas, vidros de segurança, vidros curvos, vidro duplos com ar 
incorporado. O vidro começou a ser utilizado também com o objetivo de atender às exigências de segurança e de conforto térmico, luminoso e acústico (TEIXEIRA, 2001).

$\mathrm{Na}$ arquitetura contemporânea, o vidro transcreve linhas retas e curvas; compõe perfis, formando desenhos geométricos; é pele de grandes edificações, ora envolvendo uma torre monumental como material único, ora usado com outros materiais. Os vidros são um dos elementos essenciais da imagem da arquitetura contemporânea que procura extrair seus recursos formais da expressão da evolução técnica dos dias atuais (Figura 5).

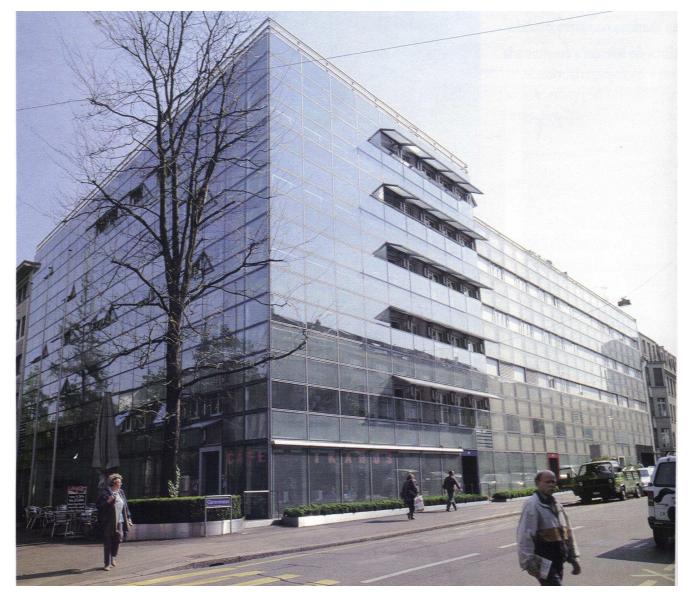

Figura 5. Edifício de Escritórios SUVA na Suíça (1991-1993)

Fonte: REVISTA Finestra Brasil, 1997, p.80

\subsubsection{Luz e arquitetura}

A arquitetura, por atender às necessidades e desejos dos homens, sempre trouxe consigo a preocupação com a luz. A luz na arquitetura tem a função de trazer boa funcionalidade ao edifício e ao mesmo tempo de trazer poesia. Desde os tempos mais antigos, a luz é responsável pela percepção espacial dos diversos componentes dentro dos ambientes. 
Pode-se dizer que, em muitos aspectos, a história e o desenvolvimento da construção correspondem à história da relação com a luz. Com o decorrer do tempo, o advento do vidro e a criação de estruturas em forma de esqueleto permitiram que todas as áreas de uma edificação pudessem ficar expostas ao exterior (SARDEIRO, 2002).

[...] a abertura para a luz é uma forma de construção espacial. A história da arquitetura é também uma história da apropriação, do domínio, do aprisionamento da 'manipulação' da luz num espaço interior, o que implica a intencionalidade de fazer dessa operação iluminadora uma operação transubstaciadora: luz em espaço qualificado. (JORGE, 1995, p.23).

A luz natural foi usada de várias maneiras em diversas épocas e lugares, de acordo com a finalidade do edifício e as características do meio onde estava sendo inserido, tanto na arquitetura doméstica como na simbólica. Vianna e Gonçalves (2001) atribuem isso ao fato de que a luz está ligada às sensações humanas, já que $70 \%$ da percepção que as pessoas têm do mundo é feita através da visão. Segundo Scarazatto (1995), a iluminação natural é a que melhor corresponde às condições normais da vista humana e que a sua qualidade é a principal razão do seu uso.

\subsubsection{As aberturas para a luz}

A janela surgiu como derivação da porta e ela aparece como uma evolução na construção do espaço arquitetônico. As diferenças no clima, nos sistemas estruturais e nos costumes sociais foram responsáveis pela variação nos tipos de janelas ao longo da história (MASCARÓ, 1983).

Segundo Jorge (1995), a janela lança-se ao olhar assumindo duas funções, a de abertura para os homens (função da visibilidade) e a de abertura para a luz. Pelo fato de ser o mecanismo mediador entre o interior e o exterior, ela qualifica esta 
relação quando sua vista é importante para o ambiente na qual ela está inserida, e quantifica quando é responsável pela criação do espaço através da luz.

Porém, a janela não esteve presente desde o início da arquitetura, sendo uma evolução na construção do espaço arquitetônico. As primeiras janelas constituíam pequenas aberturas, de forma que só havia a penetração de uma pequena quantidade de luz, ou seja, elas serviam como meio de acesso à iluminação. Já no Renascimento, com o desenvolvimento da vida urbana, as cidades tornaram-se atrativas e as pessoas começaram a se interessar por elas. Assim, a janela deixou de ser apenas uma abertura na parede para se tornar um instrumento da visão. Pode-se dizer que do período do Renascimento ao século XVII houve a introdução gradual da janela na linguagem arquitetônica (JORGE, 1995).

No século XVIII, houve o surgimento do vidro plano transparente e a janela tornou-se protagonista na composição da fachada, ocorrendo sua autonomia. Com as inovações tecnológico-construtivas e o emprego em larga escala do ferro e do vidro no século XIX, houve um aumento dos vãos e das aberturas, provocando uma ruptura nos ritmos de fachada de alvenaria. No século XX, com o desenvolvimento do aço e do concreto, o vidro passou a ser mais difundido e as janelas começaram a predominar nas fachadas dos edifícios, tornando-se elementos integrantes delas. Graças ao vidro, as aberturas puderam ganhar novas dimensões para a captação de luz, e ao mesmo tempo conseguiram proteção contra o vento e contra a chuva (MASCARÓ, 1983).

Segundo Hopkinson, Petherbridge e Longmore (1966), muitos problemas de iluminação surgem principalmente devido ao fato de que as janelas são projetadas para desempenharem diferentes funções, não apenas de admissão da luz no edifício, mas também de permitirem a visão e o contato com o exterior. De acordo 
com Koenigsberger, Mahoney e Evans (1977) quando se separam as funções da janela, consegue-se melhor desempenho.

\subsubsection{A luz natural na arquitetura do século $X X$}

A importância da luz natural pode ser vista em diferentes épocas e escolas de arquitetura, nas quais foram apresentadas várias propostas para o seu uso. No século XX com o Movimento Moderno, os ambientes foram inundados com a luz devido ao desenvolvimento do vidro, representando uma inovação nunca antes vista na história da arquitetura.

[...] toda a história da arquitetura poderia ter sido radicalmente diferente tivessem nossos antepassados usufruído esses grandes privilégios desta conexão e visibilidade que fazem as paredes - e mesmo os pilares - algo que se vê livre de qualquer custo. $O$ vidro fez isso. (WRIGHT, 1992, p.38).

De acordo com Szabo (2002), a arquitetura começou a explorar as possibilidades do vidro nos ambientes, utilizando cada vez mais o material e abrindose para o exterior, para a luz. Assim, a partir da arquitetura moderna o vidro foi adotado como um dos principais elementos construtivos. Sua função na edificação era de permitir transparência e estabelecer uma relação entre o interior e o exterior.

A aspiração de transparência, claridade e luz, característica do Movimento Moderno, foi responsável pela criação de uma nova experiência visual. O rompimento com o desenho tradicional de janela junto com o aumento da dimensão das aberturas das edificações foram responsáveis pelo surgimento de uma luminosidade diferente na arquitetura.

[...] a maior diferença entre as edificações antigas e as modernas é o uso do vidro. A necessidade de visibilidade fez com que paredes e colunas fossem intrusas, que precisavam ser eliminadas a qualquer custo [...] As sombras foram a pintura dos arquitetos quando 
modelavam as formas arquitetônicas. Que se trabalhe agora com a luz difusa, a luz refratada, a luz refletida - sombras à parte [...] lluminação integral começou com esse ideal em minha mente. Vidro e luz - duas formas de uma mesma coisa. (WRIGHT, 1975, p.197202).

Com a tendência da arquitetura moderna de fazer as paredes cada vez mais leves, as pequenas espessuras não permitem mais o trabalho com luz para uma criação mais rica de espaços, como acontecia antes.

\subsubsection{Uso do vidro na arquitetura brasileira}

O uso do vidro nas janelas brasileiras é relativamente recente. No Brasil, até o fim do século XIX e início do século XX, o vidro era utilizado em placas de pequenas dimensões devido à dificuldade de transporte. Isso porque não era fabricado no país e as vias de circulação eram precárias, encarecendo muito o produto. Em 1760, na Bahia, apenas a Igreja dos Jesuítas e o Palácio dos Governadores possuíam vidros nas janelas. Ao invés do vidro, eram utilizados balaústres de madeira para 0 fechamento (MASCARÓ, 1983).

Através da renovação das capitais no Brasil no início do século XX, o sistema de circulação desenvolveu-se com a implantação de ferrovias e a introdução do transporte rodoviário. O vidro passou a desempenhar um papel decisivo na arquitetura brasileira devido à introdução da arquitetura moderna no país. O vidro era usado devido à sua transparência, em busca de uma linguagem poética e conceitual. Com a arquitetura moderna, a luz através do vidro deixou de ser usada apenas como um elemento higienicista e quantitativo para se tornar um elemento criador de espaços (SZABO, 2002). 
Hoje no país, a "pele-de-vidro" deixou de ser utilizada com essa conotação poética para se tornar um símbolo de status. O brilho e caráter "moderno" das fachadas envidraçadas são alvos de grandes escritórios, empresas, bancos, e magazines. O vidro deixou de ser usado somente nas janelas, para alcançar as fachadas e coberturas, podendo ser visto em pisos e escadas.

\subsubsection{O vidro na arquitetura contemporânea brasileira}

O uso do vidro na arquitetura brasileira está relacionado com o desenvolvimento tecnológico do material e com as novas expressões estéticas que surgiram.

Após a Segunda Guerra Mundial, teve início uma progressiva expansão no negócio imobiliário nos centros urbanos. A produção arquitetônica americana começou a fascinar os brasileiros, pois era mais industrializada e tecnologicamente mais desenvolvida. Segundo Xavier, Lemos e Corona (1991), a necessidade de construir mais rápido e com menor custo para conseguir maior lucratividade, encontrou no racionalismo e na industrialização excelentes parceiros. Gradualmente, a busca de uma linguagem própria e qualitativa foi sufocada pela maciça produção arquitetônica comprometida, seja com o lucro imobiliário, seja com uma linguagem internacional, possível de ser consumida por qualquer cidadão do mundo.

O desenvolvimento da arquitetura brasileira e das técnicas de construção avançou muito à medida que recebeu, incorporou e reelaborou influências externas. Lúcio Costa, Oscar Niemeyer, Rino Levi e Vilanova Artigas introduziram as idéias e as formas das vanguardas modernistas, e foi neste momento que a arquitetura brasileira e o vidro cruzaram seus caminhos. 
De acordo com Szabo (2002), a procura da claridade levou ao aumento das aberturas das edificações. A arquitetura brasileira começou a explorar as possibilidades do vidro nos ambientes internos, utilizando cada vez mais o material e abrindo-se para o exterior, para a luz. A janela horizontal contínua, o pano de vidro, a grelha com vãos envidraçados e o vidro com controle solar permitiram a conquista dessa claridade. Estes elementos podem ser encontrados em vários projetos significativos da arquitetura brasileira.

A partir da década de 50, o uso do vidro na edificação intensificou-se sob influência das principais escolas da arquitetura mundial, e sob pressão interna da modernização urbano-industrial do Brasil.

A arquiteta Lina Bo Bardi e o crítico de arte Pietro Maria Bardi inauguraram, em 1951, sua residência no bairro do Morumbi em São Paulo (TEIXEIRA, 2001). Esta obra, conhecida como a "casa de vidro", estava bastante ligada às propostas arquitetônicas da época, já que explorava as possibilidades expressivas do vidro.

Com a transferência da capital do país para o Planalto Central, em 1960, Brasília serviu de paradigma para outras cidades brasileiras através da construção de torres. Pode-se dizer que foi a partir da construção dos edifícios de concreto e vidro da nova capital, projetados por Oscar Niemeyer, que o vidro passou a ser usado intensivamente, tornando-se um elemento marcante da arquitetura brasileira.

$\mathrm{Na}$ "casa de vidro", nos edifícios de Brasília e em outros que vieram depois, o vidro deixou de compor apenas janelas para constituir as próprias paredes, conferindo novas possibilidades de beleza, conforto e plasticidade.

A partir de 1964, tornou-se intenso o processo de verticalização graças à política de financiamento do Banco Nacional da Habitação, criado em 1964. O edifício sede do Banco Nacional da Habitação, projetado por Haroldo Cardoso de 
Souza e Rogério Marques de Oliveira e construído em 1968, constituiu um exemplo de arquitetura aliada ao poder e, naturalmente, segundo as tendências modernizantes da época, com fachadas de vidro (GAMMARANO, 1992).

Em 1968 é inaugurado o novo prédio do Museu de Arte de São Paulo, projeto de Lina Bo Bardi, com a fachada toda envidraçada, como mostra a Figura 6.

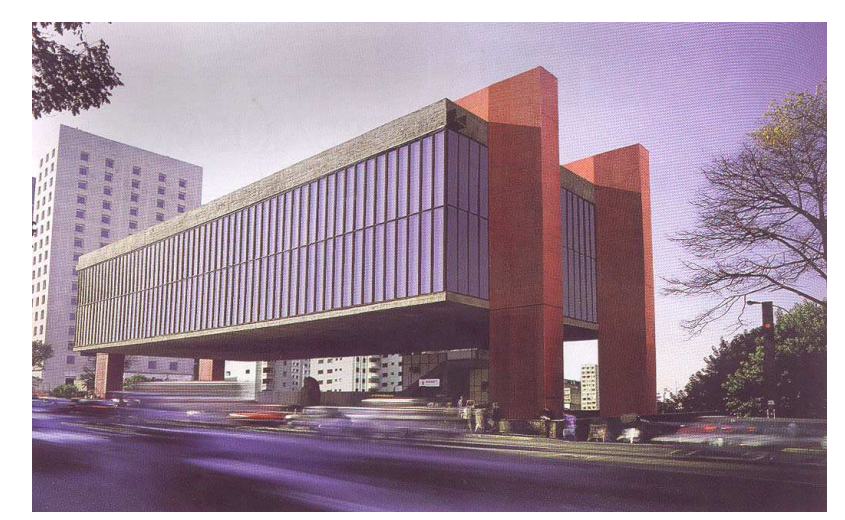

Figura 6. Museu de Arte de São Paulo Fonte: REVISTA Finestra Brasil, 2000, p.106

O edifício do MASP passou por várias intervenções de manutenção entre 1997 e 2000. Os vidros receberam em torno de $3000 \mathrm{~m} 2$ de película de controle solar incolor para que garantisse a fiel reprodução das cores das obras de arte e não interferisse na aparência original do edifício. Além disso, evitou a troca de todos os vidros por vidros isolantes ou laminados, ocasionando maiores gastos. As películas que foram usadas garantiram a barragem de $99 \%$ dos raios ultravioletas, responsáveis pelo desbotamento das cores. Já com relação ao conforto ambiental, a película não auxiliou muito, pois seu comportamento ótico é muito semelhante ao de um vidro comum, ou seja, possui alta transmissão do visível e do infravermelho, responsáveis pelo ganho de calor em edificações (CARAM DE ASSIS, 2002).

Na década de 70 foi construído o edifício da Petrobrás, no Rio de Janeiro, projeto de Abrão Assad, José Maria Gandolfi, José Sanchonete, Luiz Forte Netto, 
Roberto Luiz Gandolfi e Vicente Ferreira de Castro, com grandes panos de vidro, exemplificando o caráter monumental das obras da época.

Os anos 1970 marcaram o apogeu do concreto aparente na arquitetura brasileira, do vidro temperado e do caixilho de alumínio, com ênfase nos elementos estruturais e grandes vãos. Nesse período, houve rápida expansão das áreas metropolitanas, com grandes investimentos imobiliários de empresas estatais e privadas, assim como o setor bancário.

No final da década de 70 , a construção civil no Brasil sofreu uma forte redução em razão da crise do petróleo, da queda brusca dos investimentos estrangeiros e conseqüentes problemas econômicos.

Com a recuperação da economia nos anos 1980, a produção arquitetônica brasileira voltou a crescer e a receber atenção externa. A arquitetura no país passou a atentar mais para os aspectos econômicos, técnicos, de conservação e de planejamento urbano.

Nos anos 1990, a arquitetura nacional começou a importar produtos e tecnologias, expandiu o uso de estruturas metálicas e de grandes superfícies de vidro.

Os grandes panos de vidro começaram a aparecer cada vez mais em museus, aeroportos, shopping centers, e, principalmente, em edifícios comerciais e industriais. A aplicação parcial ou integral do vidro em fachadas de edifícios comerciais confere um certo arrojo e grandiosidade. Em São Paulo, por exemplo, o conceito usado na concepção de edifícios em centros financeiros como as avenidas Paulista, Faria Lima e, mais recentemente, Berrini, traz um significado implícito de status e poder econômico. 
Metrópoles como São Paulo e Rio de Janeiro abrigam grandes escritórios que buscam atender às demandas arquitetônicas de grandes empresas nacionais e multinacionais, produzindo uma cuidadosa arquitetura cujo compromisso de eficiência tecnológica e a imagem empresarial é definida por padrões internacionais [...]. (SEGAWA, 1999, p.196).

\subsubsection{A evolução das fachadas}

A partir da década de 50, difundiu-se por muitos países do mundo, o conceito de "pele-de-vidro" por meio do "estilo internacional" lançado pelo Movimento Moderno. Desse modo, as cidades passaram a ser marcadas por uma arquitetura das caixas de vidro.

No início dos anos 1960, havia a idéia de que para uma obra ser considerada "moderna", ela precisava apresentar vidros nas suas fachadas, sendo as aberturas os componentes que permitiam a comunicação com o exterior. Primeiramente essas aberturas visuais eram as janelas, posteriormente surgiram no país os primeiros edifícios com "pele-de-vidro".

As fachadas-cortina têm sido empregadas no Brasil como elemento arquitetônico inovador, isto é, como elemento estético, representando uma forte tendência da arquitetura contemporânea. Nos últimos vinte anos, respondendo às exigências da arquitetura, as fachadas-cortina passaram por etapas evolutivas. A primeira geração dessas fachadas com vidros no Brasil foi chamada de fachada relógio. Nessa geração os vidros eram encaixilhados em perfis de alumínio. Para tanto, a estrutura deveria ser perfeitamente executada, como um "relógio", o que restringia sua utilização.

Na segunda geração, começaram a ser feitas as fachadas "pele-de-vidro", nas quais os quadros de vidros passaram a ser aparafusados com presilhas, 
sobrepostos às colunas e travessas. O alumínio externo que sustentava os vidros era apenas um pequeno filete e por isso a fachada era chamada de "pele-de-vidro".

Muitas experiências foram feitas com o sistema "pele-de-vidro" entre 1978 e 1984 no Brasil, e muitas das obras que utilizaram esse sistema apresentaram problemas de estanqueidade à água. O vidro usado nesse período era o monolítico, na cor bronze ou fumê, com a desvantagem de ser termo-absorvente.

Somente a partir de 1984 o sistema "pele-de-vidro" evoluiu, surgindo o structural glazing. A fachada passou a revelar apenas o vidro, eliminando visualmente em definitivo o alumínio, que até então era exposto na fachada "pelede-vidro".

A fachada de vidro estrutural (structural glazing) é um tipo especial de fachada contínua, cujos painéis de vidro são montados com um selante à base de silicone, que adere aos suportes com suficiente firmeza para impedir que os vidros deslizem e com flexibilidade para suportar o peso dos painéis e permitir eventuais movimentos causados por dilatações térmicas ou acionamento dos caixilhos. Ao mesmo tempo, proporciona estanqueidade muitas vezes superior àquela obtida com os caixilhos de alumínio. A fachada de vidro estrutural proporciona também melhor isolamento térmico e acústico, eliminando na face externa, o elemento metálico responsável pela transmissão de calor e vibrações.

Da fachada "pele-de-vidro", com caixilhos aparentes, ao structural glazing, que se transformou na pele dos grandes edifícios comerciais da década de 90, a indústria vem mostrando que é possível atender aos mais sofisticados projetos arquitetônicos.

A ocupação por edifícios altos na cidade de São Paulo iniciou-se na década de 50, primeiramente para uso habitacional, mas logo também comercial, mudando 
a paisagem da cidade. Desde o início dos anos 1960 o emprego do vidro em fachadas contínuas veio sendo desenvolvido em prédios no centro de São Paulo:

A torre com núcleo central de serviços, plantas evitando pilares internos, de volume prismático simples e indiferenciado (com 0 mesmo tratamento em todas as fachadas, e de cima a baixo), é o resumo paradigmático dessa arquitetura. (ZEIN, 1985, p.78).

O edifício Wilton Paes de Almeida, projetado por Rogers Zmekhol em 1961 em São Paulo, empregou esse tipo de fechamento usando vidro esverdeado nas três fachadas. Ele foi originalmente destinado à sede da Companhia Comercial de Vidros do Brasil, o que explica sua fachada envidraçada, que emprega a solução curtain-wall. Esta solução trouxe uma novidade estética para a época, já que substituiu o jogo de luz e sombra por um jogo de reflexos (SZABO, 2002).

A partir do final dos anos 1960, iniciou-se a maior transformação nos prédios situados na Avenida Paulista. No princípio, os edifícios empregaram a linguagem do concreto aparente, depois de alguns ensaios de transição, a curtain-wall dominou o mercado. A Avenida Paulista reuniu o maior centro de economia do país, tornandose símbolo de status e da "arquitetura do poder" através das suas fachadas envidraçadas. Segundo Zein (1985), um dos edifícios chegou a mudar sua fachada durante a obra, por iniciativa dos próprios autores do projeto, para assemelhar-se aos demais prédios, passando a ter uma autêntica curtain-wall.

O Centro de Controle Operacional do Metrô, em São Paulo, inaugurado em 1972, recebeu fechamento de pano de vidro de cor ouro, com montantes de alumínio cor bronze. Plínio Croce, Roberto Aflalo e Giancarlo Gasperini optaram por recuar a estrutura da fachada, não aparecendo portanto nenhum pilar nas elevações. A vista a partir da cidade é uma imagem marcante, uma caixa de vidro dourada que flutua sobre o solo. Os lados maiores têm orientação Leste-Oeste e os menores, Norte-Sul, mas todos eles receberam o mesmo tratamento. 
No Brasil, a primeira obra a usar a tecnologia do structural glazing foi a do Citibank em 1986, projeto de Aflalo \& Gasperini (Figura 7). É um edifício de representação e de alto impacto pela sua presença e pelo tratamento arquitetônico de seus volumes. Situado na Avenida Paulista, o edifício define-se por duas empenas verticais em grelha, que não se encontram, criando entre elas uma superfície vertical envidraçada contínua (SEGAWA, 1989).

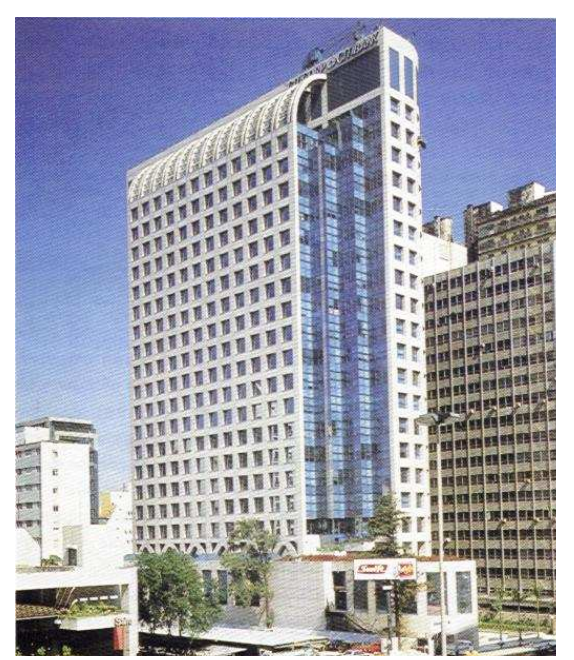

Figura 7. Edifício do Citibank em São Paulo

Fonte: REVISTA Finestra Brasil, 1997, p.110

A tendência que marcou e se produziu em maior escala foi a do emprego do vidro em fachadas contínuas que, desde o início dos anos 1970, esteve presente nos prédios do centro da cidade de São Paulo.

No Rio de Janeiro, o emprego das curtain-wall não foi muito diferente do que aconteceu em São Paulo, entretanto, só começou a ser notado mais fortemente a partir do final da década de 60.

Em 1968, Oscar Niemeyer concebeu o prédio do Hotel Nacional, em São Conrado (Figura 8). Com o objetivo de ser o maior hotel da América Latina, o prédio foi construído numa área de 60 mil metros quadrados e tornou-se referência 
arquitetônica na cidade. Além disso, foi o primeiro grande edifício a ser revestido de vidro laminado.

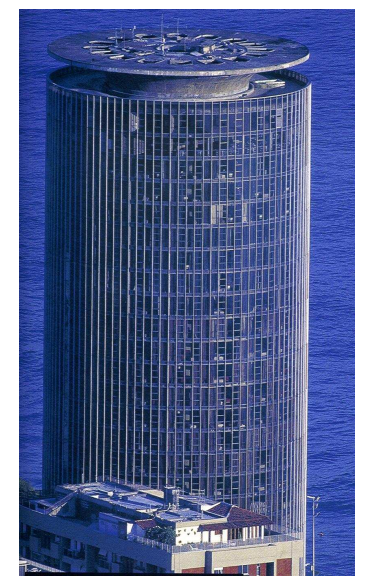

Figura 8. Hotel Nacional

Fonte: Teixeira, 2001

A partir de 1970, começaram a surgir sedes de bancos, grandes empresas, amplos complexos hoteleiros e conjuntos habitacionais para a classe alta, que apresentavam soluções urbanísticas alimentadas por critérios de status e segurança. A cidade começou a expandir-se e a torre de vidro tornou-se solução fácil e de execução segura.

A descrição do projeto do Edifício Sede do BNDES (Banco Nacional do Desenvolvimento Econômico e Social), vencedor do concurso em 1974, cujos autores foram Alfred Willer, Ariel Stelle, Joel Ramalho Jr., José Sanchotene, Leonardo Oba, Oscar Mueller e Rubens Sanchotene, justificou o partido adotado conciliando o programa às restrições estabelecidas pela proximidade de um monumento histórico - o Convento de Santo Antônio. Porém, no que se refere às fachadas, nenhuma justificativa foi dada com relação ao emprego do vidro fumê em todas elas (GAMMARANO, 1992).

Três anos mais tarde, em 1977, surgiu no Rio de Janeiro o primeiro edifício do tipo "pele-de-vidro" do país, que foi o Centro Empresarial Cândido Mendes, projeto 
de Harry Cole. Nesta obra se repete a façanha da torre envidraçada, com o emprego de 100 toneladas de alumínio enquanto que o vidro permaneceu encaixilhado (GENCIAUSKAS, 1997).

\subsubsection{Uso dos vidros refletivos na arquitetura contemporânea}

A partir da década de 50, com o final da Segunda Guerra Mundial, começaram a ser utilizadas intensamente as fachadas envidraçadas na arquitetura, ocorrendo assim a difusão do conceito de "pele-de-vidro". Este uso intensivo do vidro nas fachadas foi possível graças ao desenvolvimento da indústria do vidro e de outras tecnologias. Dessa forma, as cidades começaram a se caracterizar pelos grandes panos de vidro, que passaram a ser utilizados sem levar em consideração o local onde estavam sendo inseridos. Segundo Vianna e Gonçalves (2001), foi criada a idéia do espaço aberto sem limites através do uso dos panos de vidro, alcançando assim a transparência total.

Se no caso dos países onde surge esta proposta de arquitetura, esta linguagem e partido arquitetônicos fazem sentido - países de clima temperado / frio com grande necessidade de captação de luz e calor externos - em outros países de clima essencialmente quente, esses mesmos princípios acarretam uma arquitetura crítica do ponto de vista ambiental - com excesso de luz e principalmente grande desconforto pelo térmico. (VIANNA e GONÇALVES, 2001, p.45).

Antes da crise e do embargo do petróleo em 1974, a energia era barata e disponível em grande quantidade, e por isso não havia muitos incentivos para o seu uso racional. Com a crise energética, os edifícios de vidro eclodiram como um grande problema no que se refere à questão do uso racional da energia. A indústria vidreira, com o objetivo de minimizar os problemas de superaquecimento dos edifícios, lançou no mercado, dentre outras propostas, os vidros refletivos. Desta 
forma, muitos edifícios projetados a partir da década de 70, ao mesmo tempo em que apresentavam grandes superfícies envidraçadas, eles também começaram a fazer uso do vidro com proteção solar. Esses edifícios procuraram resolver as questões de excesso de luminosidade e calor através do uso de vidros refletivos.

O enorme desenvolvimento técnico-científico e industrial possibilitou ao homem moderno a criação de 'invólucros' isolantes com o microclima artificial. $\mathrm{O}$ 'condicionamento' do ambiente em termos de conforto humano pôde ser realizado. As ciências analisaram os fatores do problema, as técnicas concretizaram a solução. Como, neste caso, os agentes físicos são controlados pelo homem e todo processo envolve custo (instalação e manutenção-energia) impôs-se, logicamente, a necessidade do conhecimento sempre mais apurado das leis dos fenômenos e das soluções tecnológicas. (MANGE, 1956, p.27).

Devido à grande flexibilidade e liberdade de formas, a "pele-de-vidro" tem sido muito utilizada nos edifícios contemporâneos. Porém, muitas vezes, apenas o aspecto estético vem sendo buscado quando se adota este tipo de vedação, sendo que outras questões de muita importância, como a iluminação natural, aparecem como preocupação secundária dos projetistas. É importante que a arquitetura contemporânea incorpore as novas tecnologias, articulando-as com os dispositivos e mecanismos, para conseguir construir edifícios energeticamente mais econômicos.

Um fato importante a ser lembrado é que para um bom desempenho energético de um edifício, não basta apenas utilizar novas tecnologias, é necessário também um bom projeto arquitetônico, que considere a orientação do edifício e o local onde está sendo inserido.

O texto a seguir é destinado a análise das aplicações dos vidros refletivos em fachadas de edifícios paulistas contemporâneos, destacando as soluções apresentadas pelos arquitetos. Estes projetos foram escolhidos por serem marcos da arquitetura "pele-de-vidro" com a utilização dos vidros refletivos, considerados de alta performance. 


\section{Edifício Birmann 21 (1997)}

Este edifício em São Paulo foi projetado por SOM (Skidmore, Owings \& Merril) e Kogan, Villar e Associados. Durante a idealização do conjunto Birmann 21, houve a presença de consultores de esquadrias desde o início do projeto.

O Birmann 21 localiza-se na zona sul de São Paulo, às margens do Rio Pinheiros, e é composto por três edifícios: a torre, com 26 pavimentos de escritórios; o edifício para uso múltiplo, que abriga um grande salão e salas de conferência; e o edifício garagem com seis pavimentos.

O edifício foi projetado para sugerir diferentes percepções e atender a aspectos funcionais. O objetivo foi dar um tratamento compositivo peculiar a cada fachada, mas sempre com a preocupação de dar uma unidade na configuração volumétrica do edifício. As fachadas Norte, Leste e Oeste tiveram menos aberturas, enquanto que a face Sul, sujeita a menor insolação, recebeu maiores panos de vidro, como mostra a Figura 9.

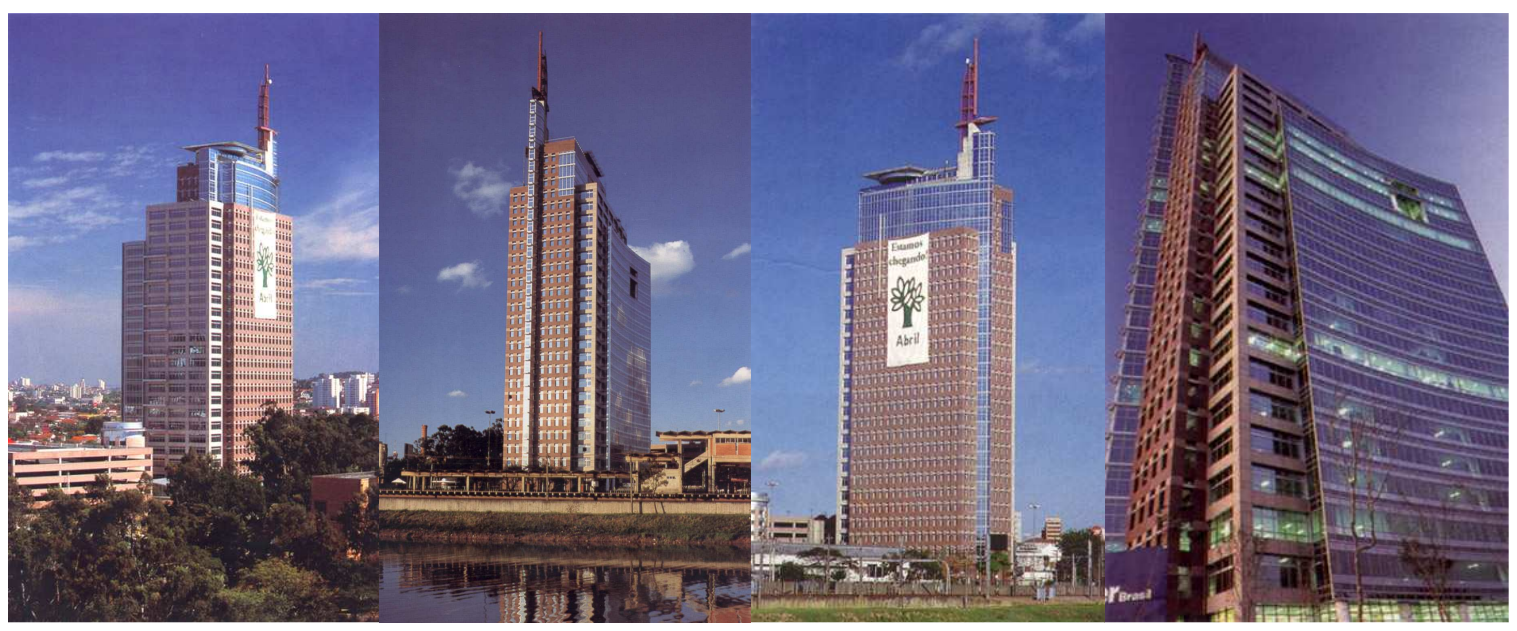

Figura 9. Fachadas Leste, Oeste, Norte e Sul Fonte: REVISTA Finestra Brasil, 1997

Além disso, atentou-se para a escolha de vidros adequados a cada situação. Foram especificados três tipos de vidros laminados refletivos prata de $10 \mathrm{~mm}$, com 
diferentes propriedades de controle solar. Os vidros com maior reflexão luminosa foram usados nas faces Norte, Leste e Oeste, enquanto que os vidros de maior transmissão luminosa foram adotados na fachada Sul (DOURADO, 1997). Os vidros especificados na face Norte foram associados a brises horizontais de alumínio, além de um pequeno recuo na caixilharia para permitir o sombreamento.

De acordo com Szabo (2002), ao mesmo tempo em que este edifício procurou aliar-se aos padrões internacionais de "pele-de-vidro", ele buscou uma certa contextualização no momento em que recebeu tratamento diferenciado para as quatro fachadas.

\section{Edifício Berrini 500 (2000)}

O Edifício Berrini 500 foi projetado por Ruy Ohtake Arquitetura e Urbanismo e localiza-se na Avenida Engenheiro Luís Carlos Berrini em São Paulo.

Uma lâmina vermelha de alumínio composto de $70 \mathrm{~m}$ de altura corta todo o edifício. O jogo volumétrico da fachada pode ser considerado a característica principal deste prédio. Foram utilizadas lajes protendidas pré-moldadas com ondulações nas bordas para conferir movimento à edificação. Este efeito foi conseguido através dos avanços e recuos dos andares (Figura 10).

Procurei fazer com que o edifício estabelecesse uma dinâmica no espaço urbano. Isso foi possível com a criação do grande pilar vermelho na fachada unindo os degraus formados pelos andares [...]. O movimento dessas ondas que vão e voltam cria uma dinâmica interessante na fachada e provoca um jogo de luz e sombra muito instigante, tanto durante o dia quanto durante a noite. (OHTAKE, 2000, p.88). 


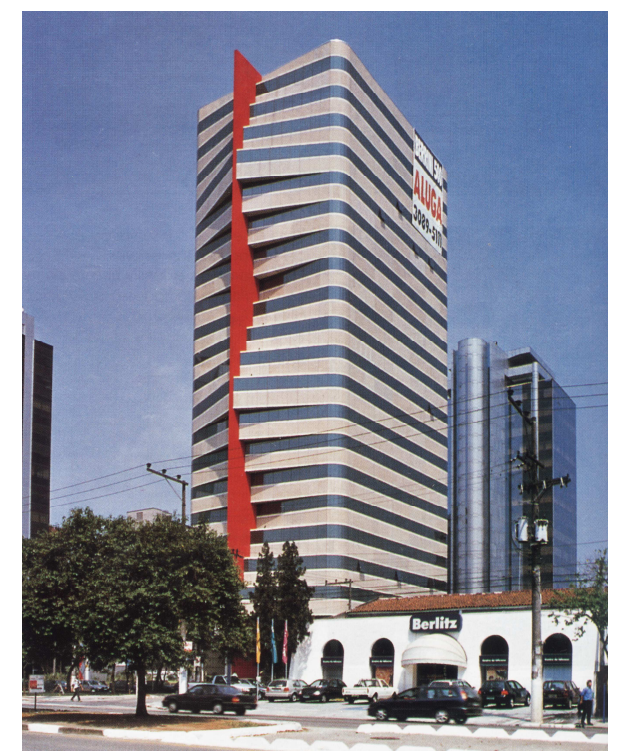

Figura 10. Faixas horizontais das fachadas Fonte: REVISTA Finestra Brasil, 2000, p.88

As faixas horizontais da fachada constituem painéis pré-moldados revestidos de granito, placas de vidro laminado refletivo verde de $10 \mathrm{~mm}$ de espessura, em placas de 1,25 x 1,59m. Segundo o fabricante Santa Marina, este é um vidro refletivo de alto desempenho, com coeficiente de sombreamento de 0,33 e atenuação acústica de 35 decibéis.

\section{Edifício Attilio Tinelli (2000)}

O edifício localiza-se no Bairro do Brooklin em São Paulo e foi projetado por Carlos Bratke. Está implantado em uma esquina e caracteriza-se por ser um prisma envidraçado marcado por formas geométricas puras e simples, como mostra a Figura 11. Porém, a fachada apresenta grande dinamismo, já que um dos planos que compõem a fachada, encontra-se rotacionado. "Procurei algo mais clean, mais limpo com a arquitetura. É como falar a mesma coisa com menos palavras, ser mais objetivo" (BRATKE, 2000, p.73). 


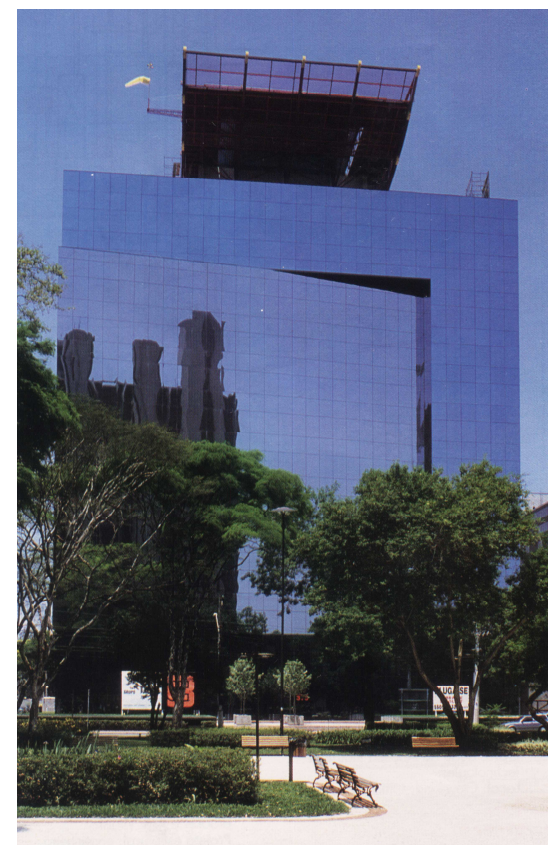

Figura 11. Prisma envidraçado

Fonte: REVISTA Finestra Brasil, 2000, p.72

Foi utilizado nas fachadas o vidro laminado refletivo de $8 \mathrm{~mm}$ de espessura, em dois tons de prata, sendo responsável por uma composição bastante suave através da reflexão do azul do céu. Neste edifício foi usado o structural glazing como sistema de fixação e a caixilharia é de alumínio anodizado preto.

\section{Edifício Torre 2000 (2002)}

O edifício projetado por Jonas Birger localiza-se no Bairro de Pinheiros em São Paulo e caracteriza-se por ser um grande bloco de vidro sobreposto a uma grelha vertical de granito (Figura 12). O edifício possui 25 andares e o prisma de vidro apóia-se em pilares circulares revestidos de alumínio composto. 


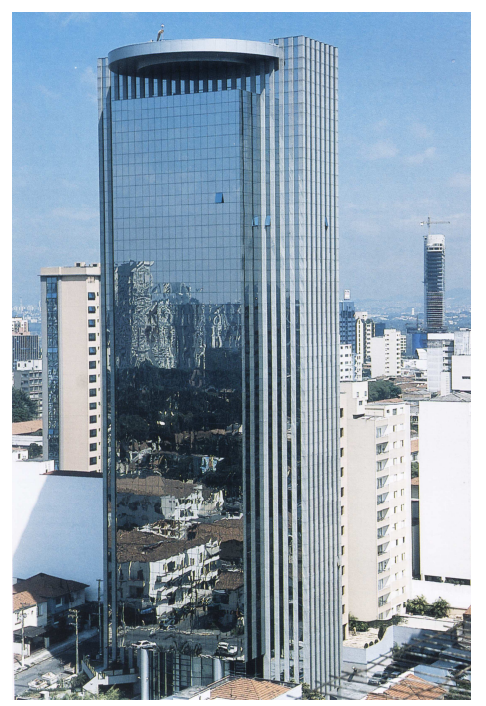

Figura 12. Vidros refletivos na fachada frontal do edifício Fonte: REVISTA Finestra Brasil, 2003, p.62

Foi utilizado o sistema stick na execução da fachada, e consiste na montagem de colunas e travessas que formam um malha estrutural, recebendo os quadros de vidro fixos e móveis.

$\mathrm{Na}$ execução da fachada frontal foi usado o silicone glazing. Nesta fachada que está voltada para o Sul, foram utilizados vidros refletivos prata de $8 \mathrm{~mm}$ de espessura, com bom desempenho térmico (GELINSKI, 2003).

Como já foi dito, a evolução das fachadas foi acompanhada pela evolução tecnológica dos vidros. A seguir são abordados os processos de fabricação e os tipos de vidros empregados na arquitetura.

\subsection{0 material vidro}

\subsubsection{Definição e constituição}

Segundo Van Vlack (1984), o vidro é uma solução resultante da solidificação progressiva, sem traços de cristalização, de misturas homogêneas em fusão. Pode- 
se dizer que o vidro é uma substância inorgânica, homogênea e amorfa, sendo obtida pelo resfriamento de uma massa em fusão. As principais características do vidro são: transparência, dureza, durabilidade, reciclabilidade, baixo índice de dilatação e condutividade térmica.

Apesar do vidro utilizado na construção civil possuir vários componentes, para sua fabricação é preciso fundir três elementos básicos:

- um vitrificante, a sílica, em forma de areia;

- um fundente, soda ou potassa, na forma de sulfato ou carbonato;

- um estabilizante, a cal, na forma de carbonatos.

A composição química do vidro float, considerado o mais moderno, compreende basicamente os seguintes elementos:

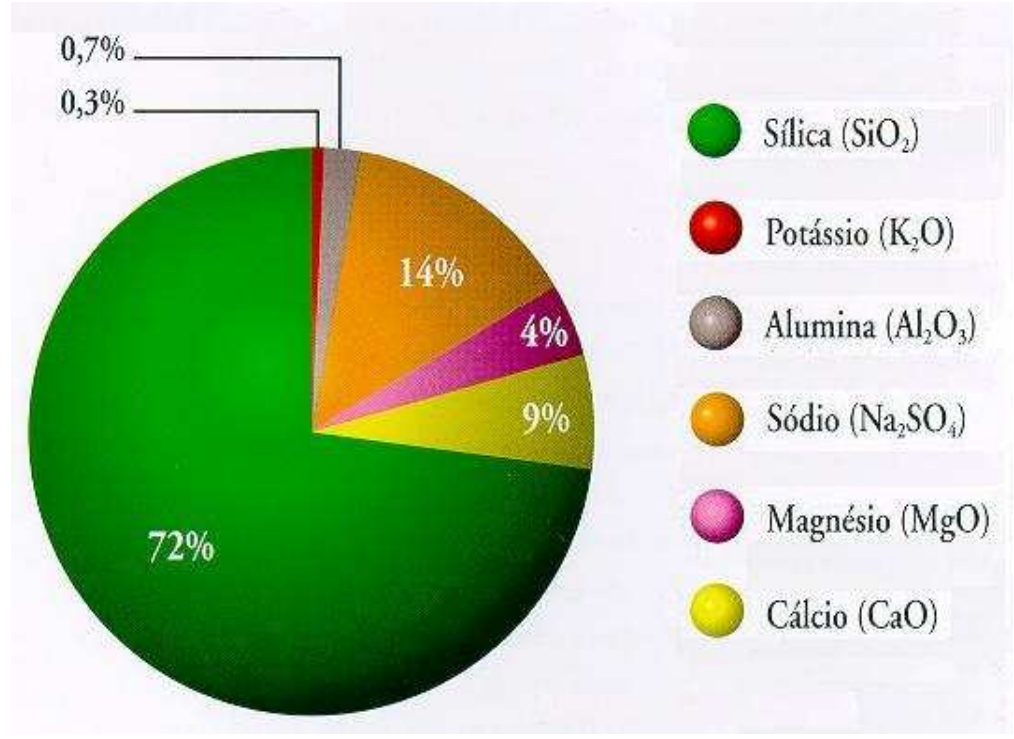

Figura 13. Composição do vidro float Fonte: CEBRACE CRISTAL PLANO, 2006

A sílica (SiO2) é a matéria-prima básica, cuja função é de vitrificante. Já a soda (Na2SO4) é introduzida para baixar o ponto de fusão da sílica. O cálcio (CaO) 
é introduzido através do calcáreo e da dolomita e tem a função de dar estabilidade ao vidro contra ataques de agentes atmosféricos.

\subsubsection{Processos de fabricação}

Os processos de fabricação evoluíram muito ao longo do tempo. Os romanos desenvolveram o processo de fabricação por sopro dentro de moldes (SANTA MARINA, 1993). Entre os anos 500 e 600 d.C. foi descoberto um novo processo de fabricação do vidro por sopro, através de uma esfera e sua ampliação por rotação, como mostra a Figura 14. Todos estes dois processos produziam vidros finos, fracos e irregulares, não sendo adequados, portanto, em aplicações que exigiam uma superfície homogênea e resistente.

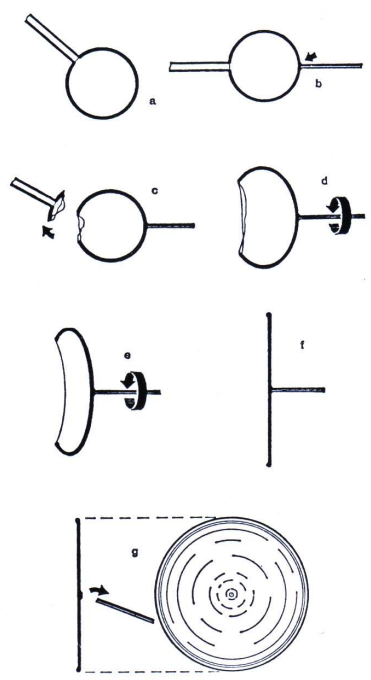

Figura 14. Vidro moldado por sopro de esfera e rotação Fonte: SANTA MARINA, 1993

Por volta do ano de 1000 d.C., foi desenvolvido na Europa Setentrional o processo de fabricação do vidro usando cilindros soprados (Figura 15). A técnica envolvia a sopragem de um grande cilindro que era cortado aberto e então 
achatado. Por ação simultânea do sopro e da força centrípeta, obtida movimentando o cano, formava-se um cilindro côncavo.

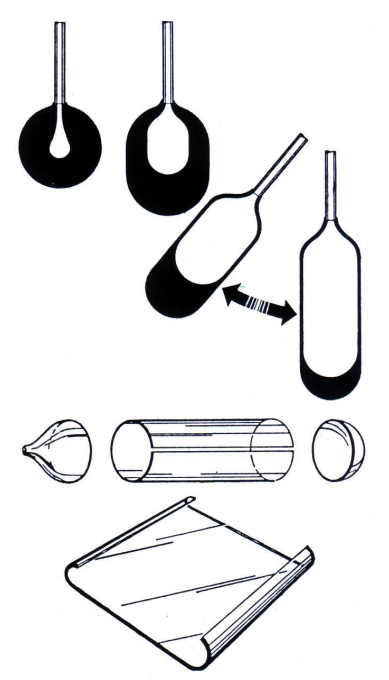

Figura 15. Sopro de cilindro Fonte: SANTA MARINA, 1993

Em 1700, a Saint-Gobain inicia o processo de fabricação de grandes placas de vidro escoadas sobre mesas, estendidas com um grande "rolo", surgindo assim o cristal escoado, como mostra a Figura 16.

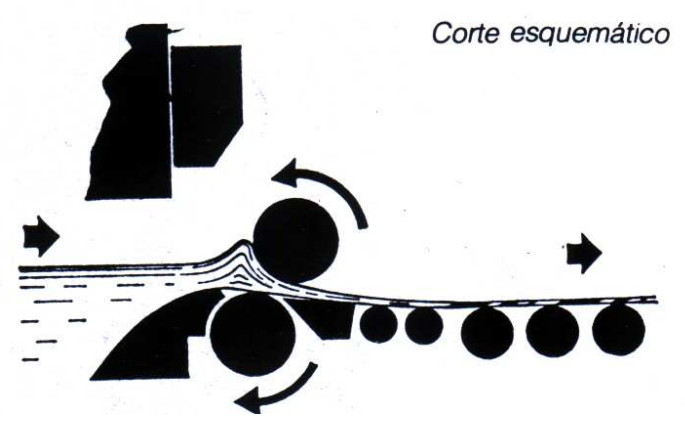

Figura 16. Processo Saint-Gobain Fonte: SANTA MARINA, 1993

O processo de fabricação do vidro estirado surgido na Bélgica e nos EUA no início do século XIX possibilitou a produção de chapas finas e de boa qualidade. 
Em 1904, Fourcault inventou um processo de estiramento vertical, no qual uma fenda moldada em barro refratário é abaixada até penetrar no vidro derretido que sobe dentro dela. $\mathrm{O}$ vidro então é fisgado por uma longa isca à qual adere, e então é estirado verticalmente através de roletes, resfriado e temperado (Figura 17). Porém este processo possui alguns problemas, como por exemplo, a degradação da superfície da fenda causada pela cristalização do vidro.
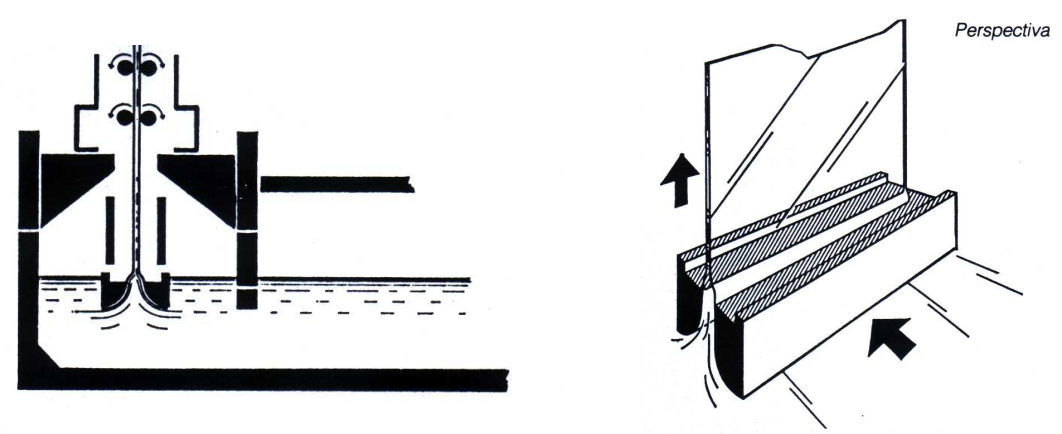

Figura 17. Processo Fourcault de fabricação

Fonte: SANTA MARINA, 1993

Já no processo de fabricação Colburn ou Libbey Owens, patenteado nos EUA em 1905, este problema não ocorre. Neste método, o vidro fundido é estirado por meio de uma isca de ferro através de roletes serrilhados e então é reaquecido e amolecido para ser arqueado sobre um rolete até ficar em posição horizontal (Figura 18).
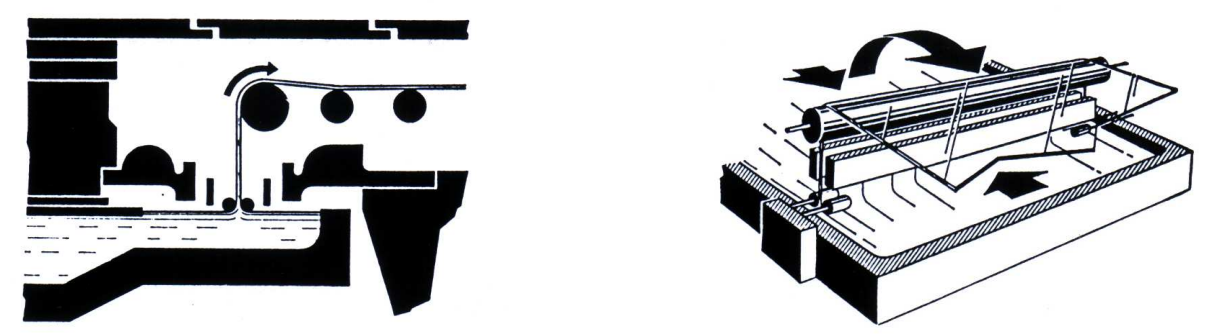

Figura 18. Processo Libbey Owens Fonte: SANTA MARINA, 1993

O processo de estiramento foi o principal método de fabricação de vidro barato para janelas e até hoje é utilizado. Mas ele também apresenta alguns defeitos 
na produção, por exemplo, a ação da gravidade sobre o líquido que está resfriando cria variações na espessura do vidro.

O processo de fabricação do vidro plano permaneceu o mesmo até o começo dos anos 1920. Neste período, surgiu o processo Bicheroux, no qual derramava o vidro entre dois cilindros, permitindo que a espessura original do vidro ficasse mais próxima do que realmente queria, além da menor perda do material. Um dos problemas deste método era a falta de continuidade na produção do vidro.

Este problema terminou quando a Ford Motor Company desenvolveu seu processo de fabricação na década de 20 para suprir a necessidade de vidros para a indústria automobilística. Neste processo, o vidro fundido era alimentado continuamente entre os cilindros sendo em seguida polido. O processo de produção contínua e dinâmica foi completada em 1938 pela fábrica Pilkington (SANTA MARINA, 1993).

Até a década de 50, todo vidro plano de janela era fabricado desta maneira. Porém, para atingir boa qualidade das superfícies, o vidro precisava ser espesso e por isso encarecia. Em 1952 foi inventado o processo float de fabricação pela Pilkington, no qual o vidro derretido fica flutuando sobre estanho também derretido, como mostra a Figura 19. A Pilkington conseguiu produzir vidro plano com espessura econômica e em grandes quantidades, através de um processo contínuo.

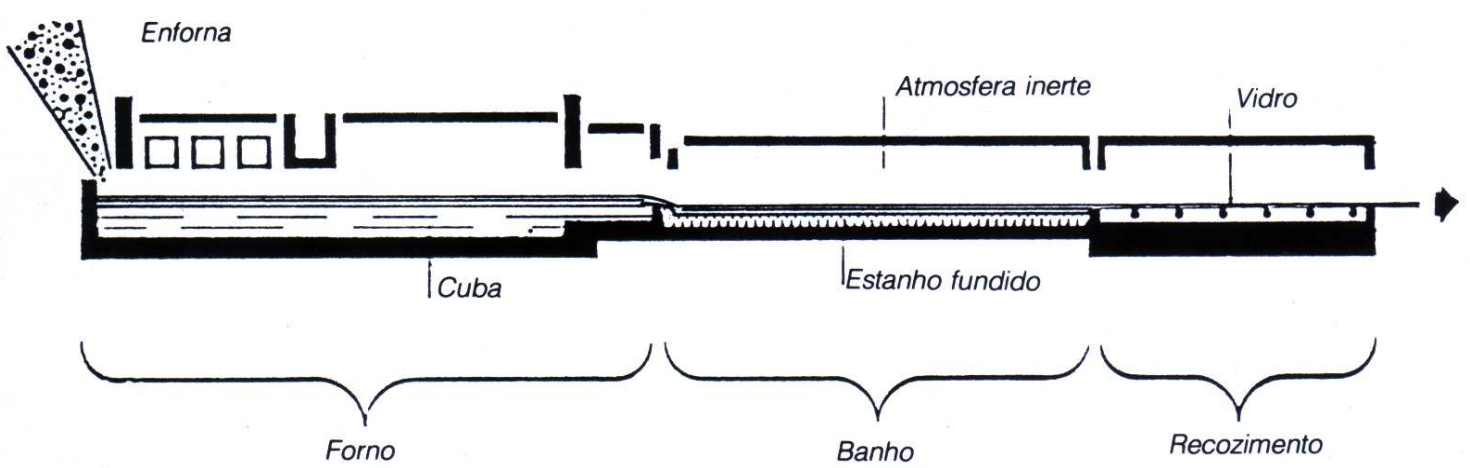

Figura 19. Processo float

Fonte: SANTA MARINA, 1993 


\section{Processo de fabricação do vidro float incolor}

De acordo com Cledwyn-Davies (1993), o vidro float é obtido através do escoamento da mistura vitrificável derretida sobre uma mesa de estanho líquido, em atmosfera controlada. $O$ processo de flutuação opera sobre o princípio de que o vidro a $110^{\circ} \mathrm{C}$ ajuda a manter o estanho fundido no qual flutua. $\mathrm{O}$ estanho tem seu ponto de fusão a $232^{\circ} \mathrm{C}$, um dos mais baixos de todos os metais, e um ponto de fervura a $2720^{\circ}$. O vidro fundido, tendo peso espec ífico mais baixo, acaba flutuando sobre o estanho.

De forma simples, a produção de vidro resume-se na reunião de matériasprimas básicas com pequenas quantidades de aditivos. O vidro plano é fabricado em um ou dois estágios: o da indústria primária e o da secundária. Na indústria primária é fabricado o produto básico plano ou produto principal. Já na indústria secundária, o produto primário é apurado e adicionado a outro.

O processo de fabricação do vidro float consiste nas seguintes fases:

1) Preparação

Nesta etapa os materiais são preparados (moagem, peneiramento), armazenados e pesados nas corretas quantidades.

2) Mistura

A mistura dos materiais é feita manualmente ou mecanicamente para depois ser lançada aos fornos.

3) Fusão 
Nesta etapa os constituintes são aquecidos até uma temperatura entre $1600{ }^{\circ} \mathrm{C}$ e $1800^{\circ} \mathrm{C}$, na qual eles tornam-se fluidos e h omogêneos. O tanque de fusão assenta-se sobre uma câmara de ventilação construída em alvenaria ventilada. Esta câmara é fonte de ar utilizada para fornecer oxigênio para a fornalha sobre a qual assenta-se o tanque.

4) Banho de estanho

A massa vítrea é derramada sobre uma mesa de estanho fundido no qual, por diferença de densidade, flutua. $\mathrm{Na}$ moldagem o vidro gradualmente esfria e endurece, passando do estado líquido para uma consistência semelhante à do melado, quando sua temperatura abaixa de $1600{ }^{\circ} \mathrm{C}$ para $800{ }^{\circ} \mathrm{C}$. A espessura "natural" do vidro no estanho (dada à tensão superficial) está entre $6 \mathrm{~mm}$ e $7 \mathrm{~mm}$. Para obter vidro mais fino é necessário aumentar a velocidade dos roletes estirandose o fluxo, enquanto que vidro mais espesso é produzido com anteparos.

5) Resfriamento (Têmpera)

O vidro resfria-se por igual sob condições controladas de $600{ }^{\circ} \mathrm{C}$ a $100^{\circ} \mathrm{C}$, sendo preparado para o corte. O lehr de resfriamento consiste em uma câmara fechada dentro da qual o vidro passa sobre roletes e a temperatura de qualquer largura do vidro é controlada.

6) Inspeção Automática

Antes de ser cortada, a lâmina de vidro passa pela inspeção do scanner com feixe laser, que identifica falhas, fazendo o refugo quando necessário. 
7) Recorte, Empilhamento e Armazenagem

As chapas são cortadas em dimensões pré-determinadas, empilhadas em pacotes para a expedição e armazenadas.

\section{Processo de fabricação do vidro float colorido}

A fabricação dos vidros coloridos é idêntica à produção do vidro incolor, sendo que a tonalidade é resultante da introdução de compostos metálicos à massa em estado coloidal, que é feita por modificação em série. As cores típicas verde, cinza e bronze são obtidas dessa forma. São incorporados aos vidros o selênio (Se), o óxido de ferro (Fe2O3), o óxido de cobalto (Co3O4), que gera o vidro azulado e o óxido de cobre ( $\mathrm{CuO}$ ), que define a cor rosa violeta. As espessuras disponíveis desses vidros são as mesmas do vidro incolor.

\subsubsection{Tipos de vidro empregados na construção civil}

No Brasil, o mercado consumidor de vidros está concentrado da seguinte maneira: $60 \%$ na construção civil, $29 \%$ na indústria automobilística e $1 \%$ na indústria do mobiliário.

\subsubsection{Produtos vítreos de base}

$\mathrm{Na}$ construção civil são utilizados os produtos vítreos de base e os vidros de segurança. Os produtos vítreos de base compreendem vidros que são aplicados da forma como são fabricados, sem a necessidade de uma elaboração posterior. Os 
produtos vítreos de base compreendem o vidro float, o vidro impresso ou "fantasia", o vidro U-glass, o vidro refletivo e o vidro insulado.

\subsection{Vidro float}

O vidro float caracteriza-se por possuir faces planas e paralelas com ótimo acabamento, não apresentando irregularidades em suas superfícies. Oferece um alto índice de transparência, não recebendo nenhum tratamento especial. É também chamado de vidro comum ou vidro liso.

Os vidros coloridos (Figura 20) são obtidos através da incorporação de aditivos minerais e as cores são o verde, o bronze, o cinza e o azul. Os vidros coloridos auxiliam na redução da transmitância solar.

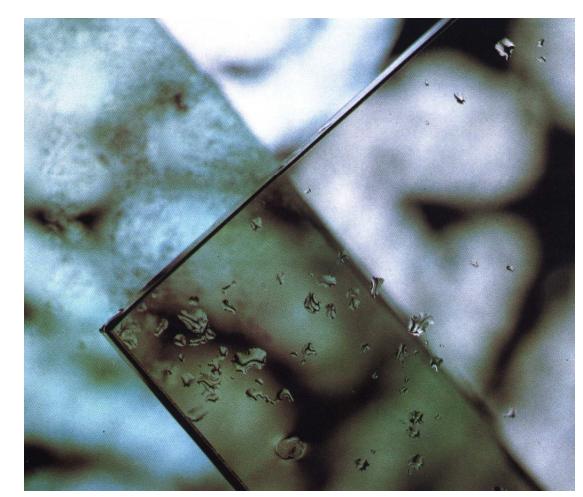

Figura 20. Vidro float colorido Fonte: SANTA MARINA, 1993

Os vidros float são mais indicados para pequenas janelas em locais pouco sujeitos a acidentes, já que são bastante frágeis e fragmentam-se em pedaços cortantes. As espessuras variam entre 2 e $19 \mathrm{~mm}$. A partir do vidro float são produzidos os temperados, laminados e refletivos. 
$\mathrm{Na}$ maioria das aplicações, os vidros float precisam receber tratamento de bordas para evitarem ferimentos e ganharem maior resistência, para que trincas sejam evitadas. Um destes tratamentos é a lapidação dos vidros.

Os vidros float também podem ser curvados em diversas inclinações ou moldados em várias formas. Para sua produção, a placa de vidro é colocada sobre um molde já preparado e instalado em fornos especiais. Em seguida o vidro é aquecido a uma elevada temperatura, para que tome a forma do molde, e depois é resfriado.

\subsection{Vidro impresso ou "fantasia"}

O vidro impresso ou "fantasia" recebe este nome por possuir em uma ou duas de suas faces desenhos ou motivos ornamentais. Estes desenhos variam, podendo ser boreal, mini-boreal, pontilhado, canelado, mosaico, tijolinho, martelado e ártico. As espessuras variam entre 4 e $10 \mathrm{~mm}$. Os vidros impressos coloridos também são obtidos através da adição de óxidos metálicos dissolvidos na mistura.

Uma característica desse vidro é que os desenhos em suas faces difundem a luz e os raios solares, como mostra a Figura 21. Por serem translúcidos, os vidros impressos são utilizados como barreira visual (SANTA MARINA, 1993).

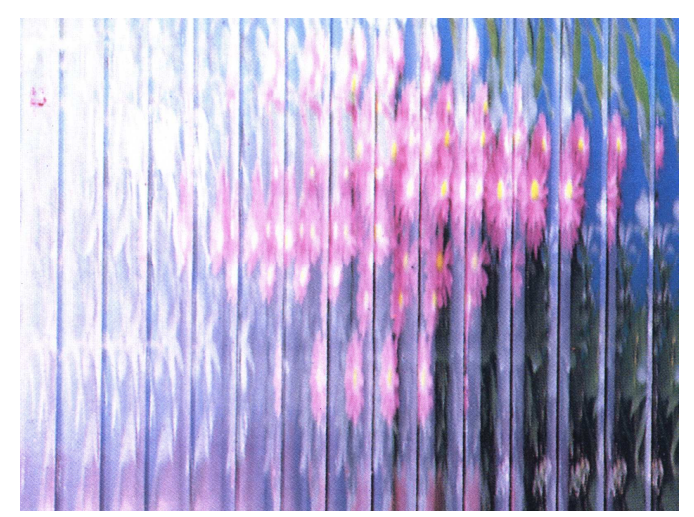

Figura 21. Vidro impresso do tipo canelado Fonte: SANTA MARINA, 1993 


\subsection{Vidro "U-glass"}

O vidro "U-glass" (Figura 22) é um vidro perfilado autoportante em forma de "U”, sendo empregado em grandes vãos. É considerado um vidro estrutural devido à sua alta resistência. A seção resistente de suas barras é sua principal característica. Segundo o fabricante (SANTA MARINA, 1993), a rigidez deste vidro faz com que seja possível o assentamento na vertical em paredes simples ou duplas, interna ou externamente.

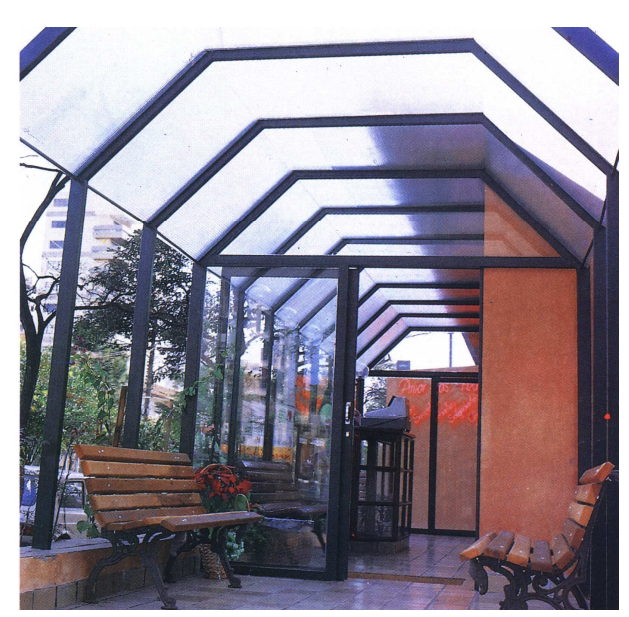

Figura 22. Cobertura usando vidro "U-glass" Fonte: SANTA MARINA, 1993

\subsection{Vidro refletivo}

Os vidros refletivos foram desenvolvidos para proporcionarem maior conforto e economia ao usuário através do controle da entrada de calor no ambiente. São denominados também de vidros termo-refletivos ou termo-refletores.

Os vidros refletivos são produzidos através do vidro float incolor ou colorido e são caracterizados pela deposição de uma camada metálica em uma de suas faces. A camada óxida acentua o grau de reflexão em uma das faces do vidro, fazendo com que a visão do lado mais iluminado em direção ao menos iluminado seja 
diretamente proporcional à quantidade de luz incidente. Desse modo, durante o dia, a visão da parte interna para a externa é maior, e da parte externa para a interna é menor, ocorrendo o chamado "efeito espelho", como mostra a Figura 23.

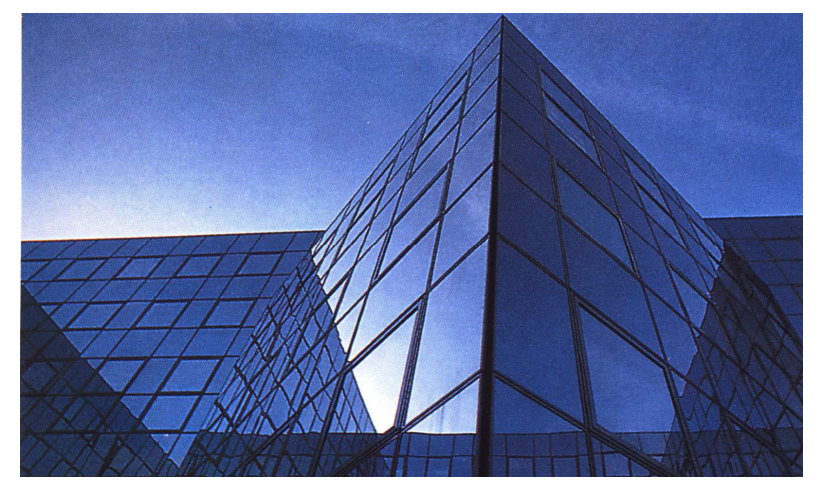

Figura 23. Vidro refletivo aplicado em fachada Fonte: SANTA MARINA, 1993

O vidro refletivo pode ser lapidado, temperado, incorporado ao laminado, ou ser usado em sistemas de envidraçamentos isolantes através de vidros duplos ou triplos. É recomendável que os vidros refletivos sejam usados na forma laminada, com a face metalizada voltada para dentro dos vidros. Desta forma, a camada metalizada fica protegida na união dos vidros em contato com a película plástica da laminação.

Atualmente existem dois processos de fabricação dos vidros refletivos, sendo um por pirólise e outro por metalização a vácuo por sputtering. Segundo Caram de Assis (1998), até 1996 havia no Brasil somente os vidros refletivos pirolíticos. A partir desse ano, entraram no país os vidros de alta performance, ou metalizados a vácuo, considerados de última geração. Os dois processos de fabricação são:

\section{- Processo pirolítico}


O processo pirolítico consiste na deposição de óxidos metálicos diretamente sobre o vidro em alta temperatura durante a linha de produção. A deposição da camada refletiva durante a fabricação do vidro float garante durabilidade e homogeneidade da camada refletida. Este tratamento é interessante para fabricação de um tipo de vidro durante longo período, já que ocorrem grandes perdas com a mudança da linha de produção.

Os vidros refletivos pirolíticos possuem grande estabilidade da camada óxida e resistência ao desgaste, podendo esta ser usada voltada para o exterior. Neste método, o desempenho do vidro como filtro solar é menor.

Devido à resistência à abrasão, o vidro refletivo pirolítico pode ser temperado, curvado, laminado ou utilizado na forma monolítica.

Os vidros refletivos pirolíticos foram desenvolvidos no hemisfério norte com o intuito de melhorar o conforto nos locais com clima predominantemente frio. Com a fabricação destes vidros buscava-se alta transmissão de luz visível, resistência química e mecânica da camada refletiva, reflexão do infravermelho longo (próximo de $85 \%$ ) para evitar perdas de calor interno, e transmissão do infravermelho próximo para permitir o aquecimento no inverno (ARNAUD, 1997).

O desenvolvimento destes vidros em países de clima frio justifica-se pelo fato da camada refletiva colocada para o interior diminuir as perdas através da radiação no infravermelho longo. Por outro lado, vidros com boa transmissão no infravermelho próximo não estão de acordo com climas quentes, mostrando que vidros desenvolvidos para um determinado tipo de clima nem sempre são apropriados para os demais climas (SANTOS, 2002).

O vidro refletctafloat é produzido pelo processo pirolítico e apresenta boa resistência à abrasão e grande versatilidade na sua aplicação. 


\section{- Processo por metalização a vácuo}

Já no processo por metalização a vácuo, a produção do vidro consiste na pulverização catódica de íons metálicos sobre a superfície em uma câmara de vácuo, em temperatura ambiente através do processo denominado Sputtering Coating. Estes vidros proporcionam melhor controle solar, porém com camada refletiva menos resistente ao desgaste.

Segundo Cledwin-Davies (1993), as chapas de vidro movem-se sobre cilindros em uma câmara a vácuo, parcialmente ocupada com um gás (argônio, oxigênio ou nitrogênio), depois são posicionadas sob uma placa e recebem uma deposição de átomos de metal. Elétrons de alta energia são produzidos entre a placa e o vidro através de uma alta voltagem. Assim, são formados íons de carga positiva no gás que colidem com a placa do metal, lançando átomos do mesmo, que são projetados e condensados na superfície do vidro formando a camada metálica. A Figura 24 a seguir mostra os dois tipos de fabricação dos vidros refletivos.

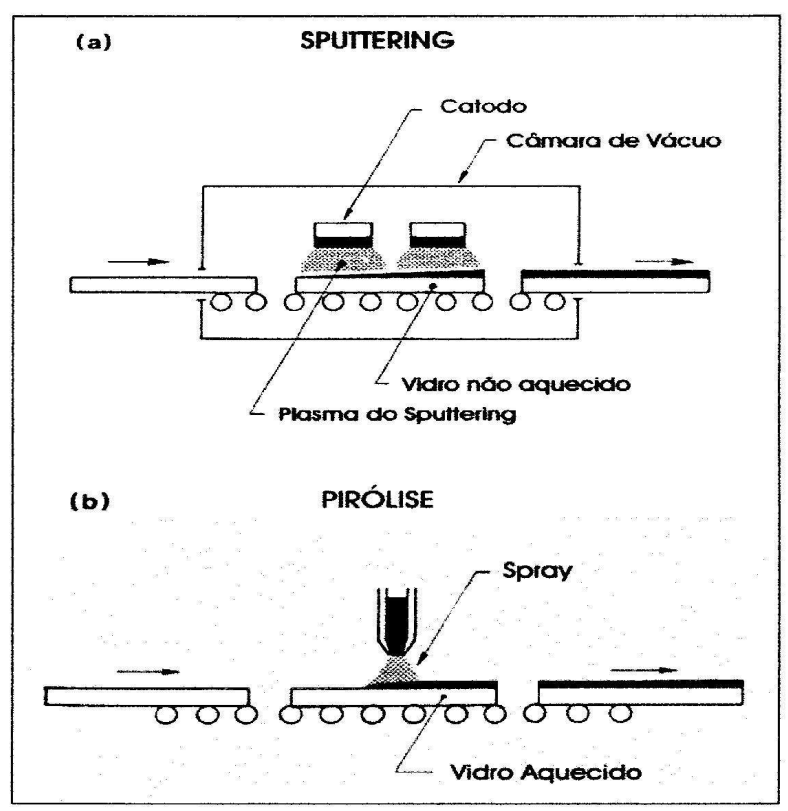

Figura 24. Processos de fabricação do vidro refletivo Fonte: Granqvist, 1991 
Segundo Arnaud (1997), os vidros refletivos metalizados a vácuo possuem alta reflexão do infravermelho longo, ótima transmissão da luz visível e baixa transmissão de infravermelho próximo. Esta última representa uma excelente qualidade para o clima brasileiro.

Pelo fato da deposição dos óxidos metálicos ser feita fora da linha de produção, estes vidros são mais flexíveis que os pirolíticos, sendo possível a utilização para períodos curtos de produção de pequenas quantidades de vidro.

Com os vidros refletivos metalizados a vácuo são obtidos diferentes níveis de transparência e diferentes cores em reflexão. As cores existentes são prata, verde, bronze, cinza, azul e dourado.

Os vidros refletivos pirolíticos e metalizados a vácuo apresentam melhor desempenho térmico em relação aos vidros comuns, pois possuem uma menor porcentagem de transmissão do calor, como mostra a Figura 25.

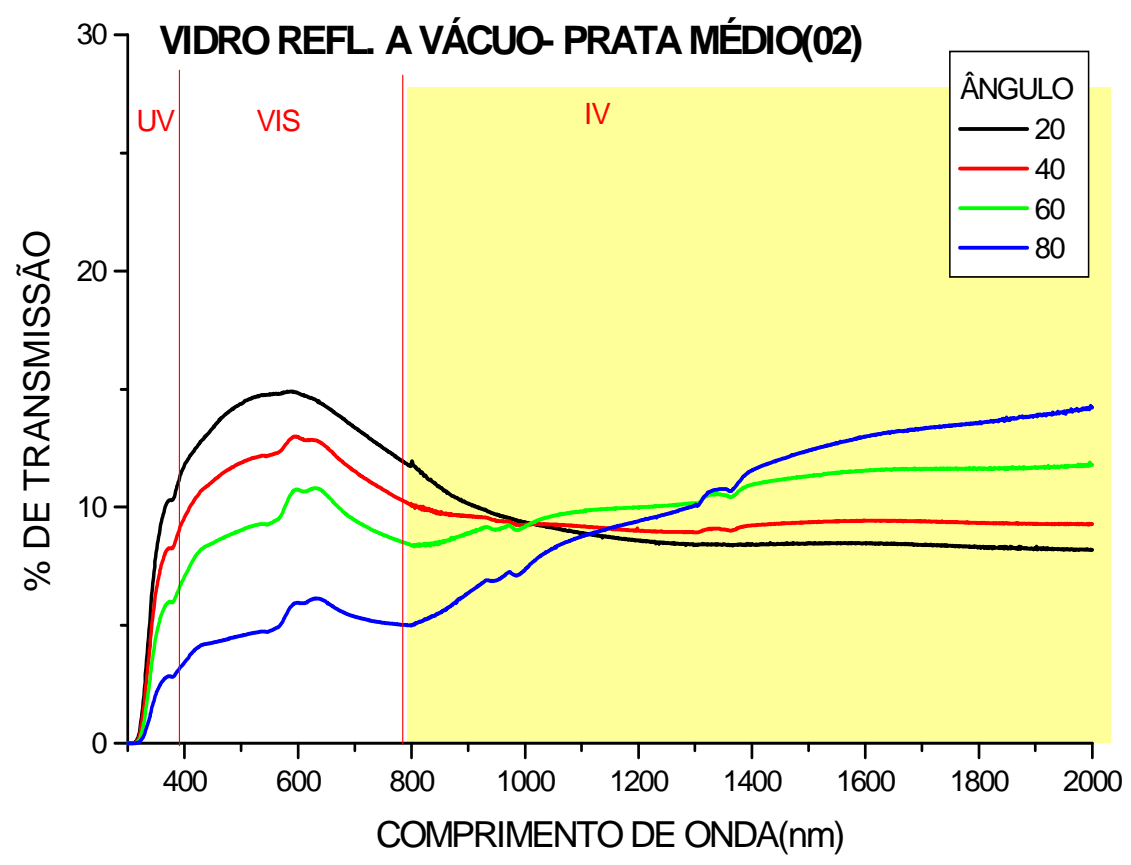

Figura 25. Transmissão do infravermelho para o vidro refletivo metalizado a vácuo prata médio

Fonte: Modificada de Santos, 2002 
Através do gráfico acima, pode-se observar que a taxa de transmissão do infravermelho próximo, radiação que constitui fonte de calor, varia entre 5 e $15 \%$ para os diferentes ângulos de incidência. Uma transmissão baixa comparada à do vidro comum incolor, cuja taxa varia de $20 \%$ a $80 \%$.

Dados obtidos em espectrofotômetro (CARAM DE ASSIS, 2002) mostraram que alguns tipos de vidros refletivos são, na verdade, muito absorventes, podendo provocar uma sobrecarga térmica no interior dos edifícios. Além disso, o vidro permite a penetração da radiação no interior do edifício e sua absorção pelas superfícies internas, elevando suas temperaturas. Porém, estas superfícies aquecidas emitem radiação em torno de $10.000 \mathrm{~nm}$, e mesmo o vidro refletivo é opaco a radiações com esses comprimentos de ondas. Dessa forma, a radiação emitida fica presa ou armazenada no interior da edificação.

Além do controle de calor, os vidros refletivos também controlam a entrada de luz nos ambientes. De modo geral, é importante existir incidência de luz natural suficientemente alta para garantir iluminação confortável no ambiente interno, porém sem excessos. Se a quantidade de luz direta transmitida for reduzida, haverá escurecimento do ambiente interno com efeitos negativos para a visão, ocorrendo também o aumento do uso da iluminação artificial.

No que se refere à luminosidade, a maioria dos vidros refletivos apresenta uma baixa taxa de transmissão luminosa, dificultando a passagem da luz natural (Figura 26). Assim, eles causam escurecimento dos ambientes internos às fachadas, fazendo com que o uso da luz artificial seja necessário, além de refletirem a radiação direta para o entorno do edifício. 


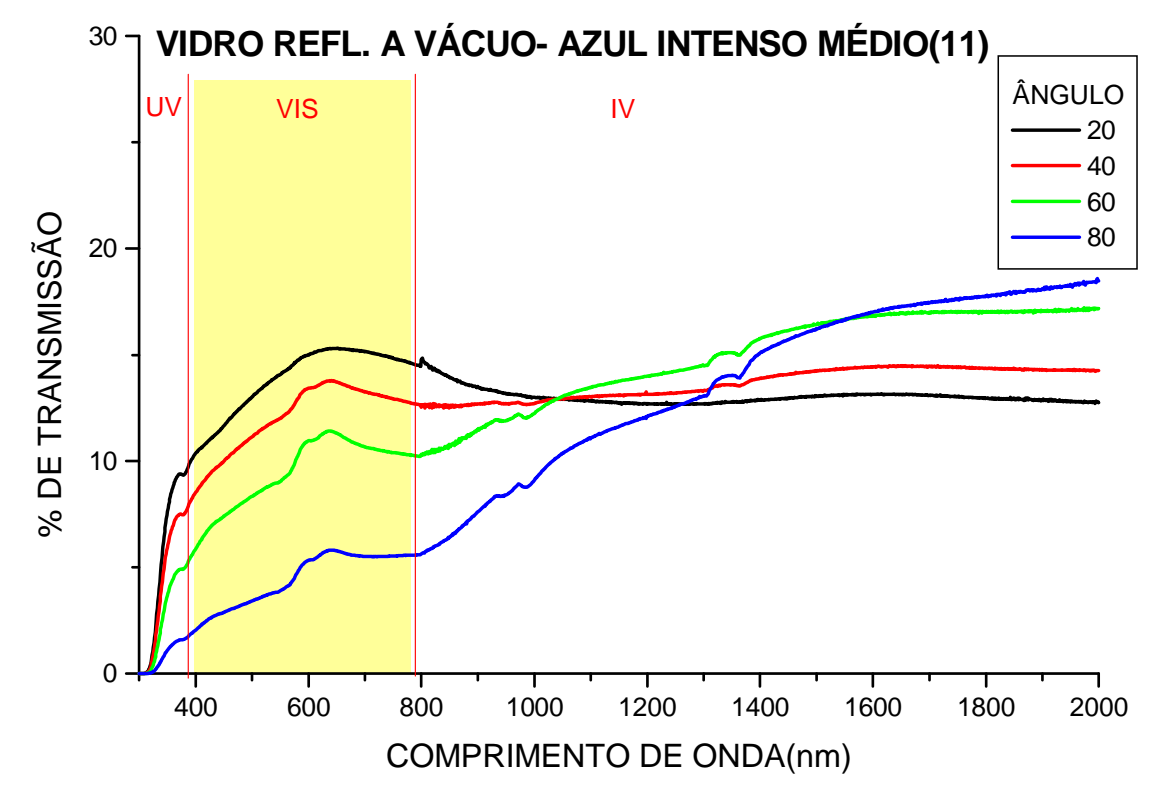

Figura 26. Transmissão do visível para o vidro refletivo metalizado a vácuo azul intenso médio

Fonte: Modificada de Santos, 2002

Através do gráfico nota-se uma baixa transmissão do infravermelho. Porém, essa diminuição de transmissão do infravermelho é acompanhada pela baixa transmissão da luz visível que varia entre 2 e 15\%.

Desta forma, pode-se observar que o bloqueio de calor destes vidros também implica no bloqueio da luz visível, mostrando que algumas das funções dos vidros são antagônicas entre si.

\subsection{Vidro insulado}

Os vidros insulados são chamados também de vidro duplos e possuem entre eles uma camada interna de ar desidratado ou gás. O duplo envidraçamento proporciona maior conforto térmico e acústico, ainda mais com a utilização de gases especiais entre os vidros. 
O envidraçamento duplo pode ser combinado por diversos tipos de vidros, com propriedades diferentes, aproveitando as características de cada um. Também pode haver persianas internas que abrem e fecham através de um sistema magnético. Os vidros duplos são muito usados em coberturas e divisórias.

\subsubsection{Vidros de segurança}

Os vidros de segurança são aqueles desenvolvidos com o intuito de reduzir os acidentes por choques, deformação ou incêndio. Estes vidros são utilizados quando se deseja que os caixilhos não sejam perigosos em caso de quebra, e por isso são empregados em terraços, coberturas, em locais escorregadios, vitrines, caixas de escadas e em lugares públicos.

Os padrões de segurança são geralmente definidos pelo número de partículas produzidas despedaçando o vidro num simples golpe, de modo padrão, e contando o número de cacos numa área de $100 \mathrm{~mm}^{2}$.

\subsection{Vidro aramado}

O vidro aramado (Figura 27) é um vidro impresso translúcido incolor que possui em seu interior uma grelha metálica antioxidante de malha quadrada que impede com que corpos o transpassem. Ele resiste ao fogo e à corrosão, e não produz estilhaços. Em caso de quebra, o vidro fica retido na rede metálica e em caso de incêndio, o vidro aramado dificulta a passagem das chamas, retardando as mesmas por até 62 minutos (SANTA MARINA, 1993). 


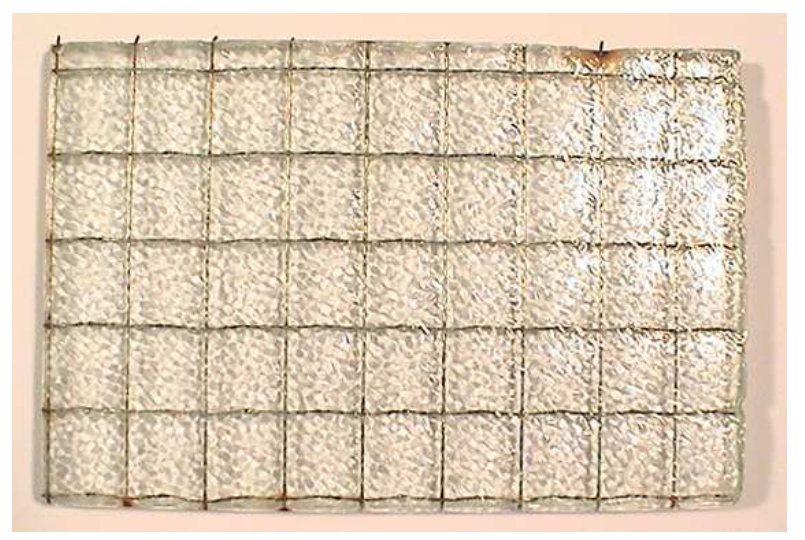

Figura 27. Vidro aramado

Devido à segurança que este vidro proporciona, ele é utilizado em caixas de escadas, coberturas, fechamentos de clarabóias, sacadas e peitoris. É produzido na espessura de $7 \mathrm{~mm}$ e é encontrado nas mesmas cores que o float.

\subsubsection{Vidro temperado}

Os vidros temperados são fabricados a partir do vidro comum e por isso possuem todas as suas características, porém com resistência cinco vezes maior que a do vidro comum.

O vidro temperado, considerado de segurança, é obtido através do processo de têmpera. Esta consiste no aquecimento até uma temperatura de $700{ }^{\circ} \mathrm{C}$ (estado plástico) e logo em seguida no resfriamento brusco do vidro, através de jatos de ar. Neste processo, pelo fato do vidro ser um mau condutor térmico, o resfriamento faz com que suas extremidades esfriem mais rápido e endureçam primeiro, ficando a parte central do vidro mais mole. A finalidade da têmpera é estabelecer tensões elevadas de compressão nas áreas superficiais do vidro, e correspondentes altas tensões no centro do mesmo (SAINT-GOBAIN GLASS, 2000). 
O tratamento de têmpera aumenta consideravelmente a resistência mecânica dos vidros, sem alterar as propriedades espectrofotométricas do produto de base. No caso de quebra, o vidro se desintegra em pequenos fragmentos arredondados e pouco cortantes.

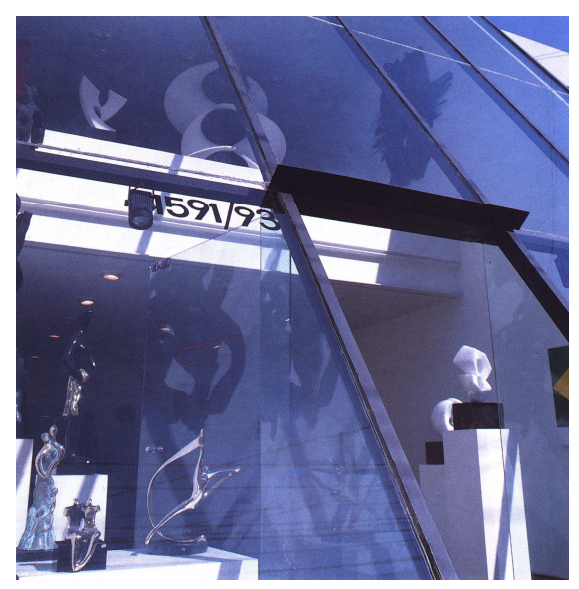

Figura 28. Vidro temperado empregado em vitrine Fonte: SANTA MARINA, 1993

As tensões provocadas no processo de endurecimento fazem com que seja impossível o trabalho com o vidro após este processo. Por isso, na prática normal, todo vidro temperado deve ser cortado e processado segundo os pedidos. São encontrados nas cores verde, fumê, bronze e incolor, e nas espessuras a partir de $6 \mathrm{~mm}$. O vidro temperado também pode ser fabricado a partir do vidro impresso ou "fantasia", em diversos desenhos de textura e em várias cores.

\subsection{Vidro laminado}

Vidros laminados são vidros de segurança formados pela aglutinação de duas ou mais chapas de vidro com uma camada intercalada (Figura 29). Com espessura mínima de $6 \mathrm{~mm}$, são encontrados em diversas cores. $\mathrm{O}$ vidro laminado atende às exigências de segurança, de controle do som e da radiação ultravioleta. 


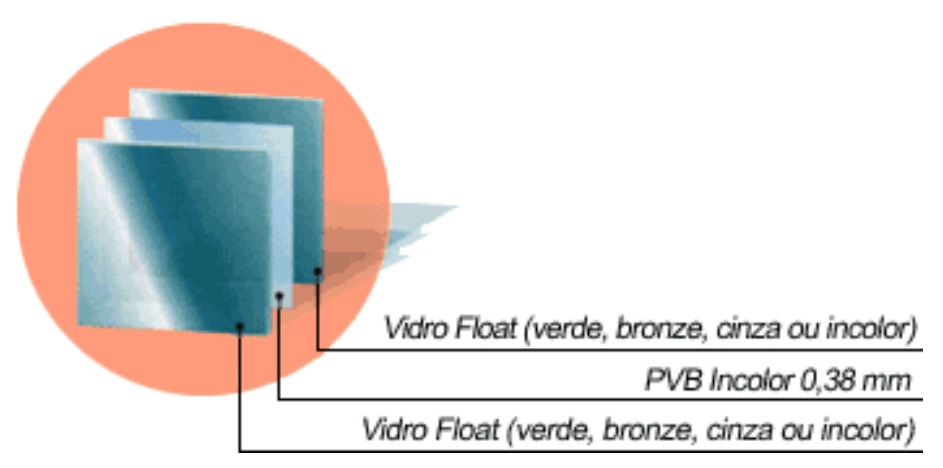

Figura 29. Camadas do vidro laminado verde Fonte: CEBRACE CRISTAL PLANO, 2006

Existem duas formas de laminação do vidro. A primeira é a laminação com resina, na qual os vidros são unidos por uma fita adesiva de dupla face. Uma quantidade determinada de resina líquida, correspondente ao volume dado de ar, é derramada na cavidade. No momento em que o ar é deslocado, a borda aberta é selada e o produto laminado é guardado horizontalmente para que a resina cure para formar a camada intercalada rígida.

O outro tipo de laminação é feito com uma película plástica intercalada chamada polivinil butiral (PVB), como mostra a Figura 30. Este material foi escolhido por apresentar grande resistência e elasticidade e boa aderência ao vidro (COMPAGNO, 1996). O polivinil butiral adere ao vidro através do tratamento térmico sob pressão, constituindo um anteparo no qual os fragmentos continuam aderidos em caso de quebra. Além disso, esta película plástica filtra até $99,6 \%$ dos raios ultravioletas, os principais responsáveis pelo desbotamento dos objetos. Existe uma grande variedade na composição dos vidros laminados, de acordo com a necessidade do projeto. Para sua composição, podem ser utilizados vidros incolores, coloridos e refletivos, e também podem ser usadas diferentes cores do filme de butiral (CARAM DE ASSIS, 2002). 


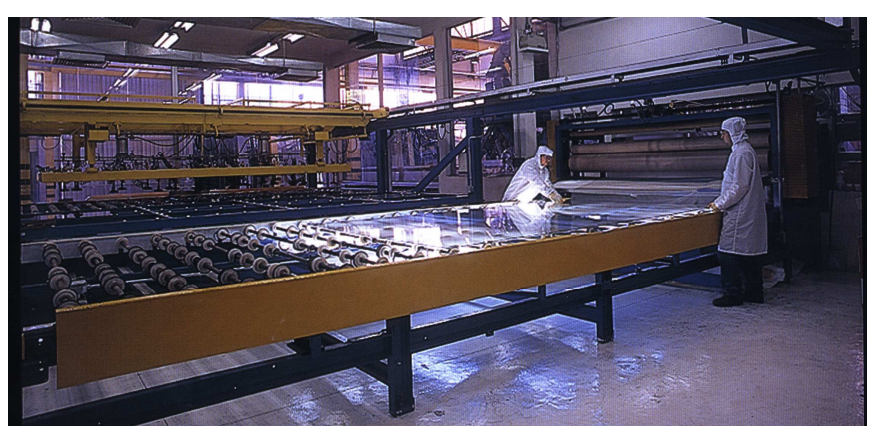

Figura 30. Colocação do PVB para a fabricação do vidro laminado Fonte: Teixeira, 2001

Os vidros laminados são utilizados contra choques acidentais, evitando quedas. Eles são usados para proteção de locais contra arrombamento e contra assaltos com armas. Os vidros laminados constituem uma eficiente barreira mecânica em vitrines, parapeitos, piscinas e clarabóias. Além disso, eles permitem uma redução de ruídos bem maior que os vidros monolíticos.

O vidro laminado pode ser fabricado com camadas múltiplas, chegando a grandes espessuras dependendo do local onde será empregado. As espessuras dos vidros laminados podem chegar até $60 \mathrm{~mm}$. Estes vidros laminados múltiplos são excelentes isolantes acústicos e por isso são utilizados em estúdios de gravação, em fábricas, hospitais e clínicas.

Vidros laminados compostos por uma lâmina interna de vidro temperado com duas lâminas externas de vidros comuns são chamados de craquelados. No processo de fabricação, o vidro temperado interno é quebrado e seus fragmentos ficam presos na película plástica. Geralmente estes vidros são usados em móveis e divisórias.

O item seguinte aborda as questões de conforto ambiental, destacando as características óticas dos vidros e seu comportamento espectrofotométrico. 


\subsection{As superfícies transparentes e o conforto térmico}

\subsubsection{Conforto ambiental}

O homem tem conseguido fixar-se em diferentes locais graças à sua grande capacidade de adaptação. Apesar de suportar diferentes tipos de clima, ele apenas se sente termicamente confortável em estreitos limites de condições ambientais (RORIZ, 2001).

As condições de conforto são uma das maiores aspirações do homem, considerando que a sensação de desconforto implica em maior número de acidentes e erros no processo de trabalho, além da diminuição do rendimento e da eficiência do mesmo. Além disso, as condições de conforto garantem um maior bem-estar dos usuários.

A forma arquitetônica influencia diretamente no conforto ambiental de uma edificação e no seu consumo de energia, já que interfere nos fluxos de ar e na quantidade de luz e calor solar recebidos pelo edifício.

A obra de arquitetura pode ser definida, nesse sentido particular, como um "envoltório material" que visa atender, em todos os sentidos, às necessidades da vida humana [...]. (MANGE, 1956, p.21).

Desta forma, a arquitetura representa uma chave importante na questão do conforto, já que as condições ambientais internas dependem do desempenho do edifício.

Segundo Harkness (1978), do ponto de vista do conforto ambiental, as superfícies transparentes da fachada devem permitir a passagem da luz, proteger do calor e do frio, além de ser um elemento estético. Por isso, a quantidade dessas 
superfícies envidraçadas ou a localização das mesmas são decisivas no controle térmico, luminoso e acústico de um edifício.

Através da análise da evolução tecnológica das janelas, nota-se uma busca por áreas de vidro cada vez maiores (MASCARÓ, 1991). Esta questão pode ser vista claramente na arquitetura do começo do século $X X$, na qual os edifícios de vidro tornaram-se protótipos de centros administrativos, sem levar em consideração questões sociais, tecnológicas ou econômicas, chegando a uma homogeneização.

Um estudo realizado em edifícios torres de vidro sem proteção adequada e climatizados artificialmente mostrou que estes prédios chegam a consumir, em média, durante sua vida útil, 23 vezes mais energia que a utilizada em sua construção (MASCARÓ, 1980).

Atualmente os problemas causados por este tipo de fechamento, como perdas e ganhos térmicos através do uso de panos de vidros comuns, problemas de ruído, de ofuscamento e de ventilação estão sendo analisados e criticados.

De acordo com Olgyay (1998), a pele de um edifício atua como filtro entre as condições internas e externas para controlar a entrada do ar, do calor, do frio, da luz, dos ruídos e dos cheiros. Por isso os materiais que constituem a pele das edificações têm um papel decisivo na utilização e no controle dos raios solares.

O trabalho está mais focado no conforto térmico, já que analisa os ganhos de calor através de aberturas providas de vidros. Dependendo da orientação das janelas e das características óticas dos vidros, o uso desses materiais sem critério pode resultar em um acúmulo de energia térmica no interior das edificações, traduzindo-se em desconforto aos usuários (LABAKI; CARAM; SICHIERI, 1995).

A radiação transmitida pelo vidro para o interior do ambiente é absorvida e/ou refletida pelos objetos existentes. Essa energia aquece os objetos e é reemitida ao 
meio na forma de infravermelho longo. Isso acaba provocando o "efeito estufa", já que o vidro permite a entrada da radiação solar de onda curta, mas não deixa sair as radiações de onda longa emitidas pelas superfícies internas, causando o aquecimento do ambiente (RORIZ, 2001).

\subsubsection{Radiação solar}

A radiação eletromagnética é um tipo de energia que é transmitida no espaço a alta velocidade, sem necessidade de meio material para ocorrer. Ela constitui a principal fonte de energia para o planeta. Os principais parâmetros associados à radiação eletromagnética são o comprimento de onda, a freqüência e a velocidade de propagação.

O Sol emite radiação de onda curta, de alta temperatura, que depois de atravessar o vácuo e ser filtrada pela atmosfera, atinge a superfície terrestre, que então passa a emitir radiação de baixa temperatura, de ondas longas. Segundo Givoni (1976), a radiação é seletivamente absorvida na atmosfera, de acordo com o comprimento de onda.

A radiação solar é considerada o principal fator na definição do clima e um dos mais importantes na definição de um projeto arquitetônico, já que influencia na orientação das fachadas, no tamanho das aberturas e nos tipos de vidro (SANTOS, 2002). Segundo Caram de Assis (1998), a radiação solar, quando bem aproveitada, pode ser muito benéfica, como também pode ser indesejável em determinadas condições. 
A radiação que atinge a superfície terrestre compreende um espectro com ondas de comprimentos que variam entre 290 a 2500 nm (DUFFIE; BECKMAN, 1980), com a seguinte composição aproximada:

$1 \%$ a $5 \%$ de ultravioleta (UV)

$41 \%$ a $45 \%$ de luz visível (LV)

$52 \%$ a $60 \%$ de infravermelho próximo (IV)

Estes três componentes da radiação correspondem cada um a uma gama de comprimentos de onda. Estas proporções variam de acordo com as condições atmosféricas, nebulosidade e presença de vapor de água.

A Figura 31 a seguir mostra a composição do espectro solar:

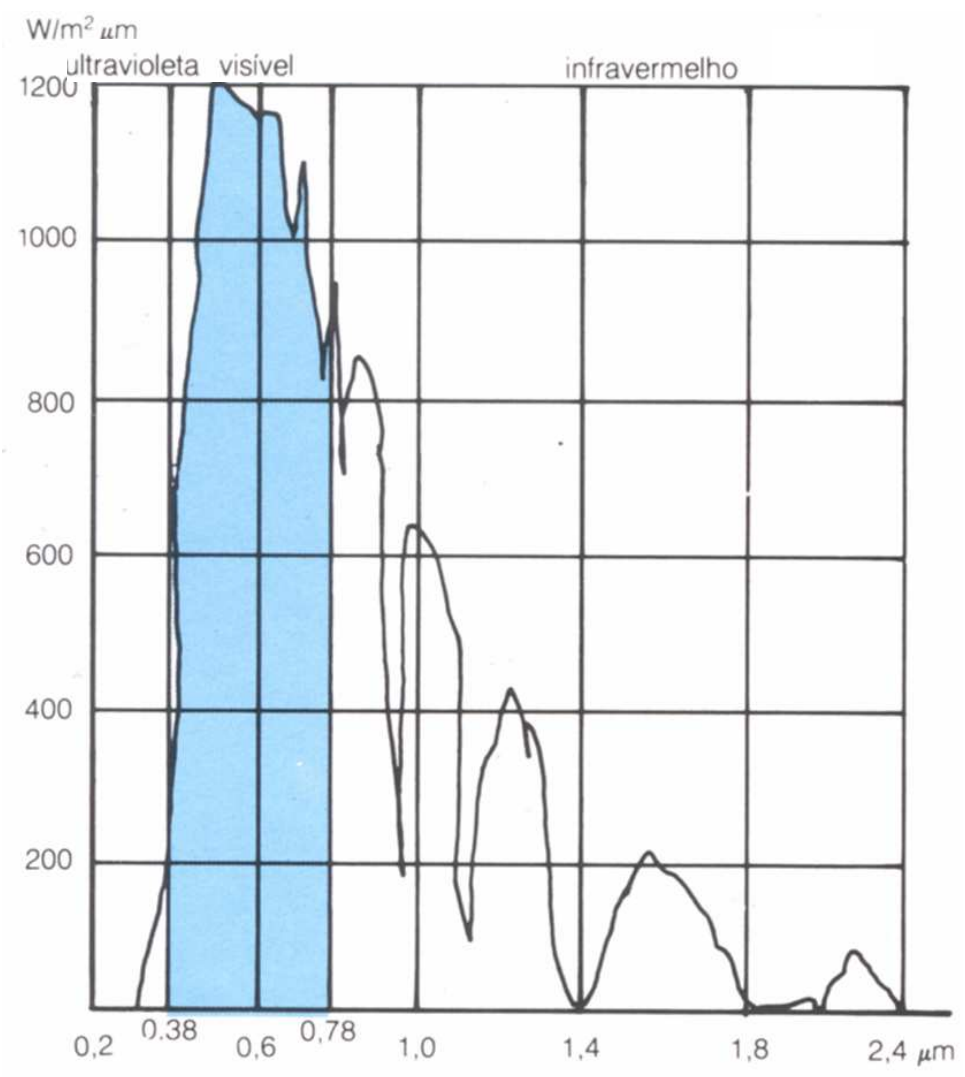

Figura 31. Espectro solar

Fonte: SANTA MARINA, 1993 
No que se refere ao aproveitamento de energia solar, pode-se considerar somente as radiações cujos comprimentos de ondas variam entre 290 e $1800 \mathrm{~nm}$ pois comprimentos de ondas maiores que esse valor atingem a superfície terrestre em quantidades muito pequenas, pois são absorvidos pelos vapores de água e dióxidos de carbono presentes na atmosfera. Com relação aos comprimentos de ondas menores que 290 nm, estes são absorvidos pela camada de ozônio (CARAM DE ASSIS, 2002).

A maior parte das superfícies transparentes usadas em fachadas é praticamente transparente, em maior ou menor intensidade, a todo o espectro solar.

A vista humana é sensível à radiação eletromagnética com comprimento de onda entre $380 \mathrm{~nm}$ e $780 \mathrm{~nm}$ aproximadamente. A radiação eletromagnética não provoca somente efeitos visuais sobre as pessoas, sendo que diferentes partes do espectro solar causam distintas ações sobre o organismo humano (MASCARÓ, 1991).

\section{Ultravioleta}

A radiação ultravioleta está compreendida entre os comprimentos de onda entre 100 e $380 \mathrm{~nm}$, sendo subdividida em três partes:

Ultravioleta A (próximo) - de 315 a 380 nm

Ultravioleta B - de 280 a 315 nm

Ultravioleta C - de 100 a 280 nm 
Mesmo chegando em pequena proporção à superfície terrestre, a radiação ultravioleta não pode ser desprezada, pois é muito energética e pode causar vários efeitos. A radiação ultravioleta auxilia na síntese de vitamina $D$ no organismo, possui efeito bactericida e é responsável por eritemas e pelo bronzeamento. Porém esta radiação, dependendo do tempo de exposição e do comprimento de onda, pode causar o desbotamento de tecidos, comprometendo a durabilidade dos materiais. A região do ultravioleta que causa o desbotamento da matéria está compreendida entre 315 e $380 \mathrm{~nm}$. Os comprimentos de onda menores a estes valores provocam também este efeito, porém quase não chegam à superfície terrestre.

\section{Visível}

A parcela de radiação visível corresponde aos comprimentos de onda na faixa entre 380nm e 780nm e está associada à intensidade de luz branca transmitida, sendo responsável pela luminosidade nos ambientes. Além disso, é através dela que os vegetais realizam a fotossíntese. A admissão da luz do Sol no interior de um edifício deve ser cuidadosamente controlada. O excesso de luz solar pode causar ofuscamento, provocar desconforto térmico com o aumento da temperatura interior, além de causar também um desconforto pela radiação direta sobre as pessoas (HOPKINSON; PETHERBRIDGE; LONGMORE, 1966).

\section{Infravermelho}


Os limites dos comprimentos de onda relativos ao infravermelho não são bem definidos, mas são geralmente considerados entre 780 nm e 1 mm. Esta região está dividida nas três faixas seguintes:

Infravermelho de ondas curtas (próximo) - de 780 a 1400 nm Infravermelho de ondas médias - de 1400 a 3000 nm Infravermelho de ondas longas - de $3000 \mathrm{~nm}$ a $1 \mathrm{~mm}$

A radiação térmica emitida pelos corpos nas temperaturas normais está na região infravermelha do espectro eletromagnético (TIPLER, 1995). O infravermelho é invisível ao olho humano, mas é sentido como calor. Esta radiação atravessa o vácuo e o ar limpo sem perda significativa de energia. O infravermelho influencia diretamente nas condições internas de conforto ambiental, através do ganho de calor. Por esse motivo não pode ser desconsiderado em ambientes que utilizam vidros nas fachadas.

O infravermelho próximo, cujo comprimento de onda vai de $780 \mathrm{~nm}$ a 1400 $\mathrm{nm}$, constitui uma fonte de calor e não pode ser captada pelo olho humano. Ele corresponde a mais da metade do espectro solar, mostrando que é bastante significativo.

$\mathrm{Na}$ faixa compreendida entre $7000 \mathrm{~nm}$ e $10000 \mathrm{~nm}$ existem radiações infravermelhas de ondas longas que são emitidas por corpos já aquecidos pela radiação solar. Apesar do vidro ser transparente ao infravermelho próximo, ele é opaco à transmissão do infravermelho longo podendo causar o efeito estufa em locais fechados. 


\subsubsection{Características óticas dos elementos transparentes}

A radiação solar ao se projetar sobre uma superfície pode ser refletida, absorvida ou refratada de acordo com a natureza da substância que forma a superfície (BARROWS, 1960).

Ao incidir a luz sobre uma superfície transparente, ocorrem basicamente os seguintes fenômenos:

- Reflexão nas interfaces entre os meios,

- Refração devido à diferença de velocidade de propagação de um meio para o outro,

- Absorção de uma parte da radiação pelo material, reduzindo sua intensidade,

- Transmissão da radiação para o meio além do material, após reflexões e absorções.

Estes fenômenos podem ser observados pela Figura 32:

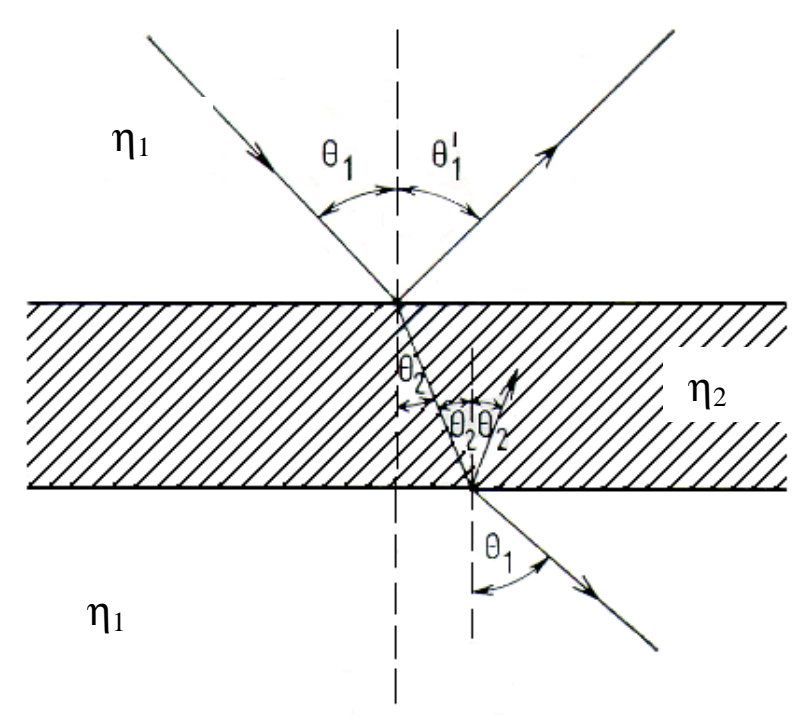

Figura 32. Propriedades óticas da luz incidindo sobre uma superfície transparente Fonte: Fanderlik, 1983 


\subsubsection{Comportamento espectrofotométrico}

Do total da radiação que incide sobre uma superfície transparente, uma parte é refletida, não tendo efeito térmico no material; outra parte é absorvida na espessura, sendo depois dissipada por convecção; e a terceira é transmitida. A quantidade em que isso ocorre depende das características do vidro em questão e do ângulo de incidência da radiação (SHOLZE, 1980). As características espectrofotométricas de transmissão, reflexão e absorção fazem com que os vidros atuem de forma seletiva com relação à radiação solar incidente. O desempenho fotoenergético do vidro é definido através da combinação entre as quantidades de radiação transmitida, refletida e absorvida (Figura 33).

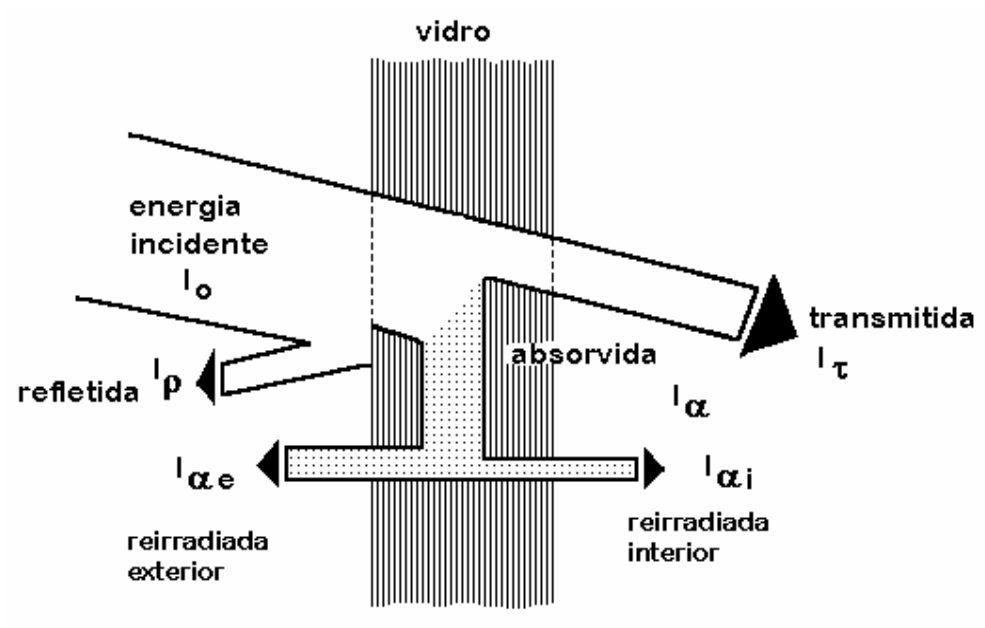

Figura 33. O vidro frente à radiação solar Fonte: Modificada de Croiset, 1972

A parte absorvida é transformada em calor, e é proporcional à absortância (A). A parcela refletida é determinada pela refletância $(R)$. A passagem da radiação de determinados comprimentos de ondas é caracterizada pela sua transmitância (T) (RORIZ, 2001). 
A radiação total incidente (Io) à superfície de determinado elemento transparente corresponde à soma das parcelas transmitida $\left(I_{T}\right)$, refletida $\left(I_{R}\right)$ e absorvida $\left(I_{A}\right)$ através do mesmo:

$$
\mathrm{Io}=\mathrm{I}_{\mathrm{T}}+\mathrm{I}_{\mathrm{R}}+\mathrm{I}_{\mathrm{A}}
$$

onde:

lo é a radiação incidente

$I_{T}$ é a radiação transmitida

$I_{R}$ é a radiação refletida

$\mathrm{I}_{\mathrm{A}}$ é a radiação absorvida

e que:

$$
1=T+R+A
$$

onde:

T é a transmitância

$\mathrm{R}$ é a refletância

A é a absortância

Os vidros são transparentes praticamente a todo espectro solar que chega à superfície terrestre. Eles atuam de forma seletiva à radiação solar incidente devido às suas características espectrofotométricas de transmissão, reflexão e absorção. Os óxidos que são introduzidos na composição do vidro são responsáveis pela 
absorção seletiva da radiação solar. De acordo com Santos (2002), estes óxidos podem modificar a transmissão na região do visível, originando a cor do material, e também podem evitar a transmissão direta pelo vidro do ultravioleta e do infravermelho através da absorção dessas radiações.

Outros fatores como a espessura, o índice de refração do vidro e o ângulo de incidência interferem também na transmissão, reflexão e absorção do vidro. Dessa forma, pode-se dizer que cada tipo de vidro tem diferentes transmissões para cada uma das faixas do espectro solar. Um vidro ideal em termos de eficiência energética seria aquele que tivesse uma alta transmissão da radiação visível e baixa transmissão do ultravioleta e infravermelho (CARAM DE ASSIS, 2002).

\section{Transmissão}

Os vidros nas janelas possuem como uma de suas funções a admissão da luz nos ambientes internos. Porém, os vidros também transmitem calor. As transmissões de luz, de infravermelho e de ultravioleta dependem do tipo de vidro em questão.

De um modo geral, a transmissão depende da composição química do material, de sua cor, de sua absorção ótica e das características superficiais do vidro.

A transmissão seletiva dos vidros depende do comprimento de onda da radiação incidente. Para determinadas regiões do espectro, ele age como se fosse um material opaco, por exemplo, para comprimentos de ondas inferiores à 300nm e superiores à 5000nm o vidro apresenta comportamento opaco, impedindo que a radiação o atravesse (CARAM DE ASSIS, 2002). 
A quantidade de energia que é transmitida diretamente através de um material transparente diminui mais acentuadamente à medida que o ângulo de incidência da radiação fica maior que $45^{\circ} \mathrm{com}$ a nor mal. A partir do ângulo de $60^{\circ}$ com a normal, a quantidade de radiação incidente transmitida diretamente diminui muito, já que seu coeficiente de reflexão passa a aumentar, como mostra a Figura 34. Quanto maior for o ângulo de incidência da radiação, maior será a parcela refletida pelo vidro (VAN STRAATEN, 1967).

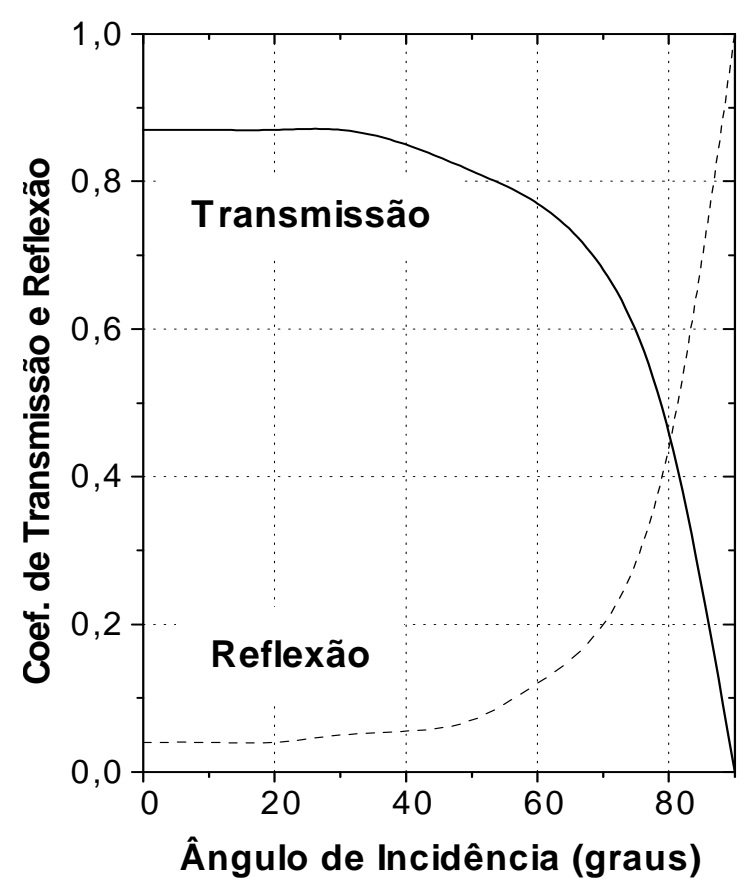

Figura 34. Variação da taxa de transmissão e reflexão em função do ângulo de incidência para o vidro incolor de $3 \mathrm{~mm}$

Fonte: Modificada de Van Straaten, 1967

Dessa forma, a diminuição da transmissão provoca um aumento progressivo da reflexão na mesma proporção, enquanto que a absorção mantém-se quase inalterada (SANTOS, 2002).

É importante lembrar que uma redução na transmissão da radiação significa quase sempre na absorção dessa radiação pelo vidro, ocasionando um aumento na temperatura do material. Para regiões de clima quente como é o caso do Brasil, 
seria bom que o infravermelho-próximo fosse refletido, pois se for absorvido, o vidro pode funcionar como uma espécie de "radiador", irradiando calor para o interior do ambiente.

Muitas vezes, os fabricantes de vidros só mostram dados do comportamento ótico dos vidros para a incidência normal, que pode ser considerada até um ângulo de incidência de $40^{\circ}$. Até este ângulo, não ocorrem reflexões significativas, no entanto, para ângulos acima deste, o uso destes dados resulta em reflexões mais pronunciadas.

\section{Absorção}

Um vidro, ao ser exposto à radiação solar, pode absorver parte desta energia, transformando-a em calor. Toda a energia incidente (ultravioleta, visível ou infravermelha), quando é absorvida, transforma-se em calor.

A absorção da radiação depende da espessura do vidro e de seu coeficiente de absorção $\alpha$ que, por sua vez, depende dos óxidos adicionados ao vidro. A Figura 35 a seguir mostra a comparação feita entre as porcentagens de radiação transmitida através de amostras de vidro incolor de várias espessuras, que influenciam na taxa de absorção. 


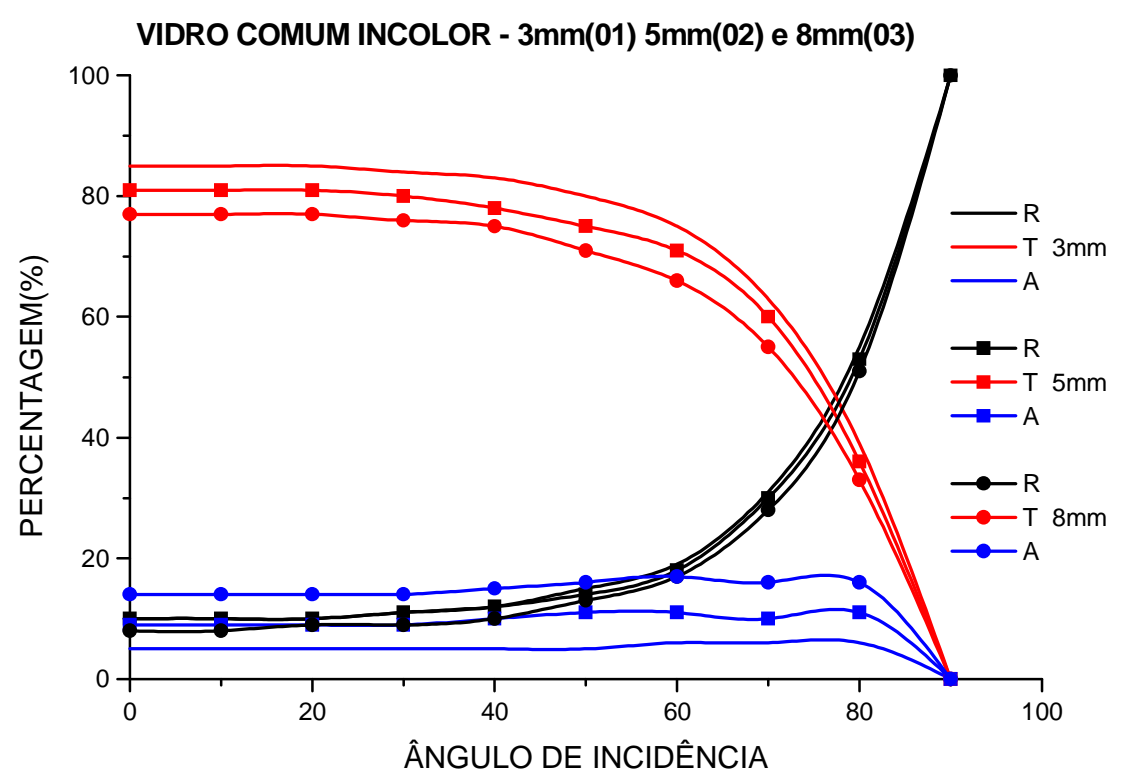

Figura 35. Variação da taxa de reflexão, transmissão e absorção para várias espessuras do vidro incolor

Fonte: Santos, 2002

Sendo lo a intensidade da radiação incidente e $\mathrm{I}_{\mathrm{T}}$ a intensidade da radiação transmitida pelo meio absorvente, tem-se a seguinte a expressão:

$$
\mathrm{I}_{\mathrm{T}}=\mathrm{lo}_{\mathrm{o}} \mathrm{e}^{-\alpha \mathrm{d}}
$$

onde:

$\alpha=$ coeficiente de absorção (absortividade)

$\mathrm{d}=$ espessura do material

que é a expressão de Lambert-Beer.

\section{Reflexão}

A refletância consiste na relação entre a intensidade da radiação refletida $I_{R}$ e a radiação incidente lo, e é expressa matematicamente como: 


$$
R=I_{R} / l o
$$

A perda da intensidade da radiação por reflexão ocorre ao passar de um meio transparente a outro de índice de refração distinto.

Para incidência perpendicular à superfície, deve ser usada a relação de Fresnel, para cálculo da reflexão em sua interface:

$$
R=\left[\left(n_{1}-n_{2}\right) /\left(n_{1}+n_{2}\right)\right]^{2}
$$

onde:

$n_{1}$ e $n_{2}$ correspondem a índices de refrações de dois meios diferentes

No caso em que o ar for um dos meios, de $n=1$, a relação pode ser expressa da seguinte maneira:

$$
R=[(n-1) /(n+1)]^{2}
$$

De um modo geral, a equação (5) pode ser usada para ângulos de incidência de até $20^{\circ} \mathrm{com}$ a normal (CARAM DE ASSIS, 2002).

A reflexão depende basicamente do ângulo de incidência e do índice de refração do vidro. Considera-se o índice de refração $n=1,5$ para os vidros utilizados na construção civil. Se o ângulo de incidência for pequeno em relação à normal, o índice de reflexão é muito baixo. Como já foi dito, a reflexão aumenta à medida que o ângulo de incidência torna-se maior em relação à normal. Altos índices de reflexão 
ocorrem em incidências a ângulos maiores que $75^{\circ} \mathrm{co} \mathrm{m}$ a normal da superfície, já para ângulos menores que $20^{\circ}$, a influência na refle xão é muito pequena.

De acordo com a expressão (5), a radiação incidente sobre uma superfície de vidro, com índice de refração $n=1,5$, perde através da reflexão 0,04 em cada interface vidro-ar, ou seja, $(1,5-1)^{2} /(1,5+1)^{2}=0,04$. Isso significa que o feixe luminoso diminui em $4 \%$ ao atravessar a primeira face ar-vidro, e depois perde mais 4\% ao atravessar a segunda interface vidro-ar. É por esse motivo que se diz que o vidro tem transmissão de $92 \%$. Mas isso só ocorre em vidros muito finos, nos quais a absorção é desprezível.

\subsubsection{Parâmetros relacionados ao desempenho térmico}

Os principais parâmetros que devem ser considerados em fechamentos transparentes em relação ao desempenho térmico são o Fator Solar, o Ganho de Calor Solar e o Coeficiente de Admissão de Calor.

\subsubsection{Fator solar}

O Fator Solar de um vidro é a razão entre a energia total que entra em um local através desse vidro e a energia solar incidente. Ele corresponde à soma das parcelas de transmissão direta pelo vidro, mais a parcela da energia absorvida e reirradiada para o interior do ambiente. Dessa forma, o Fator Solar é expresso pela seguinte expressão:

$$
\mathrm{FS}=\mathrm{T}+\mathrm{Ni} \cdot \mathrm{A}
$$


sendo:

$\mathrm{FS}=$ Fator Solar

$\mathrm{T}=$ transmitância

$\mathrm{Ni}=$ fração da energia solar incidente absorvida e reirradiada para o interior

$A=$ absortância

Genericamente adota-se que a parcela reirradiada para o interior representa 1/3 da parcela absorvida, independente das condições internas e externas da edificação. A fração de $1 / 3$ pouco significa quando se trata de um vidro incolor. Porém, para vidros com grande absorção, este percentual torna-se significativo. Por exemplo, um vidro que absorve $54 \%$ da energia incidente, terá aproximadamente $18 \%$ desta energia reirradiada para o interior na forma de calor. Para os vidros refletivos que apresentam um grande coeficiente de absorção, esta fração 1/3 pode provocar um ganho bastante significativo de calor.

Para o cálculo do Fator Solar, foi considerado o Ni para cada tipo de vidro utilizado na pesquisa baseado no trabalho desenvolvido por Santos (2002).

\subsubsection{Ganho de calor solar}

Como já foi visto, a radiação solar que incide em um fechamento transparente pode ser absorvida, refletida ou transmitida para o interior da edificação.

A parcela da radiação transmitida para o interior influenciará diretamente nas condições de conforto de forma instantânea, constituindo a principal parte nos ganhos de calor (LAMBERTS; DUTRA; PEREIRA, 1997). 
A densidade do fluxo de ganho de calor define-se como a soma do Fator Solar e da transferência de calor devida à diferença de temperatura entre o ar exterior e o interior:

$$
q=F S \cdot(l o)+U \text {. (te - ti) }
$$

onde:

$q=$ densidade do fluxo de ganho de calor através do material transparente $\left(\mathrm{W} / \mathrm{m}^{2}\right)$

FS = Fator Solar

lo = energia incidente $\left(\mathrm{W} / \mathrm{m}^{2}\right)$

$\mathrm{U}=$ transmitância térmica total $\left(\mathrm{W} / \mathrm{m}^{2} \mathrm{C}\right)$

$($ te $-\mathrm{ti})=$ diferença entre a temperatura do ar externo e interno $\left({ }^{\circ} \mathrm{C}\right)$

$\mathrm{O}$ termo $U$ (te - ti) refere-se às trocas de calor pela diferença de temperatura e representa ganho quando te $>$ ti e perda quando ti $>$ te.

Considerando o envidraçamento constituído de material homogêneo e com espessura constate (CROISET, 1972), a transmitância térmica total (U) é obtida por:

$$
U=\frac{1}{R}
$$

Sendo $\mathrm{R}$ a resistência térmica total do componente, dada por:

$$
R=\frac{1}{U}=\frac{1}{h_{i}}+\frac{d}{\lambda}+\frac{1}{h_{e}}
$$


onde:

$U=$ transmitância térmica total $\left(\mathrm{W} / \mathrm{m}^{2}{ }^{\circ} \mathrm{C}\right)$

hi $=$ coeficiente superficial interno de transmissão de calor $\left(\mathrm{W} / \mathrm{m}^{2}{ }^{\circ}\right)$

$d$ = espessura do componente $(m)$

$\lambda=$ condutividade térmica do material $\left(\mathrm{W} / \mathrm{m}^{2}{ }^{\circ} \mathrm{C}\right)$

he $=$ coeficiente superficial externo de transmissão de calor $\left(\mathrm{W} / \mathrm{m}^{2}{ }^{\mathrm{C}}\right)$

Usualmente, a resistência térmica $d / \lambda$ é pequena para envidraçados, em comparação com os outros termos da equação, devido à pequena espessura dos vidros utilizados nas janelas. Com relação à condutividade do vidro, o valor considerado é $1,0 \mathrm{~W} / \mathrm{m}^{2} \mathrm{C}$ (RIVERO, 1986).

\subsubsection{Coeficiente de admissão de calor}

O Coeficiente de Admissão de Calor (CAC) foi criado com o objetivo de substituir o Coeficiente de Sombreamento (CS), já que este acarreta erros em seu uso. Isso se deve primeiramente ao fato de um aumento no CS significar menor capacidade do elemento em diminuir o ganho de calor solar. Em segundo lugar, por ser erroneamente utilizado em alguns casos, indistintamente tanto para calor admitido como para iluminação natural (SANTOS, 2002).

Da mesma forma que o CS, o CAC é calculado pela relação entre o FCS do material analisado e o FCS de um material adotado como referência, que serve como coeficiente de correção a multiplicar os valores das tabelas de ganhos de referência do calor solar, obtendo assim os ganhos de calor solar para o elemento transparente em questão. 
Enquanto que o FCS tem seu valor variável para diferentes ângulos de incidência, o CAC é um valor constante, sendo uma característica do tipo e espessura do elemento transparente. Segundo Santos (2002), esse coeficiente só pode ser usado pra relacionar elementos que possuam um mesmo padrão de variação do FCS, de forma que o valor do CAC seja constante para os diferentes ângulos de incidência.

\subsection{Experimento em células-teste}

Atualmente, em muitas pesquisas tem-se adotado o uso de simulações quando o objetivo é obter resultados referentes ao desempenho de um determinado material ou sistema. Por isso é cada vez mais comum o uso de programas computacionais que simulam uma situação real com o intuito de adquirir dados de performance. O uso de simulações viabiliza muitas pesquisas, já que é mais prático, rápido e barato construir protótipos virtuais que reais. Muitas vezes é conseguido um resultado bom nestas simulações. Porém, o que não se deve ser feito é abandonar totalmente modelos reais e só usarem os virtuais quando o objetivo é adquirir dados de desempenho.

A reconstrução em escala real de modelos é um processo com grande potencial de aplicação porque não simula uma situação real, mas constitui a própria realidade, quando todos os cuidados são levados em consideração. O importante de uma pesquisa que utiliza modelos reais é o acompanhamento e manutenção constante desses protótipos.

Porém, há pouca literatura referente à pesquisa experimental em células-teste em relação ao desempenho térmico de materiais. Um desses poucos exemplos é o 
trabalho de Etzion e Erell (2000) que fizeram avaliação experimental em uma fachada envidraçada no Centro de Arquitetura e Planejamento Urbano, em Israel. Em um protótipo de $2,7 \times 3,5 \mathrm{~m}$ foi instalado um sistema de envidraçamento que foi monitorado no inverno e no verão, através de medições de no mínimo uma semana. As paredes de blocos vazados de concreto foram pintadas de branco e a cobertura era composta de uma laje de concreto desempenado. As janelas de dimensões de $1,4 \times 2,1 \mathrm{~m}$, localizadas na face Sul, receberam os vidros analisados. Todos os protótipos foram expostos às mesmas condições ambientais, possibilitando assim, a comparação de uma janela utilizada como referência com a janela experimental. Dentre as variáveis analisadas, foram registrados dados de radiação solar global incidente no vidro, velocidade e direção do vento, umidade, temperatura de bulbo seco no interior dos protótipos, temperaturas superficiais dos vidros.

Nota-se que esse trabalho utiliza uma metodologia similar àquela utilizada nessa pesquisa, na qual foram utilizadas células-teste construídas na escala de 1:1 para a avaliação do desempenho térmico de vidros.

Cabe ressaltar também o trabalho de Castro (2006), que utilizou as mesmas células-teste do presente trabalho com o objetivo de analisar o desempenho térmico de outros vidros utilizados nas construção civil, além dos refletivos. 


\section{MATERIAIS E MÉTODOS}

Neste capítulo são apresentados os materiais analisados, os equipamentos utilizados na pesquisa e os procedimentos de ensaio.

Foram utilizadas as células-teste e os equipamentos comprados durante a pesquisa intitulada "Sustentabilidade e eficiência energética: avaliação do desempenho térmicos de coberturas e do comportamento de materiais transparentes frente à radiação solar", financiada pela FAPESP no ano de 1999.

Para a construção dessas células-teste foram considerados vários elementos construtivos, com o objetivo de criar um modelo bastante apropriado aos objetivos da pesquisa.

\subsection{Materiais}

Os vidros ensaiados nesta pesquisa compreendem vidros planos e vidros refletivos pirolíticos e metalizados a vácuo. Estes vidros foram doados pela CEBRACE em placas para as medições nas células-teste. Os vidros são:

- Vidros planos: incolor $(4 \mathrm{~mm})$ e verde $(4 \mathrm{~mm})$.

- Vidros refletivos pirolíticos (antélios): prata $(4 \mathrm{~mm})$, verde esmeralda $(6 \mathrm{~mm})$ e bronze $(4 \mathrm{~mm})$. 
- Vidros refletivos metalizados a vácuo: prata neutro - CEB 114-PN (4mm), azul médio - CEB 130-AZ (4mm) e azul intenso médio - CEB 114-AI (4mm).

- Vidro reflectafloat $(4 \mathrm{~mm})$.

Tabela 1 - Relação de vidros

\begin{tabular}{lc}
\hline Vidros & Espessura \\
\hline Plano incolor & $4 \mathrm{~mm}$ \\
Plano verde & $4 \mathrm{~mm}$ \\
Refletivo pirolítico prata & $4 \mathrm{~mm}$ \\
Refletivo pirolítico verde esmeralda & $6 \mathrm{~mm}$ \\
Refletivo pirolítico bronze & $4 \mathrm{~mm}$ \\
Refletivo metalizado a vácuo prata neutro & $4 \mathrm{~mm}$ \\
Refletivo metalizado a vácuo azul médio & $4 \mathrm{~mm}$ \\
Refletivo metalizado a vácuo azul intenso médio & $4 \mathrm{~mm}$ \\
Reflectafloat & $4 \mathrm{~mm}$ \\
\hline
\end{tabular}

\subsection{Metodologia}

A metodologia adotada baseia-se na análise de vidros refletivos através dos seguintes processos:

- Medições in loco em células-teste com o objetivo de verificar as condições de temperaturas internas e superficiais dos vidros, além do monitoramento de outras variáveis ambientais.

- Cálculo do ganho de calor com o objetivo de comparar os dados obtidos in loco com os dados obtidos anteriormente no espectrofotômetro (SANTOS, 2002).

\subsubsection{Caracterização da área de estudo}


As células-teste foram construídas na área experimental da Faculdade de Engenharia Civil, Arquitetura e Urbanismo da UNICAMP em Campinas (Figura 36). A cidade de Campinas localiza-se de acordo com as seguintes coordenadas geográficas: $22{ }^{\circ} 54$ 'S de latitude, $473^{\circ}$ 'O de longitu de e $854 \mathrm{~m}$ de altitude. Devido sua altitude, a cidade está sujeita à intensa ventilação e insolação (CHVATAL, 1998). Com relação à amplitude térmica média, ela varia entre $9,3^{\circ} \mathrm{C}$ e $13^{\circ} \mathrm{C}$, apresentando valores menores nos meses de dezembro e janeiro, e valores maiores em agosto. A umidade relativa média do ar de outubro a março é de $77 \%$, e de abril a setembro fica em torno de $65 \%$. Os ventos predominantes são de sudeste e as velocidades na maioria dos meses são próximas de 2,0m/s.

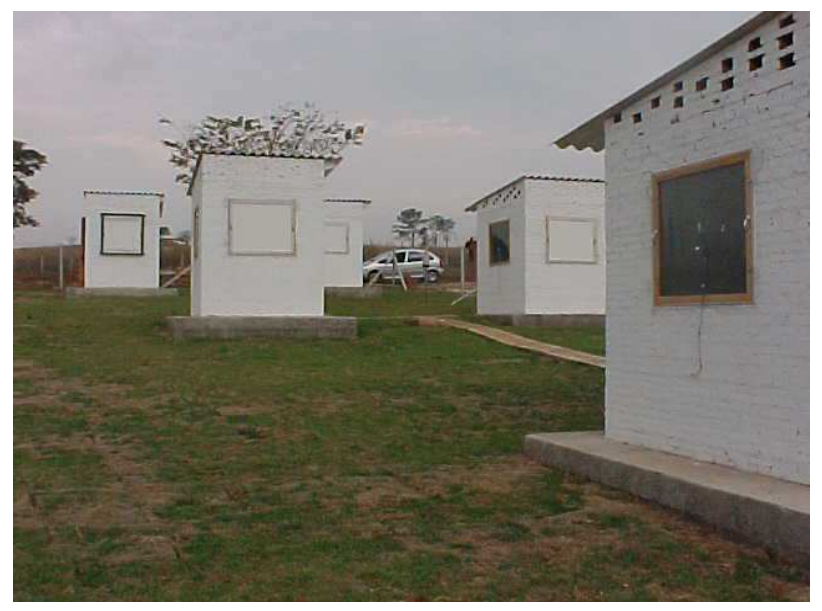

Figura 36. Conjunto de células-teste na área experimental da UNICAMP

\subsubsection{Caracterização das células-teste}

As seis células-teste construídas na UNICAMP foram dispostas na orientação Norte - Sul e foram distanciadas de forma que não houvesse sombreamento das paredes ou sombras de vento, garantindo assim as mesmas condições de implantação para todas (Figura 37). 


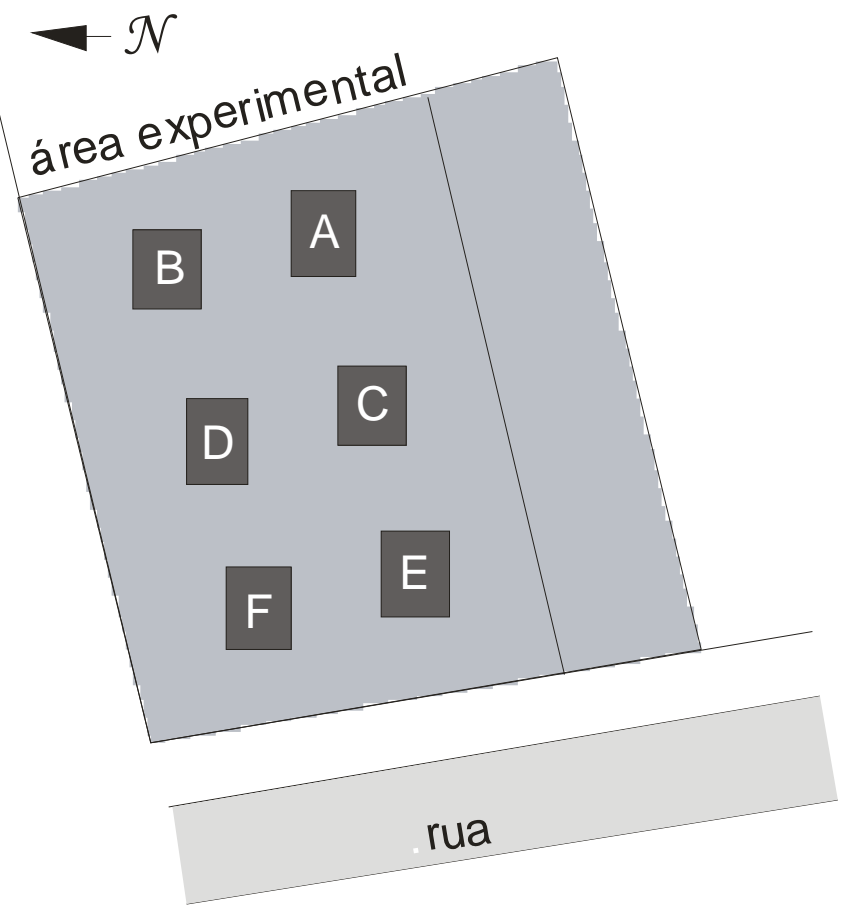

Figura 37. Implantação das células-teste (sem escala) Fonte: Gutierrez, 2004

Quanto à materialidade, todas elas foram construídas em condições idênticas, com piso interno em concreto com revestimento em argamassa de cimento desempenado, alvenaria de tijolo maciço de barro cozido $(0,10 \mathrm{~m})$ e pintura das paredes na cor branca (cal), cobertura de telha de fibro-vegetal e todas as célulasteste possuem lajes pré-fabricadas em concreto armado com isolante térmico e ventilação sob a cobertura, como mostra a Figura 38.

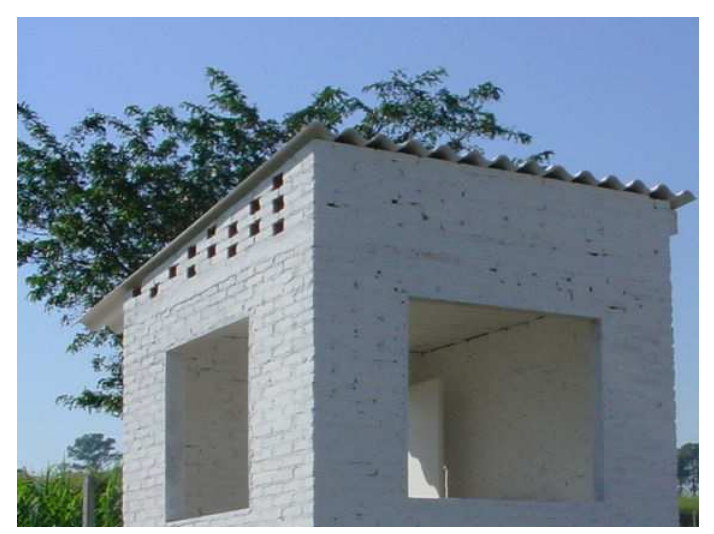

Figura 38. Detalhe da ventilação sob a cobertura 
As dimensões das células-teste são de 2,20 m por 2,70 m, apresentando uma área útil de 5,00 $\mathrm{m}^{2}$, com altura de 2,60 $\mathrm{m}$ na fachada Leste e 3,00 $\mathrm{m}$ na fachada Oeste. Cada célula-teste possui esquadrias de madeira, uma porta na face Leste e duas aberturas de $1,00 \mathrm{~m}$ por $1,00 \mathrm{~m}$ nas faces Norte e Oeste, nas quais são colocados os vidros. Estas dimensões foram definidas de acordo com o código de obras de Campinas que recomenda que a área envidraçada corresponda, no mínimo, a $10 \%$ da área do piso, e que tenha dimensão mínima de 0,60m². As áreas envidraçadas são fixas, ou seja, não possuem aberturas para a ventilação, fazendo com que o interior das células-teste seja um ambiente fechado. Para facilitar a troca e o manuseio dos vidros, foi usada uma moldura de madeira na volta do vidro, com alças e fechos de travamento.
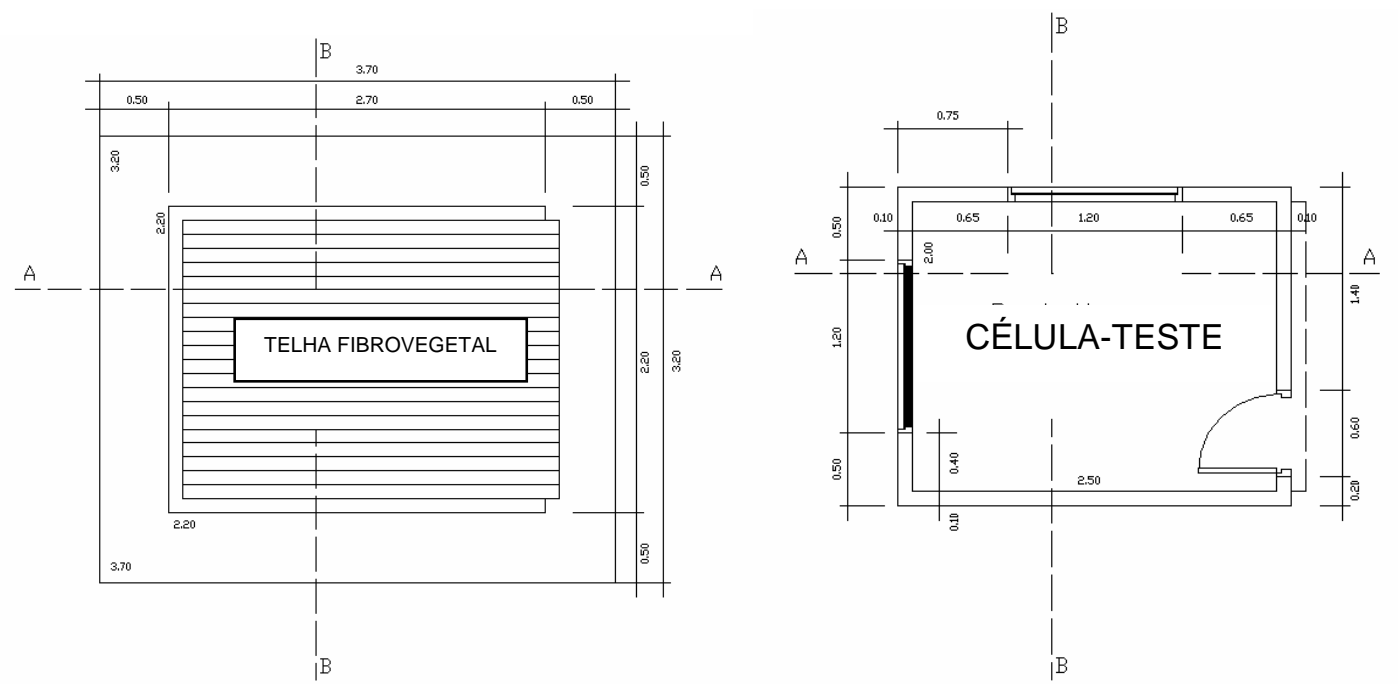

Figura 39. Planta de implantação e planta da célula-teste 


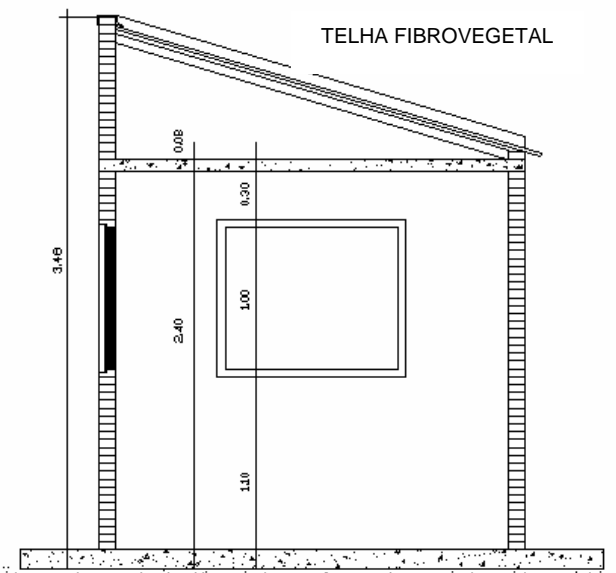

Corte AA

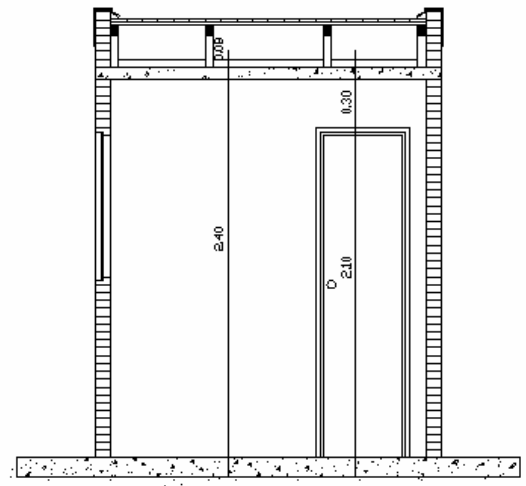

Corte BB

Figura 40. Cortes da célula-teste

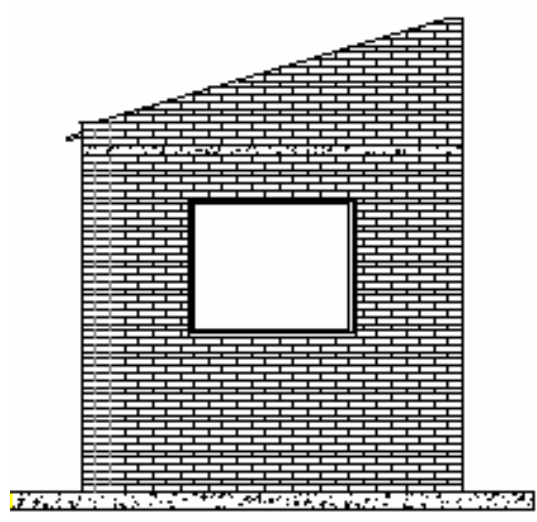

Fachada Norte

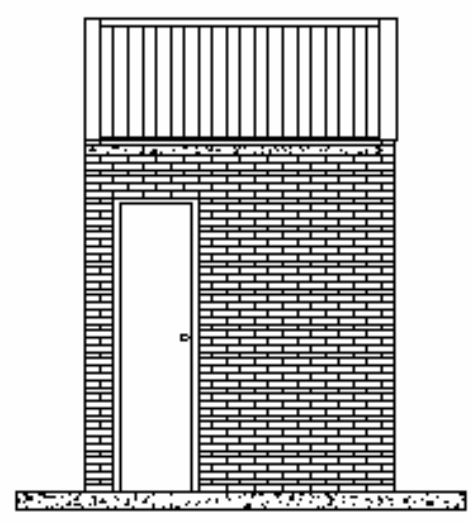

Fachada Leste

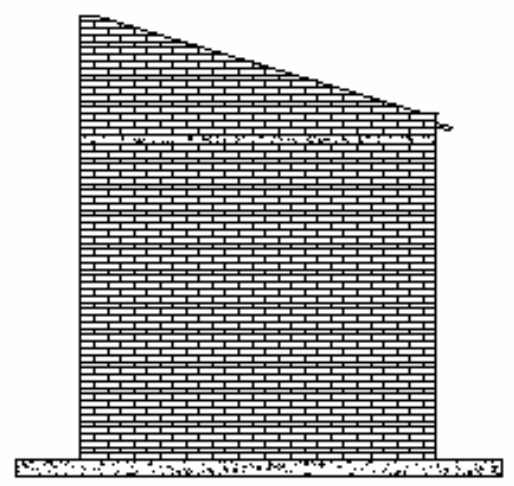

Fachada Sul

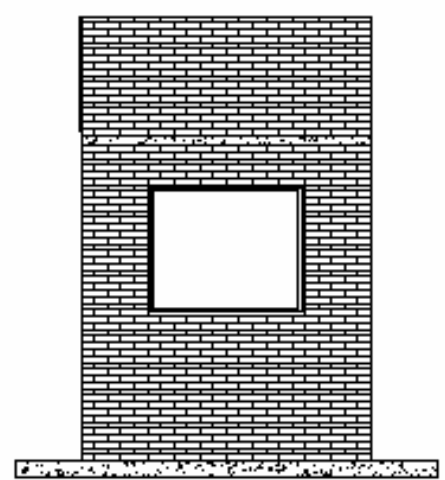

Fachodo Deste

Figura 41. Elevações da célula-teste 
Foram feitas medições durante um período no inverno (julho/agosto de 2005) e outro no verão (fevereiro/março de 2006). Foram medidas, em intervalos préestabelecidos, as temperaturas internas das células-teste e as temperaturas superficiais internas e externas dos vidros. Durante as medições, enquanto era colocado o vidro em uma das aberturas, a outra era vedada com painel com mesma resistência térmica das paredes (Figura 42).

De modo a possibilitar a realização dessa investigação, foi executada a adequação das condições físicas das células-teste, com a limpeza, pintura, colocação dos vidros e a instalação dos equipamentos de monitoramento (sensores de temperatura, umidade, radiação, etc.).

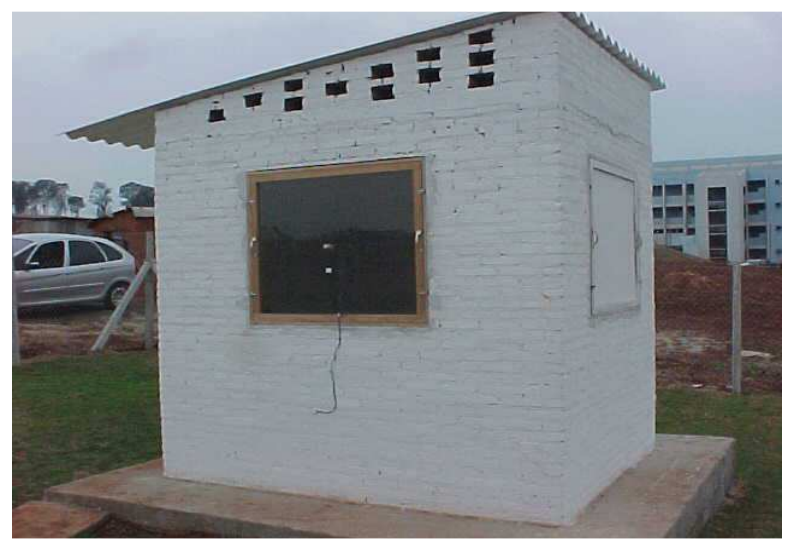

Figura 42. Célula-teste com vidro instalado

\subsubsection{Medidores de temperatura: termopares}

A medição de temperatura com termo-elementos baseia-se no efeito termoelétrico (termopares). Interligando-se dois fios de diferentes materiais, por exemplo, cobre - constantin, e colocando-se os pontos de ligação em contato com diferentes temperaturas obtém-se uma força eletromotriz, que é denominada tensão termoelétrica. 
Os termopares (cobre - constantin / Cu - Ct) utilizados nessa pesquisa são do modelo IR - Cable Extension tipo T. Em cada célula-teste foram fixados três sensores (termopares tipo T), sendo distribuídos da seguinte maneira:

- 01 termopar medindo a temperatura interna do vidro;

- 01 termopar medindo a temperatura externa do vidro;

- 01 termopar medindo a temperatura do ar interno nas células-teste.

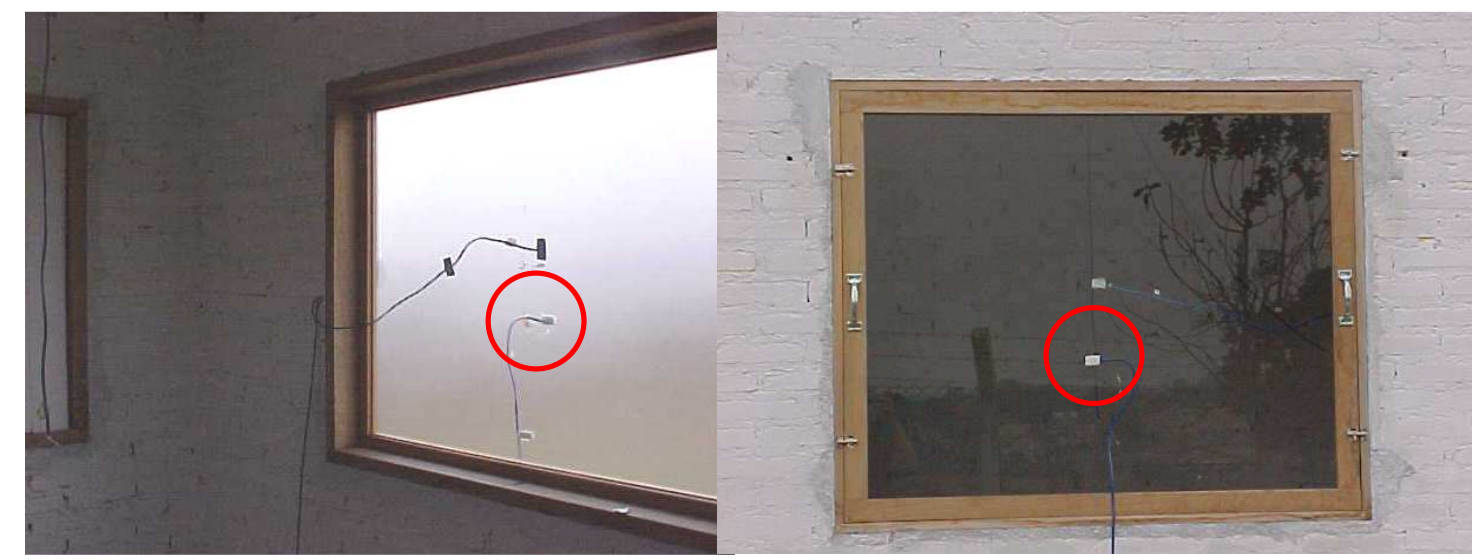

Figura 43. Detalhes dos termopares colocados nos vidros (interna e externamente)

O sistema de aquisição de dados referentes ao desempenho térmico das células-teste é composto de duas unidades básicas: um Data Logger CR10X e um multiplexador AM416, de 32 canais de aquisição de dados, que fazem a coleta automática e o armazenamento dos mesmos.

O sistema de aquisição dos dados possui terminal para conexão de 10 sensores embutidos, com porta de comunicação de 40 Kb de memória RAM interna, baterias internas recarregáveis e recarregador de bateria.

Para reduzir a influência da radiação solar incidente nas leituras dos termopares, estes foram cobertos com uma fita metalizada da 3M. Utilizou-se também pasta térmica para aumentar o contato do sensor com a superfície. 


\subsubsection{Instalação da mini-estação meteorológica}

Próximo às células-teste foi implantada uma mini-estação meteorológica automática de aquisição de dados, CR10X Campbell Scientific Inc. (Figura 44), com o objetivo de adquirir dados do microclima local, cujos registros são feitos a cada 30 segundos, definindo-se as médias a cada 10 minutos. A estação monitora os seguintes dados atmosféricos externos: temperatura do ar, umidade do ar, direção dos ventos predominantes, velocidade do vento, radiação solar incidente, índice pluviométrico.

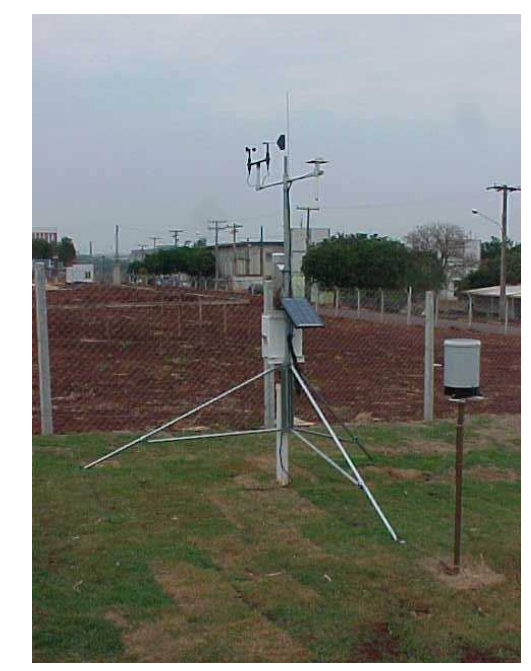

Figura 44. Estação meteorológica

A Estação Meteorológica automática é basicamente composta por:

- CR10X - Data Logger Campbell Scientific Inc.;

- Termo higrômetro CS 500 , sensor de temperatura $\left(-34{ }^{\circ} \mathrm{C} a+50^{\circ} \mathrm{C}\right)$ e umidade relativa do ar (10 a $90 \%)$;

- Piranômetro LI200X, sensor de radiação solar global (400 a 1000nm);

- Sensor de direção $\left(0^{\circ}\right.$ a 3559 e velocidade dos ven tos (0 a $\left.60 \mathrm{~m} / \mathrm{s}\right)$;

- Pluviômetro de báscula TB4-L; 
- Bateria recarregável de $12 \mathrm{~V}$ - reguladores de voltagem, filtros e proteção contra queda de raios;

- Painel solar - produção de energia;

- Abrigo meteorológico para sensor de temperatura e umidade relativa.

A estação, por meio de equipamento de aquisição e armazenamento ("Data Logger", AM416, com canais para conexão dos termopares tipo T), possibilita o monitoramento no interior dos ambientes de vários parâmetros climáticos.

Os dados coletados ficam armazenados na estação, depois são descarregados por meio do storage module (módulo de armazenamento) para, posteriormente, serem transferidos ao microcomputador, via software de programação PC208W (programa específico da Campbell Scientific Inc.) e interface de comunicação SC32A.

\subsubsection{Arranjo experimental}

Os nove tipos de vidro analisados foram reunidos em três grupos, e cada grupo foi medido durante duas semanas, sendo que em uma das semanas os vidros foram colocados na face Oeste e na outra semana eles foram posicionados na face Norte. Este arranjo foi utilizado tanto nas medições de inverno como nas medições de verão.

O primeiro grupo de vidros corresponde aos vidros planos incolor e verde; vidros refletidos pirolíticos prata, verde esmeralda e bronze; vidro reflectafloat. O segundo grupo foi constituído pelos vidros planos incolor e verde; vidros refletidos metalizados a vácuo prata neutro, azul médio e azul intenso médio; vidro 
reflectafloat. $O$ terceiro grupo reuniu os vidros planos incolor e verde; vidros refletivos pirolíticos prata e verde esmeralda; vidro refletivo metalizado a vácuo prata neutro; vidro reflectafloat.

Tomando como referência o vidro plano incolor e o vidro plano verde, considerado um vidro de bom desempenho, o objetivo dessa divisão foi reunir em um grupo os vidros refletivos pirolíticos e o reflectafloat (Grupo 1). O Grupo 2 reuniu os vidros refletivos metalizados a vácuo e o reflectafloat. Já o Grupo 3 procurou reunir vidros com coloração semelhante: pirolítico prata e metalizado a vácuo prata neutro, e plano verde e pirolítico verde esmeralda.

\section{Grupo 1}

- Célula-teste A: vidro plano verde $(4 \mathrm{~mm})$

- Célula-teste B: vidro refletivo pirolítico verde esmeralda $(6 \mathrm{~mm})$

- Célula-teste C: vidro refletivo pirolítico prata $(4 \mathrm{~mm})$

- Célula-teste $\mathrm{D}$ : vidro plano incolor $(4 \mathrm{~mm})$

- Célula-teste E: vidro refletivo pirolítico bronze $(4 \mathrm{~mm})$

- Célula-teste F: vidro reflectafloat $(4 \mathrm{~mm})$

\section{Grupo 2}

- Célula-teste A: vidro plano verde $(4 \mathrm{~mm})$

- Célula-teste B: vidro refletivo metalizado a vácuo azul intenso médio $(4 \mathrm{~mm})$

- Célula-teste C: vidro refletivo metalizado a vácuo azul médio $(4 \mathrm{~mm})$

- Célula-teste $\mathrm{D}$ : vidro plano incolor (4mm)

- Célula-teste E: vidro refletivo metalizado a vácuo prata neutro $(4 \mathrm{~mm})$

- Célula-teste F: vidro reflectafloat $(4 \mathrm{~mm})$ 


\section{Grupo 3}

- Célula-teste A: vidro plano verde $(4 \mathrm{~mm})$

- Célula-teste B: vidro refletivo pirolítico verde esmeralda $(6 \mathrm{~mm})$

- Célula-teste C: vidro refletivo pirolítico prata $(4 \mathrm{~mm})$

- Célula-teste D: vidro plano incolor $(4 \mathrm{~mm})$

- Célula-teste E: vidro refletivo metalizado a vácuo prata neutro $(4 \mathrm{~mm})$

- Célula-teste F: vidro reflectafloat $(4 \mathrm{~mm})$

\subsubsection{Avaliação dos dados obtidos}

Depois da coleta dos dados, foi feito um estudo dos resultados e confecção dos gráficos das variações da temperatura interna em relação à temperatura externa, bem como a avaliação do comportamento térmico dos vidros das célulasteste.

O processo de avaliação de dados passa pelas seguintes etapas:

1. dados de transporte (dados brutos sem tratamento);

2. dados horários (dados com análise de consistência);

3. gráfico dos elementos atmosféricos externos;

4. análise comparativa do comportamento térmico dos vidros.

O tratamento dos resultados começa após a transformação dos dados obtidos do software do CR10X para o formato do Microsoft Excel.

Foram comparadas as condições de temperatura dentro e fora das célulasteste, assim como a temperatura superficial dos vidros e paredes. 


\subsubsection{Método de tratamento e análise dos resultados}

Para cada grupo de vidros, foram realizadas medições durante uma semana, sendo descartado o dia no qual foram realizadas as trocas dos vidros, totalizando seis dias úteis para a elaboração dos dados. Além disso, foram descartados os dias de chuva. A estação forneceu as temperaturas medidas nas células-teste a cada 10 minutos e para a confecção dos gráficos e planilhas, foram feitas algumas adaptações nos dados coletados pela estação.

Para a elaboração dos gráficos e tabelas foram escolhidos os dias que apresentaram as maiores radiações, com o objetivo de descartar os dados que poderiam camuflar o verdadeiro desempenho dos vidros analisados. Foram feitos gráficos e tabelas com as temperaturas no exterior e no interior de cada célula-teste e nas superfícies dos vidros.

Primeiramente, com os valores medidos de temperaturas internas nas célulasteste, foi possível avaliar qual o vidro protege mais e qual o vidro que deixa passar mais radiação solar, aquecendo o interior das mesmas.

Os valores de temperaturas superficiais permitiram avaliar qual o vidro que absorve mais a radiação solar, aquecendo a superfície do mesmo. Além disso, as temperaturas superficiais dos vidros permitiram verificar a direção do fluxo de calor.

Dessa maneira, foi possível verificar as condições de temperatura no interior e no exterior das células-teste e nas superfícies dos vidros com relação à temperatura externa, visualizando o fluxo de calor através do vidro considerando a incidência ou não da radiação solar. 


\subsection{Método de obtenção do ganho de calor}

A densidade do fluxo de ganho de calor (q) através do material transparente é obtido através da soma do Ganho de Calor Solar e da transferência de calor devida à diferença de temperatura entre o ar exterior e o interior (AMERICAN SOCIETY OF HEATING REFRIGERATING AND AIR CONDITIONING ENGINEERS, 1997).

$$
q=F S .(l o)+U .(t e-t i)
$$

onde:

$q=$ densidade do fluxo de ganho de calor através do material transparente $\left(\mathrm{W} / \mathrm{m}^{2}\right)$

FS = Fator Solar

lo = energia incidente $\left(\mathrm{W} / \mathrm{m}^{2}\right)$

$\mathrm{U}=$ transmitância térmica total $\left(\mathrm{W} / \mathrm{m}^{2} \stackrel{\circ}{\mathrm{o}}\right)$

$($ te $-\mathrm{ti})=$ diferença entre a temperatura do ar externo e interno $\left({ }^{\circ} \mathrm{C}\right)$

Para o cálculo do ganho de calor foi utilizado o procedimento descrito no trabalho de Santos (2002). Cada componente da fórmula foi determinado conforme segue:

\section{Fator Solar}

Santos (2002) dividiu os vidros ensaiados em cinco grupos com similaridade de comportamento de variação do FCS com o ângulo de incidência. Os materiais transparentes ensaiados foram agrupados da seguinte maneira: 
- Grupo 1A - Vidros planos incolores; vidro refletivo pirolítico prata; vidro laminado refletivo prata (base do vidro refletivo pirolítico prata); películas comuns; policarbonatos incolor, verde e azul; acrílico incolor.

- Grupo 1B - Vidros planos coloridos; vidros refletivos pirolíticos verde, bronze e cinza; policarbonatos bronze e cinza fumê.

- Grupo 2A - Vidros laminados incolor, verde e azul (baixa absorção e alta transmissão).

- Grupo 2B - Demais vidros laminados (alta absorção e baixa transmissão).

- Grupo 3 - Vidros refletivos metalizados a vácuo CEBRACE; vidros laminados refletivos azul claro e cinza escuro (possuem como base os vidros refletivos metalizados a vácuo CEBRACE).

- Grupo 4 - Vidros refletivos metalizados a vácuo Guardian.

- Grupo 5 - Películas refletivas.

Para cada grupo foi definido um material de referência para o qual foi efetuado o cálculo do Ganho de Calor Solar, considerando para este material a variação do FCS com o ângulo de incidência. Para o cálculo do Fator Solar para os diferentes ângulos, para o material de referência, foi utilizada a seguinte equação (SANTOS et al., 2003):

$$
\begin{aligned}
& \text { FCS }=[\operatorname{Cos}(\text { Anglnc })]^{A} \\
& A=B \times \text { Anglnc }^{C}
\end{aligned}
$$

sendo:

Anglnc = ângulo de incidência dos raios solares sobre a fachada (radianos) $\mathrm{B}$ e $\mathrm{C}=$ parâmetros tabelados em função do grupo do material transparente 
Tabela 2 - Parâmetros da equação 12

\begin{tabular}{ccc}
\hline Grupo & B & C \\
\hline 1A & 0,18575 & 2,44111 \\
1B & 0,18575 & 2,44111 \\
3 & 0,17478 & 1,90741 \\
\hline
\end{tabular}

Fonte: Modificada de Santos, 2002

Depois de efetuado o cálculo do Ganho de Calor Solar para o material de referência, para efetuar o cálculo para o material utilizado, o valor obtido foi multiplicado pelo Coeficiente de Admissão de Calor (CAC). O CAC de um mesmo material é constante para uma mesma posição de superfície e velocidade do vento. Foi considerada a velocidade do vento como sendo $2,0 \mathrm{~m} / \mathrm{s}$, conforme se verificou nos dados coletados pela estação meteorológica durante os períodos analisados, e a superfície na posição vertical. Os valores de CAC foram tabelados da seguinte maneira:

Tabela 3 - Valores de FCS normal ou CAC para diferentes vidros

\begin{tabular}{lcc}
\hline Vidro & Espessura & $\begin{array}{c}\text { FCS normal ou CAC } \\
\text { Sup. Vertical - Vo= 2m/s }\end{array}$ \\
\hline Plano incolor & $4 \mathrm{~mm}$ & 0,86 \\
Plano verde & $4 \mathrm{~mm}$ & 0,74 \\
Refletivo pirolítico prata & $4 \mathrm{~mm}$ & 0,55 \\
Refletivo pirolítico verde esmeralda & $6 \mathrm{~mm}$ & 0,44 \\
Refletivo pirolítico bronze & $4 \mathrm{~mm}$ & 0,51 \\
Refletivo metalizado a vácuo prata neutro & $4 \mathrm{~mm}$ & 0,27 \\
Refletivo metalizado a vácuo azul médio & $4 \mathrm{~mm}$ & 0,39 \\
$\begin{array}{l}\text { Refletivo metalizado a vácuo azul intenso } \\
\text { médio }\end{array}$ & $4 \mathrm{~mm}$ & 0,31 \\
\hline
\end{tabular}

Fonte: Modificada de Santos, 2002 
Para o cálculo do ganho de calor é necessário somar os ganhos de radiação direta, difusa do céu e difusa refletida, que têm diferentes ângulos de incidência. Assim, para o cálculo do Fator Solar foram utilizados para a radiação direta os ângulos de incidência do sol no momento considerado, obtidos através de um programa computacional, enquanto que para as radiações difusas foi adotado para todos os horários um ângulo equivalente de incidência, conforme Santos (2002), que para superfície vertical é de $60^{\circ}$.

\section{Radiação solar incidente}

Para o cálculo da radiação solar incidente, foi utilizado o programa computacional RadSol desenvolvido por Maurício Roriz para a obtenção das quantidades de radiação solar para diversas orientações em superfícies verticais, usando os valores de radiação em superfície horizontal coletados pela estação meteorológica. Neste programa, os dados de entrada foram fixados para a cidade de Campinas, e também foram registrados os dias de interesse e a quantidade de horas de insolação.

Coeficientes de trocas superficiais de calor externo (he), interno (hi) e Coeficiente global de transferência de calor (Fator U)

$\mathrm{O}$ fator $\mathrm{U}$ engloba tanto as trocas térmicas envolvidas no conjunto das diversas camadas constituintes do elemento de vedação, como as trocas por radiação e convecção nas duas faces do mesmo. $O$ fator $U$, que corresponde ao inverso da resistência térmica total $(R)$, é dado por: 


$$
R=\frac{1}{U}=\frac{1}{h_{i}}+\frac{d}{\lambda}+\frac{1}{h_{e}}
$$

onde:

$\mathrm{U}=$ transmitância térmica total $\left(\mathrm{W} / \mathrm{m}^{2}{ }^{\mathrm{C}}\right)$

$h_{i}=$ coeficiente superficial interno de transmissão de calor $\left(W / m^{2}{ }^{C}\right)$

$d=$ espessura do componente $(m)$

$\lambda=$ condutividade térmica do material $\left(\mathrm{W} / \mathrm{m}^{2}{ }^{\circ} \mathrm{C}\right)$

$h_{e}=$ coeficiente superficial externo de transmissão de calor $\left(W / m^{2}{ }^{\circ}\right)$

No presente trabalho foram adotados os valores de he e hi do trabalho de Santos (2002), como mostra a Tabela 4 a seguir:

Tabela 4 - Valores de he e hi dos materiais transparentes para diferentes velocidades do vento (Vo)

\begin{tabular}{|c|c|c|c|c|c|c|c|c|c|c|c|}
\hline \multirow{2}{*}{$\begin{array}{l}\text { Material } \\
\text { Transparente }\end{array}$} & \multicolumn{2}{|c|}{$h_{r}$} & \multirow{2}{*}{ Superfície } & \multirow{2}{*}{$\begin{array}{c}h_{i} \\
V_{o}=0\end{array}$} & \multicolumn{7}{|c|}{$h_{e}$ em função de $V_{o}(\mathrm{~m} / \mathrm{s})$ e $h_{c}$ médio } \\
\hline & Int. & Ext. & & & 0 & 0,5 & 1,0 & 1,5 & 2,0 & 2,5 & 3,0 \\
\hline \multirow{2}{*}{$\begin{array}{l}\text { Vidros float sem } \\
\text { tratamento } \\
\text { superficial }\end{array}$} & \multirow{2}{*}{5,6} & \multirow{2}{*}{5,6} & Vertical & 8,7 & 8,7 & 9,1 & 9,7 & 10,4 & 11,0 & 11,7 & 12,4 \\
\hline & & & Horizontal & 7,5 & 9,4 & 9,7 & 10,2 & 10,8 & 11,4 & 12,0 & 12,7 \\
\hline \multirow{2}{*}{$\begin{array}{l}\text { Camada refletiva } \\
\text { pirolítica interna }\end{array}$} & \multirow{2}{*}{1,2} & \multirow{2}{*}{5,6} & Vertical & 4,3 & 8,7 & 9,1 & 9,7 & 10,4 & 11,0 & 11,7 & 12,4 \\
\hline & & & Horizontal & 3,1 & 9,4 & 9,7 & 10,2 & 10,8 & 11,4 & 12,0 & 12,7 \\
\hline \multirow{2}{*}{$\begin{array}{l}\text { Camada refletiva } \\
\text { a vácuo }\end{array}$} & \multirow{2}{*}{1,0} & \multirow{2}{*}{5,6} & Vertical & 4,1 & 8,7 & 9,1 & 9,7 & 10,4 & 11,0 & 11,7 & 12,4 \\
\hline & & & Horizontal & 2,9 & 9,4 & 9,7 & 10,2 & 10,8 & 11,4 & 12,0 & 12,7 \\
\hline \multirow{2}{*}{$\begin{array}{l}\text { Películas } \\
\text { refletivas }\end{array}$} & \multirow{2}{*}{1,6} & \multirow{2}{*}{5,6} & Vertical & 4,7 & 8,7 & 9,1 & 9,7 & 10,4 & 11,0 & 11,7 & 12,4 \\
\hline & & & Horizontal & 3,5 & 9,4 & 9,7 & 10,2 & 10,8 & 11,4 & 12,0 & 12,7 \\
\hline \multirow{2}{*}{$\begin{array}{l}\text { Películas não } \\
\text { refletivas }\end{array}$} & \multirow{2}{*}{5,6} & \multirow{2}{*}{5,6} & Vertical & 8,7 & 8,7 & 9,1 & 9,7 & 10,4 & 11,0 & 11,7 & 12,4 \\
\hline & & & Horizontal & 7,5 & 9,4 & 9,7 & 10,2 & 10,8 & 11,4 & 12,0 & 12,7 \\
\hline \multirow{2}{*}{$\begin{array}{l}\text { Policarbonatos e } \\
\text { acrílico }\end{array}$} & \multirow{2}{*}{6,0} & \multirow{2}{*}{6,0} & Vertical & 9,1 & 9,1 & 9,5 & 10,1 & 10,8 & 11,4 & 12,1 & 12,8 \\
\hline & & & Horizontal & 7,9 & 9,8 & 10,1 & 10,6 & 11,4 & 11,8 & 12,4 & 13,1 \\
\hline
\end{tabular}

Fonte: Santos, 2002 
Foi considerada a velocidade do vento como sendo $2,0 \mathrm{~m} / \mathrm{s}$. Assim, foram adotados os seguintes valores de he e hi, para os vidros analisados:

- Vidros planos: $h i=8,7 \mathrm{~W} / \mathrm{m}^{\circ}{ }^{\circ} \mathrm{C}$

$$
\text { he }=11,0 \mathrm{~W} / \mathrm{m}^{\circ}{ }^{\circ} \mathrm{C}
$$

- Vidros pirolíticos: $\mathrm{hi}=4,3 \mathrm{~W} / \mathrm{m}^{\circ}{ }^{\circ} \mathrm{C}$

$$
\text { he }=11,0 \mathrm{~W} / \mathrm{m}^{\circ}{ }^{\circ} \mathrm{C}
$$

- Vidros metalizados a vácuo: $\mathrm{hi}=4,1 \mathrm{~W} / \mathrm{m}^{\circ}{ }^{\circ} \mathrm{C}$

$$
\text { he }=11,0 \mathrm{~W} / \mathrm{m}^{\circ}{ }^{\circ} \mathrm{C}
$$

Em seguida, foram calculados os valores de U:

- Vidros planos $4 \mathrm{~mm}: \mathrm{U}=4,7653 \mathrm{~W} / \mathrm{m} 2^{\circ} \mathrm{C}$

- Vidros pirolíticos $4 \mathrm{~mm}: \mathrm{U}=3,0537 \mathrm{~W} / \mathrm{m}^{\circ}{ }^{\circ} \mathrm{C}$

- Vidro pirolítico $6 \mathrm{~mm}: \mathrm{U}=3,0352 \mathrm{~W} / \mathrm{m} 2^{\circ} \mathrm{C}$

- Vidros metalizados a vácuo $4 \mathrm{~mm}: \mathrm{U}=2,9515 \mathrm{~W} / \mathrm{m} 2^{\circ} \mathrm{C}$

\section{Diferença entre a temperatura do ar externo e interno (te $-\mathrm{ti})$}

As temperaturas externas foram registradas pela estação meteorológica durante os períodos de medições, enquanto que as temperaturas internas foram registradas através dos termopares localizados no centro geométrico de cada célula- 
teste, a uma altura de 1,30m. Dessa forma, tem-se o valor exato das temperaturas externas e internas para cada horário determinado e para cada período analisado. 


\section{RESULTADOS}

\subsection{Células-teste}

Os resultados referem-se às medições realizadas para os vidros refletivos pirolíticos e metalizados a vácuo, tanto no período do inverno como no período do verão. As medições foram realizadas em dias claros, com o monitoramento constante das células-teste. Objetiva-se não somente analisar os dados obtidos, mas principalmente compará-los aos dados laboratoriais. Estas análises são importantes pois muitas vezes os vidros são escolhidos por motivos estéticos e são desconsideradas as variáveis ambientais.

\subsubsection{Medições de inverno}

A primeira etapa de medições das várias tipologias de vidros abrangeu os meses de julho e agosto de 2005, sendo que as Figuras 45 a 62 expostas a seguir referem-se aos dados obtidos das temperaturas superficiais dos vidros e no interior das células-teste.

\subsubsection{Resultados para os grupos de vidros}




\section{Grupo 1}

Fachada Oeste: 14 de julho de 2005

Fachada Norte: 21 de julho de 2005

\section{- Temperaturas superficiais externas}

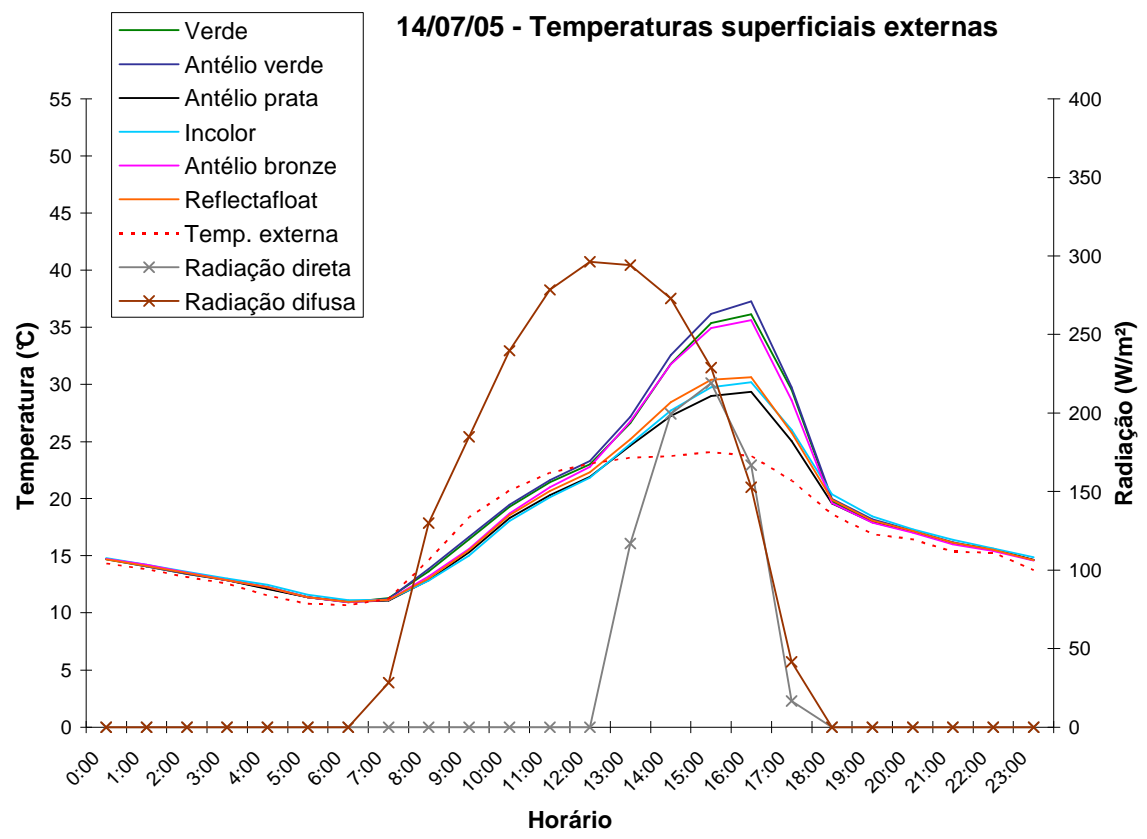

Figura 45. Temperaturas superficiais externas dos vidros e a temperatura externa - Oeste

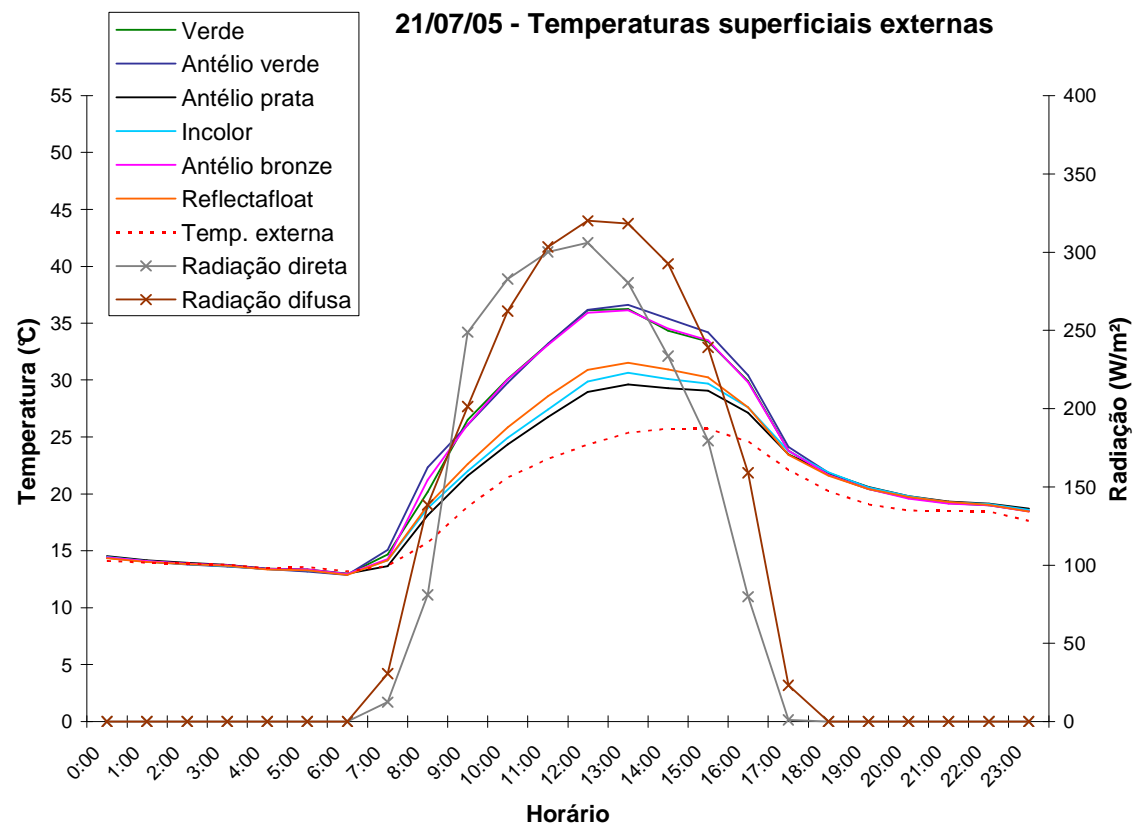

Figura 46. Temperaturas superficiais externas dos vidros e a temperatura externa - Norte 
- Temperaturas superficiais internas

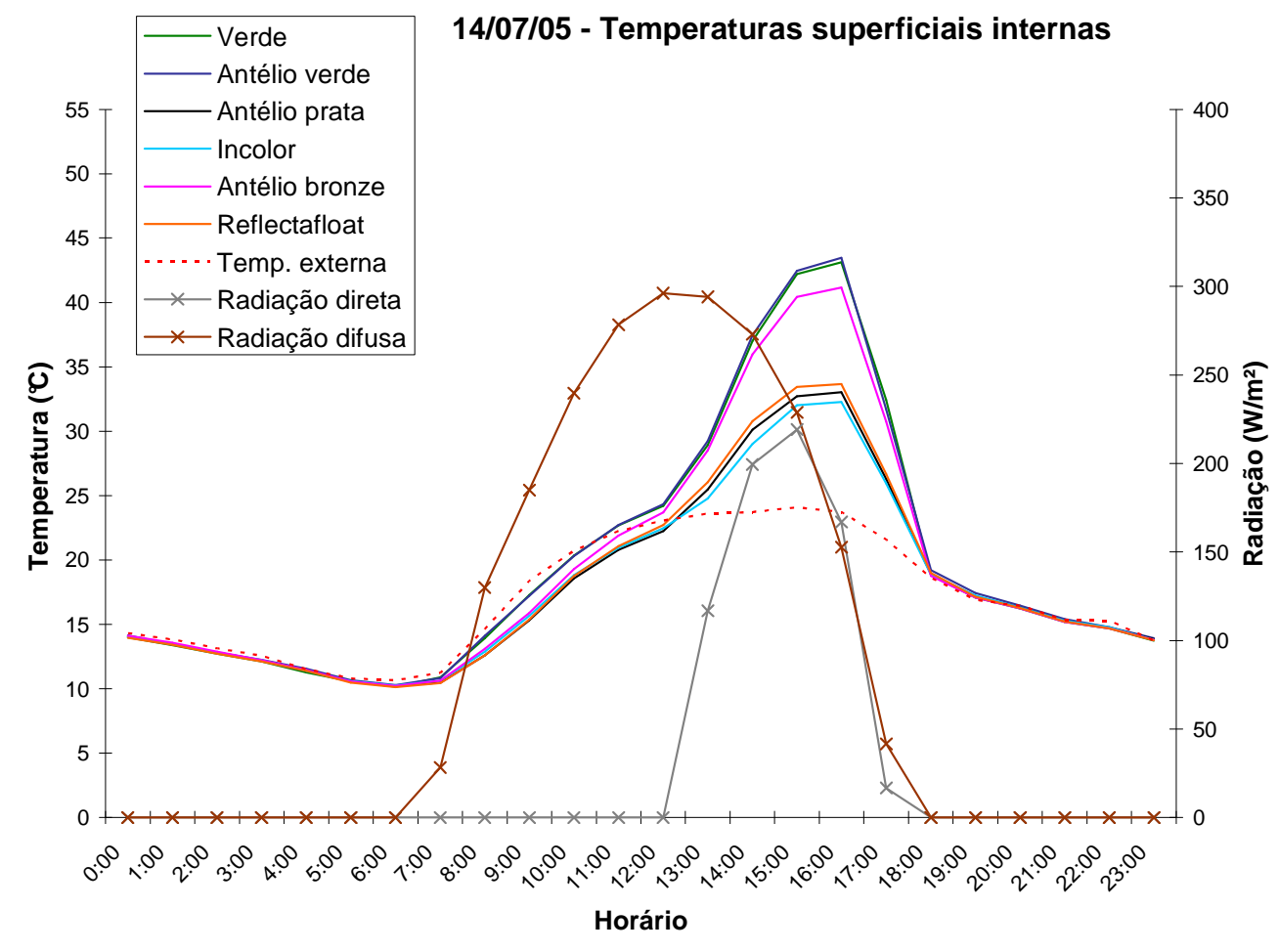

Figura 47. Temperaturas superficiais internas dos vidros e a temperatura externa - Oeste

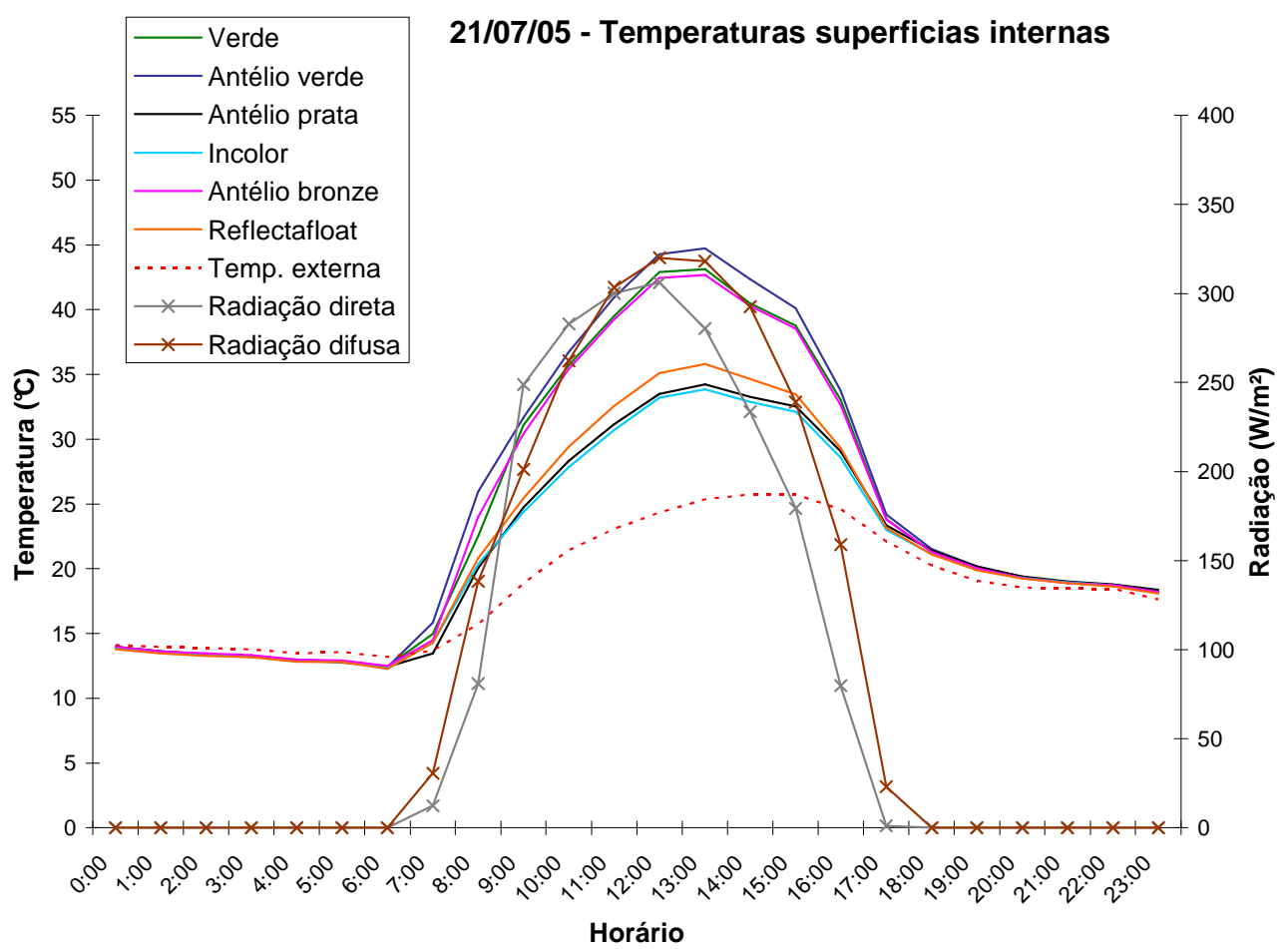

Figura 48. Temperaturas superficiais internas dos vidros e a temperatura externa - Norte 


\section{- Temperaturas internas}

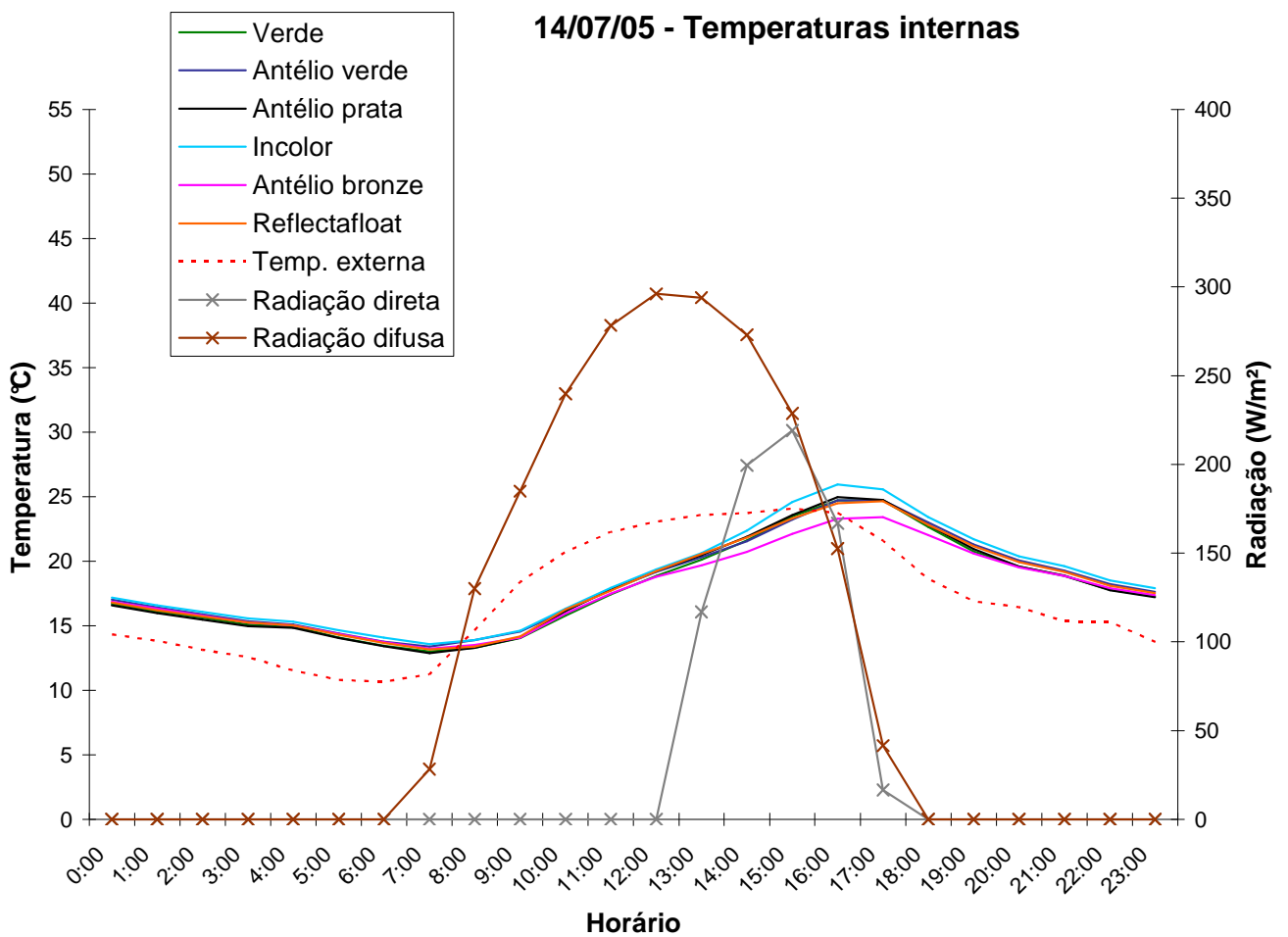

Figura 49. Temperaturas internas das células-teste e a temperatura externa - Oeste

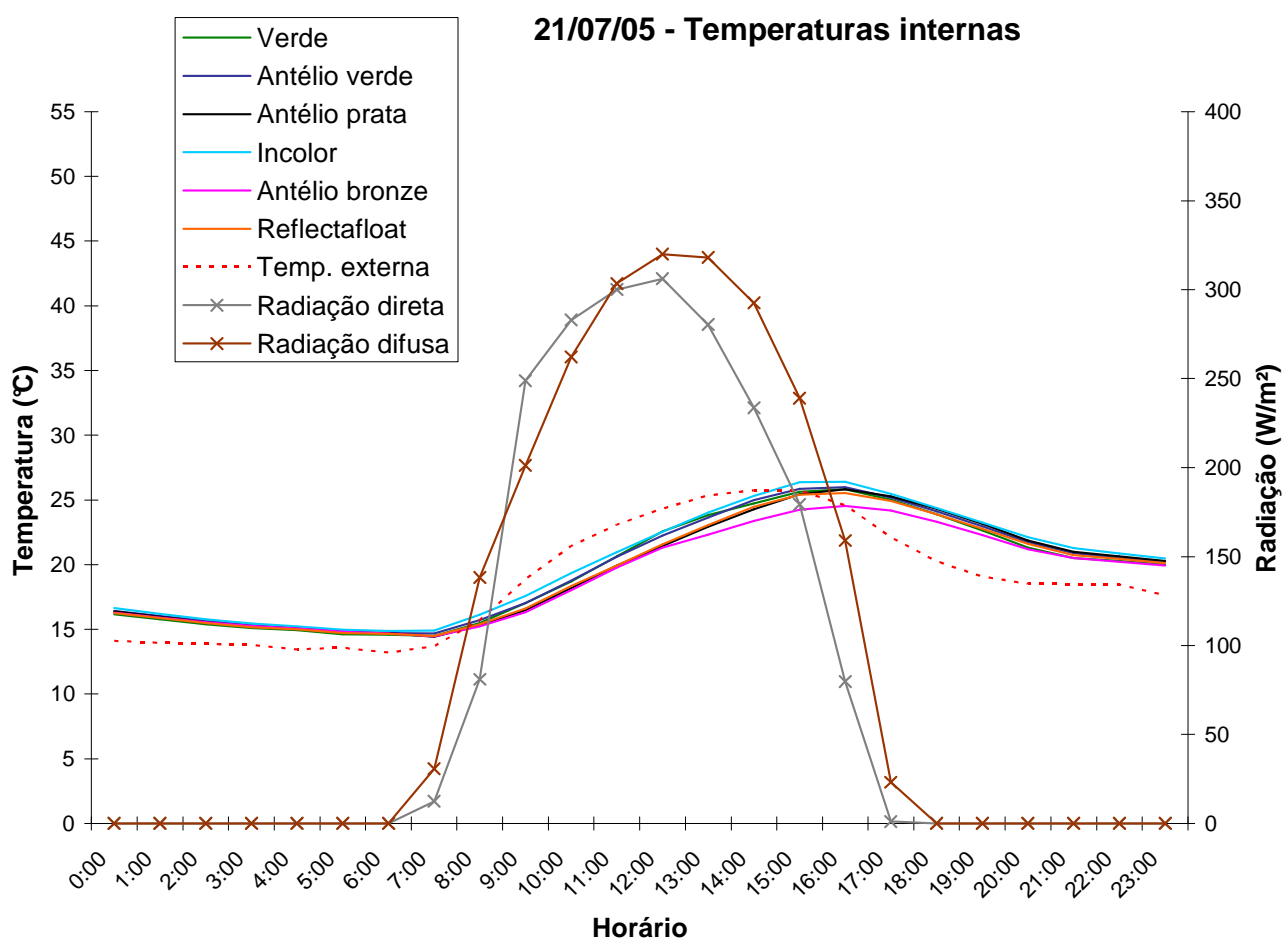

Figura 50. Temperaturas internas das células-teste e a temperatura externa - Norte 


\section{Grupo 2}

Fachada Oeste: 05 de agosto de 2005

Fachada Norte: 30 de julho de 2005

\section{- Temperaturas superficiais externas}

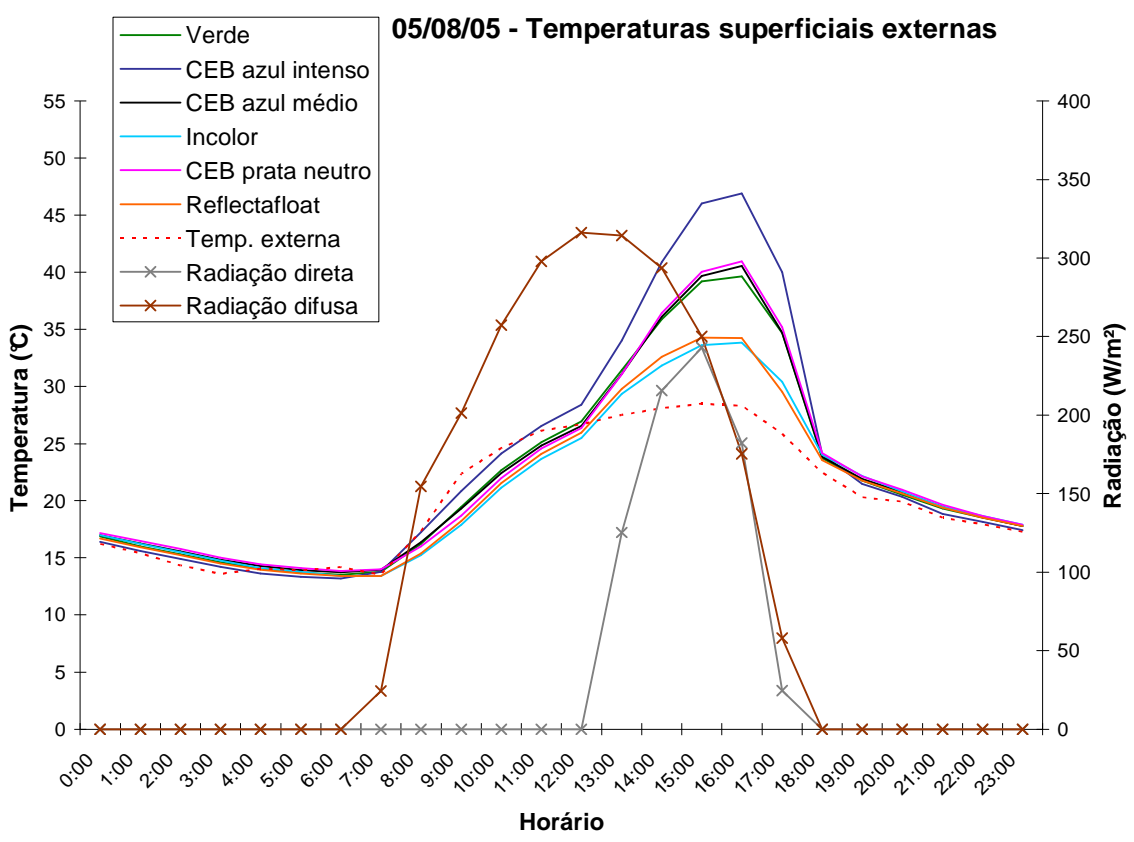

Figura 51. Temperaturas superficiais externas dos vidros e a temperatura externa - Oeste

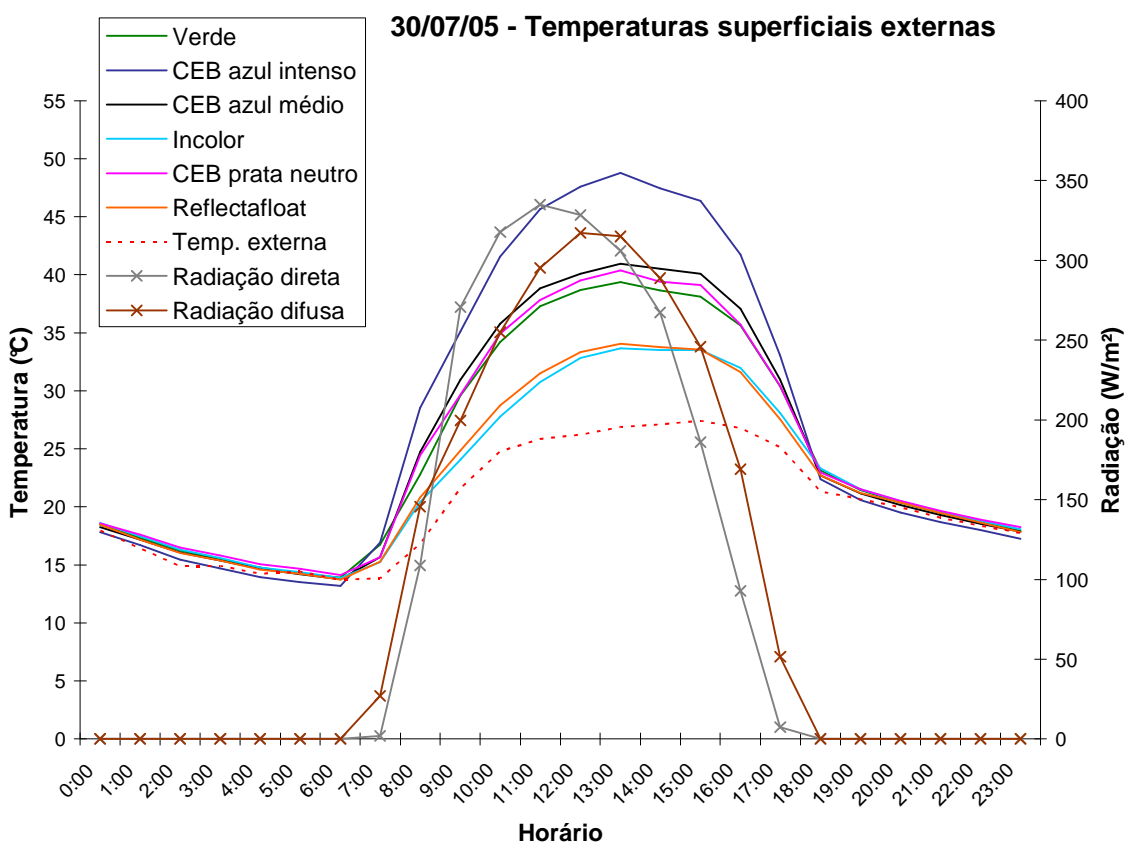

Figura 52. Temperaturas superficiais externas dos vidros e a temperatura externa - Norte 


\section{- Temperaturas superficiais internas}

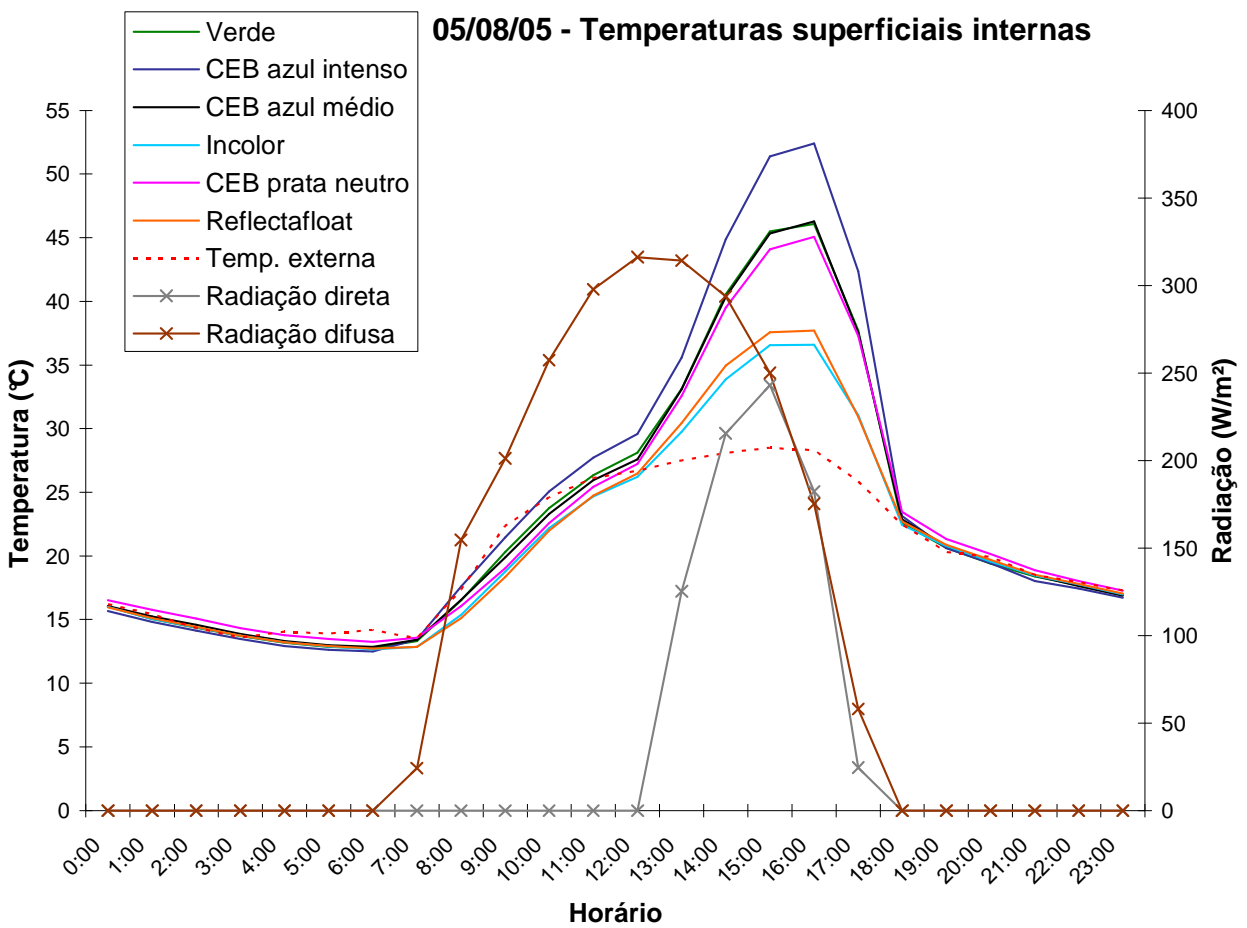

Figura 53. Temperaturas superficiais internas dos vidros e a temperatura externa - Oeste

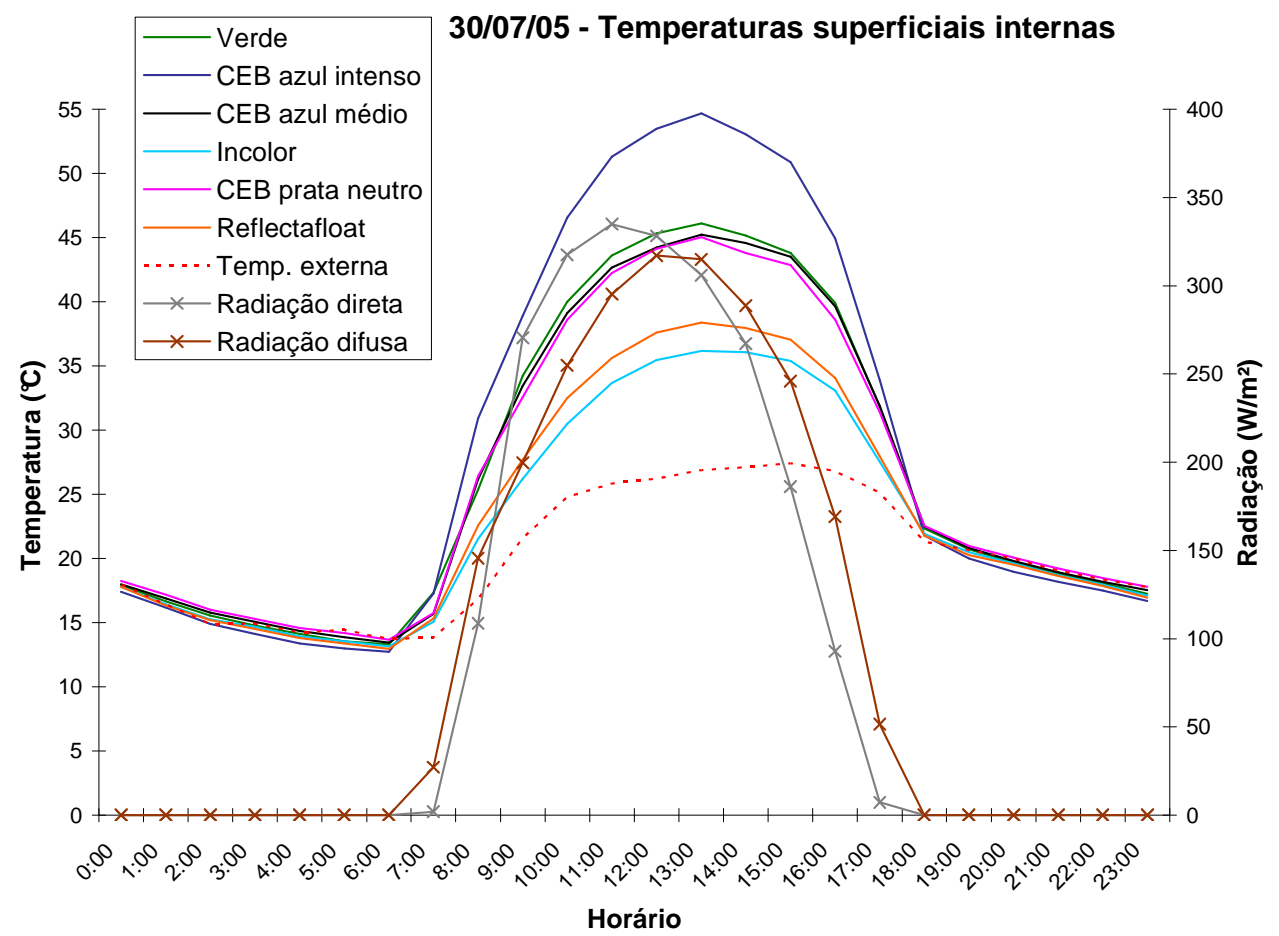

Figura 54. Temperaturas superficiais internas dos vidros e a temperatura externa - Norte 


\section{- Temperaturas internas}

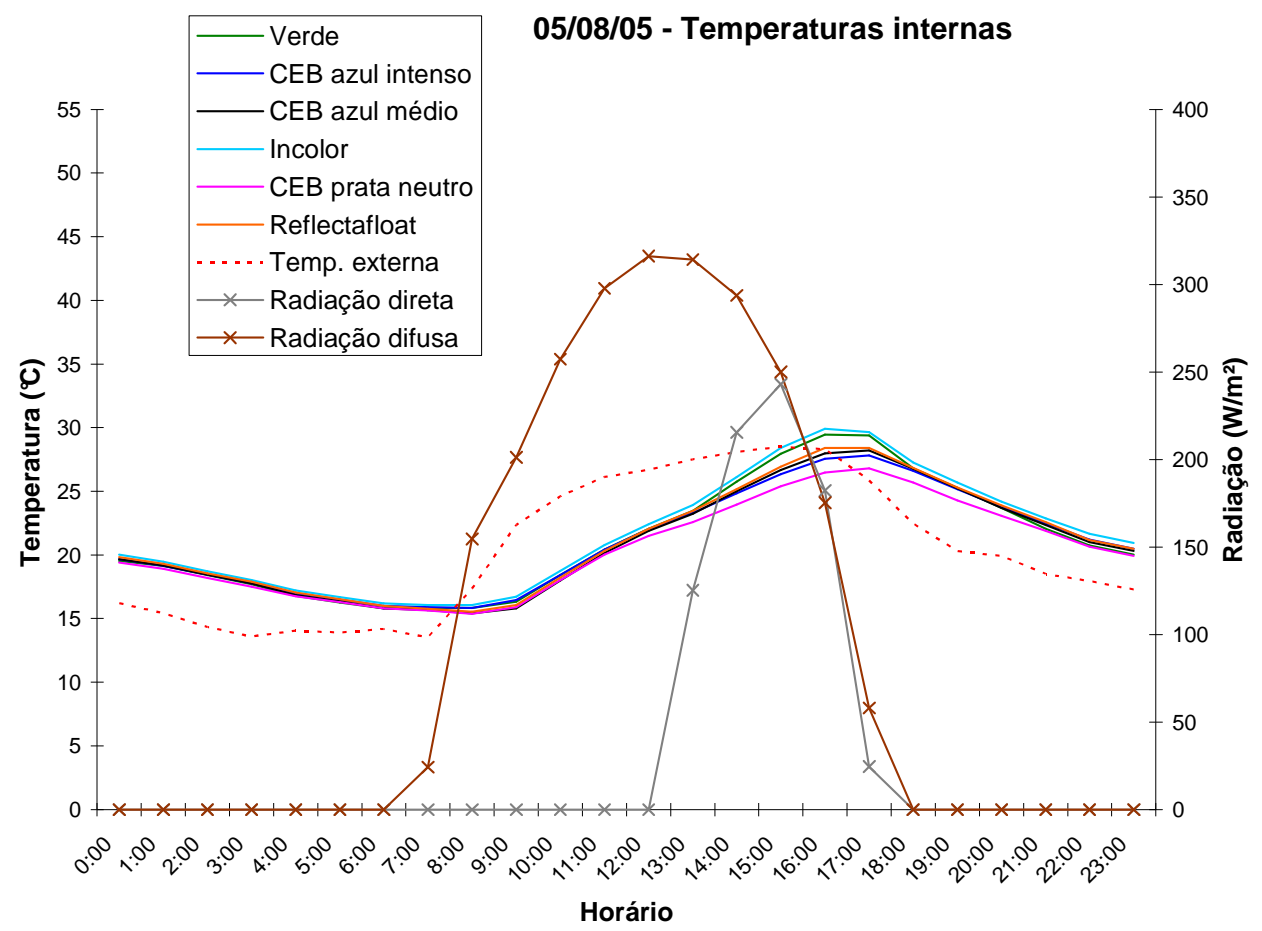

Figura 55. Temperaturas internas das células-teste e a temperatura externa - Oeste

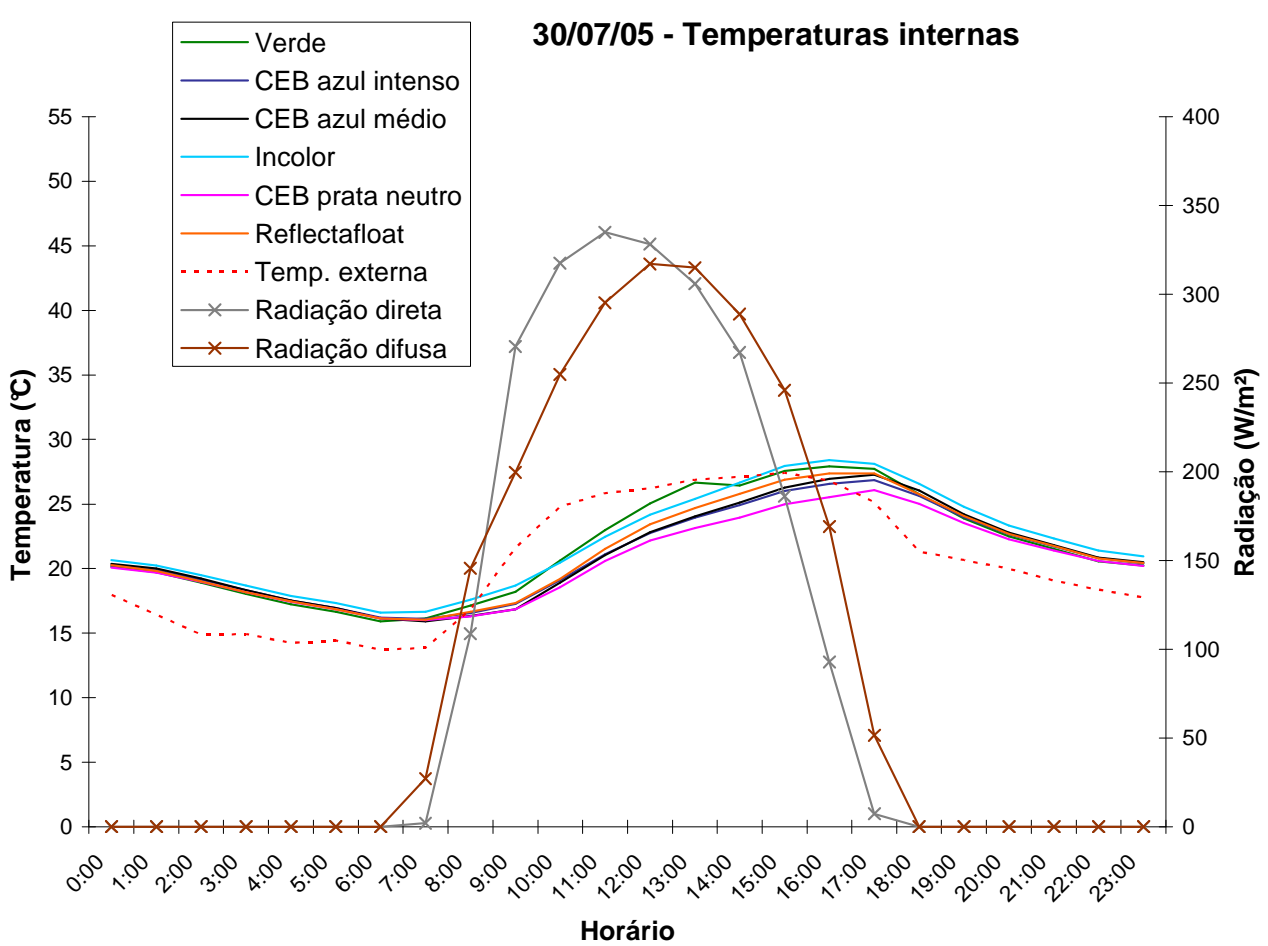

Figura 56. Temperaturas internas das células-teste e a temperatura externa - Norte 


\section{Grupo 3}

Fachada Oeste: 13 de agosto de 2005

Fachada Norte: 21 de agosto de 2005

\section{- Temperaturas superficiais externas}

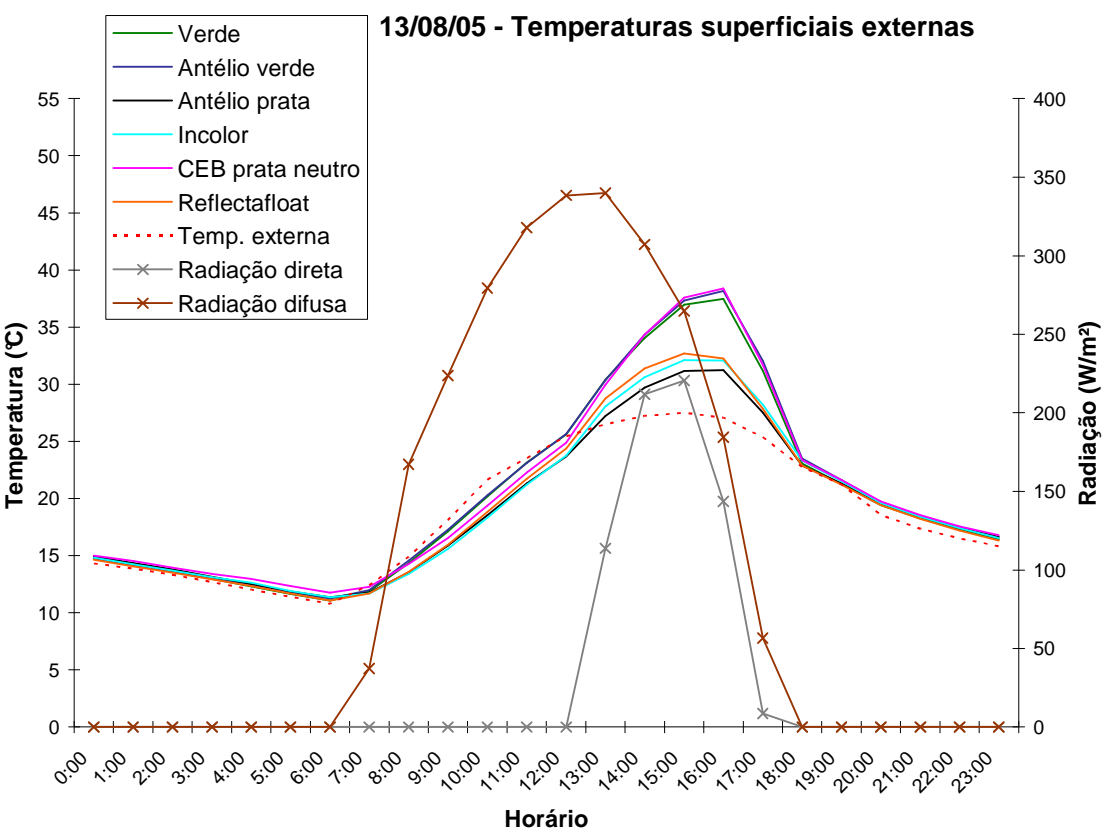

Figura 57. Temperaturas superficiais externas dos vidros e a temperatura externa - Oeste

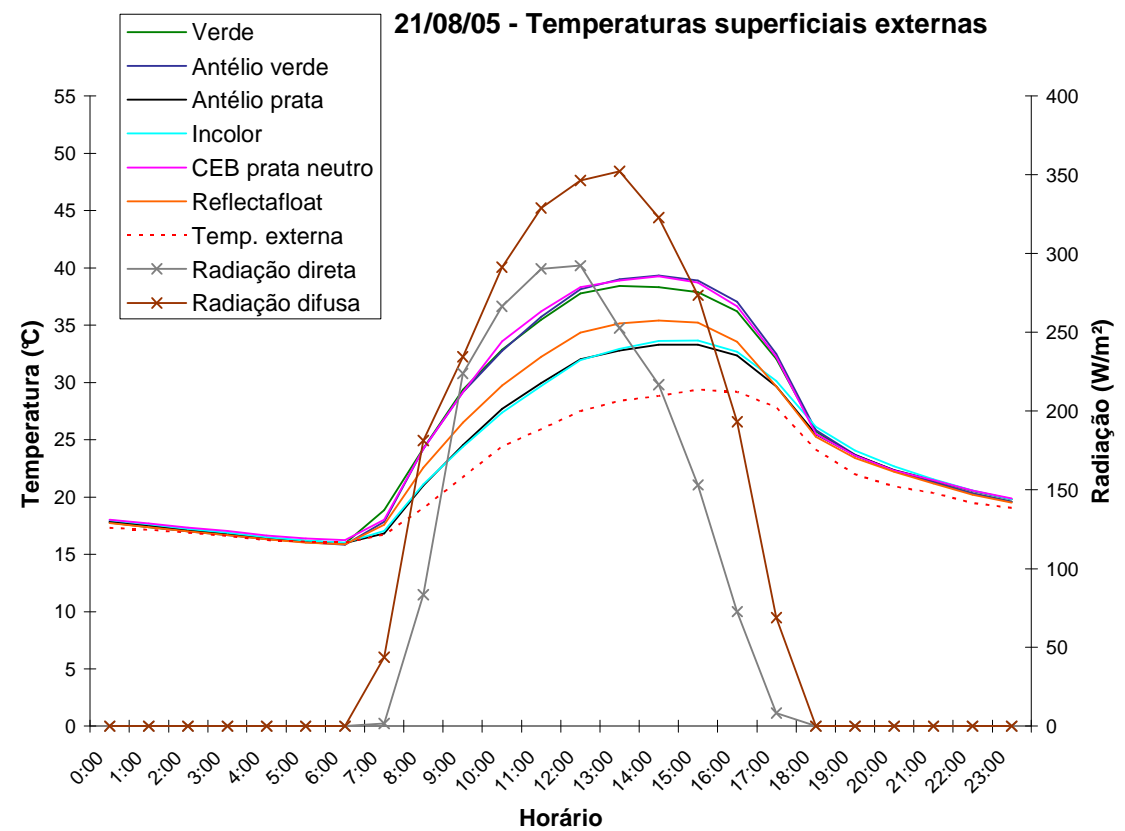

Figura 58. Temperaturas superficiais externas dos vidros e a temperatura externa - Norte 
118

- Temperaturas superficiais internas

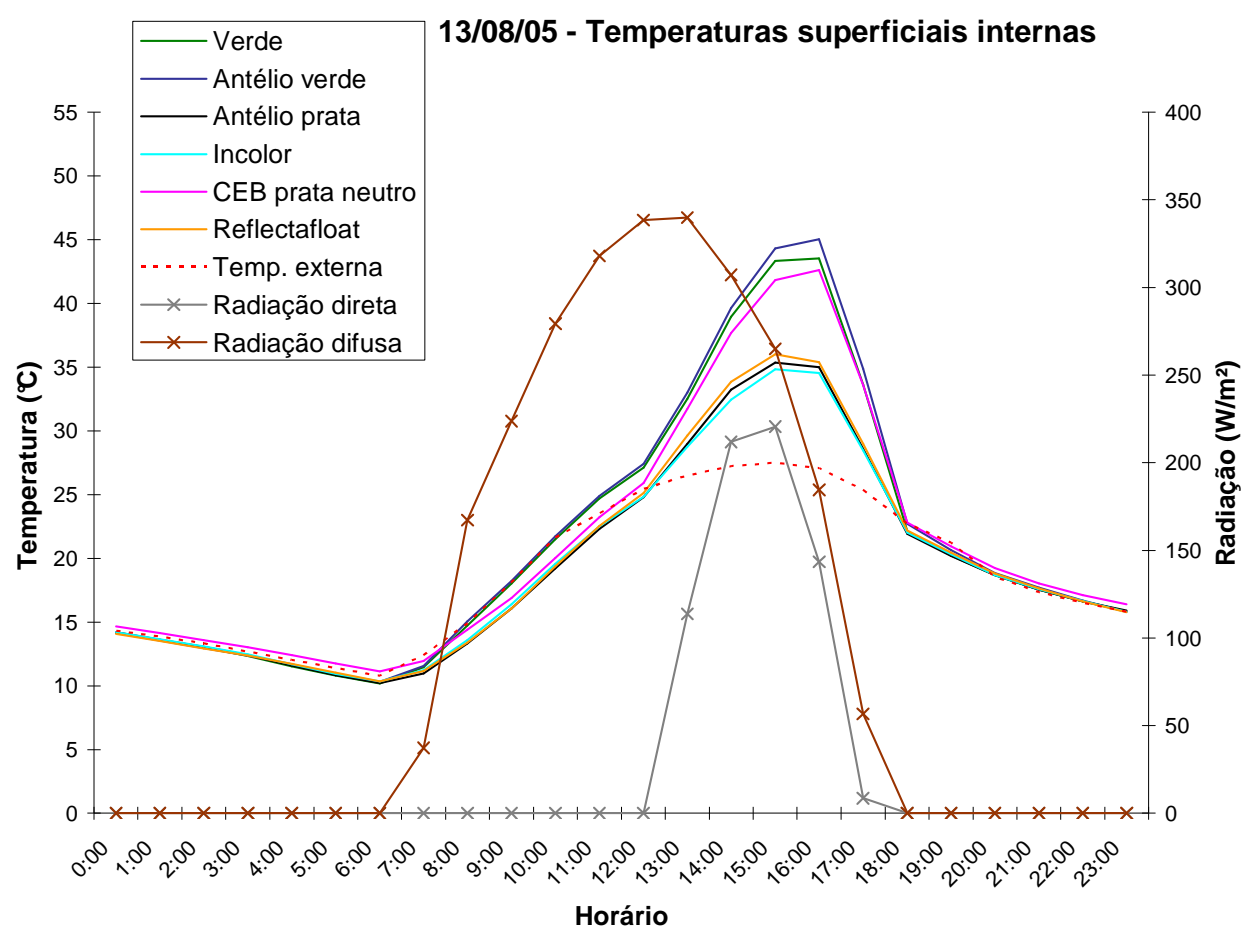

Figura 59. Temperaturas superficiais internas dos vidros e a temperatura externa - Oeste

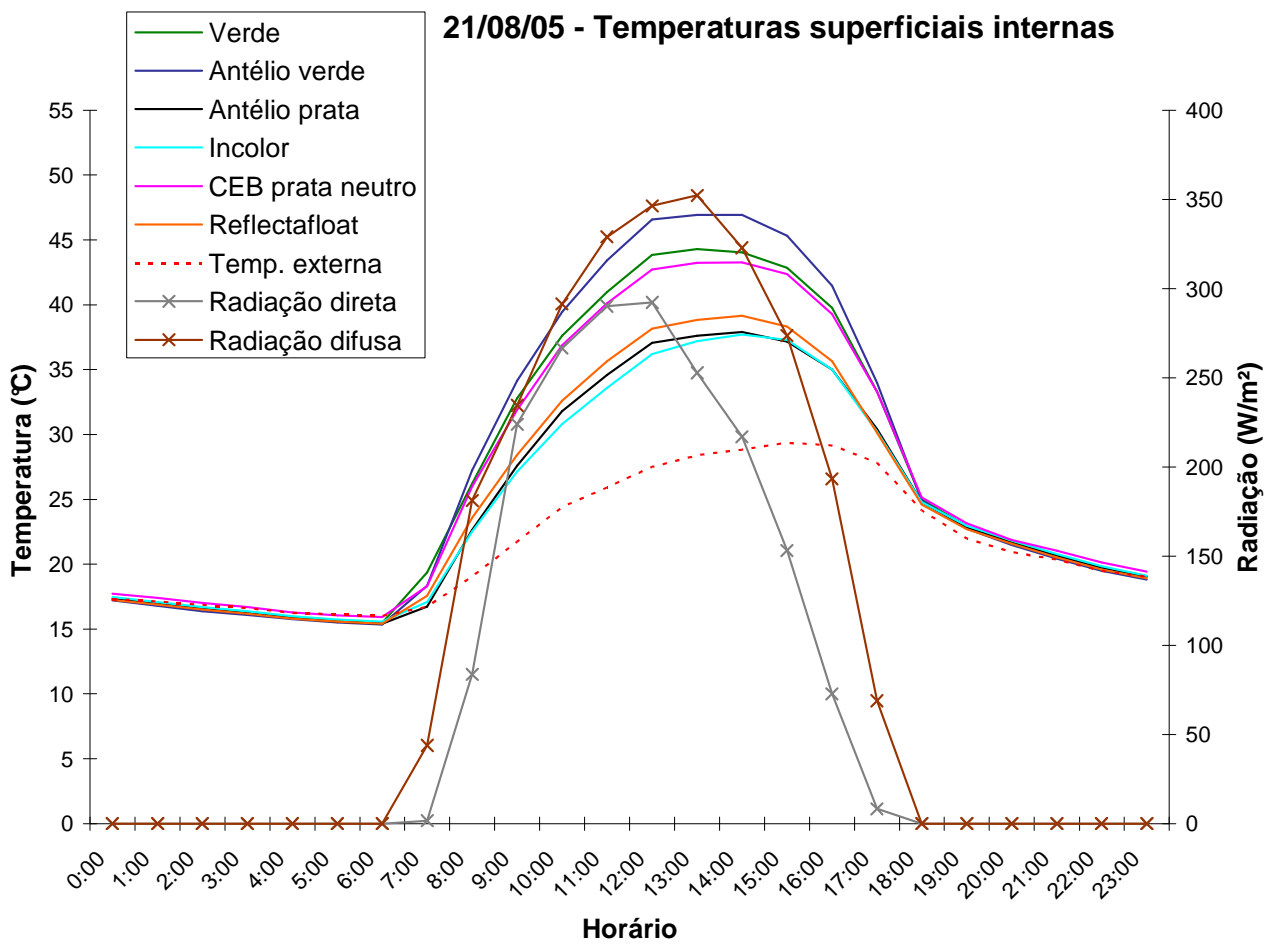

Figura 60. Temperaturas superficiais internas dos vidros e a temperatura externa - Norte 


\section{- Temperaturas internas}

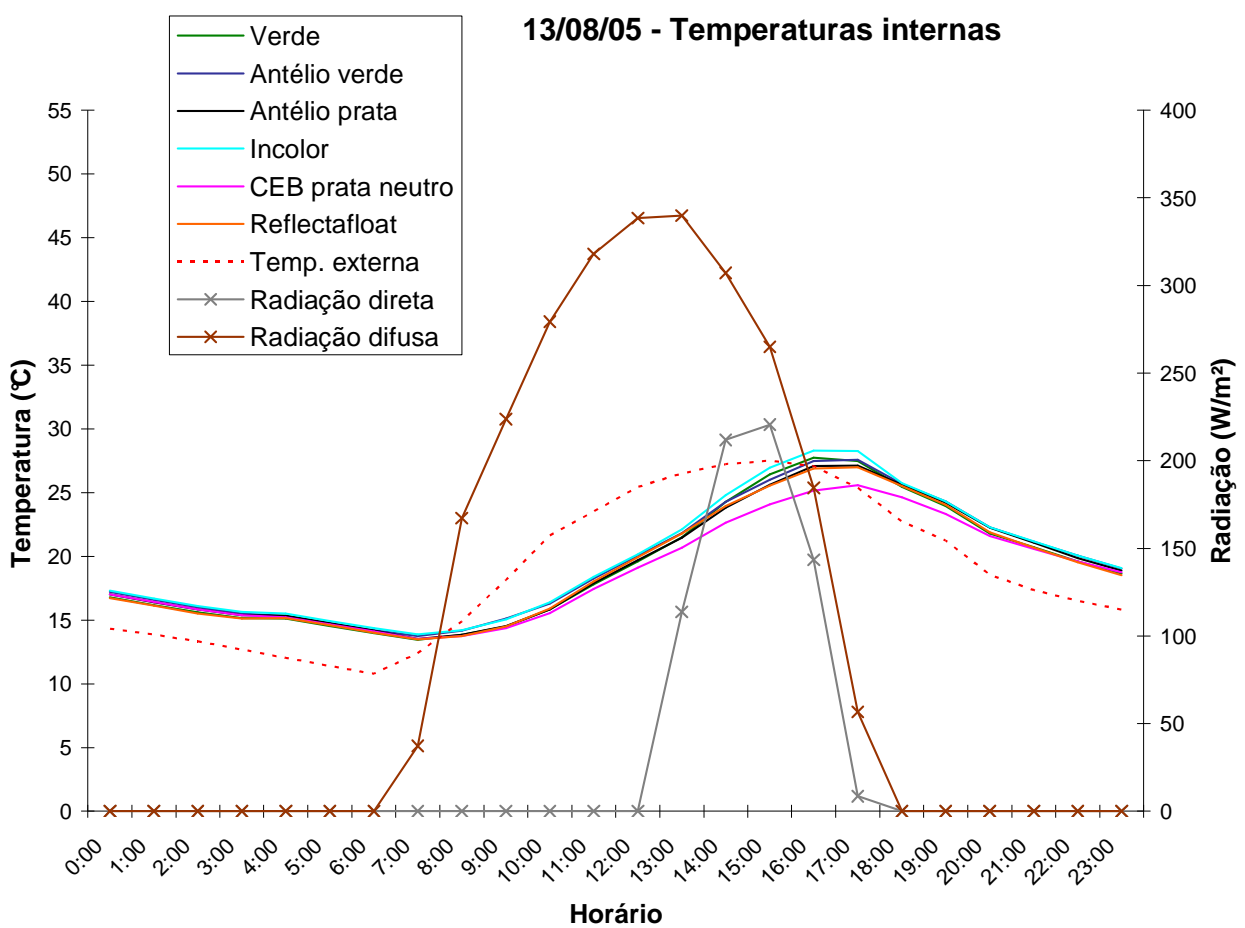

Figura 61. Temperaturas internas das células-teste e a temperatura externa - Oeste

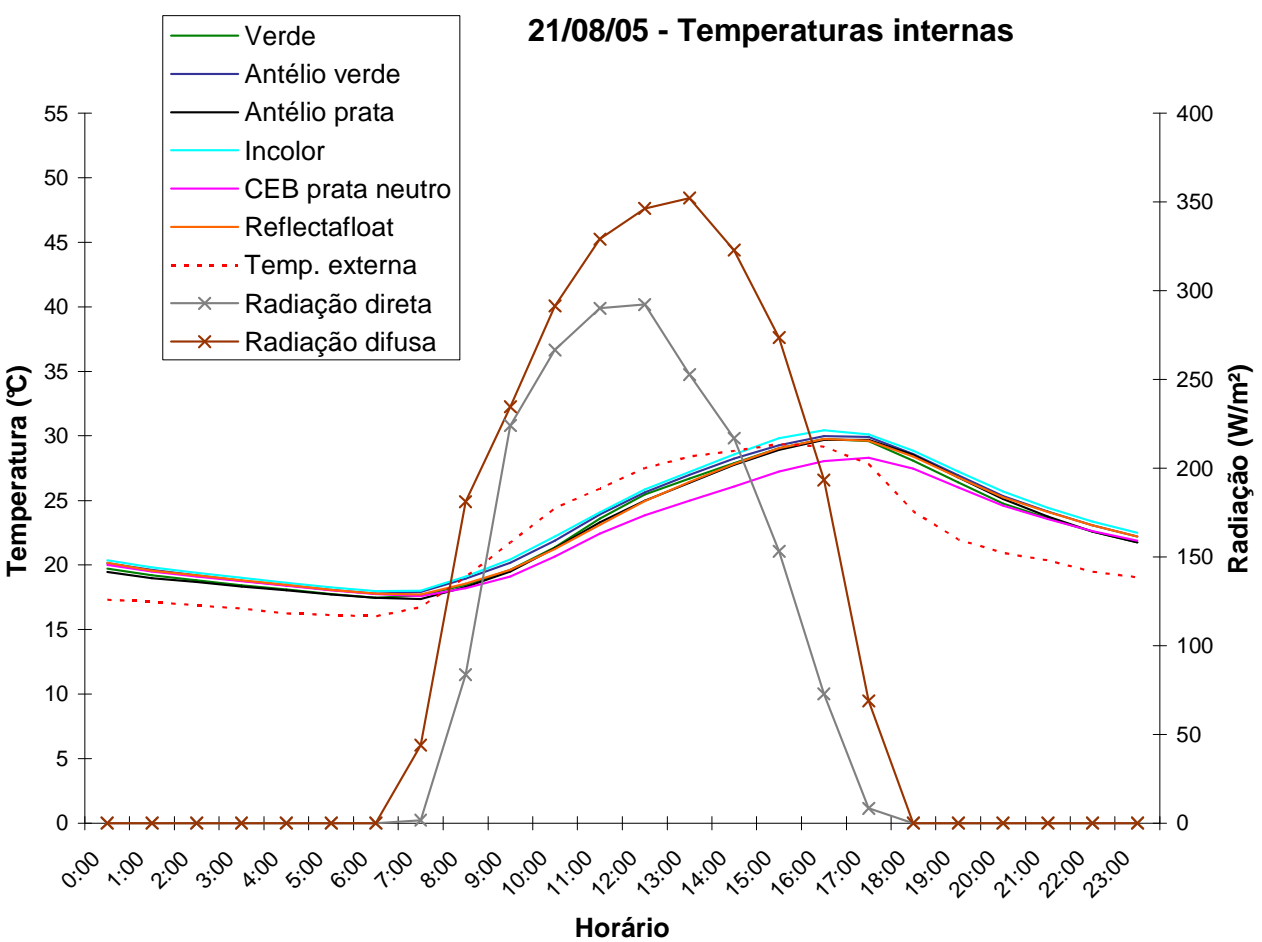

Figura 62. Temperaturas internas das células-teste e a temperatura externa - Norte 


\subsection{Discussão}

Os ensaios foram realizados em dias claros e eles visaram analisar como os vidros, em uma situação real (in loco), comportam-se com relação à radiação solar incidente. Desta forma, pôde-se verificar as temperaturas no interior das célulasteste, além das temperaturas superficiais dos vidros.

\section{- Temperaturas superficiais externas}

Os vidros do Grupo 1 que apresentaram as maiores temperaturas superficiais externas foram o vidro refletivo pirolítico (antélio) verde esmeralda, o vidro plano verde e o vidro refletivo pirolítico bronze. Este comportamento foi observado tanto no período com vidros voltados para a face Oeste (Figura 45) como para a face Norte (Figura 46). O vidro refletivo pirolítico prata chegou a apresentar as menores temperaturas superficiais externas, vindo em seguida do vidro plano incolor e do reflectafloat.

Com relação às temperaturas superficiais externas dos vidros analisados no Grupo 2, o vidro refletivo metalizado a vácuo azul intenso médio apresentou as maiores temperaturas, chegando a atingir $47^{\circ} \mathrm{C}$. Já o vidro plano incolor e o reflectafloat tiveram as menores temperaturas superficiais externas. No período de medições no qual os vidros foram colocados na face Oeste (Figura 51), o vidro refletivo metalizado a vácuo prata neutro apresentou maiores temperaturas superficiais externas que o vidro refletivo metalizado a vácuo azul médio, já com os vidros voltados para a face Norte (Figura 52), ocorreu o inverso. 
No Grupo 3, o vidro refletivo metalizado a vácuo prata neutro e o vidro refletivo pirolítico verde esmeralda apresentaram as maiores temperaturas superficiais externas, sendo que o vidro refletivo pirolítico prata e o vidro plano incolor tiveram as menores temperaturas superficiais externas. Os vidros deste grupo apresentaram o mesmo comportamento tanto na fachada Oeste (Figura 57) como na fachada Norte (Figura 58).

\section{- Temperaturas superficiais internas}

O vidro plano verde e o vidro refletivo pirolítico verde esmeralda apresentaram as maiores temperaturas superficiais internas do Grupo 1 , chegando a atingir $43^{\circ} \mathrm{C}$. Em contraponto, os vidros plano incolor, refletivo pirolítico prata e reflectafloat tiveram as menores temperaturas superficiais internas deste grupo. Os vidros do Grupo 1 apresentaram o mesmo comportamento com relação às temperaturas superficiais internas tanto no período com as aberturas voltadas para Oeste (Figura 47) quanto para Norte (Figura 48).

O vidro refletivo metalizado a vácuo azul intenso médio do Grupo 2 apresentou elevadas temperaturas superficiais internas, chegando a atingir $5^{\circ} \mathrm{C}$, vindo em seguida pelo vidro plano verde e pelo vidro refletivo metalizado a vácuo azul médio. $\mathrm{O}$ vidro plano incolor e o vidro reflectafloat apresentaram as menores temperaturas superficiais internas. Um comportamento semelhante foi observado tanto para os vidros voltados para a face Oeste (Figura 53) como para a face Norte (Figura 54).

No Grupo 3, o vidro refletivo pirolítico verde esmeralda e o vidro refletivo metalizado a vácuo prata neutro apresentaram elevadas temperaturas superficiais 
internas, chegando a $38^{\circ} \mathrm{C}$, vindo em seguida do vidr o plano verde. O vidro refletivo pirolítico prata, o vidro plano incolor e o vidro reflectafloat apresentaram as menores temperaturas superficiais internas. Este comportamento manteve-se nos dois períodos de medições, um com os vidros colocados na face Oeste (Figura 59) e o outro com os vidros colocados na face Norte (Figura 60) das células-teste.

Enquanto que no período no qual os vidros foram colocados na face Oeste as maiores temperaturas superficiais foram entre 15:00h e 17:00h, no período que eles foram colocados na face Norte, as temperaturas superficiais internas começaram a se elevar por volta das 11:00h.

Alguns vidros refletivos chegaram a registrar $7^{\circ} \mathrm{C}$ de diferença entre as temperaturas superficiais internas e externas, sendo que estas últimas foram as menores. Assim, pode-se concluir que ocorreu uma absorção na camada refletiva voltada para o interior da célula-teste, e desta forma, o coeficiente superficial interno de transmissão de calor é menor que o coeficiente superficial externo.

O vidro plano verde, devido aos óxidos responsáveis pela sua coloração, apresentou temperaturas superficiais internas mais elevadas que o vidro plano incolor, mostrando que absorve mais a radiação.

\section{- Temperaturas internas}

Em todas as células-teste, até as 15:00h, as temperaturas internas do ar mantiveram-se abaixo da temperatura externa. Após este horário, a temperatura do ar interno foi superior aos valores externos.

No Grupo 1, tanto no período no qual os vidros foram colocados na face Oeste (Figura 49) quanto no período em que os vidros ficaram na face Norte (Figura 
50), a célula-teste com o vidro plano incolor (referência) apresentou as maiores temperaturas internas, vindo em seguida da célula-teste com o vidro refletivo pirolítico prata. Já a célula-teste com o vidro refletivo pirolítico bronze obteve as menores temperaturas internas. As células-teste com o vidro plano verde e com o vidro refletivo pirolítico verde esmeralda apresentaram um comportamento semelhante.

Com relação às temperaturas medidas no interior das células-teste para os vidros do Grupo 2, as células-teste apresentaram um comportamento semelhante entre elas, destacando a célula-teste com o vidro refletivo metalizado a vácuo prata neutro por ter tido as menores temperaturas. Um comportamento semelhante foi visto tanto para os vidros voltados para a fachada Oeste (Figura 55) como para a fachada Norte (Figura 56).

No Grupo 3, a célula-teste com vidro refletivo metalizado a vácuo prata neutro também apresentou as menores temperaturas, vindo em seguida do vidro reflectafloat e vidro refletivo pirolítico prata (Figuras 61 e 62). As células-teste com os vidros planos incolor e verde apresentaram as maiores temperaturas internas.

Pode-se observar que nos três grupos analisados, o vidro plano incolor é o que mais transmite calor para o ambientes.

\subsubsection{Resultados para cada tipo de vidro}

A seguir serão mostrados gráficos e tabelas onde são comparadas as temperaturas internas, as temperaturas superficiais internas e as temperaturas superficiais externas para cada tipo de vidro analisado. 
Vidro plano incolor

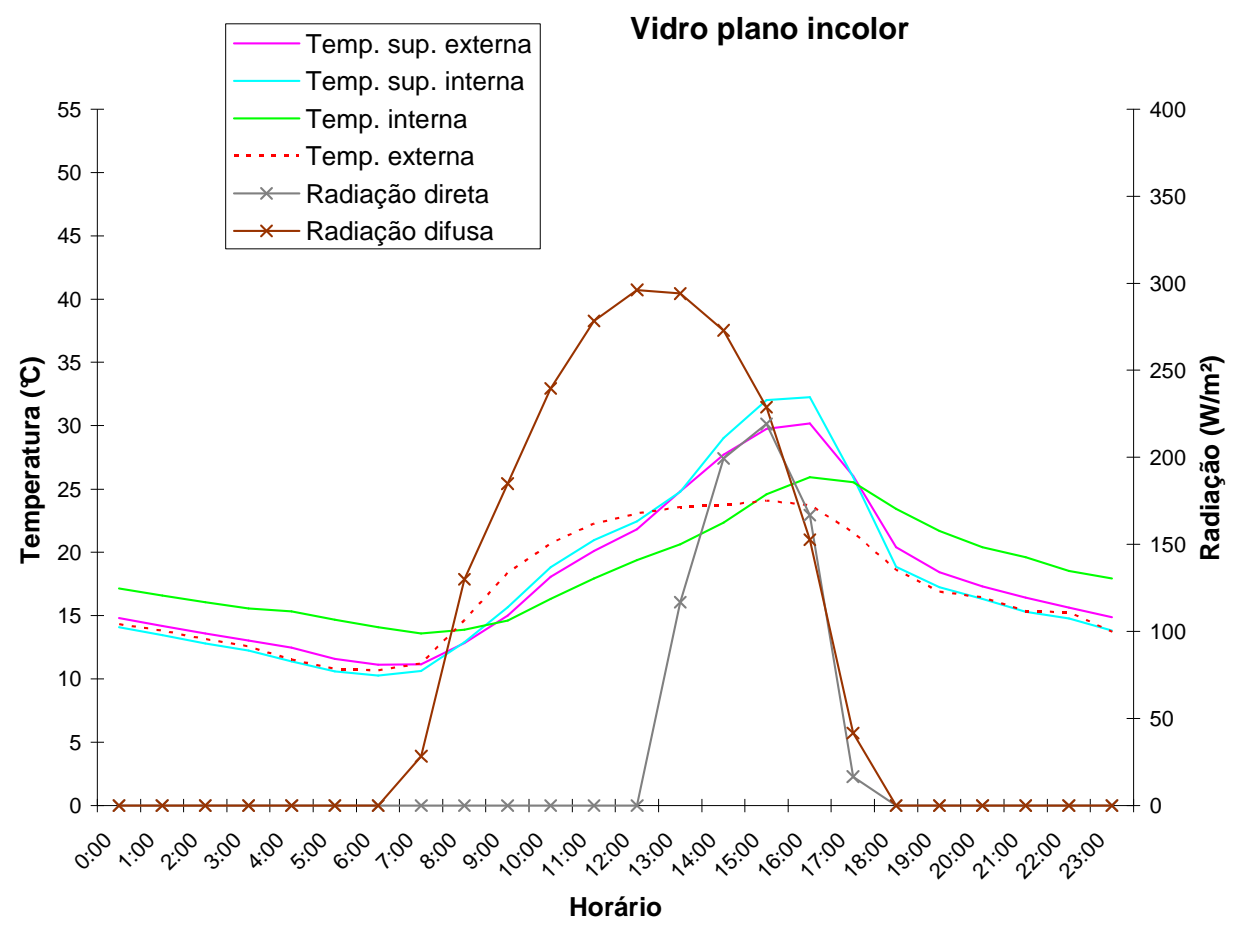

Figura 63. Temperaturas para o vidro plano incolor - Oeste

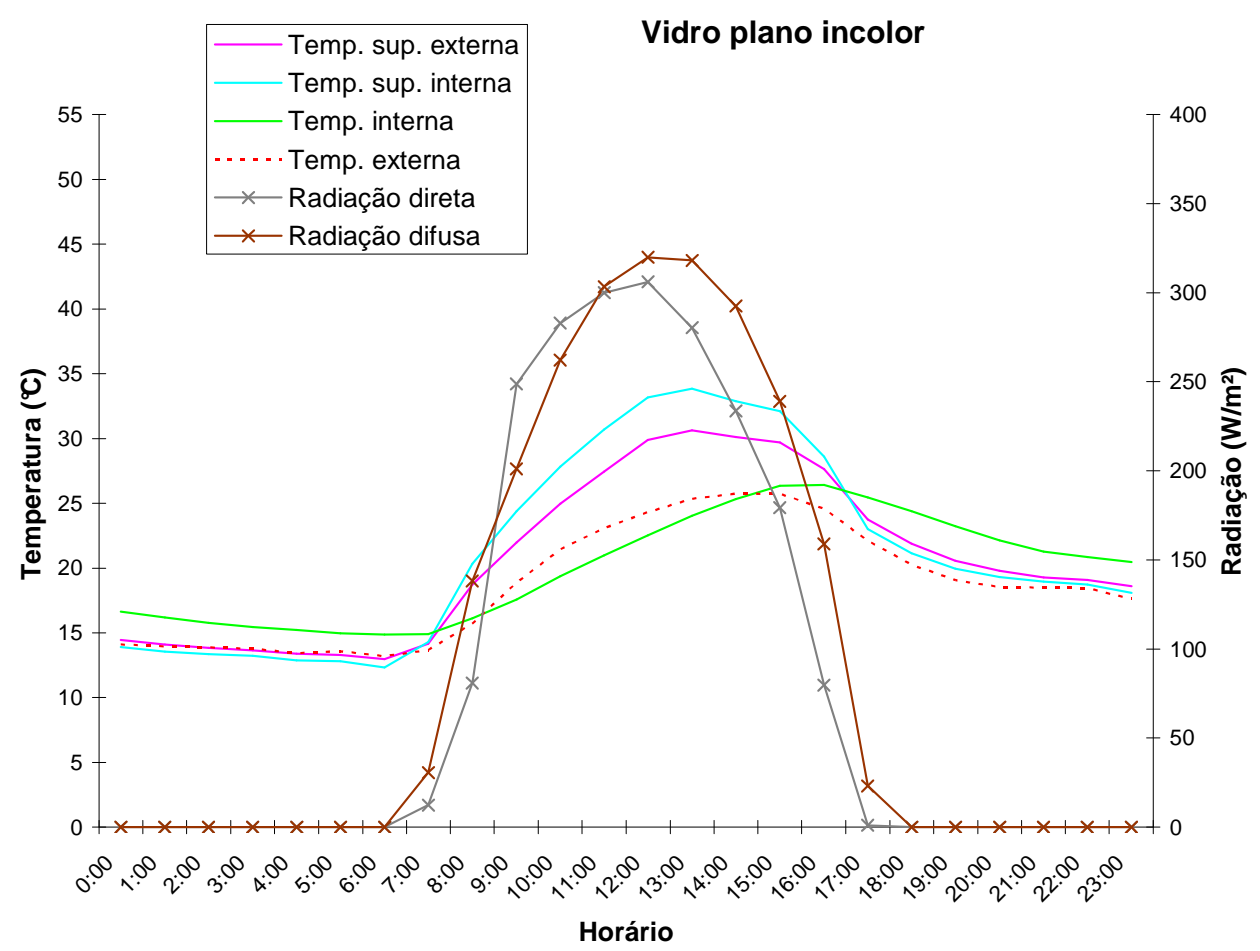

Figura 64. Temperaturas para o vidro plano incolor - Norte 


\section{Vidro plano verde}

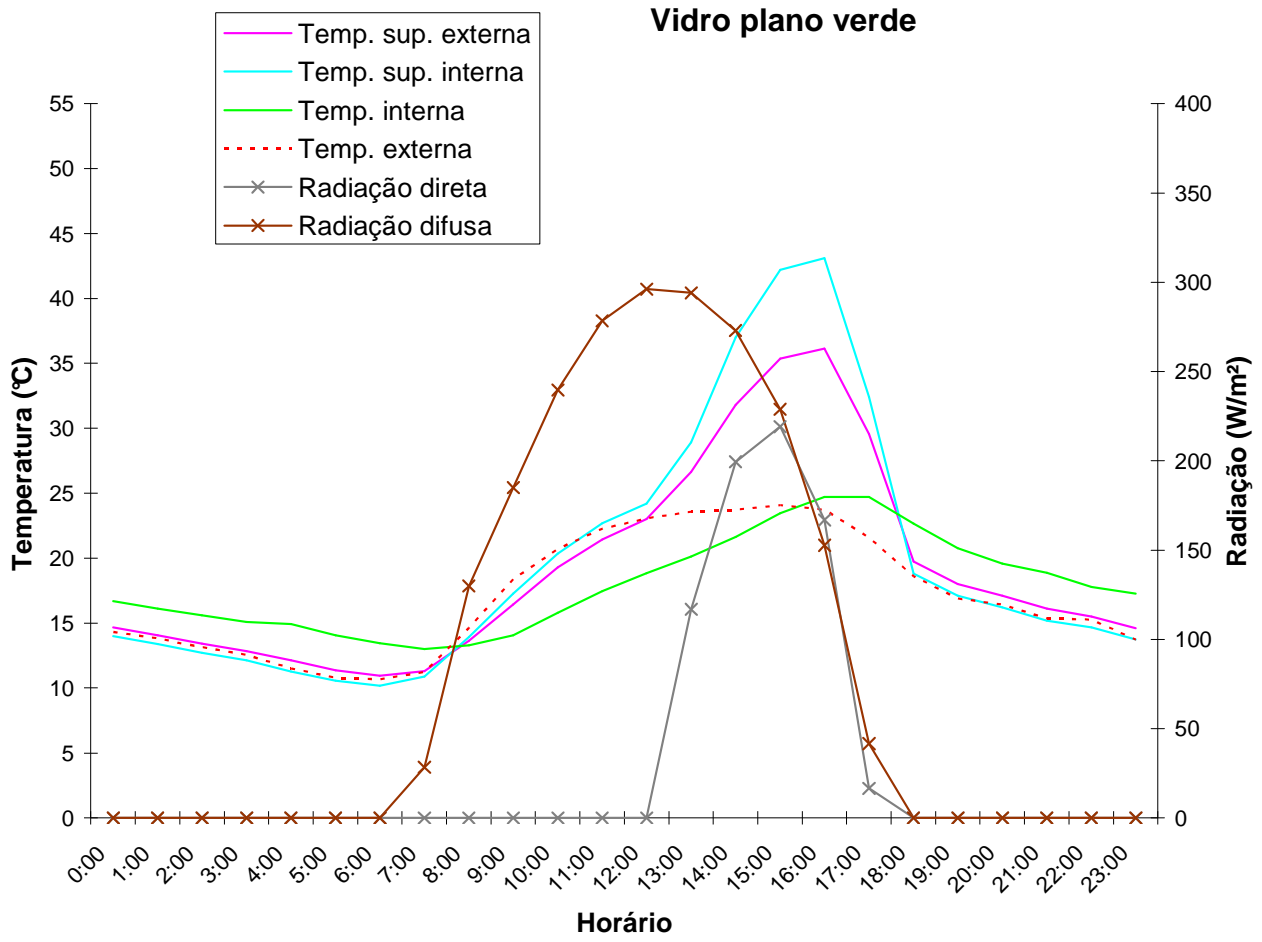

Figura 65. Temperaturas para o vidro plano verde - Oeste

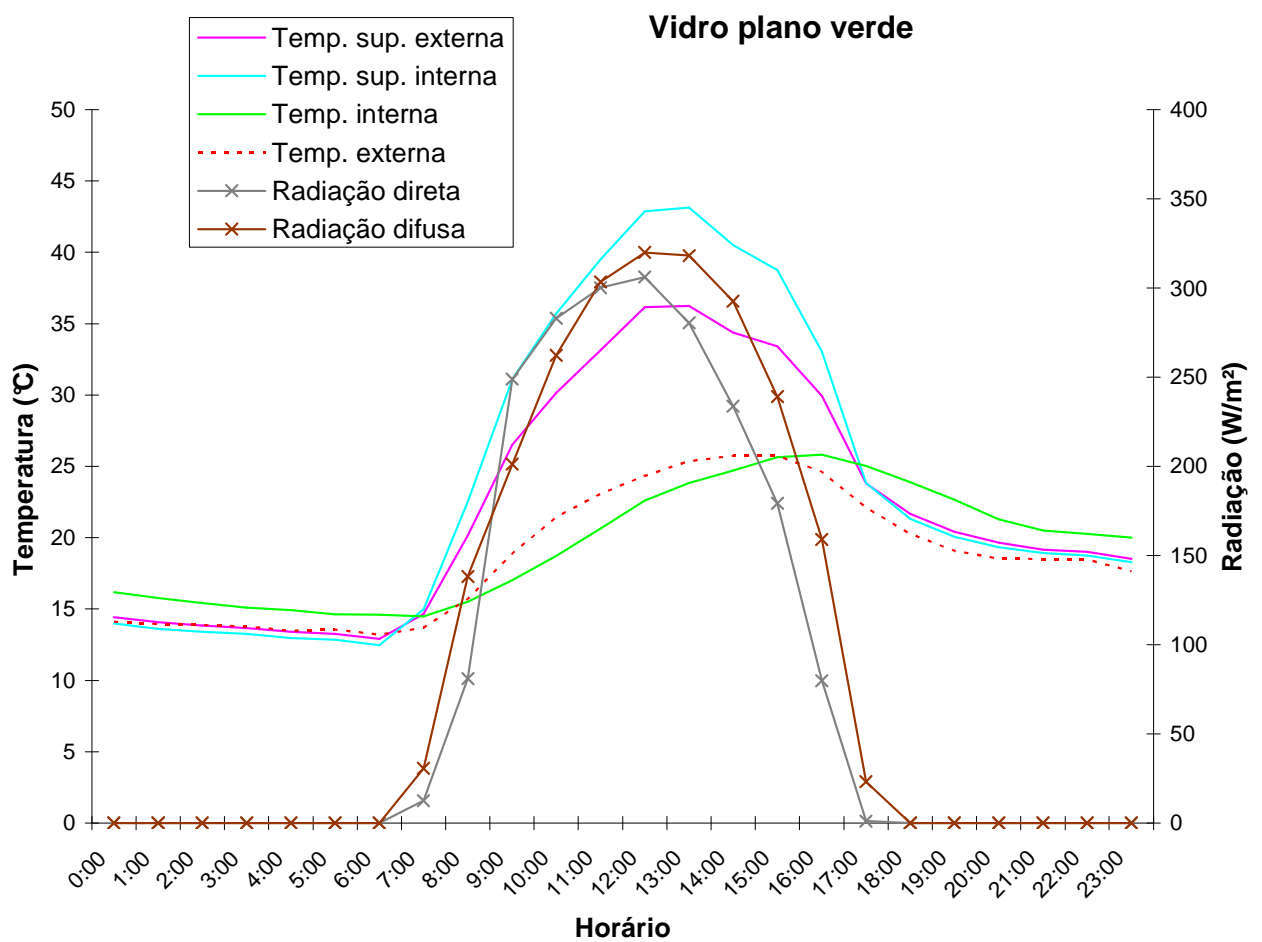

Figura 66. Temperaturas para o vidro plano verde - Norte 


\section{Vidro refletivo pirolítico verde esmeralda}

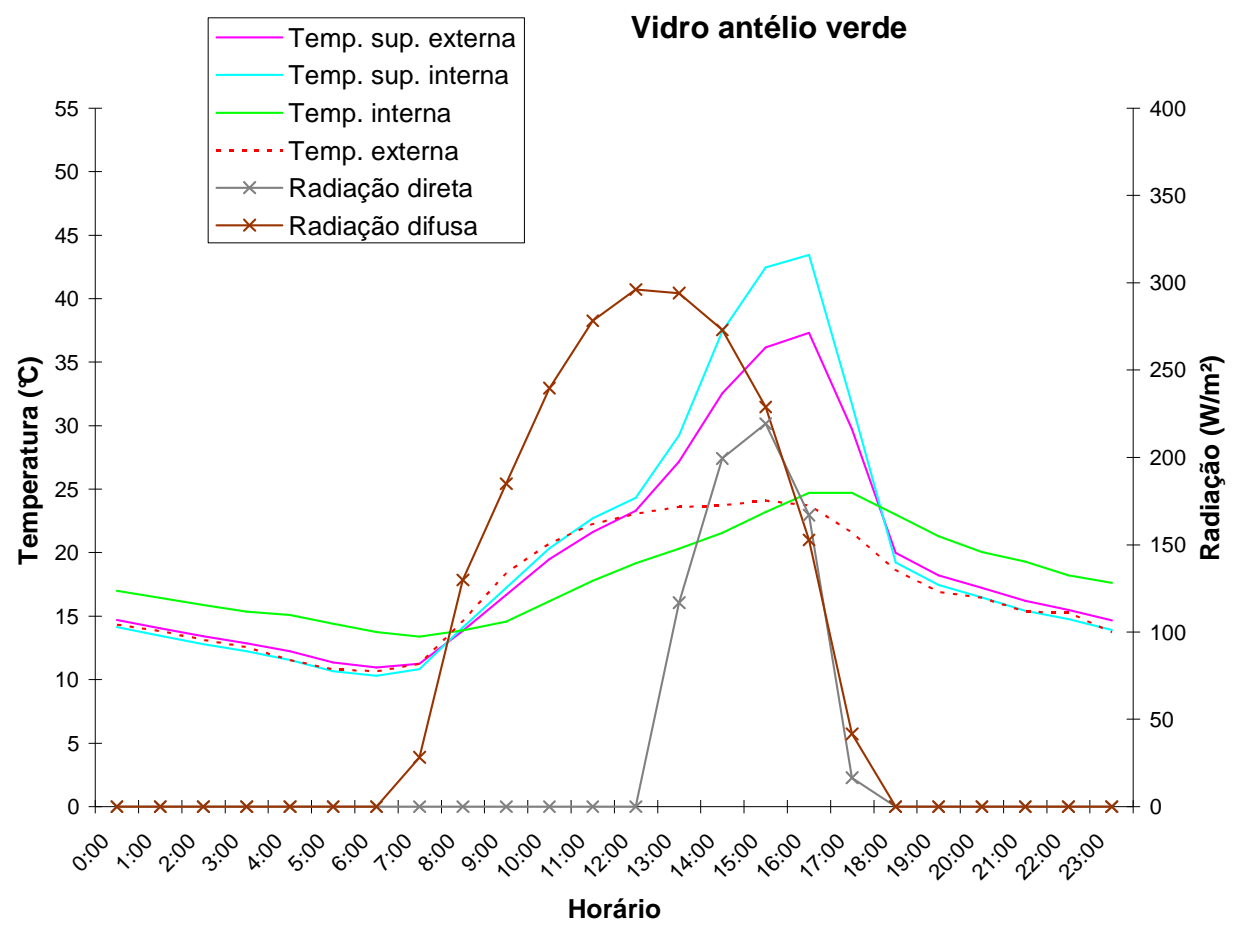

Figura 67. Temperaturas para o vidro refletivo pirolítico verde esmeralda - Oeste

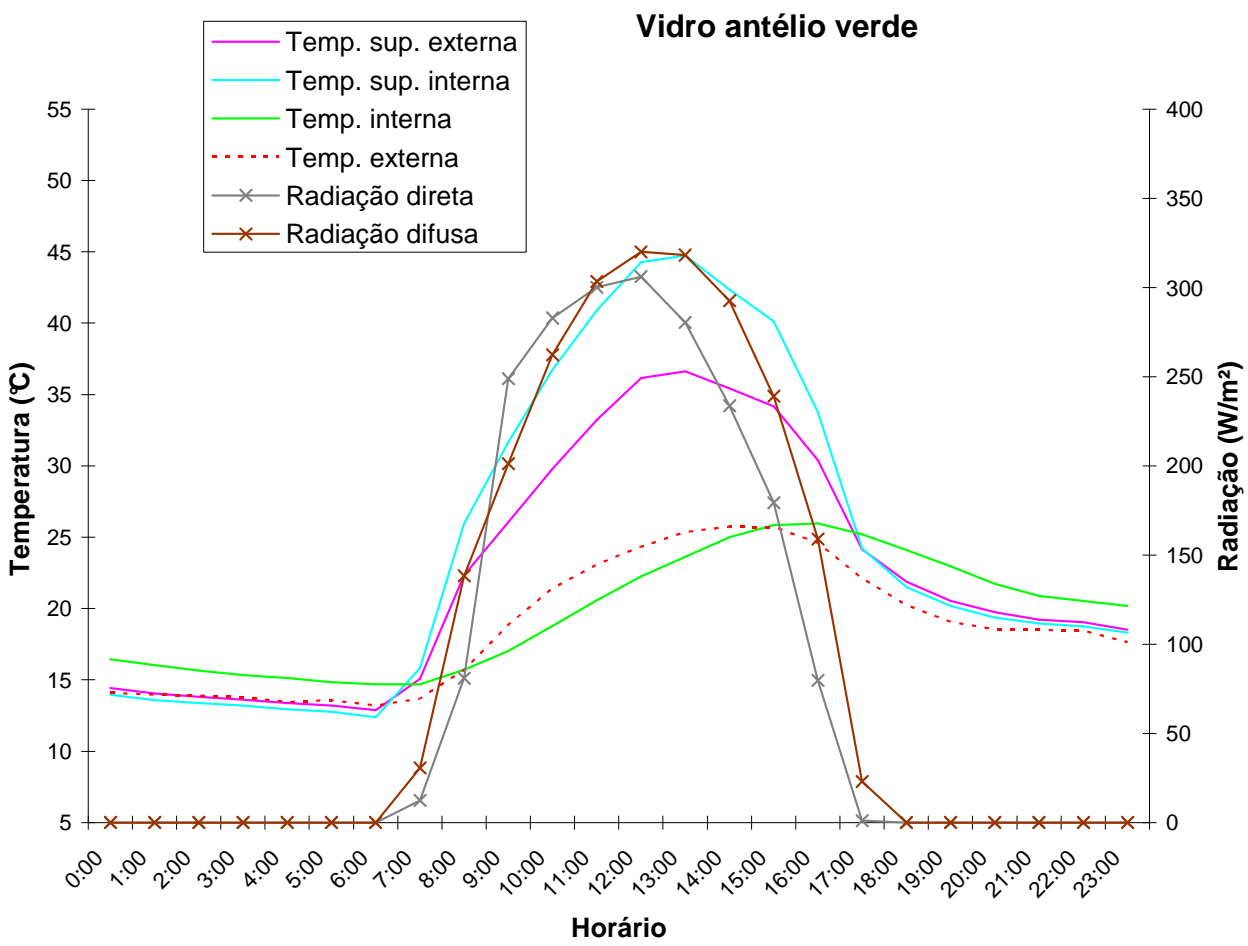

Figura 68. Temperaturas para o vidro refletivo pirolítico verde esmeralda - Norte 
127

Vidro refletivo pirolítico prata

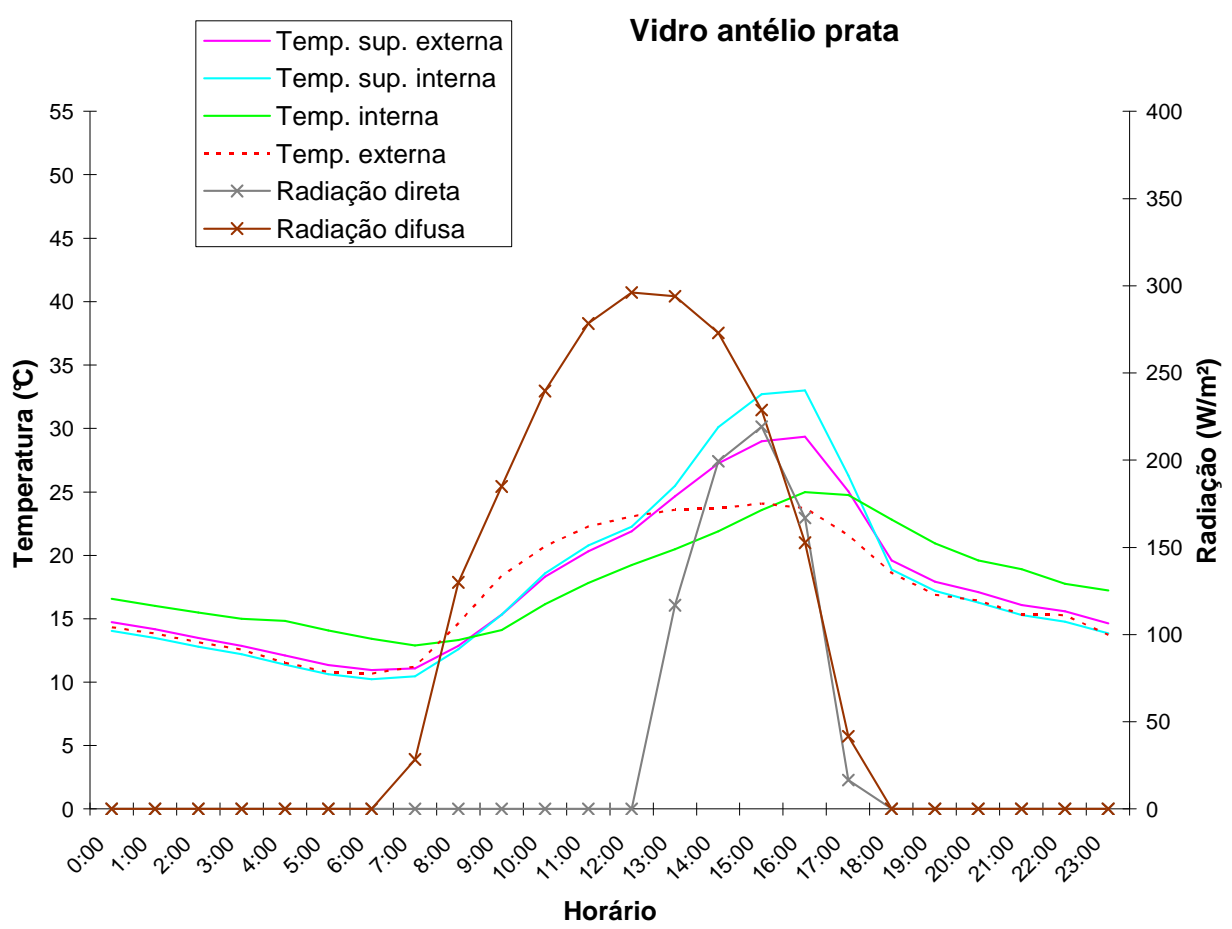

Figura 69. Temperaturas para o vidro refletivo pirolítico prata - Oeste

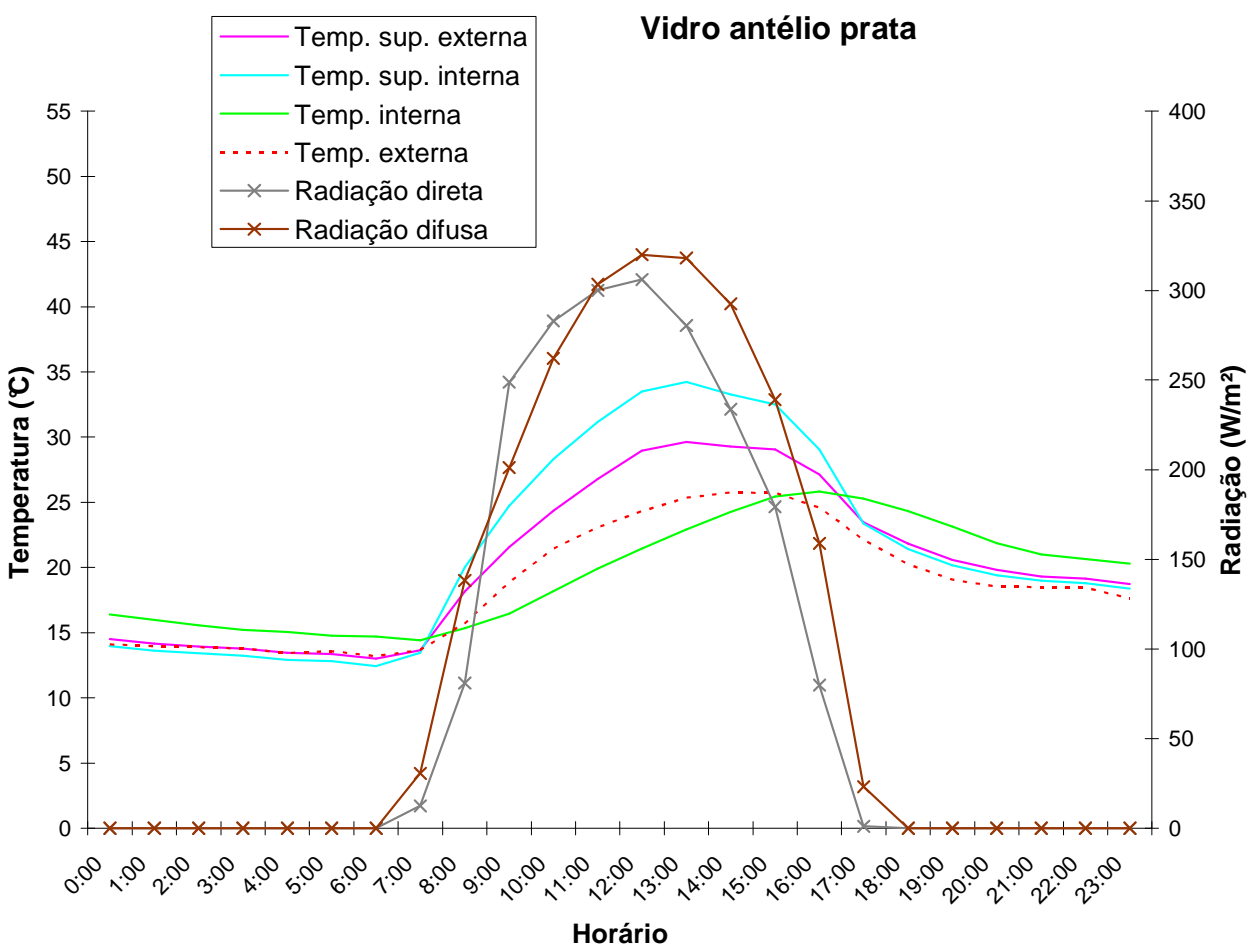

Figura 70. Temperaturas para o vidro refletivo pirolítico prata - Norte 
128

Vidro refletivo pirolítico bronze

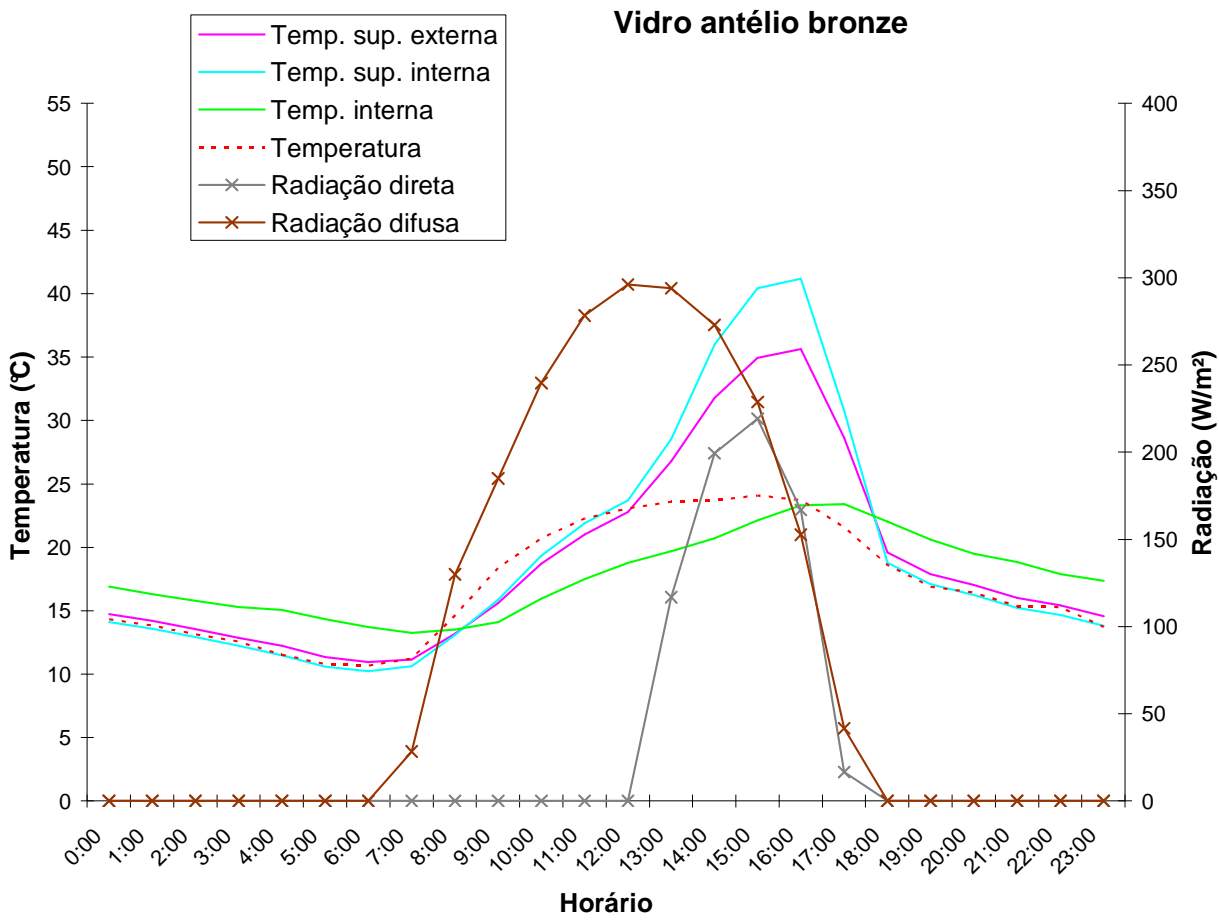

Figura 71. Temperaturas para o vidro refletivo pirolítico bronze - Oeste

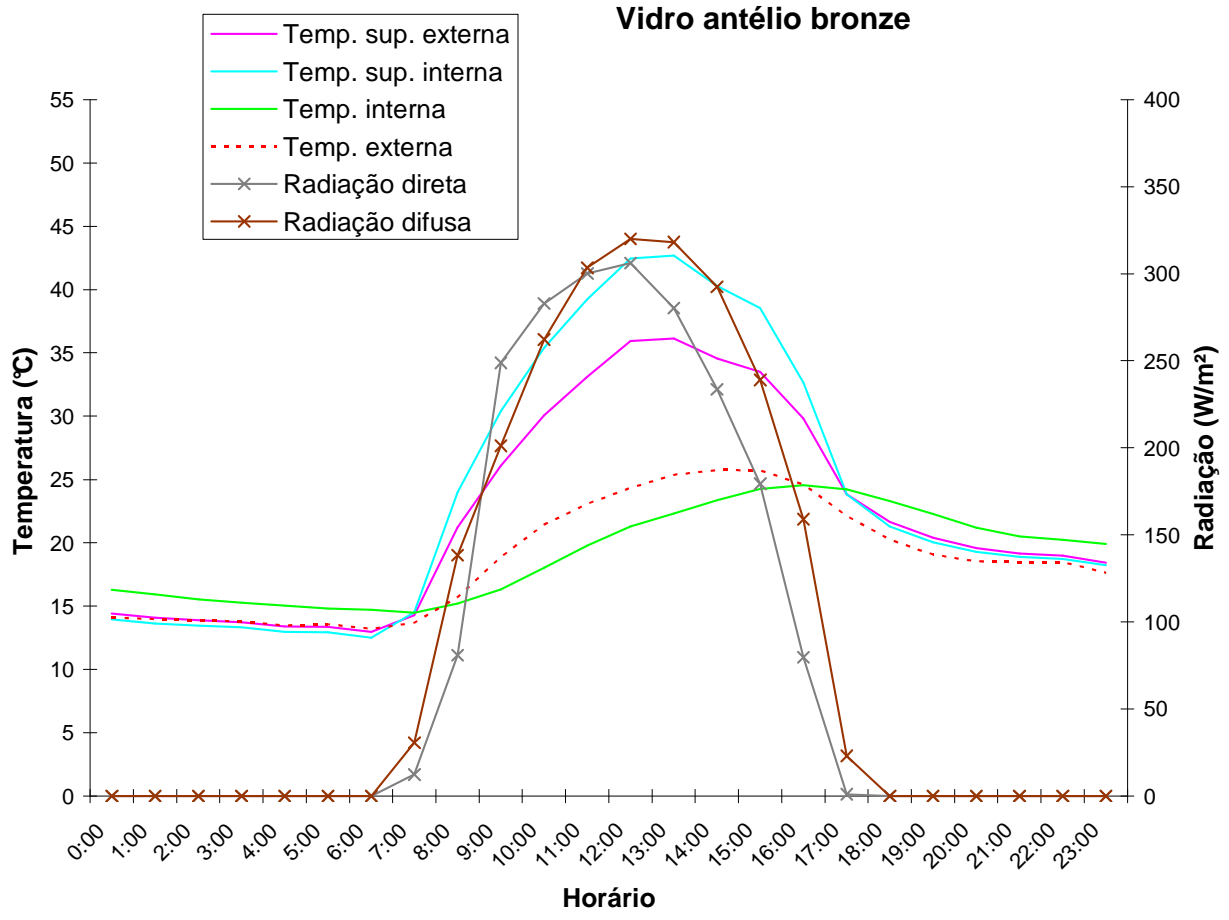

Figura 72. Temperaturas para o vidro refletivo pirolítico bronze - Norte 


\section{Vidro reflectafloat}

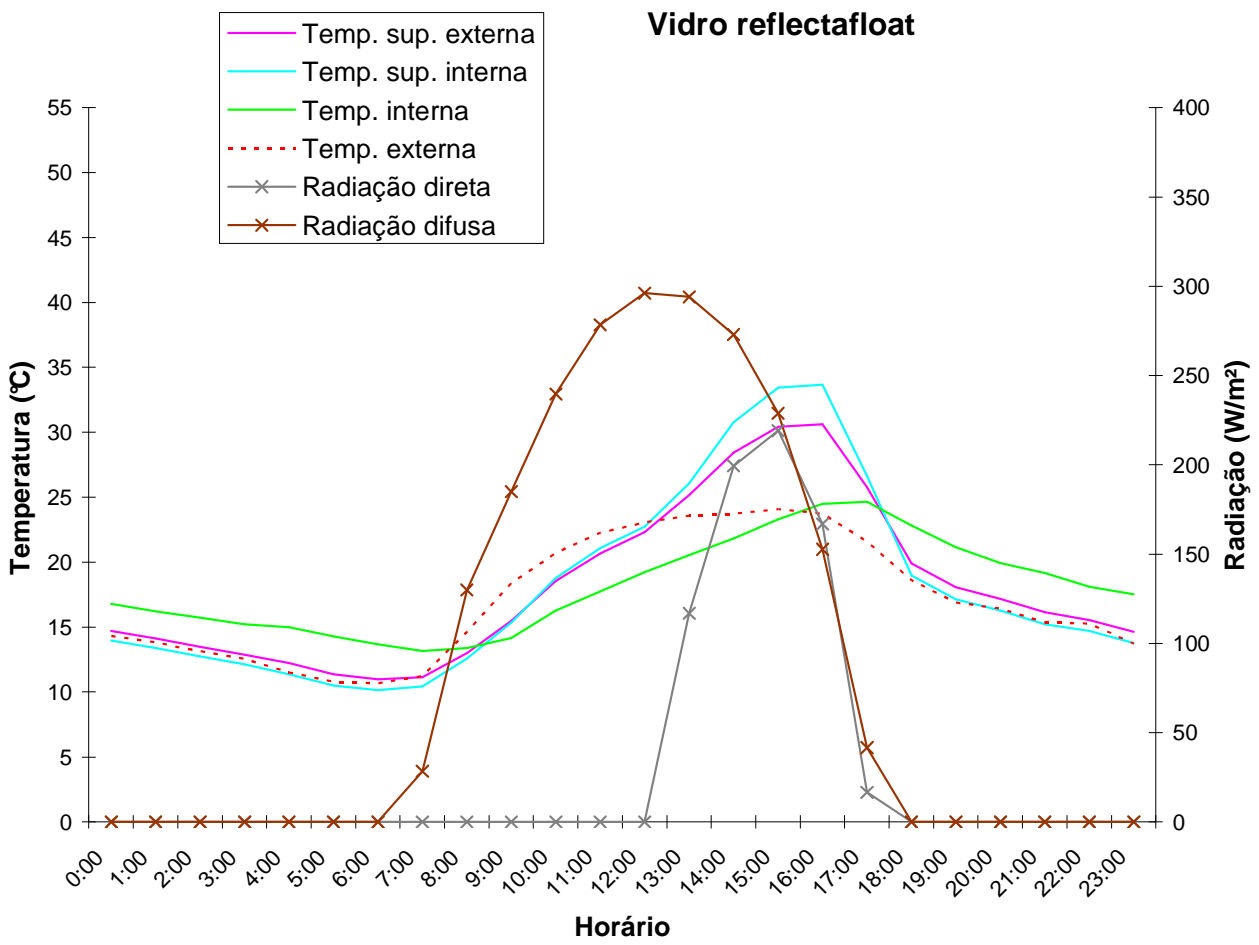

Figura 73. Temperaturas para o vidro reflectafloat - Oeste

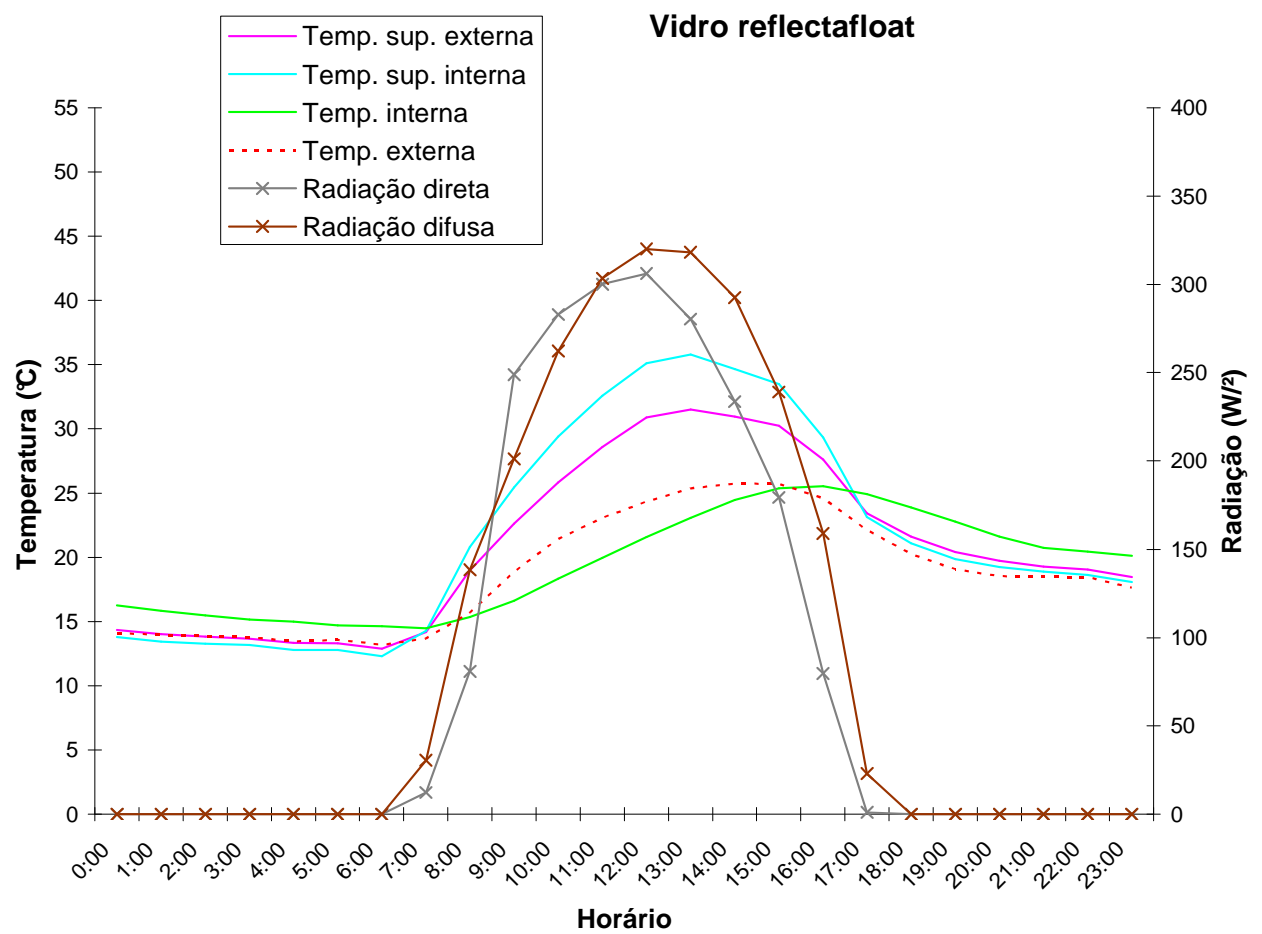

Figura 74. Temperaturas para o vidro reflectafloat - Norte 
130

Vidro refletivo metalizado a vácuo prata neutro

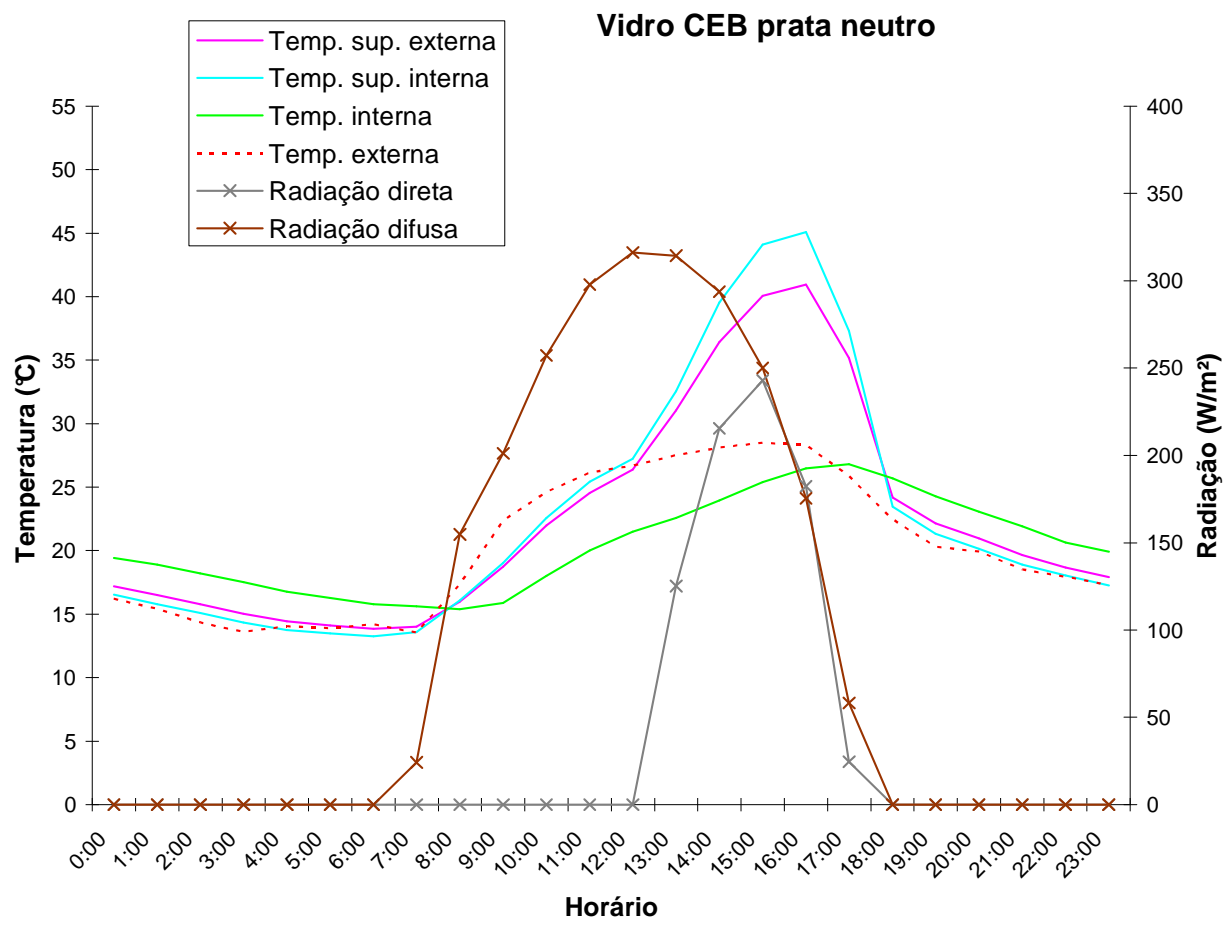

Figura 75. Temperaturas para o vidro refletivo metalizado a vácuo prata neutro - Oeste

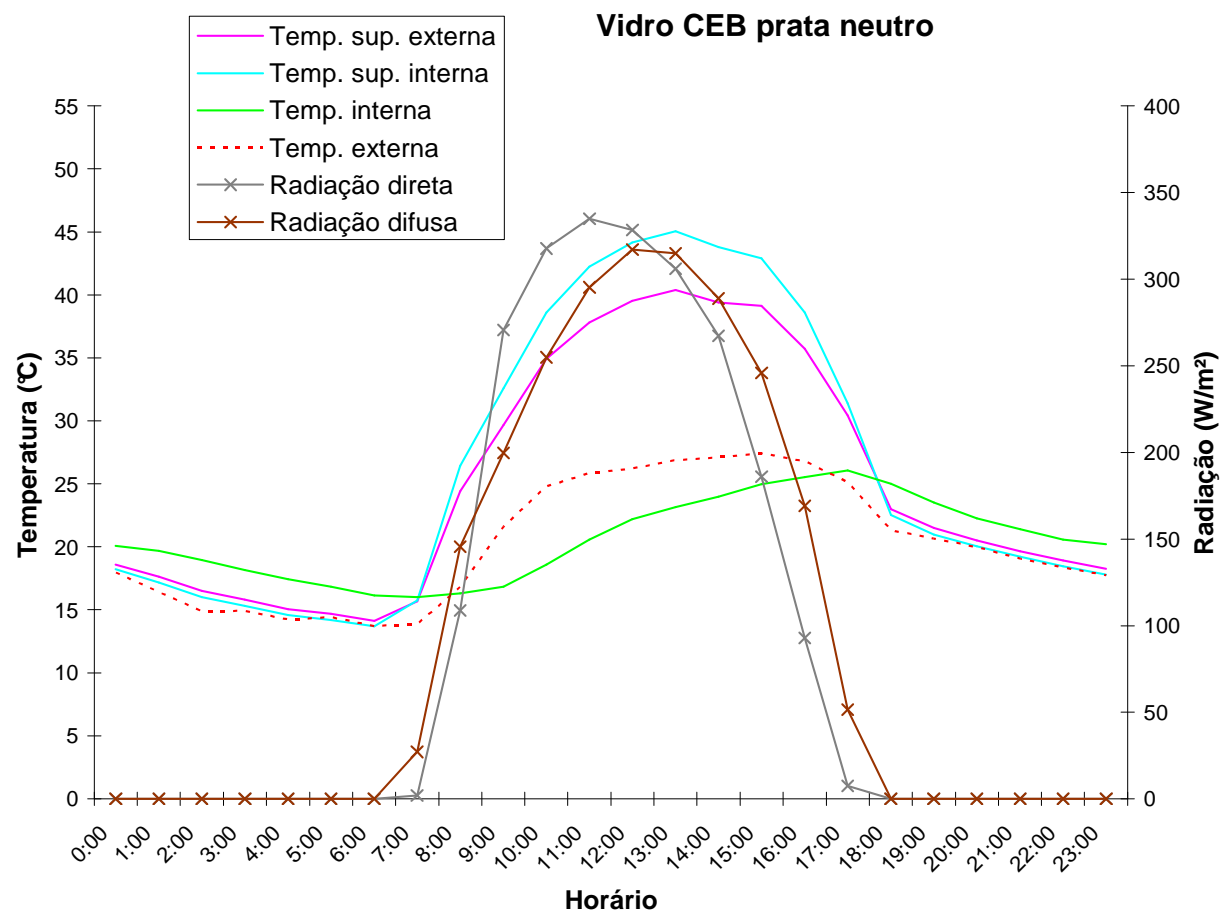

Figura 76. Temperaturas para o vidro refletivo metalizado a vácuo prata neutro - Norte 
131

Vidro refletivo metalizado a vácuo azul médio

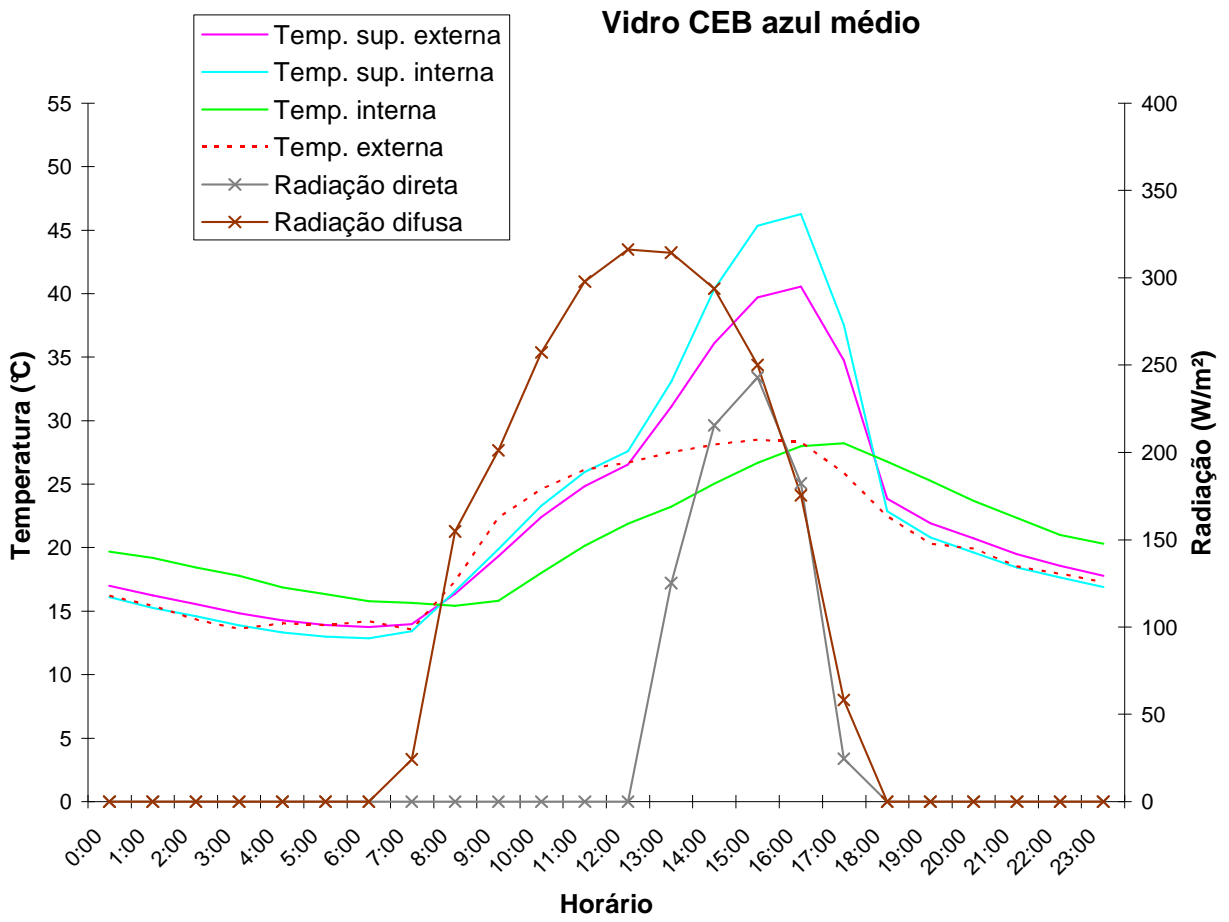

Figura 77. Temperaturas para o vidro refletivo metalizado a vácuo azul médio - Oeste

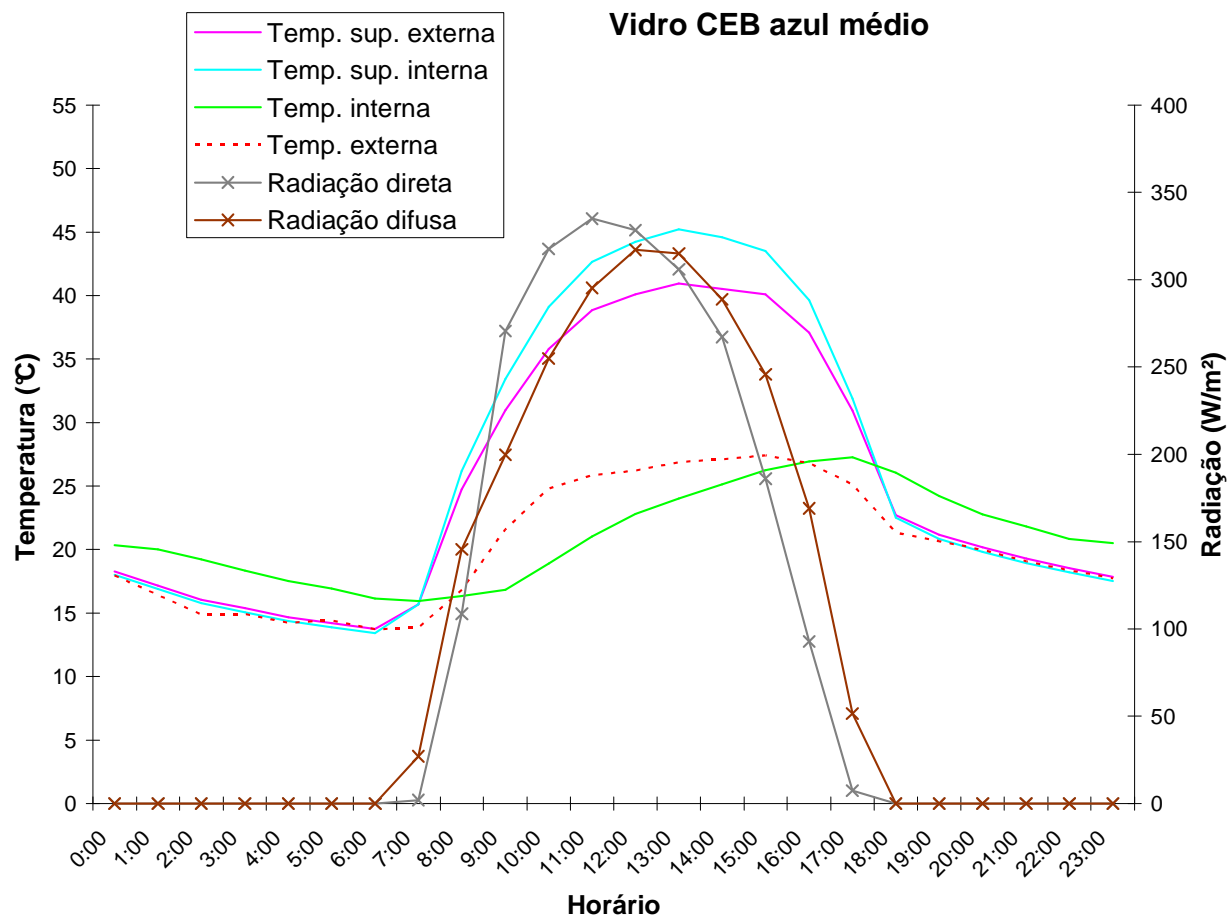

Figura 78. Temperaturas para o vidro refletivo metalizado a vácuo azul médio - Norte 


\section{Vidro refletivo metalizado a vácuo azul intenso médio}

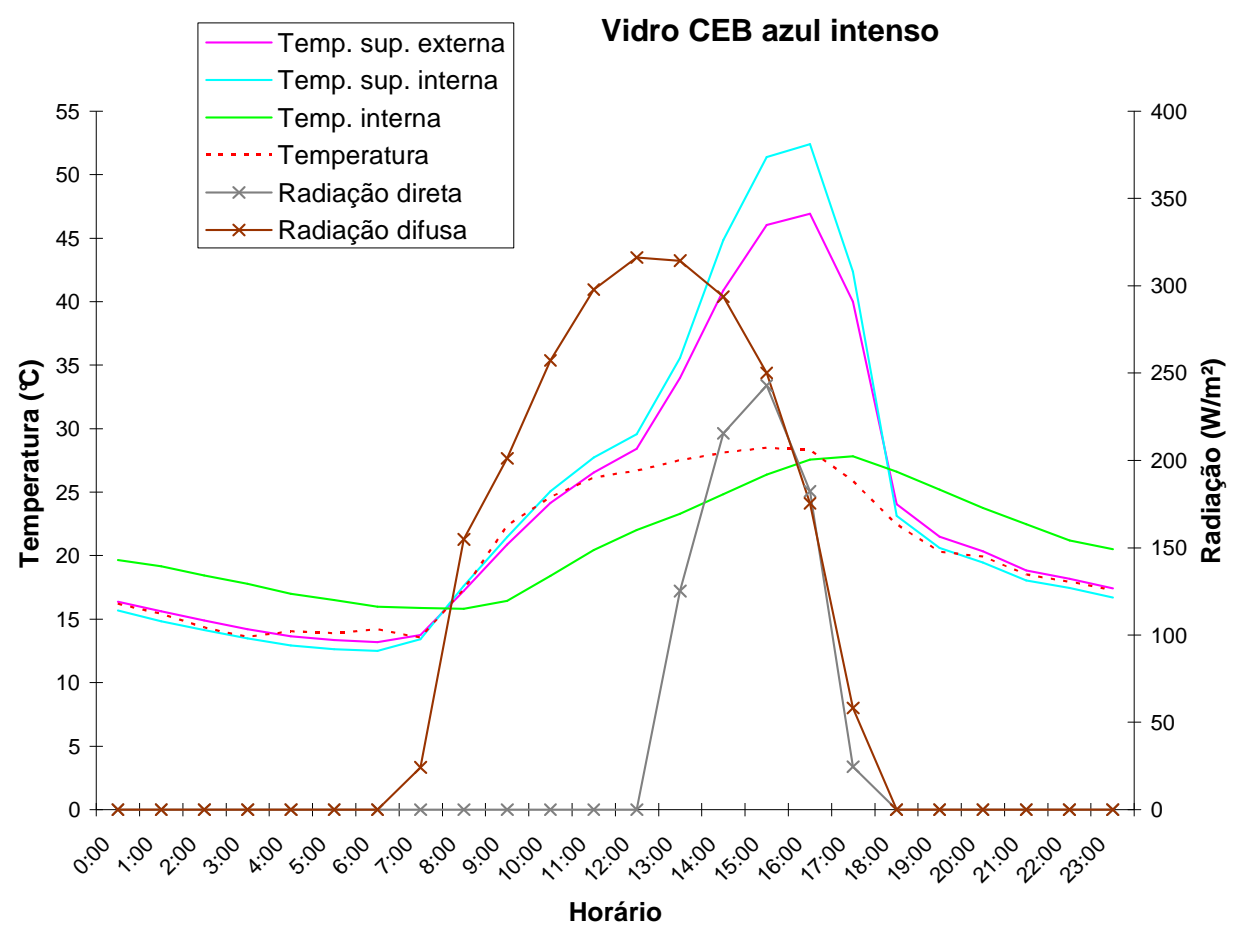

Figura 79. Temperaturas para o vidro refletivo metalizado a vácuo azul intenso médio Oeste

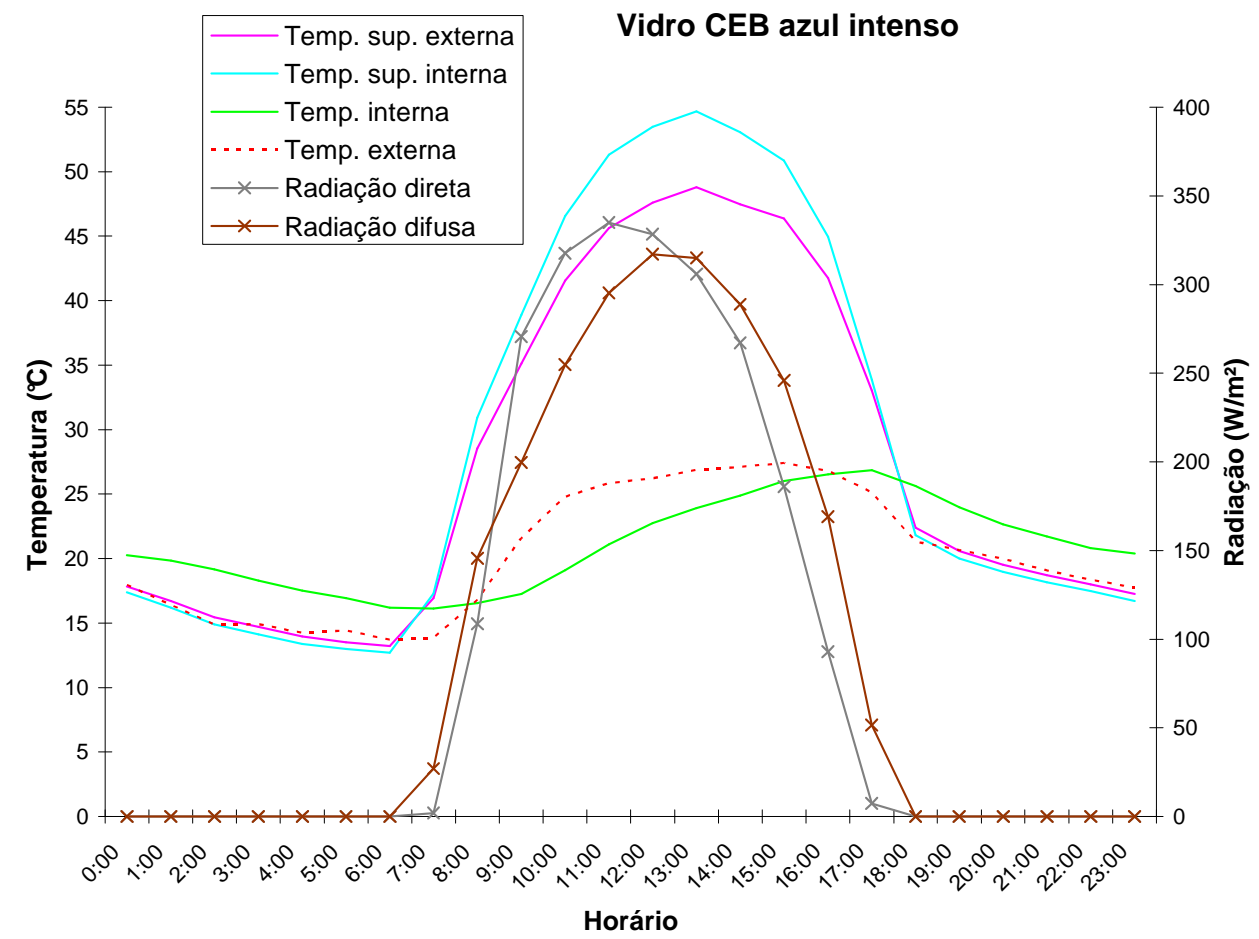

Figura 80. Temperaturas para o vidro refletivo metalizado a vácuo azul intenso médio Norte 
Tabela 5 - Temperaturas superficiais dos vidros e temperatura interna - Grupo 1 (Oeste) - 14/07/2005

\begin{tabular}{|c|c|c|c|c|c|c|c|c|c|c|c|c|c|c|c|c|c|c|c|}
\hline \multirow[b]{2}{*}{ Horário } & \multirow[b]{2}{*}{$\begin{array}{c}\text { Temp. } \\
\text { externa } \\
\left({ }^{\circ} \mathrm{C}\right)\end{array}$} & \multicolumn{3}{|c|}{ Plano verde } & \multicolumn{3}{|c|}{$\begin{array}{l}\text { Antélio verde } \\
\text { esmeralda }\end{array}$} & \multicolumn{3}{|c|}{ Antélio prata } & \multicolumn{3}{|c|}{ Plano incolor } & \multicolumn{3}{|c|}{ Antélio bronze } & \multicolumn{3}{|c|}{ Reflectafloat } \\
\hline & & \begin{tabular}{|c|} 
Temp. \\
sup. \\
externa \\
$\left({ }^{\circ} \mathrm{C}\right)$
\end{tabular} & \begin{tabular}{|c|} 
Temp. \\
sup. \\
interna \\
$\left({ }^{\circ} \mathrm{C}\right)$
\end{tabular} & $\begin{array}{c}\text { Temp. } \\
\text { interna } \\
\left({ }^{\circ} \mathrm{C}\right)\end{array}$ & $\begin{array}{l}\text { Temp. } \\
\text { sup. } \\
\text { externa } \\
\left({ }^{\circ} \mathrm{C}\right)\end{array}$ & \begin{tabular}{|c|} 
Temp. \\
sup. \\
interna \\
$\left({ }^{\circ} \mathrm{C}\right)$
\end{tabular} & $\begin{array}{c}\begin{array}{c}\text { Temp. } \\
\text { interna } \\
\left({ }^{\circ} \mathrm{C}\right)\end{array} \\
\end{array}$ & $\begin{array}{l}\text { Temp. } \\
\text { sup. } \\
\text { externa } \\
\left({ }^{\circ} \mathrm{C}\right)\end{array}$ & \begin{tabular}{|l|} 
Temp. \\
sup. \\
interna \\
('C)
\end{tabular} & $\begin{array}{c}\text { Temp. } \\
\text { interna } \\
\left({ }^{\circ} \mathrm{C}\right)\end{array}$ & \begin{tabular}{|c|} 
Temp. \\
sup. \\
exter na \\
(C)
\end{tabular} & $\begin{array}{l}\text { Temp. } \\
\text { sup. } \\
\text { interna }\end{array}$ & $\begin{array}{c}\text { Temp. } \\
\text { interna } \\
\left({ }^{\circ} \mathrm{C}\right)\end{array}$ & $\begin{array}{c}\text { Temp. } \\
\text { sup. } \\
\text { externa } \\
\text { C } \quad \text { ) } \\
\end{array}$ & \begin{tabular}{|c|} 
Temp. \\
sup. \\
interna \\
$\left({ }^{\circ} \mathrm{C}\right)$ \\
\end{tabular} & $\begin{array}{c}\begin{array}{c}\text { Temp. } \\
\text { interna } \\
\left({ }^{\circ} \mathrm{C}\right)\end{array} \\
\end{array}$ & \begin{tabular}{|c|} 
Temp. \\
sup. \\
externa \\
$\left({ }^{\circ}\right)$ \\
\end{tabular} & \begin{tabular}{|c|} 
Temp. \\
sup. \\
interna \\
$\left({ }^{\circ} \mathrm{C}\right)$
\end{tabular} & \begin{tabular}{|c}
$\begin{array}{c}\text { Temp. } \\
\text { interna } \\
\left({ }^{\circ} \mathrm{C}\right)\end{array}$ \\
\end{tabular} \\
\hline $0: 00$ & & 14,67 & 14,01 & & 14,72 & 14,14 & & 14,74 & 14,04 & & 14,79 & & 17,17 & 14,73 & 14,12 & & 14,68 & 13,96 & 16,79 \\
\hline $1: 00$ & & & & & & & & & & & & & & & & & & & \\
\hline $2: 00$ & 13,13 & 3,42 & 12,72 & 15,61 & 3,42 & 12,81 & 15,87 & 13,50 & 12,81 & & 13,59 & & & 13,53 & & & 13,47 & & \\
\hline 3:00 & 12,56 & 12,84 & 12,14 & 15,09 & 12,85 & 12,23 & 15,34 & 12,87 & 12,20 & 98 & 13,02 & 12,22 & 15,56 & 12,87 & 12,22 & 5,27 & 12,86 & & ,24 \\
\hline $4: 00$ & & 12,13 & & & 12,26 & & & 12,11 & & & 12,48 & & & 12,24 & & & & & \\
\hline 5:00 &, 80 & 1,37 & & & 11,37 & & & 11, & & & 11,59 & & & 11,36 & & & & & \\
\hline & & & & & & & & & & & & & & & & & & & \\
\hline 7:00 & 11,24 & 1,30 & & & 11,24 & & & 11,07 & & & 11,14 & & & 11, & & & & & \\
\hline $8: 00$ & & & & & 13,85 & & & 12,88 & & & 12,83 & & & 13,18 & & & & & \\
\hline $9: 00$ & & & & & 16,64 & & & 15,32 & & & 15,00 & & & 15,61 & & & & & \\
\hline $10: 00$ & 20,70 & 30 & & & 19,48 & & & 18,30 & & & & & & 18,69 & & & & & \\
\hline & & & & & & & & & & & & & & & & & & & \\
\hline $12: 00$ & & 23,02 & & & 23,30 & & & 21,91 & & & 21,81 & & & 22,78 & & & & & \\
\hline $13: 00$ & 23,59 & 26,63 & & & 27,16 & & 20,31 & 24,65 & & & 24,81 & & & 26,78 & & & & & \\
\hline $14: 00$ & 23,73 & 31,82 & 7,01 & 21,63 & 32,57 & 37,44 & 21,56 & 27,24 & & 89 & 27,70 & & & 31,77 & & & 28,44 & & 83 \\
\hline & 24,09 & & & & 36,17 & & 23,21 & 29,00 & & & & & & & & & & & \\
\hline & & & & & & & & & & & & & & & & & & & \\
\hline $17: 00$ & 21,57 & 29,55 & 32,42 & 24,73 & 29,74 & & 24,72 & 25,06 & & & 26,03 & & & 28,62 & & & 25,77 & & 24,64 \\
\hline $18: 00$ & 18,61 & 19,74 & & 22,65 & 19,98 & & 23,00 & 19,59 & & & 20,39 & & & 19,60 & & & & & 22,81 \\
\hline $19: 00$ & 16,89 & 18,00 & 17,10 & 20,77 & 18,20 & 17,44 & 21,29 & 17,94 & & 20,94 & 18,44 & & 21,70 & 17,88 & 17,09 & & 18,07 & 17,15 & 21,17 \\
\hline $20: 00$ & & 17,11 & & 19,58 & 17,23 & 16,46 & 20,05 & 17,09 & 16,28 & 19,59 & 17,32 & & & 17,01 & & & 17,17 & 16,27 & 19,93 \\
\hline 21:00 & & & 15,18 & & & & & & & & & & & 16,01 & & & & & 19,17 \\
\hline $22: 00$ & 15,28 & 15,52 & 14,68 & 17,78 & 15,49 & 14,77 & 18,23 & 15,59 & 14,76 & 17,74 & 15,63 & 14,78 & & 15,41 & 14,67 & 17,89 & 15,55 & 14,69 & 18,10 \\
\hline $23: 00$ & 13,73 & 14,60 & 13,75 & 17,26 & 14,65 & 13,92 & 17,62 & 14,62 & 13,85 & 17,22 & 14,85 & 13,82 & 17,92 & 14,56 & 13,81 & 17,37 & 14,64 & 13,77 & 17,54 \\
\hline
\end{tabular}


Tabela 6 - Temperaturas superficiais dos vidros e temperatura interna - Grupo 1 (Norte) - 21/07/2005

\begin{tabular}{|c|c|c|c|c|c|c|c|c|c|c|c|c|c|c|c|c|c|c|c|}
\hline \multirow[b]{2}{*}{ Horário } & \multirow[b]{2}{*}{$\begin{array}{c}\text { Temp. } \\
\text { externa } \\
\left({ }^{\circ} \mathrm{C}\right)\end{array}$} & \multicolumn{3}{|c|}{ Plano verde } & \multicolumn{3}{|c|}{$\begin{array}{l}\text { Antélio verde } \\
\text { esmeralda }\end{array}$} & \multicolumn{3}{|c|}{ Antélio prata } & \multicolumn{3}{|c|}{ Plano incolor } & \multicolumn{3}{|c|}{ Antélio bronze } & \multicolumn{3}{|c|}{ Reflectafloat } \\
\hline & & \begin{tabular}{|c|} 
Temp. \\
sup. \\
externa \\
$\left({ }^{\circ} \mathrm{C}\right)$
\end{tabular} & \begin{tabular}{|c|} 
Temp. \\
sup. \\
interna \\
$\left({ }^{\circ} \mathrm{C}\right)$
\end{tabular} & $\begin{array}{c}\text { Temp. } \\
\text { interna } \\
\left({ }^{\circ} \mathrm{C}\right)\end{array}$ & $\begin{array}{l}\text { Temp. } \\
\text { sup. } \\
\text { externa } \\
\left({ }^{\circ} \mathrm{C}\right)\end{array}$ & \begin{tabular}{|l|} 
Temp. \\
sup. \\
interna \\
$\left({ }^{\circ} \mathrm{C}\right)$
\end{tabular} & $\begin{array}{c}\text { Temp. } \\
\text { interna } \\
\left({ }^{\circ} \mathrm{C}\right)\end{array}$ & $\begin{array}{l}\text { Temp. } \\
\text { sup. } \\
\text { externa } \\
\left({ }^{\circ} \mathrm{C}\right)\end{array}$ & $\begin{array}{l}\text { Temp. } \\
\text { sup. } \\
\text { interna } \\
\text { (C) }\end{array}$ & $\begin{array}{c}\text { Temp. } \\
\text { interna } \\
\left({ }^{\circ} \mathrm{C}\right)\end{array}$ & \begin{tabular}{|c|} 
Temp. \\
sup. \\
externa \\
(C)
\end{tabular} & \begin{tabular}{|c|} 
Temp. \\
sup. \\
interna
\end{tabular} & $\begin{array}{c}\text { Temp. } \\
\text { interna } \\
\left({ }^{\circ} \mathrm{C}\right)\end{array}$ & $\begin{array}{c}\text { Temp. } \\
\text { sup. } \\
\text { externa } \\
\text { C } \quad \text { ) }\end{array}$ & $\begin{array}{c}\text { Temp. } \\
\text { sup. } \\
\text { interna } \\
\left({ }^{\circ} \mathrm{C}\right)\end{array}$ & $\begin{array}{c}\begin{array}{c}\text { Temp. } \\
\text { interna } \\
\left({ }^{\circ} \mathrm{C}\right)\end{array} \\
\end{array}$ & $\begin{array}{l}\text { Temp. } \\
\text { sup. } \\
\text { externa } \\
\left({ }^{\circ} \mathrm{C}\right)\end{array}$ & \begin{tabular}{|c|} 
Temp. \\
sup. \\
interna \\
$\left({ }^{\circ} \mathrm{C}\right)$ \\
\end{tabular} & $\begin{array}{c}\text { Temp. } \\
\text { interna } \\
\left({ }^{\circ} \mathrm{C}\right)\end{array}$ \\
\hline $0: 00$ & & 14,42 & 13,97 & & 14,41 & 13,95 & & 14,54 & 13,97 & & 14,45 & & 16,63 & 14,42 & 13,97 & & 14,37 & 13,79 & 16,26 \\
\hline $1: 00$ & & & & & & & & & & & & & & & & & & & \\
\hline $2: 00$ & 889 & 3,84 & 41 &, 40 & 381 & 13,36 & 15,65 & 13,95 & & & 13,85 & & & 13,88 & & & 13,83 & & \\
\hline 3:00 & 3,79 & 3,67 & 13,26 &, 09 & 13,61 & 13,20 & 15,34 & 13,77 & 13, & 5,24 & 13,66 & 3,22 & 45 & 13,72 & 13,32 & 5,25 & 13,68 & & 5,17 \\
\hline $4: 00$ & & & & & 13,39 & & & 13,45 & & & 13,38 & & & 13,39 & & & & & \\
\hline 5:00 & & 3,27 & & & 13 & & 14,84 & 13,36 & & & 28 & & & 13,34 & & & & & \\
\hline & & & & & & & & & & & & & & & & & & & \\
\hline 7:00 & 1 & ,68 & & & 15,0 & & 14,69 & 13,65 & & & 14,17 & & & 14,29 & & & & & \\
\hline $8: 00$ & & & & & 22, & & & 18,14 & & & & & & 21,23 & & & 98 & & \\
\hline $9: 00$ & & 0,51 & & & 26,07 & & 17,04 & 21,59 & & & 98 & & & 26,11 & & & & & \\
\hline $10: 00$ & &, 12 & & & 29,78 & & 18,79 & 24,35 & & & 24,96 & & & 30,08 & & & & & \\
\hline & & & & & & & & & & & & & & & & & & & \\
\hline $12: 00$ & & & & & 36,16 & & 22,25 & 28,97 & & & 29,87 & & & 35,93 & & & & & \\
\hline $13: 00$ & & 36,24 & & & 36,61 & & 23,61 & 29,63 & & & 30,64 & & & 36,13 & & & & & \\
\hline $14: 00$ & 25,74 & 34,37 & & 24,70 & 35,42 & 42,35 & 24,98 & 29,28 & & ,28 & 30,09 & 89 & & 34,55 & & & 30,94 & & \\
\hline & & & & & 34,19 & & 25,85 & 29,06 & & & & & & & & & & & \\
\hline & & & & & & & & & & & & & & & & & & & \\
\hline $17: 00$ & 22,12 & 23,80 & & 25,02 & 24,14 & & 25,19 & 23,46 & & 25,28 & 23,74 & & & 23,81 & & & 23,41 & & \\
\hline $18: 00$ & 20,25 & 21,67 & & 23,89 & 21,86 & & 24,10 & 21,82 & & 24,32 & & & & 21,65 & & & & & 23,90 \\
\hline $19: 00$ & 19,06 & 20,41 & 20,07 & 22,65 & 20,54 & 20,17 & 22,95 & 20,60 & 20,16 & 23,15 & 20,57 & & & 20,42 & 20,05 & 22,27 & 20,42 & 19,87 & 22,77 \\
\hline $20: 00$ & & 19,65 & & 21,30 & 19,73 & 19,38 & 21,74 & 19,81 & & 21,86 & 19,80 & & 22,13 & 19,59 & & & 19,74 & & 21,61 \\
\hline 21:00 & & & & & & & 20,89 & & & & & & & & & & & & 20,72 \\
\hline $22: 00$ & & 19,00 & 18,74 & 20,27 & 19,04 & 18,75 & 20,52 & 19,15 & 18,79 & 20,64 & 19,10 & & 20,86 & 19,00 & 18,74 & 20,22 & 19,04 & 18,63 & 20,46 \\
\hline $23: 00$ & 17,63 & 18,51 & 18,28 & 20,00 & 18,50 & 18,30 & 20,18 & 18,72 & 18,37 & 20,30 & 18,62 & 18,11 & 20,47 & 18,45 & 18,22 & 19,91 & 18,47 & 18,08 & 20,13 \\
\hline
\end{tabular}


Tabela 7 - Temperaturas superficiais dos vidros e temperatura interna - Grupo 2 (Oeste) - 05/08/2005

\begin{tabular}{|c|c|c|c|c|c|c|c|c|c|c|c|c|c|c|c|c|c|c|c|}
\hline \multirow[b]{2}{*}{ Horário } & \multirow[b]{2}{*}{$\begin{array}{c}\text { Temp. } \\
\text { externa } \\
\left({ }^{\circ} \mathrm{C}\right)\end{array}$} & \multicolumn{3}{|c|}{ Plano verde } & \multicolumn{3}{|c|}{$\begin{array}{c}\text { CEB azul intenso } \\
\text { médio }\end{array}$} & \multicolumn{3}{|c|}{ CEB azul médio } & \multicolumn{3}{|c|}{ Plano incolor } & \multicolumn{3}{|c|}{ CEB prata neutro } & \multicolumn{3}{|c|}{ Reflectafloat } \\
\hline & & \begin{tabular}{|c|} 
Temp. \\
sup. \\
externa \\
$\left({ }^{\circ} \mathrm{C}\right)$
\end{tabular} & \begin{tabular}{|c|} 
Temp. \\
sup. \\
interna \\
$\left({ }^{\circ} \mathrm{C}\right)$
\end{tabular} & $\begin{array}{c}\text { Temp. } \\
\text { interna } \\
\left({ }^{\circ} \mathrm{C}\right)\end{array}$ & $\begin{array}{l}\text { Temp. } \\
\text { sup. } \\
\text { externa } \\
\left({ }^{\circ} \mathrm{C}\right)\end{array}$ & \begin{tabular}{|l} 
Temp. \\
sup. \\
interna \\
$\left({ }^{\circ} \mathrm{C}\right)$
\end{tabular} & \begin{tabular}{|c|}
$\begin{array}{c}\text { Temp. } \\
\text { interna } \\
\left({ }^{\circ} \mathrm{C}\right)\end{array}$ \\
\end{tabular} & $\begin{array}{l}\text { Temp. } \\
\text { sup. } \\
\text { externa } \\
\left({ }^{\circ} \mathrm{C}\right)\end{array}$ & $\begin{array}{l}\text { Temp. } \\
\text { sup. } \\
\text { interna } \\
\text { (C) }\end{array}$ & $\begin{array}{c}\text { Temp. } \\
\text { interna } \\
\left({ }^{\circ} \mathrm{C}\right)\end{array}$ & \begin{tabular}{|c|} 
Temp. \\
sup. \\
externa \\
(C)
\end{tabular} & $\begin{array}{l}\text { Temp. } \\
\text { sup. } \\
\text { interna }\end{array}$ & $\begin{array}{c}\text { Temp. } \\
\text { interna } \\
\left({ }^{\circ} \mathrm{C}\right)\end{array}$ & $\begin{array}{c}\text { Temp. } \\
\text { sup. } \\
\text { externa } \\
\text { C } \quad \text { ) }\end{array}$ & $\begin{array}{c}\text { Temp. } \\
\text { sup. } \\
\text { interna } \\
\left({ }^{\circ} \mathrm{C}\right)\end{array}$ & $\begin{array}{c}\text { Temp. } \\
\text { interna } \\
\left({ }^{\circ} \mathrm{C}\right)\end{array}$ & $\begin{array}{l}\text { Temp. } \\
\text { sup. } \\
\text { externa } \\
\left({ }^{\circ} \mathrm{C}\right)\end{array}$ & \begin{tabular}{|c} 
Temp. \\
sup. \\
interna \\
$\left({ }^{\circ} \mathrm{C}\right)$
\end{tabular} & $\begin{array}{c}\text { Temp. } \\
\text { interna } \\
\left({ }^{\circ} \mathrm{C}\right)\end{array}$ \\
\hline $0: 00$ & & 16,88 & 16,04 & & 16,39 & 15,69 & & & 16,09 & & 16,97 & & 20,04 & 17,19 & 16,54 & & 16,71 & 15,98 & 19,83 \\
\hline $1: 00$ & & & & & & & & & & & & & & & & & & & \\
\hline $2: 00$ & 3 & ,31 & 37 &, 43 & 90 & & & 15 & & & 15,49 & & & & & & 15,23 & & \\
\hline 3:00 &, 59 & 4,60 &, 69 &, 72 & 4,22 & 13,47 & 76 & 14 & 3,88 & & 14,77 & & 18,02 & 15,03 & 33 & & 14,50 & & ,88 \\
\hline $4: 00$ & & ,03 & & & & & & & & & & & & & & & & & \\
\hline $5: 00$ & & 3,70 & 87 & 28 & 13,35 & 12,64 & & 13 & & & 13,75 & & & 09 & & & 13,65 & &, 52 \\
\hline $6: 00$ & & & & & & & & & & & & & & & & & & & \\
\hline 7:00 & & 3,79 & & & & & & & & & 13,42 & & & & & & & & \\
\hline $8: 00$ & &, 21 & & & & & & & & & 15,26 & & & & & & & & \\
\hline $9: 00$ & &, 45 & & & & & & & & & 17,89 & & & & & & & & \\
\hline $10: 00$ & 24,60 & 2,67 & & & & 05 & & 22 & & & 21,16 & & & & & & & & ,23 \\
\hline $11: 00$ & 26,13 & 25,11 & & & & 27,72 & & 24 , & & & 23,65 & & & & & & 10 & & \\
\hline & & & & & & & & & & & 25,48 & & & & & & & & \\
\hline $13: 00$ & & & & & & & & & & & & & & & & & 29 & & \\
\hline $14: 00$ & 28,11 & 35,90 & & 25,75 & & 44,86 & 24,83 & & & & 31,86 & & & 36,43 & & & 32,62 & & 17 \\
\hline & & 9,20 & & & & & & & & & & & & & & & 34,29 & & \\
\hline $16: 00$ & 28,30 & 39,64 & & 29,47 & & 52,41 & & & & ,97 & 33,85 & & & 40,95 & & & 34,26 & & ,42 \\
\hline $17: 00$ & 25,87 & 34,68 & & & & & & & & & 30,40 & & & & & & & & 8,41 \\
\hline $18: 00$ & 22,47 & 23,73 & & 26,82 & & & & & & & 24,03 & & & & & & 23,56 & & 26,83 \\
\hline $19: 00$ & 20,30 & 21,76 & 20,63 & 25,26 & 21,48 & 20,62 & & 21,90 & 20,79 & 25,25 & 22,15 & 20,78 & & 22,14 & 21,32 & & 21,77 & & 25,29 \\
\hline $20: 00$ & & & & 23,70 & & & & & & & 20,80 & & & 20,98 & & & 20,63 & & \\
\hline 21:00 & 18,51 & 19,33 & 18,41 & 22,05 & & 18,03 & 22,48 & & 18,44 & 22,33 & 19,48 & & & 19,65 & 18,89 & & 19,37 & 18,52 & 22,57 \\
\hline $22: 00$ & & 18,51 & 17,71 & 20,74 & 18,16 & 17,46 & 21,20 & & 17,65 & 21,01 & 18,65 & 17,79 & & 18,66 & 18,04 & & 18,53 & 17,81 & 21,17 \\
\hline $23: 00$ & 17,29 & 17,79 & 16,97 & 20,04 & 17,42 & 16,72 & 20,49 & 17,80 & 16,89 & 20,31 & 17,90 & 16,97 & 20,96 & 17,91 & 17,28 & 19,92 & 17,78 & 17,05 & 20,50 \\
\hline
\end{tabular}


Tabela 8 - Temperaturas superficiais dos vidros e temperatura interna - Grupo 2 (Norte) - 30/07/2005

\begin{tabular}{|c|c|c|c|c|c|c|c|c|c|c|c|c|c|c|c|c|c|c|c|}
\hline \multirow[b]{2}{*}{ Horário } & \multirow[b]{2}{*}{$\begin{array}{c}\text { Temp. } \\
\text { externa } \\
\left({ }^{\circ} \mathrm{C}\right)\end{array}$} & \multicolumn{3}{|c|}{ Plano verde } & \multicolumn{3}{|c|}{$\begin{array}{l}\text { CEB azul intenso } \\
\text { médio }\end{array}$} & \multicolumn{3}{|c|}{ CEB azul médio } & \multicolumn{3}{|c|}{ Plano incolor } & \multicolumn{3}{|c|}{ CEB prata neutro } & \multicolumn{3}{|c|}{ Reflectafloat } \\
\hline & & \begin{tabular}{|c|} 
Temp. \\
sup. \\
externa \\
$\left({ }^{\circ} \mathrm{C}\right)$
\end{tabular} & \begin{tabular}{|c|} 
Temp. \\
sup. \\
interna \\
$\left({ }^{\circ} \mathrm{C}\right)$
\end{tabular} & $\begin{array}{c}\text { Temp. } \\
\text { interna } \\
\left({ }^{\circ} \mathrm{C}\right)\end{array}$ & $\begin{array}{l}\text { Temp. } \\
\text { sup. } \\
\text { externa } \\
\left({ }^{\circ} \mathrm{C}\right)\end{array}$ & \begin{tabular}{|l} 
Temp. \\
sup. \\
interna \\
$\left({ }^{\circ} \mathrm{C}\right)$
\end{tabular} & \begin{tabular}{|c|}
$\begin{array}{c}\text { Temp. } \\
\text { interna } \\
\left({ }^{\circ} \mathrm{C}\right)\end{array}$ \\
\end{tabular} & $\begin{array}{l}\text { Temp. } \\
\text { sup. } \\
\text { externa } \\
\left({ }^{\circ} \mathrm{C}\right)\end{array}$ & $\begin{array}{l}\text { Temp. } \\
\text { sup. } \\
\text { interna } \\
\text { (C) }\end{array}$ & $\begin{array}{c}\text { Temp. } \\
\text { interna } \\
\left({ }^{\circ} \mathrm{C}\right)\end{array}$ & \begin{tabular}{|c|} 
Temp. \\
sup. \\
externa \\
(C)
\end{tabular} & \begin{tabular}{|c|} 
Temp. \\
sup. \\
interna
\end{tabular} & $\begin{array}{c}\text { Temp. } \\
\text { interna } \\
\left({ }^{\circ} \mathrm{C}\right)\end{array}$ & $\begin{array}{c}\text { Temp. } \\
\text { sup. } \\
\text { externa } \\
\text { C } \quad \text { ) }\end{array}$ & $\begin{array}{c}\text { Temp. } \\
\text { sup. } \\
\text { interna } \\
\left({ }^{\circ} \mathrm{C}\right)\end{array}$ & $\begin{array}{c}\text { Temp. } \\
\text { interna } \\
\left({ }^{\circ} \mathrm{C}\right)\end{array}$ & $\begin{array}{l}\text { Temp. } \\
\text { sup. } \\
\text { externa } \\
\left({ }^{\circ} \mathrm{C}\right)\end{array}$ & \begin{tabular}{|c} 
Temp. \\
sup. \\
interna \\
$\left({ }^{\circ} \mathrm{C}\right)$
\end{tabular} & $\begin{array}{c}\text { Temp. } \\
\text { interna } \\
\left({ }^{\circ} \mathrm{C}\right)\end{array}$ \\
\hline $0: 00$ & & 18,46 & 17,91 & & 17,84 & 17,40 & & 18,26 & 18,00 & & 18,59 & 17,80 & 20,67 & 18,58 & 18,23 & & 18,44 & 17,80 & 20,27 \\
\hline $1: 00$ & & & & & & & & & & & & & & & & & & & \\
\hline $2: 00$ & 4,88 & 16,24 & & 3,93 & 5 & & & 16,05 & & & 16,31 & & & 16,49 & & & & & \\
\hline $3: 00$ & 4,92 & 5,46 & & 3,05 & 70 & 4,14 & 3,31 & 15, & 06 & 32 & 15,58 & & 18,66 & 15,82 & & & 15,38 & & 7 \\
\hline $4: 00$ & &, 76 & & & & & & & & & 14,76 & & & & & & & & \\
\hline $5: 00$ & 42 & ,22 & & 67 & 52 & 2,97 & & 14, & & & 14,39 & & & 14, & & 82 & 14,23 & & 83 \\
\hline $6: 00$ & & & & & & & & & & & & & & & & & & & \\
\hline 7:00 & & 0,74 & & & & & & & & & 15,24 & & & & & & & & \\
\hline $8: 00$ & & 2,79 & & & & & & 24 & & & 20,39 & & & 24 & & & 79 & & \\
\hline $9: 00$ & 21,60 &, 60 & & & & & & & & & 24,07 & & & & & & & & \\
\hline $10: 00$ & 24,80 & ,21 & & 62 & & & & & & & 27,78 & & & 34,93 & & & & & 20 \\
\hline $11: 00$ & 25,84 & 37,30 & & 22,97 & & & & & & & 30,75 & & & 37,82 & & & & & \\
\hline & & 38,71 & & & & & & & & & 32,83 & & & & & & & & \\
\hline $13: 00$ & & 9,36 & & & & & & & & & 33,69 & & & & & & & & \\
\hline $14: 00$ & 27,10 & 38,66 & & 26,43 & 47 & 05 & & 40,53 & & & 33,54 & & & & & & 76 & & 79 \\
\hline & & 8,11 & & 27,55 & & & & & & & & & & & & & & & \\
\hline $16: 00$ & 26,80 & 35,61 & & 27,92 & 41,74 & & & 37, & & & 31,96 & & & 35,73 & & & 31,62 & & ,38 \\
\hline $17: 00$ & 25,12 & 30,40 & & 27,73 & & & & & & 27,27 & 28,08 & & & 30,42 & & & 27,55 & & 7,35 \\
\hline $18: 00$ & 21,32 & 23,11 & & 25,73 & & & & & & & 23,30 & & & & & & & & 25,76 \\
\hline $19: 00$ & 20,66 & 21,46 & 20,72 & 23,88 & 20,60 & 20,01 & 23,97 & 21,16 & & 24,21 & 21,53 & & 24,78 & 21,50 & 20,98 & & 21,20 & 20,25 & 24,09 \\
\hline & & & & 22,48 & & & & & & 22,78 & 20,47 & & & 20,52 & & & & & 2,68 \\
\hline 21:00 & 19,08 & 19,48 & 18,82 & 21,50 & 18,71 & 18,17 & 21,72 & 19,29 & & 21,81 & 19,59 & & & 19,66 & & & 19,47 & 18,63 & 21,74 \\
\hline $22: 00$ & 18,36 & 18,71 & & 20,55 & 18,01 & 17,48 & 20,80 & 18,54 & & 20,86 & 18,78 & 17,97 & & 18,90 & 18,48 & & 18,66 & 17,87 & 20,78 \\
\hline $23: 00$ & 17,75 & 17,93 & 17,25 & 20,25 & 17,25 & 16,69 & 20,40 & 17,85 & 17,53 & 20,50 & 18,08 & 17,11 & 20,93 & 18,27 & 17,79 & 20,21 & 17,82 & 16,94 & 20,41 \\
\hline
\end{tabular}


Tabela 9 - Temperaturas superficiais dos vidros e temperatura interna - Grupo 3 (Oeste) - 13/08/2005

\begin{tabular}{|c|c|c|c|c|c|c|c|c|c|c|c|c|c|c|c|c|c|c|c|}
\hline \multirow[b]{2}{*}{ Horário } & \multirow[b]{2}{*}{$\begin{array}{c}\text { Temp. } \\
\text { externa } \\
\text { ('C) }\end{array}$} & \multicolumn{3}{|c|}{ Plano verde } & \multicolumn{3}{|c|}{$\begin{array}{l}\text { Antélio verde } \\
\text { esmeralda }\end{array}$} & \multicolumn{3}{|c|}{ Antélio prata } & \multicolumn{3}{|c|}{ Plano incolor } & \multicolumn{3}{|c|}{ CEB prata neutro } & \multicolumn{3}{|c|}{ Reflectafloat } \\
\hline & & \begin{tabular}{|c|} 
Temp. \\
sup. \\
externa \\
(C)
\end{tabular} & $\begin{array}{l}\text { Temp. } \\
\text { sup. } \\
\text { interna } \\
\left({ }^{\circ} \mathrm{C}\right)\end{array}$ & $\begin{array}{c}\text { Temp. } \\
\text { interna } \\
\left({ }^{\circ} \mathrm{C}\right)\end{array}$ & $\begin{array}{l}\text { Temp. } \\
\text { sup. } \\
\text { externa } \\
\text { (C) }\end{array}$ & $\begin{array}{l}\text { Temp. } \\
\text { sup. } \\
\text { interna } \\
\left({ }^{\circ} \mathrm{C}\right)\end{array}$ & $\begin{array}{c}\text { Temp. } \\
\text { interna } \\
\left({ }^{\circ} \mathrm{C}\right)\end{array}$ & $\begin{array}{l}\text { Temp. } \\
\text { sup. } \\
\text { externa } \\
\text { ( }{ }^{\circ} \text { C) }\end{array}$ & $\begin{array}{l}\text { Temp. } \\
\text { sup. } \\
\text { interna } \\
\text { (C) }\end{array}$ & \begin{tabular}{|l} 
Temp. \\
interna \\
$\left({ }^{\circ} \mathrm{C}\right)$
\end{tabular} & $\begin{array}{l}\text { Temp. } \\
\text { sup. } \\
\text { externa } \\
\text { (C) }\end{array}$ & $\begin{array}{c}\text { Temp. } \\
\text { sup. } \\
\text { interna }\end{array}$ & \begin{tabular}{|l} 
Temp. \\
interna \\
('C)
\end{tabular} & $\begin{array}{l}\text { Temp. } \\
\text { sup. } \\
\text { externa }\end{array}$ & $\begin{array}{c}\text { Temp. } \\
\text { sup. } \\
\text { interna } \\
\left({ }^{\circ} \mathrm{C}\right)\end{array}$ & \begin{tabular}{|c} 
Temp. \\
interna \\
('C)
\end{tabular} & $\begin{array}{l}\text { Temp. } \\
\text { sup. } \\
\text { externa } \\
\left({ }^{\circ}\right)\end{array}$ & $\begin{array}{l}\text { Temp. } \\
\text { sup. } \\
\text { interna } \\
\left.{ }^{(} \mathrm{C}\right)\end{array}$ & \begin{tabular}{|c} 
Temp. \\
interna \\
${ }^{(\mathrm{C})}$
\end{tabular} \\
\hline 0:00 & & 14,71 & 14,15 & & 14,80 & 14.13 & & & & & & & & & & & & & \\
\hline & & & & & & & & & & & & & & & & & & & \\
\hline $2: 00$ & & & & & & & & & & & & & & & & & & & \\
\hline $3: 00$ & & & & & & & & & & & & & & & & & & & \\
\hline $4: 0$ & & & & & & & & & & & & & & & & & & & \\
\hline & & & & & & & & & & & & & & & & & & & \\
\hline & & & & & & & & & & & & & & & & & & & \\
\hline & & & & & & & & & & & & & & & & & & & \\
\hline & & & & & & & & & & & & & & & & & & & \\
\hline & & & & & & & & & & & & & & & & & & & \\
\hline & & & & & & & & & & & & & & & & & & & \\
\hline & & & & & & & & & & & & & & & & & & & \\
\hline & & & & & & & & & & & & & & & & & & & \\
\hline & & & & & & & & & & & & & & & & & & & \\
\hline & & & & & & & & & & & & & & & & & & & \\
\hline & & & & & & & & & & & & & & & & & & & \\
\hline & & & & & & & & & & & & & & & & & & & \\
\hline & & & & & & & & & & & & & & & & & & & \\
\hline 18:0 & 22,73 & & 2 & & & & 25,67 & 22,90 & & & & & & 23,34 & & & 22,89 & & \\
\hline & & & & & & & & & & & & & & & & & & & \\
\hline & & & & & & & & & & & & & & & & & & & \\
\hline & & & & & & & & & & & & & & & & & & & \\
\hline 2 & 0,50 & & & & 17,4 & & 20 , & & & & & & & 17 & 2 & & & & 19,52 \\
\hline & & & & & 10,53 & & & & & & & & & 10,17 & & & 10,32 & 15,76 & 10,03 \\
\hline
\end{tabular}


Tabela 10 - Temperaturas superficiais dos vidros e temperatura interna - Grupo 3 (Norte) - 21/08/2005

\begin{tabular}{|c|c|c|c|c|c|c|c|c|c|c|c|c|c|c|c|c|c|c|c|}
\hline \multirow[b]{2}{*}{ Horário } & \multirow[b]{2}{*}{$\begin{array}{c}\text { Temp. } \\
\text { externa } \\
\left({ }^{\circ} \mathrm{C}\right)\end{array}$} & \multicolumn{3}{|c|}{ Plano verde } & \multicolumn{3}{|c|}{$\begin{array}{l}\text { Antélio verde } \\
\text { esmeralda }\end{array}$} & \multicolumn{3}{|c|}{ Antélio prata } & \multicolumn{3}{|c|}{ Plano incolor } & \multicolumn{3}{|c|}{ CEB prata neutro } & \multicolumn{3}{|c|}{ Reflectafloat } \\
\hline & & \begin{tabular}{|c|} 
Temp. \\
sup. \\
externa \\
$\left({ }^{\circ} \mathrm{C}\right)$
\end{tabular} & \begin{tabular}{|c|} 
Temp. \\
sup. \\
interna \\
$\left({ }^{\circ} \mathrm{C}\right)$
\end{tabular} & $\begin{array}{c}\text { Temp. } \\
\text { interna } \\
\left({ }^{\circ} \mathrm{C}\right)\end{array}$ & \begin{tabular}{|c|} 
Temp. \\
sup. \\
externa \\
$\left({ }^{\circ} \mathrm{C}\right)$
\end{tabular} & \begin{tabular}{|c|} 
Temp. \\
sup. \\
interna \\
$\left({ }^{\circ} \mathrm{C}\right)$
\end{tabular} & $\begin{array}{c}\text { Temp. } \\
\text { interna } \\
\left({ }^{\circ} \mathrm{C}\right)\end{array}$ & $\begin{array}{l}\text { Temp. } \\
\text { sup. } \\
\text { externa } \\
\left({ }^{\circ} \mathrm{C}\right)\end{array}$ & $\begin{array}{l}\text { Temp. } \\
\text { sup. } \\
\text { interna } \\
\text { (') }\end{array}$ & $\begin{array}{c}\begin{array}{c}\text { Temp. } \\
\text { interna } \\
\left({ }^{\circ} \mathrm{C}\right)\end{array} \\
\end{array}$ & $\begin{array}{l}\text { Temp. } \\
\text { sup. } \\
\text { externa } \\
\text { ext) } \\
{ }^{\circ} \text { C) }\end{array}$ & \begin{tabular}{|c|} 
Temp. \\
sup. \\
interna
\end{tabular} & $\begin{array}{c}\text { Temp. } \\
\text { interna } \\
\left({ }^{\circ} \mathrm{C}\right)\end{array}$ & $\begin{array}{c}\text { Temp. } \\
\text { sup. } \\
\text { externa } \\
\text { C } \quad \text { ) }\end{array}$ & $\begin{array}{c}\text { Temp. } \\
\text { sup. } \\
\text { interna } \\
\left({ }^{\circ} \mathrm{C}\right)\end{array}$ & $\begin{array}{c}\begin{array}{c}\text { Temp. } \\
\text { interna } \\
\left({ }^{\circ} \mathrm{C}\right)\end{array} \\
\end{array}$ & $\begin{array}{c}\text { Temp. } \\
\text { sup. } \\
\text { externa } \\
\left({ }^{\circ} \mathrm{C}\right)\end{array}$ & \begin{tabular}{|c|} 
Temp. \\
sup. \\
interna \\
$\left({ }^{\circ} \mathrm{C}\right)$ \\
\end{tabular} & $\begin{array}{c}\text { Temp. } \\
\text { interna } \\
\left({ }^{\circ} \mathrm{C}\right)\end{array}$ \\
\hline 0:00 & 7,31 & 17,75 & 17,28 & & 17,80 & 17,20 & & 17,87 & 17,32 & & 17,99 & 17,47 & 20,38 & 18,05 & 17,73 & & 17,72 & 17,23 & \\
\hline $1: 00$ & & & & & & & & & & & & & & & & & & & \\
\hline $2: 00$ & 6,88 & 7,02 &, 53 & 81 & 17,00 & 16,40 & & 17,13 & & & 17,22 & & & 17,35 & & & & & \\
\hline 3:00 & & & & & & & & & & & & & & & & & & & \\
\hline $4: 00$ & 1 & 6,36 & & & 1 & & & 16,42 & & & 16 & & & & & & & & \\
\hline $5: 00$ &, 12 & 0,10 & & & 16,06 & 50 & 18,07 & 16 , & & 69 & 16,23 & & & 38 & & & 16,03 & & 08 \\
\hline $6: 00$ & & & & & & & & & & & & & & & & & & & \\
\hline 7:00 & 16,72 & 8,85 & & & 17 & & & 16,83 & & & 03 & & & & & & & & \\
\hline & & & & & & & & & & & & & & & & & & & \\
\hline $9: 0$ & & & & & 29 & & & 24,54 & & & 24,38 & & & & & & & & \\
\hline $10: 00$ & 24,40 & & & & 32 & & & 27,69 & & & 27,36 & & & & & & ,73 & & \\
\hline $11: 00$ & 25,91 & 5,47 & & & 35,72 & & 23,91 & 29,94 & & & 29,70 & & & 36,21 & & & 32,24 & & \\
\hline $12: 00$ & & & & & & & & & & & & & & & & & & & \\
\hline & & & & & & & & & & & & & & & & & & & \\
\hline & & & & & & & & & & & & & & & & & & & \\
\hline & & & & & & & & & & & & & & & & & & & \\
\hline $16: 00$ & 29,17 & 36,20 & 9,78 & 29,76 & 37,04 & 41,47 & 29,96 & 32,36 & & & 32,66 & & 30,42 & 36,64 &, 28 & & 33,53 & &, 76 \\
\hline $17: 00$ & 27,82 & 32,06 & & & 32,49 & 34,00 & 29,90 & 29,66 & & 9,70 & 30,14 & & & 32,22 & & & 29,68 & & \\
\hline $18: 00$ & & & & & & & & & & & & & & & & & & & \\
\hline $19: 00$ & 21,97 & 23,64 & 22,94 & 26,40 & 23,69 & 22,73 & 26,95 & 23,66 & 22,87 & 26,77 & 24,05 & & 27,26 & 23,64 & & 26,01 & 23,40 & & 26,79 \\
\hline $20: 00$ & 20,93 & 22,27 & 21,68 & & 22,32 & & 25,32 & 22,35 & & 25,09 & 22,68 & & & 22,32 & & & 22,20 & & 25,22 \\
\hline $21: 00$ & 20,36 & 21,31 & 20,68 & 23,62 & 21,27 & 20,42 & 24,14 & 21,47 & 20,65 & 23,76 & 21,56 & 20,77 & 24,44 & 21,49 & 21,03 & & 21,17 & 20,51 & 24,11 \\
\hline $22: 00$ & 19,49 & 20,31 & 19,70 & 22,59 & 20,31 & 19,51 & 23,06 & 20,51 & 19,75 & 22,60 & 20,57 & 19,83 & 23,37 & 20,56 & 20,12 & 22,61 & 20,21 & 19,61 & 23,06 \\
\hline 23:00 & 19,05 & 19,59 & 19,00 & 21,75 & 19,58 & 18,83 & 22,22 & 19,79 & 19,07 & 21,76 & 19,80 & 19,12 & 22,51 & 19,88 & 19,45 & 21,87 & 19,52 & 18,93 & 22,22 \\
\hline
\end{tabular}




\subsection{Discussão}

A primeira conclusão que pode ser tirada ao analisar esses gráficos é que quando houve incidência do sol, as temperaturas superficiais internas de todos os vidros analisados sempre foram superiores às temperaturas superficiais externas, às temperaturas no interior das células-teste e à temperatura externa.

Pode-se observar que dentre os vidros planos, o vidro plano incolor apresentou menores diferenças entre as temperaturas superficiais e as temperaturas internas na célula-teste (Figuras 63, 64). Já o vidro plano verde apresentou maiores diferenças entre as temperaturas internas e as temperaturas superficiais, justificando seu nome "termo-absorvente" (Figuras 65, 66). Com relação às temperaturas superficiais, o vidro plano verde apresentou diferenças de até $7^{\circ} \mathrm{C}$ entre as temperaturas superficiais internas e as externas, sendo que estas últimas foram menores.

Os vidros refletivos pirolíticos e metalizados a vácuo apresentaram maiores diferenças entre as temperaturas superficiais, temperaturas internas e temperaturas externas. As temperaturas superficiais internas dos vidros foram as maiores registradas, mostrando que a camada refletiva voltada para o interior da célula-teste absorve o calor de maneira significativa.

Pode-se concluir que, quanto mais absorvente o vidro, maiores são as diferenças entre as temperaturas superficiais internas e externas. 


\subsubsection{Medições de verão}

A segunda etapa de medições das várias tipologias de vidros abrangeu os meses de fevereiro e março de 2006. Os dados obtidos através dessas medições foram tratados e convertidos em gráficos e tabelas apresentados a seguir.

\subsubsection{Resultados para os grupos de vidros}

\section{Grupo 1}

Fachada Oeste: 15 de fevereiro de 2006

Fachada Norte: 23 de fevereiro de 2006 


\section{- Temperaturas superficiais externas}

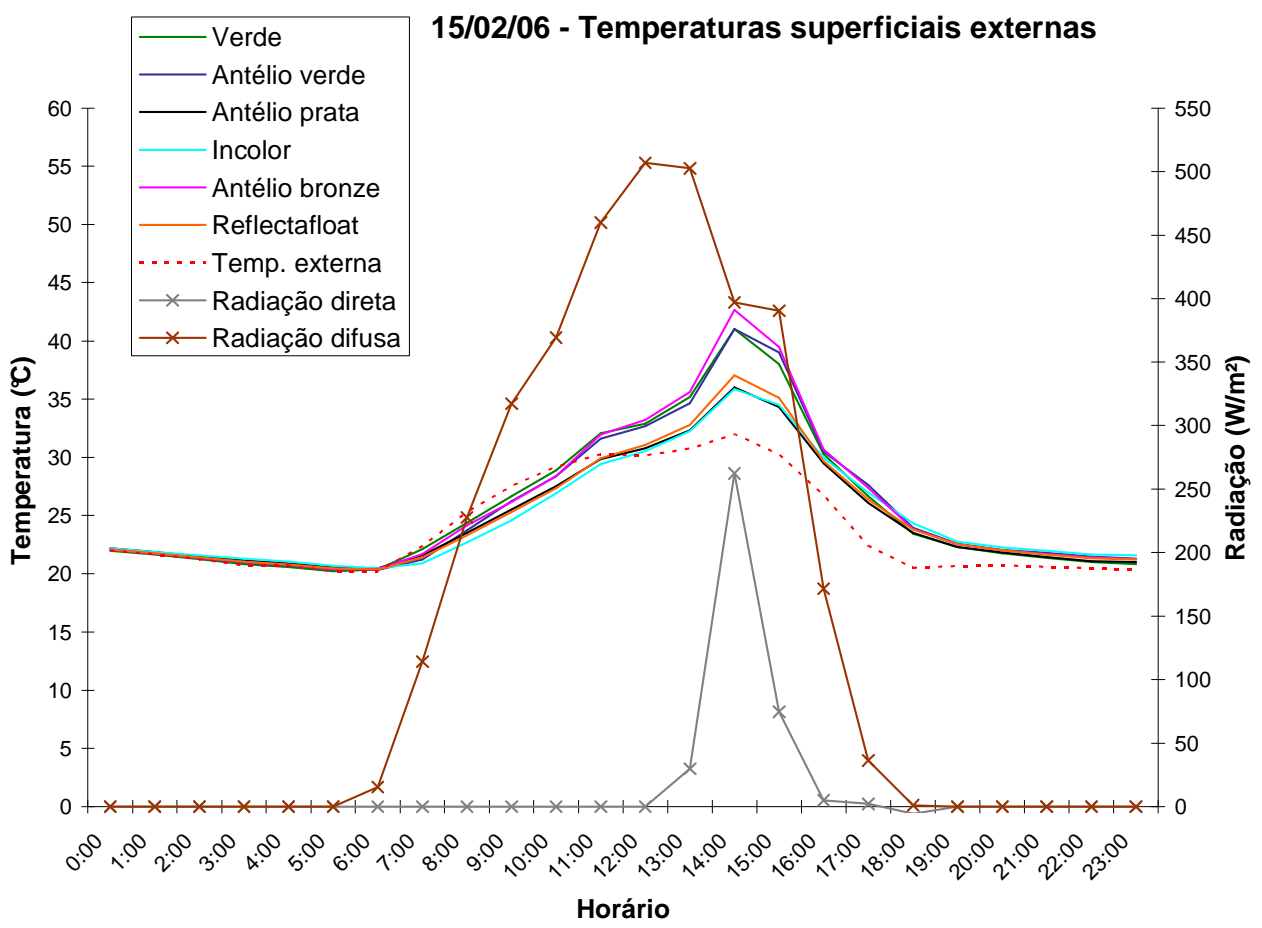

Figura 81. Temperaturas superficiais externas dos vidros e a temperatura externa - Oeste

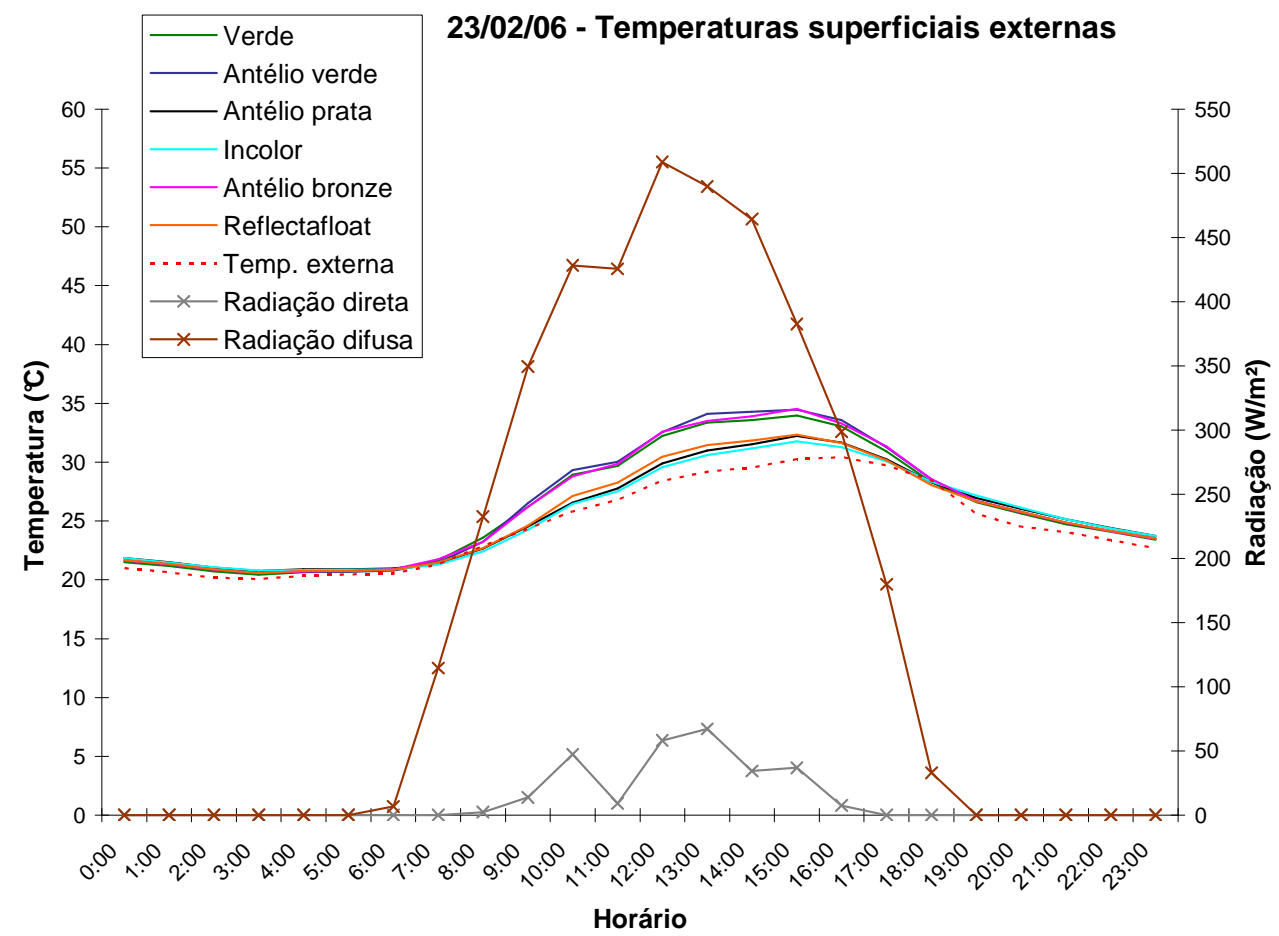

Figura 82. Temperaturas superficiais externas dos vidros e a temperatura externa - Norte 


\section{- Temperaturas superficiais internas}

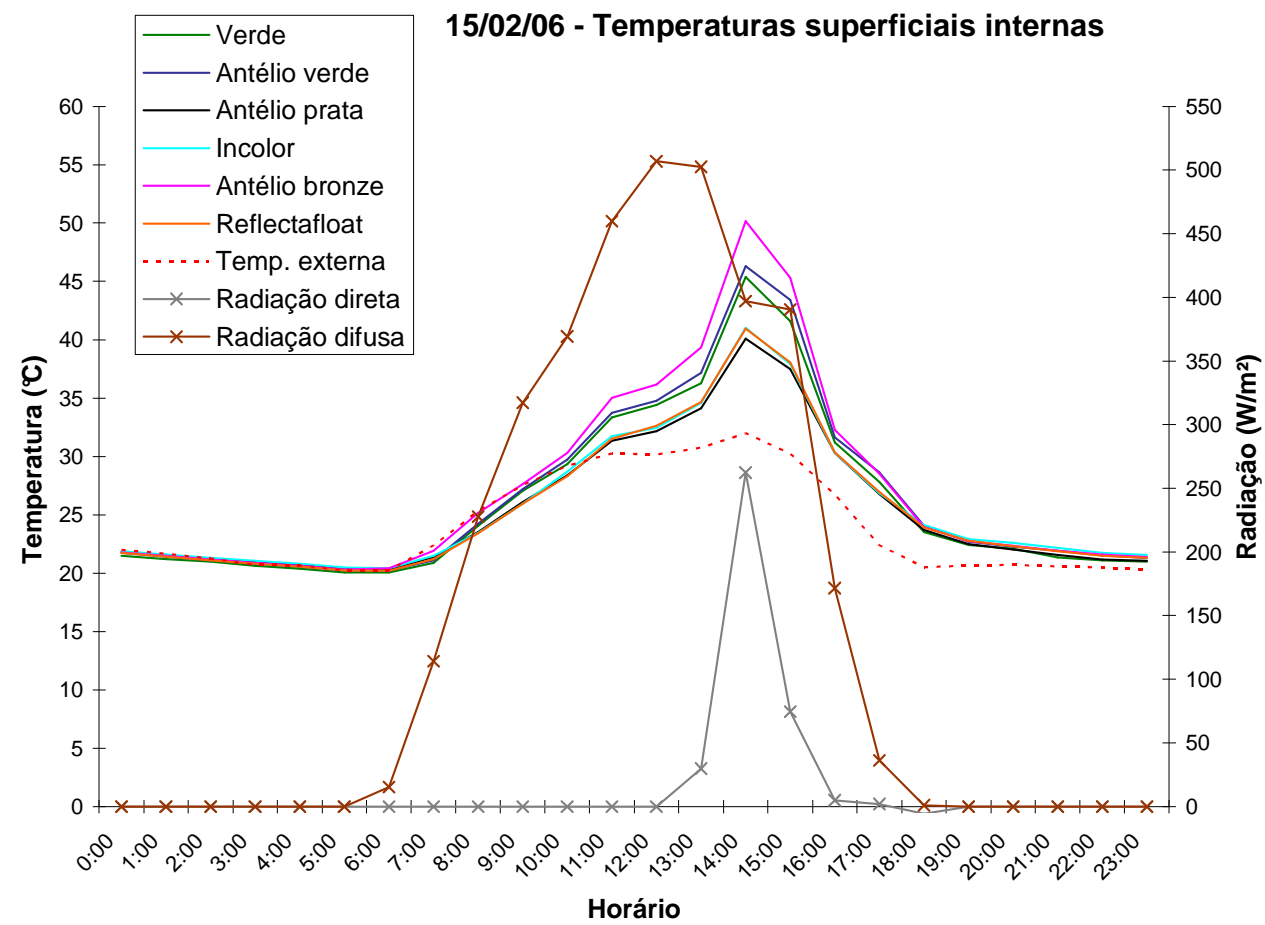

Figura 83. Temperaturas superficiais internas dos vidros e a temperatura externa - Oeste

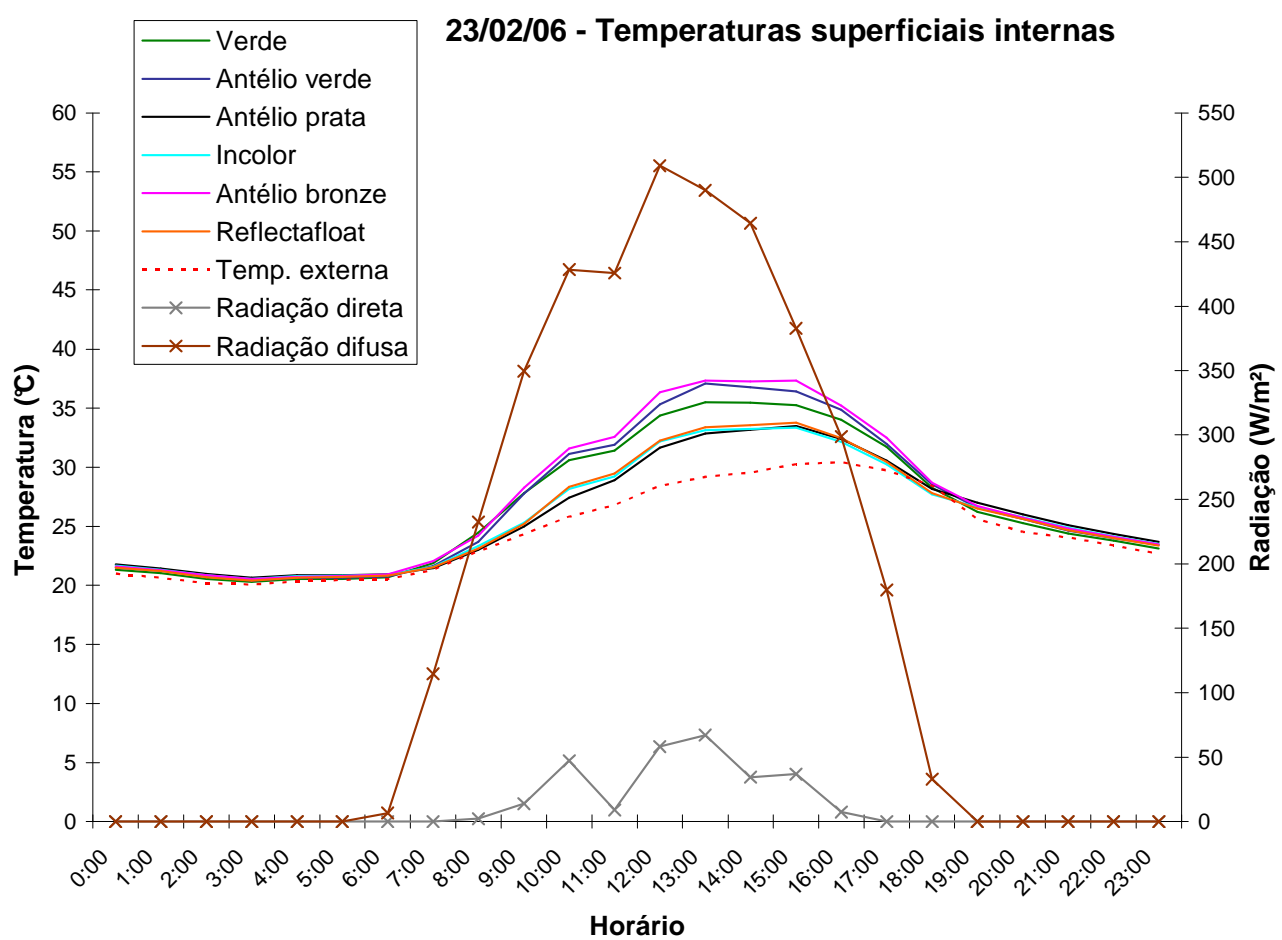

Figura 84. Temperaturas superficiais internas dos vidros e a temperatura externa - Norte 


\section{- Temperaturas internas}

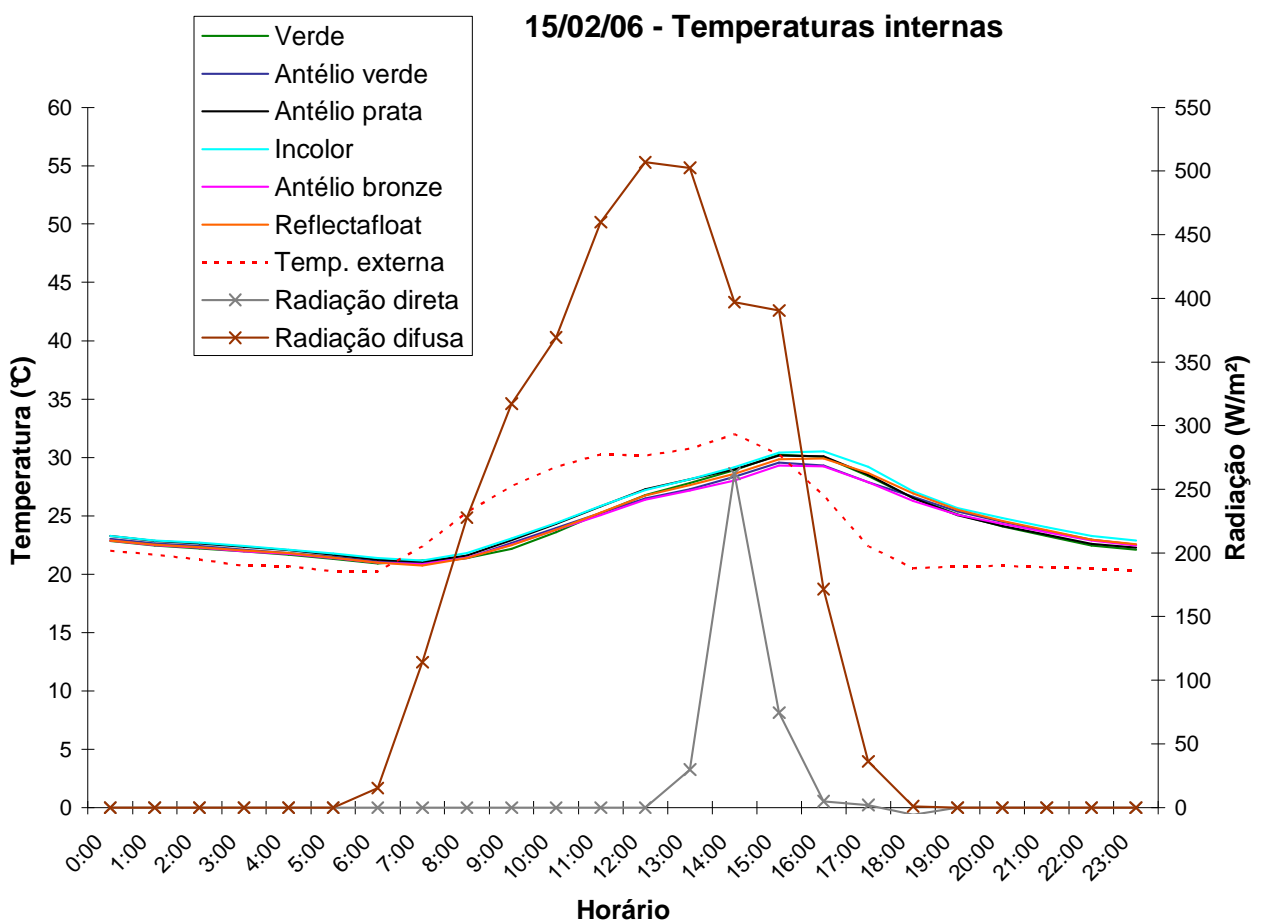

Figura 85. Temperaturas internas das células-teste e a temperatura externa - Oeste

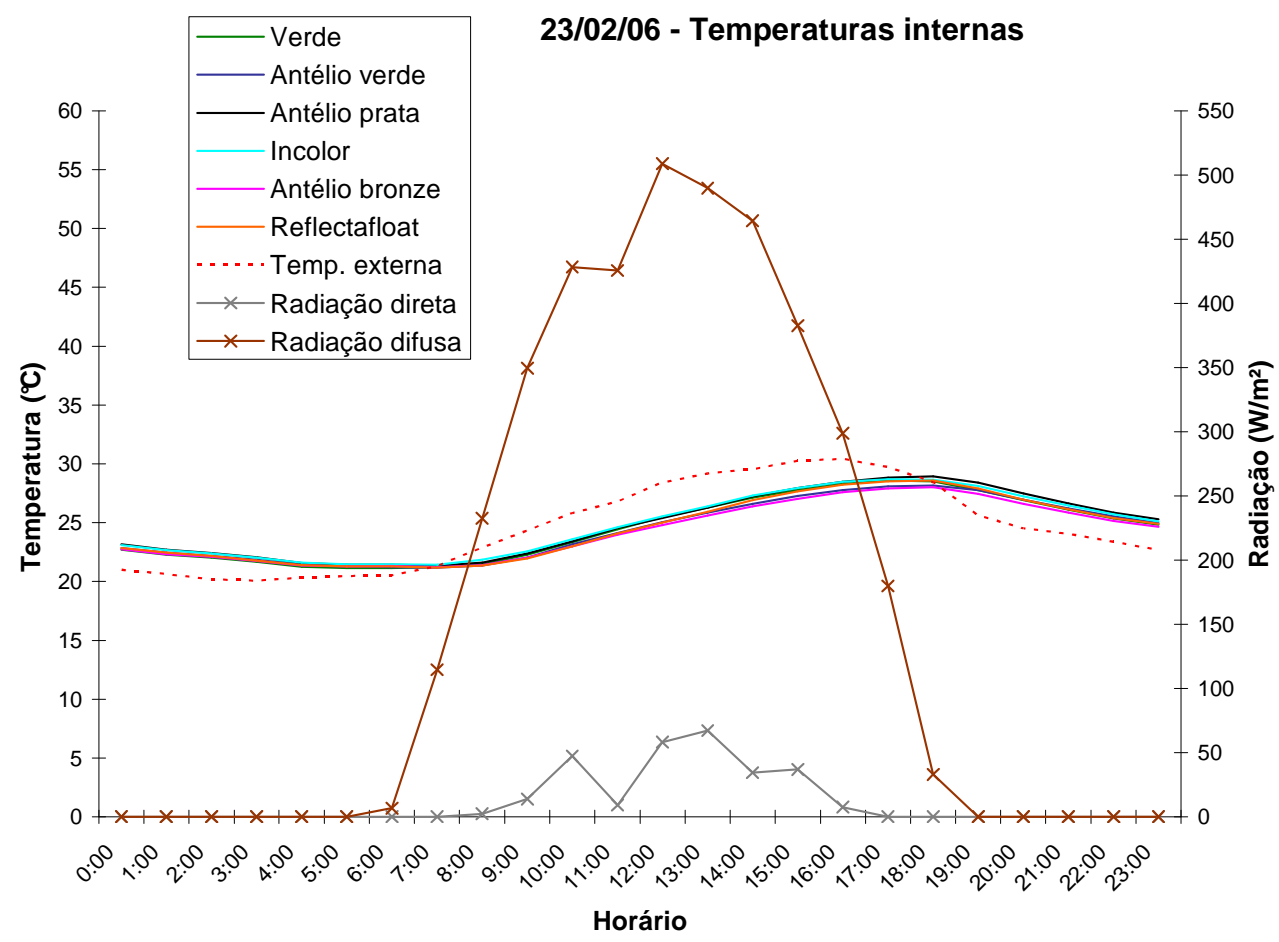

Figura 86. Temperaturas internas das células-teste e a temperatura externa - Norte 


\section{Grupo 2}

Fachada Oeste: 11 de março de 2006

Fachada Norte: 05 de março de 2006

\section{- Temperaturas superficiais externas}

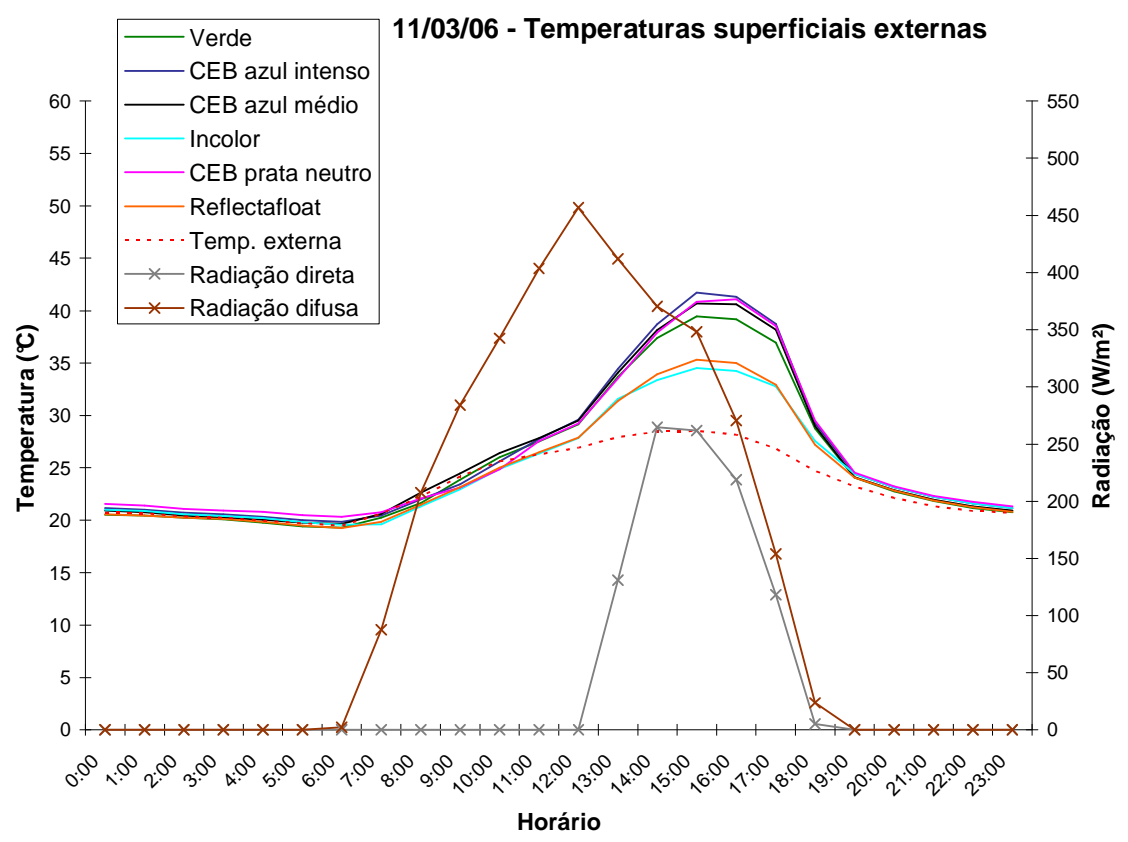

Figura 87. Temperaturas superficiais externas dos vidros e a temperatura externa - Oeste

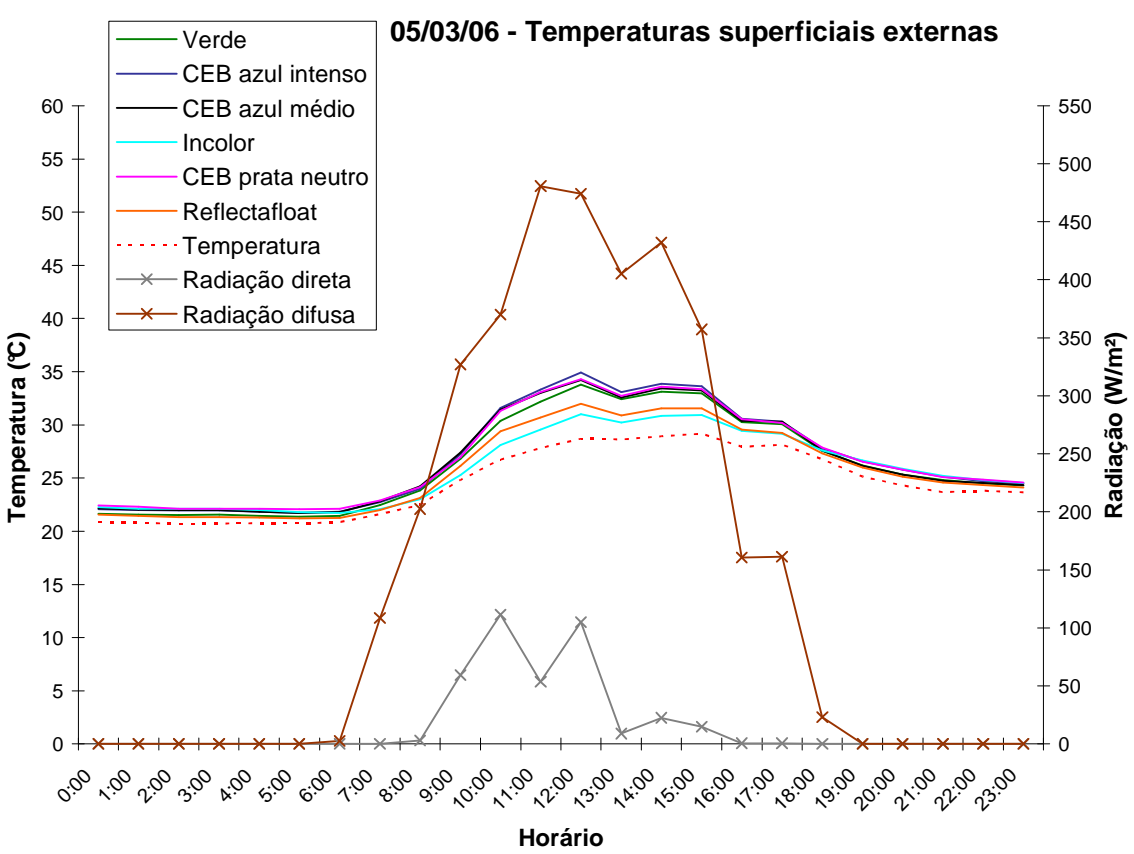

Figura 88. Temperaturas superficiais externas dos vidros e a temperatura externa - Norte 


\section{- Temperaturas superficiais internas}

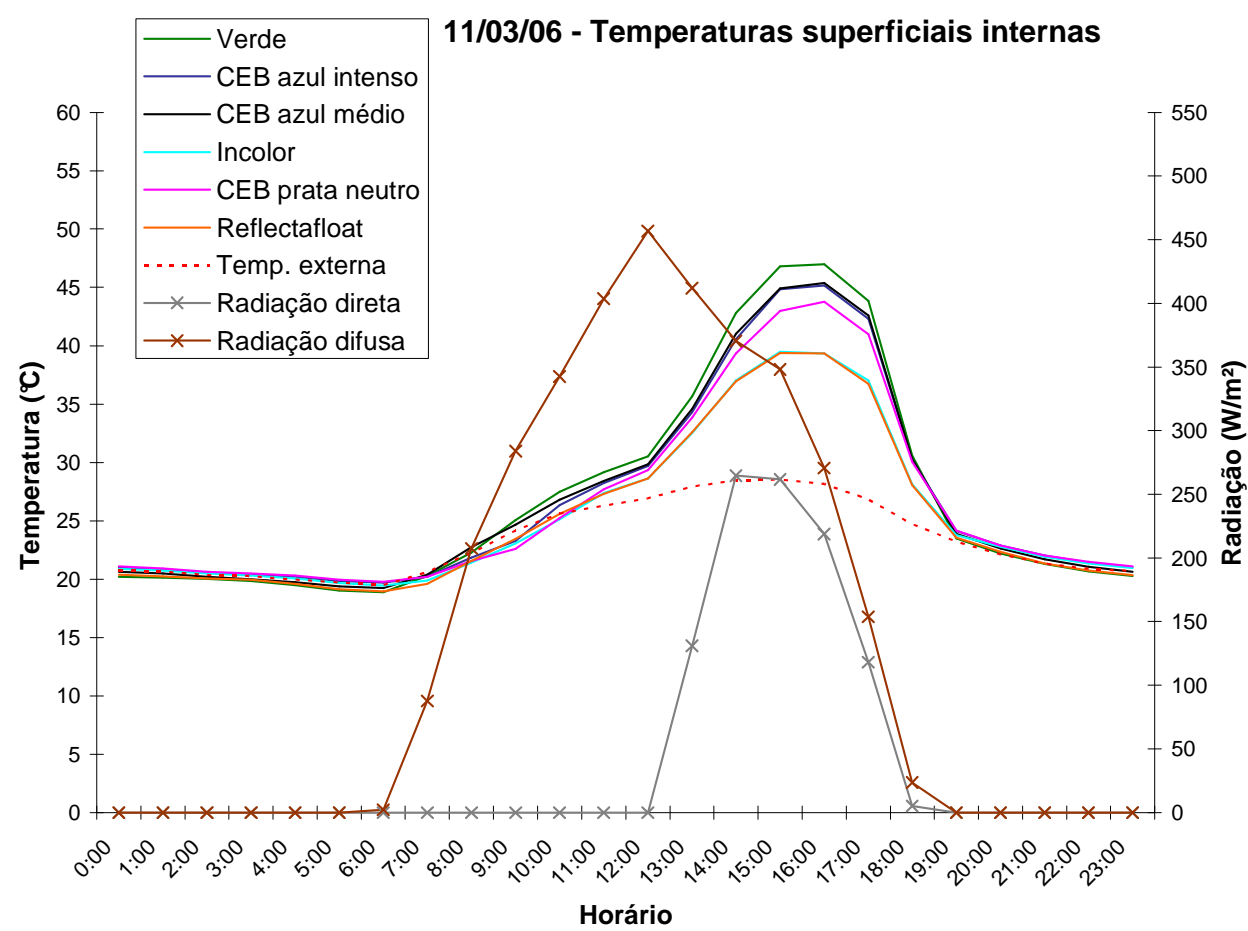

Figura 89. Temperaturas superficiais internas dos vidros e a temperatura externa - Oeste

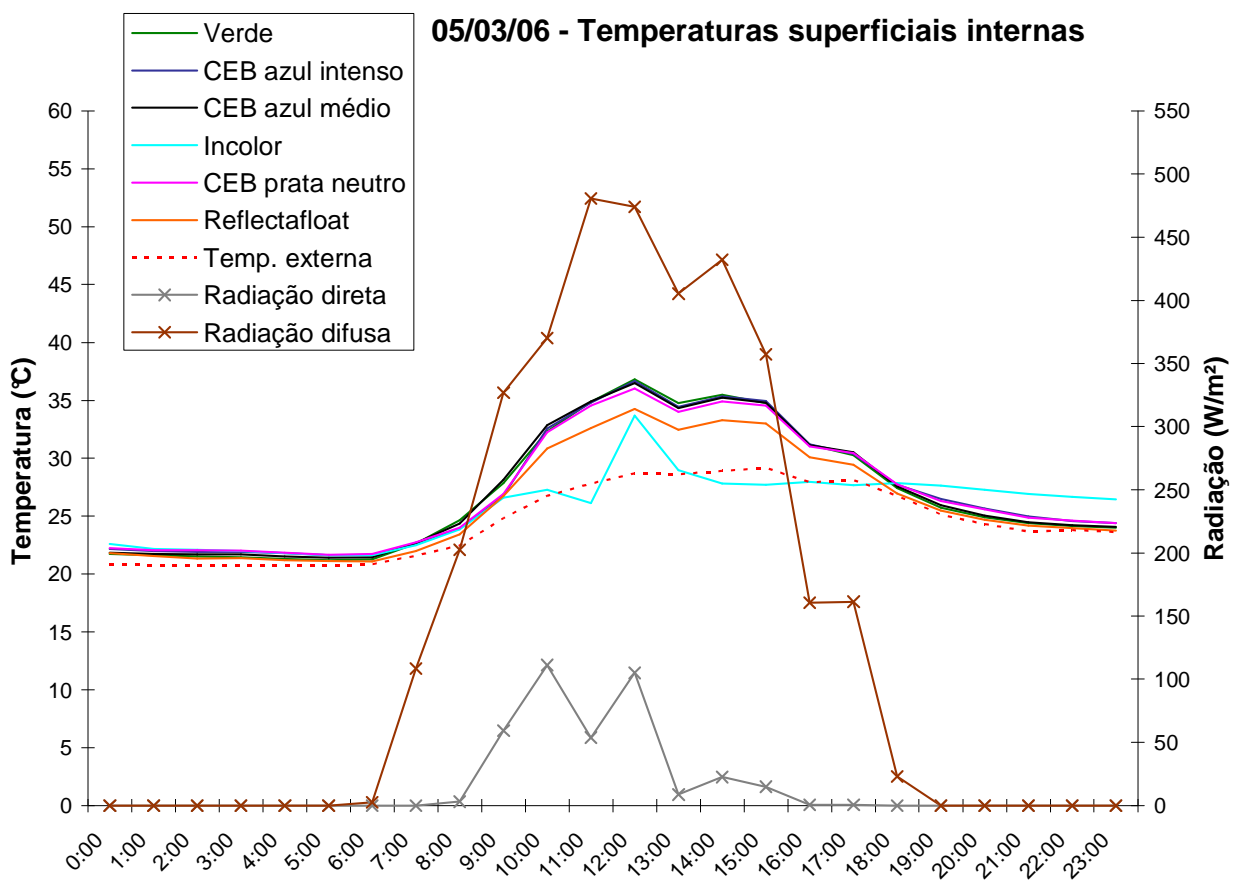

Horário

Figura 90. Temperaturas superficiais internas dos vidros e a temperatura externa - Norte 


\section{- Temperaturas internas}

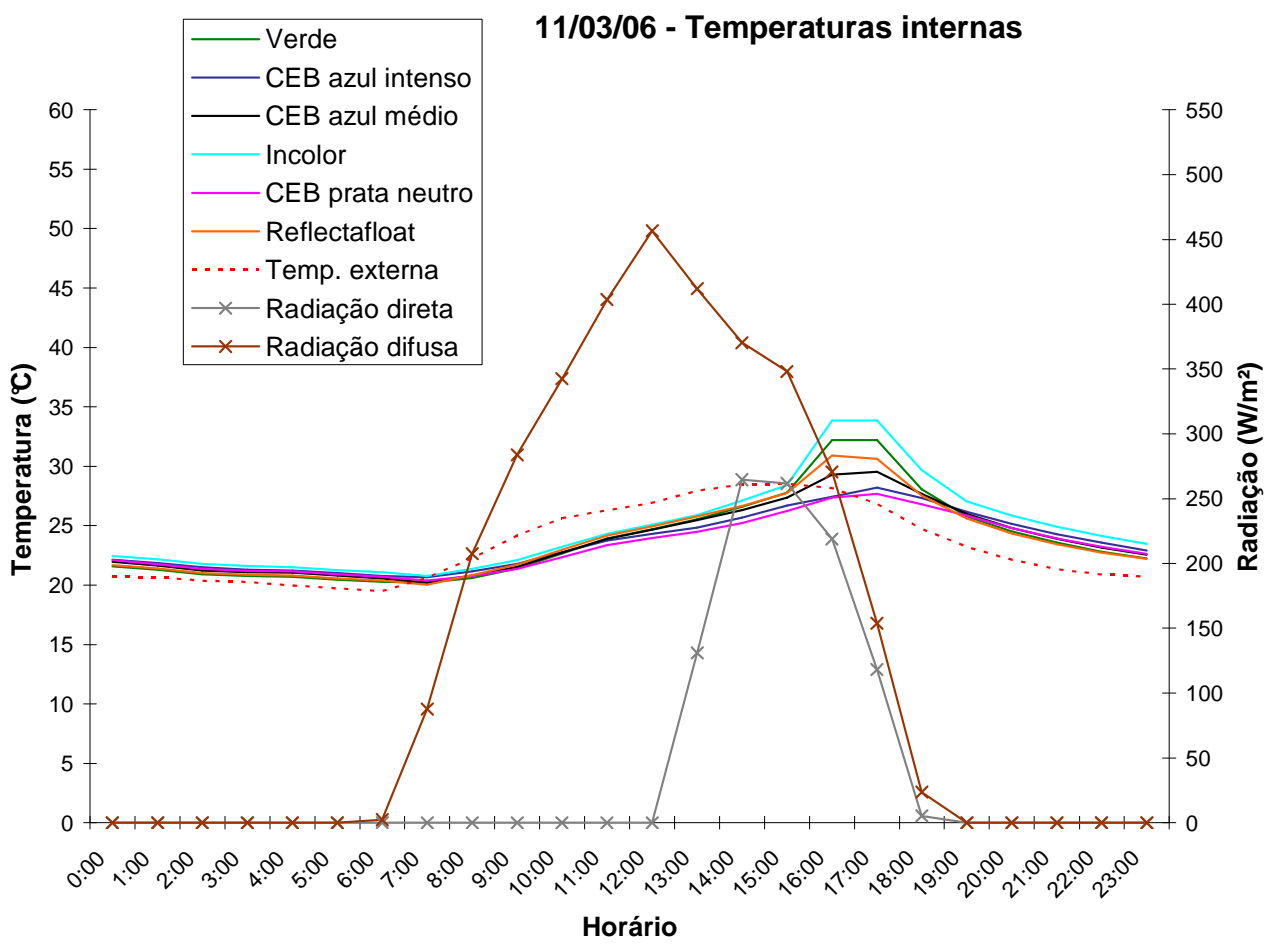

Figura 91. Temperaturas internas das células-teste e a temperatura externa - Oeste

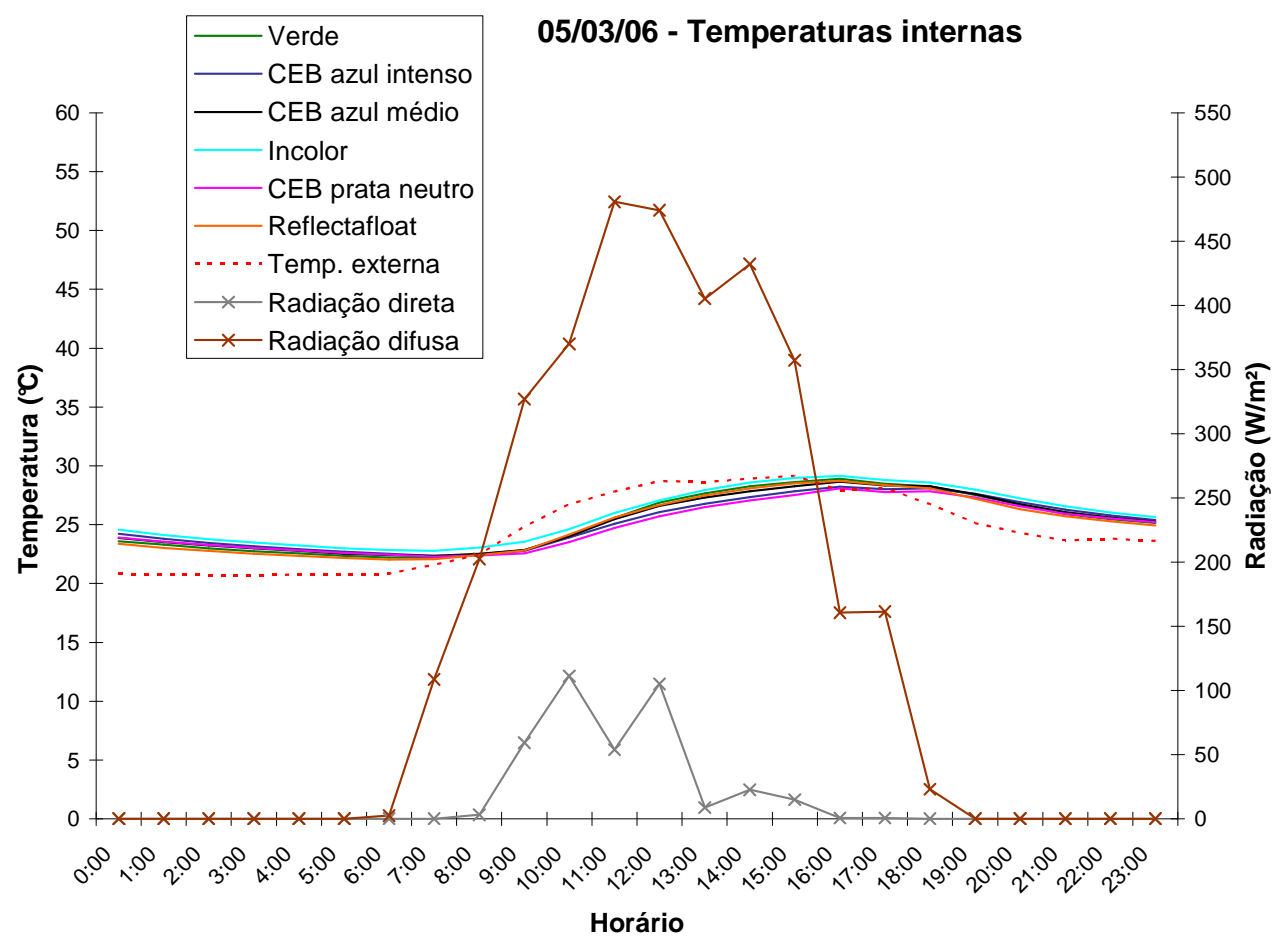

Figura 92. Temperaturas internas das células-teste e a temperatura externa - Norte 


\section{Grupo 3}

Fachada Oeste: 15 de março de 2006

Fachada Norte: 21 de março de 2006

\section{- Temperaturas superficiais externas}

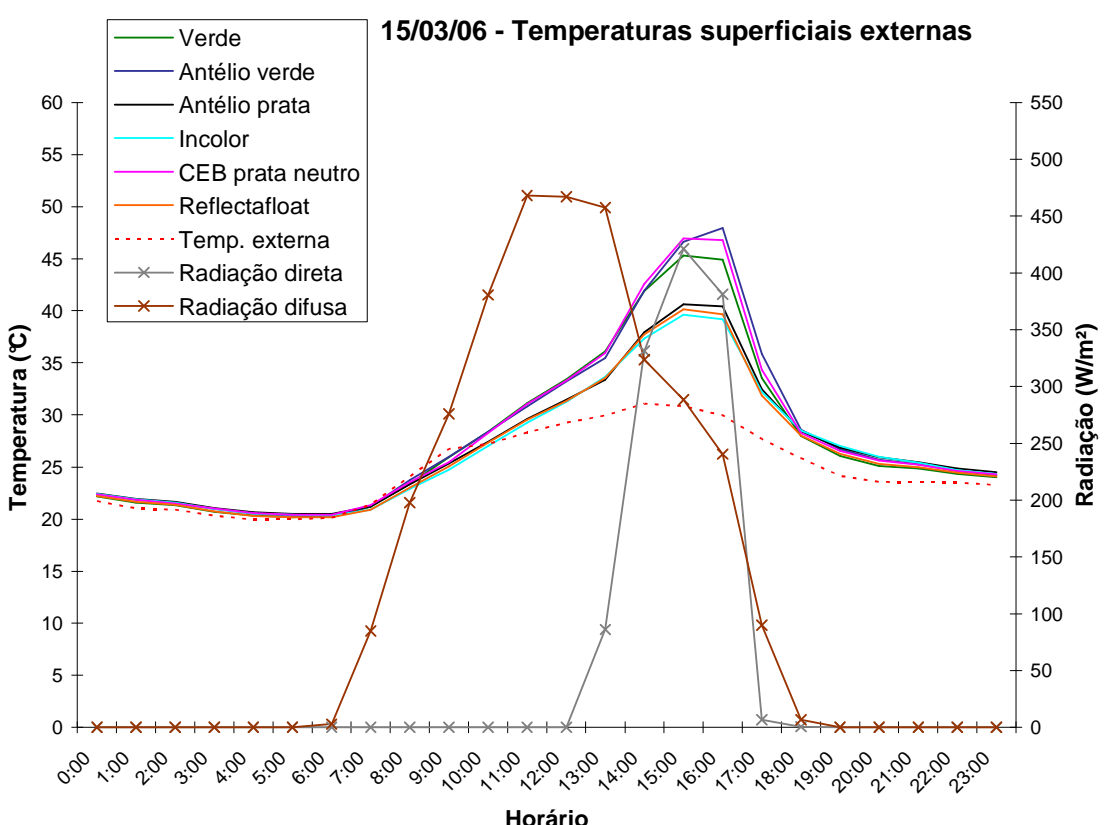

Figura 93. Temperaturas superficiais externas dos vidros e a temperatura externa - Oeste

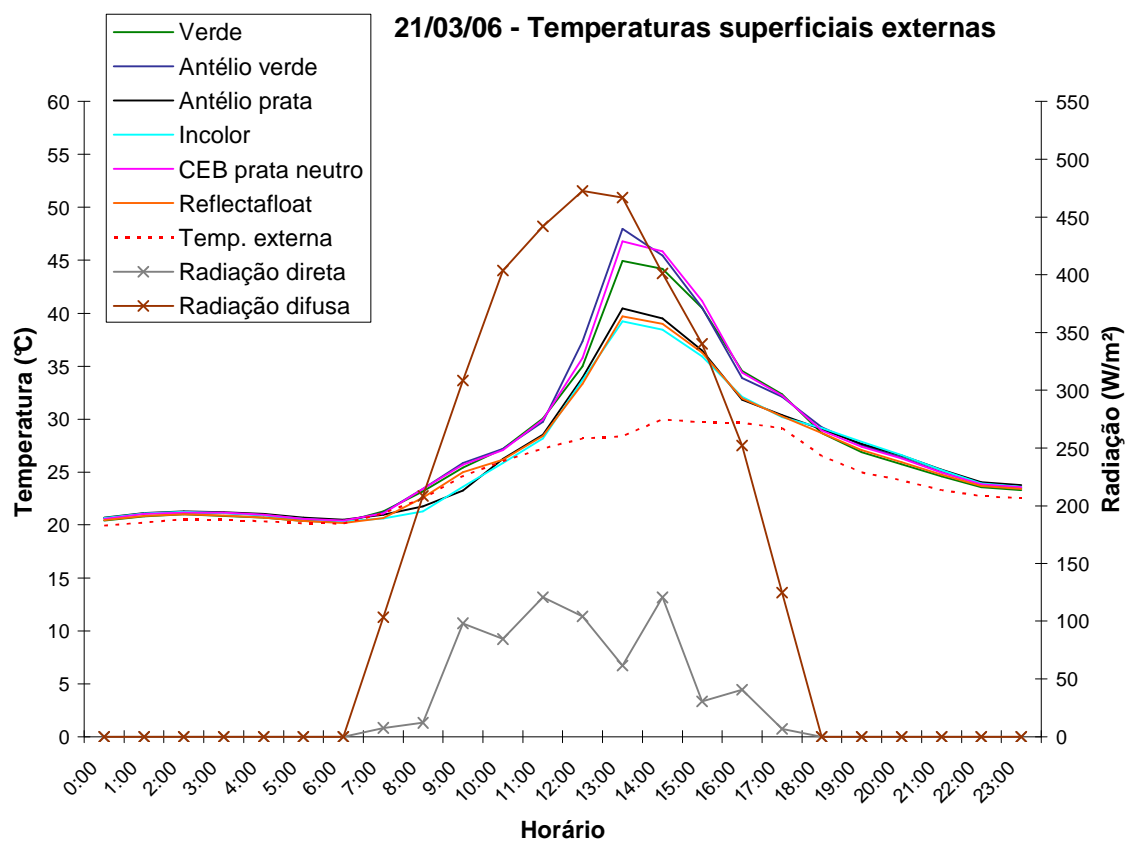

Figura 94. Temperaturas superficiais externas dos vidros e a temperatura externa - Norte 
- Temperaturas superficiais internas

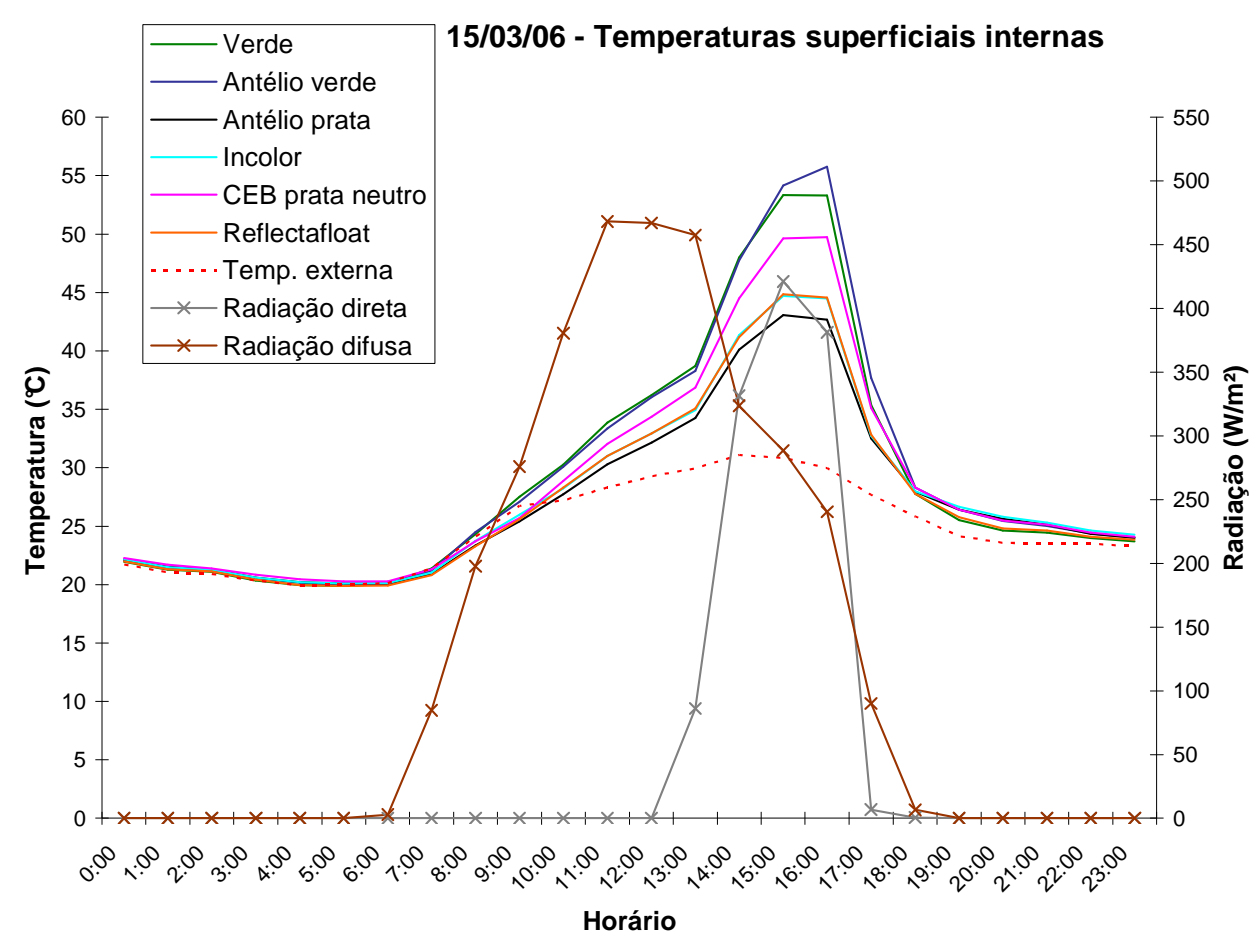

Figura 95. Temperaturas superficiais internas dos vidros e a temperatura externa - Oeste

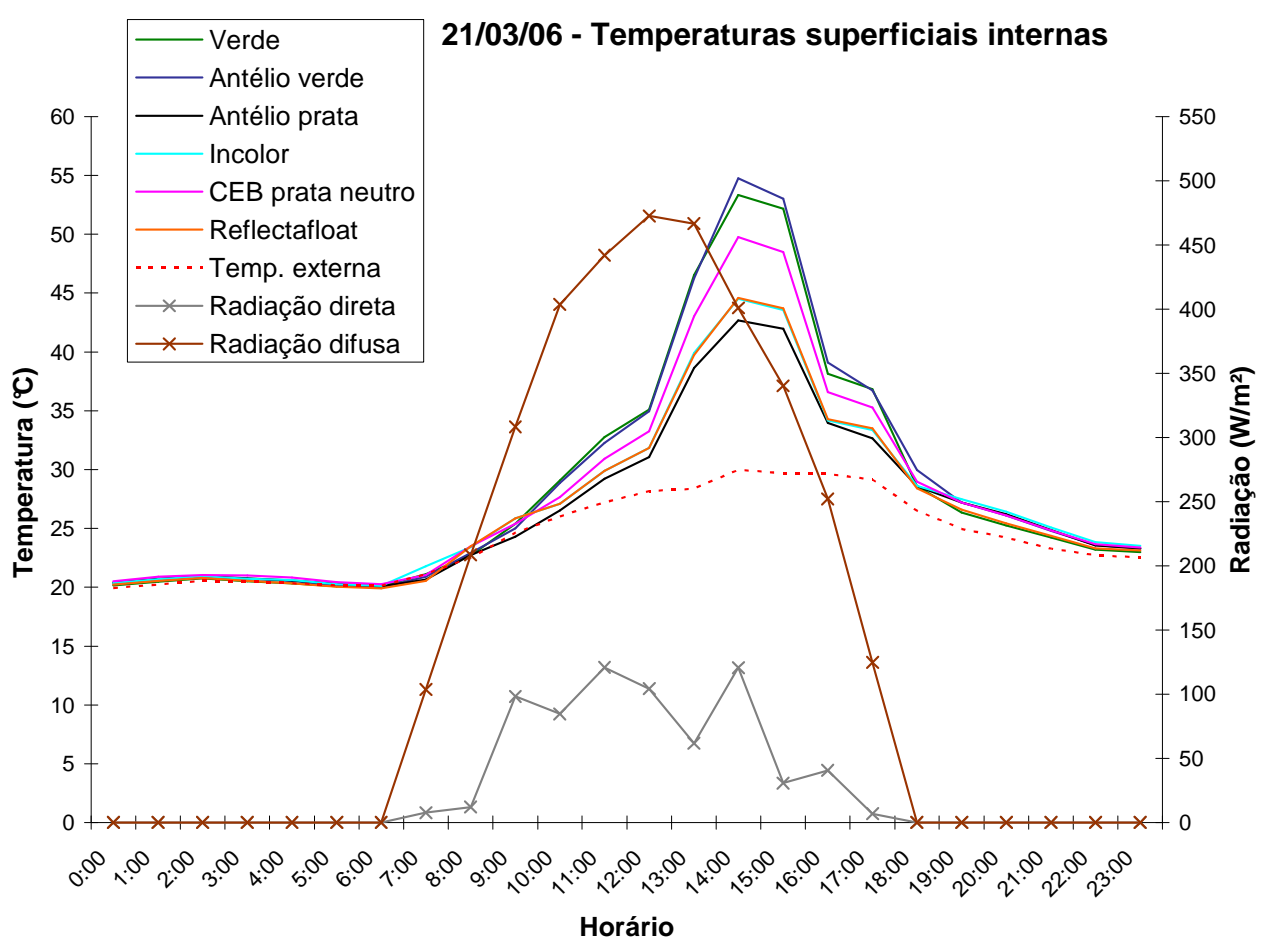

Figura 96. Temperaturas superficiais internas dos vidros e a temperatura externa - Norte 


\section{- Temperaturas internas}

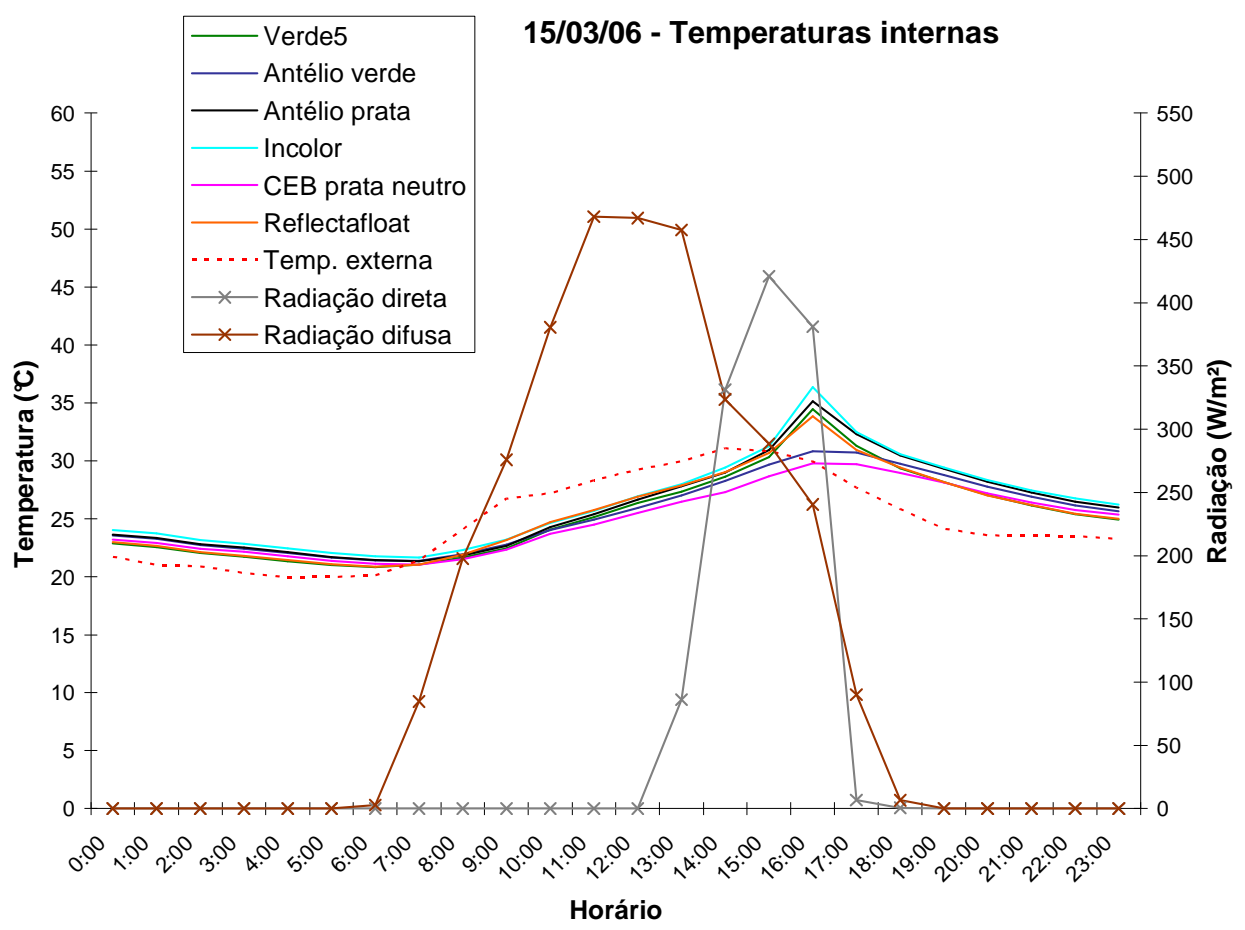

Figura 97. Temperaturas internas das células-teste e a temperatura externa - Oeste

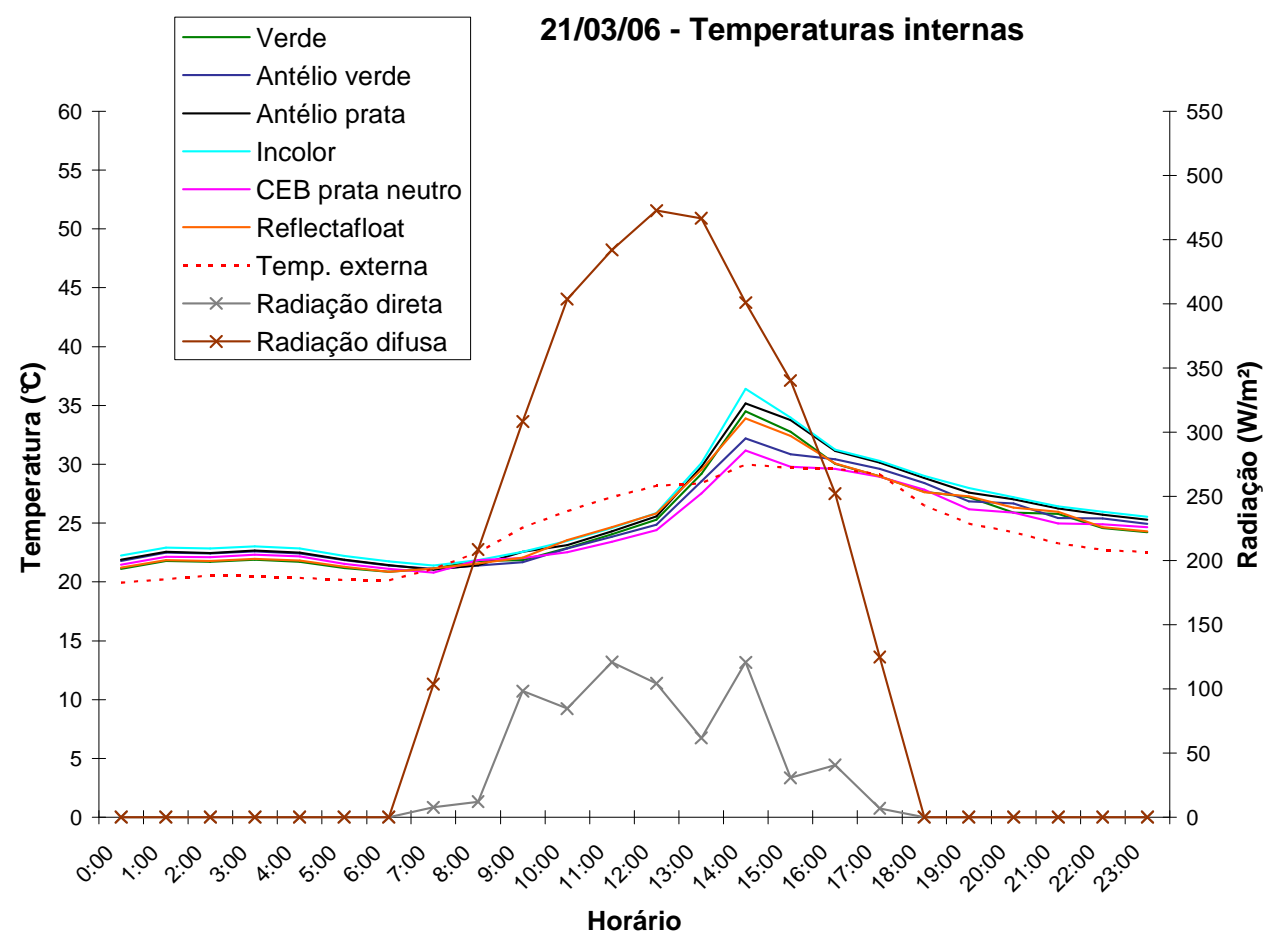

Figura 98. Temperaturas internas das células-teste e a temperatura externa - Norte 


\subsection{Discussão}

No período de medições de verão, também foi observado que as temperaturas internas nas células-teste mantiveram-se abaixo da temperatura externa até às 15:00h. Após este horário, os valores da temperatura do ar interno superou os valores externos.

\section{- Temperaturas superficiais externas}

O vidros do Grupo 1 que apresentaram as maiores temperaturas superficiais externas foram o vidro refletivo pirolítico (antélio) bronze, o vidro refletivo pirolítico verde esmeralda e o vidro plano verde. Este comportamento foi observado tanto no período com vidros voltados para a face Oeste (Figura 81) como para a face Norte (Figura 82). O vidro refletivo pirolítico bronze chegou a registrar $43^{\circ}$ quando estava colocado na abertura Oeste da célula-teste. O vidro plano incolor apresentou as menores temperaturas superficiais externas, vindo em seguida do vidro refletivo pirolítico prata e do reflectafloat.

Com relação às temperaturas superficiais externas dos vidros do Grupo 2, o vidro refletivo metalizado a vácuo azul intenso médio obteve as maiores temperaturas, chegando a atingir $43^{\circ} \mathrm{C}$ quando foi colocado na fachada Oeste (Figura 87). O vidro plano incolor e o vidro reflectafloat apresentaram as menores temperaturas superficiais externas. Os vidros deste grupo apresentaram comportamento semelhante no período em que estiveram na face Oeste e no período que foram posicionados na face Norte (Figura 88), com a única diferença 
que neste último período as temperaturas superficiais externas registradas foram menores.

No Grupo 3, o vidro refletivo pirolítico verde esmeralda e o vidro refletivo metalizado a vácuo prata neutro tiveram as maiores temperaturas superficiais externas. $O$ vidro refletivo pirolítico verde esmeralda chegou a atingir $47^{\circ}$ quando estava na face Oeste (Figura 93). Já o vidro plano incolor e o vidro reflectafloat apresentaram as menores temperaturas superficiais externas. Essa situação se repetiu nos dois períodos de medições (Oeste e Norte).

\section{- Temperaturas superficiais internas}

$\mathrm{Na}$ fachada Oeste, assim como na Norte, os valores de temperatura apresentaram diferenças a partir das 7:30h até 19:00h. Excluindo-se esse intervalo, não houve praticamente variação entre as temperaturas superficiais.

No Grupo 1, os vidros refletivos pirolíticos bronze e verde esmeralda apresentaram as maiores temperaturas superficiais internas. Em contraponto, os vidros plano incolor, refletivo pirolítico prata e reflectafloat tiveram as menores temperaturas superficiais internas deste grupo. Os vidros tiveram o mesmo comportamento com relação às temperaturas superficiais internas tanto no período com as aberturas voltadas para Oeste (Figura 83) quanto para Norte (Figura 84).

O vidro plano verde do Grupo 2 apresentou elevadas temperaturas superficiais internas, chegando a atingir $47^{\circ} \mathrm{C}$ quan do estava na fachada Oeste da célula-teste (Figura 89), vindo em seguida pelos vidros refletivos metalizados a vácuo azul médio e azul intenso médio. O vidro plano incolor e o vidro reflectafloat apresentaram as menores temperaturas superficiais internas. As temperaturas 
superficiais internas registradas foram menores com os vidros colocados na face Norte (Figura 90).

O vidro refletivo pirolítico verde esmeralda do Grupo 3 apresentou as maiores temperaturas superficiais internas, chegando atingir $55^{\circ} \mathrm{C}$ quando foi colocado na face Oeste (Figura 95), vindo em seguida do vidro plano verde. Cabe ressaltar que o vidro refletivo pirolítico verde esmeralda, sendo o de maior espessura, apresentou as maiores temperaturas superficiais internas. O vidro refletivo pirolítico prata, o vidro plano incolor e o vidro reflectafloat apresentaram as menores temperaturas superficiais internas. Este comportamento dos vidros se manteve nos dois períodos de medições, tanto com os vidros voltados para o Oeste quanto para o Norte (Figura 96). Quando os dois vidros de cor prata deste grupo são comparados, observa-se que o vidro refletivo pirolítico apresenta temperaturas superficiais internas menores que o vidro refletivo metalizado a vácuo.

O vidro plano incolor apresentou as menores temperaturas superficiais nos três grupos de vidro analisados.

\section{- Temperaturas internas}

No Grupo 1, tanto no período no qual os vidros foram colocados na face Oeste (Figura 85) quanto no período em que os vidros ficaram na face Norte (Figura 86), a célula-teste com o vidro plano incolor (referência) obteve as maiores temperaturas internas, vindo em seguida da célula-teste com o vidro refletivo pirolítico prata. A célula-teste com o vidro refletivo pirolítico bronze apresentou as menores temperaturas internas. 
Com relação às temperaturas medidas no interior das células-teste para os vidros do Grupo 2, a célula-teste com o vidro refletivo metalizado a vácuo prata neutro apresentou as menores temperaturas, vindo em seguida das células-teste com os vidros refletivos metalizados a vácuo azul intenso médio e azul médio. Um comportamento mais semelhante entre os vidros ocorreu com os vidros voltados para a fachada Norte (Figura 92).

No Grupo 3, a célula-teste com vidro refletivo metalizado a vácuo prata neutro também obteve as menores temperaturas internas, vindo em seguida o vidro refletivo pirolítico verde esmeralda. Já a célula-teste com o vidro plano incolor apresentou as maiores temperaturas internas. As células-teste tiveram o mesmo comportamento nos dois períodos de medições, tanto com os vidros voltados para o Oeste (Figura 97) quanto para o Norte (Figura 98).

Novamente pode-se observar através dos gráficos, que a célula-teste com o vidro plano incolor apresentou as maiores temperaturas internas nas duas fachadas. Quando se comparam os dois vidros planos incolor e verde, fica evidente que o verde apresenta maiores temperaturas superficiais e proporciona um aquecimento ligeiramente menor do ambiente interno, que pode ser evidenciado pelas temperaturas no interior da célula-teste.

\subsubsection{Resultados para cada tipo de vidro}

A seguir são mostrados gráficos e tabelas onde são comparadas as temperaturas internas e superficiais para cada tipo de vidro analisado no verão. 
Vidro plano incolor

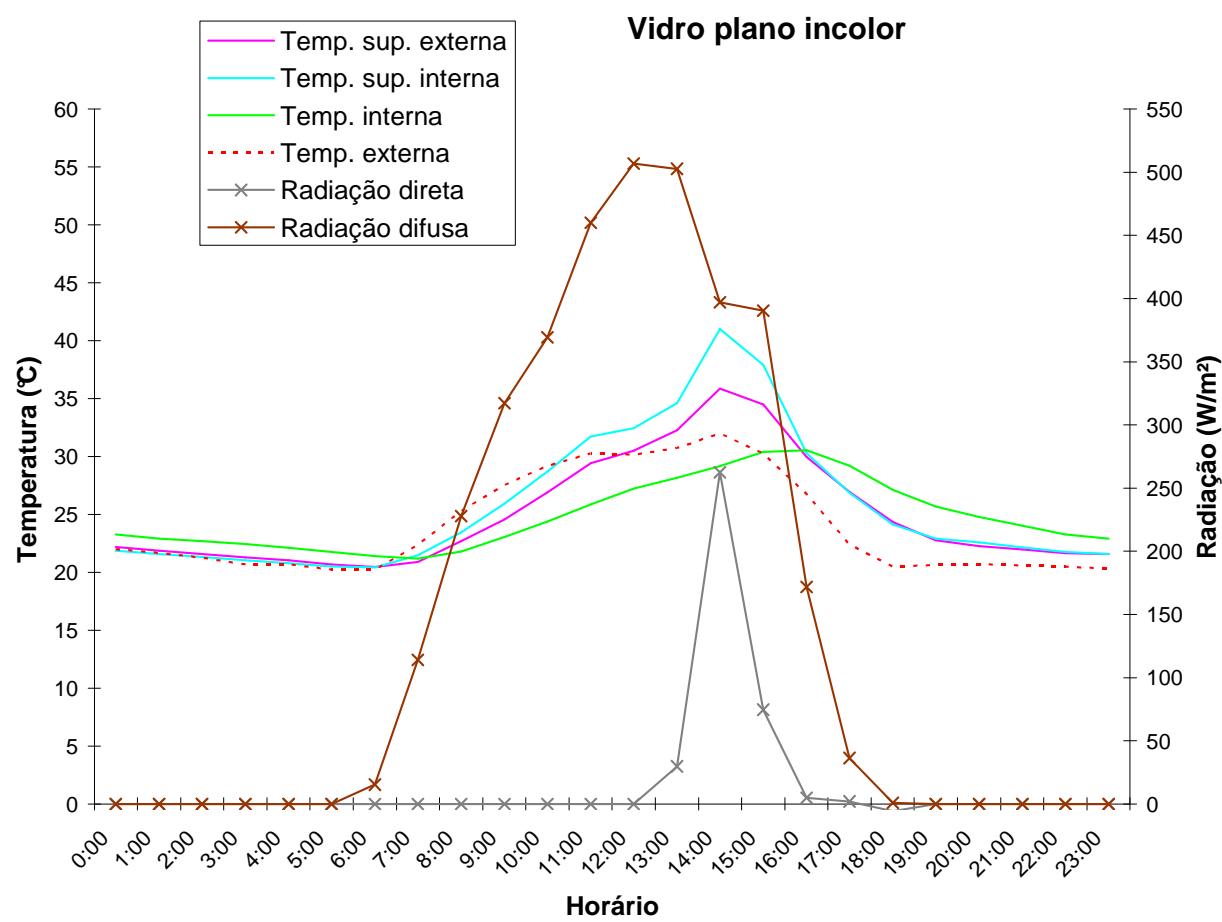

Figura 99. Temperaturas para o vidro plano incolor - Oeste

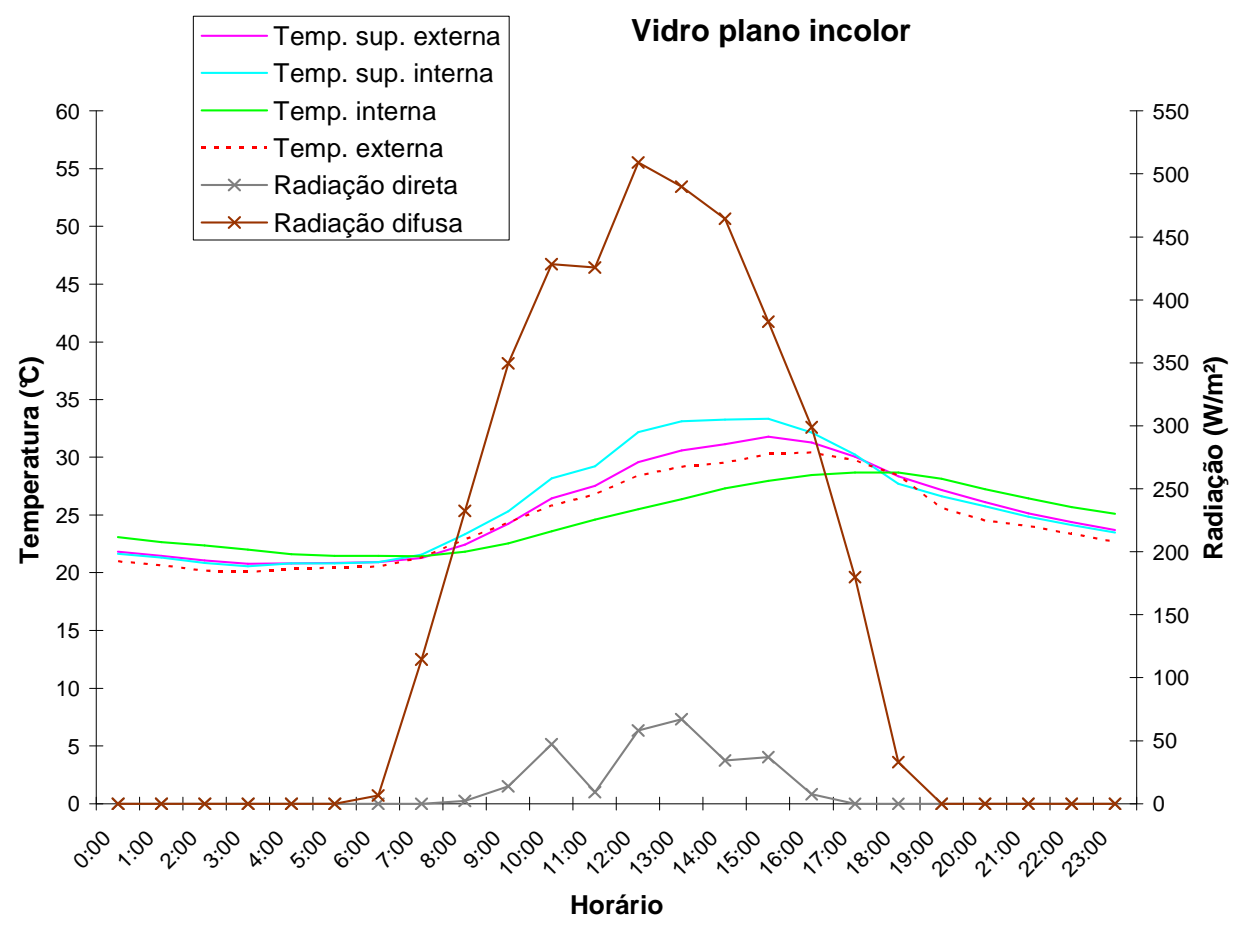

Figura 100. Temperaturas para o vidro plano incolor - Norte 
155

Vidro plano verde

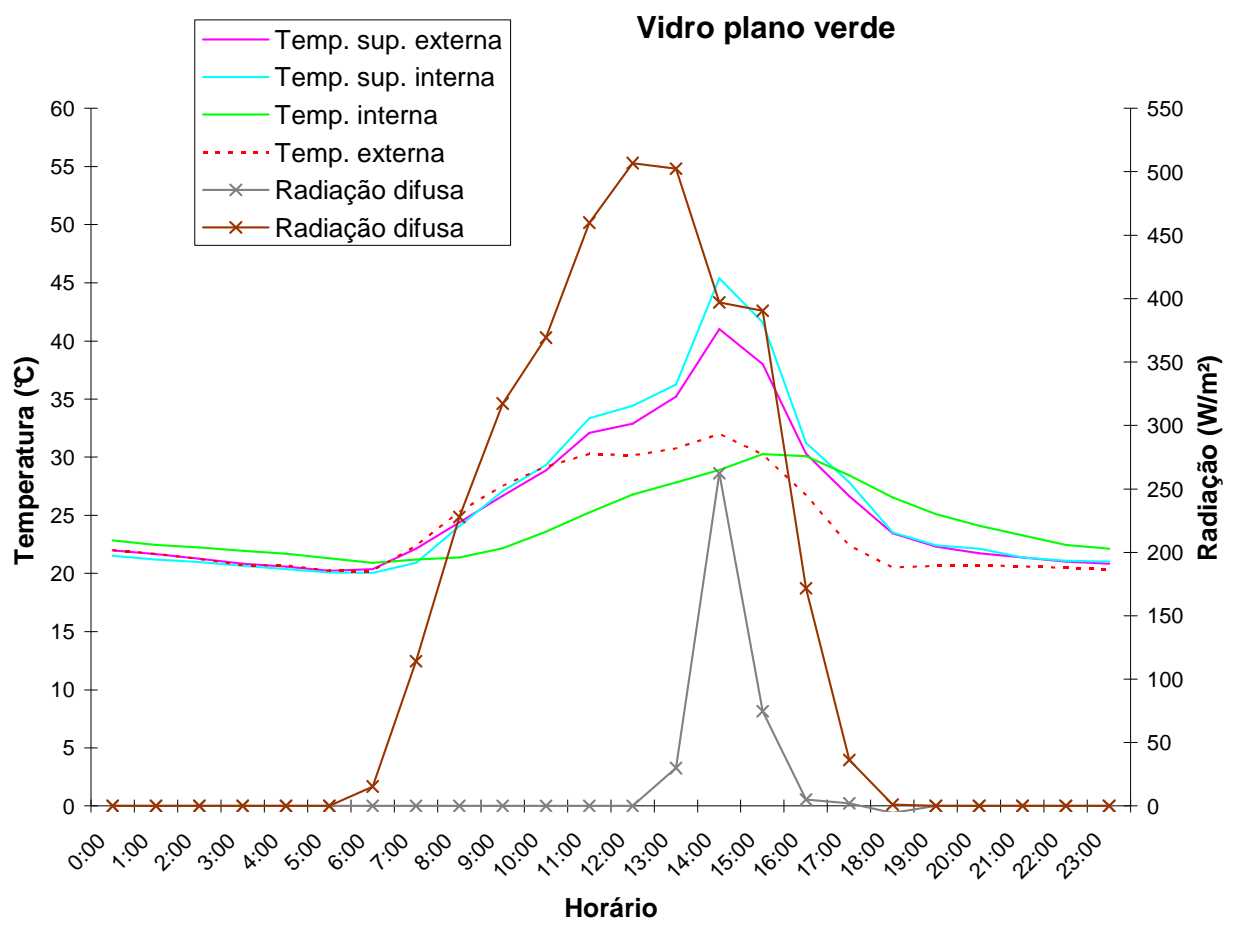

Figura 101. Temperaturas para o vidro plano verde - Oeste

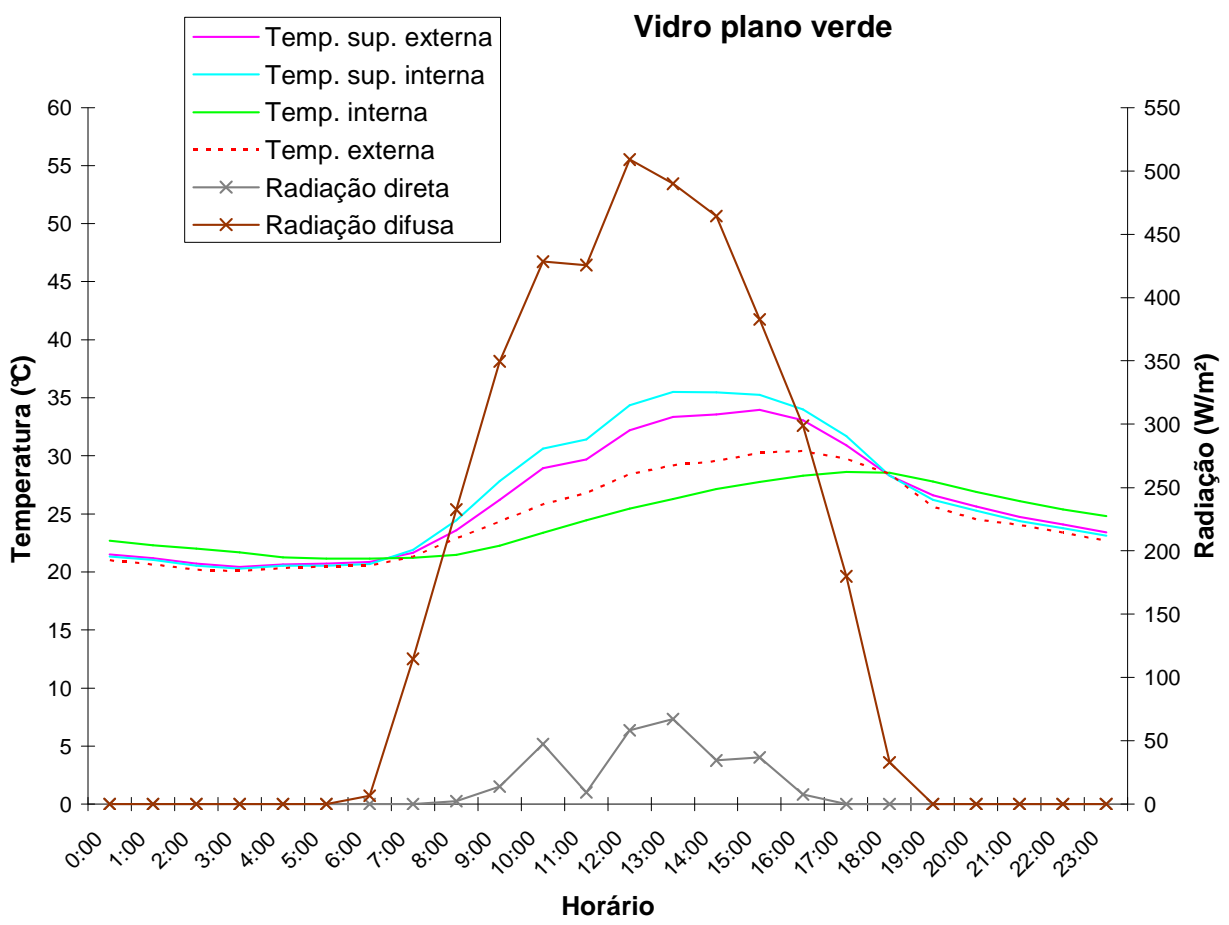

Figura 102. Temperaturas para o vidro plano verde - Norte 


\section{Vidro refletivo pirolítico verde esmeralda}

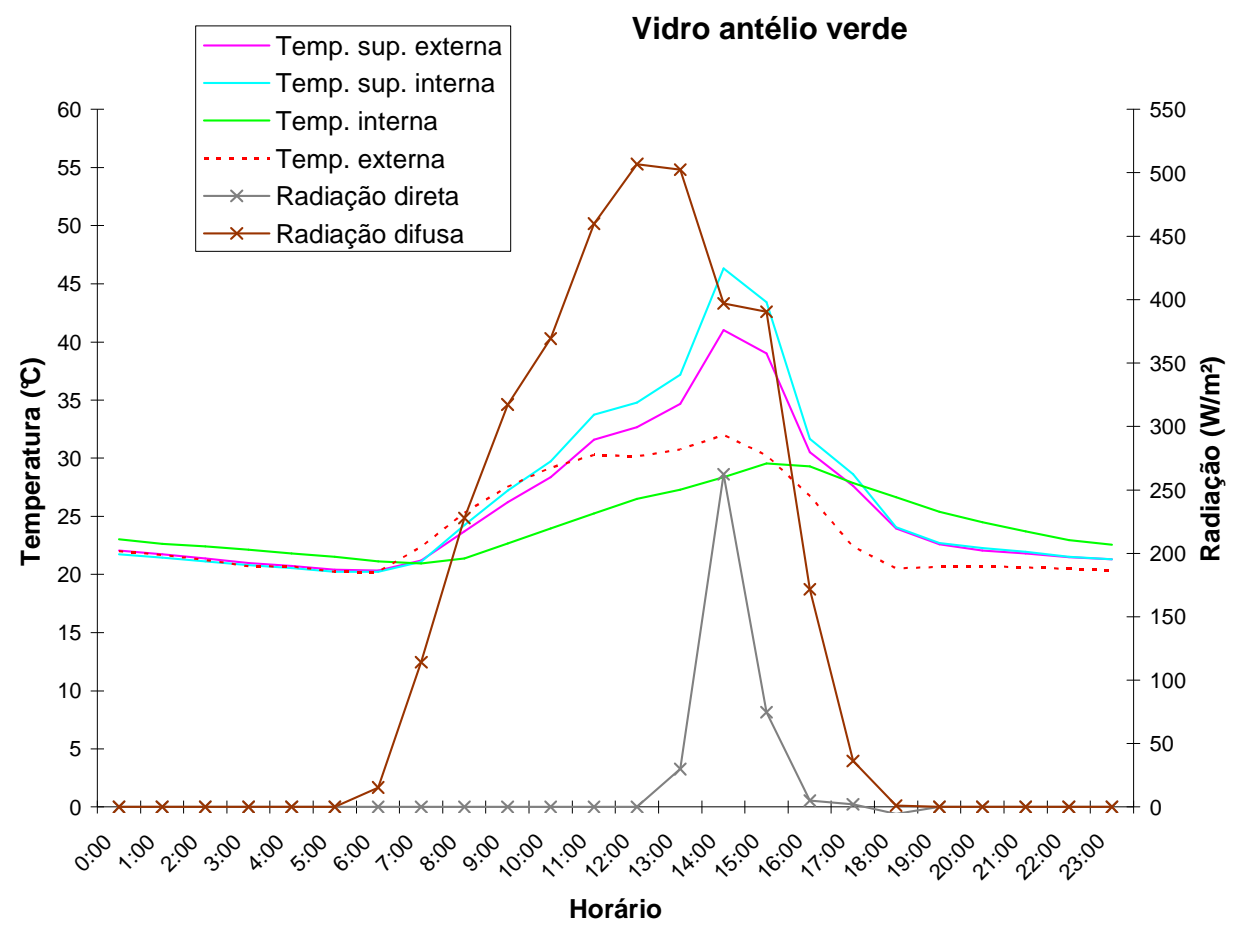

Figura 103. Temperaturas para o vidro refletivo pirolítico verde esmeralda - Oeste

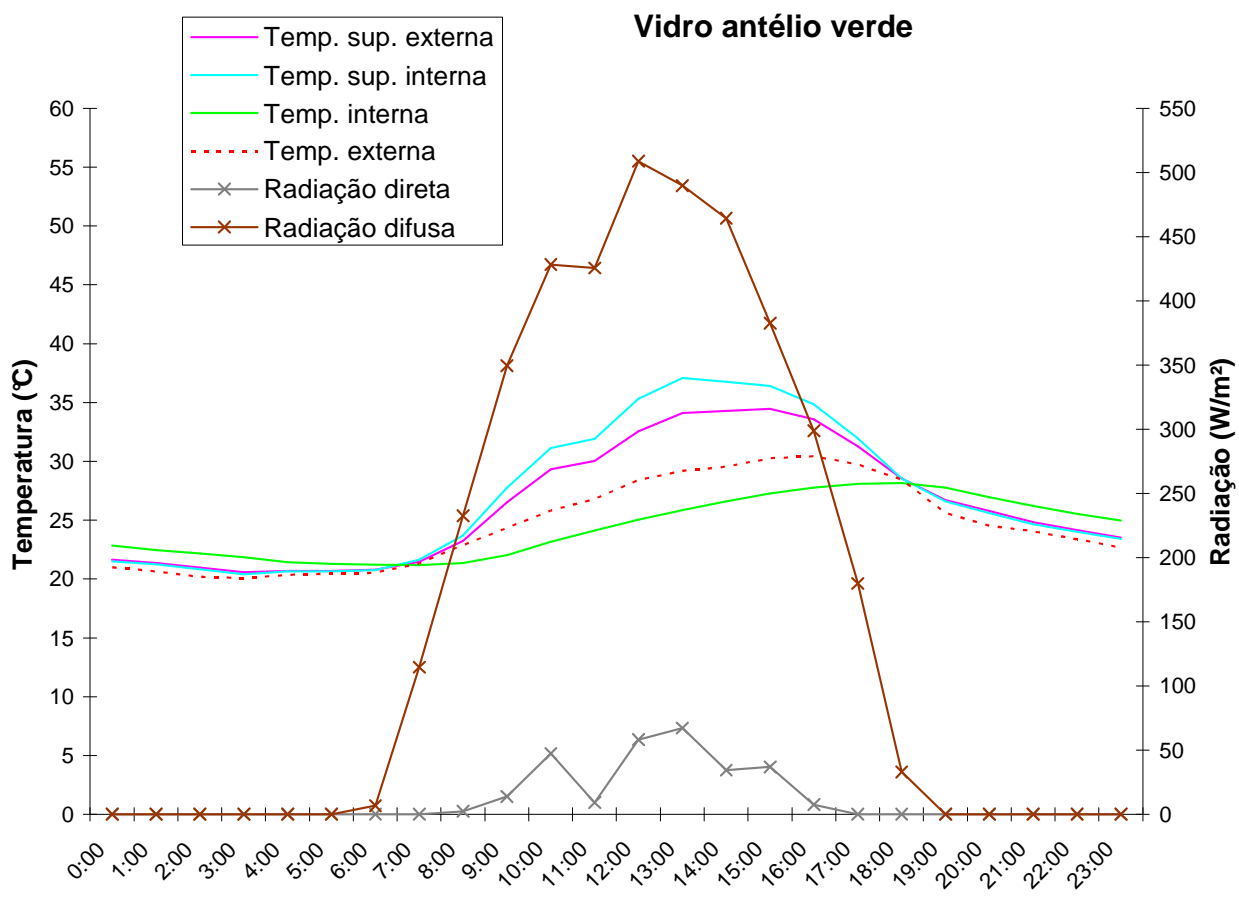

Horário

Figura 104. Temperaturas para o vidro refletivo pirolítico verde esmeralda - Norte 


\section{Vidro refletivo pirolítico prata}

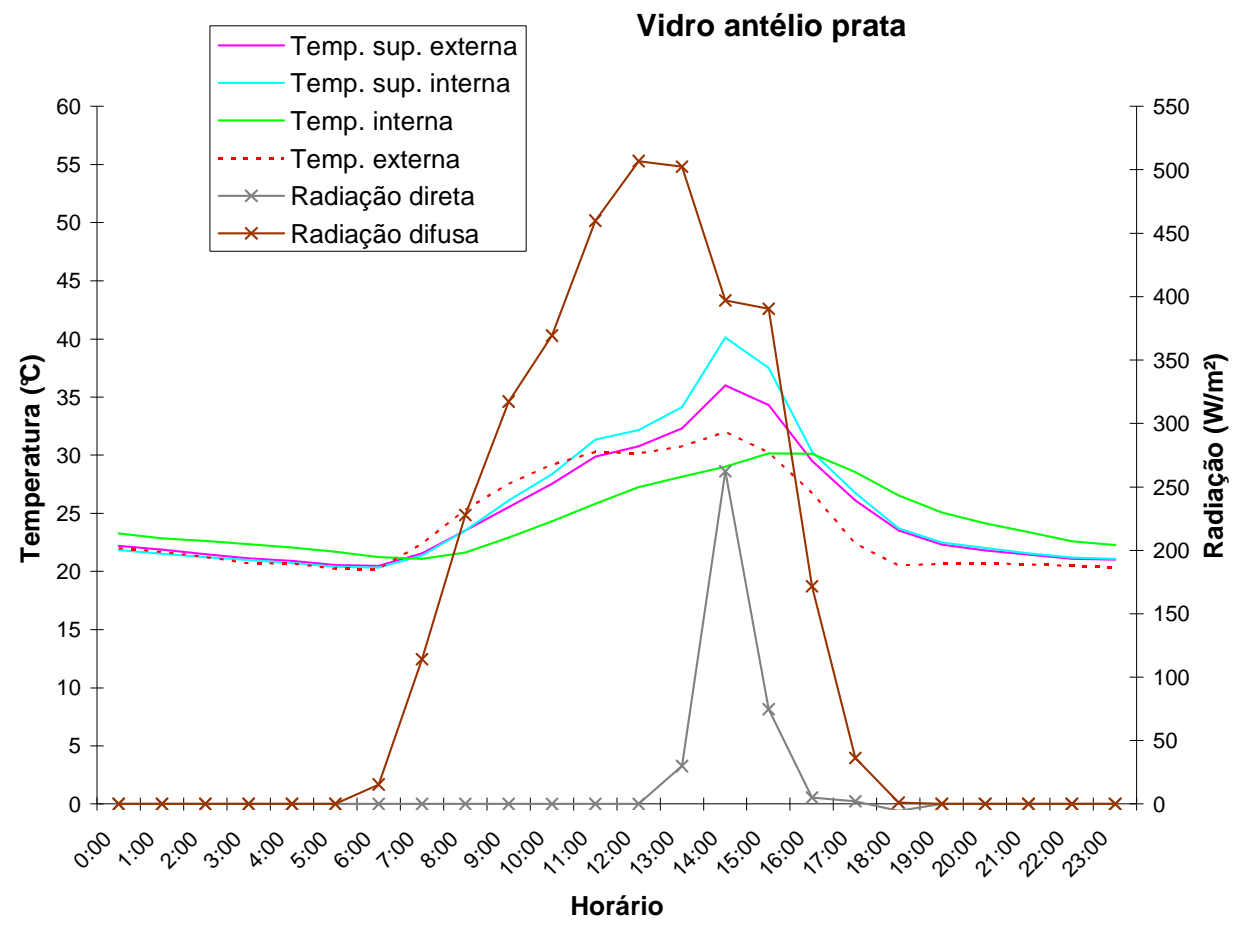

Figura 105. Temperaturas para o vidro refletivo pirolítico prata - Oeste

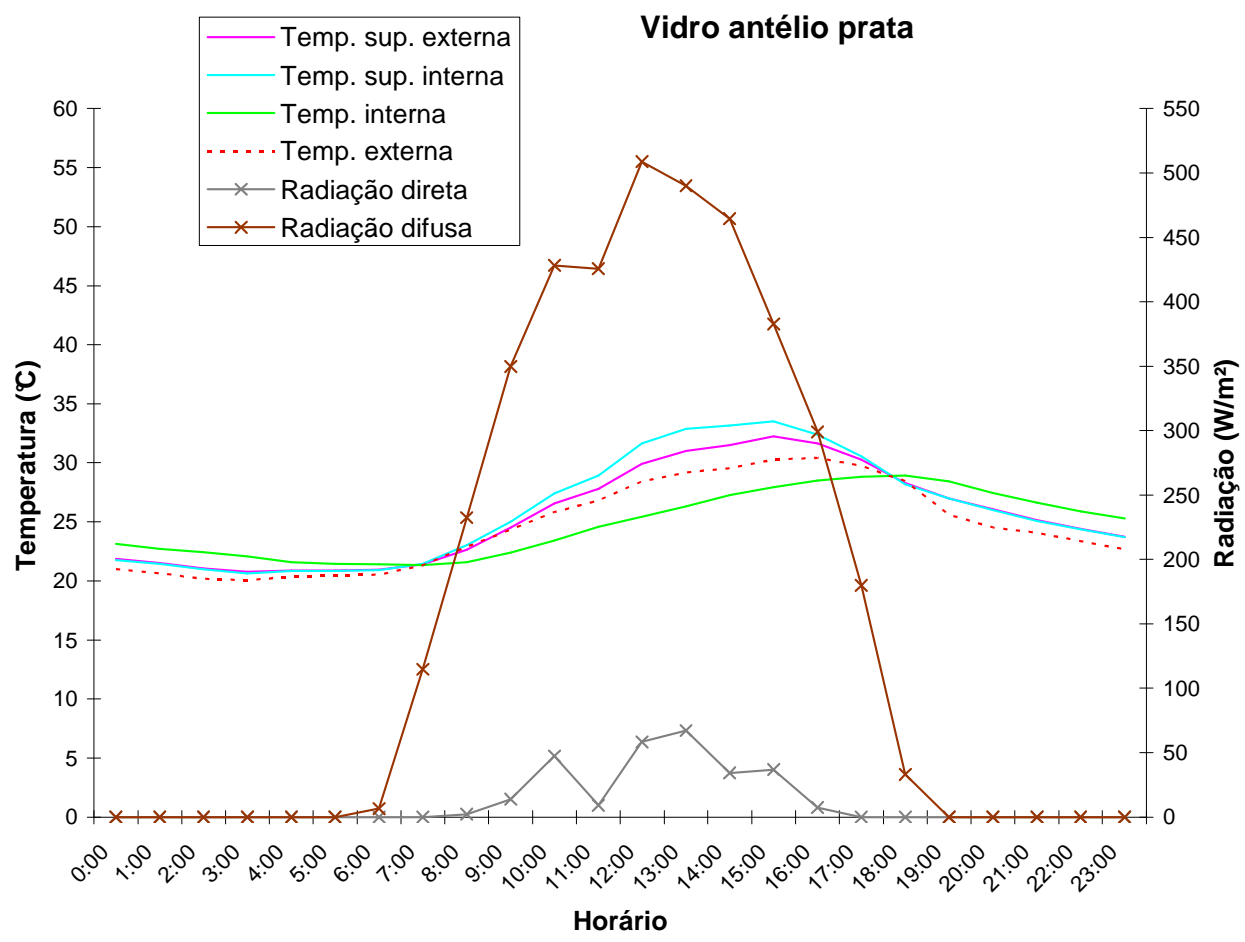

Figura 106. Temperaturas para o vidro refletivo pirolítico prata - Norte 


\section{Vidro refletivo pirolítico bronze}

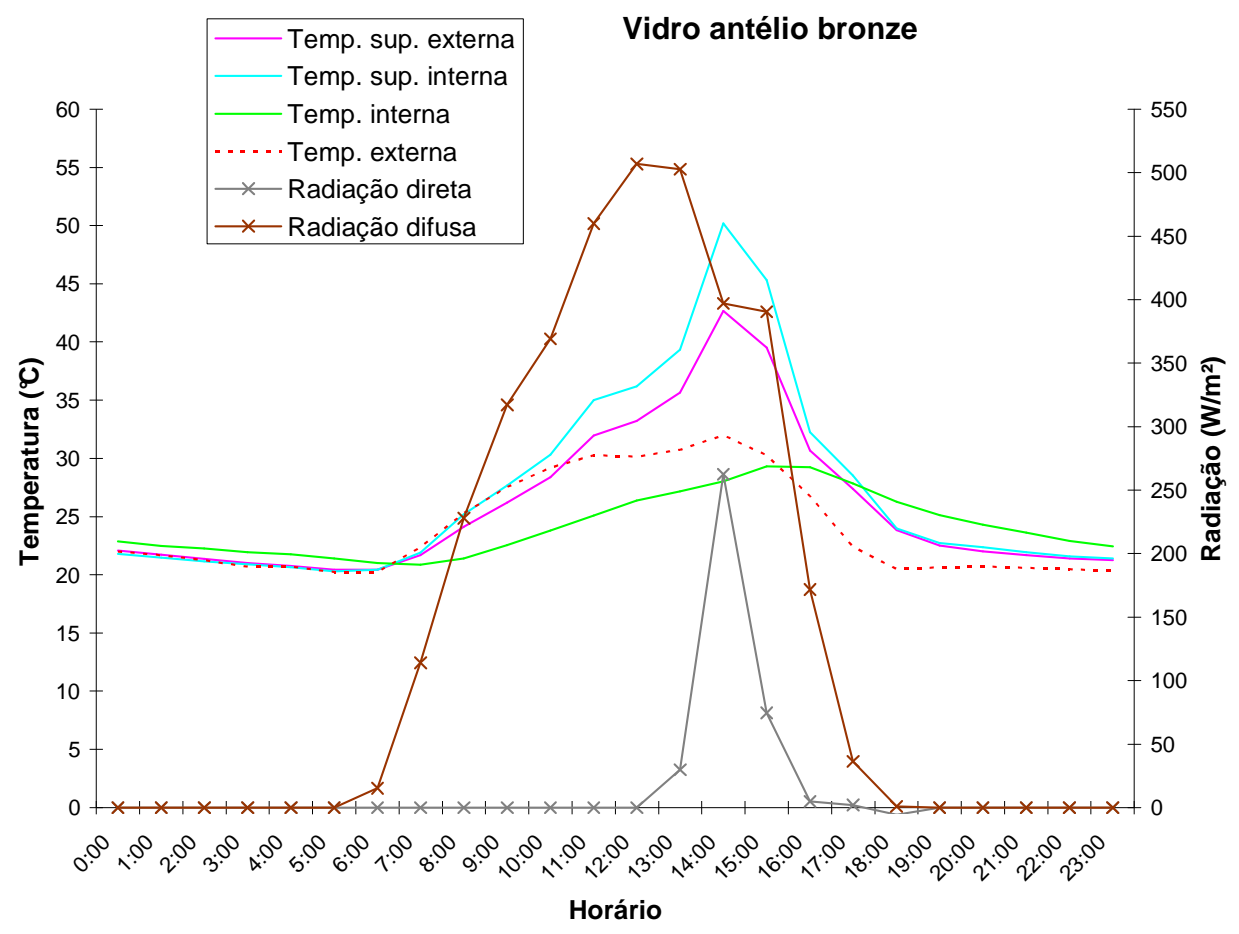

Figura 107. Temperaturas para o vidro refletivo pirolítico bronze - Oeste

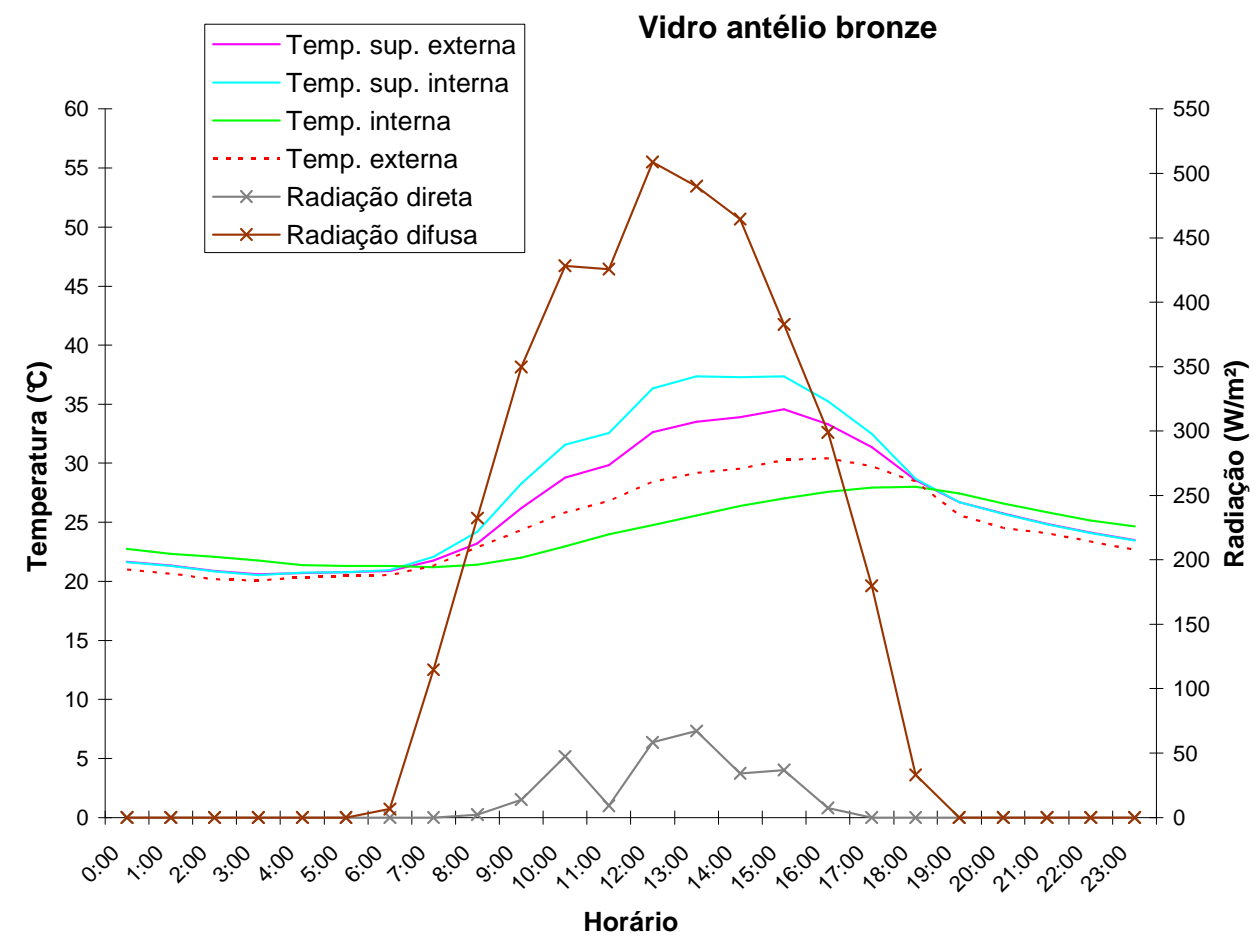

Figura 108. Temperaturas para o vidro refletivo pirolítico bronze - Norte 


\section{Vidro reflectafloat}

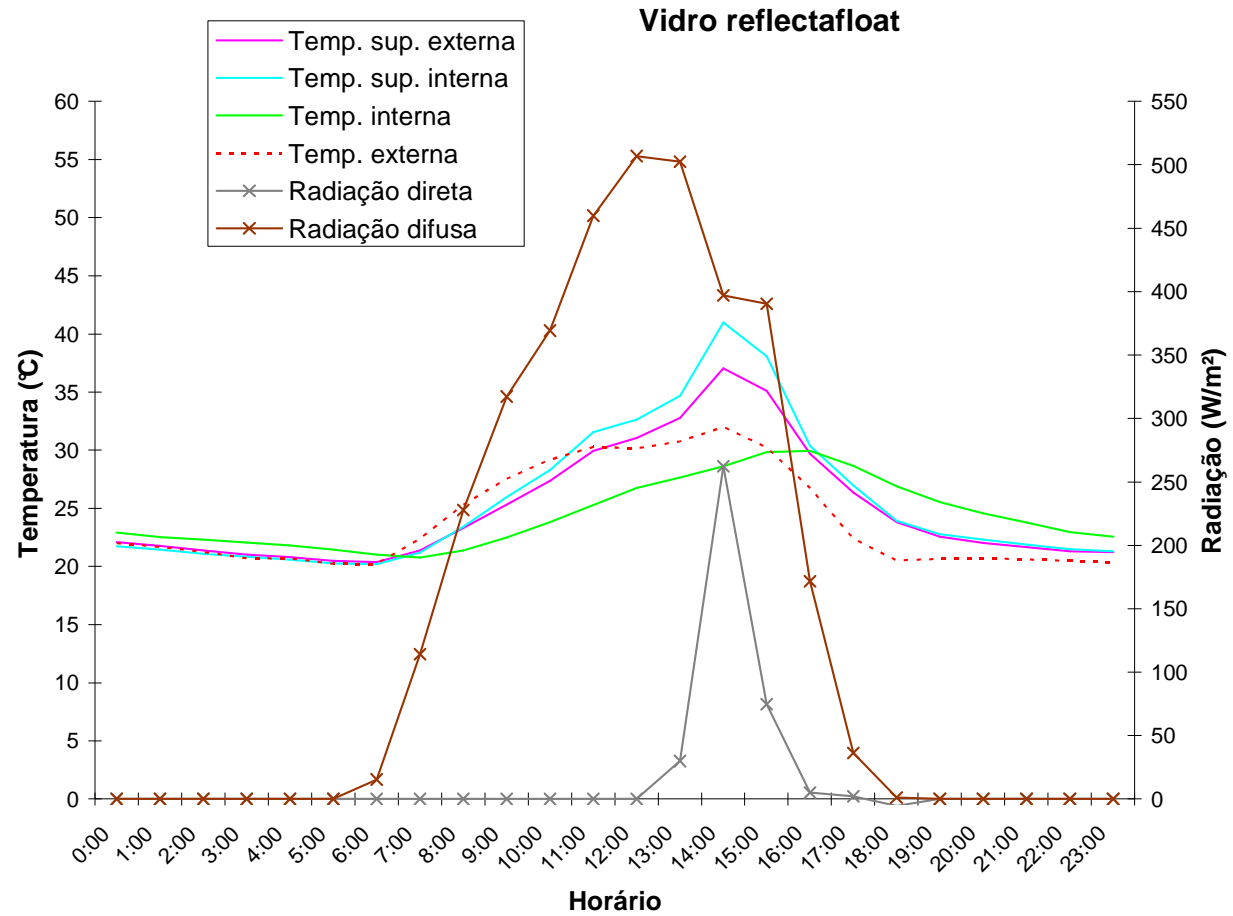

Figura 109. Temperaturas para o vidro reflectafloat - Oeste

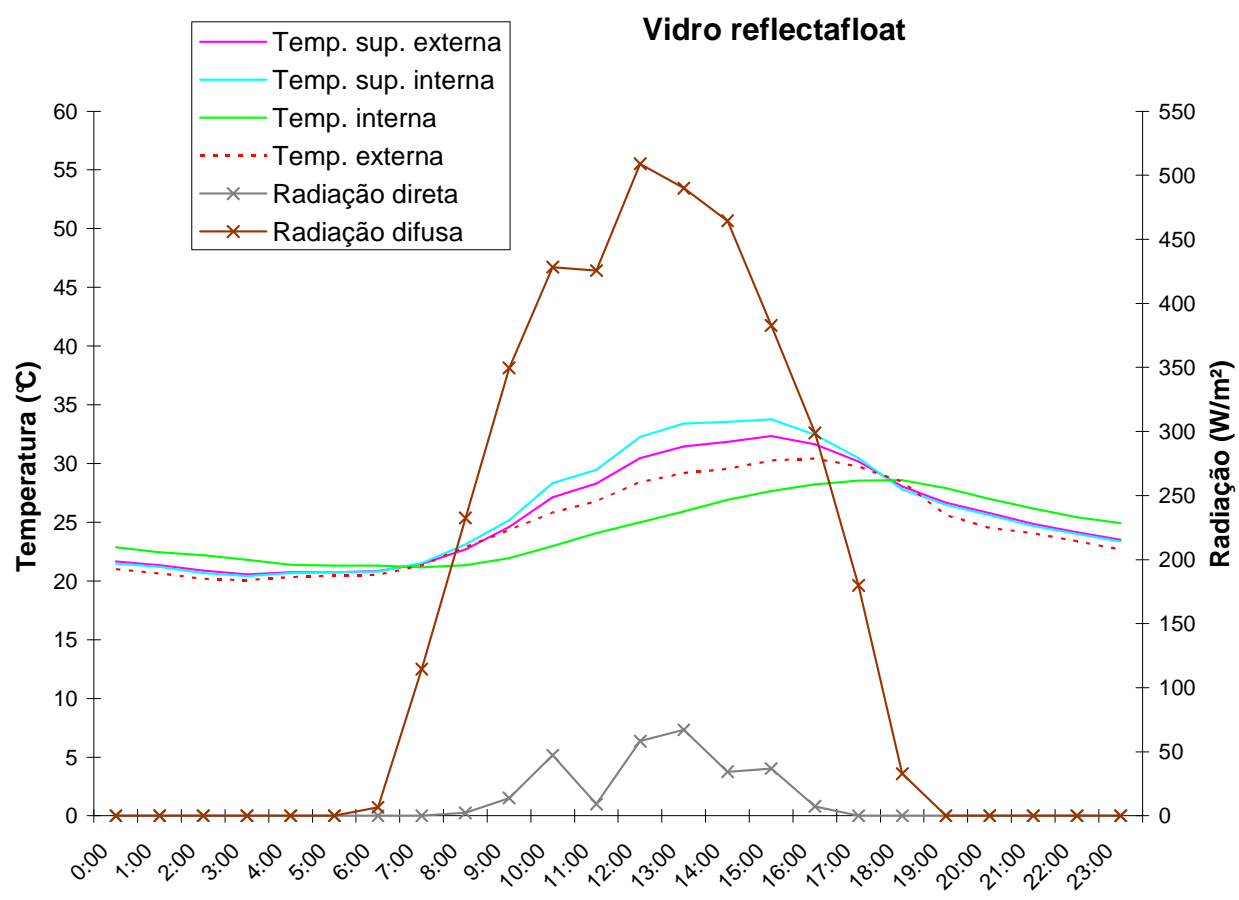

Horário

Figura 110. Temperaturas para o vidro reflectafloat - Norte 
160

Vidro refletivo metalizado a vácuo prata neutro

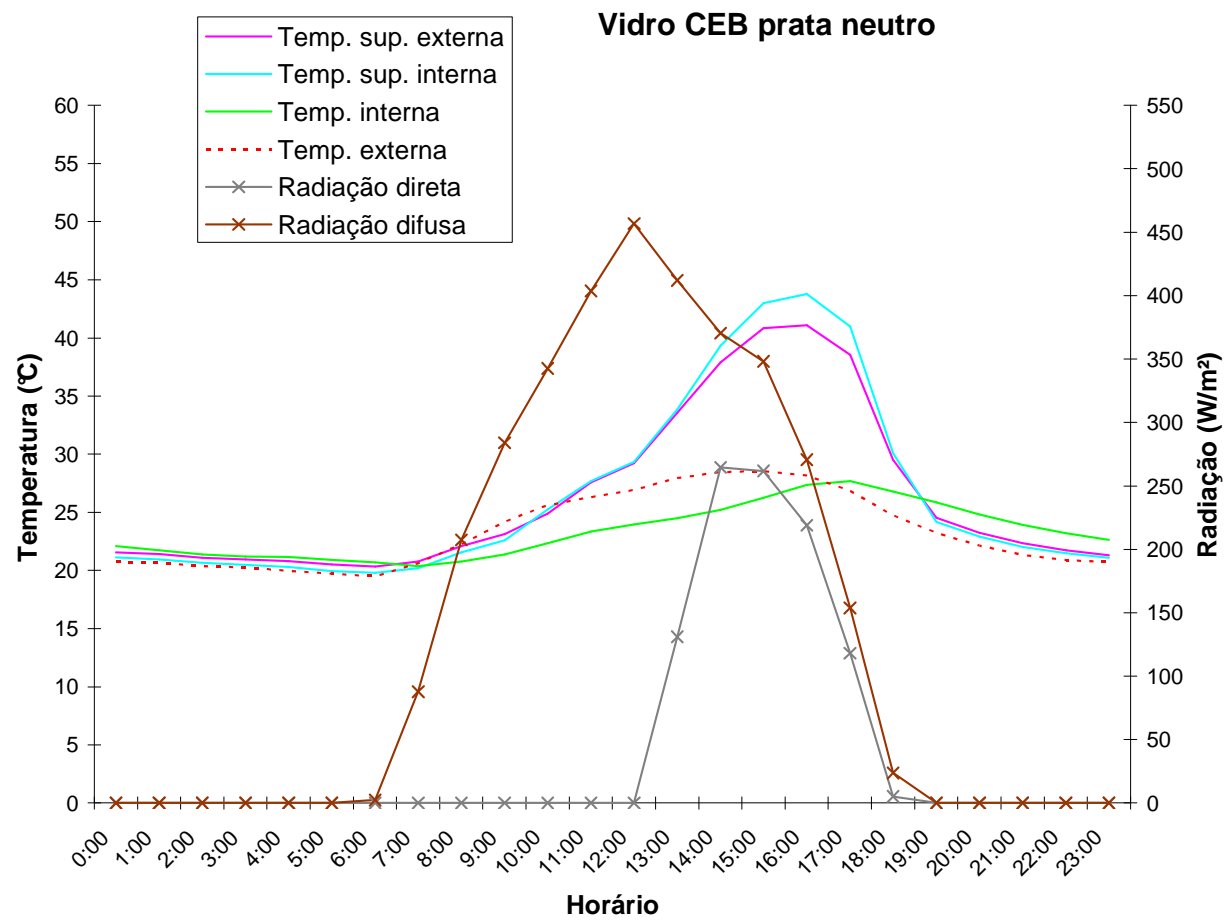

Figura 111. Temperaturas para o vidro refletivo metalizado a vácuo prata neutro - Oeste

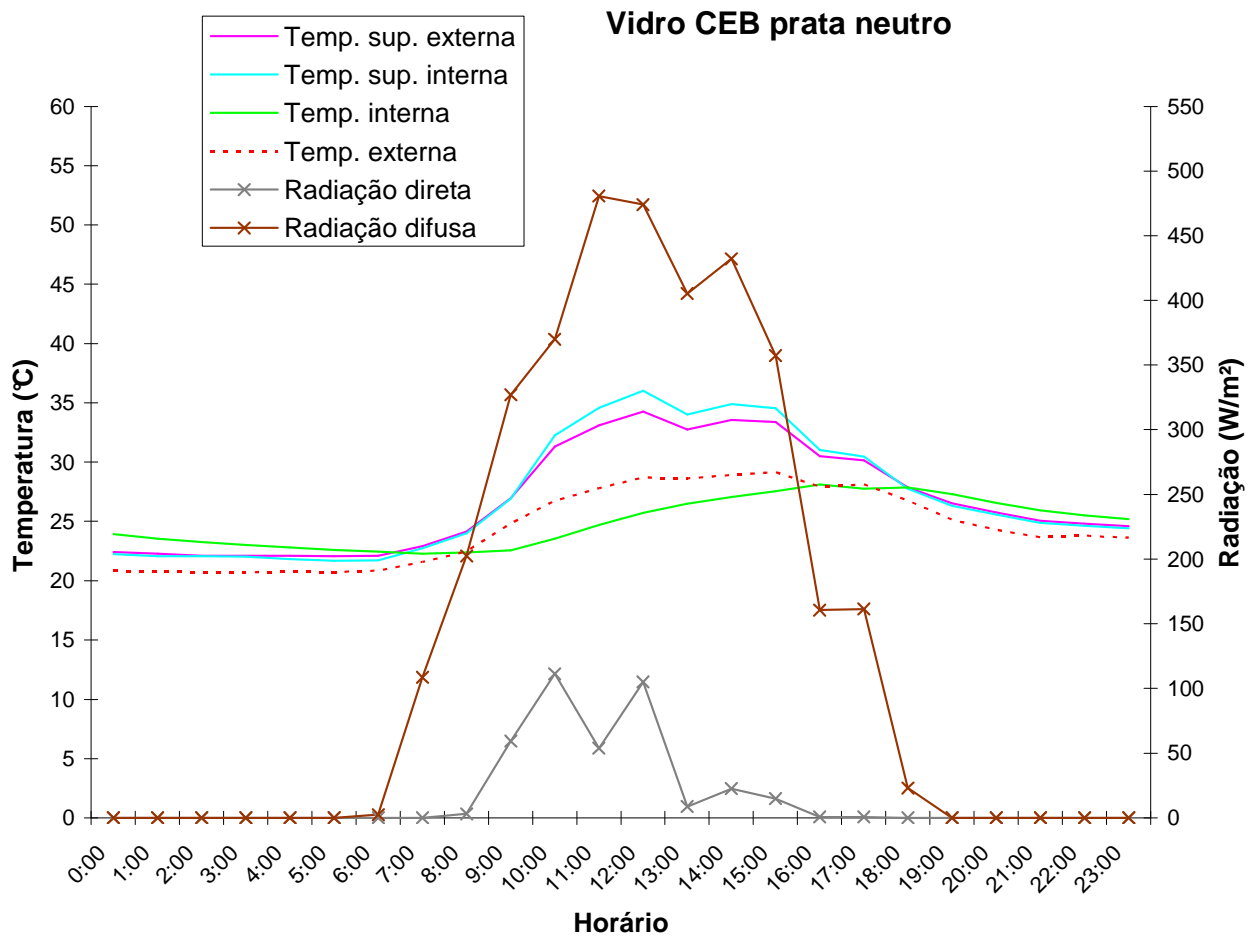

Figura 112. Temperaturas para o vidro refletivo metalizado a vácuo prata neutro - Norte 


\section{Vidro refletivo metalizado a vácuo azul médio}

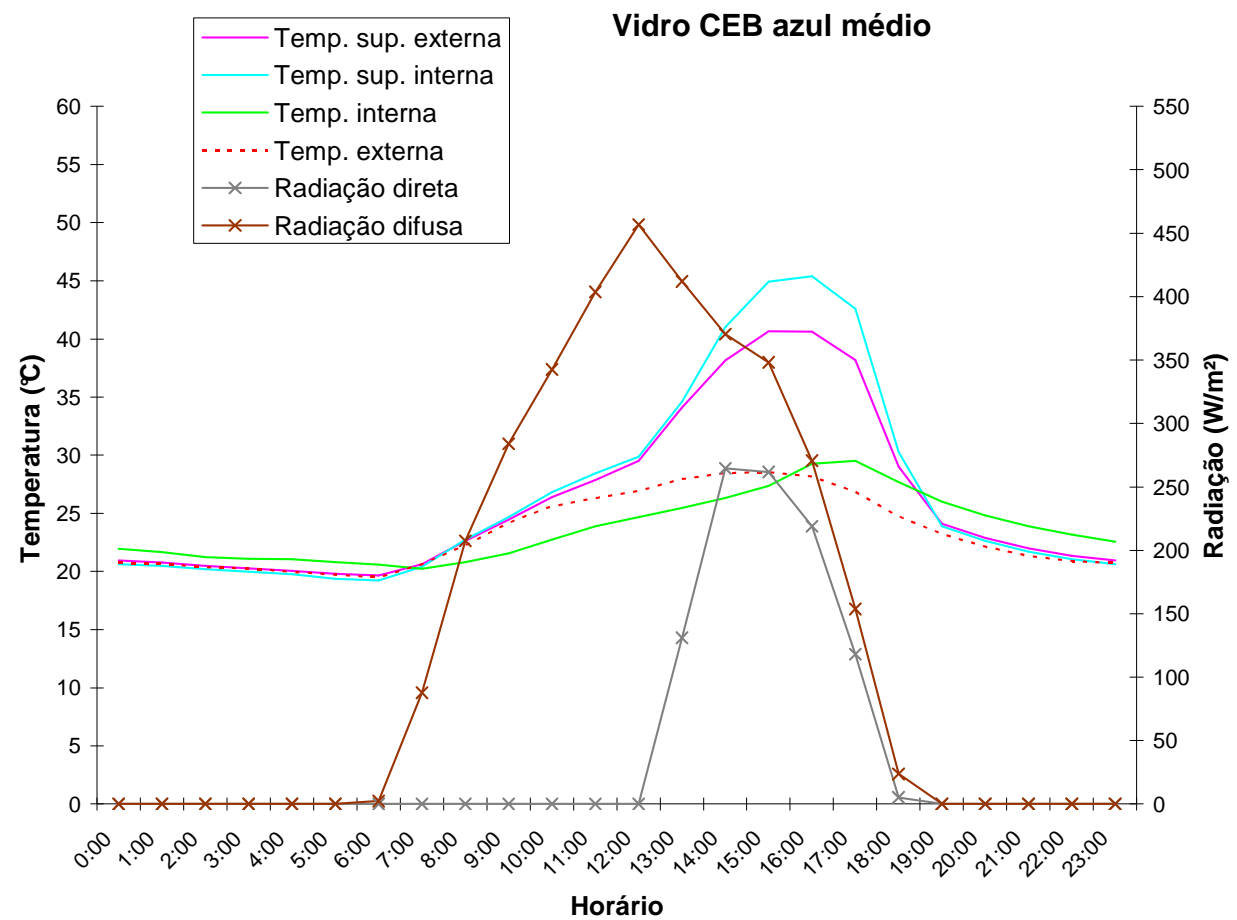

Figura 113. Temperaturas para o vidro refletivo metalizado a vácuo azul médio - Oeste

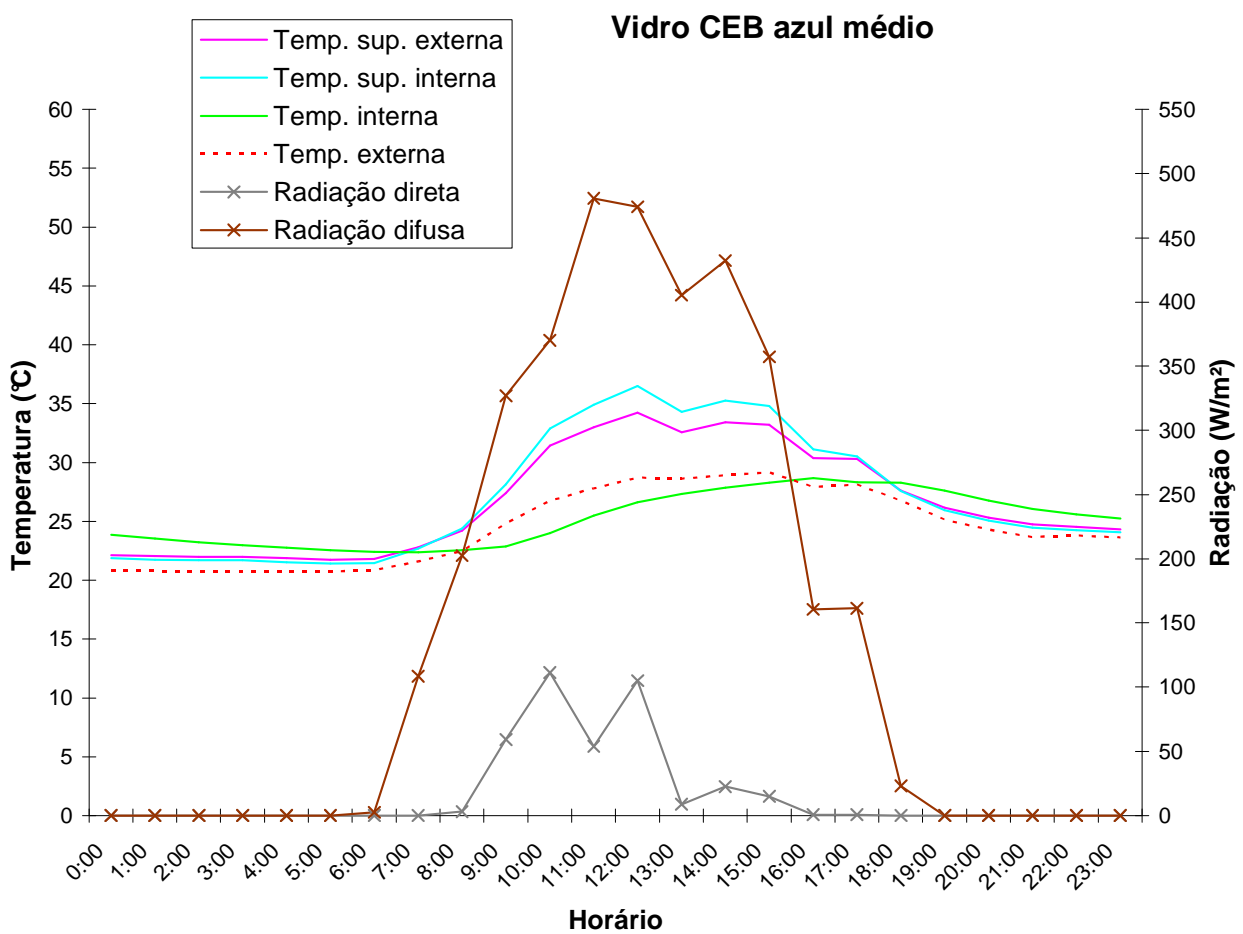

Figura 114. Temperaturas para o vidro refletivo metalizado a vácuo azul médio - Norte 


\section{Vidro refletivo metalizado a vácuo azul intenso médio}

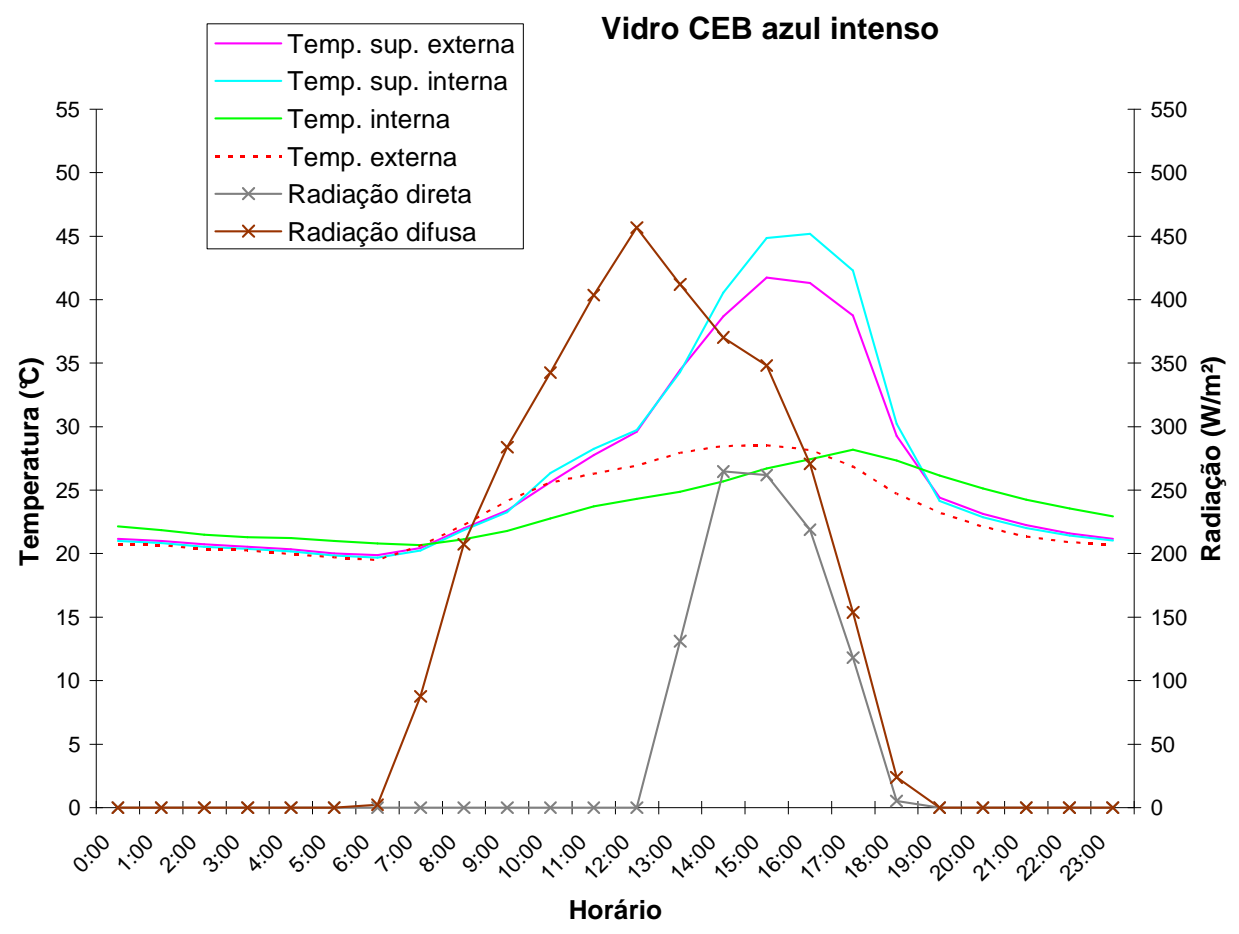

Figura 115. Temperaturas para o vidro refletivo metalizado a vácuo azul intenso médio Oeste

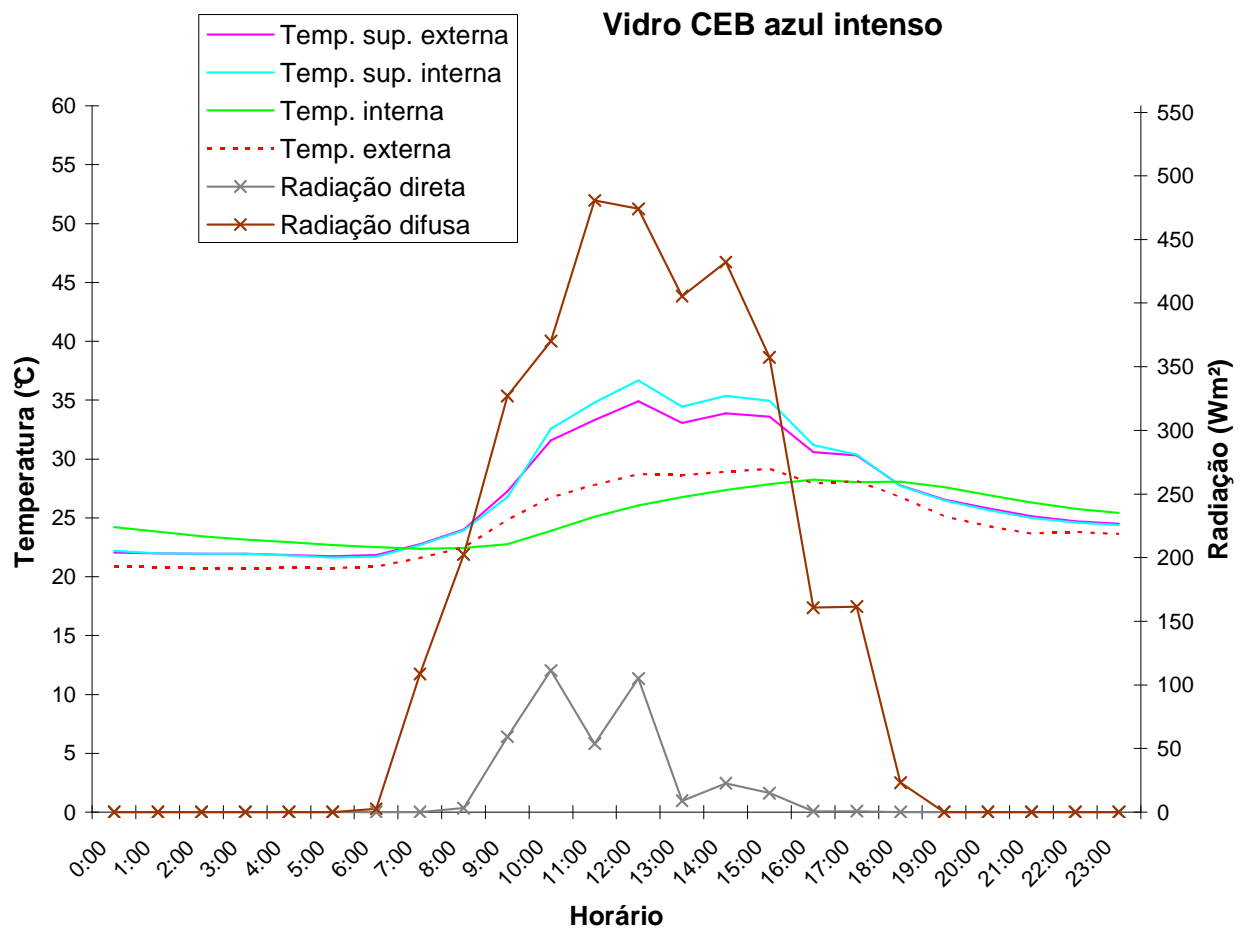

Figura 116. Temperaturas para o vidro refletivo metalizado a vácuo azul intenso médio Norte 
Tabela 11 - Temperaturas superficiais dos vidros e temperatura interna - Grupo 1 (Oeste) - 15/02/2006

\begin{tabular}{|c|c|c|c|c|c|c|c|c|c|c|c|c|c|c|c|c|c|c|c|}
\hline \multirow[b]{2}{*}{ Horário } & \multirow[b]{2}{*}{$\begin{array}{c}\text { Temp. } \\
\text { externa } \\
\left({ }^{\circ} \mathrm{C}\right)\end{array}$} & \multicolumn{3}{|c|}{ Plano verde } & \multicolumn{3}{|c|}{$\begin{array}{l}\text { Antélio verde } \\
\text { esmeralda }\end{array}$} & \multicolumn{3}{|c|}{ Antélio prata } & \multicolumn{3}{|c|}{ Plano incolor } & \multicolumn{3}{|c|}{ Antélio bronze } & \multicolumn{3}{|c|}{ Reflectafloat } \\
\hline & & \begin{tabular}{|c|} 
Temp. \\
sup. \\
externa \\
$\left({ }^{\circ} \mathrm{C}\right)$
\end{tabular} & \begin{tabular}{|c|} 
Temp. \\
sup. \\
interna \\
$\left({ }^{\circ} \mathrm{C}\right)$
\end{tabular} & \begin{tabular}{|c|}
$\begin{array}{c}\text { Temp. } \\
\text { interna }\end{array}$ \\
$\left({ }^{\circ} \mathrm{C}\right)$
\end{tabular} & $\begin{array}{l}\text { Temp. } \\
\text { sup. } \\
\text { externa } \\
\left({ }^{\circ} \mathrm{C}\right)\end{array}$ & \begin{tabular}{|c|} 
Temp. \\
sup. \\
interna \\
$\left({ }^{\circ} \mathrm{C}\right)$
\end{tabular} & \begin{tabular}{|c|}
$\begin{array}{c}\text { Temp. } \\
\text { interna } \\
\left({ }^{\circ} \mathrm{C}\right)\end{array}$ \\
\end{tabular} & $\begin{array}{l}\text { Temp. } \\
\text { sup. } \\
\text { externa } \\
\left({ }^{\circ} \mathrm{C}\right)\end{array}$ & $\begin{array}{l}\text { Temp. } \\
\text { sup. } \\
\text { interna } \\
\text { (C) }\end{array}$ & $\begin{array}{c}\text { Temp. } \\
\text { interna } \\
\left({ }^{\circ} \mathrm{C}\right)\end{array}$ & $\begin{array}{l}\text { Temp. } \\
\text { sup. } \\
\text { externa } \\
\text { ext) } \\
{ }^{\circ} \text { C) }\end{array}$ & $\begin{array}{c}\text { Temp. } \\
\text { sup. } \\
\text { interna }\end{array}$ & $\begin{array}{c}\text { Temp. } \\
\text { interna } \\
\left({ }^{\circ} \mathrm{C}\right)\end{array}$ & $\begin{array}{c}\text { Temp. } \\
\text { sup. } \\
\text { externa } \\
\text { C } \quad \text { ) }\end{array}$ & $\begin{array}{c}\text { Temp. } \\
\text { sup. } \\
\text { interna } \\
\left({ }^{\circ} \mathrm{C}\right)\end{array}$ & $\begin{array}{c}\begin{array}{c}\text { Temp. } \\
\text { interna } \\
\left({ }^{\circ} \mathrm{C}\right)\end{array} \\
\end{array}$ & \begin{tabular}{|c|} 
Temp. \\
sup. \\
externa \\
$\left({ }^{\circ} \mathrm{C}\right)$
\end{tabular} & \begin{tabular}{|c|} 
Temp. \\
sup. \\
interna \\
$\left({ }^{\circ} \mathrm{C}\right)$
\end{tabular} & $\begin{array}{c}\text { Temp. } \\
\text { interna } \\
\left({ }^{\circ} \mathrm{C}\right)\end{array}$ \\
\hline 0:00 & 2,01 & 21,98 & 21,50 & & 22,05 & 21,75 & & 22,19 & & 23,27 & 22,21 & & 23,29 & 22,06 & 21,80 & & 22,10 & 21,74 & \\
\hline $1: 00$ & & & & & & & & & & & & & & & & & & & \\
\hline $2: 00$ & 21,25 & 21,26 & 20,98 & 22,23 & 21,36 & 21,11 & 22,40 & 21,47 & & 2,62 & 21,59 & & & 21,36 & & & & & \\
\hline 3:00 & & & & & & & & & & & 21,31 & & & & & & & & \\
\hline $4: 0$ & 20,69 & 20,56 & & & 20,73 & & 21,82 & 20,90 & & & 21,05 & & & 20 & & & & & \\
\hline $5: 00$ & 20,23 & 20,23 & 0,08 & 30 & 20,41 & 20,24 & 21,49 & 20,56 & & 68 & 20,69 & & & 20,42 & & & 20,47 & & ,43 \\
\hline $6: 00$ & 20,22 & 20,37 & & & 20 & & & 20,45 & & & 20,46 & & & 20,41 & & & & & \\
\hline 7:00 & 22,38 & 22,13 & & & 21,22 & 09 & 20,94 & 21,56 & & & 20,90 & & & 21,69 & & & & & \\
\hline & & & & & & & & & & & & & & & & & & & \\
\hline $9: 0$ & & 26,67 & & & 26,21 & & & 25,54 & & & 24,57 & & & & & & & & \\
\hline $10: 00$ & & 3,87 & & & 28,36 & & & 27,54 & & & 26,92 & & & 28,38 & & & & & \\
\hline $11: 00$ & 30,28 & 32,08 & & & 31,61 & & 23 & 29,87 & & & 29,43 & & & 31,96 & & & & & \\
\hline $12: 00$ & & 32,90 & & & 32,66 & & & 30,76 & & & & & & & & & & & \\
\hline & & & & & & & & & & & & & & & & & & & \\
\hline & & & & & & & & & & & & & & & & & & & \\
\hline & & & & & 38,99 & & & 34,32 & & & & & & & & & & & \\
\hline $16: 00$ & 26,75 & 30,30 & 1,23 & 30,06 & 30,49 & & 29,31 & 29,51 & & & 29,95 & & & 30,68 & & & 29,68 & & \\
\hline $17: 00$ & 22,38 & 26,66 & & & 27,63 & 28,62 & 27,88 & 26,09 & & 52 & 26,96 & & & 27,38 & & & & & \\
\hline $18: 00$ & & & & & & & & & & & & & & & & & & & \\
\hline $19: 00$ & 20,66 & 22,30 & 22,43 & 25,11 & 22,59 & 22,69 & 25,38 & 22,29 & 22,49 & 25,07 & 22,77 & & & 22,53 & 22,74 & & 22,53 & 22,77 & 25,52 \\
\hline $20: 00$ & 20,72 & 21,76 & & & 22,04 & 22,27 & 24,50 & 21,81 & & & 22,25 & & & 22,03 & & & 22,03 & & 24,57 \\
\hline $21: 00$ & 20,60 & 21,37 & 21,37 & 23,26 & 21,80 & 21,94 & 23,72 & 21,44 & 21,58 & 23,38 & 21,97 & 22,15 & 24,04 & 21,69 & 21,94 & 23,61 & 21,66 & 21,90 & 23,78 \\
\hline $22: 00$ & 20,48 & 21,00 & 21,10 & 22,45 & 21,48 & 21,52 & 22,95 & 21,10 & 21,18 & 22,60 & 21,66 & 21,74 & 23,28 & 21,41 & 21,60 & 22,89 & 21,32 & 21,47 & 22,95 \\
\hline $23: 00$ & 20,33 & 20,84 & 21,01 & 22,11 & 21,30 & 21,29 & 22,54 & 21,01 & 21,08 & 22,26 & 21,56 & 21,57 & 22,90 & 21,27 & 21,40 & 22,46 & 21,24 & 21,29 & 22,56 \\
\hline
\end{tabular}


Tabela 12 - Temperaturas superficiais dos vidros e temperatura interna - Grupo 1 (Norte) - 23/02/2006

\begin{tabular}{|c|c|c|c|c|c|c|c|c|c|c|c|c|c|c|c|c|c|c|c|}
\hline \multirow[b]{2}{*}{ Horário } & \multirow[b]{2}{*}{$\begin{array}{c}\text { Temp. } \\
\text { externa } \\
\left({ }^{\circ} \mathrm{C}\right)\end{array}$} & \multicolumn{3}{|c|}{ Plano verde } & \multicolumn{3}{|c|}{$\begin{array}{c}\text { Antélio verde } \\
\text { esmeralda }\end{array}$} & \multicolumn{3}{|c|}{ Antélio prata } & \multicolumn{3}{|c|}{ Plano incolor } & \multicolumn{3}{|c|}{ Antélio bronze } & \multicolumn{3}{|c|}{ Reflectafloat } \\
\hline & & \begin{tabular}{|c|} 
Temp. \\
sup. \\
externa \\
$\left({ }^{\circ} \mathrm{C}\right)$
\end{tabular} & \begin{tabular}{|c|} 
Temp. \\
sup. \\
interna \\
$\left({ }^{\circ} \mathrm{C}\right)$ \\
\end{tabular} & $\begin{array}{c}\text { Temp. } \\
\text { interna } \\
\left({ }^{\circ} \mathrm{C}\right)\end{array}$ & $\begin{array}{l}\text { Temp. } \\
\text { sup. } \\
\text { externa } \\
\text { ('C) }\end{array}$ & $\begin{array}{l}\text { Temp. } \\
\text { sup. } \\
\text { interna } \\
\left({ }^{\circ}\right)\end{array}$ & $\begin{array}{c}\text { Temp. } \\
\text { interna } \\
\left({ }^{\circ} \mathrm{C}\right)\end{array}$ & $\begin{array}{l}\text { Temp. } \\
\text { sup. } \\
\text { externa } \\
\left({ }^{\circ} \mathrm{C}\right)\end{array}$ & $\begin{array}{l}\text { Temp. } \\
\text { sup. } \\
\text { interna } \\
\text { (C) }\end{array}$ & \begin{tabular}{|c} 
Temp. \\
interna \\
$\left({ }^{\circ} \mathrm{C}\right)$
\end{tabular} & $\begin{array}{l}\text { Temp. } \\
\text { sup. } \\
\text { externa } \\
\text { (C) }\end{array}$ & $\begin{array}{l}\text { Temp. } \\
\text { sup. } \\
\text { interna } \\
\text { C) }\end{array}$ & $\begin{array}{c}\text { Temp. } \\
\text { interna } \\
\left({ }^{\circ} \mathrm{C}\right)\end{array}$ & $\begin{array}{l}\text { Temp. } \\
\text { sup. } \\
\text { externa } \\
\text { c }\end{array}$ & $\begin{array}{c}\text { Temp. } \\
\text { sup. } \\
\text { interna } \\
\left({ }^{\circ} \mathrm{C}\right)\end{array}$ & $\begin{array}{c}\text { Temp. } \\
\text { interna } \\
\left({ }^{\circ} \mathrm{C}\right)\end{array}$ & $\begin{array}{l}\text { Temp. } \\
\text { sup. } \\
\text { externa } \\
\left({ }^{\circ} \mathrm{C}\right)\end{array}$ & \begin{tabular}{|c|} 
Temp. \\
sup. \\
interna \\
$\left({ }^{\circ} \mathrm{C}\right)$
\end{tabular} & $\begin{array}{c}\text { Temp. } \\
\text { interna } \\
\left({ }^{\circ} \mathrm{C}\right)\end{array}$ \\
\hline $0: 00$ & 21,00 & 21,50 & 21,32 & 22,70 & 21,64 & 21,50 & 22,86 & 21,86 & 21,77 & 23,14 & 21,85 & 21,66 & 23,09 & 21,66 & 21,62 & 22,75 & 21,68 & 21,49 & 22,85 \\
\hline $1: 00$ & 20,65 & 21,18 & 21,02 & 22,29 & 21,35 & 21,26 & 22,47 & 21,50 & 21,43 & 2,70 & 21,48 & 21,33 & 22,66 & 21,31 & 21,30 & 22,32 & 21,35 & 21,21 & 22,44 \\
\hline $2: 00$ & 20,18 & 20,72 & 20,56 & 22,03 & 20,95 & 20,83 & 22,18 & 21,06 & 20,98 & & 21,08 & & & 20,88 & & & 20,90 & & \\
\hline $3: 00$ & 20,07 & 20,44 & 20,29 & 21,68 & 20,57 & 20,42 & 21,84 & 20,76 & & & 20,77 & & 02 & 20,58 & & & 20,58 & & 80 \\
\hline $4: 00$ & 20,34 & 20,64 & 20,55 & 21,25 & 20,69 & 20,64 & 21,44 & 20,90 & 20,85 & 21,57 & 20,83 & 20,81 & 21,61 & 20,72 & 20,73 & 21,36 & 20,75 & 20,66 & 21,40 \\
\hline $5: 00$ & 20,46 & 20,71 & 20,55 & 21,13 & 20,69 & 20,66 & 21,26 & 20,89 & 20,85 & 21,44 & 20,84 & 20,81 & 21,48 & 20,75 & 20,77 & 21,30 & 20,76 & 20,74 & 21,30 \\
\hline $6: 00$ & 20,53 & 20,84 & ,68 & 21,14 & 20,78 & 20,76 & 1,23 & 20,96 & 20,93 & 1,42 & 20,92 & & & 20,89 & & & 20,85 & & \\
\hline $7: 00$ & 21,31 & 21,65 & 21,90 & 21,21 & 21,48 & 21,64 & 21,19 & 21,40 & 21,45 & 1,35 & 21,28 & & & 21,75 & & 21 & 21,46 & 53 & 18 \\
\hline $8: 00$ & 22,87 & 23,60 & 24,46 & 21,47 & 23,24 & 23,69 & 21,35 & 22,64 & 00 & & 22,42 & & & 23,23 & & & 22,71 & & ,34 \\
\hline 9:00 & 24,32 & 26,22 & 27,81 & 22,28 & 26,53 & 27,77 & 22,04 & 24,52 & 24,99 & 22,38 & 24,27 & 5,32 & 22,55 & 26,22 & 28,29 & 22,01 & 24,62 & 25,19 & 21,96 \\
\hline $10: 00$ & 25,83 & 28,93 & 30,61 & 23,36 & 29,33 & 31,14 & 23,14 & 26,57 & 27,41 & 23,42 & 26,44 & & & 28,79 & &, 98 & 27,14 & & 96 \\
\hline $11: 00$ & 26,79 & 29,68 & 31,41 & 24,44 & 30,03 & 31,91 & 24,13 & 27,79 & 28,91 & 24,56 & 27,51 & ,21 & 63 & 29,84 & &, 99 & 28,28 & 45 & 08 \\
\hline $12: 00$ & 28,42 & 32,21 & 34,36 & 25,45 & 32,56 & 35,31 & 25,02 & 29,90 & & &, 59 & & & 32,61 & & & 30,47 & 27 & 5,00 \\
\hline $13: 00$ & 29,19 & 33,38 & 35,48 & 26,27 & 34,12 & 37,10 & 25,87 & 31,00 & 32,88 & 26,30 & 30,59 & 33,12 & 26,38 & 33,51 & 37,3 & 25,58 & 31,44 & 3,38 & 25,94 \\
\hline $14: 00$ & 29,55 & 33,58 & 35,46 & 27,13 & 34,28 & 36,76 & 26,61 & 31,51 & 33,16 & 27,25 & 31,15 & 3,25 & 27,31 & 33,91 & 37,28 & 26,39 & 31,83 & 33,55 & 26,93 \\
\hline $15: 00$ & 30,27 & 33,98 & 35,28 & 27,76 & 34,48 & 36,41 & 27,27 & 32,23 & 33,51 & 27,95 & 31,79 & 33,35 & 27,95 & 34,55 & 37,34 & 27,03 & 32,35 & 33,78 & 27,65 \\
\hline $16: 00$ & 30,44 & 33,05 & 34,00 & 28,30 & 33,58 & 34,86 & 27,76 & 31,64 & 32,40 & 28,48 & 31,28 & 32,15 & 28,47 & 33,28 & 35,22 & 27,59 & 31,62 & 32,47 & 28,21 \\
\hline $17: 00$ & 29,72 & 30,93 & 31,73 & 28,59 & 31,30 & 31,97 & 28,07 & 30,24 & 30,57 & 28,82 & 30,06 & 30,25 & 28,70 & 31,35 & 32,50 & 27,92 & 30,19 & 30,46 & 28,52 \\
\hline $18: 00$ & 28,44 & 28,31 & 28,28 & 28,54 & 28,56 & 28,55 & 28,16 & 28,29 & 28,18 & 28,94 & 28,35 & 27,71 & 28,66 & 28,56 & 28,68 & 28,03 & 28,06 & 27,82 & 28,57 \\
\hline $19: 00$ & 25,61 & 26,58 & 26,23 & 27,79 & 26,71 & 26,60 & 27,76 & 26,98 & 26,99 & 28,42 & 27,15 & 26,60 & 28,13 & 26,70 & 26,70 & 27,44 & 26,65 & 26,51 & 27,90 \\
\hline $20: 00$ & 24,52 & 25,63 & 25,28 & 26,89 & 25,79 & 25,63 & 26,94 & 26,05 & 26,02 & 27,46 & 26,14 & 25,74 & 27,25 & 25,75 & 25,73 & 26,60 & 25,78 & 25,62 & 26,96 \\
\hline 21:00 & 24,07 & 24,74 & 24,37 & 26,12 & 24,83 & 24,65 & 26,22 & 25,15 & 25,09 & 26,63 & 25,15 & 24,86 & 26,46 & 24,86 & 24,83 & 25,86 & 24,86 & 24,68 & 26,16 \\
\hline 22:00 & 23,38 & 24,08 & 23,78 & 25,37 & 24,15 & 24,02 & 25,53 & 24,40 & 24,36 & 25,87 & 24,36 & & 25,70 & 24,12 & & & 24,14 & 24,02 & 25,40 \\
\hline $23: 00$ & 22,68 & 23,43 & 23,14 & 24,83 & 23,53 & 23,43 & 24,97 & 23,73 & 23,68 & 25,29 & 23,71 & 23,48 & 25,11 & 23,49 & 23,47 & 24,66 & 23,52 & 23,38 & 24,92 \\
\hline
\end{tabular}


Tabela 13 - Temperaturas superficiais dos vidros e temperatura interna - Grupo 2 (Oeste) - 11/03/2006

\begin{tabular}{|c|c|c|c|c|c|c|c|c|c|c|c|c|c|c|c|c|c|c|c|}
\hline \multirow[b]{2}{*}{ Horário } & \multirow[b]{2}{*}{$\begin{array}{c}\text { Temp. } \\
\text { externa } \\
\left({ }^{\circ} \mathrm{C}\right)\end{array}$} & \multicolumn{3}{|c|}{ Plano verde } & \multicolumn{3}{|c|}{$\begin{array}{c}\text { CEB azul intenso } \\
\text { médio }\end{array}$} & \multicolumn{3}{|c|}{ CEB azul médio } & \multicolumn{3}{|c|}{ Plano incolor } & \multicolumn{3}{|c|}{ CEB prata neutro } & \multicolumn{3}{|c|}{ Reflectafloat } \\
\hline & & \begin{tabular}{|c|} 
Temp. \\
sup. \\
externa \\
$\left({ }^{\circ} \mathrm{C}\right)$
\end{tabular} & \begin{tabular}{|c|} 
Temp. \\
sup. \\
interna \\
$\left({ }^{\circ} \mathrm{C}\right)$
\end{tabular} & $\begin{array}{c}\text { Temp. } \\
\text { interna } \\
\left({ }^{\circ} \mathrm{C}\right)\end{array}$ & $\begin{array}{l}\text { Temp. } \\
\text { sup. } \\
\text { externa } \\
\left({ }^{\circ} \mathrm{C}\right)\end{array}$ & $\begin{array}{l}\text { Temp. } \\
\text { sup. } \\
\text { interna } \\
\left({ }^{\circ} \mathrm{C}\right)\end{array}$ & 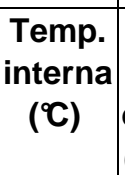 & $\begin{array}{l}\text { Temp. } \\
\text { sup. } \\
\text { externa } \\
\left({ }^{\circ} \mathrm{C}\right)\end{array}$ & $\begin{array}{l}\text { Temp. } \\
\text { sup. } \\
\text { interna } \\
\left.{ }^{\circ} \mathrm{C}\right)\end{array}$ & $\begin{array}{c}\text { Temp. } \\
\text { interna } \\
\left({ }^{\circ} \mathrm{C}\right)\end{array}$ & $\begin{array}{l}\text { Temp. } \\
\text { sup. } \\
\text { externa } \\
\left.{ }^{\circ} \mathrm{C}\right)\end{array}$ & $\begin{array}{l}\text { Temp. } \\
\text { sup. } \\
\text { interna } \\
\text { (C) }\end{array}$ & $\begin{array}{c}\text { Temp. } \\
\text { interna } \\
\left({ }^{\circ} \mathrm{C}\right)\end{array}$ & $\begin{array}{c}\text { Temp. } \\
\text { sup. } \\
\text { externa } \\
\text { C ) }\end{array}$ & $\begin{array}{c}\text { Temp. } \\
\text { sup. } \\
\text { interna } \\
\left({ }^{\circ} \mathrm{C}\right)\end{array}$ & $\begin{array}{c}\text { Temp. } \\
\text { interna } \\
\left({ }^{\circ} \mathrm{C}\right)\end{array}$ & \begin{tabular}{|c|} 
Temp. \\
sup. \\
externa \\
$\left({ }^{\circ} \mathrm{C}\right)$
\end{tabular} & \begin{tabular}{|c|} 
Temp. \\
sup. \\
interna \\
$\left({ }^{\circ} \mathrm{C}\right)$
\end{tabular} & $\begin{array}{c}\text { Temp. } \\
\text { interna } \\
\left({ }^{\circ} \mathrm{C}\right)\end{array}$ \\
\hline $0: 00$ & 20,73 & 20,53 & 20,20 & 21,56 & 21,19 & 20,99 & 22,14 & 20,94 & 20,61 & & 21,03 & 20,89 & 22,45 & 21,57 & 21,11 & & 20,56 & 20,37 & 21,68 \\
\hline $1: 00$ & & & & & & & & & & & & & & & & & & & \\
\hline $2: 00$ & 20,36 & 20,26 & & & & & & 20 & & & & & & & & & & & \\
\hline $3: 00$ & 20,25 & 20,08 & &, 76 & 20 & 20,37 & 21,31 & 20,27 & & 21,06 & 20,42 & & 21,61 & &, 48 & & 15 & &, 87 \\
\hline $4: 00$ & & & & & & & & & & & & & & & & & & & \\
\hline $5: 00$ & 19,71 & 9,40 & &, 47 & 20 & & & & & & 19 & & & & & & & & \\
\hline & & & & & & & & & & & & & & & & & & & \\
\hline 7:00 & 20,62 & 0,23 & & & & & & 20 & & & & & & & & & & & \\
\hline $8: 00$ & 22,25 & 1,66 & & & & & & 22 & & & 21 & & & & & & & & 83 \\
\hline & 24,16 & & & & & & & & & & & & & & & & & & \\
\hline $10: 00$ & 25,61 & 26,00 & & & & & & 26 & & & & & & & & & & & \\
\hline & & & & & & & & & & & & & & & & & & & \\
\hline $12: 00$ & & & & & & & & & & & & & & & & & & & \\
\hline & & & & & & & & & & & & & & & & & & & \\
\hline $14: 00$ & 28,47 & 37,39 & 82 &, 59 & 69 &, 56 & & 38,14 & 41,03 & 32 & 33 & & 12 & & & & 90 & & 65 \\
\hline & & & & & & & & & & & & & & & & & & & \\
\hline & & & & & & & & & & & & & & & & & & & \\
\hline $17: 00$ & 26,84 & & & & & & & & & & & & & & & & & & 0,63 \\
\hline & & & & & & & & & & & & & & & & & & & \\
\hline $19: 00$ & 23,23 & 24,05 & 23,49 & & & 24,14 & & & 23,87 & & 24,45 & & & & 24,18 & & & & 5,60 \\
\hline $20: 00$ & 22,13 & 22,78 & 22,23 & 24,50 & 23,14 & 22,88 & 25,14 & 22,88 & 22,62 & 24,80 & 23,17 & 22,80 & 25,87 & 23,25 & 22,90 & 24,79 & 22,83 & 22,33 & 24,35 \\
\hline $21: 00$ & 21,35 & & & & & & & & & & 22,22 & & & 22,35 & 22,02 & & & & 23,45 \\
\hline $22: 00$ & 20,88 & 21,19 & 20,66 & 22,81 & 21,59 & 21,44 & 23,55 & 21,34 & 21,04 & 23,15 & 21,60 & 21,34 & 24,12 & 21,74 & 21,47 & 23,22 & 21,25 & 20,73 & 22,75 \\
\hline $23: 00$ & 20,71 & 20,77 & 20,28 & 22,23 & 21,17 & 21,04 & 22,93 & 20,93 & 20,61 & 22,57 & 21,18 & 20,95 & 23,46 & 21,32 & 21,09 & 22,64 & 20,83 & 20,34 & 22,20 \\
\hline
\end{tabular}


Tabela 14 - Temperaturas superficiais dos vidros e temperatura interna - Grupo 2 (Norte) - 05/03/2006

\begin{tabular}{|c|c|c|c|c|c|c|c|c|c|c|c|c|c|c|c|c|c|c|c|}
\hline \multirow[b]{2}{*}{ Horário } & \multirow[b]{2}{*}{$\begin{array}{c}\text { Temp. } \\
\text { externa } \\
\left({ }^{\circ} \mathrm{C}\right)\end{array}$} & \multicolumn{3}{|c|}{ Plano verde } & \multicolumn{3}{|c|}{$\begin{array}{l}\text { CEB azul intenso } \\
\text { médio }\end{array}$} & \multicolumn{3}{|c|}{ CEB azul médio } & \multicolumn{3}{|c|}{ Plano incolor } & \multicolumn{3}{|c|}{ CEB prata neutro } & \multicolumn{3}{|c|}{ Reflectafloat } \\
\hline & & \begin{tabular}{|c|} 
Temp. \\
sup. \\
externa \\
$\left({ }^{\circ} \mathrm{C}\right)$
\end{tabular} & \begin{tabular}{|c|} 
Temp. \\
sup. \\
interna \\
$\left({ }^{\circ} \mathrm{C}\right)$
\end{tabular} & $\begin{array}{c}\text { Temp. } \\
\text { interna } \\
\left({ }^{\circ} \mathrm{C}\right)\end{array}$ & $\begin{array}{l}\text { Temp. } \\
\text { sup. } \\
\text { externa } \\
\left({ }^{\circ} \mathrm{C}\right)\end{array}$ & \begin{tabular}{|l|} 
Temp. \\
sup. \\
interna \\
$\left({ }^{\circ} \mathrm{C}\right)$
\end{tabular} & $\begin{array}{c}\text { Temp. } \\
\text { interna } \\
\left({ }^{\circ}\right)\end{array}$ & $\begin{array}{l}\text { Temp. } \\
\text { sup. } \\
\text { externa } \\
\left({ }^{\circ} \mathrm{C}\right)\end{array}$ & $\begin{array}{l}\text { Temp. } \\
\text { sup. } \\
\text { interna } \\
\left({ }^{\circ} \mathrm{C}\right)\end{array}$ & $\begin{array}{c}\text { Temp. } \\
\text { interna } \\
\left({ }^{\circ} \mathrm{C}\right)\end{array}$ & $\begin{array}{c}\text { Temp. } \\
\text { sup. } \\
\text { externa } \\
\left.{ }^{\circ} \mathrm{C}\right)\end{array}$ & \begin{tabular}{|l|} 
Temp. \\
sup. \\
interna \\
C)
\end{tabular} & $\begin{array}{c}\text { Temp. } \\
\text { interna } \\
\left({ }^{\circ} \mathrm{C}\right)\end{array}$ & $\begin{array}{c}\text { Temp. } \\
\text { sup. } \\
\text { externa } \\
\text { C ) }\end{array}$ & $\begin{array}{c}\text { Temp. } \\
\text { sup. } \\
\text { interna } \\
\left({ }^{\circ} \mathrm{C}\right)\end{array}$ & $\begin{array}{c}\text { Temp. } \\
\text { interna } \\
\left({ }^{\circ} \mathrm{C}\right)\end{array}$ & $\begin{array}{l}\text { Temp. } \\
\text { sup. } \\
\text { externa } \\
\left({ }^{\circ} \mathrm{C}\right)\end{array}$ & \begin{tabular}{|c} 
Temp. \\
sup. \\
interna \\
$\left({ }^{\circ} \mathrm{C}\right)$
\end{tabular} & $\begin{array}{c}\text { Temp. } \\
\text { interna } \\
\left({ }^{\circ} \mathrm{C}\right)\end{array}$ \\
\hline $0: 00$ & 0,84 & 21,63 & 21,74 & & 22,06 & 22,18 & & 22,13 & 21,86 & & 22,28 & 22,58 & 24,59 & 22,41 & 22,25 & & 21,58 & 21,81 & 23,37 \\
\hline $1: 00$ & & & & & & & & & & & & & & & & & & & \\
\hline $2: 00$ & 20,70 & 21,51 & & 2,99 & 21,96 & 21,93 & & 21 & & & 22,08 & & & 22,10 & & & & & \\
\hline $3: 00$ & 20,71 & 21,54 & & 22,74 & 21,92 & 21,93 & 23,16 & 21 & & 2,96 & 22,09 & 99 & & 22,12 & 2 & 3,00 & 21,33 & &, 53 \\
\hline $4: 00$ & 20,76 & & & & & & & & & & 21,97 & & & & & & & & \\
\hline $5: 00$ & 20,73 & 21,36 & & 2,34 & 21,72 & 21,63 & 22,71 & 21 & & & 21,79 & & 00 & 22,06 & & & 21,20 & & 15 \\
\hline $6: 00$ & & & & & & & & & & & & & & & & & & & \\
\hline 7:00 & 21 , & 22,46 & & 2 & & & & 22 , & & & 22,08 & & & & & & & & \\
\hline $8: 00$ & 2 & 3,86 & & & & & & 24 & & & 22,98 & & & & & & & & \\
\hline $9: 00$ & 24,82 &, 83 & & & & & & 27 & & & 25,30 & & & & & & & & \\
\hline $10: 00$ & 26,73 & ),37 & & & & 56 & & & & & 28,10 & & & & & & 29,40 & & \\
\hline $11: 00$ & 27,80 & 2,18 & & & & & & & & & 29,55 & & & & & & 0,71 & & \\
\hline & & & & & & & & & & & & & & & & & & & \\
\hline & & & & & & & & & & & & & & & & & & & \\
\hline $14: 00$ & 28,93 & 3,12 & & & & & & 33,42 & & & 30,86 & 7,80 & & & & & & & 09 \\
\hline & & & & & & & & & & & & & & & & & & & \\
\hline $16: 00$ & 27,92 & 30,24 & & 28,91 & & & & 30 , & & & 29,41 & & & 30,53 & & & & & ,73 \\
\hline $17: 00$ & & 30,05 & & 28,46 & & & & & & & & & & & & & 29,26 & & 28,37 \\
\hline $18: 00$ & 26,75 & 27,55 & & 28,28 & & & 28,09 & 27,61 & & & 27,61 & & & & & & & & 28,09 \\
\hline $19: 00$ & 25,14 & & 25,74 & 27,52 & & 26,47 & 27,62 & & & 27,60 & 26,67 & 27,65 & 27,99 & 26,53 & & & 25,96 & & 27,19 \\
\hline & & & & & & & & & & & 25,88 & & & 25,78 & 25,56 & & 25,10 & & 6,32 \\
\hline 21:00 & 23,66 & 24,79 & 24,39 & 25,90 & 25,11 & 24,98 & 26,28 & 24,73 & 24,46 & 26,08 & 25,21 & & 26,56 & 25,08 & 24,88 & & 24,58 & 24,18 & 25,71 \\
\hline $22: 00$ & 23,81 & 24,50 & 24,14 & 25,46 & 24,70 & 24,60 & 25,77 & 24,52 & 24,24 & 25,60 & 24,79 & 26,67 & 26,03 & 24,83 & 24,63 & 25,52 & 24,31 & 23,96 & 25,27 \\
\hline $23: 00$ & 23,63 & 24,29 & 24,00 & 25,15 & 24,49 & 24,39 & 25,42 & 24,32 & 24,08 & 25,26 & 24,53 & 26,45 & 25,66 & 24,59 & 24,42 & 25,20 & 24,09 & 23,74 & 24,94 \\
\hline
\end{tabular}


Tabela 15 - Temperaturas superficiais dos vidros e temperatura interna - Grupo 3 (Oeste) - 15/03/2006

\begin{tabular}{|c|c|c|c|c|c|c|c|c|c|c|c|c|c|c|c|c|c|c|c|}
\hline \multirow[b]{2}{*}{ Horário } & \multirow[b]{2}{*}{$\begin{array}{c}\text { Temp. } \\
\text { externa } \\
\left({ }^{\circ} \mathrm{C}\right)\end{array}$} & \multicolumn{3}{|c|}{ Plano verde } & \multicolumn{3}{|c|}{$\begin{array}{l}\text { Antélio verde } \\
\text { esmeralda }\end{array}$} & \multicolumn{3}{|c|}{ Antélio prata } & \multicolumn{3}{|c|}{ Plano incolor } & \multicolumn{3}{|c|}{ CEB prata neutro } & \multicolumn{3}{|c|}{ Reflectafloat } \\
\hline & & \begin{tabular}{|c|} 
Temp. \\
sup. \\
externa \\
$\left({ }^{\circ} \mathrm{C}\right)$
\end{tabular} & \begin{tabular}{|c|} 
Temp. \\
sup. \\
interna \\
$\left({ }^{\circ} \mathrm{C}\right)$
\end{tabular} & $\begin{array}{c}\text { Temp. } \\
\text { interna } \\
\left({ }^{\circ} \mathrm{C}\right)\end{array}$ & $\begin{array}{l}\text { Temp. } \\
\text { sup. } \\
\text { externa } \\
\left({ }^{\circ} \mathrm{C}\right)\end{array}$ & \begin{tabular}{|c|} 
Temp. \\
sup. \\
interna \\
$\left({ }^{\circ} \mathrm{C}\right)$
\end{tabular} & \begin{tabular}{|c|}
$\begin{array}{c}\text { Temp. } \\
\text { interna } \\
\left({ }^{\circ} \mathrm{C}\right)\end{array}$ \\
\end{tabular} & $\begin{array}{l}\text { Temp. } \\
\text { sup. } \\
\text { externa } \\
\left({ }^{\circ} \mathrm{C}\right)\end{array}$ & $\begin{array}{l}\text { Temp. } \\
\text { sup. } \\
\text { interna } \\
\text { (C) }\end{array}$ & $\begin{array}{c}\text { Temp. } \\
\text { interna } \\
\left({ }^{\circ} \mathrm{C}\right)\end{array}$ & \begin{tabular}{|c|} 
Temp. \\
sup. \\
externa \\
(C)
\end{tabular} & \begin{tabular}{|c|} 
Temp. \\
sup. \\
interna
\end{tabular} & $\begin{array}{c}\text { Temp. } \\
\text { interna } \\
\left({ }^{\circ} \mathrm{C}\right)\end{array}$ & $\begin{array}{c}\text { Temp. } \\
\text { sup. } \\
\text { externa } \\
\text { C } \quad \text { ) }\end{array}$ & $\begin{array}{c}\text { Temp. } \\
\text { sup. } \\
\text { interna } \\
\left({ }^{\circ} \mathrm{C}\right)\end{array}$ & \begin{tabular}{|c|}
$\begin{array}{c}\text { Temp. } \\
\text { interna } \\
\left({ }^{\circ} \mathrm{C}\right)\end{array}$ \\
\end{tabular} & $\begin{array}{l}\text { Temp. } \\
\text { sup. } \\
\text { externa } \\
\left({ }^{\circ} \mathrm{C}\right)\end{array}$ & \begin{tabular}{|c} 
Temp. \\
sup. \\
interna \\
$\left({ }^{\circ} \mathrm{C}\right)$
\end{tabular} & $\begin{array}{c}\text { Temp. } \\
\text { interna } \\
\left({ }^{\circ} \mathrm{C}\right)\end{array}$ \\
\hline 0:00 & 1,72 & 22,18 & 21,95 & & 22,39 & 22,06 & & 22,48 & 22,17 & 23,65 & 22,44 & & 24,03 & 22,36 & 22,28 & & 22,22 & 22,00 & \\
\hline $1: 00$ & & & & & & & & & & & & & & & & & & & \\
\hline $2: 00$ & 20,89 & 21,33 & & 22,06 & 21,52 & 21,18 & 22,75 & 21,63 & & 2,81 & 21,56 & & & & & & 21,36 & & \\
\hline 3:00 & 20,32 & & & & & & & & & & & & & & & & & & \\
\hline $4: 00$ & 96 & 20,32 & & & 20,5 & & 22,04 & 20,66 & & & 20 & & & & & & & & \\
\hline $5: 00$ & 19,98 & 20,20 & & & 20,36 & ,98 & 21,65 & 20,51 & & 71 & 20,40 & & 22,05 & 20,40 & & & 20,19 & & 09 \\
\hline $6: 00$ & & 20,27 & & & 20,32 & & & 20,49 & & & & & & & & & & & \\
\hline 7:00 & 21,38 & 21,20 & & & 21,22 & & 21,37 & 21,22 & & & 20,89 & & & & & & & & \\
\hline & & & & & & & & & & & & & & & & & & & \\
\hline $9: 0$ & 26,73 & & & & 25,96 & & & 25,34 & & & 24,74 & & & & & & & & \\
\hline $10: 00$ & 27,20 & 3,37 & & & 28,3 & & 24,03 & 27,40 & & & 27,03 & & & & & & & & \\
\hline $11: 00$ & 28,32 & 1,14 & & & 30,83 & & 24,92 & 29,62 & & & 29,26 & & & & & & & & \\
\hline $12: 00$ & & & & & 33,20 & & & & & & & & & & & & & & \\
\hline & & & & & & & & & & & & & & & & & & & \\
\hline & & & & & & & & & & & & & & & & & & & \\
\hline & & & & & & & & 40,64 & & & & & & & & & & & \\
\hline $16: 00$ & 29,95 & 4,92 &, 31 & 34,47 & 47,94 & & 30,83 & 40,42 & 42,66 & & 39,19 & & & 46,78 & 9,72 &, 77 & 39,67 & & \\
\hline $17: 00$ & 27,68 & & & & 35,86 & 37,66 & 30,72 & 32,46 & & 29 & 32,23 & & & & & & & & \\
\hline $18: 00$ & & & & & & & & & & & & & & & & & & & \\
\hline $19: 00$ & 24,14 & 26,06 & & 28,17 & 26,71 & 26,41 & 28,78 & 26,84 & & 29,31 & 27,02 & & & 26,55 & & & 26,27 & 25,77 & 28,17 \\
\hline $20: 00$ & 23,57 & 25,12 & 24,61 & 27,05 & 25,72 & & 27,77 & 25,93 & & 28,20 & 25,97 & & & 25,63 & & & 25,29 & & 27,00 \\
\hline $21: 00$ & 23,54 & 24,83 & 24,45 & 26,16 & 25,25 & 25,02 & 26,92 & 25,47 & 25,12 & 27,25 & 25,43 & & 27,46 & 25,21 & 25,10 & 26,43 & 24,99 & 24,61 & 26,20 \\
\hline $22: 00$ & 23,50 & 24,34 & 23,98 & 25,38 & 24,62 & 24,37 & 26,17 & 24,83 & 24,35 & 26,49 & 24,71 & 24,63 & 26,77 & 24,63 & 24,43 & 25,75 & 24,45 & 24,11 & 25,45 \\
\hline 23:00 & 23,26 & 24,01 & 23,71 & 24,93 & 24,21 & 23,99 & 25,65 & 24,50 & 24,03 & 25,99 & 24,34 & 24,25 & 26,23 & 24,30 & 24,09 & 25,36 & 24,12 & 23,84 & 25,01 \\
\hline
\end{tabular}


Tabela 16 - Temperaturas superficiais dos vidros e temperatura interna - Grupo 3 (Norte) - 21/03/2006

\begin{tabular}{|c|c|c|c|c|c|c|c|c|c|c|c|c|c|c|c|c|c|c|c|}
\hline \multirow[b]{2}{*}{ Horário } & \multirow[b]{2}{*}{$\begin{array}{c}\text { Temp. } \\
\text { externa } \\
\left({ }^{\circ} \mathrm{C}\right)\end{array}$} & \multicolumn{3}{|c|}{ Plano verde } & \multicolumn{3}{|c|}{$\begin{array}{l}\text { Antélio verde } \\
\text { esmeralda }\end{array}$} & \multicolumn{3}{|c|}{ Antélio prata } & \multicolumn{3}{|c|}{ Plano incolor } & \multicolumn{3}{|c|}{ CEB prata neutro } & \multicolumn{3}{|c|}{ Reflectafloat } \\
\hline & & \begin{tabular}{|c|} 
Temp. \\
sup. \\
externa \\
$\left({ }^{\circ} \mathrm{C}\right)$
\end{tabular} & \begin{tabular}{|c|} 
Temp. \\
sup. \\
interna \\
$\left({ }^{\circ} \mathrm{C}\right)$
\end{tabular} & $\begin{array}{c}\text { Temp. } \\
\text { interna } \\
\left({ }^{\circ} \mathrm{C}\right)\end{array}$ & $\begin{array}{l}\text { Temp. } \\
\text { sup. } \\
\text { externa } \\
\left({ }^{\circ} \mathrm{C}\right)\end{array}$ & \begin{tabular}{|c|} 
Temp. \\
sup. \\
interna \\
$\left({ }^{\circ} \mathrm{C}\right)$
\end{tabular} & \begin{tabular}{|c|}
$\begin{array}{c}\text { Temp. } \\
\text { interna } \\
\left({ }^{\circ} \mathrm{C}\right)\end{array}$ \\
\end{tabular} & $\begin{array}{l}\text { Temp. } \\
\text { sup. } \\
\text { externa } \\
\left({ }^{\circ} \mathrm{C}\right)\end{array}$ & $\begin{array}{l}\text { Temp. } \\
\text { sup. } \\
\text { interna } \\
\text { (C) }\end{array}$ & $\begin{array}{c}\text { Temp. } \\
\text { interna } \\
\left({ }^{\circ} \mathrm{C}\right)\end{array}$ & \begin{tabular}{|c|} 
Temp. \\
sup. \\
externa \\
(C)
\end{tabular} & $\begin{array}{l}\text { Temp. } \\
\text { sup. } \\
\text { interna }\end{array}$ & $\begin{array}{c}\text { Temp. } \\
\text { interna } \\
\left({ }^{\circ} \mathrm{C}\right)\end{array}$ & $\begin{array}{c}\text { Temp. } \\
\text { sup. } \\
\text { externa } \\
\text { C } \quad \text { ) }\end{array}$ & $\begin{array}{c}\text { Temp. } \\
\text { sup. } \\
\text { interna } \\
\left({ }^{\circ} \mathrm{C}\right)\end{array}$ & $\begin{array}{c}\begin{array}{c}\text { Temp. } \\
\text { interna } \\
\left({ }^{\circ} \mathrm{C}\right)\end{array} \\
\end{array}$ & \begin{tabular}{|c|} 
Temp. \\
sup. \\
externa \\
$\left({ }^{\circ} \mathrm{C}\right)$
\end{tabular} & \begin{tabular}{|c|} 
Temp. \\
sup. \\
interna \\
$\left({ }^{\circ} \mathrm{C}\right)$
\end{tabular} & $\begin{array}{c}\text { Temp. } \\
\text { interna } \\
\left({ }^{\circ} \mathrm{C}\right)\end{array}$ \\
\hline 0:00 & & 20,41 & 20,17 & & 20,61 & 20,29 & & 20,71 & 20,40 & 21,88 & 20,66 & & 22,26 & 20,59 & 20,50 & & 20,45 & & \\
\hline $1: 00$ & & & & & & & & & & & & & & & & & & & \\
\hline $2: 00$ & 20,55 & 20,99 & 0,75 & 21,72 & 21,18 & 20,84 & 22,40 & 21,29 & & 47 & 21,22 & & & 21,17 & & & 21,02 & & \\
\hline 3:00 & & & & & & & & & & & & & & & & & & & \\
\hline $4: 0$ & 20,34 & 20,71 & & & 20, & & 22,42 & 21,04 & & & 20 & & & & & & & & \\
\hline $5: 00$ & 20,16 & 20,38 &, 07 & & 20,54 & 20,16 & 21,83 & 20,69 & & 89 & 20,58 & & 23 & 20,58 & & & 20,37 & & ,27 \\
\hline $6: 00$ & & 20,27 & & & 20 & & & 20,48 & & & & & & & & & & & \\
\hline 7:00 & 21,11 & 21,29 & & & 21,17 & & 21,10 & 20,95 & & & 20,61 & & & & & & & & \\
\hline & & & & & & & & & & & & & & & & & & & \\
\hline $9: 0$ & & 5,43 & & & 25,86 & & 69 & 23,24 & & & 23 & & & & & & & & \\
\hline $10: 00$ & & 7,20 & & & 27,20 & & 22,86 & 26,23 & & & 25 & & & & & & & & \\
\hline $11: 00$ & 27,22 & 30,04 & & & 29,73 & 2,25 & 23,82 & 28,52 & & & 28,16 & & & & & & 28,41 & & \\
\hline $12: 00$ & & & & & 37,32 & & & & & & & & & & & & & & \\
\hline & & & & & & & & & & & & & & & & & & & \\
\hline & & & & & & & & & & & & & & & & & & & \\
\hline & & & & & & & & & & & & & & & & & & & \\
\hline $16: 00$ & 29,64 & 34,54 & & 30,04 & 33,88 & 9,12 & 30,43 & 31,82 & & & 32,11 & & & 34,38 & & & 31,97 & & 07 \\
\hline $17: 00$ & & 32,34 & & & 32,12 & & 29,61 & 30,36 & & 13 & & & & & & & & & \\
\hline $18: 00$ & & & & & & & & & & & & & & & & & & & \\
\hline $19: 00$ & 24,96 & 26,88 & & 27,19 & 27,53 & 27,23 & 26,86 & 27,66 & 27,22 & 27,59 & 27,84 & & & 27,37 & 27,22 & & 27,09 & & 27,29 \\
\hline $20: 00$ & 24,20 & 25,75 & 25,25 & & 26,35 & 26,09 & 26,67 & 26,57 & & & 26,60 & & & 26,27 & & & 25,93 & & 26,32 \\
\hline $21: 00$ & 23,30 & 24,59 & 24,20 & 25,78 & 25,01 & 24,78 & 25,44 & 25,23 & 24,87 & 26,25 & 25,18 & & 26,43 & 24,97 & 24,86 & 24,97 & 24,74 & 24,36 & 25,96 \\
\hline $22: 00$ & 22,71 & 23,55 & 23,19 & 24,60 & 23,83 & 23,59 & 25,38 & 24,04 & 23,56 & 25,71 & 23,93 & 23,85 & 25,98 & 23,84 & 23,64 & 24,90 & 23,67 & 23,32 & 24,67 \\
\hline $23: 00$ & 22,55 & 23,29 & 23,00 & 24,22 & 23,49 & 23,28 & 24,93 & 23,78 & 23,32 & 25,28 & 23,62 & 23,54 & 25,52 & 23,59 & 23,38 & 24,65 & 23,41 & 23,13 & 24,30 \\
\hline
\end{tabular}




\subsection{Discussão}

Da mesma forma que as medições no inverno, as temperaturas superficiais internas dos vidros refletivos analisados no verão foram superiores às temperaturas superficiais externas no período com incidência do sol.

O vidro plano incolor apresentou menores temperaturas superficiais que o vidro plano verde, enquanto a célula-teste com o vidro plano incolor apresentou maiores temperaturas internas (Figuras 99, 100), mostrando que o vidro plano incolor não é uma boa opção para o bloqueio de calor nos ambientes.

Dentre os vidros refletivos pirolíticos analisados, o vidro bronze apresentou as maiores temperaturas superficiais internas e externas (Figuras 107, 108). Além disso, a célula-teste com o vidro refletivo pirolítico bronze obteve as menores temperaturas internas.

Com relação aos vidros refletivos metalizados a vácuo, a célula-teste com o vidro prata neutro apresentou as menores temperaturas internas (Figuras 111, 112), vindo em seguida da célula-teste com o vidro azul intenso médio. Já com relação às temperaturas superficiais dos vidros refletivos metalizados a vácuo, o vidro azul intenso médio apresentou as maiores temperaturas superficiais internas e externas (Figuras 115, 116).

Os vidros mais escuros apresentaram maiores temperaturas superficiais internas e externas que os vidros de coloração mais clara, mostrando que os primeiros são muito absorventes.

Outra conclusão que se pode chegar, tanto no período de medições no inverno quanto no verão, é que quando há incidência do sol, o fluxo de calor é do interior do vidro para dentro da célula-teste e para fora. 
4.2 Ganhos de calor

\subsubsection{Resultados}

As tabelas e gráficos a seguir referem-se aos resultados obtidos através dos cálculos do ganho de calor solar nas células-teste para cada tipo de vidro. 
- Inverno

Tabela 17 - Ganho de calor solar dos vidros do Grupo 1 (Oeste) - 14/07/2005

\begin{tabular}{|c|c|c|c|c|c|c|c|c|}
\hline & \multicolumn{3}{|c|}{ Radiação incidente } & \multicolumn{4}{c|}{ Ganhos de calor solar } \\
\cline { 2 - 9 } Horário & $\begin{array}{c}\text { Radiação } \\
\text { direta }\end{array}$ & $\begin{array}{c}\text { Radiação } \\
\text { difusa }\end{array}$ & $\begin{array}{c}\text { Radiação } \\
\text { refletida }\end{array}$ & $\begin{array}{c}\text { Plano } \\
\text { incolor }\end{array}$ & $\begin{array}{c}\text { Plano } \\
\text { verde }\end{array}$ & $\begin{array}{c}\text { Antélio } \\
\text { verde }\end{array}$ & $\begin{array}{c}\text { Antélio } \\
\text { prata }\end{array}$ & $\begin{array}{c}\text { Antélio } \\
\text { bronze }\end{array}$ \\
\hline $7: 00$ & 0 & 24,5 & 3,8 & 9,85 & 9,66 & 4,26 & 8,43 & 6,38 \\
$8: 00$ & 0 & 107,9 & 22 & 100,35 & 89,66 & 51,81 & 65,95 & 60,82 \\
$9: 00$ & 0 & 140,6 & 44,4 & 155,73 & 139,24 & 82,11 & 101,23 & 94,85 \\
$10: 00$ & 0 & 180,7 & 59 & 199,31 & 176,97 & 105,03 & 128,09 & 120,35 \\
$11: 00$ & 0 & 210,4 & 67,9 & 227,77 & 201,23 & 119,60 & 146,03 & 137,43 \\
$12: 00$ & 0 & 225,3 & 70,8 & 238,08 & 209,74 & 124,60 & 152,68 & 143,83 \\
$13: 00$ & 116,8 & 226,9 & 67,1 & 292,29 & 255,87 & 152,27 & 187,39 & 176,87 \\
$14: 00$ & 199,4 & 216,2 & 56,8 & 353,78 & 308,84 & 184,28 & 227,74 & 215,13 \\
$15: 00$ & 219,2 & 187,8 & 41 & 346,82 & 303,41 & 181,32 & 224,92 & 213,07 \\
$16: 00$ & 166,9 & 129,9 & 22,7 & 244,64 & 214,92 & 127,62 & 159,45 & 152,71 \\
$17: 00$ & 16,6 & 36,8 & 4,8 & 26,24 & 23,86 & 13,58 & 19,24 & 21,20 \\
\hline
\end{tabular}

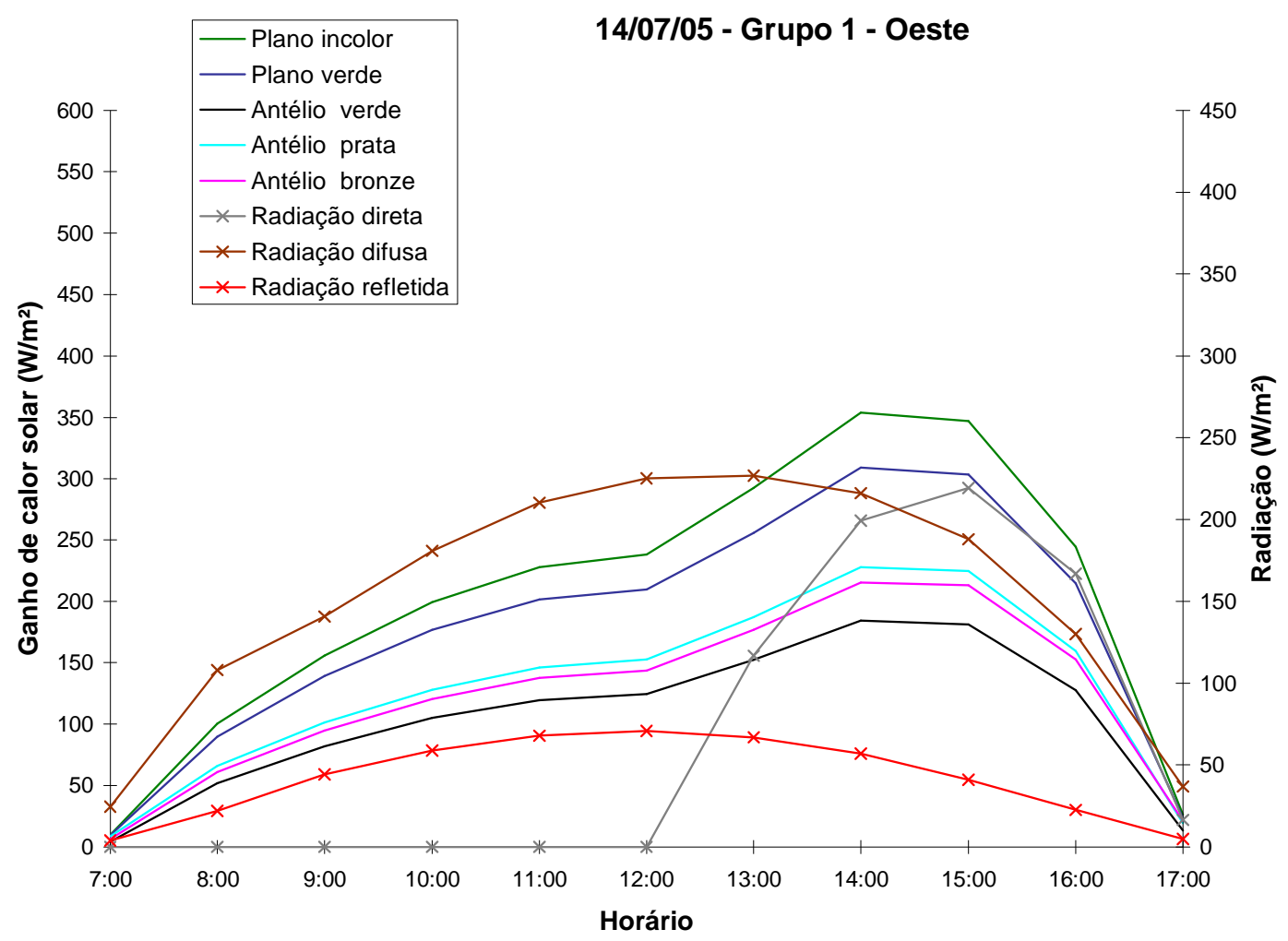

Figura 117. Ganho de calor solar dos vidros do Grupo 1 - Oeste 
Tabela 18 - Ganho de calor solar dos vidros do Grupo 1 (Norte) - 21/07/2005

\begin{tabular}{|c|c|c|c|c|c|c|c|c|}
\hline & \multicolumn{3}{|c|}{ Radiação incidente } & \multicolumn{4}{c|}{ Ganhos de calor solar } \\
\cline { 2 - 9 } Horário & $\begin{array}{c}\text { Radiação } \\
\text { direta }\end{array}$ & $\begin{array}{c}\text { Radiação } \\
\text { difusa }\end{array}$ & $\begin{array}{c}\text { Radiação } \\
\text { refletida }\end{array}$ & $\begin{array}{c}\text { Plano } \\
\text { incolor }\end{array}$ & $\begin{array}{c}\text { Plano } \\
\text { verde }\end{array}$ & $\begin{array}{c}\text { Antélio } \\
\text { verde }\end{array}$ & $\begin{array}{c}\text { Antélio } \\
\text { prata }\end{array}$ & $\begin{array}{c}\text { Antélio } \\
\text { bronze }\end{array}$ \\
\hline $7: 00$ & 12,4 & 26,8 & 3,8 & 25,51 & 23,12 & 12,94 & 17,71 & 16,15 \\
$8: 00$ & 81 & 118,4 & 19,9 & 161,52 & 141,63 & 83,55 & 105,67 & 98,40 \\
$9: 00$ & 248,9 & 157,8 & 43,4 & 351,55 & 305,93 & 182,26 & 228,22 & 212,62 \\
$10: 00$ & 282,9 & 205 & 57,2 & 433,94 & 377,85 & 224,98 & 281,10 & 261,87 \\
$11: 00$ & 300,1 & 237,5 & 65,9 & 482,15 & 417,82 & 249,05 & 311,58 & 290,10 \\
$12: 00$ & 306,1 & 250,8 & 69,1 & 498,97 & 430,31 & 257,24 & 322,44 & 300,12 \\
$13: 00$ & 280,4 & 252,8 & 65,3 & 473,26 & 409,12 & 244,19 & 306,03 & 286,20 \\
$14: 00$ & 233,6 & 237,1 & 55,4 & 408,75 & 354,88 & 210,37 & 264,56 & 248,40 \\
$15: 00$ & 179,3 & 197,6 & 41,4 & 315,72 & 274,69 & 162,73 & 204,78 & 193,55 \\
$16: 00$ & 79,8 & 136,9 & 22,1 & 169,27 & 147,23 & 86,87 & 110,04 & 105,71 \\
$17: 00$ & 1 & 20,6 & 2,5 & 1,97 & 1,54 & 0,19 & 1,78 & 4,24 \\
\hline
\end{tabular}

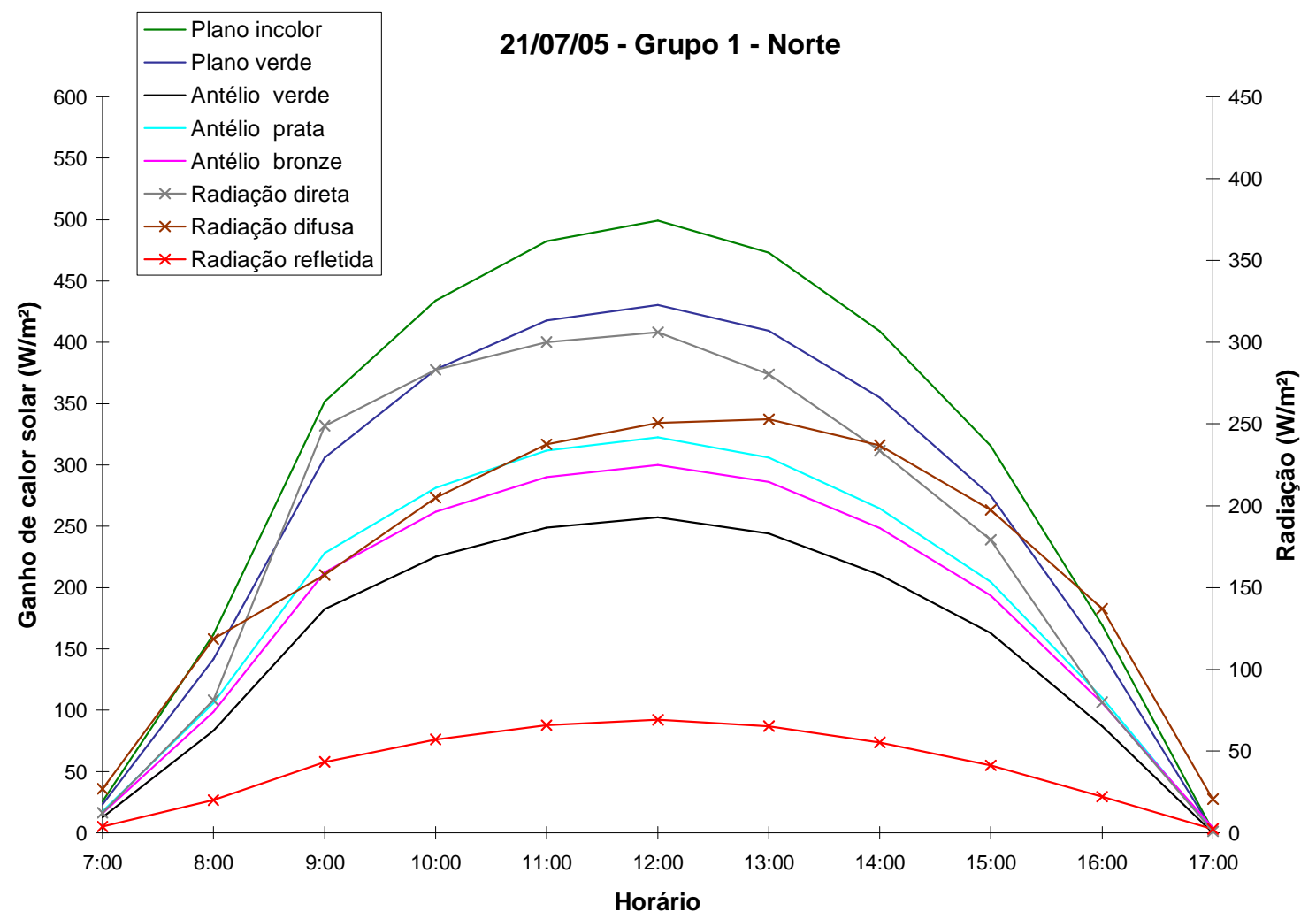

Figura 118. Ganho de calor solar dos vidros do Grupo 1 - Norte 
Tabela 19 - Ganho de calor solar dos vidros do Grupo 2 (Oeste) - 05/08/2005

\begin{tabular}{|c|c|c|c|c|c|c|c|c|}
\hline \multirow{2}{*}{ Horário } & \multicolumn{3}{|c|}{ Radiação incidente } & \multicolumn{5}{|c|}{ Ganhos de calor solar } \\
\hline & $\begin{array}{c}\text { Radiação } \\
\text { direta }\end{array}$ & $\begin{array}{c}\text { Radiaçãc } \\
\text { difusa }\end{array}$ & $\begin{array}{c}\text { Radiação } \\
\text { refletida }\end{array}$ & $\begin{array}{l}\text { Plano } \\
\text { incolor }\end{array}$ & $\begin{array}{l}\text { Plano } \\
\text { verde }\end{array}$ & $\begin{array}{c}\text { CEB prata } \\
\text { neutro }\end{array}$ & $\begin{array}{c}\text { CEB azul } \\
\text { médio }\end{array}$ & $\begin{array}{c}\text { CEB azul } \\
\text { intenso }\end{array}$ \\
\hline 7:00 & 0 & 21,6 & 2,6 & 5,93 & 4,56 & 0,44 & 2,00 & 0,36 \\
\hline 8:00 & 0 & 131,2 & 23,5 & 121,36 & 106,45 & 42,48 & 58,59 & 46,56 \\
\hline 9:00 & 0 & 151 & 50,2 & 176,65 & 157,63 & 66,69 & 88,12 & 72,10 \\
\hline $10: 00$ & 0 & 191,9 & 65,4 & 219,48 & 194,28 & 80,29 & 107,37 & 88,14 \\
\hline $11: 00$ & 0 & 223,3 & 74,5 & 247,29 & 218,01 & 88,50 & 119,43 & 97,70 \\
\hline $12: 00$ & 0 & 238,7 & 77,5 & 255,80 & 224,68 & 90,14 & 122,23 & 99,63 \\
\hline 13:00 & 125,2 & 240,6 & 73,7 & 315,76 & 276,20 & 111,26 & 152,25 & 123,42 \\
\hline $14: 00$ & 215,5 & 230,8 & 62,9 & 385,84 & 335,04 & 131,94 & 182,04 & 147,13 \\
\hline $15: 00$ & 242,9 & 203,6 & 46,4 & 386,21 & 334,55 & 130,82 & 181,12 & 145,99 \\
\hline $16: 00$ & 182,2 & 148,8 & 26,5 & 278,02 & 240,29 & 95,44 & 131,07 & 105,59 \\
\hline $17: 00$ & 24,5 & 51,4 & 6,7 & 46,22 & 38,56 & 17,61 & 22,41 & 17,61 \\
\hline
\end{tabular}

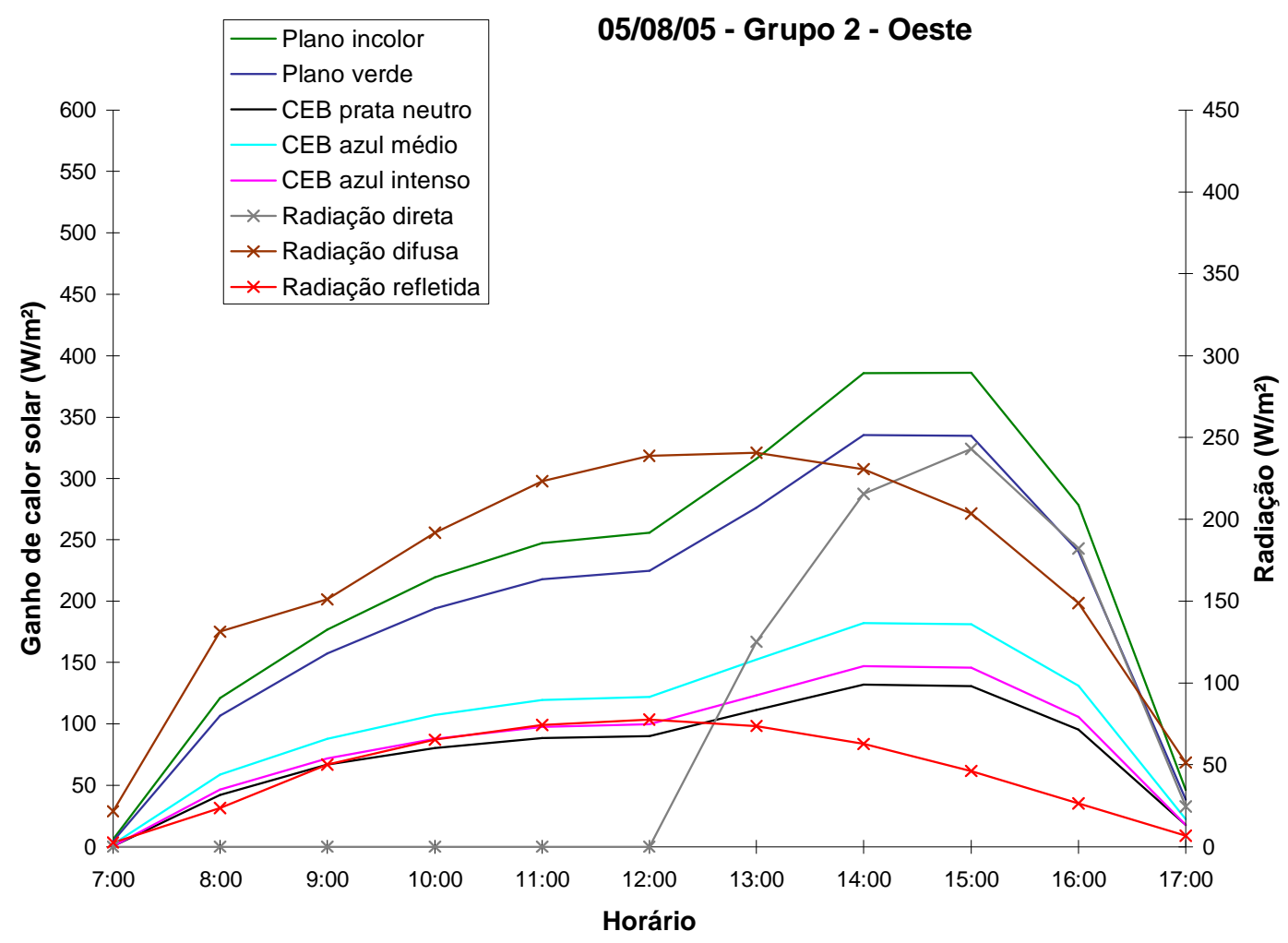

Figura 119. Ganho de calor solar dos vidros do Grupo 2 - Oeste 
Tabela 20 - Ganho de calor solar dos vidros do Grupo 2 (Norte) - 30/07/2005

\begin{tabular}{|c|c|c|c|c|c|c|c|c|}
\hline & \multicolumn{3}{|c|}{ Radiação incidente } & \multicolumn{4}{c|}{ Ganhos de calor solar } \\
\cline { 2 - 9 } Horário & Radiação & Radiação & Radiação & Plano & Plano & CEB prata & CEB azul & CEB azul \\
& direta & difusa & refletida & incolor & verde & neutro & médio & intenso \\
\hline $7: 00$ & 2 & 24,1 & 3 & 8,07 & 7,53 & 0,49 & 3,72 & 1,14 \\
$8: 00$ & 108,6 & 122,3 & 23,3 & 183,97 & 160,02 & 61,24 & 87,67 & 69,35 \\
$9: 00$ & 270,6 & 152,3 & 47,4 & 371,70 & 324,14 & 127,37 & 177,72 & 142,88 \\
$10: 00$ & 317,6 & 192,2 & 62,6 & 464,21 & 401,52 & 158,40 & 219,66 & 177,62 \\
$11: 00$ & 334,9 & 223,7 & 71,6 & 508,02 & 437,00 & 170,75 & 238,36 & 192,18 \\
$12: 00$ & 328,3 & 243,1 & 74 & 513,86 & 439,38 & 170,96 & 239,79 & 192,86 \\
$13: 00$ & 306 & 244,7 & 70,3 & 490,13 & 416,78 & 163,47 & 228,64 & 183,77 \\
$14: 00$ & 267,2 & 228,1 & 60,7 & 430,59 & 371,88 & 144,65 & 201,40 & 161,92 \\
$15: 00$ & 186,1 & 201,6 & 44,3 & 324,39 & 280,62 & 110,76 & 152,99 & 123,05 \\
$16: 00$ & 92,9 & 144,4 & 24,7 & 185,97 & 161,25 & 65,31 & 88,57 & 71,49 \\
$17: 00$ & 7,3 & 45,7 & 5,9 & 28,97 & 24,74 & 10,93 & 13,54 & 10,68 \\
\hline
\end{tabular}

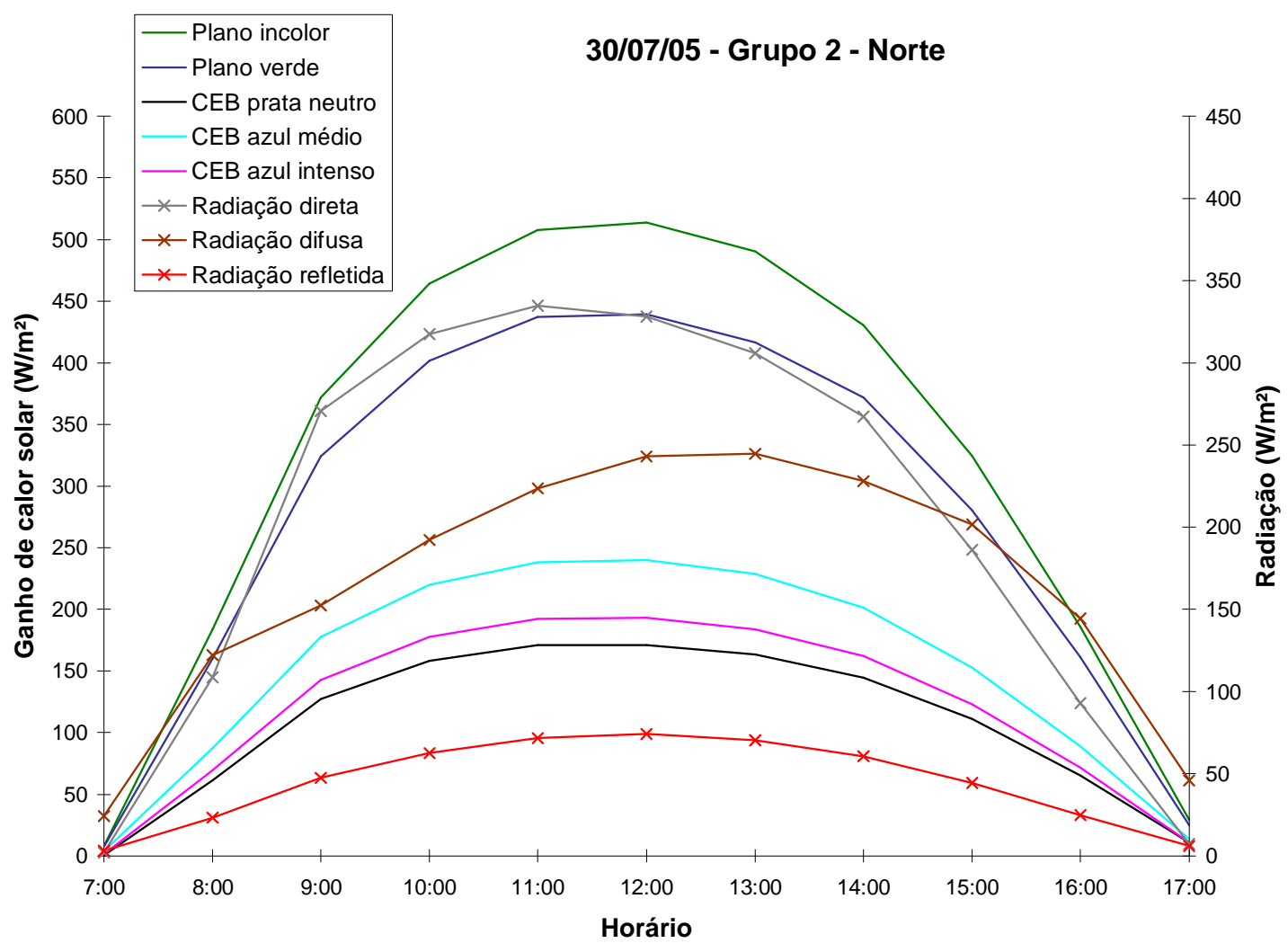

Figura 120. Ganho de calor solar dos vidros do Grupo 2 - Norte 
Tabela 21 - Ganho de calor solar dos vidros do Grupo 3 (Oeste) - 13/08/2005

\begin{tabular}{|c|c|c|c|c|c|c|c|c|}
\hline & \multicolumn{3}{|c|}{ Radiação incidente } & \multicolumn{4}{c|}{ Ganhos de calor solar } \\
\cline { 2 - 9 } Horário & $\begin{array}{c}\text { Radiação } \\
\text { direta }\end{array}$ & Radiação & Radiação & Plano & Plano & Antélio & Antélio & CEB prata \\
& defletida & incolor & verde & verde & prata & neutro \\
\hline $7: 00$ & 0 & 33,1 & 4,1 & 20,68 & 18,78 & 10,01 & 14,26 & 5,46 \\
$8: 00$ & 0 & 142 & 25,3 & 127,89 & 112,26 & 65,96 & 82,93 & 42,94 \\
$9: 00$ & 0 & 173 & 50,8 & 181,44 & 160,72 & 94,50 & 117,65 & 64,02 \\
$10: 00$ & 0 & 212,9 & 66,4 & 232,85 & 206,63 & 122,58 & 150,74 & 83,98 \\
$11: 00$ & 0 & 242,1 & 75,8 & 261,19 & 230,85 & 137,12 & 168,53 & 93,13 \\
$12: 00$ & 0 & 260 & 78,4 & 277,04 & 244,62 & 145,22 & 178,70 & 98,72 \\
$13: 00$ & 113,7 & 266,3 & 73,6 & 333,03 & 292,52 & 173,94 & 215,02 & 117,99 \\
$14: 00$ & 211,8 & 242,6 & 64,6 & 396,00 & 344,80 & 205,65 & 256,21 & 135,84 \\
$15: 00$ & 220,6 & 218,1 & 46,8 & 381,56 & 331,19 & 198,41 & 248,16 & 129,69 \\
$16: 00$ & 143,5 & 158,3 & 26,2 & 253,87 & 220,23 & 131,65 & 166,07 & 87,61 \\
$17: 00$ & 8,6 & 50,4 & 6,2 & 35,66 & 32,52 & 18,64 & 26,31 & 15,05 \\
\hline
\end{tabular}

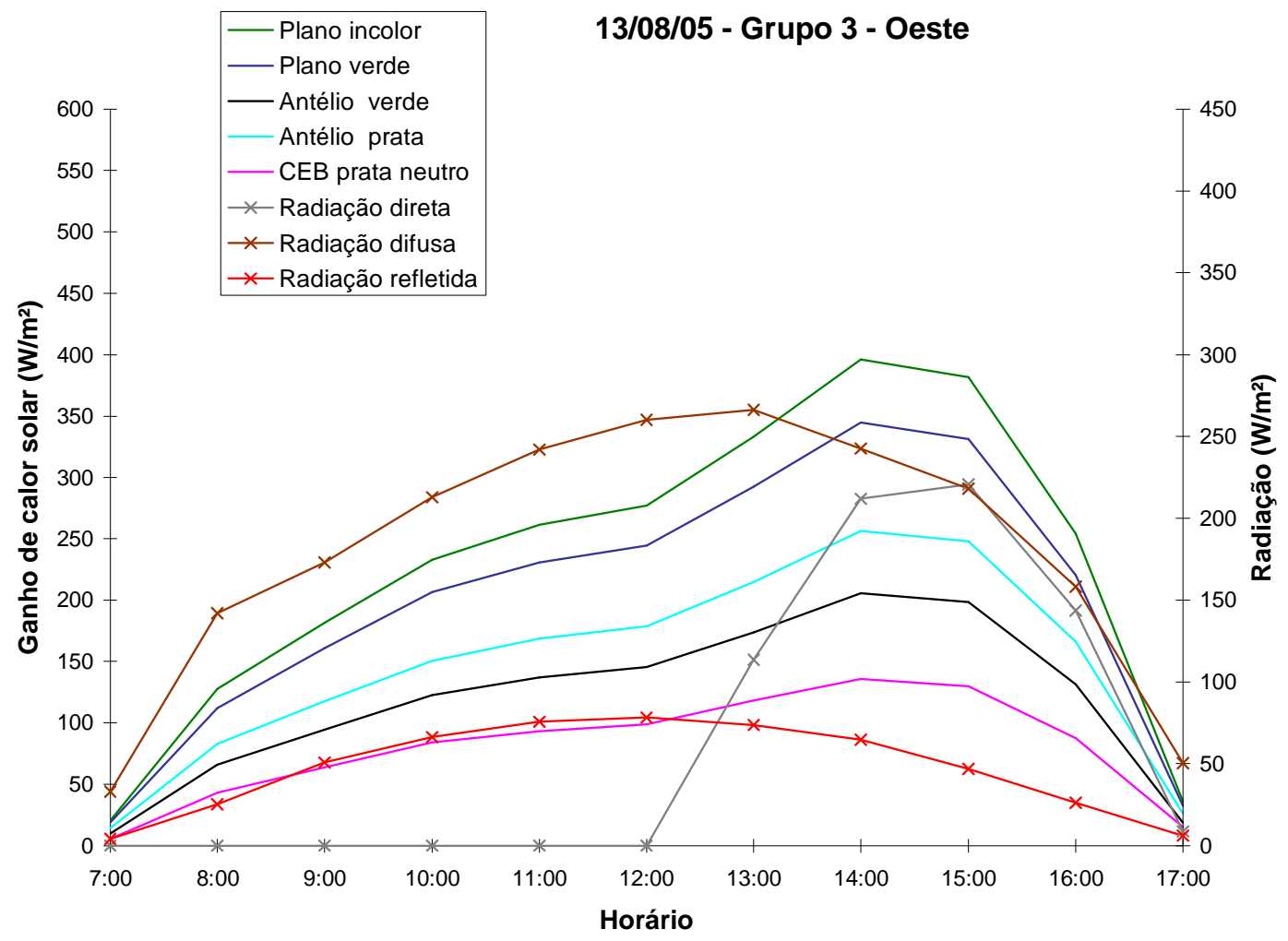

Figura 121. Ganho de calor solar dos vidros do Grupo 3 - Oeste 
Tabela 22 - Ganho de calor solar dos vidros do Grupo 3 (Norte) - 21/08/2005

\begin{tabular}{|c|c|c|c|c|c|c|c|c|c|}
\hline & \multicolumn{3}{|c|}{ Radiação incidente } & \multicolumn{4}{c|}{ Ganhos de calor solar } \\
\cline { 2 - 9 } Horário & $\begin{array}{c}\text { Radiação } \\
\text { direta }\end{array}$ & $\begin{array}{c}\text { Radiação } \\
\text { difusa }\end{array}$ & $\begin{array}{c}\text { Radiação } \\
\text { refletida }\end{array}$ & $\begin{array}{c}\text { Plano } \\
\text { incolor }\end{array}$ & $\begin{array}{c}\text { Plano } \\
\text { verde }\end{array}$ & $\begin{array}{c}\text { Antélio } \\
\text { verde }\end{array}$ & $\begin{array}{c}\text { Antélio } \\
\text { prata }\end{array}$ & $\begin{array}{c}\text { CEB prata } \\
\text { neutro }\end{array}$ \\
\hline $7: 00$ & 1,7 & 39 & 4,8 & 27,40 & 24,40 & 13,60 & 19,52 & 8,07 \\
$8: 00$ & 83,6 & 153,1 & 28,1 & 189,57 & 166,29 & 97,48 & 123,70 & 63,27 \\
$9: 00$ & 223,9 & 180,4 & 54,1 & 341,86 & 299,01 & 176,53 & 221,57 & 114,77 \\
$10: 00$ & 266,6 & 221,7 & 69,6 & 429,13 & 374,69 & 221,81 & 277,13 & 143,93 \\
$11: 00$ & 290,1 & 249,8 & 79,2 & 478,85 & 415,64 & 246,63 & 308,61 & 159,20 \\
$12: 00$ & 292,2 & 264,2 & 82,1 & 494,30 & 428,36 & 254,56 & 318,78 & 164,77 \\
$13: 00$ & 252,8 & 276,1 & 76,1 & 464,08 & 402,59 & 238,86 & 299,33 & 155,34 \\
$14: 00$ & 216,9 & 256,9 & 65,9 & 405,70 & 352,46 & 208,68 & 261,87 & 136,39 \\
$15: 00$ & 153,1 & 224,3 & 49,2 & 311,53 & 271,42 & 160,75 & 202,01 & 106,20 \\
$16: 00$ & 72,8 & 165 & 28,3 & 185,78 & 162,15 & 95,70 & 121,06 & 64,62 \\
$17: 00$ & 8,3 & 61 & 7,9 & 45,03 & 39,76 & 22,32 & 30,05 & 16,50 \\
\hline
\end{tabular}

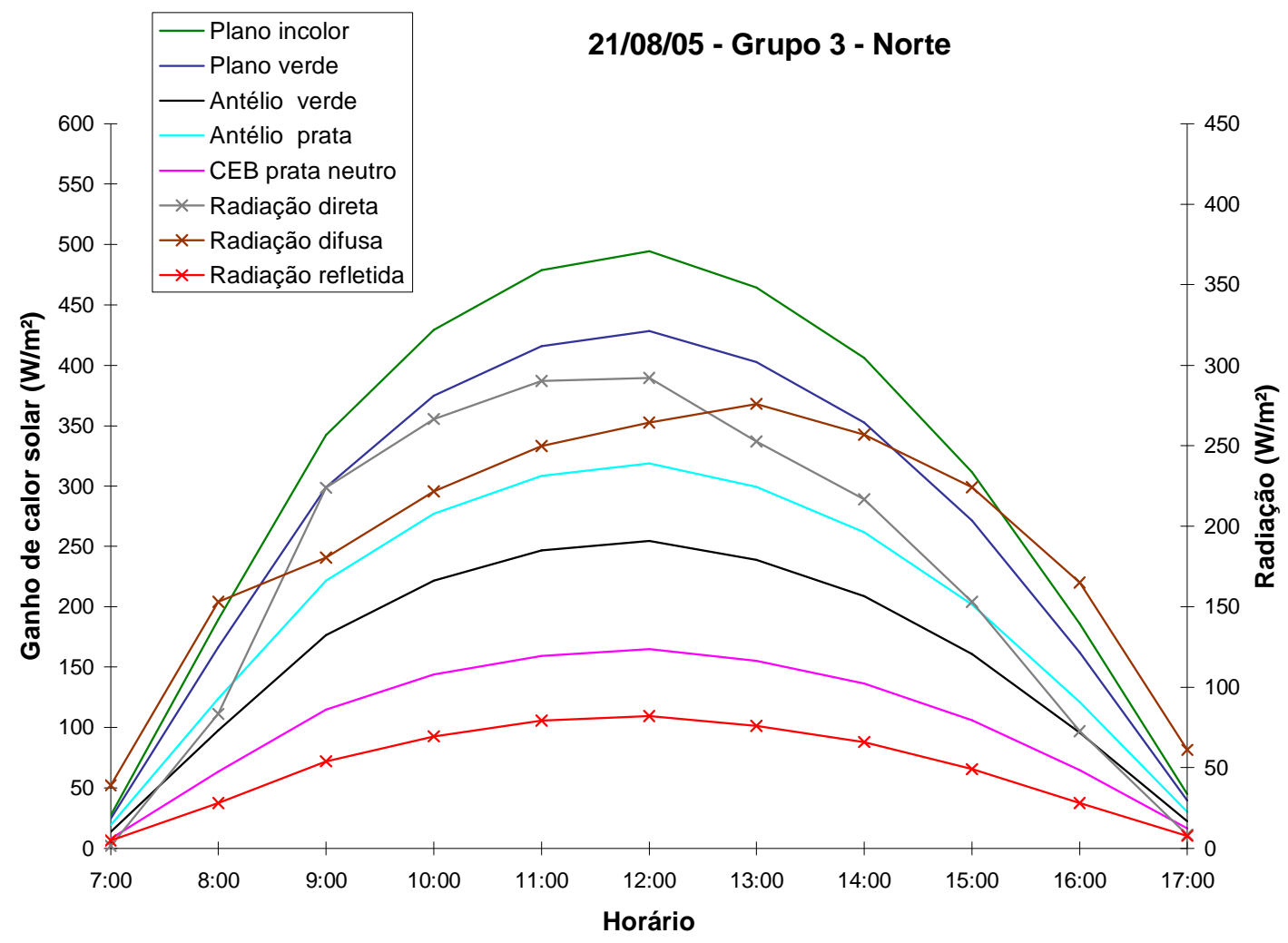

Figura 122. Ganho de calor solar dos vidros do Grupo 3 - Norte 


\section{- Verão}

Tabela 23 - Ganho de calor solar dos vidros do Grupo 1 (Oeste) - 15/02/2006

\begin{tabular}{|c|c|c|c|c|c|c|c|c|}
\hline \multirow[b]{2}{*}{ Horário } & \multicolumn{3}{|c|}{ Radiação incidente } & \multicolumn{5}{|c|}{ Ganhos de calor solar } \\
\hline & \begin{tabular}{|c} 
Radiação \\
direta
\end{tabular} & $\begin{array}{c}\text { Radiaçãc } \\
\text { difusa }\end{array}$ & $\begin{array}{c}\text { Radiação } \\
\text { refletida }\end{array}$ & $\begin{array}{l}\text { Plano } \\
\text { incolor }\end{array}$ & \begin{tabular}{|l} 
Plano \\
verde
\end{tabular} & $\begin{array}{c}\text { Antélio } \\
\text { verde }\end{array}$ & $\begin{array}{c}\text { Antélio } \\
\text { prata }\end{array}$ & $\begin{array}{l}\text { Antélio } \\
\text { bronze }\end{array}$ \\
\hline 7:00 & 0 & 86 & 28,1 & 90,67 & 78,82 & 47,85 & 58,37 & 55,01 \\
\hline 8:00 & 0 & 179,4 & 48,4 & 186,25 & 164,60 & 98,66 & 119,73 & 112,48 \\
\hline 9:00 & 0 & 249,2 & 68 & 257,52 & 228,81 & 135,63 & 165,10 & 155,27 \\
\hline $10: 00$ & 0 & 282,2 & 87,1 & 297,90 & 263,24 & 156,65 & 190,74 & 179,52 \\
\hline $11: 00$ & 0 & 371 & 88,9 & 363,58 & 318,60 & 190,52 & 232,66 & 218,94 \\
\hline $12: 00$ & 0 & 441,4 & 65,5 & 391,44 & 340,80 & 204,24 & 250,23 & 235,34 \\
\hline $13: 00$ & 29,8 & 436,7 & 65,9 & 402,16 & 349,35 & 209,92 & 257,25 & 242,08 \\
\hline $14: 00$ & 262,4 & 304,8 & 92,3 & 502,54 & 435,52 & 261,30 & 321,93 & 302,15 \\
\hline $15: 00$ & 74,6 & 340,2 & 50,2 & 351,44 & 303,03 & 182,30 & 225,49 & 211,77 \\
\hline $16: 00$ & 4,9 & 152,9 & 18,7 & 113,90 & 97,78 & 59,76 & 74,09 & 70,63 \\
\hline $17: 00$ & 2,1 & 32,3 & 4 & 0,78 & 0,99 & 0,94 & 0,33 & 0,33 \\
\hline
\end{tabular}

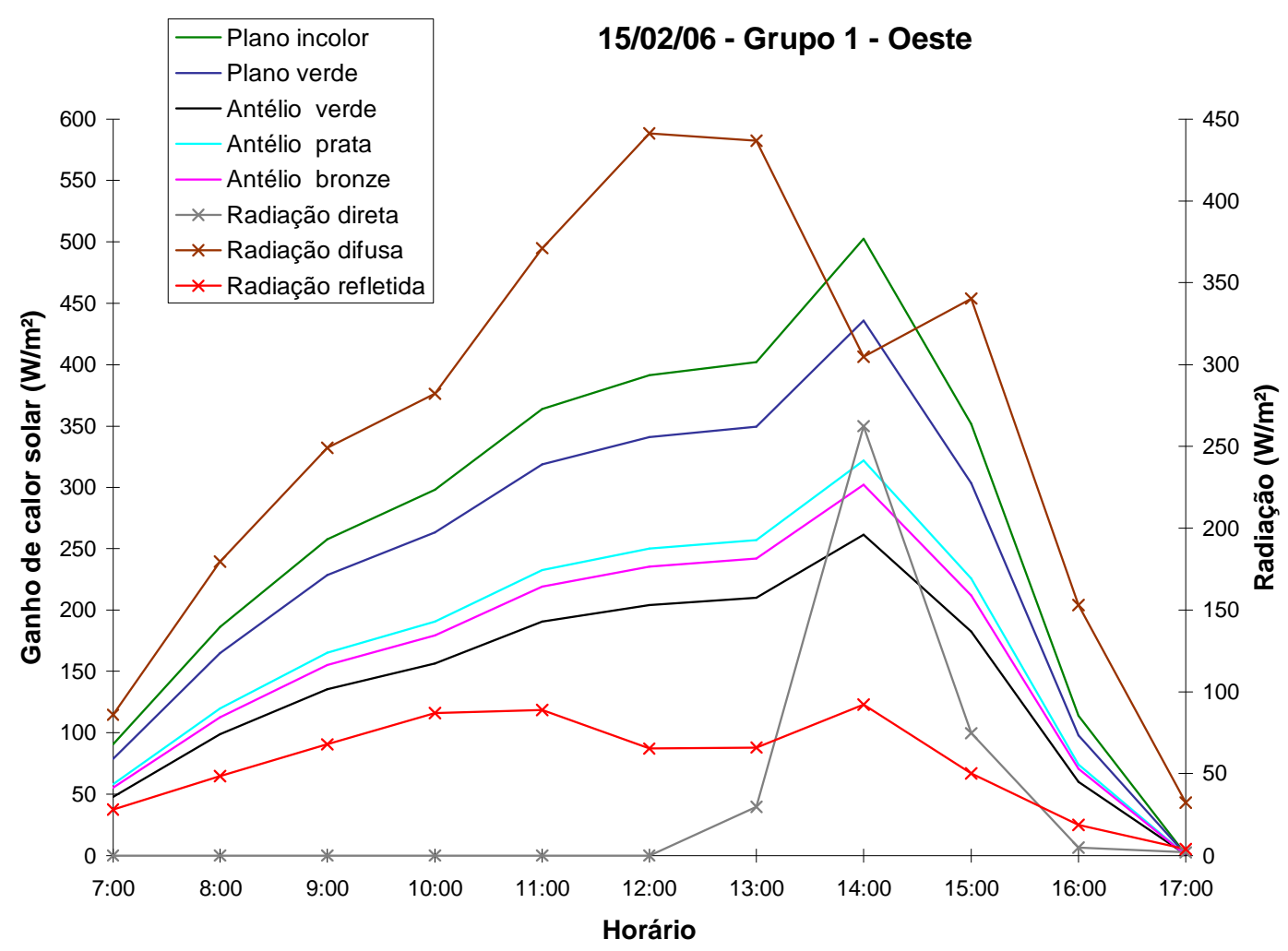

Figura 123. Ganho de calor solar dos vidros do Grupo 1 - Oeste 
Tabela 24 - Ganho de calor solar dos vidros do Grupo 1 (Norte) - 23/02/2006

\begin{tabular}{|c|c|c|c|c|c|c|c|c|}
\hline & \multicolumn{3}{|c|}{ Radiação incidente } & \multicolumn{4}{c|}{ Ganhos de calor solar } \\
\cline { 2 - 9 } Horário & $\begin{array}{c}\text { Radiação } \\
\text { direta }\end{array}$ & $\begin{array}{c}\text { Radiação } \\
\text { difusa }\end{array}$ & $\begin{array}{c}\text { Radiação } \\
\text { refletida }\end{array}$ & $\begin{array}{c}\text { Plano } \\
\text { incolor }\end{array}$ & $\begin{array}{c}\text { Plano } \\
\text { verde }\end{array}$ & $\begin{array}{c}\text { Antélio } \\
\text { verde }\end{array}$ & $\begin{array}{c}\text { Antélio } \\
\text { prata }\end{array}$ & $\begin{array}{c}\text { Antélio } \\
\text { bronze }\end{array}$ \\
\hline $7: 00$ & 0 & 101,2 & 13,4 & 84,71 & 73,92 & 44,02 & 54,44 & 50,90 \\
$8: 00$ & 2,2 & 204,1 & 28,4 & 178,38 & 155,90 & 93,36 & 114,83 & 107,30 \\
$9: 00$ & 13,8 & 303,1 & 46,6 & 273,14 & 237,52 & 142,36 & 175,23 & 164,04 \\
$10: 00$ & 47,3 & 358 & 70,4 & 349,37 & 303,17 & 181,42 & 223,92 & 209,54 \\
$11: 00$ & 9,1 & 375,8 & 49,9 & 331,59 & 287,67 & 172,45 & 212,28 & 199,09 \\
$12: 00$ & 58,3 & 427,7 & 81,2 & 421,23 & 364,78 & 218,80 & 269,78 & 252,79 \\
$13: 00$ & 67,1 & 406 & 84 & 409,97 & 355,16 & 212,98 & 262,45 & 246,19 \\
$14: 00$ & 34,3 & 397 & 67,4 & 370,79 & 321,40 & 193,16 & 237,33 & 223,20 \\
$15: 00$ & 36,8 & 317,8 & 65 & 307,74 & 267,25 & 160,90 & 196,84 & 185,82 \\
$16: 00$ & 7,5 & 255,6 & 43,3 & 233,08 & 202,68 & 122,57 & 149,02 & 141,36 \\
$17: 00$ & 0 & 156,8 & 23 & 138,75 & 120,57 & 73,50 & 88,37 & 84,90 \\
\hline
\end{tabular}

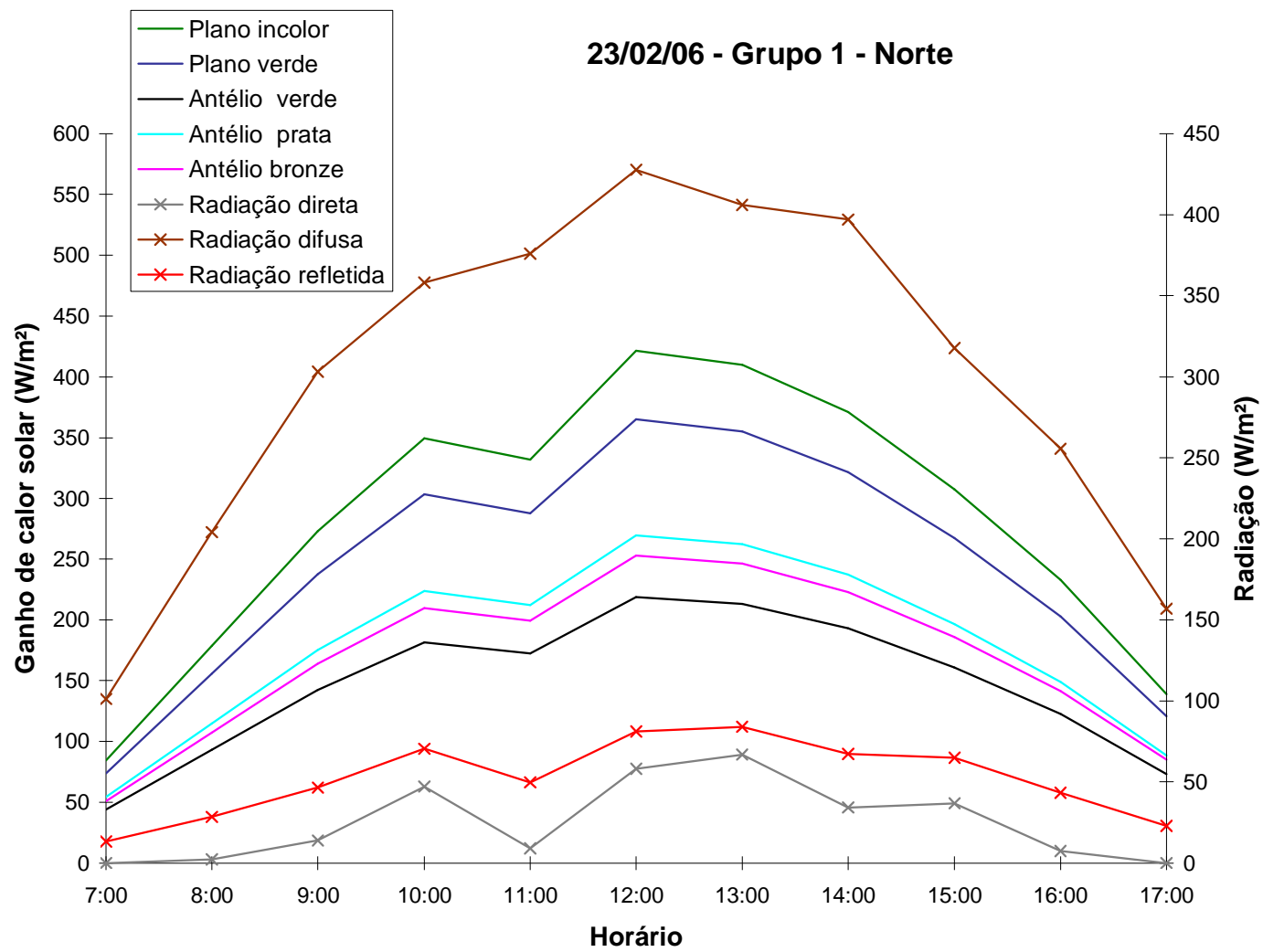

Figura 124. Ganho de calor solar dos vidros do Grupo 1 - Norte 
Tabela 25 - Ganho de calor solar dos vidros do Grupo 2 (Oeste) - 11/03/2006

\begin{tabular}{|c|c|c|c|c|c|c|c|c|}
\hline & \multicolumn{3}{|c|}{ Radiação incidente } & \multicolumn{4}{c|}{ Ganhos de calor solar } \\
\cline { 2 - 9 } Horário & $\begin{array}{c}\text { Radiação } \\
\text { direta }\end{array}$ & Radiação & Radiação & Plano & Plano & CEB prata & CEB azul & CEB azul \\
& refletida & incolor & verde & neutro & médio & intenso \\
\hline $7: 00$ & 0 & 77,9 & 9,8 & 64,69 & 58,21 & 21,48 & 31,13 & 23,69 \\
$8: 00$ & 0 & 163 & 44,4 & 158,64 & 140,79 & 53,43 & 75,18 & 59,59 \\
$9: 00$ & 0 & 217,4 & 66,5 & 221,16 & 195,06 & 75,37 & 104,74 & 84,15 \\
$10: 00$ & 0 & 258,6 & 84 & 266,51 & 233,46 & 90,65 & 125,49 & 101,40 \\
$11: 00$ & 0 & 312,2 & 91,4 & 309,95 & 269,97 & 104,21 & 144,99 & 117,22 \\
$12: 00$ & 0 & 368,1 & 88,7 & 348,83 & 303,30 & 116,76 & 162,71 & 131,75 \\
$13: 00$ & 131 & 318,2 & 93,7 & 385,84 & 334,99 & 131,45 & 182,49 & 148,34 \\
$14: 00$ & 264,6 & 284 & 86,3 & 479,06 & 415,65 & 159,81 & 223,24 & 180,60 \\
$15: 00$ & 261,7 & 284 & 64,1 & 476,81 & 413,37 & 157,08 & 220,64 & 178,05 \\
$16: 00$ & 218,9 & 228,5 & 42,1 & 361,55 & 315,31 & 125,10 & 173,93 & 143,01 \\
$17: 00$ & 118,2 & 133,9 & 19,9 & 182,67 & 160,35 & 65,78 & 90,67 & 74,40 \\
\hline
\end{tabular}

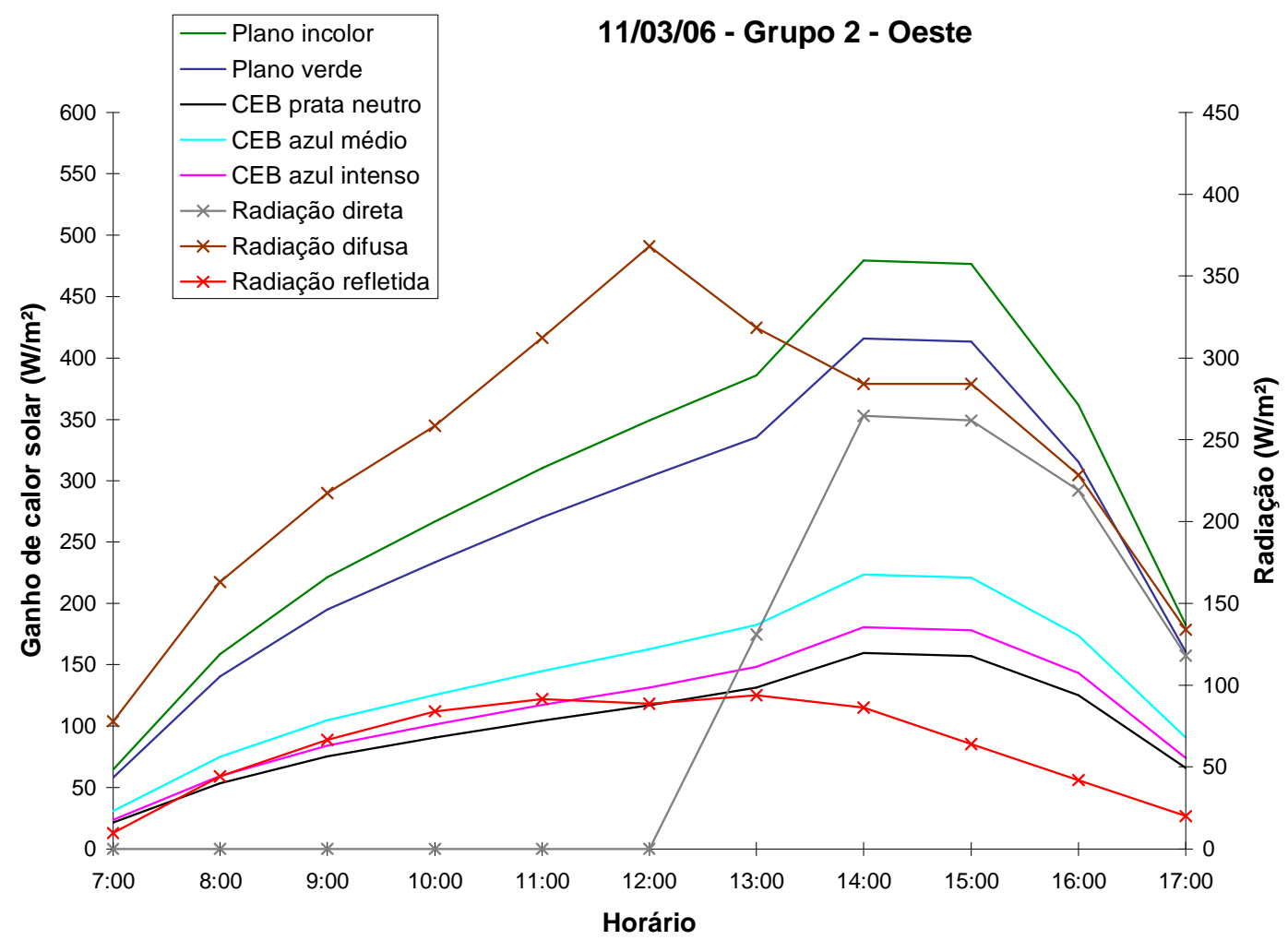

Figura 125. Ganho de calor solar dos vidros do Grupo 2 - Oeste 
Tabela 26 - Ganho de calor solar dos vidros do Grupo 2 (Norte) - 05/03/2006

\begin{tabular}{|c|c|c|c|c|c|c|c|c|}
\hline & \multicolumn{3}{|c|}{ Radiação incidente } & \multicolumn{5}{c|}{ Ganhos de calor solar } \\
\cline { 2 - 9 } Horário & Radiação & Radiação & Radiação & Plano & Plano & CEB prata & CEB azul & CEB azul \\
& direta & difusa & refletida & incolor & verde & neutro & médio & intenso \\
\hline $7: 00$ & 0,1 & 95,7 & 12,8 & 75,06 & 66,46 & 23,61 & 34,83 & 27,21 \\
$8: 00$ & 3,1 & 179 & 23,4 & 148,78 & 130,25 & 48,46 & 69,44 & 55,47 \\
$9: 00$ & 59,2 & 267,4 & 59,6 & 274,21 & 240,24 & 93,08 & 130,62 & 105,24 \\
$10: 00$ & 111,3 & 288,9 & 81,2 & 341,88 & 298,65 & 116,52 & 162,70 & 131,34 \\
$11: 00$ & 53,8 & 410,1 & 70,7 & 396,33 & 344,28 & 132,96 & 185,73 & 150,17 \\
$12: 00$ & 105 & 386,4 & 87,7 & 420,46 & 363,82 & 141,09 & 197,25 & 159,65 \\
$13: 00$ & 8,8 & 358,8 & 46,6 & 310,02 & 268,54 & 103,84 & 144,76 & 117,49 \\
$14: 00$ & 22,6 & 377,6 & 54,7 & 335,03 & 289,92 & 111,74 & 156,60 & 126,59 \\
$15: 00$ & 14,9 & 312,9 & 44,4 & 273,26 & 236,86 & 91,60 & 127,97 & 103,54 \\
$16: 00$ & 0,6 & 143,1 & 17,5 & 113,86 & 98,35 & 37,55 & 52,76 & 42,73 \\
$17: 00$ & 0,6 & 141,1 & 20,3 & 117,10 & 101,89 & 39,28 & 54,60 & 44,15 \\
\hline
\end{tabular}

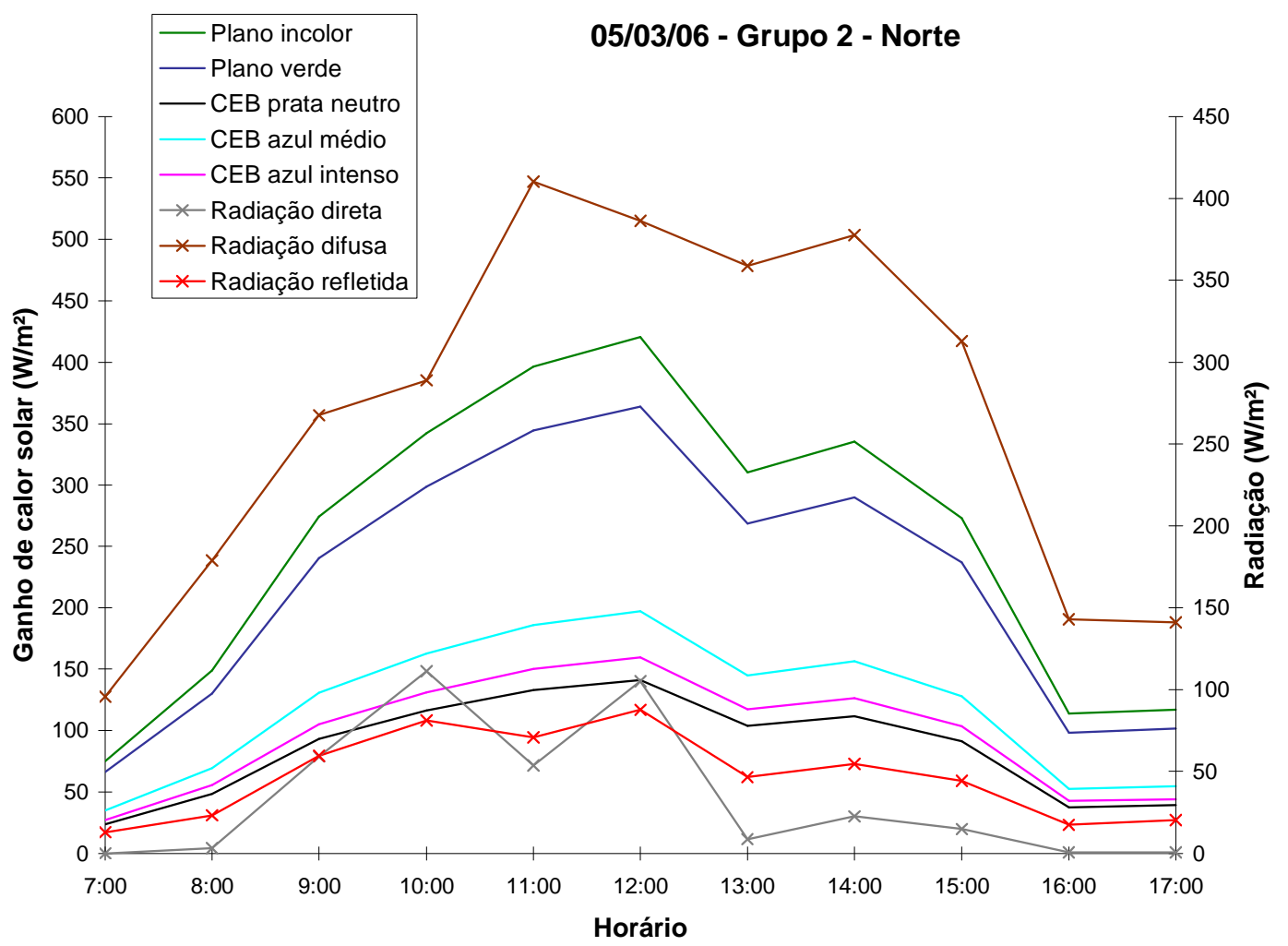

Figura 126. Ganho de calor solar dos vidros do Grupo 2 - Norte 
Tabela 27 - Ganho de calor solar dos vidros do Grupo 3 (Oeste) - 15/03/2006

\begin{tabular}{|c|c|c|c|c|c|c|c|c|c|}
\hline & \multicolumn{3}{|c|}{ Radiação incidente } & \multicolumn{4}{c|}{ Ganhos de calor solar } \\
\cline { 2 - 9 } Horário & $\begin{array}{c}\text { Radiação } \\
\text { direta }\end{array}$ & Radiação & Radiação & Plano & Plano & Antélio & Antélio & CEB prata \\
& defletida & incolor & verde & verde & prata & neutro \\
\hline $7: 00$ & 0 & 75,2 & 9,5 & 61,77 & 55,93 & 32,30 & 40,52 & 20,99 \\
$8: 00$ & 0 & 152,9 & 44,9 & 155,75 & 138,16 & 81,75 & 101,02 & 54,30 \\
$9: 00$ & 0 & 209,4 & 66,5 & 222,21 & 197,16 & 117,07 & 143,80 & 78,14 \\
$10: 00$ & 0 & 334,5 & 46,1 & 295,49 & 258,89 & 154,61 & 190,10 & 100,30 \\
$11: 00$ & 0 & 398,6 & 69,5 & 361,03 & 314,95 & 188,63 & 231,86 & 122,03 \\
$12: 00$ & 0 & 383,4 & 83,6 & 358,76 & 312,96 & 187,93 & 230,32 & 121,56 \\
$13: 00$ & 86,2 & 376,2 & 81,2 & 395,51 & 344,72 & 206,52 & 253,51 & 134,14 \\
$14: 00$ & 331,4 & 231,3 & 92,3 & 495,56 & 431,28 & 257,94 & 318,14 & 165,99 \\
$15: 00$ & 421 & 215,2 & 73,3 & 562,20 & 487,88 & 292,17 & 360,51 & 184,08 \\
$16: 00$ & 381,3 & 192,3 & 48,1 & 474,52 & 413,07 & 255,75 & 307,15 & 159,60 \\
$17: 00$ & 6,9 & 80,2 & 9,8 & 50,00 & 45,45 & 28,08 & 32,56 & 17,18 \\
\hline
\end{tabular}

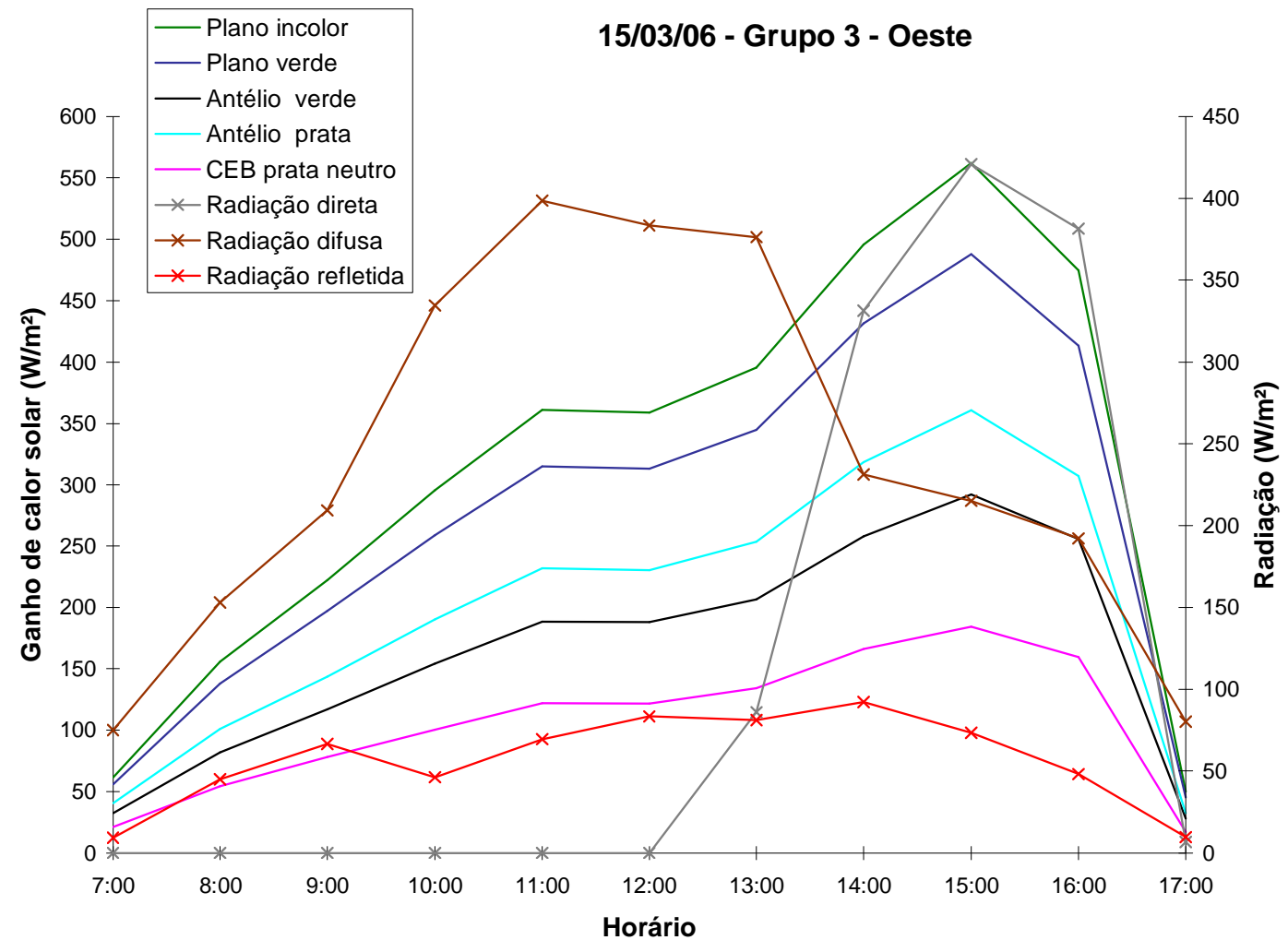

Figura 127. Ganho de calor solar dos vidros do Grupo 3 - Oeste 
Tabela 28 - Ganho de calor solar dos vidros do Grupo 3 (Norte) - 21/03/2006

\begin{tabular}{|c|c|c|c|c|c|c|c|c|}
\hline & \multicolumn{3}{|c|}{ Radiação incidente } & \multicolumn{4}{c|}{ Ganhos de calor solar } \\
\cline { 2 - 9 } Horário & $\begin{array}{c}\text { Radiação } \\
\text { direta }\end{array}$ & Radiação & Radiação & Plano & Plano & Antélio & Antélio & CEB prata \\
& refletida & incolor & verde & verde & prata & neutro \\
\hline $7: 00$ & 7,7 & 90,6 & 13 & 78,13 & 68,23 & 40,67 & 50,98 & 26,38 \\
$8: 00$ & 12,1 & 183,1 & 25,3 & 163,60 & 141,66 & 85,53 & 105,94 & 53,15 \\
$9: 00$ & 98,3 & 250,8 & 57,5 & 293,91 & 257,75 & 154,27 & 188,01 & 99,11 \\
$10: 00$ & 84,5 & 339,3 & 64,3 & 365,11 & 318,80 & 190,23 & 234,63 & 123,08 \\
$11: 00$ & 120,9 & 364,5 & 77,5 & 421,10 & 366,64 & 219,37 & 270,28 & 141,76 \\
$12: 00$ & 104,3 & 396,1 & 76,7 & 432,88 & 376,73 & 225,85 & 277,72 & 145,59 \\
$13: 00$ & 61,8 & 401,2 & 65,4 & 379,79 & 330,03 & 198,04 & 243,85 & 126,12 \\
$14: 00$ & 120,7 & 328,1 & 73 & 343,20 & 300,07 & 184,54 & 223,16 & 116,17 \\
$15: 00$ & 30,7 & 296,2 & 44 & 250,19 & 218,08 & 134,86 & 160,59 & 86,02 \\
$16: 00$ & 40,7 & 215,3 & 37 & 198,70 & 175,61 & 103,17 & 127,39 & 66,36 \\
$17: 00$ & 6,9 & 109,8 & 15 & 89,64 & 82,46 & 47,19 & 57,74 & 30,91 \\
\hline
\end{tabular}

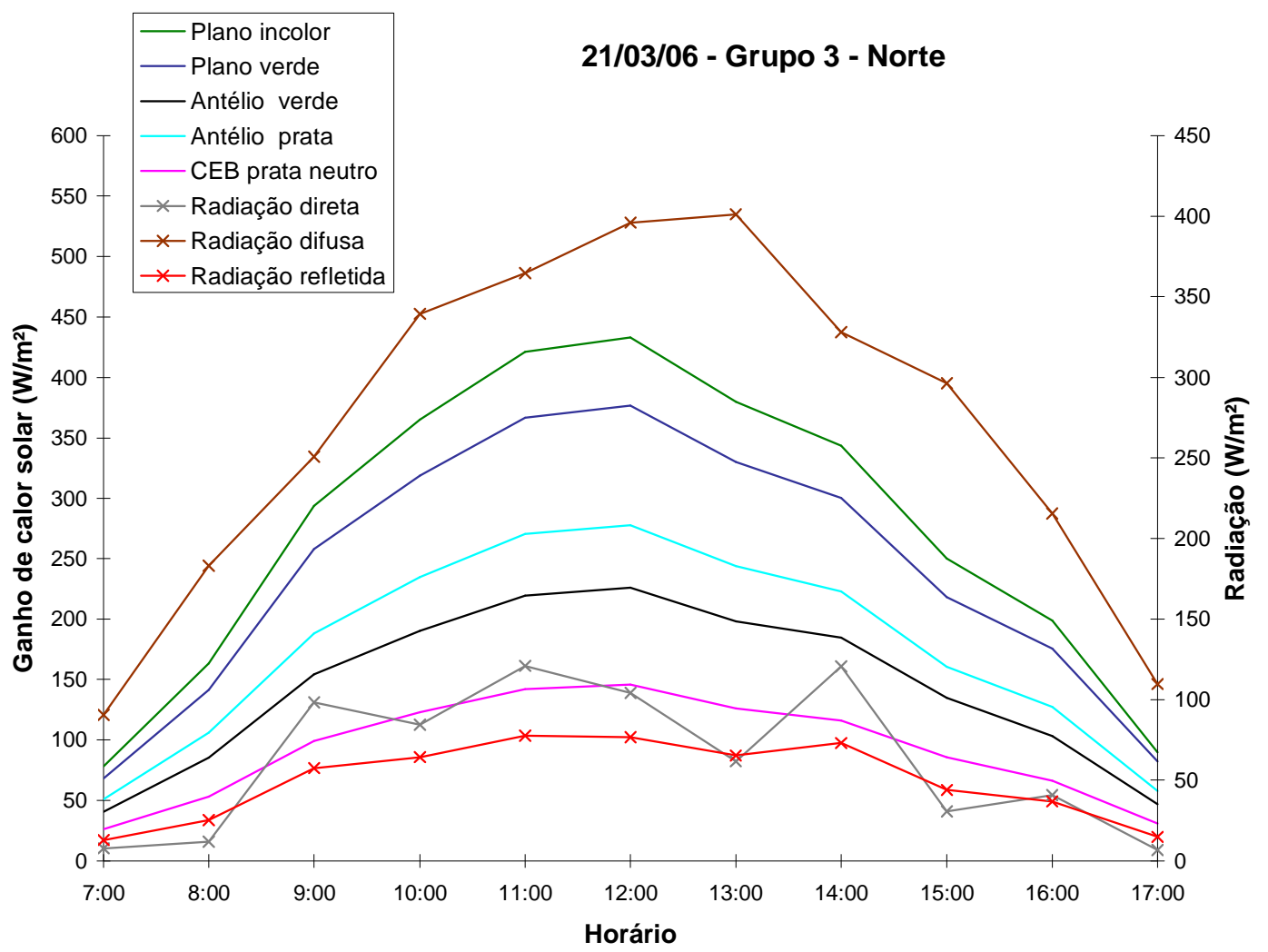

Figura 128. Ganho de calor solar dos vidros do Grupo 3 - Norte 


\subsubsection{Discussão}

Através dos gráficos e tabelas, pode-se observar que os picos de ganho de calor foram às 12:00h para todos os vidros na face Norte e entre 14:00 e 15:00h na face Oeste.

No período do inverno, os maiores ganhos de calor ocorreram na fachada Norte, enquanto no verão os maiores ganhos de calor foram na fachada Oeste.

O vidro plano incolor foi o que representou maior ganho de calor, nas duas fachadas e nos dois períodos de medições, tanto no inverno quanto no verão. $\mathrm{O}$ vidro plano incolor, de maior ganho de calor solar, apresenta as maiores transmitâncias e menores absortâncias dentre os vidros analisados. Quando se comparam os dois vidros planos (incolor e verde), fica evidente o maior ganho de calor em um ambiente com o vidro incolor instalado. O valor da absortância do vidro plano incolor é $1 / 3$ do valor do vidro plano verde e o seu valor da transmitância é cerca de $70 \%$ maior que o vidro plano verde. Isso mostra que as propriedades óticas do vidro influenciam muito no ganho de calor solar.

Com relação aos vidros refletivos pirolíticos, o vidro refletivo pirolítico verde esmeralda apresentou menor ganho de calor, enquanto que o vidro refletivo pirolítico prata apresentou o maior ganho de calor. Vale lembrar que o vidro refletivo pirolítico verde esmeralda é o vidro de maior espessura. Esse comportamento foi o mesmo nas duas fachadas e nos dois períodos de medições (Figuras 117, 118, 123, 124). Pode-se dizer que o vidro refletivo pirolítico verde esmeralda é o mais indicado quando o objetivo é atenuação do ganho de calor, seguido pelo vidro refletivo pirolítico bronze. 
Dentre os vidros refletivos metalizados a vácuo, o vidro prata neutro apresentou menor ganho de calor, enquanto que o vidro refletivo metalizado a vácuo azul médio apresentou o maior ganho de calor (Figuras 119, 120, 125, 126). Dessa forma, o vidro mais indicado para o controle do ganho de calor seria o prata neutro. Em segundo lugar seria o vidro refletivo metalizado a vácuo azul intenso médio. Este mesmo comportamento foi observado nas medições de temperaturas internas in loco. A célula-teste com o vidro refletivo metalizado a vácuo prata neutro apresentou as menores temperaturas internas.

Com relação aos dois vidros verdes, é evidente o melhor desempenho térmico do vidro refletivo pirolítico verde esmeralda (Figuras 121, 122, 127, 128). Este vidro, além de ter o tratamento refletivo, possui maior espessura que o vidro plano verde.

Dentre os vidros de cor prata, observa-se que o metalizado a vácuo apresenta um melhor desempenho térmico que o pirolítico, com menor ganho de calor.

A parcela $U$ (te $-\mathrm{ti})$, referentes às trocas térmicas entre o exterior e o interior, tem pouca contribuição no cálculo do ganho de calor, pois as diferenças de temperaturas são pequenas, assim como o fator $U$. O fator mais relevante no cálculo do ganho de calor é a parcela referente às características óticas do material, como também a radiação solar incidente.

O vidro reflectafloat foi excluído do cálculo do ganho de calor por não haver dados referentes à transmissão, absorção e reflexão. 


\subsection{Considerações finais}

Após a análise dos gráficos e tabelas, pôde-se verificar que os vidros refletivos apresentaram um melhor desempenho térmico que os vidros planos, no que se refere à temperatura do ar no interior da célula-teste. Em todos os períodos de medições, a célula-teste com o vidro plano incolor (referência) obteve as maiores temperaturas internas, fato este comprovado nos cálculos de ganho de calor. A célula-teste com o vidro plano verde apresentou também temperaturas internas altas, além disso, esse vidro registrou elevadas temperaturas superficiais internas e externas.

Os valores de temperaturas superficiais internas dos vidros estão relacionados com os valores de absortância, ou seja, o vidro de maior temperatura superficial interna possui a maior absortância. Já o comportamento dos vidros com relação à temperatura interna na célula-teste está relacionado com os valores de transmitância e absortância do vidro em questão.

Com relação às temperaturas superficiais internas e externas, os vidros de coloração mais intensa como o refletivo metalizado a vácuo azul intenso médio e o refletivo pirolítico verde esmeralda apresentaram os maiores valores medidos, sendo que as temperaturas superficiais internas sempre foram maiores que as externas.

O vidro refletivo metalizado a vácuo prata neutro e o vidro refletivo pirolítico bronze apresentaram o melhor desempenho no que se refere à temperatura do ar no interior das células-teste, com uma redução de temperatura em comparação com os demais tipos de vidro. Dessa forma, eles seriam os mais indicados na atenuação do ganho de calor. 
Pode-se dizer que o vidro reflectafloat apresentou um desempenho intermediário entre os vidros planos e os refletivos, tanto com relação às temperaturas internas medidas na célula-teste quanto às temperaturas superficiais.

Quando são comparados os vidros refletivos pirolíticos e metalizados a vácuo, observa-se um melhor desempenho desses últimos no que diz respeito ao ganho de calor no interior das células-teste.

Com relação aos cálculos realizados na segunda parte da metodologia, pode ser destacado o desempenho do vidro refletivo metalizado a vácuo prata neutro, por ter apresentado os menores ganhos de calor entre todos os vidros analisados. Dentre os vidros refletivos pirolíticos, o verde esmeralda apresentou os menores ganhos de calor através dos cálculos, vindo em seguida do bronze.

Quando se comparam os dados de laboratório com os resultados in loco, notam-se algumas diferenças dos dados obtidos, principalmente com relação aos vidros refletivos pirolíticos bronze e verde esmeralda. Nas medições in loco, a célulateste com o vidro bronze apresentou as menores temperaturas internas, já nos cálculos, o vidro verde esmeralda apresentou os menores ganhos de calor. Estas diferenças podem estar relacionadas com algum dado utilizado nos cálculos que não confere com o que acontece na realidade.

O vidro refletivo metalizado a vácuo azul médio e o pirolítico prata seriam os menos indicados no que se refere à proteção térmica, já que eles apresentaram os maiores ganhos de calor nos cálculos, além das células-teste com esses vidros terem registrado elevadas temperaturas internas. 


\section{CONCLUSÕES}

A pesquisa foi importante porque os dados adquiridos durante as medições nas células-teste comprovaram que os resultados obtidos anteriormente através do espectrofotômetro podem ser usados, que eles condizem com o que acontece na realidade. Além disso, o trabalho conseguiu obter dados de temperaturas superficiais para cada vidro, mostrando de forma mais detalhada como acontece o fluxo de calor.

Analisando os resultados, pode-se dizer que os vidros refletivos apresentaram um melhor desempenho térmico em relação ao vidro plano incolor (referência), sendo que este é o que mais permite a transmissão do calor para o ambiente.

Com relação ao ganho de calor total nas células-teste, os vidros planos incolor e verde apresentaram elevados valores, mostrando um melhor desempenho desse último. Dentre os vidros refletivos, os metalizados a vácuo destacaram-se por terem apresentado menores ganhos de calor que os pirolíticos.

A partir dos dados das medições nas células-teste e dos cálculos, pode-se afirmar que o vidro refletivo metalizado a vácuo prata neutro apresentou o melhor desempenho térmico dentre os vidros analisados nessa pesquisa, mostrando que ele atenua de forma significativa a entrada do calor. Pode também ser destacado o vidro refletivo metalizado a vácuo azul intenso, e os vidros refletivos pirolíticos verde esmeralda e bronze. 
Através dos valores de temperaturas internas obtidos in loco e dos cálculos do ganho de calor solar, pode-se concluir que os vidros refletivos apresentam um menor ganho de calor que os vidros planos. Isso mostra que o uso desses vidros pela arquitetura é bastante pertinente quando se trata da redução da entrada de calor no interior das edificações, principalmente em locais de clima quente como o Brasil. Porém, não se pode esquecer que este bloqueio do calor implica também no bloqueio da luz natural nos ambientes.

Como sugestões para trabalhos futuros, podem-se citar:

- Análise dos vidros refletivos na forma laminada, já que o presente trabalho utilizou apenas vidros na forma monolítica.

- Análise dos níveis de iluminância nas células-teste com o uso dos vidros refletivos. 


\section{REFERÊNCIAS}

AMERICAN SOCIETY OF HEATING REFRIGERATING AND AIR CONDITIONING ENGINEERS. Fundamental handbook. Cap.27. Atlanta: ASHRAE, 1997.

ARGAN, G.C. Arte moderna. São Paulo: Companhia das Letras, 1998.

ARNAUD, A. Industrial production of coated glass: future trends for expanding. Journal of Non-Crystalline Solids, Amsterdam, v.218, p.12-18, Sept. 1997.

BARROWS, W.E. Luz, fotometria y Iuminotecnia. Buenos Aires: Hispano Americana, 1960.

BRATKE, C. Desenho Prismático - Edifício Attilio Tinelli. Finestra Brasil, São Paulo, ano 6, n. 23, p.72-76, 2000.

CARAM DE ASSIS, R.M. Caracterização ótica de materiais transparentes e sua relação com o conforto ambiental em edificações. 1998. 118f. Tese (Doutorado) Universidade Estadual de Campinas, Campinas, 1998.

Estudo e caracterização de fachadas transparentes para uso na arquitetura: ênfase na eficiência energética. 2002. Tese (Livre-Docência) - Escola de Engenharia de São Carlos, Universidade de São Paulo, São Carlos, 2002.

CARMODY, J. et al. Residential windows: a guide to new technologies and energy performance. New York: W.W.Norton, 2000.

CASTRO, A.P.A.S. Desempenho térmico de vidros utilizados na construção civil: estudo em células-teste. 2006. Tese (Doutorado) - Universidade Estadual de Campinas, Campinas, 2006.

CEBRACE CRISTAL PLANO. Disponível em:<http://www.cebrace.com.br>. Acesso em: 20 jun. 2006. 
CENTRO DE ENSINO DE INFORMÁTICA. Colégio Santa Cruz. Arquitetura. Disponível em: <http://www.cei.santacruz.g12.br/cemanos/arqmain.htm>. Acesso em: 20 jun. 2006.

CHVATAL, F.M.S. A prática do projeto arquitetônico em Campinas, SP e diretrizes para o projeto de edificações adequadas ao clima. 1998. 173f. Dissertação (Mestrado) - Universidade Estadual de Campinas, Campinas, 1998.

CLEDWYN-DAVIES, D.N. Float in glass architecture. Glass Technology, Shbeffield, v.34, n.6, p.223-228, 1993.

COMPAGNO, A. Intelligent glass façades. Berlim: Birkhaüser, 1996.

CROISET, M. L'Higrothermique dans le batiment, confort thermique d'hiver et d'été condensations. Paris: Eyrolles, 1972.

DOURADO, G.M. Referencial urbano e construtivo. Finestra Brasil, São Paulo, ano 3, n.10, p.82-86, 1997.

DUFFIE, J.A.; BECKMAN, W.A.. Solar engineering of thermal processes. New York: Wiley Interscience, 1980.

ETZION, Y.; ERELL, E. Controlling the transmission of radiant energy through windows: a novel ventilated reversible glazing system. Building and Environment, Oxford, v.35, n.5, p.433-444, July 2000.

FANDERLIK, I. Optical properties of glass. Praga: SNTL Publishers of Technical Literature, 1983.

GAMMARANO, B. As fachadas de vidro e o modernismo: uma reflexão. 1992. Dissertação (Mestrado) - Universidade Federal do Rio de Janeiro, Rio de Janeiro, 1992.

GELINSKI, G. Torre de vidro e granito. Finestra Brasil, São Paulo, n.32, p.62-67, jan./mar. 2003.

GENCIAUSKAS, S. Evolução das fachadas-cortina na arquitetura brasileira. Finestra Brasil, São Paulo, ano 3, n.11, p.108-111, 1997. 
GIVONI, B. Man, climate and architecture. London: Applied Science, 1976.

GÖSSEL, P.; LEUTHÄUSER, G. Arquitetura no século XX. Colônia: Benedikt Taschen, 1996.

GRANDE ENCICLOPÉDIA LAROUSSE CULTURAL. São Paulo: Nova Cultural. v.18, 1998, p.4418.

GRANQVIST, C.G. Materials science for solar energy conversion systems. Suécia: Physics Department, Chalmers University of Technology, 1991.

GUTIERREZ, G.C.R. Avaliação do desempenho térmico de três tipologias de brise-soleil fixo. 2004. Dissertação (Mestrado) - Universidade Estadual de Campinas, Campinas, 2004.

HARKNESS, E.L. Solar radiation control in buildings. London: Applied Science, 1978.

HOPKINSON, R.G.; PETHERBRIDGE, P.; LONGMORE, J. Iluminação natural. Lisboa: Fundação Calouste Gulbenkian, 1966.

JORGE, L.A. O Desenho da janela. São Paulo: AnnaBlume, 1995.

KOENIGSBERGER, O.; MAHONEY, C.; EVANS, M. El clima u il diseno de casas: diseno de vivendas econômicas y servicio de la comunidad. Nueva York: ONU, 1977.

LABAKI, L.C.; CARAM, R.M.; SICHIERI, E.P. Os Vidros e o conforto ambiental. In: ENCONTRO NACIONAL DE CONFORTO NO AMBIENTE CONTRUÍDO, 3./ ENCONTRO LATINO-AMERICANO DE CONFORTO NO AMBIENTE CONSTRUÍDO, 1995, Gramado. Anais... Porto Alegre: ANTAC, 1995. p.215-220.

LAMBERTS, R.; DUTRA, L.; PEREIRA, F.O.R. Eficiência energética na arquitetura. São Paulo: PW, 1997.

MANGE, E.R.C. A função abrigo em arquitetura. São Paulo: Atena, 1956. 
MASCARÓ, J.L. Consumo de energia e construção de edifícios. São Paulo: SECOVI, 1980.

MASCARO, L.R. Luz, clima e arquitetura. São Paulo: Nobel, 1983.

Projeto, 1991.

Energia na edificação: estratégia para minimizar seu consumo. São Paulo:

OHTAKE, R. Fachada Geométrica - Edifício Berrini 500. Finestra Brasil, São Paulo, ano 6, n. 23, p.88-91, 2000.

OLGYAY, V. Arquitectura y clima: manual de diseño bioclimático para arquitectos y urbanistas. Barcelona: Gustavo Gili, 1998.

PETRONE, M. Conservação e utilização racional de energia em edificações: um pacto de responsabilidade. In: ENCONTRO NACIONAL DE CONFORTO NO AMBIENTE CONSTRUÍDO, 2., 1993, Florianópolis. Anais... Florianópolis: ANTAC, 1993.

REVISTA Finestra Brasil, São Paulo, ano 3, n. 10, 1997.

REVISTA Finestra Brasil, São Paulo, ano 3, n. 11, 1997.

REVISTA Finestra Brasil, São Paulo, ano 6, n. 23, 2000.

REVISTA Finestra Brasil, São Paulo, n. 32, 2003.

RIVERO, R. Arquitetura e clima: acondicionamento térmico natural. 2.ed. Porto Alegre: D.C.Luzzatto, 1986.

ROMERO, M.A.; GONÇALVES, J.C.; DILONARDO, L.F.P. A evolução da arquitetura e dos aspectos energéticos dos edifícios de escritórios nos últimos 30 anos na cidade de São Paulo. In: ENCONTRO NACIONAL DE CONFORTO NO AMBIENTE CONSTRUÍDO, 5./ ENCONTRO LATINO-AMERICANO DE CONFORTO NO AMBIENTE CONSTRUÍDO, 2., 1999, Fortaleza. Anais... Fortaleza: ANTAC, 1999.

RORIZ, M. Higiene do trabalho: temperatura: apostila. São Carlos: Departamento de Engenharia de Produção, Universidade Federal de São Carlos, 2001. 
SAINT-GOBAIN GLASS. Manual do vidro. Milão: Rotolito Lombarda, 2000.

SANTA MARINA. O Vidro na arquitetura. São Paulo: Projeto, 1993.

SANTOS, J.C.P. Desempenho térmico e visual de elementos transparentes frente à radiação solar. 2002. 363p. Tese (Doutorado) - Escola de Engenharia de São Carlos, Universidade de São Paulo, São Carlos, 2002.

SANTOS, J.C.P. et al. Procedimento prático para cálculo de ganhos de calor solar através de materiais transparentes. In: ENCONTRO NACIONAL DE CONFORTO NO AMBIENTE CONSTRUÍDO, 7./ CONFERÊNCIA LATINO-AMERICANA SOBRE CONFORTO E DESEMPENHO ENERGÉTICO, 3., 2003, Curitiba. Anais... Curitiba: ANTAC, 2003.

SARDEIRO, P.S. Estudo das janelas laterais e a iluminação natural: estudo de caso. 2002. 134p. Dissertação (Mestrado) - Escola de Engenharia de São Carlos, Universidade de São Paulo, São Carlos, 2002.

SCARAZZATO, P.S. Conceito de dia típico de projeto aplicado à iluminação natural: dados referenciais para localidades brasileiras. 1995. 2v. Tese (Doutorado) - Faculdade de Arquitetura e Urbanismo, Universidade de São Paulo, São Paulo, 1995.

SCHOLZE, H. Le Verre: nature, structure et propiétés. Paris: Institut du Verre, 1980.

SEGAWA, H. Arquiteturas no Brasil 1900-1990. São Paulo: EDUSP, 1999.

SEGAWA, H. et al. Arquiteturas no Brasil / Anos 80. São Paulo: Projeto, 1989.

SZABO, L.P. Em busca de uma luz paulistana: a concepção de luz natural no projeto de arquitetos da cidade de São Paulo. 2002. 501p. Tese (Doutorado) Faculdade de Arquitetura e Urbanismo, Universidade de São Paulo, São Paulo, 2002.

SZOKOLAY, S.V. O Imperativo ambiental. Tradução M.A.Sattler. Trabalho apresentado para o PLEA, Kushiro, 1997.

TEIXEIRA, F. O Vidro plano no Brasil. São Paulo: Prêmio Editorial, 2001. 
TIPLER, P.A. Física para cientistas e engenheiros. 3.ed. Tradução Horácio Macedo. Rio de Janeiro: Livros Técnicos e Científicos, 1995.

VAN STRAATEN, J.F. Thermal performance of buildings. London: Elsevier, 1967.

VAN VLACK, L.H. Princípios de ciências e tecnologia dos materiais. Tradução Edson Monteiro. Rio de Janeiro: Campus, 1984.

VIANNA, N.S.; GONÇALVES, J.C.S. Iluminação e arquitetura. São Paulo: Virtus; Universidade do Grande ABC, 2001.

WRIGHT, F.L. In the cause of architecture. New York: Architectural Record, 1975. Collected writings. New York: Rizzoli, 1992.

XAVIER, A.; BRITTO, A.; NOBRE, A.L. Arquitetura moderna no Rio de Janeiro. São Paulo: Pini/Fundação Vilanova Artigas; Rio de Janeiro: RioArte, 1991.

ZEIN, R.V. A harmonia e a melodia de uma orquestra onde cada instrumento ensaia sozinho. Projeto, São Paulo, n.78, p.69-89, ago. 1985. 


\section{APÊNDICE - A}

Neste apêndice são apresentados os resultados referentes aos cálculos de ganho de calor solar para cada tipo de vidro analisado.

\begin{tabular}{|c|c|c|c|c|c|c|c|c|c|c|c|c|c|}
\hline Vidro & Data & Horário & $\begin{array}{c}\text { Radiação } \\
\text { Direta } \\
\left(W / m^{2}\right)\end{array}$ & $\begin{array}{c}\text { Radiação } \\
\text { Difusa Céu } \\
\left(W / m^{2}\right)\end{array}$ & $\begin{array}{c}\text { Radiação } \\
\text { Refletida } \\
\left(\mathrm{W} / \mathrm{m}^{2}\right)\end{array}$ & FCS $(609)$ & $\begin{array}{c}\text { FCS } \\
\text { (referência) }\end{array}$ & CAC & FCS & te $\left({ }^{\circ} \mathrm{C}\right)$ & $\mathrm{ti}\left({ }^{\circ} \mathrm{C}\right)$ & $\mathrm{U}\left(\mathrm{W} / \mathrm{m}^{2} \mathrm{C}\right)$ & $q\left(W / m^{2}\right)$ \\
\hline \multirow{11}{*}{ 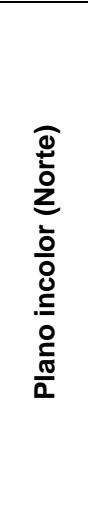 } & 21/7/2005 & $7: 00$ & 12,4 & 26,8 & 3,8 & 0,8658062 & 0,7980588 & 0,86 & 0,6863306 & 13,68 & 14,89 & 4,7653 & 25,51 \\
\hline & 21/7/2005 & 8:00 & 81 & 118,4 & 19,9 & 0,8658062 & 0,8682078 & 0,86 & 0,7466587 & 15,70 & 16,11 & 4,7653 & 161,52 \\
\hline & $21 / 7 / 2005$ & $9: 00$ & 248,9 & 157,8 & 43,4 & 0,8658062 & 0,9135651 & 0,86 & 0,7856660 & 18,87 & 17,58 & 4,7653 & 351,55 \\
\hline & $21 / 7 / 2005$ & $10: 00$ & 282,9 & 205 & 57,2 & 0,8658062 & 0,9403938 & 0,86 & 0,8087387 & 21,44 & 19,35 & 4,7653 & 433,94 \\
\hline & $21 / 7 / 2005$ & $11: 00$ & 300,1 & 237,5 & 65,9 & 0,8658062 & 0,9541120 & 0,86 & 0,8205364 & 23,07 & 20,97 & 4,7653 & 482,15 \\
\hline & $21 / 7 / 2005$ & $12: 00$ & 306,1 & 250,8 & 69,1 & 0,8658062 & 0,9582419 & 0,86 & 0,8240880 & 24,33 & 22,54 & 4,7653 & 498,97 \\
\hline & $21 / 7 / 2005$ & $13: 00$ & 280,4 & 252,8 & 65,3 & 0,8658062 & 0,9540227 & 0,86 & 0,8204595 & 25,36 & 24,03 & 4,7653 & 473,26 \\
\hline & $21 / 7 / 2005$ & $14: 00$ & 233,6 & 237,1 & 55,4 & 0,8658062 & 0,9402286 & 0,86 & 0,8085966 & 25,74 & 25,30 & 4,7653 & 408,75 \\
\hline & $21 / 7 / 2005$ & $15: 00$ & 179,3 & 197,6 & 41,4 & 0,8658062 & 0,9132685 & 0,86 & 0,7854109 & 25,73 & 26,37 & 4,7653 & 315,72 \\
\hline & 21/7/2005 & $16: 00$ & 79,8 & 136,9 & 22,1 & 0,8658062 & 0,8675846 & 0,86 & 0,7461228 & 24,60 & 26,41 & 4,7653 & 169,27 \\
\hline & $21 / 7 / 2005$ & $17: 00$ & 1 & 20,6 & 2,5 & 0,8658062 & 0,7970386 & 0,86 & 0,6854532 & 22,12 & 25,46 & 4,7653 & 1,97 \\
\hline
\end{tabular}




\begin{tabular}{|c|c|c|c|c|c|c|c|c|c|c|c|c|c|}
\hline Vidro & Data & Horário & $\begin{array}{c}\text { Radiação } \\
\text { Direta } \\
\left(\mathrm{W} / \mathrm{m}^{2}\right)\end{array}$ & $\begin{array}{c}\text { Radiação } \\
\text { Difusa Céu } \\
\left(\mathrm{W} / \mathrm{m}^{2}\right)\end{array}$ & $\begin{array}{l}\text { Radiação } \\
\text { Refletida } \\
\left(\mathrm{W} / \mathrm{m}^{2}\right)\end{array}$ & FCS (609) & $\begin{array}{c}\text { FCS } \\
\text { (referência) }\end{array}$ & CAC & FCS & te $\left({ }^{\circ} \mathrm{C}\right)$ & ti $\left({ }^{\circ} \mathrm{C}\right)$ & $\mathrm{U}\left(\mathrm{W} / \mathrm{m}^{2} \mathrm{C}\right)$ & $q\left(W / m^{2}\right)$ \\
\hline \multirow{11}{*}{ 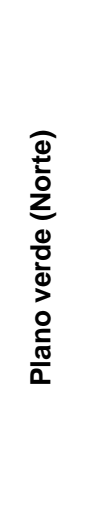 } & $21 / 7 / 2005$ & 7:00 & 12,4 & 26,8 & 3,8 & 0,8658062 & 0,7980588 & 0,74 & 0,5905635 & 13,68 & 14,48 & 4,7653 & 23,12 \\
\hline & 21/7/2005 & 8:00 & 81 & 118,4 & 19,9 & 0,8658062 & 0,8682078 & 0,74 & 0,6424738 & 15,70 & 15,50 & 4,7653 & 141,63 \\
\hline & $21 / 7 / 2005$ & 9:00 & 248,9 & 157,8 & 43,4 & 0,8658062 & 0,9135651 & 0,74 & 0,6760382 & 18,87 & 17,04 & 4,7653 & 305,93 \\
\hline & 21/7/2005 & $10: 00$ & 282,9 & 205 & 57,2 & 0,8658062 & 0,9403938 & 0,74 & 0,6958914 & 21,44 & 18,71 & 4,7653 & 377,85 \\
\hline & $21 / 7 / 2005$ & $11: 00$ & 300,1 & 237,5 & 65,9 & 0,8658062 & 0,9541120 & 0,74 & 0,7060429 & 23,07 & 20,65 & 4,7653 & 417,82 \\
\hline & 21/7/2005 & $12: 00$ & 306,1 & 250,8 & 69,1 & 0,8658062 & 0,9582419 & 0,74 & 0,7090990 & 24,33 & 22,59 & 4,7653 & 430,31 \\
\hline & 21/7/2005 & $13: 00$ & 280,4 & 252,8 & 65,3 & 0,8658062 & 0,9540227 & 0,74 & 0,7059768 & 25,36 & 23,81 & 4,7653 & 409,12 \\
\hline & $21 / 7 / 2005$ & $14: 00$ & 233,6 & 237,1 & 55,4 & 0,8658062 & 0,9402286 & 0,74 & 0,6957691 & 25,74 & 24,70 & 4,7653 & 354,88 \\
\hline & 21/7/2005 & $15: 00$ & 179,3 & 197,6 & 41,4 & 0,8658062 & 0,9132685 & 0,74 & 0,6758187 & 25,73 & 25,65 & 4,7653 & 274,69 \\
\hline & 21/7/2005 & $16: 00$ & 79,8 & 136,9 & 22,1 & 0,8658062 & 0,8675846 & 0,74 & 0,6420126 & 24,60 & 25,83 & 4,7653 & 147,23 \\
\hline & 21/7/2005 & $17: 00$ & 1 & 20,6 & 2,5 & 0,8658062 & 0,7970386 & 0,74 & 0,5898085 & 22,12 & 25,02 & 4,7653 & 1,54 \\
\hline
\end{tabular}

\begin{tabular}{|c|c|c|c|c|c|c|c|c|c|c|c|c|c|}
\hline Vidro & Data & Horário & $\begin{array}{c}\text { Radiação } \\
\text { Direta } \\
\left(W / m^{2}\right)\end{array}$ & $\begin{array}{c}\text { Radiação } \\
\text { Difusa Céu } \\
\left(W / m^{2}\right)\end{array}$ & $\begin{array}{c}\text { Radiação } \\
\text { Refletida } \\
\left(W / m^{2}\right)\end{array}$ & FCS (60) & $\begin{array}{c}\text { FCS } \\
\text { (referência) }\end{array}$ & CAC & FCS & te $\left({ }^{\circ} \mathrm{C}\right)$ & $\mathrm{ti}\left({ }^{\circ} \mathrm{C}\right)$ & $\mathrm{U}\left(\mathrm{W} / \mathrm{m}^{2} \mathrm{C}\right)$ & $q\left(W / m^{2}\right)$ \\
\hline \multirow{11}{*}{ 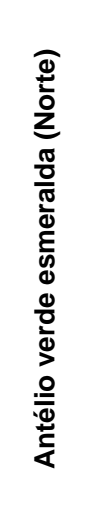 } & 21/7/2005 & 7:00 & 12,4 & 26,8 & 3,8 & 0,8658062 & 0,7980588 & 0,44 & 0,3511459 & 13,68 & 14,69 & 3,0352 & 12,94 \\
\hline & $21 / 7 / 2005$ & 8:00 & 81 & 118,4 & 19,9 & 0,8658062 & 0,8682078 & 0,44 & 0,3820114 & 15,70 & 15,73 & 3,0352 & 83,55 \\
\hline & $21 / 7 / 2005$ & 9:00 & 248,9 & 157,8 & 43,4 & 0,8658062 & 0,9135651 & 0,44 & 0,4019687 & 18,87 & 17,04 & 3,0352 & 182,26 \\
\hline & $21 / 7 / 2005$ & $10: 00$ & 282,9 & 205 & 57,2 & 0,8658062 & 0,9403938 & 0,44 & 0,4137733 & 21,44 & 18,79 & 3,0352 & 224,98 \\
\hline & $21 / 7 / 2005$ & $11: 00$ & 300,1 & 237,5 & 65,9 & 0,8658062 & 0,9541120 & 0,44 & 0,4198093 & 23,07 & 20,60 & 3,0352 & 249,05 \\
\hline & $21 / 7 / 2005$ & $12: 00$ & 306,1 & 250,8 & 69,1 & 0,8658062 & 0,9582419 & 0,44 & 0,4216264 & 24,33 & 22,25 & 3,0352 & 257,24 \\
\hline & $21 / 7 / 2005$ & $13: 00$ & 280,4 & 252,8 & 65,3 & 0,8658062 & 0,9540227 & 0,44 & 0,4197700 & 25,36 & 23,61 & 3,0352 & 244,19 \\
\hline & $21 / 7 / 2005$ & $14: 00$ & 233,6 & 237,1 & 55,4 & 0,8658062 & 0,9402286 & 0,44 & 0,4137006 & 25,74 & 24,98 & 3,0352 & 210,37 \\
\hline & 21/7/2005 & $15: 00$ & 179,3 & 197,6 & 41,4 & 0,8658062 & 0,9132685 & 0,44 & 0,4018382 & 25,73 & 25,85 & 3,0352 & 162,73 \\
\hline & 21/7/2005 & $16: 00$ & 79,8 & 136,9 & 22,1 & 0,8658062 & 0,8675846 & 0,44 & 0,3817372 & 24,60 & 25,97 & 3,0352 & 86,87 \\
\hline & 21/7/2005 & $17: 00$ & 1 & 20,6 & 2,5 & 0,8658062 & 0,7970386 & 0,44 & 0,3506970 & 22,12 & 25,19 & 3,0352 & 0,19 \\
\hline
\end{tabular}




\begin{tabular}{|c|c|c|c|c|c|c|c|c|c|c|c|c|c|}
\hline Vidro & Data & Horário & $\begin{array}{c}\text { Radiação } \\
\text { Direta } \\
\left(W / m^{2}\right)\end{array}$ & $\begin{array}{c}\text { Radiação } \\
\text { Difusa Céu } \\
\left(W / m^{2}\right)\end{array}$ & $\begin{array}{c}\text { Radiação } \\
\text { Refletida } \\
\left(\mathrm{W} / \mathrm{m}^{2}\right)\end{array}$ & FCS $(609)$ & $\begin{array}{c}\text { FCS } \\
\text { (referência) }\end{array}$ & CAC & FCS & te $\left({ }^{\circ} \mathrm{C}\right)$ & $\mathrm{ti}\left({ }^{\circ} \mathrm{C}\right)$ & $\mathrm{U}\left(\mathrm{W} / \mathrm{m}^{2} \mathrm{C}\right)$ & $q\left(W / m^{2}\right)$ \\
\hline \multirow{11}{*}{ 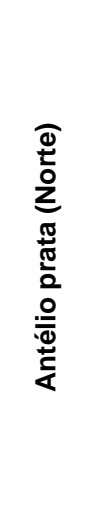 } & 21/7/2005 & $7: 00$ & 12,4 & 26,8 & 3,8 & 0,8658062 & 0,7980588 & 0,55 & 0,4389324 & 13,68 & 14,43 & 3,0537 & 17,71 \\
\hline & $21 / 7 / 2005$ & $8: 00$ & 81 & 118,4 & 19,9 & 0,8658062 & 0,8682078 & 0,55 & 0,4775143 & 15,70 & 15,33 & 3,0537 & 105,67 \\
\hline & 21/7/2005 & $9: 00$ & 248,9 & 157,8 & 43,4 & 0,8658062 & 0,9135651 & 0,55 & 0,5024608 & 18,87 & 16,47 & 3,0537 & 228,22 \\
\hline & 21/7/2005 & $10: 00$ & 282,9 & 205 & 57,2 & 0,8658062 & 0,9403938 & 0,55 & 0,5172166 & 21,44 & 18,19 & 3,0537 & 281,10 \\
\hline & $21 / 7 / 2005$ & $11: 00$ & 300,1 & 237,5 & 65,9 & 0,8658062 & 0,9541120 & 0,55 & 0,5247616 & 23,07 & 19,92 & 3,0537 & 311,58 \\
\hline & 21/7/2005 & $12: 00$ & 306,1 & 250,8 & 69,1 & 0,8658062 & 0,9582419 & 0,55 & 0,5270330 & 24,33 & 21,45 & 3,0537 & 322,44 \\
\hline & $21 / 7 / 2005$ & $13: 00$ & 280,4 & 252,8 & 65,3 & 0,8658062 & 0,9540227 & 0,55 & 0,5247125 & 25,36 & 22,93 & 3,0537 & 306,03 \\
\hline & $21 / 7 / 2005$ & $14: 00$ & 233,6 & 237,1 & 55,4 & 0,8658062 & 0,9402286 & 0,55 & 0,5171257 & 25,74 & 24,28 & 3,0537 & 264,56 \\
\hline & $21 / 7 / 2005$ & $15: 00$ & 179,3 & 197,6 & 41,4 & 0,8658062 & 0,9132685 & 0,55 & 0,5022977 & 25,73 & 25,43 & 3,0537 & 204,78 \\
\hline & $21 / 7 / 2005$ & $16: 00$ & 79,8 & 136,9 & 22,1 & 0,8658062 & 0,8675846 & 0,55 & 0,4771715 & 24,60 & 25,83 & 3,0537 & 110,04 \\
\hline & $21 / 7 / 2005$ & $17: 00$ & 1 & 20,6 & 2,5 & 0,8658062 & 0,7970386 & 0,55 & 0,4383712 & 22,12 & 25,28 & 3,0537 & 1,78 \\
\hline
\end{tabular}

\begin{tabular}{|c|c|c|c|c|c|c|c|c|c|c|c|c|c|}
\hline Vidro & Data & Horário & $\begin{array}{c}\text { Radiação } \\
\text { Direta } \\
\left(W / m^{2}\right)\end{array}$ & $\begin{array}{c}\text { Radiação } \\
\text { Difusa Céu } \\
\left(W / m^{2}\right)\end{array}$ & $\begin{array}{c}\text { Radiação } \\
\text { Refletida } \\
\left(\mathrm{W} / \mathbf{m}^{2}\right)\end{array}$ & FCS $(60)$ & $\begin{array}{c}\text { FCS } \\
\text { (referência) }\end{array}$ & CAC & FCS & te $\left({ }^{\circ} \mathrm{C}\right)$ & ti $\left({ }^{\circ} \mathrm{C}\right)$ & $\mathrm{U}\left(\mathrm{W} / \mathrm{m}^{2} \mathrm{C}\right)$ & $q\left(W / m^{2}\right)$ \\
\hline \multirow{9}{*}{ 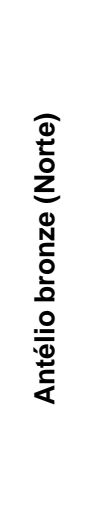 } & $21 / 7 / 2005$ & $8: 00$ & 81 & 118,4 & 19,9 & 0,8658062 & 0,8682078 & 0,51 & 0,4427860 & 15,70 & 15,22 & 3,0537 & 98,40 \\
\hline & $21 / 7 / 2005$ & $9: 00$ & 248,9 & 157,8 & 43,4 & 0,8658062 & 0,9135651 & 0,51 & 0,4659182 & 18,87 & 16,32 & 3,0537 & 212,62 \\
\hline & $21 / 7 / 2005$ & $10: 00$ & 282,9 & 205 & 57,2 & 0,8658062 & 0,9403938 & 0,51 & 0,4796009 & 21,44 & 18,02 & 3,0537 & 261,87 \\
\hline & $21 / 7 / 2005$ & $12: 00$ & 306,1 & 250,8 & 69,1 & 0,8658062 & 0,9582419 & 0,51 & 0,4887034 & 24,33 & 21,29 & 3,0537 & 300,12 \\
\hline & 21/7/2005 & $13: 00$ & 280,4 & 252,8 & 65,3 & 0,8658062 & 0,9540227 & 0,51 & 0,4865516 & 25,36 & 22,31 & 3,0537 & 286,20 \\
\hline & $21 / 7 / 2005$ & $14: 00$ & 233,6 & 237,1 & 55,4 & 0,8658062 & 0,9402286 & 0,51 & 0,4795166 & 25,74 & 23,37 & 3,0537 & 248,40 \\
\hline & 21/7/2005 & $15: 00$ & 179,3 & 197,6 & 41,4 & 0,8658062 & 0,9132685 & 0,51 & 0,465767 & 25,73 & 24,25 & 3,0537 & 193,55 \\
\hline & $21 / 7 / 2005$ & $16: 00$ & 79,8 & 136,9 & 22,1 & 0,8658062 & 0,8675846 & 0,51 & 0,4424682 & 24,60 & 24,53 & 3,0537 & 105,71 \\
\hline & $21 / 7 / 2005$ & $17: 00$ & 1 & 20,6 & 2,5 & 0,8658062 & 0,7970386 & 0,51 & 0,4064897 & 22,12 & 24,20 & 3,0537 & 4,24 \\
\hline
\end{tabular}




\begin{tabular}{|c|c|c|c|c|c|c|c|c|c|c|c|c|c|}
\hline Vidro & Data & Horário & $\begin{array}{c}\text { Radiação } \\
\text { Direta } \\
\left(W / m^{2}\right)\end{array}$ & $\begin{array}{c}\text { Radiação } \\
\text { Difusa Céu } \\
\left(W / m^{2}\right)\end{array}$ & $\begin{array}{c}\text { Radiação } \\
\text { Refletida } \\
\left(W / m^{2}\right)\end{array}$ & FCS $(609)$ & $\begin{array}{c}\text { FCS } \\
\text { (referência) }\end{array}$ & CAC & FCS & te $\left({ }^{\circ} \mathrm{C}\right)$ & $\mathrm{ti}\left({ }^{\circ} \mathrm{C}\right)$ & $\mathrm{U}\left(\mathrm{W} / \mathrm{m}^{2} \mathrm{C}\right)$ & $q\left(W / m^{2}\right)$ \\
\hline \multirow{11}{*}{ 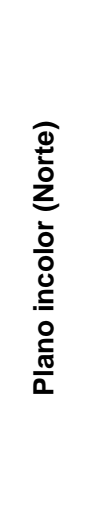 } & $30 / 7 / 2005$ & $7: 00$ & 2 & 24,1 & 3 & 0,8658062 & 0,7704999 & 0,86 & 0,6626299 & 13,84 & 16,66 & 4,7653 & 8,07 \\
\hline & $30 / 7 / 2005$ & $8: 00$ & 108,6 & 122,3 & 23,3 & 0,8658062 & 0,8482348 & 0,86 & 0,7294820 & 16,81 & 17,58 & 4,7653 & 183,97 \\
\hline & $30 / 7 / 2005$ & $9: 00$ & 270,6 & 152,3 & 47,4 & 0,8658062 & 0,8988885 & 0,86 & 0,7730441 & 21,60 & 18,70 & 4,7653 & 371,70 \\
\hline & $30 / 7 / 2005$ & $10: 00$ & 317,6 & 192,2 & 62,6 & 0,8658062 & 0,9290542 & 0,86 & 0,7989866 & 24,80 & 20,45 & 4,7653 & 464,21 \\
\hline & $30 / 7 / 2005$ & $11: 00$ & 334,9 & 223,7 & 71,6 & 0,8658062 & 0,9446160 & 0,86 & 0,8123698 & 25,84 & 22,47 & 4,7653 & 508,02 \\
\hline & $30 / 7 / 2005$ & $12: 00$ & 328,3 & 243,1 & 74 & 0,8658062 & 0,9493250 & 0,86 & 0,8164195 & 26,22 & 24,18 & 4,7653 & 513,86 \\
\hline & $30 / 7 / 2005$ & $13: 00$ & 306 & 244,7 & 70,3 & 0,8658062 & 0,9445122 & 0,86 & 0,8122805 & 26,88 & 25,40 & 4,7653 & 490,13 \\
\hline & $30 / 7 / 2005$ & $14: 00$ & 267,2 & 228,1 & 60,7 & 0,8658062 & 0,9288009 & 0,86 & 0,7987687 & 27,10 & 26,65 & 4,7653 & 430,59 \\
\hline & $30 / 7 / 2005$ & $15: 00$ & 186,1 & 201,6 & 44,3 & 0,8658062 & 0,8983840 & 0,86 & 0,7726102 & 27,42 & 27,94 & 4,7653 & 324,39 \\
\hline & $30 / 7 / 2005$ & $16: 00$ & 92,9 & 144,4 & 24,7 & 0,8658062 & 0,8473047 & 0,86 & 0,7286821 & 26,80 & 28,40 & 4,7653 & 185,97 \\
\hline & $30 / 7 / 2005$ & $17: 00$ & 7,3 & 45,7 & 5,9 & 0,8658062 & 0,7690480 & 0,86 & 0,6613812 & 25,12 & 28,11 & 4,7653 & 28,97 \\
\hline
\end{tabular}

\begin{tabular}{|c|c|c|c|c|c|c|c|c|c|c|c|c|c|}
\hline Vidro & Data & Horário & $\begin{array}{c}\text { Radiação } \\
\text { Direta } \\
\left(W / m^{2}\right)\end{array}$ & $\begin{array}{c}\text { Radiação } \\
\text { Difusa Céu } \\
\left(W / m^{2}\right)\end{array}$ & $\begin{array}{c}\text { Radiação } \\
\text { Refletida } \\
\left(W / m^{2}\right)\end{array}$ & FCS $(609)$ & $\begin{array}{c}\text { FCS } \\
\text { (referência) }\end{array}$ & CAC & FCS & te $\left({ }^{\circ} \mathrm{C}\right)$ & $\mathrm{ti}\left({ }^{\circ} \mathrm{C}\right)$ & $\mathrm{U}\left(\mathrm{W} / \mathrm{m}^{2} \mathrm{C}\right)$ & $q\left(W / m^{2}\right)$ \\
\hline \multirow{11}{*}{ 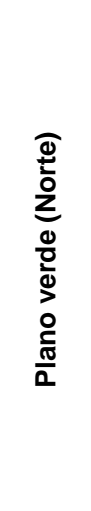 } & $30 / 7 / 2005$ & 7:00 & 2 & 24,1 & 3 & 0,8658062 & 0,7704999 & 0,74 & 0,5701699 & 13,84 & 16,14 & 4,7653 & 7,53 \\
\hline & $30 / 7 / 2005$ & 8:00 & 108,6 & 122,3 & 23,3 & 0,8658062 & 0,8482348 & 0,74 & 0,6276938 & 16,81 & 17,11 & 4,7653 & 160,02 \\
\hline & $30 / 7 / 2005$ & 9:00 & 270,6 & 152,3 & 47,4 & 0,8658062 & 0,8988885 & 0,74 & 0,6651775 & 21,60 & 18,20 & 4,7653 & 324,14 \\
\hline & $30 / 7 / 2005$ & $10: 00$ & 317,6 & 192,2 & 62,6 & 0,8658062 & 0,9290542 & 0,74 & 0,6875001 & 24,80 & 20,62 & 4,7653 & 401,52 \\
\hline & $30 / 7 / 2005$ & $11: 00$ & 334,9 & 223,7 & 71,6 & 0,8658062 & 0,9446160 & 0,74 & 0,6990159 & 25,84 & 22,97 & 4,7653 & 437,00 \\
\hline & $30 / 7 / 2005$ & $12: 00$ & 328,3 & 243,1 & 74 & 0,8658062 & 0,9493250 & 0,74 & 0,7025005 & 26,22 & 25,05 & 4,7653 & 439,38 \\
\hline & $30 / 7 / 2005$ & 13:00 & 306 & 244,7 & 70,3 & 0,8658062 & 0,9445122 & 0,74 & 0,6989390 & 26,88 & 26,65 & 4,7653 & 416,78 \\
\hline & $30 / 7 / 2005$ & $14: 00$ & 267,2 & 228,1 & 60,7 & 0,8658062 & 0,9288009 & 0,74 & 0,6873126 & 27,10 & 26,43 & 4,7653 & 371,88 \\
\hline & $30 / 7 / 2005$ & $15: 00$ & 186,1 & 201,6 & 44,3 & 0,8658062 & 0,8983840 & 0,74 & 0,6648041 & 27,42 & 27,55 & 4,7653 & 280,62 \\
\hline & $30 / 7 / 2005$ & $16: 00$ & 92,9 & 144,4 & 24,7 & 0,8658062 & 0,8473047 & 0,74 & 0,6270055 & 26,80 & 27,92 & 4,7653 & 161,25 \\
\hline & $30 / 7 / 2005$ & $17: 00$ & 7,3 & 45,7 & 5,9 & 0,8658062 & 0,7690480 & 0,74 & 0,5690955 & 25,12 & 27,73 & 4,7653 & 24,74 \\
\hline
\end{tabular}




\begin{tabular}{|c|c|c|c|c|c|c|c|c|c|c|c|c|c|}
\hline Vidro & Data & Horário & $\begin{array}{c}\text { Radiação } \\
\text { Direta } \\
\left(\mathrm{W} / \mathrm{m}^{2}\right)\end{array}$ & $\begin{array}{c}\text { Radiação } \\
\text { Difusa Céu } \\
\left(\mathrm{W} / \mathrm{m}^{2}\right)\end{array}$ & $\begin{array}{c}\text { Radiação } \\
\text { Refletida } \\
\left(\mathrm{W} / \mathrm{m}^{2}\right)\end{array}$ & FCS $(609$ & $\begin{array}{c}\text { FCS } \\
\text { (referência) }\end{array}$ & CAC & FCS & te $\left({ }^{(C)}\right)$ & $t i\left({ }^{(C)}\right)$ & $u\left(\mathrm{~W} / \mathrm{m}^{2} \mathrm{C}\right)$ & $q\left(W / m^{2}\right)$ \\
\hline \multirow{11}{*}{ 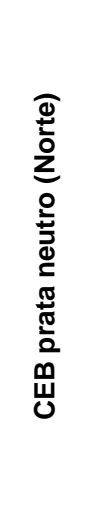 } & 30/7/2005 & 7:00 & 2 & 24,1 & 3 & 0,8760888 & 0,7983288 & 0,27 & 0,2155488 & 13,84 & 15,99 & 2,9515 & 0,49 \\
\hline & $30 / 7 / 2005$ & $8: 00$ & 108,6 & 122,3 & 23,3 & 0,8760888 & 0,8615546 & 0,27 & 0,2326198 & 16,81 & 16,29 & 2,9515 & 61,24 \\
\hline & 30/7/2005 & 9:00 & 270,6 & 152,3 & 47,4 & 0,8760888 & 0,9038770 & 0,27 & 0,2440468 & 21,60 & 16,83 & 2,9515 & 127,37 \\
\hline & 30/7/2005 & $10: 00$ & 317,6 & 192,2 & 62,6 & 0,8760888 & 0,9299307 & 0,27 & 0,2510813 & 24,80 & 18,57 & 2,9515 & 158,40 \\
\hline & 30/7/2005 & $11: 00$ & 334,9 & 223,7 & 71,6 & 0,8760888 & 0,9437779 & 0,27 & 0,2548200 & 25,84 & 20,57 & 2,9515 & 170,75 \\
\hline & 30/7/2005 & 12:00 & 328,3 & 243,1 & 74 & 0,8760888 & 0,9480428 & 0,27 & 0,2559715 & 26,22 & 22,18 & 2,9515 & 170,96 \\
\hline & 30/7/2005 & 13:00 & 306 & 244,7 & 70,3 & 0,8760888 & 0,9436842 & 0,27 & 0,2547947 & 26,88 & 23,15 & 2,9515 & 163,47 \\
\hline & 30/7/2005 & 14:00 & 267,2 & 228,1 & 60,7 & 0,8760888 & 0,9297080 & 0,27 & 0,2510212 & 27,10 & 23,96 & 2,9515 & 144,65 \\
\hline & 30/7/2005 & $15: 00$ & 186,1 & 201,6 & 44,3 & 0,8760888 & 0,9034480 & 0,27 & 0,2439310 & 27,42 & 24,98 & 2,9515 & 110,76 \\
\hline & 30/7/2005 & $16: 00$ & 92,9 & 144,4 & 24,7 & 0,8760888 & 0,8607887 & 0,27 & 0,2324130 & 26,80 & 25,54 & 2,9515 & 65,31 \\
\hline & $30 / 7 / 2005$ & $17: 00$ & 7,3 & 45,7 & 5,9 & 0,8760888 & 0,7971581 & 0,27 & 0,2152327 & 25,12 & 26,08 & 2,9515 & 10,93 \\
\hline
\end{tabular}

\begin{tabular}{|c|c|c|c|c|c|c|c|c|c|c|c|c|c|}
\hline Vidro & Data & Horário & $\begin{array}{c}\text { Radiação } \\
\text { Direta } \\
\left(\mathrm{W} / \mathrm{m}^{2}\right)\end{array}$ & $\begin{array}{c}\text { Radiação } \\
\text { Difusa Céu } \\
\left(\mathrm{W} / \mathrm{m}^{2}\right)\end{array}$ & $\begin{array}{c}\text { Radiação } \\
\text { Refletida } \\
\left(\mathrm{W} / \mathrm{m}^{2}\right)\end{array}$ & FCS $(609)$ & $\begin{array}{c}\text { FCS } \\
\text { (referência) }\end{array}$ & CAC & FCS & te $(\mathrm{C})$ & $\mathrm{ti}\left({ }^{(} \mathrm{C}\right)$ & $\mathrm{u}\left(\mathrm{W} / \mathrm{m}^{2} \mathrm{C}\right)$ & $q\left(W / m^{2}\right)$ \\
\hline \multirow{11}{*}{ 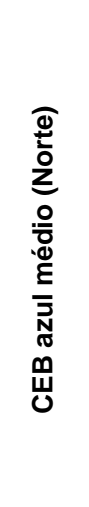 } & 30/7/2005 & 7:00 & 2 & 24,1 & 3 & 0,8760888 & 0,7983288 & 0,39 & 0,3113482 & 13,84 & 15,93 & 2,9515 & 3,72 \\
\hline & 30/7/2005 & 8:00 & 108,6 & 122,3 & 23,3 & 0,8760888 & 0,8615546 & 0,39 & 0,3360063 & 16,81 & 16,33 & 2,9515 & 87,67 \\
\hline & 30/7/2005 & 9:00 & 270,6 & 152,3 & 47,4 & 0,8760888 & 0,9038770 & 0,39 & 0,3525120 & 21,60 & 16,82 & 2,9515 & 177,72 \\
\hline & 30/7/2005 & 10:00 & 317,6 & 192,2 & 62,6 & 0,8760888 & 0,9299307 & 0,39 & 0,3626730 & 24,80 & 18,90 & 2,9515 & 219,66 \\
\hline & 30/7/2005 & 11:00 & 334,9 & 223,7 & 71,6 & 0,8760888 & 0,9437779 & 0,39 & 0,3680734 & 25,84 & 21,03 & 2,9515 & 238,36 \\
\hline & 30/7/2005 & 12:00 & 328,3 & 243,1 & 74 & 0,8760888 & 0,9480428 & 0,39 & 0,3697367 & 26,22 & 22,81 & 2,9515 & 239,79 \\
\hline & 30/7/2005 & 13:00 & 306 & 244,7 & 70,3 & 0,8760888 & 0,9436842 & 0,39 & 0,3680369 & 26,88 & 24,03 & 2,9515 & 228,64 \\
\hline & 30/7/2005 & 14:00 & 267,2 & 228,1 & 60,7 & 0,8760888 & 0,9297080 & 0,39 & 0,3625861 & 27,10 & 25,12 & 2,9515 & 201,40 \\
\hline & $30 / 7 / 2005$ & 15:00 & 186,1 & 201,6 & 44,3 & 0,8760888 & 0,9034480 & 0,39 & 0,3523447 & 27,42 & 26,27 & 2,9515 & 152,99 \\
\hline & $30 / 7 / 2005$ & 16:00 & 92,9 & 144,4 & 24,7 & 0,8760888 & 0,8607887 & 0,39 & 0,3357076 & 26,80 & 26,93 & 2,9515 & 88,57 \\
\hline & $30 / 7 / 2005$ & 17:00 & 7,3 & 45,7 & 5,9 & 0,8760888 & 0,7971581 & 0,39 & 0,3108916 & 25,12 & 27,27 & 2,9515 & 13,54 \\
\hline
\end{tabular}




\begin{tabular}{|c|c|c|c|c|c|c|c|c|c|c|c|c|c|}
\hline Vidro & Data & Horário & $\begin{array}{c}\text { Radiação } \\
\text { Direta } \\
\left(\mathrm{W} / \mathbf{m}^{2}\right)\end{array}$ & $\begin{array}{c}\text { Radiação } \\
\text { Difusa Céu } \\
\left(W / m^{2}\right)\end{array}$ & $\begin{array}{c}\text { Radiação } \\
\text { Refletida } \\
\left(\mathrm{W} / \mathbf{m}^{2}\right)\end{array}$ & FCS $(609)$ & $\begin{array}{c}\text { FCS } \\
\text { (referência) }\end{array}$ & CAC & FCS & te $\left({ }^{\circ} \mathrm{C}\right)$ & $\mathrm{ti}\left({ }^{\circ} \mathrm{C}\right)$ & $\mathrm{U}\left(\mathrm{W} / \mathrm{m}^{2} \mathrm{C}\right)$ & $q\left(W / m^{2}\right)$ \\
\hline \multirow{11}{*}{ 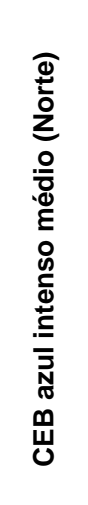 } & $30 / 7 / 2005$ & 7:00 & 2 & 24,1 & 3 & 0,8760888 & 0,7983288 & 0,31 & 0,2474819 & 13,84 & 16,11 & 2,9515 & 1,14 \\
\hline & $30 / 7 / 2005$ & $8: 00$ & 108,6 & 122,3 & 23,3 & 0,8760888 & 0,8615546 & 0,31 & 0,2670819 & 16,81 & 16,54 & 2,9515 & 69,35 \\
\hline & $30 / 7 / 2005$ & $9: 00$ & 270,6 & 152,3 & 47,4 & 0,8760888 & 0,9038770 & 0,31 & 0,2802019 & 21,60 & 17,25 & 2,9515 & 142,88 \\
\hline & $30 / 7 / 2005$ & $10: 00$ & 317,6 & 192,2 & 62,6 & 0,8760888 & 0,9299307 & 0,31 & 0,2882785 & 24,80 & 19,08 & 2,9515 & 177,62 \\
\hline & $30 / 7 / 2005$ & $11: 00$ & 334,9 & 223,7 & 71,6 & 0,8760888 & 0,9437779 & 0,31 & 0,2925711 & 25,84 & 21,10 & 2,9515 & 192,18 \\
\hline & $30 / 7 / 2005$ & $12: 00$ & 328,3 & 243,1 & 74 & 0,8760888 & 0,9480428 & 0,31 & 0,2938933 & 26,22 & 22,75 & 2,9515 & 192,86 \\
\hline & $30 / 7 / 2005$ & $13: 00$ & 306 & 244,7 & 70,3 & 0,8760888 & 0,9436842 & 0,31 & 0,2925421 & 26,88 & 23,93 & 2,9515 & 183,77 \\
\hline & $30 / 7 / 2005$ & $14: 00$ & 267,2 & 228,1 & 60,7 & 0,8760888 & 0,9297080 & 0,31 & 0,2882095 & 27,10 & 24,91 & 2,9515 & 161,92 \\
\hline & $30 / 7 / 2005$ & $15: 00$ & 186,1 & 201,6 & 44,3 & 0,8760888 & 0,9034480 & 0,31 & 0,2800689 & 27,42 & 26,01 & 2,9515 & 123,05 \\
\hline & $30 / 7 / 2005$ & $16: 00$ & 92,9 & 144,4 & 24,7 & 0,8760888 & 0,8607887 & 0,31 & 0,2668445 & 26,80 & 26,54 & 2,9515 & 71,49 \\
\hline & $30 / 7 / 2005$ & $17: 00$ & 7,3 & 45,7 & 5,9 & 0,8760888 & 0,7971581 & 0,31 & 0,2471190 & 25,12 & 26,86 & 2,9515 & 10,68 \\
\hline
\end{tabular}

\begin{tabular}{|c|c|c|c|c|c|c|c|c|c|c|c|c|c|}
\hline Vidro & Data & Horário & $\begin{array}{c}\text { Radiação } \\
\text { Direta } \\
\left(W / m^{2}\right)\end{array}$ & $\begin{array}{c}\text { Radiação } \\
\text { Difusa Céu } \\
\left(\mathrm{W} / \mathrm{m}^{2}\right)\end{array}$ & $\begin{array}{c}\text { Radiação } \\
\text { Refletida } \\
\left(\mathrm{W} / \mathrm{m}^{2}\right)\end{array}$ & FCS $(609)$ & $\begin{array}{c}\text { FCS } \\
\text { (referência) }\end{array}$ & CAC & FCS & te $\left({ }^{\circ} \mathrm{C}\right)$ & $\mathrm{ti}\left({ }^{\circ} \mathrm{C}\right)$ & $\mathrm{U}\left(\mathrm{W} / \mathrm{m}^{2} \mathrm{C}\right)$ & $q\left(W / m^{2}\right)$ \\
\hline \multirow{11}{*}{ 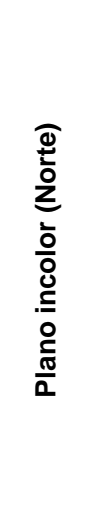 } & $21 / 8 / 2005$ & 7:00 & 1,7 & 39 & 4,8 & 0,8658062 & 0,6590731 & 0,86 & 0,5668028 & 16,72 & 18,01 & 4,7653 & 27,40 \\
\hline & $21 / 8 / 2005$ & 8:00 & 83,6 & 153,1 & 28,1 & 0,8658062 & 0,7654683 & 0,86 & 0,6583027 & 19,04 & 19,12 & 4,7653 & 189,57 \\
\hline & $21 / 8 / 2005$ & 9:00 & 223,9 & 180,4 & 54,1 & 0,8658062 & 0,8364021 & 0,86 & 0,7193058 & 21,74 & 20,44 & 4,7653 & 341,86 \\
\hline & $21 / 8 / 2005$ & $10: 00$ & 266,6 & 221,7 & 69,6 & 0,8658062 & 0,8797075 & 0,86 & 0,7565485 & 24,40 & 22,19 & 4,7653 & 429,13 \\
\hline & $21 / 8 / 2005$ & $11: 00$ & 290,1 & 249,8 & 79,2 & 0,8658062 & 0,9026091 & 0,86 & 0,7762438 & 25,91 & 24,09 & 4,7653 & 478,85 \\
\hline & $21 / 8 / 2005$ & $12: 00$ & 292,2 & 264,2 & 82,1 & 0,8658062 & 0,9095690 & 0,86 & 0,7822293 & 27,51 & 25,86 & 4,7653 & 494,30 \\
\hline & $21 / 8 / 2005$ & $13: 00$ & 252,8 & 276,1 & 76,1 & 0,8658062 & 0,9023645 & 0,86 & 0,7760335 & 28,40 & 27,21 & 4,7653 & 464,08 \\
\hline & $21 / 8 / 2005$ & $14: 00$ & 216,9 & 256,9 & 65,9 & 0,8658062 & 0,8792248 & 0,86 & 0,7561333 & 28,83 & 28,55 & 4,7653 & 405,70 \\
\hline & $21 / 8 / 2005$ & $15: 00$ & 153,1 & 224,3 & 49,2 & 0,8658062 & 0,8354149 & 0,86 & 0,7184568 & 29,37 & 29,82 & 4,7653 & 311,53 \\
\hline & $21 / 8 / 2005$ & $16: 00$ & 72,8 & 165 & 28,3 & 0,8658062 & 0,7636621 & 0,86 & 0,6567494 & 29,17 & 30,42 & 4,7653 & 185,78 \\
\hline & $21 / 8 / 2005$ & $17: 00$ & 8,3 & 61 & 7,9 & 0,8658062 & 0,6562095 & 0,86 & 0,5643402 & 27,82 & 30,12 & 4,7653 & 45,03 \\
\hline
\end{tabular}




\begin{tabular}{|c|c|c|c|c|c|c|c|c|c|c|c|c|c|}
\hline Vidro & Data & Horário & $\begin{array}{c}\text { Radiação } \\
\text { Direta } \\
\left(W / m^{2}\right)\end{array}$ & $\begin{array}{c}\text { Radiação } \\
\text { Difusa Céu } \\
\left(W / m^{2}\right)\end{array}$ & $\begin{array}{c}\text { Radiação } \\
\text { Refletida } \\
\left(\mathrm{W} / \mathrm{m}^{2}\right)\end{array}$ & FCS (60) & $\begin{array}{c}\text { FCS } \\
\text { (referência) }\end{array}$ & CAC & FCS & te $\left({ }^{\circ} \mathrm{C}\right)$ & ti $\left({ }^{\circ} \mathrm{C}\right)$ & $\mathrm{U}\left(\mathrm{W} / \mathrm{m}^{2} \mathrm{C}\right)$ & $q\left(W / m^{2}\right)$ \\
\hline \multirow{11}{*}{ 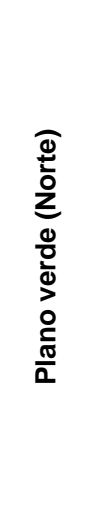 } & 21/8/2005 & $7: 00$ & 1,7 & 39 & 4,8 & 0,8658062 & 0,6590731 & 0,74 & 0,4877141 & 16,72 & 17,66 & 4,7653 & 24,40 \\
\hline & $21 / 8 / 2005$ & $8: 00$ & 83,6 & 153,1 & 28,1 & 0,8658062 & 0,7654683 & 0,74 & 0,5664465 & 19,04 & 18,44 & 4,7653 & 166,29 \\
\hline & $21 / 8 / 2005$ & 9:00 & 223,9 & 180,4 & 54,1 & 0,8658062 & 0,8364021 & 0,74 & 0,6189376 & 21,74 & 19,60 & 4,7653 & 299,01 \\
\hline & $21 / 8 / 2005$ & $10: 00$ & 266,6 & 221,7 & 69,6 & 0,8658062 & 0,8797075 & 0,74 & 0,6509836 & 24,40 & 21,36 & 4,7653 & 374,69 \\
\hline & $21 / 8 / 2005$ & $11: 00$ & 290,1 & 249,8 & 79,2 & 0,8658062 & 0,9026091 & 0,74 & 0,6679307 & 25,91 & 23,59 & 4,7653 & 415,64 \\
\hline & $21 / 8 / 2005$ & $12: 00$ & 292,2 & 264,2 & 82,1 & 0,8658062 & 0,9095690 & 0,74 & 0,6730810 & 27,51 & 25,45 & 4,7653 & 428,36 \\
\hline & $21 / 8 / 2005$ & $13: 00$ & 252,8 & 276,1 & 76,1 & 0,8658062 & 0,9023645 & 0,74 & 0,6677497 & 28,40 & 26,69 & 4,7653 & 402,59 \\
\hline & $21 / 8 / 2005$ & $14: 00$ & 216,9 & 256,9 & 65,9 & 0,8658062 & 0,8792248 & 0,74 & 0,6506263 & 28,83 & 27,88 & 4,7653 & 352,46 \\
\hline & $21 / 8 / 2005$ & $15: 00$ & 153,1 & 224,3 & 49,2 & 0,8658062 & 0,8354149 & 0,74 & 0,6182070 & 29,37 & 29,05 & 4,7653 & 271,42 \\
\hline & $21 / 8 / 2005$ & $16: 00$ & 72,8 & 165 & 28,3 & 0,8658062 & 0,7636621 & 0,74 & 0,5651099 & 29,17 & 29,76 & 4,7653 & 162,15 \\
\hline & $21 / 8 / 2005$ & $17: 00$ & 8,3 & 61 & 7,9 & 0,8658062 & 0,6562095 & 0,74 & 0,4855951 & 27,82 & 29,59 & 4,7653 & 39,76 \\
\hline
\end{tabular}

\begin{tabular}{|c|c|c|c|c|c|c|c|c|c|c|c|c|c|}
\hline Vidro & Data & Horário & $\begin{array}{c}\text { Radiação } \\
\text { Direta } \\
\left(W / m^{2}\right)\end{array}$ & $\begin{array}{c}\text { Radiação } \\
\text { Difusa Céu } \\
\left(\mathrm{W} / \mathrm{m}^{2}\right)\end{array}$ & $\begin{array}{c}\text { Radiação } \\
\text { Refletida } \\
\left(\mathrm{W} / \mathrm{m}^{2}\right)\end{array}$ & FCS $(609)$ & $\begin{array}{c}\text { FCS } \\
\text { (referência) }\end{array}$ & CAC & FCS & te $\left({ }^{\circ} \mathrm{C}\right)$ & $\mathrm{ti}\left({ }^{\circ} \mathrm{C}\right)$ & $\mathrm{U}\left(\mathrm{W} / \mathrm{m}^{2} \mathrm{C}\right)$ & $q\left(W / m^{2}\right)$ \\
\hline \multirow{11}{*}{ 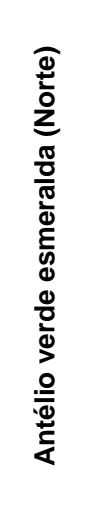 } & $21 / 8 / 2005$ & 7:00 & 1,7 & 39 & 4,8 & 0,8658062 & 0,6590731 & 0,44 & 0,2899921 & 16,72 & 17,90 & 3,0352 & 13,60 \\
\hline & $21 / 8 / 2005$ & 8:00 & 83,6 & 153,1 & 28,1 & 0,8658062 & 0,7654683 & 0,44 & 0,3368060 & 19,04 & 18,94 & 3,0352 & 97,48 \\
\hline & $21 / 8 / 2005$ & 9:00 & 223,9 & 180,4 & 54,1 & 0,8658062 & 0,8364021 & 0,44 & 0,3680169 & 21,74 & 20,16 & 3,0352 & 176,53 \\
\hline & $21 / 8 / 2005$ & $10: 00$ & 266,6 & 221,7 & 69,6 & 0,8658062 & 0,8797075 & 0,44 & 0,3870713 & 24,40 & 21,88 & 3,0352 & 221,81 \\
\hline & $21 / 8 / 2005$ & $11: 00$ & 290,1 & 249,8 & 79,2 & 0,8658062 & 0,9026091 & 0,44 & 0,3971480 & 25,91 & 23,91 & 3,0352 & 246,63 \\
\hline & $21 / 8 / 2005$ & $12: 00$ & 292,2 & 264,2 & 82,1 & 0,8658062 & 0,9095690 & 0,44 & 0,4002103 & 27,51 & 25,63 & 3,0352 & 254,56 \\
\hline & $21 / 8 / 2005$ & $13: 00$ & 252,8 & 276,1 & 76,1 & 0,8658062 & 0,9023645 & 0,44 & 0,3970404 & 28,40 & 26,98 & 3,0352 & 238,86 \\
\hline & $21 / 8 / 2005$ & $14: 00$ & 216,9 & 256,9 & 65,9 & 0,8658062 & 0,8792248 & 0,44 & 0,3868589 & 28,83 & 28,24 & 3,0352 & 208,68 \\
\hline & $21 / 8 / 2005$ & $15: 00$ & 153,1 & 224,3 & 49,2 & 0,8658062 & 0,8354149 & 0,44 & 0,3675826 & 29,37 & 29,28 & 3,0352 & 160,75 \\
\hline & $21 / 8 / 2005$ & $16: 00$ & 72,8 & 165 & 28,3 & 0,8658062 & 0,7636621 & 0,44 & 0,3360113 & 29,17 & 29,96 & 3,0352 & 95,70 \\
\hline & 21/8/2005 & $17: 00$ & 8,3 & 61 & 7,9 & 0,8658062 & 0,6562095 & 0,44 & 0,2887322 & 27,82 & 29,90 & 3,0352 & 22,32 \\
\hline
\end{tabular}




\begin{tabular}{|c|c|c|c|c|c|c|c|c|c|c|c|c|c|}
\hline Vidro & Data & Horário & $\begin{array}{c}\text { Radiação } \\
\text { Direta } \\
\left(W / m^{2}\right)\end{array}$ & $\begin{array}{c}\text { Radiação } \\
\text { Difusa Céu } \\
\left(\mathrm{W} / \mathrm{m}^{2}\right)\end{array}$ & $\begin{array}{c}\text { Radiação } \\
\text { Refletida } \\
\left(\mathrm{W} / \mathrm{m}^{2}\right)\end{array}$ & FCS $(609)$ & $\begin{array}{c}\text { FCS } \\
\text { (referência) }\end{array}$ & CAC & FCS & te $\left({ }^{\circ} \mathrm{C}\right)$ & $\mathrm{ti}\left({ }^{\circ} \mathrm{C}\right)$ & $\mathrm{U}\left(\mathrm{W} / \mathrm{m}^{2} \mathrm{C}\right)$ & $q\left(W / m^{2}\right)$ \\
\hline \multirow{11}{*}{ 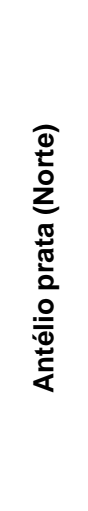 } & $21 / 8 / 2005$ & $7: 00$ & 1,7 & 39 & 4,8 & 0,8658062 & 0,6590731 & 0,55 & 0,3624902 & 16,72 & 17,36 & 3,0537 & 19,52 \\
\hline & $21 / 8 / 2005$ & $8: 00$ & 83,6 & 153,1 & 28,1 & 0,8658062 & 0,7654683 & 0,55 & 0,4210075 & 19,04 & 18,31 & 3,0537 & 123,70 \\
\hline & $21 / 8 / 2005$ & $9: 00$ & 223,9 & 180,4 & 54,1 & 0,8658062 & 0,8364021 & 0,55 & 0,4600212 & 21,74 & 19,48 & 3,0537 & 221,57 \\
\hline & $21 / 8 / 2005$ & $10: 00$ & 266,6 & 221,7 & 69,6 & 0,8658062 & 0,8797075 & 0,55 & 0,4838391 & 24,40 & 21,31 & 3,0537 & 277,13 \\
\hline & $21 / 8 / 2005$ & $11: 00$ & 290,1 & 249,8 & 79,2 & 0,8658062 & 0,9026091 & 0,55 & 0,4964350 & 25,91 & 23,32 & 3,0537 & 308,61 \\
\hline & $21 / 8 / 2005$ & $12: 00$ & 292,2 & 264,2 & 82,1 & 0,8658062 & 0,9095690 & 0,55 & 0,5002624 & 27,51 & 24,99 & 3,0537 & 318,78 \\
\hline & $21 / 8 / 2005$ & $13: 00$ & 252,8 & 276,1 & 76,1 & 0,8658062 & 0,9023645 & 0,55 & 0,4963005 & 28,40 & 26,39 & 3,0537 & 299,33 \\
\hline & $21 / 8 / 2005$ & $14: 00$ & 216,9 & 256,9 & 65,9 & 0,8658062 & 0,8792248 & 0,55 & 0,4835736 & 28,83 & 27,76 & 3,0537 & 261,87 \\
\hline & $21 / 8 / 2005$ & $15: 00$ & 153,1 & 224,3 & 49,2 & 0,8658062 & 0,8354149 & 0,55 & 0,4594782 & 29,37 & 28,91 & 3,0537 & 202,01 \\
\hline & $21 / 8 / 2005$ & $16: 00$ & 72,8 & 165 & 28,3 & 0,8658062 & 0,7636621 & 0,55 & 0,4200141 & 29,17 & 29,68 & 3,0537 & 121,06 \\
\hline & $21 / 8 / 2005$ & $17: 00$ & 8,3 & 61 & 7,9 & 0,8658062 & 0,6562095 & 0,55 & 0,3609152 & 27,82 & 29,70 & 3,0537 & 30,05 \\
\hline
\end{tabular}

\begin{tabular}{|c|c|c|c|c|c|c|c|c|c|c|c|c|c|}
\hline Vidro & Data & Horário & $\begin{array}{c}\text { Radiação } \\
\text { Direta } \\
\left(\mathrm{W} / \mathrm{m}^{2}\right)\end{array}$ & $\begin{array}{c}\text { Radiação } \\
\text { Difusa Céu } \\
\left(\mathrm{W} / \mathrm{m}^{2}\right)\end{array}$ & $\begin{array}{c}\text { Radiação } \\
\text { Refletida } \\
\left(\mathrm{W} / \mathrm{m}^{2}\right)\end{array}$ & FCS $(609)$ & $\begin{array}{c}\text { FCS } \\
\text { (referência) }\end{array}$ & CAC & FCS & te $\left({ }^{\circ} \mathrm{C}\right)$ & $\mathrm{ti}\left({ }^{\circ} \mathrm{C}\right)$ & $\mathrm{U}\left(\mathrm{W} / \mathrm{m}^{2} \mathrm{C}\right)$ & $q\left(W / m^{2}\right)$ \\
\hline \multirow{11}{*}{ 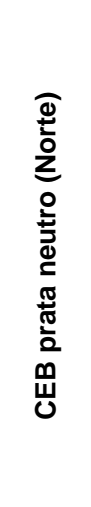 } & $21 / 8 / 2005$ & $7: 00$ & 1,7 & 39 & 4,8 & 0,8760888 & 0,7086479 & 0,27 & 0,1913349 & 16,72 & 17,60 & 2,9515 & 8,07 \\
\hline & $21 / 8 / 2005$ & $8: 00$ & 83,6 & 153,1 & 28,1 & 0,8760888 & 0,7942725 & 0,27 & 0,2144536 & 19,04 & 18,20 & 2,9515 & 63,27 \\
\hline & $21 / 8 / 2005$ & $9: 00$ & 223,9 & 180,4 & 54,1 & 0,8760888 & 0,8518333 & 0,27 & 0,2299950 & 21,74 & 19,10 & 2,9515 & 114,77 \\
\hline & 21/8/2005 & $10: 00$ & 266,6 & 221,7 & 69,6 & 0,8760888 & 0,8876880 & 0,27 & 0,2396758 & 24,40 & 20,63 & 2,9515 & 143,93 \\
\hline & $21 / 8 / 2005$ & $11: 00$ & 290,1 & 249,8 & 79,2 & 0,8760888 & 0,9070466 & 0,27 & 0,2449026 & 25,91 & 22,41 & 2,9515 & 159,20 \\
\hline & $21 / 8 / 2005$ & $12: 00$ & 292,2 & 264,2 & 82,1 & 0,8760888 & 0,9130055 & 0,27 & 0,2465115 & 27,51 & 23,84 & 2,9515 & 164,77 \\
\hline & $21 / 8 / 2005$ & $13: 00$ & 252,8 & 276,1 & 76,1 & 0,8760888 & 0,9068379 & 0,27 & 0,2448462 & 28,40 & 24,97 & 2,9515 & 155,34 \\
\hline & $21 / 8 / 2005$ & $14: 00$ & 216,9 & 256,9 & 65,9 & 0,8760888 & 0,8872835 & 0,27 & 0,2395666 & 28,83 & 26,10 & 2,9515 & 136,39 \\
\hline & $21 / 8 / 2005$ & $15: 00$ & 153,1 & 224,3 & 49,2 & 0,8760888 & 0,8510243 & 0,27 & 0,2297766 & 29,37 & 27,23 & 2,9515 & 106,20 \\
\hline & $21 / 8 / 2005$ & $16: 00$ & 72,8 & 165 & 28,3 & 0,8760888 & 0,7928170 & 0,27 & 0,2140606 & 29,17 & 28,04 & 2,9515 & 64,62 \\
\hline & 21/8/2005 & $17: 00$ & 8,3 & 61 & 7,9 & 0,8760888 & 0,7063364 & 0,27 & 0,1907108 & 27,82 & 28,29 & 2,9515 & 16,50 \\
\hline
\end{tabular}




\begin{tabular}{|c|c|c|c|c|c|c|c|c|c|c|c|c|c|}
\hline Vidro & Data & Horário & $\begin{array}{c}\text { Radiação } \\
\text { Direta } \\
\left(W / m^{2}\right)\end{array}$ & $\begin{array}{c}\text { Radiação } \\
\text { Difusa Céu } \\
\left(W / m^{2}\right)\end{array}$ & $\begin{array}{c}\text { Radiação } \\
\text { Refletida } \\
\left(\mathrm{W} / \mathrm{m}^{2}\right)\end{array}$ & FCS (60) & $\begin{array}{c}\text { FCS } \\
\text { (referência) }\end{array}$ & CAC & FCS & te $\left({ }^{\circ} \mathrm{C}\right)$ & ti $\left({ }^{\circ} \mathrm{C}\right)$ & $\mathrm{U}\left(\mathrm{W} / \mathrm{m}^{2} \mathrm{C}\right)$ & $q\left(W / m^{2}\right)$ \\
\hline \multirow{11}{*}{ 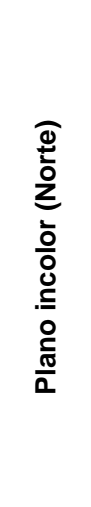 } & 23/2/2006 & $7: 00$ & 0 & 101,2 & 13,4 & 0,8658062 & 0 & 0,86 & 0 & 21,31 & 21,44 & 4,7653 & 84,71 \\
\hline & 23/2/2006 & $8: 00$ & 2,2 & 204,1 & 28,4 & 0,8658062 & 0,1697477 & 0,86 & 0,1459830 & 22,87 & 21,83 & 4,7653 & 178,38 \\
\hline & $23 / 2 / 2006$ & $9: 00$ & 13,8 & 303,1 & 46,6 & 0,8658062 & 0,3657647 & 0,86 & 0,3145576 & 24,32 & 22,55 & 4,7653 & 273,14 \\
\hline & 23/2/2006 & $10: 00$ & 47,3 & 358 & 70,4 & 0,8658062 & 0,4836914 & 0,86 & 0,4159746 & 25,83 & 23,58 & 4,7653 & 349,37 \\
\hline & $23 / 2 / 2006$ & $11: 00$ & 9,1 & 375,8 & 49,9 & 0,8658062 & 0,5489763 & 0,86 & 0,4721196 & 26,79 & 24,63 & 4,7653 & 331,59 \\
\hline & $23 / 2 / 2006$ & $12: 00$ & 58,3 & 427,7 & 81,2 & 0,8658062 & 0,5699132 & 0,86 & 0,4901254 & 28,42 & 25,54 & 4,7653 & 421,23 \\
\hline & 23/2/2006 & $13: 00$ & 67,1 & 406 & 84 & 0,8658062 & 0,5497962 & 0,86 & 0,4728247 & 29,19 & 26,38 & 4,7653 & 409,97 \\
\hline & $23 / 2 / 2006$ & $14: 00$ & 34,3 & 397 & 67,4 & 0,8658062 & 0,4855178 & 0,86 & 0,4175453 & 29,55 & 27,31 & 4,7653 & 370,79 \\
\hline & $23 / 2 / 2006$ & $15: 00$ & 36,8 & 317,8 & 65 & 0,8658062 & 0,3690361 & 0,86 & 0,3173710 & 30,27 & 27,95 & 4,7653 & 307,74 \\
\hline & $23 / 2 / 2006$ & $16: 00$ & 7,5 & 255,6 & 43,3 & 0,8658062 & 0,1755328 & 0,86 & 0,1509582 & 30,44 & 28,47 & 4,7653 & 233,08 \\
\hline & $23 / 2 / 2006$ & $17: 00$ & 0 & 156,8 & 23 & 0,8658062 & 0 & 0,86 & 0 & 29,72 & 28,70 & 4,7653 & 138,75 \\
\hline
\end{tabular}

\begin{tabular}{|c|c|c|c|c|c|c|c|c|c|c|c|c|c|}
\hline Vidro & Data & Horário & $\begin{array}{c}\text { Radiação } \\
\text { Direta } \\
\left(W / m^{2}\right)\end{array}$ & $\begin{array}{c}\text { Radiação } \\
\text { Difusa Céu } \\
\left(\mathrm{W} / \mathrm{m}^{2}\right)\end{array}$ & $\begin{array}{c}\text { Radiação } \\
\text { Refletida } \\
\left(\mathrm{W} / \mathrm{m}^{2}\right)\end{array}$ & FCS $(609)$ & $\begin{array}{c}\text { FCS } \\
\text { (referência) }\end{array}$ & CAC & FCS & te $\left({ }^{\circ} \mathrm{C}\right)$ & $\mathrm{ti}\left({ }^{\circ} \mathrm{C}\right)$ & $\mathrm{U}\left(\mathrm{W} / \mathrm{m}^{2} \mathrm{C}\right)$ & $q\left(W / m^{2}\right)$ \\
\hline \multirow{11}{*}{$\begin{array}{l}\widehat{\Phi} \\
\frac{ \pm}{0} \\
\text { Z } \\
\frac{0}{0} \\
\frac{0}{0} \\
\frac{0}{0} \\
0 \\
\frac{\pi}{0}\end{array}$} & $23 / 2 / 2006$ & $7: 00$ & 0 & 101,2 & 13,4 & 0,8658062 & 0 & 0,74 & 0 & 21,31 & 21,21 & 4,7653 & 73,92 \\
\hline & 23/2/2006 & $8: 00$ & 2,2 & 204,1 & 28,4 & 0,8658062 & 0,1697477 & 0,74 & 0,1256133 & 22,87 & 21,47 & 4,7653 & 155,90 \\
\hline & 23/2/2006 & 9:00 & 13,8 & 303,1 & 46,6 & 0,8658062 & 0,3657647 & 0,74 & 0,2706659 & 24,32 & 22,28 & 4,7653 & 237,52 \\
\hline & 23/2/2006 & $10: 00$ & 47,3 & 358 & 70,4 & 0,8658062 & 0,4836914 & 0,74 & 0,3579316 & 25,83 & 23,36 & 4,7653 & 303,17 \\
\hline & $23 / 2 / 2006$ & $11: 00$ & 9,1 & 375,8 & 49,9 & 0,8658062 & 0,5489763 & 0,74 & 0,4062425 & 26,79 & 24,44 & 4,7653 & 287,67 \\
\hline & 23/2/2006 & $12: 00$ & 58,3 & 427,7 & 81,2 & 0,8658062 & 0,5699132 & 0,74 & 0,4217358 & 28,42 & 25,45 & 4,7653 & 364,78 \\
\hline & 23/2/2006 & $13: 00$ & 67,1 & 406 & 84 & 0,8658062 & 0,5497962 & 0,74 & 0,4068492 & 29,19 & 26,27 & 4,7653 & 355,16 \\
\hline & 23/2/2006 & $14: 00$ & 34,3 & 397 & 67,4 & 0,8658062 & 0,4855178 & 0,74 & 0,3592832 & 29,55 & 27,13 & 4,7653 & 321,40 \\
\hline & 23/2/2006 & $15: 00$ & 36,8 & 317,8 & 65 & 0,8658062 & 0,3690361 & 0,74 & 0,2730867 & 30,27 & 27,76 & 4,7653 & 267,25 \\
\hline & 23/2/2006 & $16: 00$ & 7,5 & 255,6 & 43,3 & 0,8658062 & 0,1755328 & 0,74 & 0,1298943 & 30,44 & 28,30 & 4,7653 & 202,68 \\
\hline & 23/2/2006 & $17: 00$ & 0 & 156,8 & 23 & 0,8658062 & 0 & 0,74 & 0 & 29,72 & 28,59 & 4,7653 & 120,57 \\
\hline
\end{tabular}




\begin{tabular}{|c|c|c|c|c|c|c|c|c|c|c|c|c|c|}
\hline Vidro & Data & Horário & $\begin{array}{c}\text { Radiação } \\
\text { Direta } \\
\left(\mathrm{W} / \mathbf{m}^{2}\right)\end{array}$ & $\begin{array}{c}\text { Radiação } \\
\text { Difusa Céu } \\
\left(W / m^{2}\right)\end{array}$ & $\begin{array}{c}\text { Radiação } \\
\text { Refletida } \\
\left(\mathrm{W} / \mathbf{m}^{2}\right)\end{array}$ & FCS $(609)$ & $\begin{array}{c}\text { FCS } \\
\text { (referência) }\end{array}$ & CAC & FCS & te $\left({ }^{\circ} \mathrm{C}\right)$ & $\mathrm{ti}\left({ }^{\circ} \mathrm{C}\right)$ & $\mathrm{U}\left(\mathrm{W} / \mathrm{m}^{2} \mathrm{C}\right)$ & $q\left(W / m^{2}\right)$ \\
\hline \multirow{11}{*}{ 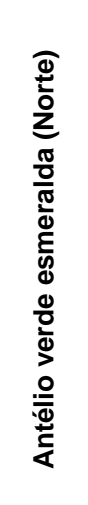 } & $23 / 2 / 2006$ & 7:00 & 0 & 101,2 & 13,4 & 0,8658062 & 0 & 0,44 & 0 & 21,31 & 21,19 & 3,0352 & 44,02 \\
\hline & $23 / 2 / 2006$ & $8: 00$ & 2,2 & 204,1 & 28,4 & 0,8658062 & 0,1697477 & 0,44 & 0,0746890 & 22,87 & 21,35 & 3,0352 & 93,36 \\
\hline & 23/2/2006 & $9: 00$ & 13,8 & 303,1 & 46,6 & 0,8658062 & 0,3657647 & 0,44 & 0,1609365 & 24,32 & 22,04 & 3,0352 & 142,36 \\
\hline & $23 / 2 / 2006$ & $10: 00$ & 47,3 & 358 & 70,4 & 0,8658062 & 0,4836914 & 0,44 & 0,2128242 & 25,83 & 23,14 & 3,0352 & 181,42 \\
\hline & $23 / 2 / 2006$ & $11: 00$ & 9,1 & 375,8 & 49,9 & 0,8658062 & 0,5489763 & 0,44 & 0,2415496 & 26,79 & 24,13 & 3,0352 & 172,45 \\
\hline & $23 / 2 / 2006$ & $12: 00$ & 58,3 & 427,7 & 81,2 & 0,8658062 & 0,5699132 & 0,44 & 0,2507618 & 28,42 & 25,02 & 3,0352 & 218,80 \\
\hline & $23 / 2 / 2006$ & $13: 00$ & 67,1 & 406 & 84 & 0,8658062 & 0,5497962 & 0,44 & 0,2419103 & 29,19 & 25,87 & 3,0352 & 212,98 \\
\hline & 23/2/2006 & $14: 00$ & 34,3 & 397 & 67,4 & 0,8658062 & 0,4855178 & 0,44 & 0,2136278 & 29,55 & 26,61 & 3,0352 & 193,16 \\
\hline & $23 / 2 / 2006$ & $15: 00$ & 36,8 & 317,8 & 65 & 0,8658062 & 0,3690361 & 0,44 & 0,1623759 & 30,27 & 27,27 & 3,0352 & 160,90 \\
\hline & $23 / 2 / 2006$ & $16: 00$ & 7,5 & 255,6 & 43,3 & 0,8658062 & 0,1755328 & 0,44 & 0,0772344 & 30,44 & 27,76 & 3,0352 & 122,57 \\
\hline & $23 / 2 / 2006$ & $17: 00$ & 0 & 156,8 & 23 & 0,8658062 & 0 & 0,44 & 0 & 29,72 & 28,07 & 3,0352 & 73,50 \\
\hline
\end{tabular}

\begin{tabular}{|c|c|c|c|c|c|c|c|c|c|c|c|c|c|}
\hline Vidro & Data & Horário & $\begin{array}{c}\text { Radiação } \\
\text { Direta } \\
\left(W / m^{2}\right)\end{array}$ & $\begin{array}{c}\text { Radiação } \\
\text { Difusa Céu } \\
\left(W / m^{2}\right)\end{array}$ & $\begin{array}{c}\text { Radiação } \\
\text { Refletida } \\
\left(W / m^{2}\right)\end{array}$ & FCS $(609)$ & $\begin{array}{c}\text { FCS } \\
\text { (referência) }\end{array}$ & CAC & FCS & te $\left({ }^{\circ} \mathrm{C}\right)$ & $\mathrm{ti}\left({ }^{\circ} \mathrm{C}\right)$ & $\mathrm{U}\left(\mathrm{W} / \mathrm{m}^{2} \mathrm{C}\right)$ & $q\left(W / m^{2}\right)$ \\
\hline \multirow{11}{*}{ 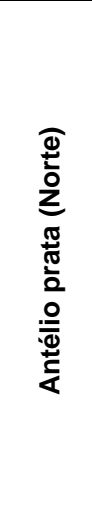 } & $23 / 2 / 2006$ & 7:00 & 0 & 101,2 & 13,4 & 0,8658062 & 0 & 0,55 & 0 & 21,31 & 21,35 & 3,0537 & 54,44 \\
\hline & 23/2/2006 & 8:00 & 2,2 & 204,1 & 28,4 & 0,8658062 & 0,1697477 & 0,55 & 0,0933612 & 22,87 & 21,59 & 3,0537 & 114,83 \\
\hline & 23/2/2006 & 9:00 & 13,8 & 303,1 & 46,6 & 0,8658062 & 0,3657647 & 0,55 & 0,2011706 & 24,32 & 22,38 & 3,0537 & 175,23 \\
\hline & 23/2/2006 & $10: 00$ & 47,3 & 358 & 70,4 & 0,8658062 & 0,4836914 & 0,55 & 0,2660303 & 25,83 & 23,42 & 3,0537 & 223,92 \\
\hline & 23/2/2006 & $11: 00$ & 9,1 & 375,8 & 49,9 & 0,8658062 & 0,5489763 & 0,55 & 0,3019370 & 26,79 & 24,56 & 3,0537 & 212,28 \\
\hline & 23/2/2006 & $12: 00$ & 58,3 & 427,7 & 81,2 & 0,8658062 & 0,5699132 & 0,55 & 0,3134523 & 28,42 & 25,41 & 3,0537 & 269,78 \\
\hline & 23/2/2006 & $13: 00$ & 67,1 & 406 & 84 & 0,8658062 & 0,5497962 & 0,55 & 0,3023879 & 29,19 & 26,30 & 3,0537 & 262,45 \\
\hline & $23 / 2 / 2006$ & $14: 00$ & 34,3 & 397 & 67,4 & 0,8658062 & 0,4855178 & 0,55 & 0,2670348 & 29,55 & 27,25 & 3,0537 & 237,33 \\
\hline & 23/2/2006 & $15: 00$ & 36,8 & 317,8 & 65 & 0,8658062 & 0,3690361 & 0,55 & 0,2029699 & 30,27 & 27,95 & 3,0537 & 196,84 \\
\hline & 23/2/2006 & $16: 00$ & 7,5 & 255,6 & 43,3 & 0,8658062 & 0,1755328 & 0,55 & 0,0965430 & 30,44 & 28,48 & 3,0537 & 149,02 \\
\hline & 23/2/2006 & $17: 00$ & 0 & 156,8 & 23 & 0,8658062 & 0 & 0,55 & 0 & 29,72 & 28,82 & 3,0537 & 88,37 \\
\hline
\end{tabular}




\begin{tabular}{|c|c|c|c|c|c|c|c|c|c|c|c|c|c|}
\hline Vidro & Data & Horário & $\begin{array}{l}\text { Radiação } \\
\text { Direta } \\
\left(W / m^{2}\right)\end{array}$ & $\begin{array}{c}\text { Radiação } \\
\text { Difusa Céu } \\
\left(W / m^{2}\right)\end{array}$ & $\begin{array}{c}\text { Radiação } \\
\text { Refletida } \\
\left(\mathrm{W} / \mathrm{m}^{2}\right)\end{array}$ & FCS (609) & $\begin{array}{c}\text { FCS } \\
\text { (referência) }\end{array}$ & CAC & FCS & te $\left({ }^{\circ} \mathrm{C}\right)$ & $\mathrm{ti}\left({ }^{\circ} \mathrm{C}\right)$ & $\mathrm{U}\left(\mathrm{W} / \mathrm{m}^{2} \mathrm{C}\right)$ & $q\left(W / m^{2}\right)$ \\
\hline \multirow{11}{*}{ 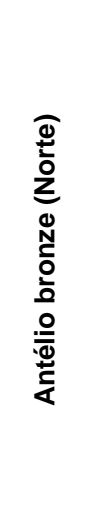 } & 23/2/2006 & 7:00 & 0 & 101,2 & 13,4 & 0,8658062 & 0 & 0,51 & 0 & 21,31 & 21,21 & 3,0537 & 50,90 \\
\hline & 23/2/2006 & 8:00 & 2,2 & 204,1 & 28,4 & 0,8658062 & 0,1697477 & 0,51 & 0,0865713 & 22,87 & 21,41 & 3,0537 & 107,30 \\
\hline & 23/2/2006 & 9:00 & 13,8 & 303,1 & 46,6 & 0,8658062 & 0,3657647 & 0,51 & 0,1865400 & 24,32 & 22,01 & 3,0537 & 164,04 \\
\hline & 23/2/2006 & $10: 00$ & 47,3 & 358 & 70,4 & 0,8658062 & 0,4836914 & 0,51 & 0,2466826 & 25,83 & 22,98 & 3,0537 & 209,54 \\
\hline & 23/2/2006 & 11:00 & 9,1 & 375,8 & 49,9 & 0,8658062 & 0,5489763 & 0,51 & 0,2799779 & 26,79 & 23,99 & 3,0537 & 199,09 \\
\hline & 23/2/2006 & $12: 00$ & 58,3 & 427,7 & 81,2 & 0,8658062 & 0,5699132 & 0,51 & 0,2906557 & 28,42 & 24,77 & 3,0537 & 252,79 \\
\hline & 23/2/2006 & $13: 00$ & 67,1 & 406 & 84 & 0,8658062 & 0,5497962 & 0,51 & 0,2803960 & 29,19 & 25,58 & 3,0537 & 246,19 \\
\hline & 23/2/2006 & $14: 00$ & 34,3 & 397 & 67,4 & 0,8658062 & 0,4855178 & 0,51 & 0,2476140 & 29,55 & 26,39 & 3,0537 & 223,20 \\
\hline & 23/2/2006 & $15: 00$ & 36,8 & 317,8 & 65 & 0,8658062 & 0,3690361 & 0,51 & 0,1882084 & 30,27 & 27,03 & 3,0537 & 185,82 \\
\hline & 23/2/2006 & $16: 00$ & 7,5 & 255,6 & 43,3 & 0,8658062 & 0,1755328 & 0,51 & 0,0895217 & 30,44 & 27,59 & 3,0537 & 141,36 \\
\hline & 23/2/2006 & $17: 00$ & 0 & 156,8 & 23 & 0,8658062 & 0 & 0,51 & 0 & 29,72 & 27,92 & 3,0537 & 84,90 \\
\hline
\end{tabular}

\begin{tabular}{|c|c|c|c|c|c|c|c|c|c|c|c|c|c|}
\hline Vidro & Data & Horário & $\begin{array}{c}\text { Radiação } \\
\text { Direta } \\
\left(\mathrm{W} / \mathrm{m}^{2}\right)\end{array}$ & $\begin{array}{c}\text { Radiação } \\
\text { Difusa Céu } \\
\left(\mathrm{W} / \mathrm{m}^{2}\right)\end{array}$ & $\begin{array}{c}\text { Radiação } \\
\text { Refletida } \\
\left(\mathrm{W} / \mathrm{m}^{2}\right)\end{array}$ & FCS $(609)$ & $\begin{array}{c}\text { FCS } \\
\text { (referência) }\end{array}$ & CAC & FCS & te $\left({ }^{\circ} \mathrm{C}\right)$ & $\mathrm{ti}\left({ }^{\circ} \mathrm{C}\right)$ & $\mathrm{U}\left(\mathrm{W} / \mathrm{m}^{2} \mathrm{C}\right)$ & $q\left(W / m^{2}\right)$ \\
\hline \multirow{11}{*}{ 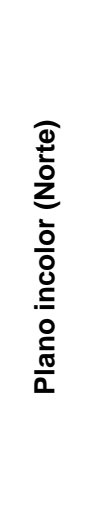 } & $5 / 3 / 2006$ & 7:00 & 0,1 & 95,7 & 12,8 & 0,8658062 & 0,0417172 & 0,86 & 0,0358768 & 21,59 & 22,79 & 4,7653 & 75,06 \\
\hline & $5 / 3 / 2006$ & $8: 00$ & 3,1 & 179 & 23,4 & 0,8658062 & 0,3275127 & 0,86 & 0,2816609 & 22,47 & 23,05 & 4,7653 & 148,78 \\
\hline & $5 / 3 / 2006$ & 9:00 & 59,2 & 267,4 & 59,6 & 0,8658062 & 0,4864290 & 0,86 & 0,4183289 & 24,82 & 23,56 & 4,7653 & 274,21 \\
\hline & $5 / 3 / 2006$ & $10: 00$ & 111,3 & 288,9 & 81,2 & 0,8658062 & 0,5872787 & 0,86 & 0,5050597 & 26,73 & 24,62 & 4,7653 & 341,88 \\
\hline & $5 / 3 / 2006$ & $11: 00$ & 53,8 & 410,1 & 70,7 & 0,8658062 & 0,6429761 & 0,86 & 0,5529595 & 27,80 & 26,00 & 4,7653 & 396,33 \\
\hline & $5 / 3 / 2006$ & $12: 00$ & 105 & 386,4 & 87,7 & 0,8658062 & 0,6608259 & 0,86 & 0,5683103 & 28,70 & 27,07 & 4,7653 & 420,46 \\
\hline & $5 / 3 / 2006$ & $13: 00$ & 8,8 & 358,8 & 46,6 & 0,8658062 & 0,6436585 & 0,86 & 0,5535463 & 28,62 & 27,93 & 4,7653 & 310,02 \\
\hline & $5 / 3 / 2006$ & $14: 00$ & 22,6 & 377,6 & 54,7 & 0,8658062 & 0,5888065 & 0,86 & 0,5063736 & 28,93 & 28,57 & 4,7653 & 335,03 \\
\hline & $5 / 3 / 2006$ & $15: 00$ & 14,9 & 312,9 & 44,4 & 0,8658062 & 0,4891547 & 0,86 & 0,4206731 & 29,16 & 28,96 & 4,7653 & 273,26 \\
\hline & $5 / 3 / 2006$ & $16: 00$ & 0,6 & 143,1 & 17,5 & 0,8658062 & 0,3321307 & 0,86 & 0,2856324 & 27,92 & 29,16 & 4,7653 & 113,86 \\
\hline & $5 / 3 / 2006$ & $17: 00$ & 0,6 & 141,1 & 20,3 & 0,8658062 & 0,0583436 & 0,86 & 0,0501755 & 28,13 & 28,78 & 4,7653 & 117,10 \\
\hline
\end{tabular}




\begin{tabular}{|c|c|c|c|c|c|c|c|c|c|c|c|c|c|}
\hline Vidro & Data & Horário & $\begin{array}{c}\text { Radiação } \\
\text { Direta } \\
\left(W / m^{2}\right)\end{array}$ & $\begin{array}{c}\text { Radiação } \\
\text { Difusa Céu } \\
\left(W / m^{2}\right)\end{array}$ & $\begin{array}{c}\text { Radiação } \\
\text { Refletida } \\
\left(W / m^{2}\right)\end{array}$ & FCS (60) & $\begin{array}{c}\text { FCS } \\
\text { (referência) }\end{array}$ & CAC & FCS & te $\left({ }^{\circ} \mathrm{C}\right)$ & $\mathrm{ti}\left({ }^{\circ} \mathrm{C}\right)$ & $\mathrm{U}\left(\mathrm{W} / \mathrm{m}^{2} \mathrm{C}\right)$ & $q\left(W / m^{2}\right)$ \\
\hline \multirow{11}{*}{ 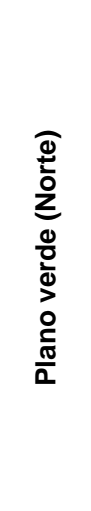 } & $5 / 3 / 2006$ & 7:00 & 0,1 & 95,7 & 12,8 & 0,8658062 & 0,0417172 & 0,74 & 0,0308707 & 21,59 & 22,23 & 4,7653 & 66,46 \\
\hline & $5 / 3 / 2006$ & $8: 00$ & 3,1 & 179 & 23,4 & 0,8658062 & 0,3275127 & 0,74 & 0,2423594 & 22,47 & 22,50 & 4,7653 & 130,25 \\
\hline & $5 / 3 / 2006$ & $9: 00$ & 59,2 & 267,4 & 59,6 & 0,8658062 & 0,4864290 & 0,74 & 0,3599575 & 24,82 & 22,84 & 4,7653 & 240,24 \\
\hline & $5 / 3 / 2006$ & $10: 00$ & 111,3 & 288,9 & 81,2 & 0,8658062 & 0,5872787 & 0,74 & 0,4345863 & 26,73 & 23,97 & 4,7653 & 298,65 \\
\hline & $5 / 3 / 2006$ & $11: 00$ & 53,8 & 410,1 & 70,7 & 0,8658062 & 0,6429761 & 0,74 & 0,4758023 & 27,80 & 25,57 & 4,7653 & 344,28 \\
\hline & $5 / 3 / 2006$ & $12: 00$ & 105 & 386,4 & 87,7 & 0,8658062 & 0,6608259 & 0,74 & 0,4890112 & 28,70 & 26,87 & 4,7653 & 363,82 \\
\hline & $5 / 3 / 2006$ & $13: 00$ & 8,8 & 358,8 & 46,6 & 0,8658062 & 0,6436585 & 0,74 & 0,4763073 & 28,62 & 27,66 & 4,7653 & 268,54 \\
\hline & $5 / 3 / 2006$ & $14: 00$ & 22,6 & 377,6 & 54,7 & 0,8658062 & 0,5888065 & 0,74 & 0,4357168 & 28,93 & 28,28 & 4,7653 & 289,92 \\
\hline & $5 / 3 / 2006$ & $15: 00$ & 14,9 & 312,9 & 44,4 & 0,8658062 & 0,4891547 & 0,74 & 0,3619745 & 29,16 & 28,63 & 4,7653 & 236,86 \\
\hline & $5 / 3 / 2006$ & $16: 00$ & 0,6 & 143,1 & 17,5 & 0,8658062 & 0,3321307 & 0,74 & 0,2457767 & 27,92 & 28,91 & 4,7653 & 98,35 \\
\hline & $5 / 3 / 2006$ & $17: 00$ & 0,6 & 141,1 & 20,3 & 0,8658062 & 0,0583436 & 0,74 & 0,0431742 & 28,13 & 28,46 & 4,7653 & 101,89 \\
\hline
\end{tabular}

\begin{tabular}{|c|c|c|c|c|c|c|c|c|c|c|c|c|c|}
\hline Vidro & Data & Horário & $\begin{array}{c}\text { Radiação } \\
\text { Direta } \\
\left(W / m^{2}\right)\end{array}$ & $\begin{array}{c}\text { Radiação } \\
\text { Difusa Céu } \\
\left(W / m^{2}\right)\end{array}$ & $\begin{array}{c}\text { Radiação } \\
\text { Refletida } \\
\left(W / m^{2}\right)\end{array}$ & FCS $(609)$ & $\begin{array}{c}\text { FCS } \\
\text { (referência) }\end{array}$ & CAC & FCS & te $\left({ }^{\circ} \mathrm{C}\right)$ & $\mathrm{ti}\left({ }^{\circ} \mathrm{C}\right)$ & $\mathrm{U}\left(\mathrm{W} / \mathrm{m}^{2} \mathrm{C}\right)$ & $q\left(W / m^{2}\right)$ \\
\hline \multirow{11}{*}{ 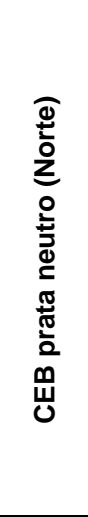 } & $5 / 3 / 2006$ & 7:00 & 0,1 & 95,7 & 12,8 & 0,8760888 & 0,0952086 & 0,27 & 0,0257063 & 21,59 & 22,29 & 2,9515 & 23,61 \\
\hline & $5 / 3 / 2006$ & 8:00 & 3,1 & 179 & 23,4 & 0,8760888 & 0,4257113 & 0,27 & 0,1149421 & 22,47 & 22,39 & 2,9515 & 48,46 \\
\hline & $5 / 3 / 2006$ & $9: 00$ & 59,2 & 267,4 & 59,6 & 0,8760888 & 0,5664969 & 0,27 & 0,1529542 & 24,82 & 22,56 & 2,9515 & 93,08 \\
\hline & $5 / 3 / 2006$ & $10: 00$ & 111,3 & 288,9 & 81,2 & 0,8760888 & 0,6503499 & 0,27 & 0,1755945 & 26,73 & 23,54 & 2,9515 & 116,52 \\
\hline & $5 / 3 / 2006$ & $11: 00$ & 53,8 & 410,1 & 70,7 & 0,8760888 & 0,6956424 & 0,27 & 0,1878235 & 27,80 & 24,71 & 2,9515 & 132,96 \\
\hline & $5 / 3 / 2006$ & $12: 00$ & 105 & 386,4 & 87,7 & 0,8760888 & 0,7100624 & 0,27 & 0,1917168 & 28,70 & 25,72 & 2,9515 & 141,09 \\
\hline & $5 / 3 / 2006$ & $13: 00$ & 8,8 & 358,8 & 46,6 & 0,8760888 & 0,6961944 & 0,27 & 0,1879725 & 28,62 & 26,49 & 2,9515 & 103,84 \\
\hline & $5 / 3 / 2006$ & $14: 00$ & 22,6 & 377,6 & 54,7 & 0,8760888 & 0,6515997 & 0,27 & 0,1759319 & 28,93 & 27,06 & 2,9515 & 111,74 \\
\hline & $5 / 3 / 2006$ & $15: 00$ & 14,9 & 312,9 & 44,4 & 0,8760888 & 0,5688053 & 0,27 & 0,1535774 & 29,16 & 27,54 & 2,9515 & 91,60 \\
\hline & $5 / 3 / 2006$ & $16: 00$ & 0,6 & 143,1 & 17,5 & 0,8760888 & 0,4300207 & 0,27 & 0,1161056 & 27,92 & 28,09 & 2,9515 & 37,55 \\
\hline & $5 / 3 / 2006$ & $17: 00$ & 0,6 & 141,1 & 20,3 & 0,8760888 & 0,1218148 & 0,27 & 0,0328900 & 28,13 & 27,77 & 2,9515 & 39,28 \\
\hline
\end{tabular}




\begin{tabular}{|c|c|c|c|c|c|c|c|c|c|c|c|c|c|}
\hline Vidro & Data & Horário & $\begin{array}{c}\text { Radiação } \\
\text { Direta } \\
\left(W / m^{2}\right)\end{array}$ & $\begin{array}{c}\text { Radiação } \\
\text { Difusa Céu } \\
\left(\mathrm{W} / \mathrm{m}^{2}\right)\end{array}$ & $\begin{array}{c}\text { Radiação } \\
\text { Refletida } \\
\left(\mathrm{W} / \mathrm{m}^{2}\right)\end{array}$ & FCS (609) & $\begin{array}{c}\text { FCS } \\
\text { (referência) }\end{array}$ & CAC & FCS & te $\left({ }^{\circ} \mathrm{C}\right)$ & $\operatorname{ti}\left({ }^{\circ} \mathrm{C}\right)$ & $\mathrm{U}\left(\mathrm{W} / \mathrm{m}^{2} \mathrm{C}\right)$ & $q\left(W / m^{2}\right)$ \\
\hline \multirow{9}{*}{ 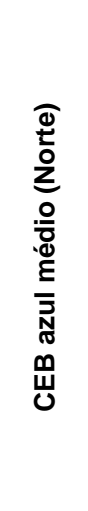 } & $5 / 3 / 2006$ & $8: 00$ & 3,1 & 179 & 23,4 & 0,8760888 & 0,4257113 & 0,39 & 0,1660274 & 22,47 & 22,54 & 2,9515 & 69,44 \\
\hline & $5 / 3 / 2006$ & $9: 00$ & 59,2 & 267,4 & 59,6 & 0,8760888 & 0,5664969 & 0,39 & 0,2209338 & 24,82 & 22,85 & 2,9515 & 130,62 \\
\hline & $5 / 3 / 2006$ & $10: 00$ & 111,3 & 288,9 & 81,2 & 0,8760888 & 0,6503499 & 0,39 & 0,2536364 & 26,73 & 24,02 & 2,9515 & 162,70 \\
\hline & $5 / 3 / 2006$ & $12: 00$ & 105 & 386,4 & 87,7 & 0,8760888 & 0,7100624 & 0,39 & 0,2769243 & 28,70 & 26,61 & 2,9515 & 197,25 \\
\hline & $5 / 3 / 2006$ & $13: 00$ & 8,8 & 358,8 & 46,6 & 0,8760888 & 0,6961944 & 0,39 & 0,2715158 & 28,62 & 27,32 & 2,9515 & 144,76 \\
\hline & $5 / 3 / 2006$ & $14: 00$ & 22,6 & 377,6 & 54,7 & 0,8760888 & 0,6515997 & 0,39 & 0,2541239 & 28,93 & 27,86 & 2,9515 & 156,60 \\
\hline & $5 / 3 / 2006$ & $15: 00$ & 14,9 & 312,9 & 44,4 & 0,8760888 & 0,5688053 & 0,39 & 0,2218341 & 29,16 & 28,29 & 2,9515 & 127,97 \\
\hline & $5 / 3 / 2006$ & $16: 00$ & 0,6 & 143,1 & 17,5 & 0,8760888 & 0,4300207 & 0,39 & 0,1677081 & 27,92 & 28,67 & 2,9515 & 52,76 \\
\hline & $5 / 3 / 2006$ & $17: 00$ & 0,6 & 141,1 & 20,3 & 0,8760888 & 0,1218148 & 0,39 & 0,0475078 & 28,13 & 28,33 & 2,9515 & 54,60 \\
\hline
\end{tabular}

\begin{tabular}{|c|c|c|c|c|c|c|c|c|c|c|c|c|c|}
\hline Vidro & Data & Horário & $\begin{array}{c}\text { Radiação } \\
\text { Direta } \\
\left(W / m^{2}\right)\end{array}$ & $\begin{array}{c}\text { Radiação } \\
\text { Difusa Céu } \\
\left(\mathrm{W} / \mathrm{m}^{2}\right)\end{array}$ & $\begin{array}{c}\text { Radiação } \\
\text { Refletida } \\
\left(W / m^{2}\right)\end{array}$ & FCS $(60)$ & $\begin{array}{c}\text { FCS } \\
\text { (referência) }\end{array}$ & CAC & FCS & te $\left({ }^{\circ} \mathrm{C}\right)$ & ti $\left({ }^{\circ} \mathrm{C}\right)$ & $\mathrm{U}\left(\mathrm{W} / \mathrm{m}^{2} \mathrm{C}\right)$ & $q\left(W / m^{2}\right)$ \\
\hline \multirow{9}{*}{ 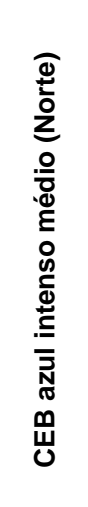 } & $5 / 3 / 2006$ & $8: 00$ & 3,1 & 179 & 23,4 & 0,8760888 & 0,4257113 & 0,31 & 0,1319705 & 22,47 & 22,43 & 2,9515 & 55,47 \\
\hline & $5 / 3 / 2006$ & $9: 00$ & 59,2 & 267,4 & 59,6 & 0,8760888 & 0,5664969 & 0,31 & 0,1756140 & 24,82 & 22,77 & 2,9515 & 105,24 \\
\hline & $5 / 3 / 2006$ & $10: 00$ & 111,3 & 288,9 & 81,2 & 0,8760888 & 0,6503499 & 0,31 & 0,2016085 & 26,73 & 23,89 & 2,9515 & 131,34 \\
\hline & $5 / 3 / 2006$ & $12: 00$ & 105 & 386,4 & 87,7 & 0,8760888 & 0,7100624 & 0,31 & 0,2201193 & 28,70 & 26,07 & 2,9515 & 159,65 \\
\hline & $5 / 3 / 2006$ & $13: 00$ & 8,8 & 358,8 & 46,6 & 0,8760888 & 0,6961944 & 0,31 & 0,2158203 & 28,62 & 26,76 & 2,9515 & 117,49 \\
\hline & $5 / 3 / 2006$ & $14: 00$ & 22,6 & 377,6 & 54,7 & 0,8760888 & 0,6515997 & 0,31 & 0,2019959 & 28,93 & 27,36 & 2,9515 & 126,59 \\
\hline & $5 / 3 / 2006$ & $15: 00$ & 14,9 & 312,9 & 44,4 & 0,8760888 & 0,5688053 & 0,31 & 0,1763296 & 29,16 & 27,85 & 2,9515 & 103,54 \\
\hline & $5 / 3 / 2006$ & $16: 00$ & 0,6 & 143,1 & 17,5 & 0,8760888 & 0,4300207 & 0,31 & 0,1333064 & 27,92 & 28,25 & 2,9515 & 42,73 \\
\hline & $5 / 3 / 2006$ & $17: 00$ & 0,6 & 141,1 & 20,3 & 0,8760888 & 0,1218148 & 0,31 & 0,0377626 & 28,13 & 28,03 & 2,9515 & 44,15 \\
\hline
\end{tabular}




\begin{tabular}{|c|c|c|c|c|c|c|c|c|c|c|c|c|c|}
\hline Vidro & Data & Horário & $\begin{array}{c}\text { Radiação } \\
\text { Direta } \\
\left(W / m^{2}\right)\end{array}$ & $\begin{array}{c}\text { Radiação } \\
\text { Difusa Céu } \\
\left(\mathrm{W} / \mathrm{m}^{2}\right)\end{array}$ & $\begin{array}{c}\text { Radiação } \\
\text { Refletida } \\
\left(\mathrm{W} / \mathrm{m}^{2}\right)\end{array}$ & FCS $(609)$ & $\begin{array}{c}\text { FCS } \\
\text { (referência) }\end{array}$ & CAC & FCS & te $\left({ }^{\circ} \mathrm{C}\right)$ & $\mathrm{ti}\left({ }^{\circ} \mathrm{C}\right)$ & $\mathrm{U}\left(\mathrm{W} / \mathrm{m}^{2} \mathrm{C}\right)$ & $q\left(W / m^{2}\right)$ \\
\hline \multirow{11}{*}{ 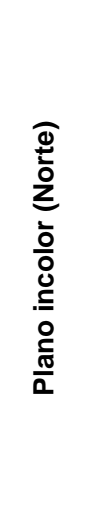 } & $21 / 3 / 2006$ & $7: 00$ & 7,7 & 90,6 & 13 & 0,8658062 & 0,3446635 & 0,86 & 0,2964106 & 21,11 & 21,38 & 4,7653 & 78,13 \\
\hline & $21 / 3 / 2006$ & $8: 00$ & 12,1 & 183,1 & 25,3 & 0,8658062 & 0,5235371 & 0,86 & 0,4502419 & 22,49 & 21,86 & 4,7653 & 163,60 \\
\hline & $21 / 3 / 2006$ & $9: 00$ & 98,3 & 250,8 & 57,5 & 0,8658062 & 0,6452467 & 0,86 & 0,5549121 & 24,63 & 22,57 & 4,7653 & 293,91 \\
\hline & $21 / 3 / 2006$ & $10: 00$ & 84,5 & 339,3 & 64,3 & 0,8658062 & 0,7223862 & 0,86 & 0,6212521 & 26,03 & 23,49 & 4,7653 & 365,11 \\
\hline & $21 / 3 / 2006$ & $11: 00$ & 120,9 & 364,5 & 77,5 & 0,8658062 & 0,7646486 & 0,86 & 0,6575978 & 27,22 & 24,60 & 4,7653 & 421,10 \\
\hline & $21 / 3 / 2006$ & $12: 00$ & 104,3 & 396,1 & 76,7 & 0,8658062 & 0,7781226 & 0,86 & 0,6691854 & 28,17 & 25,85 & 4,7653 & 432,88 \\
\hline & $21 / 3 / 2006$ & $13: 00$ & 61,8 & 401,2 & 65,4 & 0,8658062 & 0,7651407 & 0,86 & 0,6580210 & 28,38 & 30,12 & 4,7653 & 379,79 \\
\hline & $21 / 3 / 2006$ & $14: 00$ & 120,7 & 328,1 & 73 & 0,8658062 & 0,7236922 & 0,86 & 0,6223753 & 29,98 & 36,40 & 4,7653 & 343,20 \\
\hline & $21 / 3 / 2006$ & $15: 00$ & 30,7 & 296,2 & 44 & 0,8658062 & 0,6472805 & 0,86 & 0,5566612 & 29,71 & 33,95 & 4,7653 & 250,19 \\
\hline & $21 / 3 / 2006$ & $16: 00$ & 40,7 & 215,3 & 37 & 0,8658062 & 0,5269556 & 0,86 & 0,4531818 & 29,64 & 31,24 & 4,7653 & 198,70 \\
\hline & $21 / 3 / 2006$ & $17: 00$ & 6,9 & 109,8 & 15 & 0,8658062 & 0,3502819 & 0,86 & 0,3012425 & 29,14 & 30,26 & 4,7653 & 89,64 \\
\hline
\end{tabular}

\begin{tabular}{|c|c|c|c|c|c|c|c|c|c|c|c|c|c|}
\hline Vidro & Data & Horário & $\begin{array}{c}\text { Radiação } \\
\text { Direta } \\
\left(W / m^{2}\right)\end{array}$ & $\begin{array}{c}\text { Radiação } \\
\text { Difusa Céu } \\
\left(\mathrm{W} / \mathrm{m}^{2}\right)\end{array}$ & $\begin{array}{c}\text { Radiação } \\
\text { Refletida } \\
\left(\mathrm{W} / \mathrm{m}^{2}\right)\end{array}$ & FCS $(609)$ & $\begin{array}{c}\text { FCS } \\
\text { (referência) }\end{array}$ & CAC & FCS & te $\left({ }^{\circ} \mathrm{C}\right)$ & $\mathrm{ti}\left({ }^{\circ} \mathrm{C}\right)$ & $\mathrm{U}\left(\mathrm{W} / \mathrm{m}^{2} \mathrm{C}\right)$ & $q\left(W / m^{2}\right)$ \\
\hline \multirow{11}{*}{ 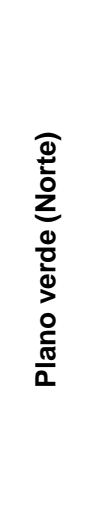 } & $21 / 3 / 2006$ & 7:00 & 7,7 & 90,6 & 13 & 0,8658062 & 0,3446635 & 0,74 & 0,2550510 & 21,11 & 21,13 & 4,7653 & 68,23 \\
\hline & $21 / 3 / 2006$ & 8:00 & 12,1 & 183,1 & 25,3 & 0,8658062 & 0,5235371 & 0,74 & 0,3874175 & 22,49 & 21,76 & 4,7653 & 141,66 \\
\hline & $21 / 3 / 2006$ & 9:00 & 98,3 & 250,8 & 57,5 & 0,8658062 & 0,6452467 & 0,74 & 0,4774825 & 24,63 & 21,84 & 4,7653 & 257,75 \\
\hline & $21 / 3 / 2006$ & $10: 00$ & 84,5 & 339,3 & 64,3 & 0,8658062 & 0,7223862 & 0,74 & 0,5345658 & 26,03 & 22,87 & 4,7653 & 318,80 \\
\hline & $21 / 3 / 2006$ & $11: 00$ & 120,9 & 364,5 & 77,5 & 0,8658062 & 0,7646486 & 0,74 & 0,5658400 & 27,22 & 24,06 & 4,7653 & 366,64 \\
\hline & $21 / 3 / 2006$ & $12: 00$ & 104,3 & 396,1 & 76,7 & 0,8658062 & 0,7781226 & 0,74 & 0,5758107 & 28,17 & 25,28 & 4,7653 & 376,73 \\
\hline & $21 / 3 / 2006$ & 13:00 & 61,8 & 401,2 & 65,4 & 0,8658062 & 0,7651407 & 0,74 & 0,5662041 & 28,38 & 29,20 & 4,7653 & 330,03 \\
\hline & $21 / 3 / 2006$ & $14: 00$ & 120,7 & 328,1 & 73 & 0,8658062 & 0,7236922 & 0,74 & 0,5355322 & 29,98 & 34,50 & 4,7653 & 300,07 \\
\hline & $21 / 3 / 2006$ & $15: 00$ & 30,7 & 296,2 & 44 & 0,8658062 & 0,6472805 & 0,74 & 0,4789875 & 29,71 & 32,77 & 4,7653 & 218,08 \\
\hline & $21 / 3 / 2006$ & $16: 00$ & 40,7 & 215,3 & 37 & 0,8658062 & 0,5269556 & 0,74 & 0,3899472 & 29,64 & 30,04 & 4,7653 & 175,61 \\
\hline & $21 / 3 / 2006$ & $17: 00$ & 6,9 & 109,8 & 15 & 0,8658062 & 0,3502819 & 0,74 & 0,2592086 & 29,14 & 28,99 & 4,7653 & 82,46 \\
\hline
\end{tabular}




\begin{tabular}{|c|c|c|c|c|c|c|c|c|c|c|c|c|c|}
\hline Vidro & Data & Horário & $\begin{array}{c}\text { Radiação } \\
\text { Direta } \\
\left(W / m^{2}\right)\end{array}$ & $\begin{array}{c}\text { Radiação } \\
\text { Difusa Céu } \\
\left(\mathrm{W} / \mathrm{m}^{2}\right)\end{array}$ & $\begin{array}{c}\text { Radiação } \\
\text { Refletida } \\
\left(\mathrm{W} / \mathrm{m}^{2}\right)\end{array}$ & FCS $(609)$ & $\begin{array}{c}\text { FCS } \\
\text { (referência) }\end{array}$ & CAC & FCS & te $\left({ }^{\circ} \mathrm{C}\right)$ & $\mathrm{ti}\left({ }^{\circ} \mathrm{C}\right)$ & $\mathrm{U}\left(\mathrm{W} / \mathrm{m}^{2} \mathrm{C}\right)$ & $q\left(W / m^{2}\right)$ \\
\hline \multirow{11}{*}{ 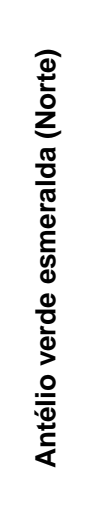 } & $21 / 3 / 2006$ & $7: 00$ & 7,7 & 90,6 & 13 & 0,8658062 & 0,3446635 & 0,44 & 0,1516519 & 21,11 & 21,10 & 3,0352 & 40,67 \\
\hline & $21 / 3 / 2006$ & $8: 00$ & 12,1 & 183,1 & 25,3 & 0,8658062 & 0,5235371 & 0,44 & 0,2303563 & 22,49 & 21,38 & 3,0352 & 85,53 \\
\hline & $21 / 3 / 2006$ & $9: 00$ & 98,3 & 250,8 & 57,5 & 0,8658062 & 0,6452467 & 0,44 & 0,2839085 & 24,63 & 21,69 & 3,0352 & 154,27 \\
\hline & $21 / 3 / 2006$ & $10: 00$ & 84,5 & 339,3 & 64,3 & 0,8658062 & 0,7223862 & 0,44 & 0,3178499 & 26,03 & 22,86 & 3,0352 & 190,23 \\
\hline & $21 / 3 / 2006$ & $11: 00$ & 120,9 & 364,5 & 77,5 & 0,8658062 & 0,7646486 & 0,44 & 0,3364454 & 27,22 & 23,82 & 3,0352 & 219,37 \\
\hline & $21 / 3 / 2006$ & $12: 00$ & 104,3 & 396,1 & 76,7 & 0,8658062 & 0,7781226 & 0,44 & 0,3423739 & 28,17 & 24,87 & 3,0352 & 225,85 \\
\hline & $21 / 3 / 2006$ & $13: 00$ & 61,8 & 401,2 & 65,4 & 0,8658062 & 0,7651407 & 0,44 & 0,3366619 & 28,38 & 28,55 & 3,0352 & 198,04 \\
\hline & $21 / 3 / 2006$ & $14: 00$ & 120,7 & 328,1 & 73 & 0,8658062 & 0,7236922 & 0,44 & 0,3184246 & 29,98 & 32,18 & 3,0352 & 184,54 \\
\hline & $21 / 3 / 2006$ & $15: 00$ & 30,7 & 296,2 & 44 & 0,8658062 & 0,6472805 & 0,44 & 0,2848034 & 29,71 & 30,86 & 3,0352 & 134,86 \\
\hline & $21 / 3 / 2006$ & $16: 00$ & 40,7 & 215,3 & 37 & 0,8658062 & 0,5269556 & 0,44 & 0,2318605 & 29,64 & 30,43 & 3,0352 & 103,17 \\
\hline & $21 / 3 / 2006$ & $17: 00$ & 6,9 & 109,8 & 15 & 0,8658062 & 0,3502819 & 0,44 & 0,1541240 & 29,14 & 29,61 & 3,0352 & 47,19 \\
\hline
\end{tabular}

\begin{tabular}{|c|c|c|c|c|c|c|c|c|c|c|c|c|c|}
\hline Vidro & Data & Horário & $\begin{array}{c}\text { Radiação } \\
\text { Direta } \\
\left(W / m^{2}\right)\end{array}$ & $\begin{array}{c}\text { Radiação } \\
\text { Difusa Céu } \\
\left(\mathrm{W} / \mathrm{m}^{2}\right)\end{array}$ & $\begin{array}{c}\text { Radiação } \\
\text { Refletida } \\
\left(\mathrm{W} / \mathrm{m}^{2}\right)\end{array}$ & FCS $(609)$ & $\begin{array}{c}\text { FCS } \\
\text { (referência) }\end{array}$ & CAC & FCS & te $\left({ }^{\circ} \mathrm{C}\right)$ & $\mathrm{ti}\left({ }^{\circ} \mathrm{C}\right)$ & $\mathrm{U}\left(\mathrm{W} / \mathrm{m}^{2} \mathrm{C}\right)$ & $q\left(W / m^{2}\right)$ \\
\hline \multirow{11}{*}{ 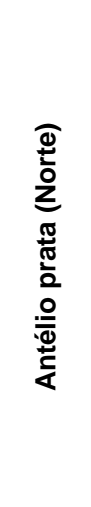 } & $21 / 3 / 2006$ & 7:00 & 7,7 & 90,6 & 13 & 0,8658062 & 0,3446635 & 0,55 & 0,1895649 & 21,11 & 21,05 & 3,0537 & 50,98 \\
\hline & $21 / 3 / 2006$ & $8: 00$ & 12,1 & 183,1 & 25,3 & 0,8658062 & 0,5235371 & 0,55 & 0,2879454 & 22,49 & 21,43 & 3,0537 & 105,94 \\
\hline & $21 / 3 / 2006$ & $9: 00$ & 98,3 & 250,8 & 57,5 & 0,8658062 & 0,6452467 & 0,55 & 0,3548857 & 24,63 & 22,56 & 3,0537 & 188,01 \\
\hline & $21 / 3 / 2006$ & $10: 00$ & 84,5 & 339,3 & 64,3 & 0,8658062 & 0,7223862 & 0,55 & 0,3973124 & 26,03 & 23,12 & 3,0537 & 234,63 \\
\hline & $21 / 3 / 2006$ & $11: 00$ & 120,9 & 364,5 & 77,5 & 0,8658062 & 0,7646486 & 0,55 & 0,4205567 & 27,22 & 24,28 & 3,0537 & 270,28 \\
\hline & $21 / 3 / 2006$ & $12: 00$ & 104,3 & 396,1 & 76,7 & 0,8658062 & 0,7781226 & 0,55 & 0,4279674 & 28,17 & 25,57 & 3,0537 & 277,72 \\
\hline & $21 / 3 / 2006$ & $13: 00$ & 61,8 & 401,2 & 65,4 & 0,8658062 & 0,7651407 & 0,55 & 0,4208274 & 28,38 & 29,80 & 3,0537 & 243,85 \\
\hline & $21 / 3 / 2006$ & $14: 00$ & 120,7 & 328,1 & 73 & 0,8658062 & 0,7236922 & 0,55 & 0,3980307 & 29,98 & 35,18 & 3,0537 & 223,16 \\
\hline & $21 / 3 / 2006$ & $15: 00$ & 30,7 & 296,2 & 44 & 0,8658062 & 0,6472805 & 0,55 & 0,3560043 & 29,71 & 33,75 & 3,0537 & 160,59 \\
\hline & $21 / 3 / 2006$ & $16: 00$ & 40,7 & 215,3 & 37 & 0,8658062 & 0,5269556 & 0,55 & 0,28982556 & 29,64 & 31,13 & 3,0537 & 127,39 \\
\hline & $21 / 3 / 2006$ & $17: 00$ & 6,9 & 109,8 & 15 & 0,8658062 & 0,3502819 & 0,55 & 0,1926551 & 29,14 & 30,13 & 3,0537 & 57,74 \\
\hline
\end{tabular}




\begin{tabular}{|c|c|c|c|c|c|c|c|c|c|c|c|c|c|}
\hline Vidro & Data & Horário & $\begin{array}{c}\text { Radiação } \\
\text { Direta } \\
\left(W / m^{2}\right)\end{array}$ & $\begin{array}{c}\text { Radiação } \\
\text { Difusa Céu } \\
\left(W / m^{2}\right)\end{array}$ & $\begin{array}{c}\text { Radiação } \\
\text { Refletida } \\
\left(W / m^{2}\right)\end{array}$ & FCS $(609)$ & $\begin{array}{c}\text { FCS } \\
\text { (referência) }\end{array}$ & CAC & FCS & te $\left({ }^{\circ} \mathrm{C}\right)$ & $\mathrm{ti}\left({ }^{\circ} \mathrm{C}\right)$ & $\mathrm{U}\left(\mathrm{W} / \mathrm{m}^{2} \mathrm{C}\right)$ & $q\left(W / m^{2}\right)$ \\
\hline \multirow{11}{*}{ 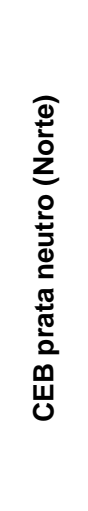 } & $21 / 3 / 2006$ & $7: 00$ & 7,7 & 90,6 & 13 & 0,8760888 & 0,4416352 & 0,27 & 0,1192415 & 21,11 & 20,78 & 2,9515 & 26,38 \\
\hline & $21 / 3 / 2006$ & $8: 00$ & 12,1 & 183,1 & 25,3 & 0,8760888 & 0,5977004 & 0,27 & 0,1613791 & 22,49 & 21,84 & 2,9515 & 53,15 \\
\hline & $21 / 3 / 2006$ & $9: 00$ & 98,3 & 250,8 & 57,5 & 0,8760888 & 0,6974787 & 0,27 & 0,1883193 & 24,63 & 22,03 & 2,9515 & 99,11 \\
\hline & $21 / 3 / 2006$ & $10: 00$ & 84,5 & 339,3 & 64,3 & 0,8760888 & 0,7596093 & 0,27 & 0,2050945 & 26,03 & 22,54 & 2,9515 & 123,08 \\
\hline & $21 / 3 / 2006$ & $11: 00$ & 120,9 & 364,5 & 77,5 & 0,8760888 & 0,7936119 & 0,27 & 0,21427532 & 27,22 & 23,39 & 2,9515 & 141,76 \\
\hline & $21 / 3 / 2006$ & $12: 00$ & 104,3 & 396,1 & 76,7 & 0,8760888 & 0,8044792 & 0,27 & 0,2172094 & 28,17 & 24,41 & 2,9515 & 145,59 \\
\hline & $21 / 3 / 2006$ & $13: 00$ & 61,8 & 401,2 & 65,4 & 0,8760888 & 0,7940085 & 0,27 & 0,2143823 & 28,38 & 27,53 & 2,9515 & 126,12 \\
\hline & $21 / 3 / 2006$ & $14: 00$ & 120,7 & 328,1 & 73 & 0,8760888 & 0,7606592 & 0,27 & 0,2053780 & 29,98 & 31,16 & 2,9515 & 116,17 \\
\hline & $21 / 3 / 2006$ & $15: 00$ & 30,7 & 296,2 & 44 & 0,8760888 & 0,6991231 & 0,27 & 0,1887632 & 29,71 & 29,80 & 2,9515 & 86,02 \\
\hline & $21 / 3 / 2006$ & $16: 00$ & 40,7 & 215,3 & 37 & 0,8760888 & 0,6005523 & 0,27 & 0,1621491 & 29,64 & 29,61 & 2,9515 & 66,36 \\
\hline & $21 / 3 / 2006$ & $17: 00$ & 6,9 & 109,8 & 15 & 0,8760888 & 0,4468051 & 0,27 & 0,1206374 & 29,14 & 28,95 & 2,9515 & 30,91 \\
\hline
\end{tabular}

\begin{tabular}{|c|c|c|c|c|c|c|c|c|c|c|c|c|c|}
\hline Vidro & Data & Horário & $\begin{array}{c}\text { Radiação } \\
\text { Direta } \\
\left(W / m^{2}\right)\end{array}$ & $\begin{array}{c}\text { Radiação } \\
\text { Difusa Céu } \\
\left(\mathrm{W} / \mathrm{m}^{2}\right)\end{array}$ & $\begin{array}{c}\text { Radiação } \\
\text { Refletida } \\
\left(\mathrm{W} / \mathrm{m}^{2}\right)\end{array}$ & FCS (60) & $\begin{array}{c}\text { FCS } \\
\text { (ângulo } \\
\text { incidência) }\end{array}$ & CAC & FCS & te $\left({ }^{\circ} \mathrm{C}\right)$ & $\mathrm{ti}\left({ }^{\circ} \mathrm{C}\right)$ & $\mathrm{U}\left(\mathrm{W} / \mathrm{m}^{2} \mathrm{C}\right)$ & $q\left(W / m^{2}\right)$ \\
\hline \multirow{11}{*}{ 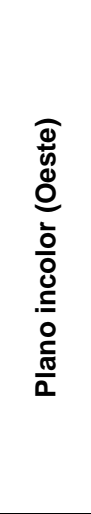 } & $14 / 7 / 2005$ & 7:00 & 0 & 24,5 & 3,8 & 0,8658062 & 0 & 0,86 & 0 & 11,24 & 13,59 & 4,7653 & 9,85 \\
\hline & $14 / 7 / 2005$ & 8:00 & 0 & 107,9 & 22 & 0,8658062 & 0 & 0,86 & 0 & 14,64 & 13,88 & 4,7653 & 100,35 \\
\hline & $14 / 7 / 2005$ & 9:00 & 0 & 140,6 & 44,4 & 0,8658062 & 0 & 0,86 & 0 & 18,39 & 14,62 & 4,7653 & 155,73 \\
\hline & $14 / 7 / 2005$ & $10: 00$ & 0 & 180,7 & 59 & 0,8658062 & 0 & 0,86 & 0 & 20,70 & 16,33 & 4,7653 & 199,31 \\
\hline & $14 / 7 / 2005$ & $11: 00$ & 0 & 210,4 & 67,9 & 0,8658062 & 0 & 0,86 & 0 & 22,25 & 17,94 & 4,7653 & 227,77 \\
\hline & $14 / 7 / 2005$ & $12: 00$ & 0 & 225,3 & 70,8 & 0,8658062 & 0 & 0,86 & 0 & 23,07 & 19,37 & 4,7653 & 238,08 \\
\hline & $14 / 7 / 2005$ & 13:00 & 116,8 & 226,9 & 67,1 & 0,8658062 & 0,5895687 & 0,86 & 0,5070291 & 23,59 & 20,62 & 4,7653 & 292,29 \\
\hline & $14 / 7 / 2005$ & $14: 00$ & 199,4 & 216,2 & 56,8 & 0,8658062 & 0,8399416 & 0,86 & 0,7223498 & 23,73 & 22,37 & 4,7653 & 353,78 \\
\hline & $14 / 7 / 2005$ & $15: 00$ & 219,2 & 187,8 & 41 & 0,8658062 & 0,9484980 & 0,86 & 0,8157083 & 24,09 & 24,58 & 4,7653 & 346,82 \\
\hline & $14 / 7 / 2005$ & $16: 00$ & 166,9 & 129,9 & 22,7 & 0,8658062 & 0,9868339 & 0,86 & 0,8486772 & 23,72 & 25,95 & 4,7653 & 244,64 \\
\hline & $14 / 7 / 2005$ & $17: 00$ & 16,6 & 36,8 & 4,8 & 0,8658062 & 0,9970938 & 0,86 & 0,8575007 & 21,57 & 25,55 & 4,7653 & 26,24 \\
\hline
\end{tabular}




\begin{tabular}{|c|c|c|c|c|c|c|c|c|c|c|c|c|c|}
\hline Vidro & Data & Horário & $\begin{array}{c}\text { Radiação } \\
\text { Direta } \\
\left(W / m^{2}\right)\end{array}$ & $\begin{array}{c}\text { Radiação } \\
\text { Difusa Céu } \\
\left(W / m^{2}\right)\end{array}$ & $\begin{array}{c}\text { Radiação } \\
\text { Refletida } \\
\left(W / m^{2}\right)\end{array}$ & FCS (60) & $\begin{array}{c}\text { FCS } \\
\text { (referência) }\end{array}$ & CAC & FCS & te $\left({ }^{\circ} \mathrm{C}\right)$ & ti $\left({ }^{\circ} \mathrm{C}\right)$ & $\mathrm{U}\left(\mathrm{W} / \mathrm{m}^{2} \mathrm{C}\right)$ & $q\left(W / m^{2}\right)$ \\
\hline \multirow{11}{*}{ 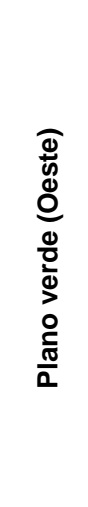 } & $14 / 7 / 2005$ & $7: 00$ & 0 & 24,5 & 3,8 & 0,8658062 & 0 & 0,74 & 0 & 11,24 & 13,01 & 4,7653 & 9,66 \\
\hline & $14 / 7 / 2005$ & $8: 00$ & 0 & 107,9 & 22 & 0,8658062 & 0 & 0,74 & 0 & 14,64 & 13,29 & 4,7653 & 89,66 \\
\hline & 14/7/2005 & 9:00 & 0 & 140,6 & 44,4 & 0,8658062 & 0 & 0,74 & 0 & 18,39 & 14,05 & 4,7653 & 139,24 \\
\hline & 14/7/2005 & $10: 00$ & 0 & 180,7 & 59 & 0,8658062 & 0 & 0,74 & 0 & 20,70 & 15,79 & 4,7653 & 176,97 \\
\hline & 14/7/2005 & $11: 00$ & 0 & 210,4 & 67,9 & 0,8658062 & 0 & 0,74 & 0 & 22,25 & 17,44 & 4,7653 & 201,23 \\
\hline & $14 / 7 / 2005$ & $12: 00$ & 0 & 225,3 & 70,8 & 0,8658062 & 0 & 0,74 & 0 & 23,07 & 18,86 & 4,7653 & 209,74 \\
\hline & $14 / 7 / 2005$ & 13:00 & 116,8 & 226,9 & 67,1 & 0,8658062 & 0,5895687 & 0,74 & 0,4362809 & 23,59 & 20,12 & 4,7653 & 255,87 \\
\hline & $14 / 7 / 2005$ & $14: 00$ & 199,4 & 216,2 & 56,8 & 0,8658062 & 0,8399416 & 0,74 & 0,6215568 & 23,73 & 21,63 & 4,7653 & 308,84 \\
\hline & 14/7/2005 & $15: 00$ & 219,2 & 187,8 & 41 & 0,8658062 & 0,9484980 & 0,74 & 0,7018885 & 24,09 & 23,47 & 4,7653 & 303,41 \\
\hline & 14/7/2005 & $16: 00$ & 166,9 & 129,9 & 22,7 & 0,8658062 & 0,9868339 & 0,74 & 0,7302571 & 23,72 & 24,71 & 4,7653 & 214,92 \\
\hline & $14 / 7 / 2005$ & $17: 00$ & 16,6 & 36,8 & 4,8 & 0,8658062 & 0,9970938 & 0,74 & 0,7378494 & 21,57 & 24,73 & 4,7653 & 23,86 \\
\hline
\end{tabular}

\begin{tabular}{|c|c|c|c|c|c|c|c|c|c|c|c|c|c|}
\hline Vidro & Data & Horário & $\begin{array}{c}\text { Radiação } \\
\text { Direta } \\
\left(W / m^{2}\right)\end{array}$ & $\begin{array}{c}\text { Radiação } \\
\text { Difusa Céu } \\
\left(W / m^{2}\right)\end{array}$ & $\begin{array}{c}\text { Radiação } \\
\text { Refletida } \\
\left(W / m^{2}\right)\end{array}$ & FCS $(609)$ & $\begin{array}{c}\text { FCS } \\
\text { (ângulo } \\
\text { incidência) }\end{array}$ & CAC & FCS & te $\left({ }^{\circ} \mathrm{C}\right)$ & $\mathrm{ti}\left({ }^{\circ} \mathrm{C}\right)$ & $\mathrm{U}\left(\mathrm{W} / \mathrm{m}^{2} \mathrm{C}\right)$ & $q\left(W / m^{2}\right)$ \\
\hline \multirow{11}{*}{ 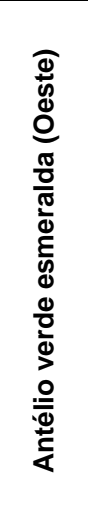 } & $14 / 7 / 2005$ & $7: 00$ & 0 & 24,5 & 3,8 & 0,8658062 & 0 & 0,44 & 0 & 11,24 & 13,38 & 3,0352 & 4,26 \\
\hline & $14 / 7 / 2005$ & $8: 00$ & 0 & 107,9 & 22 & 0,8658062 & 0 & 0,44 & 0 & 14,64 & 13,87 & 3,0352 & 51,81 \\
\hline & $14 / 7 / 2005$ & 9:00 & 0 & 140,6 & 44,4 & 0,8658062 & 0 & 0,44 & 0 & 18,39 & 14,56 & 3,0352 & 82,11 \\
\hline & $14 / 7 / 2005$ & $10: 00$ & 0 & 180,7 & 59 & 0,8658062 & 0 & 0,44 & 0 & 20,70 & 16,18 & 3,0352 & 105,03 \\
\hline & $14 / 7 / 2005$ & $11: 00$ & 0 & 210,4 & 67,9 & 0,8658062 & 0 & 0,44 & 0 & 22,25 & 17,78 & 3,0352 & 119,60 \\
\hline & $14 / 7 / 2005$ & $12: 00$ & 0 & 225,3 & 70,8 & 0,8658062 & 0 & 0,44 & 0 & 23,07 & 19,18 & 3,0352 & 124,60 \\
\hline & $14 / 7 / 2005$ & $13: 00$ & 116,8 & 226,9 & 67,1 & 0,8658062 & 0,5895687 & 0,44 & 0,2594102 & 23,59 & 20,31 & 3,0352 & 152,27 \\
\hline & $14 / 7 / 2005$ & $14: 00$ & 199,4 & 216,2 & 56,8 & 0,8658062 & 0,8399416 & 0,44 & 0,3695743 & 23,73 & 21,56 & 3,0352 & 184,28 \\
\hline & $14 / 7 / 2005$ & $15: 00$ & 219,2 & 187,8 & 41 & 0,8658062 & 0,9484980 & 0,44 & 0,4173391 & 24,09 & 23,21 & 3,0352 & 181,32 \\
\hline & $14 / 7 / 2005$ & $16: 00$ & 166,9 & 129,9 & 22,7 & 0,8658062 & 0,9868339 & 0,44 & 0,4342069 & 23,72 & 24,70 & 3,0352 & 127,62 \\
\hline & $14 / 7 / 2005$ & $17: 00$ & 16,6 & 36,8 & 4,8 & 0,8658062 & 0,9970938 & 0,44 & 0,4387213 & 21,57 & 24,72 & 3,0352 & 13,58 \\
\hline
\end{tabular}




\begin{tabular}{|c|c|c|c|c|c|c|c|c|c|c|c|c|c|}
\hline Vidro & Data & Horário & $\begin{array}{c}\text { Radiação } \\
\text { Direta } \\
\left(W / m^{2}\right)\end{array}$ & $\begin{array}{c}\text { Radiação } \\
\text { Difusa Céu } \\
\left(W / m^{2}\right)\end{array}$ & $\begin{array}{c}\text { Radiação } \\
\text { Refletida } \\
\left(\mathrm{W} / \mathbf{m}^{2}\right)\end{array}$ & FCS (60) & $\begin{array}{c}\text { FCS } \\
\text { (referência) }\end{array}$ & CAC & FCS & te $\left({ }^{\circ} \mathrm{C}\right)$ & $\mathrm{ti}\left({ }^{\circ} \mathrm{C}\right)$ & $\mathrm{U}\left(\mathrm{W} / \mathrm{m}^{2} \mathrm{C}\right)$ & $q\left(W / m^{2}\right)$ \\
\hline \multirow{11}{*}{ 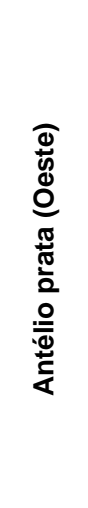 } & $14 / 7 / 2005$ & $7: 00$ & 0 & 24,5 & 3,8 & 0,8658062 & 0 & 0,55 & 0 & 11,24 & 12,89 & 3,0537 & 8,43 \\
\hline & $14 / 7 / 2005$ & $8: 00$ & 0 & 107,9 & 22 & 0,8658062 & 0 & 0,55 & 0 & 14,64 & 13,30 & 3,0537 & 65,95 \\
\hline & $14 / 7 / 2005$ & $9: 00$ & 0 & 140,6 & 44,4 & 0,8658062 & 0 & 0,55 & 0 & 18,39 & 14,09 & 3,0537 & 101,23 \\
\hline & $14 / 7 / 2005$ & $10: 00$ & 0 & 180,7 & 59 & 0,8658062 & 0 & 0,55 & 0 & 20,70 & 16,13 & 3,0537 & 128,09 \\
\hline & $14 / 7 / 2005$ & $11: 00$ & 0 & 210,4 & 67,9 & 0,8658062 & 0 & 0,55 & 0 & 22,25 & 17,83 & 3,0537 & 146,03 \\
\hline & $14 / 7 / 2005$ & $12: 00$ & 0 & 225,3 & 70,8 & 0,8658062 & 0 & 0,55 & 0 & 23,07 & 19,24 & 3,0537 & 152,68 \\
\hline & $14 / 7 / 2005$ & $13: 00$ & 116,8 & 226,9 & 67,1 & 0,8658062 & 0,5895687 & 0,55 & 0,3242628 & 23,59 & 20,48 & 3,0537 & 187,39 \\
\hline & $14 / 7 / 2005$ & $14: 00$ & 199,4 & 216,2 & 56,8 & 0,8658062 & 0,8399416 & 0,55 & 0,4619679 & 23,73 & 21,89 & 3,0537 & 227,74 \\
\hline & $14 / 7 / 2005$ & $15: 00$ & 219,2 & 187,8 & 41 & 0,8658062 & 0,9484980 & 0,55 & 0,5216739 & 24,09 & 23,56 & 3,0537 & 224,92 \\
\hline & $14 / 7 / 2005$ & $16: 00$ & 166,9 & 129,9 & 22,7 & 0,8658062 & 0,9868339 & 0,55 & 0,5427586 & 23,72 & 24,97 & 3,0537 & 159,45 \\
\hline & $14 / 7 / 2005$ & $17: 00$ & 16,6 & 36,8 & 4,8 & 0,8658062 & 0,9970938 & 0,55 & 0,5484016 & 21,57 & 24,74 & 3,0537 & 19,24 \\
\hline
\end{tabular}

\begin{tabular}{|c|c|c|c|c|c|c|c|c|c|c|c|c|c|}
\hline Vidro & Data & Horário & $\begin{array}{c}\text { Radiação } \\
\text { Direta } \\
\left(W / m^{2}\right)\end{array}$ & $\begin{array}{c}\text { Radiação } \\
\text { Difusa Céu } \\
\left(\mathrm{W} / \mathrm{m}^{2}\right)\end{array}$ & $\begin{array}{c}\text { Radiação } \\
\text { Refletida } \\
\left(\mathrm{W} / \mathrm{m}^{2}\right)\end{array}$ & FCS $(609)$ & $\begin{array}{c}\text { FCS } \\
\text { (referência) }\end{array}$ & CAC & FCS & te $\left({ }^{\circ} \mathrm{C}\right)$ & ti $\left({ }^{\circ} \mathrm{C}\right)$ & $\mathrm{U}\left(\mathrm{W} / \mathrm{m}^{2} \mathrm{C}\right)$ & $q\left(W / m^{2}\right)$ \\
\hline \multirow{11}{*}{ 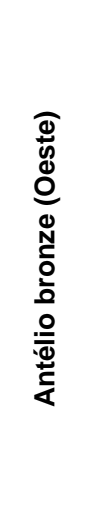 } & $14 / 7 / 2005$ & 7:00 & 0 & 24,5 & 3,8 & 0,8658062 & 0 & 0,51 & 0 & 11,24 & 13,24 & 3,0537 & 6,38 \\
\hline & $14 / 7 / 2005$ & $8: 00$ & 0 & 107,9 & 22 & 0,8658062 & 0 & 0,51 & 0 & 14,64 & 13,51 & 3,0537 & 60,82 \\
\hline & $14 / 7 / 2005$ & 9:00 & 0 & 140,6 & 44,4 & 0,8658062 & 0 & 0,51 & 0 & 18,39 & 14,08 & 3,0537 & 94,85 \\
\hline & $14 / 7 / 2005$ & $10: 00$ & 0 & 180,7 & 59 & 0,8658062 & 0 & 0,51 & 0 & 20,70 & 15,95 & 3,0537 & 120,35 \\
\hline & $14 / 7 / 2005$ & $11: 00$ & 0 & 210,4 & 67,9 & 0,8658062 & 0 & 0,51 & 0 & 22,25 & 17,49 & 3,0537 & 137,43 \\
\hline & $14 / 7 / 2005$ & $12: 00$ & 0 & 225,3 & 70,8 & 0,8658062 & 0 & 0,51 & 0 & 23,07 & 18,78 & 3,0537 & 143,83 \\
\hline & $14 / 7 / 2005$ & $13: 00$ & 116,8 & 226,9 & 67,1 & 0,8658062 & 0,5895687 & 0,51 & 0,3006801 & 23,59 & 19,69 & 3,0537 & 176,87 \\
\hline & $14 / 7 / 2005$ & $14: 00$ & 199,4 & 216,2 & 56,8 & 0,8658062 & 0,8399416 & 0,51 & 0,4283702 & 23,73 & 20,72 & 3,0537 & 215,13 \\
\hline & $14 / 7 / 2005$ & $15: 00$ & 219,2 & 187,8 & 41 & 0,8658062 & 0,9484980 & 0,51 & 0,4837340 & 24,09 & 22,12 & 3,0537 & 213,07 \\
\hline & $14 / 7 / 2005$ & $16: 00$ & 166,9 & 129,9 & 22,7 & 0,8658062 & 0,9868339 & 0,51 & 0,5032853 & 23,72 & 23,29 & 3,0537 & 152,71 \\
\hline & $14 / 7 / 2005$ & $17: 00$ & 16,6 & 36,8 & 4,8 & 0,8658062 & 0,9970938 & 0,51 & 0,5085178 & 21,57 & 23,41 & 3,0537 & 21,20 \\
\hline
\end{tabular}




\begin{tabular}{|c|c|c|c|c|c|c|c|c|c|c|c|c|c|}
\hline Vidro & Data & Horário & $\begin{array}{c}\text { Radiação } \\
\text { Direta } \\
\left(W / m^{2}\right)\end{array}$ & $\begin{array}{c}\text { Radiação } \\
\text { Difusa Céu } \\
\left(W / m^{2}\right)\end{array}$ & $\begin{array}{c}\text { Radiação } \\
\text { Refletida } \\
\left(\mathrm{W} / \mathrm{m}^{2}\right)\end{array}$ & FCS (60) & $\begin{array}{c}\text { FCS } \\
\text { (referência) }\end{array}$ & CAC & FCS & te $\left({ }^{\circ} \mathrm{C}\right)$ & ti $\left({ }^{\circ} \mathrm{C}\right)$ & $\mathrm{U}\left(\mathrm{W} / \mathrm{m}^{2} \mathrm{C}\right)$ & $q\left(W / m^{2}\right)$ \\
\hline \multirow{11}{*}{ 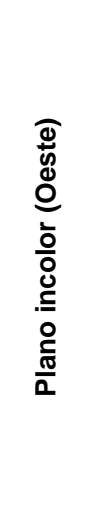 } & $5 / 8 / 2005$ & $7: 00$ & 0 & 21,6 & 2,6 & 0,8658062 & 0 & 0,86 & 0 & 13,54 & 16,08 & 4,7653 & 5,93 \\
\hline & $5 / 8 / 2005$ & $8: 00$ & 0 & 131,2 & 23,5 & 0,8658062 & 0 & 0,86 & 0 & 17,37 & 16,07 & 4,7653 & 121,36 \\
\hline & $5 / 8 / 2005$ & $9: 00$ & 0 & 151 & 50,2 & 0,8658062 & 0 & 0,86 & 0 & 22,36 & 16,73 & 4,7653 & 176,65 \\
\hline & $5 / 8 / 2005$ & $10: 00$ & 0 & 191,9 & 65,4 & 0,8658062 & 0 & 0,86 & 0 & 24,60 & 18,75 & 4,7653 & 219,48 \\
\hline & $5 / 8 / 2005$ & $11: 00$ & 0 & 223,3 & 74,5 & 0,8658062 & 0 & 0,86 & 0 & 26,13 & 20,77 & 4,7653 & 247,29 \\
\hline & $5 / 8 / 2005$ & $12: 00$ & 0 & 238,7 & 77,5 & 0,8658062 & 0 & 0,86 & 0 & 26,69 & 22,42 & 4,7653 & 255,80 \\
\hline & $5 / 8 / 2005$ & $13: 00$ & 125,2 & 240,6 & 73,7 & 0,8658062 & 0,5998751 & 0,86 & 0,5158926 & 27,51 & 23,91 & 4,7653 & 315,76 \\
\hline & $5 / 8 / 2005$ & $14: 00$ & 215,5 & 230,8 & 62,9 & 0,8658062 & 0,8504259 & 0,86 & 0,7313662 & 28,11 & 26,11 & 4,7653 & 385,84 \\
\hline & $5 / 8 / 2005$ & $15: 00$ & 242,9 & 203,6 & 46,4 & 0,8658062 & 0,9553925 & 0,86 & 0,8216375 & 28,49 & 28,38 & 4,7653 & 386,21 \\
\hline & $5 / 8 / 2005$ & $16: 00$ & 182,2 & 148,8 & 26,5 & 0,8658062 & 0,9903184 & 0,86 & 0,8516738 & 28,30 & 29,91 & 4,7653 & 278,02 \\
\hline & $5 / 8 / 2005$ & $17: 00$ & 24,5 & 51,4 & 6,7 & 0,8658062 & 0,9985410 & 0,86 & 0,8587452 & 25,87 & 29,66 & 4,7653 & 46,22 \\
\hline
\end{tabular}

\begin{tabular}{|c|c|c|c|c|c|c|c|c|c|c|c|c|c|}
\hline Vidro & Data & Horário & $\begin{array}{c}\text { Radiação } \\
\text { Direta } \\
\left(W / m^{2}\right)\end{array}$ & $\begin{array}{c}\text { Radiação } \\
\text { Difusa Céu } \\
\left(\mathrm{W} / \mathrm{m}^{2}\right)\end{array}$ & $\begin{array}{c}\text { Radiação } \\
\text { Refletida } \\
\left(\mathrm{W} / \mathrm{m}^{2}\right)\end{array}$ & FCS $(60)$ & $\begin{array}{c}\text { FCS } \\
\text { (referência) }\end{array}$ & CAC & FCS & te $\left({ }^{\circ} \mathrm{C}\right)$ & ti $\left({ }^{\circ} \mathrm{C}\right)$ & $\mathrm{U}\left(\mathrm{W} / \mathrm{m}^{2} \mathrm{C}\right)$ & $q\left(W / m^{2}\right)$ \\
\hline \multirow{9}{*}{ 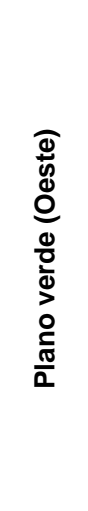 } & 5/8/2005 & $8: 00$ & 0 & 131,2 & 23,5 & 0,8658062 & 0 & 0,74 & 0 & 17,37 & 15,83 & 4,7653 & 106,45 \\
\hline & $5 / 8 / 2005$ & $9: 00$ & 0 & 151 & 50,2 & 0,8658062 & 0 & 0,74 & 0 & 22,36 & 16,34 & 4,7653 & 157,63 \\
\hline & $5 / 8 / 2005$ & $10: 00$ & 0 & 191,9 & 65,4 & 0,8658062 & 0 & 0,74 & 0 & 24,60 & 18,43 & 4,7653 & 194,28 \\
\hline & $5 / 8 / 2005$ & $12: 00$ & 0 & 238,7 & 77,5 & 0,8658062 & 0 & 0,74 & 0 & 26,69 & 22,05 & 4,7653 & 224,68 \\
\hline & $5 / 8 / 2005$ & 13:00 & 125,2 & 240,6 & 73,7 & 0,8658062 & 0,5998751 & 0,74 & 0,4439076 & 27,51 & 23,47 & 4,7653 & 276,20 \\
\hline & $5 / 8 / 2005$ & $14: 00$ & 215,5 & 230,8 & 62,9 & 0,8658062 & 0,8504259 & 0,74 & 0,6293151 & 28,11 & 25,75 & 4,7653 & 335,04 \\
\hline & $5 / 8 / 2005$ & $15: 00$ & 242,9 & 203,6 & 46,4 & 0,8658062 & 0,9553925 & 0,74 & 0,7069904 & 28,49 & 27,93 & 4,7653 & 334,55 \\
\hline & $5 / 8 / 2005$ & $16: 00$ & 182,2 & 148,8 & 26,5 & 0,8658062 & 0,9903184 & 0,74 & 0,7328356 & 28,30 & 29,47 & 4,7653 & 240,29 \\
\hline & $5 / 8 / 2005$ & $17: 00$ & 24,5 & 51,4 & 6,7 & 0,8658062 & 0,9985410 & 0,74 & 0,7389203 & 25,87 & 29,39 & 4,7653 & 38,56 \\
\hline
\end{tabular}




\begin{tabular}{|c|c|c|c|c|c|c|c|c|c|c|c|c|c|}
\hline Vidro & Data & Horário & $\begin{array}{c}\text { Radiação } \\
\text { Direta } \\
\left(W / m^{2}\right)\end{array}$ & $\begin{array}{c}\text { Radiação } \\
\text { Difusa Céu } \\
\left(W / m^{2}\right)\end{array}$ & $\begin{array}{c}\text { Radiação } \\
\text { Refletida } \\
\left(W / m^{2}\right)\end{array}$ & FCS $(609)$ & $\begin{array}{c}\text { FCS } \\
\text { (referência) }\end{array}$ & CAC & FCS & te $\left({ }^{\circ} \mathrm{C}\right)$ & $\mathrm{ti}\left({ }^{\circ} \mathrm{C}\right)$ & $\mathrm{U}\left(\mathrm{W} / \mathrm{m}^{2} \mathrm{C}\right)$ & $q\left(W / m^{2}\right)$ \\
\hline \multirow{11}{*}{ 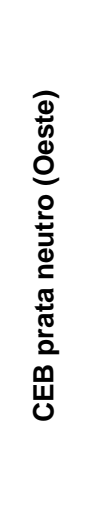 } & $5 / 8 / 2005$ & $7: 00$ & 0 & 21,6 & 2,6 & 0,8760888 & 0 & 0,27 & 0 & 13,54 & 15,63 & 2,9515 & $-0,44$ \\
\hline & $5 / 8 / 2005$ & $8: 00$ & 0 & 131,2 & 23,5 & 0,8760888 & 0 & 0,27 & 0 & 17,37 & 15,37 & 2,9515 & 42,48 \\
\hline & $5 / 8 / 2005$ & $9: 00$ & 0 & 151 & 50,2 & 0,8760888 & 0 & 0,27 & 0 & 22,36 & 15,89 & 2,9515 & 66,69 \\
\hline & $5 / 8 / 2005$ & $10: 00$ & 0 & 191,9 & 65,4 & 0,8760888 & 0 & 0,27 & 0 & 24,60 & 18,02 & 2,9515 & 80,29 \\
\hline & $5 / 8 / 2005$ & $11: 00$ & 0 & 223,3 & 74,5 & 0,8760888 & 0 & 0,27 & 0 & 26,13 & 20,02 & 2,9515 & 88,50 \\
\hline & $5 / 8 / 2005$ & $12: 00$ & 0 & 238,7 & 77,5 & 0,8760888 & 0 & 0,27 & 0 & 26,69 & 21,49 & 2,9515 & 90,14 \\
\hline & $5 / 8 / 2005$ & $13: 00$ & 125,2 & 240,6 & 73,7 & 0,8760888 & 0,6606408 & 0,27 & 0,17837302 & 27,51 & 22,57 & 2,9515 & 111,26 \\
\hline & $5 / 8 / 2005$ & $14: 00$ & 215,5 & 230,8 & 62,9 & 0,8760888 & 0,8633601 & 0,27 & 0,233107236 & 28,11 & 23,97 & 2,9515 & 131,94 \\
\hline & $5 / 8 / 2005$ & $15: 00$ & 242,9 & 203,6 & 46,4 & 0,8760888 & 0,9536005 & 0,27 & 0,257472127 & 28,49 & 25,39 & 2,9515 & 130,82 \\
\hline & $5 / 8 / 2005$ & $16: 00$ & 182,2 & 148,8 & 26,5 & 0,8760888 & 0,9879766 & 0,27 & 0,266753688 & 28,30 & 26,48 & 2,9515 & 95,44 \\
\hline & $5 / 8 / 2005$ & $17: 00$ & 24,5 & 51,4 & 6,7 & 0,8760888 & 0,9977325 & 0,27 & 0,269387776 & 25,87 & 26,79 & 2,9515 & 17,61 \\
\hline
\end{tabular}

\begin{tabular}{|c|c|c|c|c|c|c|c|c|c|c|c|c|c|}
\hline Vidro & Data & Horário & $\begin{array}{c}\text { Radiação } \\
\text { Direta } \\
\left(\mathrm{W} / \mathbf{m}^{2}\right)\end{array}$ & $\begin{array}{c}\text { Radiação } \\
\text { Difusa Céu } \\
\left(\mathrm{W} / \mathrm{m}^{2}\right)\end{array}$ & $\begin{array}{c}\text { Radiação } \\
\text { Refletida } \\
\left(\mathrm{W} / \mathbf{m}^{2}\right)\end{array}$ & FCS (60) & $\begin{array}{c}\text { FCS } \\
\text { (referência) }\end{array}$ & CAC & FCS & te $\left({ }^{\circ} \mathrm{C}\right)$ & $\mathrm{ti}\left({ }^{\circ} \mathrm{C}\right)$ & $\mathrm{U}\left(\mathrm{W} / \mathrm{m}^{2} \mathrm{C}\right)$ & $q\left(W / m^{2}\right)$ \\
\hline \multirow{10}{*}{ 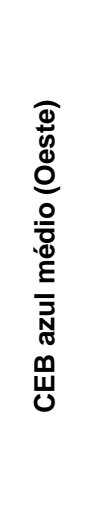 } & $5 / 8 / 2005$ & $8: 00$ & 0 & 131,2 & 23,5 & 0,8760888 & 0 & 0,39 & 0 & 17,37 & 15,42 & 2,9515 & 58,59 \\
\hline & $5 / 8 / 2005$ & $9: 00$ & 0 & 151 & 50,2 & 0,8760888 & 0 & 0,39 & 0 & 22,36 & 15,80 & 2,9515 & 88,12 \\
\hline & $5 / 8 / 2005$ & $10: 00$ & 0 & 191,9 & 65,4 & 0,8760888 & 0 & 0,39 & 0 & 24,60 & 18,01 & 2,9515 & 107,37 \\
\hline & $5 / 8 / 2005$ & $11: 00$ & 0 & 223,3 & 74,5 & 0,8760888 & 0 & 0,39 & 0 & 26,13 & 20,14 & 2,9515 & 119,43 \\
\hline & $5 / 8 / 2005$ & $12: 00$ & 0 & 238,7 & 77,5 & 0,8760888 & 0 & 0,39 & 0 & 26,69 & 21,88 & 2,9515 & 122,23 \\
\hline & $5 / 8 / 2005$ & $13: 00$ & 125,2 & 240,6 & 73,7 & 0,8760888 & 0,6606408 & 0,39 & 0,2576499 & 27,51 & 23,24 & 2,9515 & 152,25 \\
\hline & $5 / 8 / 2005$ & $14: 00$ & 215,5 & 230,8 & 62,9 & 0,8760888 & 0,8633601 & 0,39 & 0,3367105 & 28,11 & 25,02 & 2,9515 & 182,04 \\
\hline & $5 / 8 / 2005$ & $15: 00$ & 242,9 & 203,6 & 46,4 & 0,8760888 & 0,9536005 & 0,39 & 0,3719042 & 28,49 & 26,67 & 2,9515 & 181,12 \\
\hline & $5 / 8 / 2005$ & $16: 00$ & 182,2 & 148,8 & 26,5 & 0,8760888 & 0,9879766 & 0,39 & 0,3853109 & 28,30 & 27,97 & 2,9515 & 131,07 \\
\hline & $5 / 8 / 2005$ & $17: 00$ & 24,5 & 51,4 & 6,7 & 0,8760888 & 0,9977325 & 0,39 & 0,3891157 & 25,87 & 28,23 & 2,9515 & 22,41 \\
\hline
\end{tabular}




\begin{tabular}{|c|c|c|c|c|c|c|c|c|c|c|c|c|c|}
\hline Vidro & Data & Horário & $\begin{array}{c}\text { Radiação } \\
\text { Direta } \\
\left(W / m^{2}\right)\end{array}$ & $\begin{array}{c}\text { Radiação } \\
\text { Difusa Céu } \\
\left(\mathrm{W} / \mathrm{m}^{2}\right)\end{array}$ & $\begin{array}{c}\text { Radiação } \\
\text { Refletida } \\
\left(\mathrm{W} / \mathrm{m}^{2}\right)\end{array}$ & FCS $(609)$ & $\begin{array}{c}\text { FCS } \\
\text { (referência) }\end{array}$ & CAC & FCS & te $\left({ }^{\circ} \mathrm{C}\right)$ & $\mathrm{ti}\left({ }^{\circ} \mathrm{C}\right)$ & $\mathrm{U}\left(\mathrm{W} / \mathrm{m}^{2} \mathrm{C}\right)$ & $q\left(W / m^{2}\right)$ \\
\hline \multirow{11}{*}{ 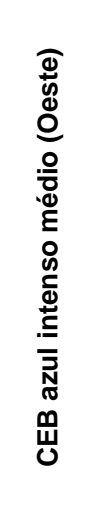 } & $5 / 8 / 2005$ & $7: 00$ & 0 & 21,6 & 2,6 & 0,8760888 & 0 & 0,31 & 0 & 13,54 & 15,89 & 2,9515 & 0,36 \\
\hline & $5 / 8 / 2005$ & $8: 00$ & 0 & 131,2 & 23,5 & 0,8760888 & 0 & 0,31 & 0 & 17,37 & 15,82 & 2,9515 & 46,56 \\
\hline & $5 / 8 / 2005$ & $9: 00$ & 0 & 151 & 50,2 & 0,8760888 & 0 & 0,31 & 0 & 22,36 & 16,45 & 2,9515 & 72,10 \\
\hline & $5 / 8 / 2005$ & $10: 00$ & 0 & 191,9 & 65,4 & 0,8760888 & 0 & 0,31 & 0 & 24,60 & 18,42 & 2,9515 & 88,14 \\
\hline & $5 / 8 / 2005$ & $11: 00$ & 0 & 223,3 & 74,5 & 0,8760888 & 0 & 0,31 & 0 & 26,13 & 20,43 & 2,9515 & 97,70 \\
\hline & $5 / 8 / 2005$ & $12: 00$ & 0 & 238,7 & 77,5 & 0,8760888 & 0 & 0,31 & 0 & 26,69 & 22,03 & 2,9515 & 99,63 \\
\hline & $5 / 8 / 2005$ & $13: 00$ & 125,2 & 240,6 & 73,7 & 0,8760888 & 0,6606408 & 0,31 & 0,2047987 & 27,51 & 23,30 & 2,9515 & 123,42 \\
\hline & $5 / 8 / 2005$ & $14: 00$ & 215,5 & 230,8 & 62,9 & 0,8760888 & 0,8633601 & 0,31 & 0,2676416 & 28,11 & 24,83 & 2,9515 & 147,13 \\
\hline & $5 / 8 / 2005$ & $15: 00$ & 242,9 & 203,6 & 46,4 & 0,8760888 & 0,9536005 & 0,31 & 0,2956161 & 28,49 & 26,36 & 2,9515 & 145,99 \\
\hline & $5 / 8 / 2005$ & $16: 00$ & 182,2 & 148,8 & 26,5 & 0,8760888 & 0,9879766 & 0,31 & 0,3062728 & 28,30 & 27,57 & 2,9515 & 105,59 \\
\hline & 5/8/2005 & $17: 00$ & 24,5 & 51,4 & 6,7 & 0,8760888 & 0,9977325 & 0,31 & 0,3092971 & 25,87 & 27,81 & 2,9515 & 17,61 \\
\hline
\end{tabular}

\begin{tabular}{|c|c|c|c|c|c|c|c|c|c|c|c|c|c|}
\hline Vidro & Data & Horário & $\begin{array}{c}\text { Radiação } \\
\text { Direta } \\
\left(W / m^{2}\right)\end{array}$ & $\begin{array}{c}\text { Radiação } \\
\text { Difusa Céu } \\
\left(W / m^{2}\right)\end{array}$ & $\begin{array}{c}\text { Radiação } \\
\text { Refletida } \\
\left(W / m^{2}\right)\end{array}$ & FCS (60) & $\begin{array}{c}\text { FCS } \\
\text { (referência) }\end{array}$ & CAC & FCS & te $\left({ }^{\circ} \mathrm{C}\right)$ & ti $\left({ }^{\circ} \mathrm{C}\right)$ & $\mathrm{U}\left(\mathrm{W} / \mathrm{m}^{2} \mathrm{C}\right)$ & $q\left(W / m^{2}\right)$ \\
\hline \multirow{9}{*}{ 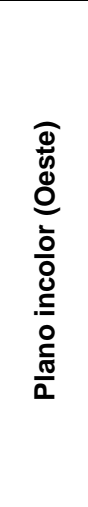 } & $13 / 8 / 2005$ & $8: 00$ & 0 & 142 & 25,3 & 0,8658062 & 0 & 0,86 & 0 & 14,90 & 14,21 & 4,7653 & 127,89 \\
\hline & $13 / 8 / 2005$ & $9: 00$ & 0 & 173 & 50,8 & 0,8658062 & 0 & 0,86 & 0 & 18,15 & 15,04 & 4,7653 & 181,44 \\
\hline & $13 / 8 / 2005$ & $10: 00$ & 0 & 212,9 & 66,4 & 0,8658062 & 0 & 0,86 & 0 & 21,63 & 16,41 & 4,7653 & 232,85 \\
\hline & $13 / 8 / 2005$ & $12: 00$ & 0 & 260 & 78,4 & 0,8658062 & 0 & 0,86 & 0 & 25,43 & 20,17 & 4,7653 & 277,04 \\
\hline & $13 / 8 / 2005$ & $13: 00$ & 113,7 & 266,3 & 73,6 & 0,8658062 & 0,6040884 & 0,86 & 0,5195160 & 26,50 & 22,12 & 4,7653 & 333,03 \\
\hline & $13 / 8 / 2005$ & $14: 00$ & 211,8 & 242,6 & 64,6 & 0,8658062 & 0,8543961 & 0,86 & 0,7347806 & 27,23 & 24,79 & 4,7653 & 396,00 \\
\hline & $13 / 8 / 2005$ & $15: 00$ & 220,6 & 218,1 & 46,8 & 0,8658062 & 0,9579928 & 0,86 & 0,8238738 & 27,50 & 26,96 & 4,7653 & 381,56 \\
\hline & $13 / 8 / 2005$ & $16: 00$ & 143,5 & 158,3 & 26,2 & 0,8658062 & 0,9915252 & 0,86 & 0,8527117 & 27,06 & 28,29 & 4,7653 & 253,87 \\
\hline & $13 / 8 / 2005$ & $17: 00$ & 8,6 & 50,4 & 6,2 & 0,8658062 & 0,9989657 & 0,86 & 0,8591105 & 25,36 & 28,27 & 4,7653 & 35,66 \\
\hline
\end{tabular}




\begin{tabular}{|c|c|c|c|c|c|c|c|c|c|c|c|c|c|}
\hline Vidro & Data & Horário & $\begin{array}{c}\text { Radiação } \\
\text { Direta } \\
\left(W / m^{2}\right)\end{array}$ & $\begin{array}{c}\text { Radiação } \\
\text { Difusa Céu } \\
\left(\mathrm{W} / \mathrm{m}^{2}\right)\end{array}$ & $\begin{array}{c}\text { Radiação } \\
\text { Refletida } \\
\left(\mathrm{W} / \mathrm{m}^{2}\right)\end{array}$ & FCS $(609)$ & $\begin{array}{c}\text { FCS } \\
\text { (referência) }\end{array}$ & CAC & FCS & te $\left({ }^{\circ} \mathrm{C}\right)$ & $\mathrm{ti}\left({ }^{\circ} \mathrm{C}\right)$ & $\mathrm{U}\left(\mathrm{W} / \mathrm{m}^{2} \mathrm{C}\right)$ & $q\left(W / m^{2}\right)$ \\
\hline \multirow{11}{*}{ 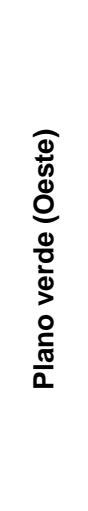 } & $13 / 8 / 2005$ & $7: 00$ & 0 & 33,1 & 4,1 & 0,8658062 & 0 & 0,74 & 0 & 12,40 & 13,46 & 4,7653 & 18,78 \\
\hline & $13 / 8 / 2005$ & $8: 00$ & 0 & 142 & 25,3 & 0,8658062 & 0 & 0,74 & 0 & 14,90 & 13,84 & 4,7653 & 112,26 \\
\hline & $13 / 8 / 2005$ & $9: 00$ & 0 & 173 & 50,8 & 0,8658062 & 0 & 0,74 & 0 & 18,15 & 14,51 & 4,7653 & 160,72 \\
\hline & $13 / 8 / 2005$ & $10: 00$ & 0 & 212,9 & 66,4 & 0,8658062 & 0 & 0,74 & 0 & 21,63 & 15,82 & 4,7653 & 206,63 \\
\hline & $13 / 8 / 2005$ & $11: 00$ & 0 & 242,1 & 75,8 & 0,8658062 & 0 & 0,74 & 0 & 23,52 & 17,82 & 4,7653 & 230,85 \\
\hline & $13 / 8 / 2005$ & $12: 00$ & 0 & 260 & 78,4 & 0,8658062 & 0 & 0,74 & 0 & 25,43 & 19,60 & 4,7653 & 244,62 \\
\hline & $13 / 8 / 2005$ & $13: 00$ & 113,7 & 266,3 & 73,6 & 0,8658062 & 0,6040884 & 0,74 & 0,4470254 & 26,50 & 21,48 & 4,7653 & 292,52 \\
\hline & $13 / 8 / 2005$ & $14: 00$ & 211,8 & 242,6 & 64,6 & 0,8658062 & 0,8543961 & 0,74 & 0,6322531 & 27,23 & 24,28 & 4,7653 & 344,80 \\
\hline & $13 / 8 / 2005$ & $15: 00$ & 220,6 & 218,1 & 46,8 & 0,8658062 & 0,9579928 & 0,74 & 0,7089147 & 27,50 & 26,43 & 4,7653 & 331,19 \\
\hline & $13 / 8 / 2005$ & $16: 00$ & 143,5 & 158,3 & 26,2 & 0,8658062 & 0,9915252 & 0,74 & 0,7337286 & 27,06 & 27,75 & 4,7653 & 220,23 \\
\hline & $13 / 8 / 2005$ & $17: 00$ & 8,6 & 50,4 & 6,2 & 0,8658062 & 0,9989657 & 0,74 & 0,7392346 & 25,36 & 27,48 & 4,7653 & 32,52 \\
\hline
\end{tabular}

\begin{tabular}{|c|c|c|c|c|c|c|c|c|c|c|c|c|c|}
\hline Vidro & Data & Horário & $\begin{array}{c}\text { Radiação } \\
\text { Direta } \\
\left(W / m^{2}\right)\end{array}$ & $\begin{array}{c}\text { Radiação } \\
\text { Difusa Céu } \\
\left(\mathrm{W} / \mathrm{m}^{2}\right)\end{array}$ & $\begin{array}{c}\text { Radiação } \\
\text { Refletida } \\
\left(\mathrm{W} / \mathrm{m}^{2}\right)\end{array}$ & FCS (60) & $\begin{array}{c}\text { FCS } \\
\text { (referência) }\end{array}$ & CAC & FCS & te $\left({ }^{\circ} \mathrm{C}\right)$ & $\mathrm{ti}\left({ }^{\circ} \mathrm{C}\right)$ & $\mathrm{U}\left(\mathrm{W} / \mathrm{m}^{2} \mathrm{C}\right)$ & $q\left(W / m^{2}\right)$ \\
\hline \multirow{11}{*}{ 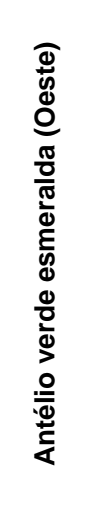 } & 13/8/2005 & 7:00 & 0 & 33,1 & 4,1 & 0,8658062 & 0 & 0,44 & 0 & 12,40 & 13,77 & 3,0352 & 10,01 \\
\hline & $13 / 8 / 2005$ & 8:00 & 0 & 142 & 25,3 & 0,8658062 & 0 & 0,44 & 0 & 14,90 & 14,17 & 3,0352 & 65,96 \\
\hline & $13 / 8 / 2005$ & 9:00 & 0 & 173 & 50,8 & 0,8658062 & 0 & 0,44 & 0 & 18,15 & 15,10 & 3,0352 & 94,50 \\
\hline & $13 / 8 / 2005$ & $10: 00$ & 0 & 212,9 & 66,4 & 0,8658062 & 0 & 0,44 & 0 & 21,63 & 16,30 & 3,0352 & 122,58 \\
\hline & $13 / 8 / 2005$ & $11: 00$ & 0 & 242,1 & 75,8 & 0,8658062 & 0 & 0,44 & 0 & 23,52 & 18,25 & 3,0352 & 137,12 \\
\hline & $13 / 8 / 2005$ & $12: 00$ & 0 & 260 & 78,4 & 0,8658062 & 0 & 0,44 & 0 & 25,43 & 20,06 & 3,0352 & 145,22 \\
\hline & $13 / 8 / 2005$ & 13:00 & 113,7 & 266,3 & 73,6 & 0,8658062 & 0,6040884 & 0,44 & 0,2657989 & 26,50 & 21,81 & 3,0352 & 173,94 \\
\hline & $13 / 8 / 2005$ & $14: 00$ & 211,8 & 242,6 & 64,6 & 0,8658062 & 0,8543961 & 0,44 & 0,3759343 & 27,23 & 24,27 & 3,0352 & 205,65 \\
\hline & $13 / 8 / 2005$ & $15: 00$ & 220,6 & 218,1 & 46,8 & 0,8658062 & 0,9579928 & 0,44 & 0,4215168 & 27,50 & 26,01 & 3,0352 & 198,41 \\
\hline & $13 / 8 / 2005$ & $16: 00$ & 143,5 & 158,3 & 26,2 & 0,8658062 & 0,9915252 & 0,44 & 0,4362711 & 27,06 & 27,47 & 3,0352 & 131,65 \\
\hline & $13 / 8 / 2005$ & $17: 00$ & 8,6 & 50,4 & 6,2 & 0,8658062 & 0,9989657 & 0,44 & 0,4395449 & 25,36 & 27,57 & 3,0352 & 18,64 \\
\hline
\end{tabular}




\begin{tabular}{|c|c|c|c|c|c|c|c|c|c|c|c|c|c|}
\hline Vidro & Data & Horário & $\begin{array}{c}\text { Radiação } \\
\text { Direta } \\
\left(W / m^{2}\right)\end{array}$ & $\begin{array}{c}\text { Radiação } \\
\text { Difusa Céu } \\
\left(W / m^{2}\right)\end{array}$ & $\begin{array}{c}\text { Radiação } \\
\text { Refletida } \\
\left(\mathrm{W} / \mathrm{m}^{2}\right)\end{array}$ & FCS $(609)$ & $\begin{array}{c}\text { FCS } \\
\text { (referência) }\end{array}$ & CAC & FCS & te $\left({ }^{\circ} \mathrm{C}\right)$ & $\mathrm{ti}\left({ }^{\circ} \mathrm{C}\right)$ & $\mathrm{U}\left(\mathrm{W} / \mathrm{m}^{2} \mathrm{C}\right)$ & $q\left(W / m^{2}\right)$ \\
\hline \multirow{11}{*}{ 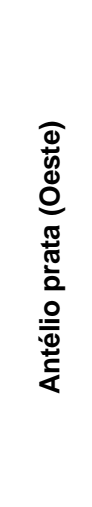 } & $13 / 8 / 2005$ & $7: 00$ & 0 & 33,1 & 4,1 & 0,8658062 & 0 & 0,55 & 0 & 12,40 & 13,53 & 3,0537 & 14,26 \\
\hline & $13 / 8 / 2005$ & $8: 00$ & 0 & 142 & 25,3 & 0,8658062 & 0 & 0,55 & 0 & 14,90 & 13,84 & 3,0537 & 82,93 \\
\hline & $13 / 8 / 2005$ & $9: 00$ & 0 & 173 & 50,8 & 0,8658062 & 0 & 0,55 & 0 & 18,15 & 14,52 & 3,0537 & 117,65 \\
\hline & $13 / 8 / 2005$ & $10: 00$ & 0 & 212,9 & 66,4 & 0,8658062 & 0 & 0,55 & 0 & 21,63 & 15,82 & 3,0537 & 150,74 \\
\hline & $13 / 8 / 2005$ & $11: 00$ & 0 & 242,1 & 75,8 & 0,8658062 & 0 & 0,55 & 0 & 23,52 & 17,91 & 3,0537 & 168,53 \\
\hline & $13 / 8 / 2005$ & $12: 00$ & 0 & 260 & 78,4 & 0,8658062 & 0 & 0,55 & 0 & 25,43 & 19,68 & 3,0537 & 178,70 \\
\hline & $13 / 8 / 2005$ & 13:00 & 113,7 & 266,3 & 73,6 & 0,8658062 & 0,6040884 & 0,55 & 0,3322486 & 26,50 & 21,46 & 3,0537 & 215,02 \\
\hline & $13 / 8 / 2005$ & $14: 00$ & 211,8 & 242,6 & 64,6 & 0,8658062 & 0,8543961 & 0,55 & 0,4699178 & 27,23 & 23,83 & 3,0537 & 256,21 \\
\hline & $13 / 8 / 2005$ & $15: 00$ & 220,6 & 218,1 & 46,8 & 0,8658062 & 0,9579928 & 0,55 & 0,5268960 & 27,50 & 25,60 & 3,0537 & 248,16 \\
\hline & $13 / 8 / 2005$ & $16: 00$ & 143,5 & 158,3 & 26,2 & 0,8658062 & 0,9915252 & 0,55 & 0,5453389 & 27,06 & 27,08 & 3,0537 & 166,07 \\
\hline & $13 / 8 / 2005$ & $17: 00$ & 8,6 & 50,4 & 6,2 & 0,8658062 & 0,9989657 & 0,55 & 0,5494311 & 25,36 & 27,12 & 3,0537 & 26,31 \\
\hline
\end{tabular}

\begin{tabular}{|c|c|c|c|c|c|c|c|c|c|c|c|c|c|}
\hline Vidro & Data & Horário & $\begin{array}{c}\text { Radiação } \\
\text { Direta } \\
\left(W / m^{2}\right)\end{array}$ & $\begin{array}{c}\text { Radiação } \\
\text { Difusa Céu } \\
\left(W / m^{2}\right)\end{array}$ & $\begin{array}{c}\text { Radiação } \\
\text { Refletida } \\
\left(\mathrm{W} / \mathrm{m}^{2}\right)\end{array}$ & FCS (609) & $\begin{array}{c}\text { FCS } \\
\text { (referência) }\end{array}$ & CAC & FCS & te $\left({ }^{\circ} \mathrm{C}\right)$ & $\mathrm{ti}\left({ }^{\circ} \mathrm{C}\right)$ & $\mathrm{U}\left(\mathrm{W} / \mathrm{m}^{2} \mathrm{C}\right)$ & $q\left(W / m^{2}\right)$ \\
\hline \multirow{11}{*}{ 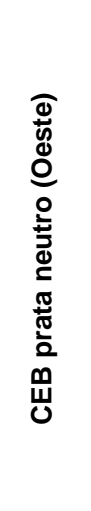 } & $13 / 8 / 2005$ & 7:00 & 0 & 33,1 & 4,1 & 0,8760888 & 0 & 0,27 & 0 & 12,40 & 13,53 & 2,9515 & 5,46 \\
\hline & $13 / 8 / 2005$ & $8: 00$ & 0 & 142 & 25,3 & 0,8760888 & 0 & 0,27 & 0 & 14,90 & 13,76 & 2,9515 & 42,94 \\
\hline & $13 / 8 / 2005$ & 9:00 & 0 & 173 & 50,8 & 0,8760888 & 0 & 0,27 & 0 & 18,15 & 14,39 & 2,9515 & 64,02 \\
\hline & $13 / 8 / 2005$ & $10: 00$ & 0 & 212,9 & 66,4 & 0,8760888 & 0 & 0,27 & 0 & 21,63 & 15,56 & 2,9515 & 83,98 \\
\hline & 13/8/2005 & $11: 00$ & 0 & 242,1 & 75,8 & 0,8760888 & 0 & 0,27 & 0 & 23,52 & 17,45 & 2,9515 & 93,13 \\
\hline & $13 / 8 / 2005$ & $12: 00$ & 0 & 260 & 78,4 & 0,8760888 & 0 & 0,27 & 0 & 25,43 & 19,10 & 2,9515 & 98,72 \\
\hline & $13 / 8 / 2005$ & $13: 00$ & 113,7 & 266,3 & 73,6 & 0,8760888 & 0,6640761 & 0,27 & 0,1793005 & 26,50 & 20,67 & 2,9515 & 117,99 \\
\hline & 13/8/2005 & $14: 00$ & 211,8 & 242,6 & 64,6 & 0,8760888 & 0,8666364 & 0,27 & 0,2339918 & 27,23 & 22,62 & 2,9515 & 135,84 \\
\hline & $13 / 8 / 2005$ & $15: 00$ & 220,6 & 218,1 & 46,8 & 0,8760888 & 0,9560065 & 0,27 & 0,2581218 & 27,50 & 24,08 & 2,9515 & 129,69 \\
\hline & $13 / 8 / 2005$ & $16: 00$ & 143,5 & 158,3 & 26,2 & 0,8760888 & 0,9893090 & 0,27 & 0,2671134 & 27,06 & 25,15 & 2,9515 & 87,61 \\
\hline & $13 / 8 / 2005$ & $17: 00$ & 8,6 & 50,4 & 6,2 & 0,8760888 & 0,9983253 & 0,27 & 0,2695478 & 25,36 & 25,59 & 2,9515 & 15,05 \\
\hline
\end{tabular}




\begin{tabular}{|c|c|c|c|c|c|c|c|c|c|c|c|c|c|}
\hline Vidro & Data & Horário & $\begin{array}{c}\text { Radiação } \\
\text { Direta } \\
\left(W / m^{2}\right)\end{array}$ & $\begin{array}{c}\text { Radiação } \\
\text { Difusa Céu } \\
\left(W / m^{2}\right)\end{array}$ & $\begin{array}{c}\text { Radiação } \\
\text { Refletida } \\
\left(\mathrm{W} / \mathbf{m}^{2}\right)\end{array}$ & FCS (60) & $\begin{array}{c}\text { FCS } \\
\text { (referência) }\end{array}$ & CAC & FCS & te $\left({ }^{\circ} \mathrm{C}\right)$ & $\mathrm{ti}\left({ }^{\circ} \mathrm{C}\right)$ & $\mathrm{U}\left(\mathrm{W} / \mathrm{m}^{2} \mathrm{C}\right)$ & $q\left(W / m^{2}\right)$ \\
\hline \multirow{11}{*}{ 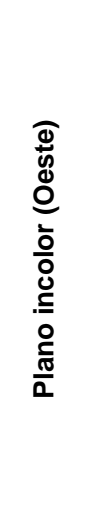 } & $15 / 2 / 2006$ & $7: 00$ & 0 & 86 & 28,1 & 0,8658062 & 0 & 0,86 & 0 & 22,38 & 21,19 & 4,7653 & 90,67 \\
\hline & $15 / 2 / 2006$ & $8: 00$ & 0 & 179,4 & 48,4 & 0,8658062 & 0 & 0,86 & 0 & 25,30 & 21,81 & 4,7653 & 186,25 \\
\hline & $15 / 2 / 2006$ & $9: 00$ & 0 & 249,2 & 68 & 0,8658062 & 0 & 0,86 & 0 & 27,53 & 23,05 & 4,7653 & 257,52 \\
\hline & $15 / 2 / 2006$ & $10: 00$ & 0 & 282,2 & 87,1 & 0,8658062 & 0 & 0,86 & 0 & 29,19 & 24,38 & 4,7653 & 297,90 \\
\hline & $15 / 2 / 2006$ & $11: 00$ & 0 & 371 & 88,9 & 0,8658062 & 0 & 0,86 & 0 & 30,28 & 25,84 & 4,7653 & 363,58 \\
\hline & $15 / 2 / 2006$ & $12: 00$ & 0 & 441,4 & 65,5 & 0,8658062 & 0 & 0,86 & 0 & 30,16 & 27,22 & 4,7653 & 391,44 \\
\hline & $15 / 2 / 2006$ & $13: 00$ & 29,8 & 436,7 & 65,9 & 0,8658062 & 0,6070415 & 0,86 & 0,5220557 & 30,75 & 28,16 & 4,7653 & 402,16 \\
\hline & $15 / 2 / 2006$ & $14: 00$ & 262,4 & 304,8 & 92,3 & 0,8658062 & 0,8572907 & 0,86 & 0,7372700 & 31,98 & 29,17 & 4,7653 & 502,54 \\
\hline & $15 / 2 / 2006$ & $15: 00$ & 74,6 & 340,2 & 50,2 & 0,8658062 & 0,9597922 & 0,86 & 0,8254213 & 30,24 & 30,41 & 4,7653 & 351,44 \\
\hline & $15 / 2 / 2006$ & $16: 00$ & 4,9 & 152,9 & 18,7 & 0,8658062 & 0,9923443 & 0,86 & 0,8534161 & 26,75 & 30,54 & 4,7653 & 113,90 \\
\hline & $15 / 2 / 2006$ & $17: 00$ & 2,1 & 32,3 & 4 & 0,8658062 & 0,9992211 & 0,86 & 0,8593302 & 22,38 & 29,22 & 4,7653 & 0,78 \\
\hline
\end{tabular}

\begin{tabular}{|c|c|c|c|c|c|c|c|c|c|c|c|c|c|}
\hline Vidro & Data & Horário & $\begin{array}{c}\text { Radiação } \\
\text { Direta } \\
\left(W / m^{2}\right)\end{array}$ & $\begin{array}{c}\text { Radiação } \\
\text { Difusa Céu } \\
\left(\mathrm{W} / \mathrm{m}^{2}\right)\end{array}$ & $\begin{array}{c}\text { Radiação } \\
\text { Refletida } \\
\left(\mathrm{W} / \mathrm{m}^{2}\right)\end{array}$ & FCS $(609)$ & $\begin{array}{c}\text { FCS } \\
\text { (referência) }\end{array}$ & CAC & FCS & te $\left({ }^{\circ} \mathrm{C}\right)$ & $\mathrm{ti}\left({ }^{\circ} \mathrm{C}\right)$ & $\mathrm{U}\left(\mathrm{W} / \mathrm{m}^{2} \mathrm{C}\right)$ & $q\left(W / m^{2}\right)$ \\
\hline \multirow{11}{*}{ 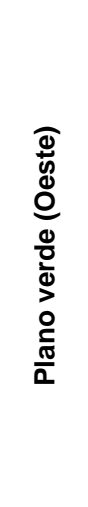 } & $15 / 2 / 2006$ & $7: 00$ & 0 & 86 & 28,1 & 0,8658062 & 0 & 0,74 & 0 & 22,38 & 21,18 & 4,7653 & 78,82 \\
\hline & $15 / 2 / 2006$ & $8: 00$ & 0 & 179,4 & 48,4 & 0,8658062 & 0 & 0,74 & 0 & 25,30 & 21,38 & 4,7653 & 164,60 \\
\hline & $15 / 2 / 2006$ & 9:00 & 0 & 249,2 & 68 & 0,8658062 & 0 & 0,74 & 0 & 27,53 & 22,16 & 4,7653 & 228,81 \\
\hline & $15 / 2 / 2006$ & $10: 00$ & 0 & 282,2 & 87,1 & 0,8658062 & 0 & 0,74 & 0 & 29,19 & 23,61 & 4,7653 & 263,24 \\
\hline & $15 / 2 / 2006$ & $11: 00$ & 0 & 371 & 88,9 & 0,8658062 & 0 & 0,74 & 0 & 30,28 & 25,25 & 4,7653 & 318,60 \\
\hline & $15 / 2 / 2006$ & $12: 00$ & 0 & 441,4 & 65,5 & 0,8658062 & 0 & 0,74 & 0 & 30,16 & 26,80 & 4,7653 & 340,80 \\
\hline & $15 / 2 / 2006$ & $13: 00$ & 29,8 & 436,7 & 65,9 & 0,8658062 & 0,6070415 & 0,74 & 0,4492107 & 30,75 & 27,83 & 4,7653 & 349,35 \\
\hline & $15 / 2 / 2006$ & $14: 00$ & 262,4 & 304,8 & 92,3 & 0,8658062 & 0,8572907 & 0,74 & 0,6343951 & 31,98 & 28,91 & 4,7653 & 435,52 \\
\hline & $15 / 2 / 2006$ & $15: 00$ & 74,6 & 340,2 & 50,2 & 0,8658062 & 0,9597922 & 0,74 & 0,7102462 & 30,24 & 30,25 & 4,7653 & 303,03 \\
\hline & $15 / 2 / 2006$ & $16: 00$ & 4,9 & 152,9 & 18,7 & 0,8658062 & 0,9923443 & 0,74 & 0,7343348 & 26,75 & 30,06 & 4,7653 & 97,78 \\
\hline & $15 / 2 / 2006$ & $17: 00$ & 2,1 & 32,3 & 4 & 0,8658062 & 0,9992211 & 0,74 & 0,7394236 & 22,38 & 28,42 & 4,7653 & 0,99 \\
\hline
\end{tabular}




\begin{tabular}{|c|c|c|c|c|c|c|c|c|c|c|c|c|c|}
\hline Vidro & Data & Horário & $\begin{array}{c}\text { Radiação } \\
\text { Direta } \\
\left(W / m^{2}\right)\end{array}$ & $\begin{array}{c}\text { Radiação } \\
\text { Difusa Céu } \\
\left(W / m^{2}\right)\end{array}$ & $\begin{array}{c}\text { Radiação } \\
\text { Refletida } \\
\left(\mathrm{W} / \mathrm{m}^{2}\right)\end{array}$ & FCS $(609)$ & $\begin{array}{c}\text { FCS } \\
\text { (referência) }\end{array}$ & CAC & FCS & te $\left({ }^{\circ} \mathrm{C}\right)$ & $\mathrm{ti}\left({ }^{\circ} \mathrm{C}\right)$ & $\mathrm{U}\left(\mathrm{W} / \mathrm{m}^{2} \mathrm{C}\right)$ & $q\left(W / m^{2}\right)$ \\
\hline \multirow{11}{*}{ 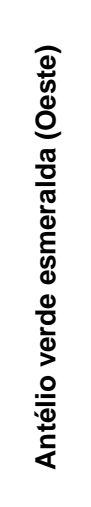 } & $15 / 2 / 2006$ & $7: 00$ & 0 & 86 & 28,1 & 0,8658062 & 0 & 0,44 & 0 & 22,38 & 20,94 & 3,0352 & 47,85 \\
\hline & $15 / 2 / 2006$ & $8: 00$ & 0 & 179,4 & 48,4 & 0,8658062 & 0 & 0,44 & 0 & 25,30 & 21,38 & 3,0352 & 98,66 \\
\hline & $15 / 2 / 2006$ & $9: 00$ & 0 & 249,2 & 68 & 0,8658062 & 0 & 0,44 & 0 & 27,53 & 22,65 & 3,0352 & 135,63 \\
\hline & $15 / 2 / 2006$ & $10: 00$ & 0 & 282,2 & 87,1 & 0,8658062 & 0 & 0,44 & 0 & 29,19 & 23,94 & 3,0352 & 156,65 \\
\hline & $15 / 2 / 2006$ & $11: 00$ & 0 & 371 & 88,9 & 0,8658062 & 0 & 0,44 & 0 & 30,28 & 25,23 & 3,0352 & 190,52 \\
\hline & $15 / 2 / 2006$ & $12: 00$ & 0 & 441,4 & 65,5 & 0,8658062 & 0 & 0,44 & 0 & 30,16 & 26,49 & 3,0352 & 204,24 \\
\hline & $15 / 2 / 2006$ & $13: 00$ & 29,8 & 436,7 & 65,9 & 0,8658062 & 0,6070415 & 0,44 & 0,2670983 & 30,75 & 27,30 & 3,0352 & 209,92 \\
\hline & $15 / 2 / 2006$ & $14: 00$ & 262,4 & 304,8 & 92,3 & 0,8658062 & 0,8572907 & 0,44 & 0,3772079 & 31,98 & 28,34 & 3,0352 & 261,30 \\
\hline & $15 / 2 / 2006$ & $15: 00$ & 74,6 & 340,2 & 50,2 & 0,8658062 & 0,9597922 & 0,44 & 0,4223086 & 30,24 & 29,56 & 3,0352 & 182,30 \\
\hline & $15 / 2 / 2006$ & $16: 00$ & 4,9 & 152,9 & 18,7 & 0,8658062 & 0,9923443 & 0,44 & 0,4366315 & 26,75 & 29,31 & 3,0352 & 59,76 \\
\hline & $15 / 2 / 2006$ & $17: 00$ & 2,1 & 32,3 & 4 & 0,8658062 & 0,9992211 & 0,44 & 0,4396573 & 22,38 & 27,88 & 3,0352 & 0,94 \\
\hline
\end{tabular}

\begin{tabular}{|c|c|c|c|c|c|c|c|c|c|c|c|c|c|}
\hline Vidro & Data & Horário & $\begin{array}{c}\text { Radiação } \\
\text { Direta } \\
\left(W / m^{2}\right)\end{array}$ & $\begin{array}{c}\text { Radiação } \\
\text { Difusa Céu } \\
\left(W / m^{2}\right)\end{array}$ & $\begin{array}{c}\text { Radiação } \\
\text { Refletida } \\
\left(\mathrm{W} / \mathbf{m}^{2}\right)\end{array}$ & FCS $(60)$ & $\begin{array}{c}\text { FCS } \\
\text { (referência) }\end{array}$ & CAC & FCS & te $\left({ }^{\circ} \mathrm{C}\right)$ & ti $\left({ }^{\circ} \mathrm{C}\right)$ & $\mathrm{U}\left(\mathrm{W} / \mathrm{m}^{2} \mathrm{C}\right)$ & $q\left(W / m^{2}\right)$ \\
\hline \multirow{9}{*}{ 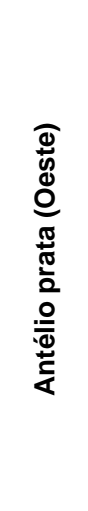 } & $15 / 2 / 2006$ & $8: 00$ & 0 & 179,4 & 48,4 & 0,8658062 & 0 & 0,55 & 0 & 25,30 & 21,61 & 3,0537 & 119,73 \\
\hline & $15 / 2 / 2006$ & $9: 00$ & 0 & 249,2 & 68 & 0,8658062 & 0 & 0,55 & 0 & 27,53 & 22,92 & 3,0537 & 165,10 \\
\hline & $15 / 2 / 2006$ & $10: 00$ & 0 & 282,2 & 87,1 & 0,8658062 & 0 & 0,55 & 0 & 29,19 & 24,32 & 3,0537 & 190,74 \\
\hline & $15 / 2 / 2006$ & $12: 00$ & 0 & 441,4 & 65,5 & 0,8658062 & 0 & 0,55 & 0 & 30,16 & 27,26 & 3,0537 & 250,23 \\
\hline & $15 / 2 / 2006$ & $13: 00$ & 29,8 & 436,7 & 65,9 & 0,8658062 & 0,6070415 & 0,55 & 0,3338728 & 30,75 & 28,14 & 3,0537 & 257,25 \\
\hline & $15 / 2 / 2006$ & $14: 00$ & 262,4 & 304,8 & 92,3 & 0,8658062 & 0,8572907 & 0,55 & 0,4715099 & 31,98 & 29,00 & 3,0537 & 321,93 \\
\hline & $15 / 2 / 2006$ & $15: 00$ & 74,6 & 340,2 & 50,2 & 0,8658062 & 0,9597922 & 0,55 & 0,5278857 & 30,24 & 30,17 & 3,0537 & 225,49 \\
\hline & $15 / 2 / 2006$ & $16: 00$ & 4,9 & 152,9 & 18,7 & 0,8658062 & 0,9923443 & 0,55 & 0,5457894 & 26,75 & 30,12 & 3,0537 & 74,09 \\
\hline & $15 / 2 / 2006$ & $17: 00$ & 2,1 & 32,3 & 4 & 0,8658062 & 0,9992211 & 0,55 & 0,5495716 & 22,38 & 28,52 & 3,0537 & 0,33 \\
\hline
\end{tabular}




\begin{tabular}{|c|c|c|c|c|c|c|c|c|c|c|c|c|c|}
\hline Vidro & Data & Horário & $\begin{array}{c}\text { Radiação } \\
\text { Direta } \\
\left(W / m^{2}\right)\end{array}$ & $\begin{array}{c}\text { Radiação } \\
\text { Difusa Céu } \\
\left(W / m^{2}\right)\end{array}$ & $\begin{array}{c}\text { Radiação } \\
\text { Refletida } \\
\left(W / m^{2}\right)\end{array}$ & FCS (609) & $\begin{array}{c}\text { FCS } \\
\text { (referência) }\end{array}$ & CAC & FCS & te $\left({ }^{\circ} \mathrm{C}\right)$ & $\mathrm{ti}\left({ }^{\circ} \mathrm{C}\right)$ & $\mathrm{U}\left(\mathrm{W} / \mathrm{m}^{2} \mathrm{C}\right)$ & $q\left(W / m^{2}\right)$ \\
\hline \multirow{11}{*}{ 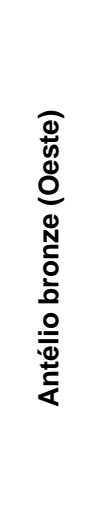 } & $15 / 2 / 2006$ & $7: 00$ & 0 & 86 & 28,1 & 0,8658062 & 0 & 0,51 & 0 & 22,38 & 20,87 & 3,0537 & 55,01 \\
\hline & $15 / 2 / 2006$ & $8: 00$ & 0 & 179,4 & 48,4 & 0,8658062 & 0 & 0,51 & 0 & 25,30 & 21,40 & 3,0537 & 112,48 \\
\hline & $15 / 2 / 2006$ & $9: 00$ & 0 & 249,2 & 68 & 0,8658062 & 0 & 0,51 & 0 & 27,53 & 22,55 & 3,0537 & 155,27 \\
\hline & $15 / 2 / 2006$ & $10: 00$ & 0 & 282,2 & 87,1 & 0,8658062 & 0 & 0,51 & 0 & 29,19 & 23,81 & 3,0537 & 179,52 \\
\hline & $15 / 2 / 2006$ & $11: 00$ & 0 & 371 & 88,9 & 0,8658062 & 0 & 0,51 & 0 & 30,28 & 25,08 & 3,0537 & 218,94 \\
\hline & $15 / 2 / 2006$ & $12: 00$ & 0 & 441,4 & 65,5 & 0,8658062 & 0 & 0,51 & 0 & 30,16 & 26,39 & 3,0537 & 235,34 \\
\hline & $15 / 2 / 2006$ & $13: 00$ & 29,8 & 436,7 & 65,9 & 0,8658062 & 0,6070415 & 0,51 & 0,3095912 & 30,75 & 27,17 & 3,0537 & 242,08 \\
\hline & $15 / 2 / 2006$ & $14: 00$ & 262,4 & 304,8 & 92,3 & 0,8658062 & 0,8572907 & 0,51 & 0,4372183 & 31,98 & 28,02 & 3,0537 & 302,15 \\
\hline & $15 / 2 / 2006$ & $15: 00$ & 74,6 & 340,2 & 50,2 & 0,8658062 & 0,9597922 & 0,51 & 0,4894940 & 30,24 & 29,30 & 3,0537 & 211,77 \\
\hline & $15 / 2 / 2006$ & $16: 00$ & 4,9 & 152,9 & 18,7 & 0,8658062 & 0,9923443 & 0,51 & 0,5060956 & 26,75 & 29,25 & 3,0537 & 70,63 \\
\hline & $15 / 2 / 2006$ & $17: 00$ & 2,1 & 32,3 & 4 & 0,8658062 & 0,9992211 & 0,51 & 0,5096028 & 22,38 & 27,87 & 3,0537 & 0,33 \\
\hline
\end{tabular}

\begin{tabular}{|c|c|c|c|c|c|c|c|c|c|c|c|c|c|}
\hline Vidro & Data & Horário & $\begin{array}{c}\text { Radiação } \\
\text { Direta } \\
\left(W / m^{2}\right)\end{array}$ & $\begin{array}{c}\text { Radiação } \\
\text { Difusa Céu } \\
\left(\mathrm{W} / \mathrm{m}^{2}\right)\end{array}$ & $\begin{array}{c}\text { Radiação } \\
\text { Refletida } \\
\left(\mathrm{W} / \mathrm{m}^{2}\right)\end{array}$ & FCS $(609)$ & $\begin{array}{c}\text { FCS } \\
\text { (referência) }\end{array}$ & CAC & FCS & te $\left({ }^{\circ} \mathrm{C}\right)$ & $\mathrm{ti}\left({ }^{\circ} \mathrm{C}\right)$ & $\mathrm{U}\left(\mathrm{W} / \mathrm{m}^{2} \mathrm{C}\right)$ & $q\left(W / m^{2}\right)$ \\
\hline \multirow{11}{*}{ 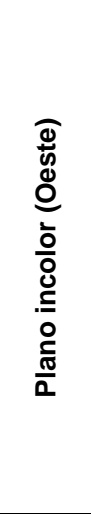 } & $11 / 3 / 2006$ & 7:00 & 0 & 77,9 & 9,8 & 0,8658062 & 0 & 0,86 & 0 & 20,62 & 20,75 & 4,7653 & 64,69 \\
\hline & $11 / 3 / 2006$ & 8:00 & 0 & 163 & 44,4 & 0,8658062 & 0 & 0,86 & 0 & 22,25 & 21,37 & 4,7653 & 158,64 \\
\hline & $11 / 3 / 2006$ & 9:00 & 0 & 217,4 & 66,5 & 0,8658062 & 0 & 0,86 & 0 & 24,16 & 22,11 & 4,7653 & 221,16 \\
\hline & $11 / 3 / 2006$ & $10: 00$ & 0 & 258,6 & 84 & 0,8658062 & 0 & 0,86 & 0 & 25,61 & 23,21 & 4,7653 & 266,51 \\
\hline & $11 / 3 / 2006$ & $11: 00$ & 0 & 312,2 & 91,4 & 0,8658062 & 0 & 0,86 & 0 & 26,30 & 24,32 & 4,7653 & 309,95 \\
\hline & $11 / 3 / 2006$ & $12: 00$ & 0 & 368,1 & 88,7 & 0,8658062 & 0 & 0,86 & 0 & 26,92 & 25,10 & 4,7653 & 348,83 \\
\hline & $11 / 3 / 2006$ & 13:00 & 131 & 318,2 & 93,7 & 0,8658062 & 0,6153149 & 0,86 & 0,5291708 & 27,94 & 25,88 & 4,7653 & 385,84 \\
\hline & $11 / 3 / 2006$ & $14: 00$ & 264,6 & 284 & 86,3 & 0,8658062 & 0,8651740 & 0,86 & 0,7440497 & 28,47 & 27,12 & 4,7653 & 479,06 \\
\hline & $11 / 3 / 2006$ & $15: 00$ & 261,7 & 284 & 64,1 & 0,8658062 & 0,9645348 & 0,86 & 0,8295000 & 28,54 & 28,43 & 4,7653 & 476,81 \\
\hline & $11 / 3 / 2006$ & $16: 00$ & 218,9 & 228,5 & 42,1 & 0,8658062 & 0,9943495 & 0,86 & 0,8551406 & 28,17 & 33,86 & 4,7653 & 361,55 \\
\hline & $11 / 3 / 2006$ & $17: 00$ & 118,2 & 133,9 & 19,9 & 0,8658062 & 0,9997252 & 0,86 & 0,8597637 & 26,84 & 33,86 & 4,7653 & 182,67 \\
\hline
\end{tabular}




\begin{tabular}{|c|c|c|c|c|c|c|c|c|c|c|c|c|c|}
\hline Vidro & Data & Horário & $\begin{array}{c}\text { Radiação } \\
\text { Direta } \\
\left(W / m^{2}\right)\end{array}$ & $\begin{array}{c}\text { Radiação } \\
\text { Difusa Céu } \\
\left(W / m^{2}\right)\end{array}$ & $\begin{array}{c}\text { Radiação } \\
\text { Refletida } \\
\left(\mathrm{W} / \mathrm{m}^{2}\right)\end{array}$ & FCS (60) & $\begin{array}{c}\text { FCS } \\
\text { (referência) }\end{array}$ & CAC & FCS & te $\left({ }^{\circ} \mathrm{C}\right)$ & ti $\left({ }^{\circ} \mathrm{C}\right)$ & $\mathrm{U}\left(\mathrm{W} / \mathrm{m}^{2} \mathrm{C}\right)$ & $q\left(W / m^{2}\right)$ \\
\hline \multirow{11}{*}{ 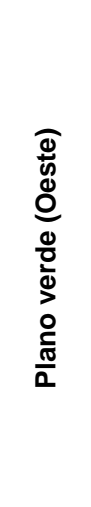 } & $11 / 3 / 2006$ & $7: 00$ & 0 & 77,9 & 9,8 & 0,8658062 & 0 & 0,74 & 0 & 20,62 & 20,19 & 4,7653 & 58,21 \\
\hline & $11 / 3 / 2006$ & $8: 00$ & 0 & 163 & 44,4 & 0,8658062 & 0 & 0,74 & 0 & 22,25 & 20,59 & 4,7653 & 140,79 \\
\hline & $11 / 3 / 2006$ & 9:00 & 0 & 217,4 & 66,5 & 0,8658062 & 0 & 0,74 & 0 & 24,16 & 21,40 & 4,7653 & 195,06 \\
\hline & $11 / 3 / 2006$ & $10: 00$ & 0 & 258,6 & 84 & 0,8658062 & 0 & 0,74 & 0 & 25,61 & 22,68 & 4,7653 & 233,46 \\
\hline & $11 / 3 / 2006$ & $11: 00$ & 0 & 312,2 & 91,4 & 0,8658062 & 0 & 0,74 & 0 & 26,30 & 23,91 & 4,7653 & 269,97 \\
\hline & $11 / 3 / 2006$ & $12: 00$ & 0 & 368,1 & 88,7 & 0,8658062 & 0 & 0,74 & 0 & 26,92 & 24,69 & 4,7653 & 303,30 \\
\hline & $11 / 3 / 2006$ & $13: 00$ & 131 & 318,2 & 93,7 & 0,8658062 & 0,6153149 & 0,74 & 0,4553330 & 27,94 & 25,54 & 4,7653 & 334,99 \\
\hline & $11 / 3 / 2006$ & $14: 00$ & 264,6 & 284 & 86,3 & 0,8658062 & 0,8651740 & 0,74 & 0,6402288 & 28,47 & 26,59 & 4,7653 & 415,65 \\
\hline & $11 / 3 / 2006$ & $15: 00$ & 261,7 & 284 & 64,1 & 0,8658062 & 0,9645348 & 0,74 & 0,7137558 & 28,54 & 27,79 & 4,7653 & 413,37 \\
\hline & $11 / 3 / 2006$ & $16: 00$ & 218,9 & 228,5 & 42,1 & 0,8658062 & 0,9943495 & 0,74 & 0,7358187 & 28,17 & 32,19 & 4,7653 & 315,31 \\
\hline & $11 / 3 / 2006$ & $17: 00$ & 118,2 & 133,9 & 19,9 & 0,8658062 & 0,9997252 & 0,74 & 0,7397966 & 26,84 & 32,21 & 4,7653 & 160,35 \\
\hline
\end{tabular}

\begin{tabular}{|c|c|c|c|c|c|c|c|c|c|c|c|c|c|}
\hline Vidro & Data & Horário & $\begin{array}{c}\text { Radiação } \\
\text { Direta } \\
\left(W / m^{2}\right)\end{array}$ & $\begin{array}{c}\text { Radiação } \\
\text { Difusa Céu } \\
\left(W / m^{2}\right)\end{array}$ & $\begin{array}{c}\text { Radiação } \\
\text { Refletida } \\
\left(\mathrm{W} / \mathbf{m}^{2}\right)\end{array}$ & FCS $(60)$ & $\begin{array}{c}\text { FCS } \\
\text { (referência) }\end{array}$ & CAC & FCS & te $\left({ }^{\circ} \mathrm{C}\right)$ & ti $\left({ }^{\circ} \mathrm{C}\right)$ & $\mathrm{U}\left(\mathrm{W} / \mathrm{m}^{2} \mathrm{C}\right)$ & $q\left(W / m^{2}\right)$ \\
\hline \multirow{10}{*}{ 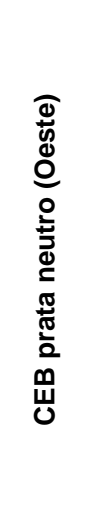 } & $11 / 3 / 2006$ & $8: 00$ & 0 & 163 & 44,4 & 0,8760888 & 0 & 0,27 & 0 & 22,25 & 20,77 & 2,9515 & 53,43 \\
\hline & $11 / 3 / 2006$ & $9: 00$ & 0 & 217,4 & 66,5 & 0,8760888 & 0 & 0,27 & 0 & 24,16 & 21,38 & 2,9515 & 75,37 \\
\hline & $11 / 3 / 2006$ & $10: 00$ & 0 & 258,6 & 84 & 0,8760888 & 0 & 0,27 & 0 & 25,61 & 22,35 & 2,9515 & 90,65 \\
\hline & $11 / 3 / 2006$ & $11: 00$ & 0 & 312,2 & 91,4 & 0,8760888 & 0 & 0,27 & 0 & 26,30 & 23,34 & 2,9515 & 104,21 \\
\hline & $11 / 3 / 2006$ & $12: 00$ & 0 & 368,1 & 88,7 & 0,8760888 & 0 & 0,27 & 0 & 26,92 & 23,97 & 2,9515 & 116,76 \\
\hline & $11 / 3 / 2006$ & 13:00 & 131 & 318,2 & 93,7 & 0,8760888 & 0,6732138 & 0,27 & 0,1817677 & 27,94 & 24,48 & 2,9515 & 131,45 \\
\hline & $11 / 3 / 2006$ & $14: 00$ & 264,6 & 284 & 86,3 & 0,8760888 & 0,8755635 & 0,27 & 0,2364022 & 28,47 & 25,20 & 2,9515 & 159,81 \\
\hline & $11 / 3 / 2006$ & $15: 00$ & 261,7 & 284 & 64,1 & 0,8760888 & 0,9621338 & 0,27 & 0,2597761 & 28,54 & 26,25 & 2,9515 & 157,08 \\
\hline & $11 / 3 / 2006$ & $16: 00$ & 218,9 & 228,5 & 42,1 & 0,8760888 & 0,9925225 & 0,27 & 0,2679811 & 28,17 & 27,35 & 2,9515 & 125,10 \\
\hline & $11 / 3 / 2006$ & $17: 00$ & 118,2 & 133,9 & 19,9 & 0,8760888 & 0,9994787 & 0,27 & 0,2698593 & 26,84 & 27,68 & 2,9515 & 65,78 \\
\hline
\end{tabular}




\begin{tabular}{|c|c|c|c|c|c|c|c|c|c|c|c|c|c|}
\hline Vidro & Data & Horário & $\begin{array}{c}\text { Radiação } \\
\text { Direta } \\
\left(W / m^{2}\right)\end{array}$ & $\begin{array}{c}\text { Radiação } \\
\text { Difusa Céu } \\
\left(W / m^{2}\right)\end{array}$ & $\begin{array}{c}\text { Radiação } \\
\text { Refletida } \\
\left(W / m^{2}\right)\end{array}$ & FCS (60) & $\begin{array}{c}\text { FCS } \\
\text { (referência) }\end{array}$ & CAC & FCS & te $\left({ }^{\circ} \mathrm{C}\right)$ & $\mathrm{ti}\left({ }^{\circ} \mathrm{C}\right)$ & $\mathrm{U}\left(\mathrm{W} / \mathrm{m}^{2} \mathrm{C}\right)$ & $q\left(W / m^{2}\right)$ \\
\hline \multirow{11}{*}{ 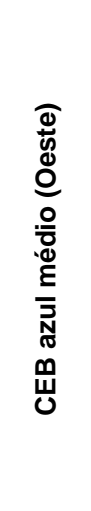 } & $11 / 3 / 2006$ & 7:00 & 0 & 77,9 & 9,8 & 0,8760888 & 0 & 0,39 & 0 & 20,62 & 20,22 & 2,9515 & 31,13 \\
\hline & $11 / 3 / 2006$ & $8: 00$ & 0 & 163 & 44,4 & 0,8760888 & 0 & 0,39 & 0 & 22,25 & 20,79 & 2,9515 & 75,18 \\
\hline & $11 / 3 / 2006$ & 9:00 & 0 & 217,4 & 66,5 & 0,8760888 & 0 & 0,39 & 0 & 24,16 & 21,54 & 2,9515 & 104,74 \\
\hline & $11 / 3 / 2006$ & $10: 00$ & 0 & 258,6 & 84 & 0,8760888 & 0 & 0,39 & 0 & 25,61 & 22,75 & 2,9515 & 125,49 \\
\hline & $11 / 3 / 2006$ & $11: 00$ & 0 & 312,2 & 91,4 & 0,8760888 & 0 & 0,39 & 0 & 26,30 & 23,90 & 2,9515 & 144,99 \\
\hline & $11 / 3 / 2006$ & $12: 00$ & 0 & 368,1 & 88,7 & 0,8760888 & 0 & 0,39 & 0 & 26,92 & 24,67 & 2,9515 & 162,71 \\
\hline & $11 / 3 / 2006$ & $13: 00$ & 131 & 318,2 & 93,7 & 0,8760888 & 0,6732138 & 0,39 & 0,2625534 & 27,94 & 25,45 & 2,9515 & 182,49 \\
\hline & $11 / 3 / 2006$ & $14: 00$ & 264,6 & 284 & 86,3 & 0,8760888 & 0,8755635 & 0,39 & 0,3414698 & 28,47 & 26,32 & 2,9515 & 223,24 \\
\hline & $11 / 3 / 2006$ & $15: 00$ & 261,7 & 284 & 64,1 & 0,8760888 & 0,9621338 & 0,39 & 0,3752322 & 28,54 & 27,35 & 2,9515 & 220,64 \\
\hline & $11 / 3 / 2006$ & $16: 00$ & 218,9 & 228,5 & 42,1 & 0,8760888 & 0,9925225 & 0,39 & 0,3870838 & 28,17 & 29,28 & 2,9515 & 173,93 \\
\hline & $11 / 3 / 2006$ & $17: 00$ & 118,2 & 133,9 & 19,9 & 0,8760888 & 0,9994787 & 0,39 & 0,3897967 & 26,84 & 29,53 & 2,9515 & 90,67 \\
\hline
\end{tabular}

\begin{tabular}{|c|c|c|c|c|c|c|c|c|c|c|c|c|c|}
\hline Vidro & Data & Horário & $\begin{array}{c}\text { Radiação } \\
\text { Direta } \\
\left(W / m^{2}\right)\end{array}$ & $\begin{array}{c}\text { Radiação } \\
\text { Difusa Céu } \\
\left(\mathrm{W} / \mathrm{m}^{2}\right)\end{array}$ & $\begin{array}{c}\text { Radiação } \\
\text { Refletida } \\
\left(\mathrm{W} / \mathrm{m}^{2}\right)\end{array}$ & FCS $(609)$ & $\begin{array}{c}\text { FCS } \\
\text { (referência) }\end{array}$ & CAC & FCS & te $\left({ }^{\circ} \mathrm{C}\right)$ & $\mathrm{ti}\left({ }^{\circ} \mathrm{C}\right)$ & $\mathrm{U}\left(\mathrm{W} / \mathrm{m}^{2} \mathrm{C}\right)$ & $q\left(W / m^{2}\right)$ \\
\hline \multirow{11}{*}{ 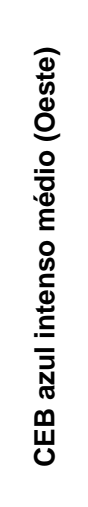 } & $11 / 3 / 2006$ & 7:00 & 0 & 77,9 & 9,8 & 0,8760888 & 0 & 0,31 & 0 & 20,62 & 20,66 & 2,9515 & 23,69 \\
\hline & $11 / 3 / 2006$ & 8:00 & 0 & 163 & 44,4 & 0,8760888 & 0 & 0,31 & 0 & 22,25 & 21,15 & 2,9515 & 59,59 \\
\hline & $11 / 3 / 2006$ & 9:00 & 0 & 217,4 & 66,5 & 0,8760888 & 0 & 0,31 & 0 & 24,16 & 21,77 & 2,9515 & 84,15 \\
\hline & $11 / 3 / 2006$ & $10: 00$ & 0 & 258,6 & 84 & 0,8760888 & 0 & 0,31 & 0 & 25,61 & 22,78 & 2,9515 & 101,40 \\
\hline & $11 / 3 / 2006$ & $11: 00$ & 0 & 312,2 & 91,4 & 0,8760888 & 0 & 0,31 & 0 & 26,30 & 23,73 & 2,9515 & 117,22 \\
\hline & $11 / 3 / 2006$ & $12: 00$ & 0 & 368,1 & 88,7 & 0,8760888 & 0 & 0,31 & 0 & 26,92 & 24,32 & 2,9515 & 131,75 \\
\hline & $11 / 3 / 2006$ & $13: 00$ & 131 & 318,2 & 93,7 & 0,8760888 & 0,6732138 & 0,31 & 0,2086963 & 27,94 & 24,85 & 2,9515 & 148,34 \\
\hline & $11 / 3 / 2006$ & $14: 00$ & 264,6 & 284 & 86,3 & 0,8760888 & 0,8755635 & 0,31 & 0,2714247 & 28,47 & 25,69 & 2,9515 & 180,60 \\
\hline & $11 / 3 / 2006$ & $15: 00$ & 261,7 & 284 & 64,1 & 0,8760888 & 0,9621338 & 0,31 & 0,2982615 & 28,54 & 26,69 & 2,9515 & 178,05 \\
\hline & $11 / 3 / 2006$ & $16: 00$ & 218,9 & 228,5 & 42,1 & 0,8760888 & 0,9925225 & 0,31 & 0,3076820 & 28,17 & 27,44 & 2,9515 & 143,01 \\
\hline & $11 / 3 / 2006$ & $17: 00$ & 118,2 & 133,9 & 19,9 & 0,8760888 & 0,9994787 & 0,31 & 0,3098384 & 26,84 & 28,19 & 2,9515 & 74,40 \\
\hline
\end{tabular}




\begin{tabular}{|c|c|c|c|c|c|c|c|c|c|c|c|c|c|}
\hline Vidro & Data & Horário & $\begin{array}{c}\text { Radiação } \\
\text { Direta } \\
\left(W / m^{2}\right)\end{array}$ & $\begin{array}{c}\text { Radiação } \\
\text { Difusa Céu } \\
\left(\mathrm{W} / \mathrm{m}^{2}\right)\end{array}$ & $\begin{array}{c}\text { Radiação } \\
\text { Refletida } \\
\left(W / m^{2}\right)\end{array}$ & FCS (60) & $\begin{array}{c}\text { FCS } \\
\text { (referência) }\end{array}$ & CAC & FCS & te $\left({ }^{\circ} \mathrm{C}\right)$ & $\mathrm{ti}\left({ }^{\circ} \mathrm{C}\right)$ & $\mathrm{U}\left(\mathrm{W} / \mathrm{m}^{2} \mathrm{C}\right)$ & $q\left(W / m^{2}\right)$ \\
\hline \multirow{11}{*}{ 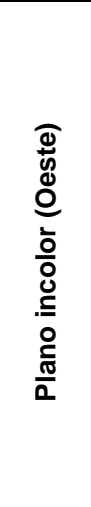 } & $15 / 3 / 2006$ & $7: 00$ & 0 & 75,2 & 9,5 & 0,8658062 & 0 & 0,86 & 0 & 21,38 & 21,65 & 4,7653 & 61,77 \\
\hline & $15 / 3 / 2006$ & $8: 00$ & 0 & 152,9 & 44,9 & 0,8658062 & 0 & 0,86 & 0 & 24,07 & 22,29 & 4,7653 & 155,75 \\
\hline & $15 / 3 / 2006$ & $9: 00$ & 0 & 209,4 & 66,5 & 0,8658062 & 0 & 0,86 & 0 & 26,73 & 23,21 & 4,7653 & 222,21 \\
\hline & $15 / 3 / 2006$ & $10: 00$ & 0 & 334,5 & 46,1 & 0,8658062 & 0 & 0,86 & 0 & 27,20 & 24,66 & 4,7653 & 295,49 \\
\hline & $15 / 3 / 2006$ & $11: 00$ & 0 & 398,6 & 69,5 & 0,8658062 & 0 & 0,86 & 0 & 28,32 & 25,70 & 4,7653 & 361,03 \\
\hline & $15 / 3 / 2006$ & $12: 00$ & 0 & 383,4 & 83,6 & 0,8658062 & 0 & 0,86 & 0 & 29,25 & 26,94 & 4,7653 & 358,76 \\
\hline & $15 / 3 / 2006$ & $13: 00$ & 86,2 & 376,2 & 81,2 & 0,8658062 & 0,6157973 & 0,86 & 0,5295857 & 29,95 & 28,00 & 4,7653 & 395,51 \\
\hline & $15 / 3 / 2006$ & $14: 00$ & 331,4 & 231,3 & 92,3 & 0,8658062 & 0,8655958 & 0,86 & 0,7444124 & 31,07 & 29,41 & 4,7653 & 495,56 \\
\hline & $15 / 3 / 2006$ & $15: 00$ & 421 & 215,2 & 73,3 & 0,8658062 & 0,9648248 & 0,86 & 0,8297493 & 30,84 & 31,25 & 4,7653 & 562,20 \\
\hline & $15 / 3 / 2006$ & $16: 00$ & 381,3 & 192,3 & 48,1 & 0,8658062 & 0,9944589 & 0,86 & 0,8552347 & 29,95 & 36,37 & 4,7653 & 474,52 \\
\hline & $15 / 3 / 2006$ & $17: 00$ & 6,9 & 80,2 & 9,8 & 0,8658062 & 0,9997468 & 0,86 & 0,8597823 & 27,68 & 32,49 & 4,7653 & 50,00 \\
\hline
\end{tabular}

\begin{tabular}{|c|c|c|c|c|c|c|c|c|c|c|c|c|c|}
\hline Vidro & Data & Horário & $\begin{array}{c}\text { Radiação } \\
\text { Direta } \\
\left(W / m^{2}\right)\end{array}$ & $\begin{array}{c}\text { Radiação } \\
\text { Difusa Céu } \\
\left(W / m^{2}\right)\end{array}$ & $\begin{array}{c}\text { Radiação } \\
\text { Refletida } \\
\left(W / m^{2}\right)\end{array}$ & FCS (60) & $\begin{array}{c}\text { FCS } \\
\text { (referência) }\end{array}$ & CAC & FCS & te $\left({ }^{\circ} \mathrm{C}\right)$ & ti $\left({ }^{\circ} \mathrm{C}\right)$ & $\mathrm{U}\left(\mathrm{W} / \mathrm{m}^{2} \mathrm{C}\right)$ & $q\left(W / m^{2}\right)$ \\
\hline \multirow{9}{*}{ 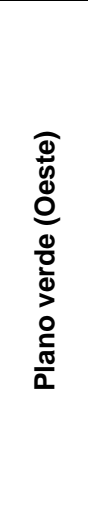 } & $15 / 3 / 2006$ & $8: 00$ & 0 & 152,9 & 44,9 & 0,8658062 & 0 & 0,74 & 0 & 24,07 & 21,67 & 4,7653 & 138,16 \\
\hline & $15 / 3 / 2006$ & $9: 00$ & 0 & 209,4 & 66,5 & 0,8658062 & 0 & 0,74 & 0 & 26,73 & 22,45 & 4,7653 & 197,16 \\
\hline & $15 / 3 / 2006$ & $10: 00$ & 0 & 334,5 & 46,1 & 0,8658062 & 0 & 0,74 & 0 & 27,20 & 24,05 & 4,7653 & 258,89 \\
\hline & $15 / 3 / 2006$ & $12: 00$ & 0 & 383,4 & 83,6 & 0,8658062 & 0 & 0,74 & 0 & 29,25 & 26,37 & 4,7653 & 312,96 \\
\hline & $15 / 3 / 2006$ & 13:00 & 86,2 & 376,2 & 81,2 & 0,8658062 & 0,6157973 & 0,74 & 0,4556900 & 29,95 & 27,35 & 4,7653 & 344,72 \\
\hline & $15 / 3 / 2006$ & $14: 00$ & 331,4 & 231,3 & 92,3 & 0,8658062 & 0,8655958 & 0,74 & 0,6405409 & 31,07 & 28,62 & 4,7653 & 431,28 \\
\hline & $15 / 3 / 2006$ & $15: 00$ & 421 & 215,2 & 73,3 & 0,8658062 & 0,9648248 & 0,74 & 0,7139703 & 30,84 & 30,33 & 4,7653 & 487,88 \\
\hline & $15 / 3 / 2006$ & $16: 00$ & 381,3 & 192,3 & 48,1 & 0,8658062 & 0,9944589 & 0,74 & 0,7358996 & 29,95 & 34,47 & 4,7653 & 413,07 \\
\hline & $15 / 3 / 2006$ & $17: 00$ & 6,9 & 80,2 & 9,8 & 0,8658062 & 0,9997468 & 0,74 & 0,7398126 & 27,68 & 31,31 & 4,7653 & 45,45 \\
\hline
\end{tabular}




\begin{tabular}{|c|c|c|c|c|c|c|c|c|c|c|c|c|c|}
\hline Vidro & Data & Horário & $\begin{array}{c}\text { Radiação } \\
\text { Direta } \\
\left(W / m^{2}\right)\end{array}$ & $\begin{array}{c}\text { Radiação } \\
\text { Difusa Céu } \\
\left(W / m^{2}\right)\end{array}$ & $\begin{array}{c}\text { Radiação } \\
\text { Refletida } \\
\left(W / m^{2}\right)\end{array}$ & FCS $(609)$ & $\begin{array}{c}\text { FCS } \\
\text { (referência) }\end{array}$ & CAC & FCS & te $\left({ }^{\circ} \mathrm{C}\right)$ & $\mathrm{ti}\left({ }^{\circ} \mathrm{C}\right)$ & $\mathrm{U}\left(\mathrm{W} / \mathrm{m}^{2} \mathrm{C}\right)$ & $q\left(W / m^{2}\right)$ \\
\hline \multirow{11}{*}{ 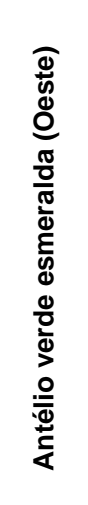 } & $15 / 3 / 2006$ & $7: 00$ & 0 & 75,2 & 9,5 & 0,8658062 & 0 & 0,44 & 0 & 21,38 & 21,37 & 3,0352 & 32,30 \\
\hline & $15 / 3 / 2006$ & $8: 00$ & 0 & 152,9 & 44,9 & 0,8658062 & 0 & 0,44 & 0 & 24,07 & 21,96 & 3,0352 & 81,75 \\
\hline & $15 / 3 / 2006$ & $9: 00$ & 0 & 209,4 & 66,5 & 0,8658062 & 0 & 0,44 & 0 & 26,73 & 22,79 & 3,0352 & 117,07 \\
\hline & $15 / 3 / 2006$ & $10: 00$ & 0 & 334,5 & 46,1 & 0,8658062 & 0 & 0,44 & 0 & 27,20 & 24,03 & 3,0352 & 154,61 \\
\hline & $15 / 3 / 2006$ & $11: 00$ & 0 & 398,6 & 69,5 & 0,8658062 & 0 & 0,44 & 0 & 28,32 & 24,92 & 3,0352 & 188,63 \\
\hline & $15 / 3 / 2006$ & $12: 00$ & 0 & 383,4 & 83,6 & 0,8658062 & 0 & 0,44 & 0 & 29,25 & 25,95 & 3,0352 & 187,93 \\
\hline & $15 / 3 / 2006$ & $13: 00$ & 86,2 & 376,2 & 81,2 & 0,8658062 & 0,6157973 & 0,44 & 0,2709508 & 29,95 & 27,01 & 3,0352 & 206,52 \\
\hline & $15 / 3 / 2006$ & $14: 00$ & 331,4 & 231,3 & 92,3 & 0,8658062 & 0,8655958 & 0,44 & 0,3808621 & 31,07 & 28,29 & 3,0352 & 257,94 \\
\hline & $15 / 3 / 2006$ & $15: 00$ & 421 & 215,2 & 73,3 & 0,8658062 & 0,9648248 & 0,44 & 0,4245229 & 30,84 & 29,68 & 3,0352 & 292,17 \\
\hline & $15 / 3 / 2006$ & $16: 00$ & 381,3 & 192,3 & 48,1 & 0,8658062 & 0,9944589 & 0,44 & 0,4375619 & 29,95 & 30,83 & 3,0352 & 255,75 \\
\hline & $15 / 3 / 2006$ & $17: 00$ & 6,9 & 80,2 & 9,8 & 0,8658062 & 0,9997468 & 0,44 & 0,4398886 & 27,68 & 30,72 & 3,0352 & 28,08 \\
\hline
\end{tabular}

\begin{tabular}{|c|c|c|c|c|c|c|c|c|c|c|c|c|c|}
\hline Vidro & Data & Horário & $\begin{array}{c}\text { Radiação } \\
\text { Direta } \\
\left(W / m^{2}\right)\end{array}$ & $\begin{array}{c}\text { Radiação } \\
\text { Difusa Céu } \\
\left(W / m^{2}\right)\end{array}$ & $\begin{array}{c}\text { Radiação } \\
\text { Refletida } \\
\left(W / m^{2}\right)\end{array}$ & FCS $(609)$ & $\begin{array}{c}\text { FCS } \\
\text { (referência) }\end{array}$ & CAC & FCS & te $\left({ }^{\circ} \mathrm{C}\right)$ & $\mathrm{ti}\left({ }^{\circ} \mathrm{C}\right)$ & $\mathrm{U}\left(\mathrm{W} / \mathrm{m}^{2} \mathrm{C}\right)$ & $q\left(W / m^{2}\right)$ \\
\hline \multirow{11}{*}{ 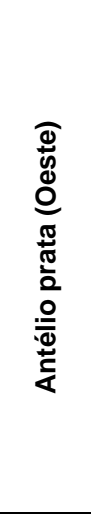 } & $15 / 3 / 2006$ & 7:00 & 0 & 75,2 & 9,5 & 0,8658062 & 0 & 0,55 & 0 & 21,38 & 21,32 & 3,0537 & 40,52 \\
\hline & $15 / 3 / 2006$ & 8:00 & 0 & 152,9 & 44,9 & 0,8658062 & 0 & 0,55 & 0 & 24,07 & 21,84 & 3,0537 & 101,02 \\
\hline & $15 / 3 / 2006$ & 9:00 & 0 & 209,4 & 66,5 & 0,8658062 & 0 & 0,55 & 0 & 26,73 & 22,67 & 3,0537 & 143,80 \\
\hline & $15 / 3 / 2006$ & $10: 00$ & 0 & 334,5 & 46,1 & 0,8658062 & 0 & 0,55 & 0 & 27,20 & 24,30 & 3,0537 & 190,10 \\
\hline & $15 / 3 / 2006$ & $11: 00$ & 0 & 398,6 & 69,5 & 0,8658062 & 0 & 0,55 & 0 & 28,32 & 25,39 & 3,0537 & 231,86 \\
\hline & $15 / 3 / 2006$ & $12: 00$ & 0 & 383,4 & 83,6 & 0,8658062 & 0 & 0,55 & 0 & 29,25 & 26,65 & 3,0537 & 230,32 \\
\hline & $15 / 3 / 2006$ & $13: 00$ & 86,2 & 376,2 & 81,2 & 0,8658062 & 0,6157973 & 0,55 & 0,3386885 & 29,95 & 27,82 & 3,0537 & 253,51 \\
\hline & $15 / 3 / 2006$ & $14: 00$ & 331,4 & 231,3 & 92,3 & 0,8658062 & 0,8655958 & 0,55 & 0,4760777 & 31,07 & 29,02 & 3,0537 & 318,14 \\
\hline & $15 / 3 / 2006$ & $15: 00$ & 421 & 215,2 & 73,3 & 0,8658062 & 0,9648248 & 0,55 & 0,5306536 & 30,84 & 30,93 & 3,0537 & 360,51 \\
\hline & $15 / 3 / 2006$ & $16: 00$ & 381,3 & 192,3 & 48,1 & 0,8658062 & 0,9944589 & 0,55 & 0,5469524 & 29,95 & 35,15 & 3,0537 & 307,15 \\
\hline & $15 / 3 / 2006$ & $17: 00$ & 6,9 & 80,2 & 9,8 & 0,8658062 & 0,9997468 & 0,55 & 0,5498607 & 27,68 & 32,29 & 3,0537 & 32,56 \\
\hline
\end{tabular}




\begin{tabular}{|c|c|c|c|c|c|c|c|c|c|c|c|c|c|}
\hline Vidro & Data & Horário & $\begin{array}{c}\text { Radiação } \\
\text { Direta } \\
\left(W / m^{2}\right)\end{array}$ & $\begin{array}{c}\text { Radiação } \\
\text { Difusa Céu } \\
\left(W / m^{2}\right)\end{array}$ & $\begin{array}{c}\text { Radiação } \\
\text { Refletida } \\
\left(W / m^{2}\right)\end{array}$ & FCS (609) & $\begin{array}{c}\text { FCS } \\
\text { (referência) }\end{array}$ & CAC & FCS & te $\left({ }^{\circ} \mathrm{C}\right)$ & ti $\left({ }^{\circ} \mathrm{C}\right)$ & $\mathrm{U}\left(\mathrm{W} / \mathrm{m}^{2} \mathrm{C}\right)$ & $q\left(W / m^{2}\right)$ \\
\hline \multirow{11}{*}{ 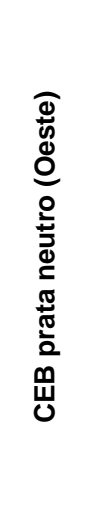 } & $15 / 3 / 2006$ & $7: 00$ & 0 & 75,2 & 9,5 & 0,8760888 & 0 & 0,27 & 0 & 21,38 & 21,06 & 2,9515 & 20,99 \\
\hline & $15 / 3 / 2006$ & $8: 00$ & 0 & 152,9 & 44,9 & 0,8760888 & 0 & 0,27 & 0 & 24,07 & 21,53 & 2,9515 & 54,30 \\
\hline & $15 / 3 / 2006$ & $9: 00$ & 0 & 209,4 & 66,5 & 0,8760888 & 0 & 0,27 & 0 & 26,73 & 22,37 & 2,9515 & 78,14 \\
\hline & $15 / 3 / 2006$ & $10: 00$ & 0 & 334,5 & 46,1 & 0,8760888 & 0 & 0,27 & 0 & 27,20 & 23,72 & 2,9515 & 100,30 \\
\hline & $15 / 3 / 2006$ & $11: 00$ & 0 & 398,6 & 69,5 & 0,8760888 & 0 & 0,27 & 0 & 28,32 & 24,49 & 2,9515 & 122,03 \\
\hline & $15 / 3 / 2006$ & $12: 00$ & 0 & 383,4 & 83,6 & 0,8760888 & 0 & 0,27 & 0 & 29,25 & 25,49 & 2,9515 & 121,56 \\
\hline & $15 / 3 / 2006$ & $13: 00$ & 86,2 & 376,2 & 81,2 & 0,8760888 & 0,6736060 & 0,27 & 0,1818736 & 29,95 & 26,47 & 2,9515 & 134,14 \\
\hline & $15 / 3 / 2006$ & $14: 00$ & 331,4 & 231,3 & 92,3 & 0,8760888 & 0,8759139 & 0,27 & 0,2364968 & 31,07 & 27,32 & 2,9515 & 165,99 \\
\hline & $15 / 3 / 2006$ & $15: 00$ & 421 & 215,2 & 73,3 & 0,8760888 & 0,9624081 & 0,27 & 0,2598502 & 30,84 & 28,66 & 2,9515 & 184,08 \\
\hline & $15 / 3 / 2006$ & $16: 00$ & 381,3 & 192,3 & 48,1 & 0,8760888 & 0,9926503 & 0,27 & 0,2680156 & 29,95 & 29,77 & 2,9515 & 159,60 \\
\hline & $15 / 3 / 2006$ & $17: 00$ & 6,9 & 80,2 & 9,8 & 0,8760888 & 0,9995150 & 0,27 & 0,2698690 & 27,68 & 29,70 & 2,9515 & 17,18 \\
\hline
\end{tabular}

